\title{
Biografía y autobiografía de la mujer en tránsito en la expresión audiovisual contemporánea
}

MIKI YOKOIGAWA 


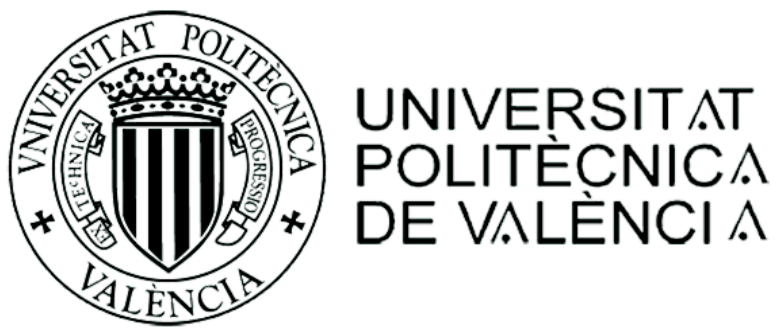

UNIVERSIDAD POLITÉCNICA DE VALENCIA FACULTAD DE BELLAS ARTES DE SAN CARLOS

DEPARTAMENTO DE ESCULTURA

Programa de doctorado:

ARTES VISUALES E INTERMEDIA

$\underline{\text { Tesis doctoral: }}$

\section{Biografía y autobiografía} de la mujer en tránsito

en la expresión audiovisual contemporánea

Presentada por:

Miki Yokoigawa

Dirigida por:

Dra. Dña. Maribel Domènech Ibáñez

Catedrática de Universidad UPV

Enero 2012, Valencia, España 
Esta editorial es miembro de la UNE, lo que garantiza la difusión y comercialización de sus publicaciones a nivel nacional e internacional.

\section{(c) Miki Yokoigawa}

Primera edición, 2012

(c) de la presente edición:

Editorial Universitat Politècnica de València

www.editorial. upv.es

ISBN: 978-84-8363-878-1 (versión impresa)

Queda prohibida la reproducción, distribución, comercialización, transformación, y en general, cualquier otra forma de explotación, por cualquier procedimiento, de todo o parte de los contenidos de esta obra sin autorización expresa y por escrito de sus autores. 
Agradecimientos:

Quisiera expresar mi más sincero agradecimiento a todos mis profesores y maestros de la Universidad Politécnica de Valencia por la transmisión de sus amplios conocimientos, en especial a la Dra. Dña. Maribel Domènech Ibáñez, como directora de la presente tesis y como tutora durante mis estudios de doctorado. Ella siempre me ha ofrecido una amable atención y ha sido un gran apoyo gracias a su inigualable paciencia. Sin ello no podría haber concluido esta tesis.

Gracias a la Dra. Blanca Gutiérrez Galindo de la Antigua Academia San Carlos de la Escuela Nacional de Artes Plásticas de Universidad Nacional Autónoma de México, por haberme recomendado los estudios de doctorado de la UPV. El método de investigación que me enseñó ha resultado un apoyo fundamental para el estudio que concluye en la presentación de esta tesis, y sus agudos y precisos comentarios sobre mi trabajo han supuesto un gran avance.

También quisiera mostrar mi agradecimiento a los artistas y realizadores de los trabajos artísticos que he estudiado en la presente tesis. Sobre todo, a la artista Fiona Tan y a la galería Frith Street Gallery de Londres. Ellos han mostrado una gran generosidad al permitirme acceder a su trabajo personalmente. Del mismo modo, un sincero agradecimiento para Kimsooja y sin olvidar a Trinh T. Minh-ha.

A la Cineteca Nacional de México, al Festival Internacional de Cine Documental de Navarra, al Festival Internacional de Cine de Las Palmas de Gran Canaria, a la videoteca del Instituto Valenciano del Audiovisual y la Cinematografía, al Centro de Documentación y Estudios Avanzados de Arte Contemporáneo (Murcia España), gracias por el apoyo y las facilidades ofrecidas durante la investigación.

A los encuentros con mis amigos y compañeros en muchas partes del mundo (Alemania, Argelia, Argentina, Bélgica, Brasil, Chile, China, Colombia, Corea, Cuba, Dinamarca, España, Estados Unidos, Francia, Holanda, Irán, Italia, Japón, México, Reino Unido y otros), porque las conversaciones con ellos me han permitido reflexionar sobre el tema desde distintos puntos de vista. Sobre todo, a Agathe y a la familia Keller, pues habría sido muy diferente si no los hubiera encontrado, tanto en lo que se refiere a la trayectoria de mi vida como a la perspectiva de esta tesis. No puedo a nombrarlos a todos, pero quiero dar las gracias a cada uno de ellos y ellas desde mi corazón.

Por último, dedico esta tesis a la memoria de las abuelas.

Miki Yokoigawa.

Enero 2012. Valencia, España. 


\section{ÍNDICE:}

Resumen (en castellano, valenciano, inglés) 9.

INTRODUCCIÓN 15.

Primera parte:

La autobiografía de la mujer en distintos contextos culturales.

I. ¿Puede hablar la mujer con la historia del "otro"? según Shoshana Felman. Una aproximación a la teoría de la autobiografía de la mujer. 35.

I.1. La autobiografía de la mujer como testimonio. 43.

I.1.1. Nosotras en el discurso feminista.

I.1.2. La vida de la mujer con trauma.

I.2. La resistencia femenina como posible auto expresión. 65.

I.2.1. Freud y las mujeres histéricas.

I.2.2. El relato de la otra mujer, entre la fisura y la articulación.

II. ¿Puede hablar la mujer subalterna? según Gayatri C. Spivak.

Una reflexión sobre el estado mudo de las mujeres en la Historia. 89.

II.1. Occidente como Sujeto. El límite y la violencia epistémica europea. 99. II.1.1. La voz del "otro" en nosotros.

II.1.2. La protección de la «mujer del Tercer Mundo».

II.1.3. El sujeto subalterno doblemente mudo.

II.2. La paradoja de la libre elección de la mujer. 121.

II.2.1. Contranarrativa de la mujer.

II.2.2. Una aporía de contrafrases y el différend.

II.2.3. La reproducción del subalterno sexuado.

II.2.4. El subalterno sexuado en capas narrativas ideológicas.

II.2.5. Una posibilidad de hablar el subalterno en el acto "performativo". 
III. ¿Puede hablar la historia con el "otro"? según Drucilla Cornell.

Una consideración sobre la posible comunidad que supone el "otro".

147.

III.1. El silencio de las mujeres en La Historia.

151.

III.1.1. "Relato" de Rigoberta Menchú; contradicción de la autobiografía con secreto.

III.1.2. El acto performativo para buscar el pathos perdido.

III.2. La dignidad y la comunidad posible para el arte del testimonio. 169.

II.2.1. Testificar la muerte de la mujer con dignidad: una biografía de mujeres entre generaciones, como posible autobiografía de la mujer.

Segunda parte:

El arte como testigo: la representación entre realidad, ficción y subjetividad en el documental.

IV. El documental audiovisual sobre el testimonio de la memoria traumática. 195.

IV.1. La relación entre el arte y la política: el arte después de Auschwitz. 201.

IV.1.1. Arte y testimonio contra el asesinato de la memoria.

IV.1.2. Testificar lo imposible en las diferencias: rupturas e inconexiones.

IV.1.3. La cuestión de la traducción: el silencio y la aparición de la voz.

IV.2. Viaje entre el exterior y el interior como un trayecto autobiográfico. 223.

IV.2.1. Un viajero como testigo.

IV.2.2. El límite ético de la representación.

IV.2.3. El arte del testimonio y el poder del audiovisual.

IV.2.3.1. El silencio del testigo en la expresión audiovisual.

IV.2.3.2. La representación del encuentro fallido.

IV.2.4. Hablar en primera persona: el principio de la obra de arte como testimonio. 
V. El camino para llegar a hablar en primera persona en el documental japonés: cuestiones de subjetividad, ficción y realidad.

\section{V.1. El movimiento documental como proceso paralelo de occidentalización}

del país.

V.1.1. El inicio de la imagen en movimiento y su forma de presentación.

V.1.2. La contradicción en el desarrollo del documental como propaganda.

V.1.3. El nuevo documental de la posguerra: observación de la intervención dinámica.

V.2. La subjetividad en el documental de los años sesenta y setenta.

V.2.1. El autor como sujeto en el documental y la nueva ola japonesa.

V.2.2. La renovación radical: Cinéma-vérité y Direct Cinema.

V.2.3. El documental en la colectividad.

V.2.4. Encuentro con el "otro" interior, para enfrentarse al "otro" exterior.

\section{V.3. El flujo entre ficción y realidad en:}

Private Documentary y Self-documentary.

V.3.1. El relato de la mujer en la transición del tema y del soporte.

V.3.2. Los límites en el documental: ética social, ficción y privacidad.

V.3.3. El video digital en los años noventa.

V.3.3.1. Private Documentary con el tema familiar y la Digital Handy-Cam.

V.3.3.2. Self Documentary con temas sociales.

V.3.3.3 La auto-búsqueda en el Private Documentary. 


\section{V.4 La voz de las mujeres en el documental. Articulación entre}

lo público y lo privado.

V.4.1. El testimonio de la memoria traumática,

por autoras norteamericana-japonesas.

V.4.1.1. La contradicción de la identidad y la imagen

del inmigrante ejemplar en el cine.

V.4.1.2. La identidad, la memoria y la historia, desde el campo de concentración.

V.4.2. La historia y la memoria de los migrantes contados por la mujer.

V.4.2.1. Las mujeres documentalistas que escuchan los murmullos del "otro".

Tercera parte:

Autobiografía de la mujer en tránsito en la expresión audiovisual contemporánea.

VI. La autobiografía de la mujer en tránsito

en el campo de las artes audiovisuales. 435.

VI.1. Measures of Distance (1988), Mona Hatoum:

la representación de las discrepancias entre los sentimientos de una madre y su hija.

VI.1.1. La expresión audiovisual de la autobiografía de la mujer.

VI.1.2. Mi querida Mona. Cartas de la madre.

VI.1.3. La traducción en la dinámica de los códigos culturales: occidental, y no occidental.

VI.1.4. La relación entre madre e hija bajo la sombra del padre.

VI.1.4.1. La distancia entre la nostalgia y la realidad.

VI.1.4.2. My dear Mona, etcetera, etcetera.

La distancia desde el sentido del humor. 


\section{VI.2. Surname Viet Given Name Nam (1989), Trinh T. Minh-ha:}

un documental entre ficción y realidad sobre entrevistas a mujeres.

VI.2.1. Entre la representación interactiva y reflexiva de Trinh T. Minh-ha.

VI.2.2. Los relatos multivocales y su relación jerárquica.

VI.2.2.1. Entre los soliloquios de mujeres representadas por otras mujeres.

VI.2.2.2. El espacio crítico donde se entrecruzan las voces múltiples y el silencio como fenómeno heterogéneo.

VI.2.3. La obra autobiográfica de la mujer anónima en relación a la artista.

\section{VI.3. Night Cries: A Rural Tragedy (1989), Tracey Moffatt:}

un cortometraje de la mujer sin palabras y la llegada de la canción. 509.

VI.3.1. La canción como fe de comunicación.

VI.3.2. Entre el silencio y el estado mudo, con mucho ruido.

VI.3.3. Una parodia trágica como testimonio de lo indecible.

\section{VI.4. May You Live in Interesting Times (1997), Fiona Tan: el documental} como un viaje de búsqueda de la propia identidad.

VI.4.1. May You Live in Interesting Times (願你生活 多姿多采 )

VI.4.2. Whilst Drinking the Water Remember to Thank the Well (飲水思源)

VI.4.3. Sleeping in the Same Bed Dreaming Different Dreams ( 同床異夢 )

VI.4.4. Yellow Jews ( 黄種猶太人 )

VI.4.5. Disaster Comes From the Mouth (禍从口出 )

VI.4.6. Bringing in New Blood (新陳代謝)

VI.4.7. Know Yourself, Know Your Opponent, 100 Battles, 100 Victories ( 知已知彼 百勝百彼)

VI.4.8. A Nation of Siblings ( 同宗同体 ) 


\section{VI.5. A Needle Woman (1999-2001 y 2005), Kimsooja:}

una representación del performance de una mujer muda en tránsito.

VI.5.1. La representación audiovisual de la performance.

VI.5.2. "Tanta gente y ninguna comunicación":

una performance en medio de la multitud.

VI.5.3. La proyección multicanal: instalación e interacción.

VI.5.4. Un desacuerdo con la unificación armónica del mundo.

VI.6. Veuves de Noirmoutier (2004-2005), Agnès Varda:

otra dimensión de la mujer en tránsito.

VI.6.1. La autorepresentación de la mujer contada por otras mujeres; entrevistas y performance.

VI.7. En memoria de Harue: vida y muerte de una inmigrante japonesa en México, 1929- 1949 (2006-2009), Miki Yokoigawa:

biografía y autobiografía de la mujer en tránsito.

VI.7.1. El viaje en la busca de una imagen olvidada.

VI.7.2. La evocación y los relatos fragmentados en torno a las fotografías.

VI.7.3. El álbum de la abuela y cerrar las cajas de la memoria.

VI.7.4. Entre relatos de memoria y olvido. 


\section{RESUMEN}

La presente tesis doctoral analiza la autoexpresión audiovisual de la mujer en tránsito en el ámbito artístico. La investigación tiene un carácter interdisciplinar, ya que el análisis se realiza a través de las teorías feministas, la literatura comparativa, la teoría poscolonial, el psicoanálisis, la filosofía estética, la historia y, por último, el estudio del cine y de las artes visuales.

En el análisis se destacan las problemáticas de la representación que encontramos al contrastar realidad con ficción y subjetividad en la expresión audiovisual. Nos basamos en el estudio de diversos documentales para poder observar con posterioridad la transición de los temas y la construcción de los lenguajes. También reflexionamos sobre el sentido del arte como testigo de nuestra época según los argumentos de Walter Benjamin, Philippe Lacoue-Labarthe y Jean-Luc Nancy, quienes realizan una crítica a la estetización de la política como punto de partida. Asimismo, se desarrolla un discurso sobre la subjetividad en el documental fundamentado en las reflexiones de Gilles Deleuze, Bill Nichols y Michael Renov. Por otra parte, se verifica la trayectoria e historia del documental japonés apoyándonos en las referencias de Tadao Sato, Makoto Sato y Tetsuya Mori.

Nuestro objetivo al analizar las obras audiovisuales seleccionadas es profundizar en el discurso de la autobiografía de la mujer según contextos y características distintos. Para ello seguimos las reflexiones feministas de Shoshana Felman, Gayatri C. Spivak y Drucilla Cornell, quienes nos conducen -a través de la crítica de las teorías de Sigmund Freud, Jaques Derrida e Immanuel Kant, respectivamente- a la búsqueda de diversas expresiones audiovisuales de artistas contemporáneas que trabajan la autobiografía de la mujer en tránsito desde varias perspectivas y experiencias vitales.

En el ámbito artístico cada vez son más visibles los trabajos sobre migraciones y otros movimientos sociales que cuestionan la identidad cultural, familiar e individual basándose en la reflexión sobre el multiculturalismo y el poscolonialismo. Es obvio que en nuestra sociedad contemporánea existe un enorme y veloz tránsito. Resulta, entonces, inevitable 
enfrentarse a ello y analizar estos nuevos encuentros que ocurren, cuyo fruto es una confusa mezcla entre identidad y diferencia. Así pues, todas nuestras artistas buscan la autoexpresión y cuestionan su identidad: una, como artista viajera; otra, como hija de emigrantes, etc. Las artistas exiliadas, nómadas, como Mona Hatoum, Trinh T. Minh-Ha, Shirin Neshat, Kimsooja, Fiona Tan y otras más, abordan el tema de la identidad cuando traspasan las fronteras e irremediablemente se ven enfrentadas a una cultura diferente de la propia. 


\section{RESUM}

La present tesi doctoral analitza l'autoexpressió audiovisual de la dona en trànsit en l'àmbit artístic. La investigació té un caràcter interdisciplinari, ja que l'anàlisi es realitza a través de les teories feministes, la literatura comparativa, la teoria postcolonial, la psicoanàlisi, la filosofia estètica, la història i, finalment, l'estudi del cinema i de les arts visuals.

En l'anàlisi es destaquen les problemàtiques de la representació que trobem contrastant realitat amb ficció i subjectivitat en l'expressió audiovisual. Ens basem en l'estudi de diversos documentals per poder observar amb posterioritat la transició dels temes i la construcció dels llenguatges. També reflexionem sobre el sentit de l'art com a testimoni de la nostra època segons els arguments de Walter Benjamin, Philippe Lacoue-Labarthe i JeanLuc Nancy, els qui realitzen una crítica a l'estetizació de la política com a punt de partida. Així mateix, es desenvolupa un discurs sobre la subjectivitat en el documental fonamentat en les reflexions de Gilles Deleuze, Bill Nichols i Michael Renov. D'altra banda, es verifica la trajectòria i història del documental japonès recolzant-nos en les referències de Tadao Sato, Makoto Sato i Tetsuya Mori.

El nostre objectiu en analitzar les obres audiovisuals seleccionades és aprofundir en el discurs de l'autobiografia de la dona segons contextos i característiques diferents. Per a això seguim les reflexions feministes de Shoshana Felman, Gayatri C. Spivak i Drucilla Cornell, que ens condueixen -a través de la crítica de les teories de Sigmund Freud, Jaques Derrida e Immanuel Kant, respectivament- a la cerca de diverses expressions audiovisuals d'artistes contemporànies que treballen l'autobiografia de la dona en trànsit des de diverses perspectives i experiències vitals.

En l'àmbit artístic són cada vegada més visibles els treballs sobre migracions i altres moviments socials que qüestionen la identitat cultural, familiar i individual i es basen en la reflexió sobre el multiculturalisme i el postcolonialisme. És obvi que en la nostra societat contemporània hi ha un trànsit enorme i veloç. Resulta, aleshores, inevitable enfrontar-se a això i analitzar aquestes noves trobades que ocorren, el fruit de les quals és una barreja 
confusa entre identitat i diferència. Així doncs, totes nostres artistes busquen l'autoexpressió i qüestionen la seva identitat: una, com a artista viatgera; una altra, com a filla d'emigrants, etc. Les artistes exiliades, nòmades, com Mona Hatoum, Trinh T. MinhHa, Shirin Neshat, Kimsooja, Fiona Tan i d'altres més, aborden el tema de la identitat quan traspassen les fronteres i irremeiablement es veuen enfrontades a una cultura diferent de la pròpia. 


\section{SUMMARY}

In the present doctoral thesis the audiovisual self-expression of women who find themselves in physical "transit" is analyzed from an artistic perspective. This research has an interdisciplinary character, since the analysis is carried out across feminist theories, comparative literature, post-colonial theory, psychoanalysis, aesthetic philosophy, history and, finally, the study of cinema and of the visual arts.

The problem of the representation that we encounter on having reality contrasted with fiction and subjectivity in audiovisual expression is outlined in the analysis, which is based on the study of several documentaries that enable us to later observe the transition of the topics and the construction of the languages. Furthermore, we think about the meaning of art as a witness of our era, according to the arguments of Walter Benjamin, Philippe Lacoue-Labarthe and Jean-Luc Nancy, who do a critique of the aesthetics of politics as a point of departure. Likewise, our speech focuses on the subjectivity in the documentary following the reflections of Gilles Deleuze, Bill Nichols and Michael Renov. On the other hand, the path and the history of the Japanese documentary are verified after studying the references of Tadao Sato, Makoto Sato y Tetsuya Mori.

Our aim when analyzing the selected audiovisual works is to penetrate into the speech of the woman's autobiography according to different contexts and characteristics. For that purpose, we follow the feminist reflections of Shoshana Felman, Gayatri C. Spivak and Drucilla Cornell, who led us -through their reviews of the theories of Sigmund Freud, Jaques Derrida and Immanuel Kant, respectively- to the search of diverse audiovisual expressions of contemporary artists who are active within the autobiography of the women in traffic from diverse perspectives and vital experiences.

In the artistic area, the works on migrations and other social movements are every time more visible. They question the cultural, family and individual identity based on reflections on multiculturalism and post-colonialism theories. It is obvious that in our contemporary society there is an enormous and fast circulation. It seems inevitable, then, to face this 
reality and to analyze the new encounters which are happening and whose consequence is a confused mixture between identity and difference. In that sense, all our artists look for their self-expression and question their identity: one, as a travelling artist; another, as the daughter of emigrants, etc. Our exiled, nomadic artists (Mona Hatoum, Trinh T. Minh-Ha, Shirin Neshat, Kimsooja, Fiona Tan and others) irreparably approach the topic of the identity when they penetrate a culture that is different from the own one. 
INTRODUCCIÓN 
Podríamos calificar al siglo XX de varias maneras: el siglo de las guerras, del choque ideológico, de la tecnología, de la liberación de los países africanos, de la mujer y también como el siglo de la migración. En algunos estudios específicos ya se ha enfocado la cuestión de la migración desde la década de los setenta como un movimiento paralelo a otros movimientos, como el estudiantil, el de los derechos civiles o el feminismo.

El capitalismo envuelve al mundo, y aunque uno nunca se mueva de su sitio, o se sitúe siempre cerca de él, casi inevitablemente habrá ciertos movimientos, éxodos y traslados. La gente, la mercancía y la información circulan traspasando las fronteras de cualquier país en un transporte mundial que además ha aumentado su velocidad tras la caída del muro de Berlín como símbolo del fin del régimen totalitarista comunista. Actualmente, nadie puede encontrarse al margen de este estado de tránsito en nuestra sociedad global, y cada vez será más notable. Podríamos decir que el tránsito es uno de los más importantes asuntos de nuestra sociedad contemporánea y nómada.

En el campo artístico, cada vez se hacen más visibles los trabajos sobre el movimiento social y las migraciones. Las obras cuestionan la identidad cultural, familiar y personal, basándose en reflexiones sobre el multiculturalismo y el poscolonialismo. En la sociedad contemporánea se percibe una enorme movilidad y un veloz tránsito. Resulta, pues, inevitable afrontar los nuevos encuentros que tienen lugar dentro de una confusa mezcla entre identidad y diferencia.

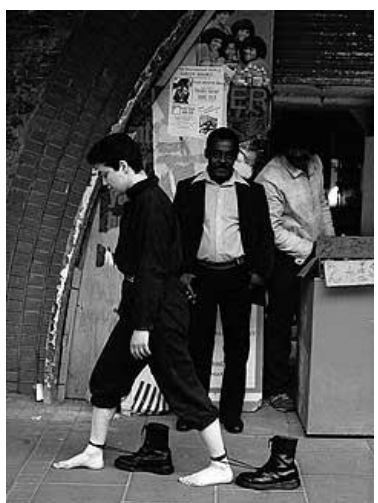

1. Roadworks (1985), Mona Hatoum

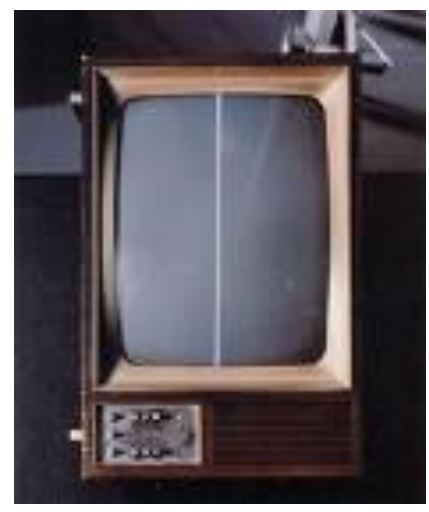

2. Zen TV (1965), Nam June Paik 
Las autoras de las obras - unas como artistas nómadas, otras como hijas de inmigrantesexpresan y cuestionan su identidad. Artistas exiliadas y nómadas como Mona Hatoun, Trinh T. Minh-Ha, Shirin Neshat, Fiona Tan, Kimsooja y otras más, abordan el tema de la identidad cuando traspasan las fronteras y se enfrentan a otra cultura. Si ampliamos nuestra búsqueda, también Nam June Paik, Jonas Mekas o Krzysztof Wodiczko fueron artistas inmigrantes exiliados. En un término más amplio, incluso Picasso, Kandinsky o Chagall serían uno de ellos. En este sentido, unos y otros se aproximan a la cuestión sin desplazarse del lugar donde han nacido. Como ejemplo, la artista australiana Tracey Moffatt ${ }^{1}$ presenta sus trabajos cuestionando la identidad y su conflicto.

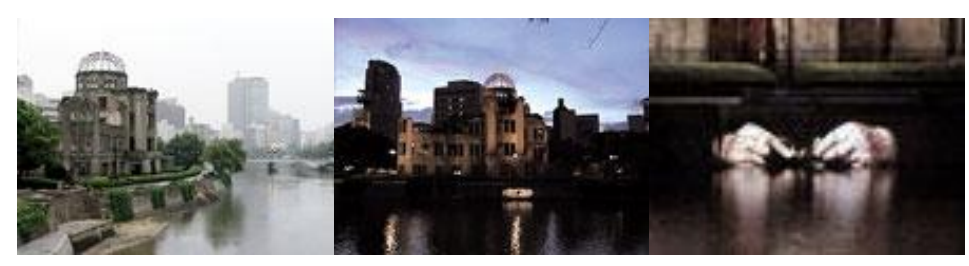

3. Proyecciones Públicas: A-Bomb Dome, Hiroshima (1999), Krzysztof Wodiczko

En este contexto, consideramos que cada vez es más necesario analizar y reflexionar sobre la representación de uno/a misma y reconocer de qué manera es posible la autoexpresión. Inmediatamente, nos surge una pregunta: ¿cómo se puede hablar sobre uno mismo? Es precisamente la cuestión que nos preocupa a lo largo de nuestras reflexiones en esta investigación. La autorepresentación del autor en la expresión artística tiene, de hecho, una amplia variedad. Encontramos diversos estudios sobre las obras seleccionadas en cada disciplina. Y es que la autobiografía sigue siendo un tema interesante en el campo de la literatura, del mismo modo que el autorretrato lo es en las artes visuales. En el ámbito artístico, la autorepresentación siempre ha tenido un valor importante, sobre todo en el arte moderno. En la investigación, nos interesa pensarlo en el contexto contemporáneo. En concreto, analizaremos la autobiografía en la representación audiovisual de las mujeres artistas que expresan su conciencia del tránsito y las consecuencias de éste.

\footnotetext{
${ }^{1}$ Descendiente de aborígenes australianos, Tracey Moffatt es adoptada por una familia de raza blanca, a través de la cual entra en contacto con una cultura de la imagen marcada por el uso de las nuevas tecnologías. MUSAC http://musac.es/index.php?obr=190, accedido el 15 de junio 2009.
} 
Consideramos que el análisis y la interpretación que planteamos del arte contemporáneo serían más comprensibles mediante un estudio transdisciplinar. La división de las disciplinas no es absoluta, ni en las prácticas ni en los estudios teóricos, aunque no ponemos en duda que existen muchos trabajos excelentes realizados dentro de cada campo específico. Nuestro paso por el estudio transdisciplinar es muy modesto porque principalmente queremos aproximarnos a la autobiografía en las expresiones audiovisuales. Además, tenemos en cuenta que no somos los únicos, ya que en estos últimos años se encuentran bastantes investigaciones activas y aproximaciones a los temas de la biografía y autobiografía en la expresión de las artes visuales.

Por ejemplo, en EXIT BOOK (2009), publicado con el título El mito del artista. Biografía / Autobiografía ${ }^{2}$, encontramos diversas referencias interesantes que aluden a la gran variedad de obras de artistas existentes, desde la pintura clásica hasta las expresiones audiovisuales, además de una amplia bibliografía relacionada con el tema. En el mismo año, en 2009, encontramos un resultado extraordinario en el trabajo Autobiografías visuales. Del archivo al índice $e^{3}$ de Anna María Guasch. Según ella, su libro inició su andadura en el marco del programa de investigación «Biography» desarrollado en Getty Research Institute de Los Ángeles (California) en 2003. En él señala el gran interés sobre este tema en el ámbito académico, el cual tiene como resultado su publicación. Gracias a su brillante trabajo, en el que plantea una nueva y mucho más dinámica visión sobre el tema, nos descubre una profunda riqueza artística que dota de una nueva dimensión a la obra. El desarrollo de su argumentación sobre la autobiografía visual, basada en el análisis de obras específicas de On Kawara, Mary Kelly, Hanne Darboven, Jean-Luc Godard, Sol LeWitt y Cindy Sherman, nos abre una posible nueva lectura cuando Guasch califica a los artistas mencionados como:

... artistas que «problematizan» y desafían algunas de las constantes tradiciones de la autobiografía unidas al yo romántico como el sujeto único y trascendente o la narración continua, secuencial o consecutiva y el culto al ego a partir del recurso al archivo, la relación entre el registro y el recuerdo, el diálogo entre lugar y memoria

\footnotetext{
${ }^{2}$ VV.AA. Exit Book n ${ }^{\circ}$ 11, Madrid: Olivares y Asociados, 2009.

${ }^{3}$ Guasch, Anna María, Autobiografías visuales. Del archivo al índice. Madrid: Ediciones Siruela, 2009, p.11.
} 
(lo privado, lo arcaico) y el concepto de índice y en todos los casos desde una «desfiguración» del yo autobiográfico, tal como sugiere Paul de Man. ${ }^{4}$

Paul de Man, en su artículo La autobiografía como des-figuración (1984), señala una aporía en la autobiografía, difícil de categorizar debido a una serie de contradicciones en las aproximaciones académicas:

La autobiografía entonces, no es ni un género ni un modo, sino es una figura de la lectura o de la comprensión que tiene lugar, en algún grado, en todos los textos. El momento autobiográfico ocurre como un alineamiento entre los dos sujetos involucrados en el proceso de la lectura en el que se determina uno al otro mediante una mutua sustitución reflexiva. La estructura implica tanto diferenciación como similaridad, pues ambas dependen de un intercambio sustitutivo que constituye al sujeto. ${ }^{5}$

Concluye indicando el sentido de la muerte dentro de la expresión linguiística y su interpretación en la autobiografía de la siguiente manera:

Tan pronto como comprendamos que la función retórica de la prosopopeya postula voz o rostro mediante el lenguaje, comprenderemos que aquello de lo que se nos priva no es la vida sino la forma y el sentido de un mundo accesible únicamente en la manera privativa de la comprensión. La muerte es el nombre desplazado de una aporía lingüística, y la restauración de la mortalidad mediante autobiografía (la prosopopeya de la voz y el nombre) priva y desfigura en la medida exacta en que restaura. La autobiografía vale una desfiguración de la mente de la que ella misma es la causa. ${ }^{6}$

\footnotetext{
${ }^{4}$ Ibíd., pp.19-20.

${ }^{5}$ De Man, Paul, La autobiografía como des-figuración en La retórica del romanticismo, trad. Julián Jiménez Heffernan, Madrid: Akal, 2007, p. 149.

${ }^{6}$ Ibíd., pp. 157-158.
} 
En la presente investigación nos permitimos analizar, estudiar y desarrollar nuestra propia interpretación sobre ciertas obras audiovisuales acerca de la mujer en tránsito. Concretamente, hemos seleccionado siete obras de mujeres artistas: Measures of Distance (1988) de Mona Hatoum, Surname Viet Given Name Nam (1989) de Trinh T. Minh-Ha, Night Cries: A Rural Tragedy (1989) de Tracey Moffatt, May You Live in Interesting Times (1997) de Fiona Tan, A Needle Woman (1999-2001, 2005) de Kimsooja, Les Veuves de Noirmoutire (2004-2005) de Agnès Varda y En memoria de Harue: vida y muerte de una inmigrante japonesa en México, 1929- 1949 (2006-2009) de Miki Yokoigawa, la doctoranda de presente trabajo. A pesar de que estas artistas son muy distintas de los que seleccionó Guasch en su libro, sí comparten la conciencia de la expresión en todos los casos desde una «des-figuración» del yo autobiográfico.

Por otro lado, consideramos que la teoría feminista es adecuada como punto de partida para nuestro desarrollo de la investigación debido principalmente a que hemos elegido estas obras de mujeres artistas. Somos muy conscientes de que la autoexpresión artística que aborda cuestiones de identidad no surge sólo en los trabajos de artistas "extranjeras". Sin embargo, en el caso de la expresión autorreferencial de las artistas en situaciones de nomadismo y/o exilio, además de cuestionarse el tema de la mujer, se evidencian, aún más, las contradicciones del yo romántico como el sujeto único y trascendente. En otras palabras, consideramos que a través de las cuestiones de la identidad femenina en un estado de tránsito, inevitablemente, se accede a la crítica hacia un modelo universal como producto de la modernidad occidental. Ana Martínez-Collado indica el carácter de la teoría feminista en relación con el arte de una manera muy clara:

La reflexión estética en torno a la relación arte y feminismo se enmarca en el desarrollo de una teoría crítica. Una teoría que se ve obligada a darse en un mundo que sabe de su fragmentariedad, de la imposibilidad de elaborar una visión global y absolutamente verdadera, y en la que se acepta la escisión del sujeto, su carácter inconcluible, la imposibilidad de construirle según un modelo universal y acabado. ... La relación entre arte y feminismo se inscribe entonces en una problemática que 
se puede interpretar como una vuelta de tuerca más a la contradicción y la situación paradójica en la que se conjugan las experiencias de lo moderno. ${ }^{7}$

El desarrollo de nuestra investigación está basado en un trabajo de carácter teórico-práctico que nos ha posibilitado ampliar nuestro conocimiento sobre el arte con los nuevos medios y la experiencia práctica. La última obra analizada en esta investigación de la doctoranda es fruto del trabajo de investigación que se presentó en el año 2009 para la obtención del Diploma de Estudios Avanzados de la Universidad Politécnica de Valencia y fue un punto de partida para la presente tesis.

\section{Motivación personal:}

Los estudios de doctorado me inspiraron para realizar un trabajo audiovisual con un medio adecuado para abordar el tema de la autorepresentación femenina en relación con la memoria y con la identidad de la mujer en tránsito. Y, ¿por qué la mujer en tránsito? Hay dos razones principales: una es porque, desde el año 1996, mi propia experiencia de traslados y posterior readaptación en distintos contextos culturales me obliga a cuestionar mi propia identidad: ¿quién soy? ¿De dónde vengo? ¿A qué cultura pertenezco? Además, resulta interesante el tema de la identidad y de la autoexpresión de la mujer. Después del estudio de la licenciatura de Artes Visuales en la Universidad de Arte de Osaka en Japón, realicé una estancia en México para el estudio de maestría desde el año 1996 al 2001. Al mismo tiempo, comencé a presentar unos trabajos de instalación con el tema de la mujer por medio de diversos materiales. Tras presentar la tesis de maestría ${ }^{8}$ con el tema de la autoexpresión de las artistas femeninas contemporáneas, basado en un estudio sobre la representación del cuerpo femenino desnudo en la historia del arte, realicé una estancia en Francia y regresé a mi país natal.

\footnotetext{
${ }^{7}$ Martínez-Collado, Ana, Tendenci@s. Perspectivas feministas en el arte actual(segunda edici), Murcia, Cendeac, 2008, pp. 34-25.

${ }^{8}$ Yokoigawa, Miki, Idealidad y realidad en la representación del cuerpo femenino: algunos casos de arte contemporáneo. México D.F. Tesis para obtener el grado de Maestría en Artes Visuales, orientación Escultura. Director de tesis: Mtro. Francisco Moyao. División de estudios de posgrado, Antigua Academia San Carlos de Escuela Nacional de Artes Plásticas de la Universidad Nacional Autónoma de México, 2001.
} 
Las cuestiones sobre la identidad personal me han interesado desde siempre, ya cuando residía en mi país natal, sin conocer otros lugares, y más aun durante mi trayectoria de traslados de un país a otro (cuando se me obliga, al atravesar las distintas fronteras, a cuestionar mi identidad por una incómoda situación frente a la imagen de "japonesa", reflejo de un estereotipo y de un extraño exotismo cultural). Y también el regreso a "mi país" me produjo un choque cultural causado por la experiencia de haber vivido fuera. Siendo franca, me he llegado a sentir como una extranjera en mi propio país. Precisamente, mi breve adaptación a un código cultural distinto -como el de México o Francia- me hizo problematizar el código cultural de "mi propio país". En otras palabras, la ausencia fuera de Japón me posibilitó conocer un distanciamiento y una discrepancia con "la cultura de mi propio país", desmoronando mi seguridad de pertenencia a "la cultura japonesa". La segunda larga estancia fuera de Japón es en la actualidad, en España, y la misma sensación incómoda tiene lugar como consecuencia de mi identidad como "japonesa" y "extranjera asiática”. Es más, esta vez no se debe solo al malestar con un estereotipo equivocado, sino que ya no tengo la misma confianza de pertenecer a la cultura japonesa aunque no tenga ninguna otra opción. Ello me motivó a reflexionar sobre las cuestiones de la identidad femenina en tránsito como una cuestión global a la vez que personal.

Quizás ello provenga también de un contexto diferenciador o excluyente de mi imagen como "inmigrante-extranjera” en España. Cada vez más, me sorprenden los estereotipos de la "inmigrante-extranjera" como "el otro", así como la manera de presentar esa imagen por los medios de comunicación. En España, a pesar de su historia como país emigrante en un pasado no muy lejano, se hace difícil comprender las razones para la construcción de ese tipo de imágenes negativas y el fuerte rechazo contra los inmigrantes. Puede que exista una gran amnesia sobre la propia historia y un olvido que luego se convierte en ignorancia. Pero éste no es solo el caso español.

Esta cuestión se refleja en mi propio país. Inmediatamente, me resultó extraño reconocer que soy una de las personas que lo ignoraban: la migración japonesa forma una parte esencial de la historia del país nipón. A pesar de tener ocasiones de conocer a la colonia japonesa que forman los inmigrantes japoneses y sus familiares en México, nunca me había 
surgido la oportunidad de estudiar ni investigar sobre ello. Una crítica hacia los demás siempre acaba reflejándose en nosotros mismos. Por ello, antes de seguir cuestionando a España, me siento obligada a aclarar qué ocurre en mi país.

Inevitablemente, todos nos enfrentamos con la diferencia y tenemos que sobrevivir con esta situación de variabilidad. No pretendemos juzgar nuestra situación en el mundo actual dilucidando si es malo o bueno; sin embargo, por lo menos, tenemos que ser conscientes de la necesidad de convivir con las diferencias.

A menudo ignoramos la diferencia o la posibilidad de comunicarnos debido a esa diferencia. Es cierto que existe la diferencia, y que existen rupturas como consecuencia. En muchas ocasiones, esa diferencia provoca crisis y conflictos tanto a nivel personal, como social. Existen muchos ejemplos graves y horrorosos a lo largo de nuestra historia, como el sacrificio de las ovejas negras o la quema de brujas. Éstos son solo ejemplos de la época medieval. Pero incluso en el siglo pasado vimos la serie más nefasta de consecuencias del rechazo a la diferencia, como el exterminio de "los judíos"9 en campos de concentración. Con el fin de reflexionar sobre la historia de nuestro rechazo al otro ser diferente y hallar la repetición del conflicto a lo largo de la historia, no hace falta esperar a T. L.W. Adorno para llegar casi a la desesperación por su escepticismo al considerar si el arte puede existir en nuestro tiempo.

A pesar de esto, y paradójicamente por ello, insistiremos en la posibilidad y la necesidad de buscar una articulación en ese punto de ruptura entre las diferencias. Estamos seguros de que existen ciertas expresiones artísticas que comparten esa conciencia. La posible articulación que esperamos crear nosotros entre las diferencias no es una fácil unificación armónica que ignora las diferencias. Es decir, las obras que pretenden evocar la posible

\footnotetext{
${ }^{9}$ El sentido de "los judíos" queremos considerarlo, por esta razón desarrollamos los detalles en el capítulo IV. Pero ahora citaremos una frase de Jean-Lu Nancy sobre la palabra (para él, es un soplo, ni si quiera es una palabra): Un soplo judio, pero en el que se sopla al «judio» mismo: el judío es un gitano, un pederasta, un preso, un eslavo, un comunista; el judio es la canalla, un musulmán, un Mensch, no importa quién. [Nancy, Jean-Luc, La representación prohibida. Seguido del Shoah, un soplo, trad. Margarita Martínez, Buenos Aires y Madrid, Amorrortu, 2006, pp. 73-74.]
} 
articulación entre las diferencias deberían visibilizar las rupturas, por lo menos visualizar las discrepancias con la imagen unificada que aplasta las diferencias.

En este sentido, exploramos las expresiones de los trabajos artísticos que comparten nuestra conciencia, evocan una articulación entre generaciones, culturas, idiomas, ideologías, políticas, clases sociales y géneros, visualizando sus diferencias mediante la autobiografía de la mujer, la cual es anónima y se encuentra olvidada y escondida entre las diferencias, generaciones, culturas, idiomas, ideologías, políticas, clases sociales y géneros. Visibilizaremos la presencia y la voz de la mujer; al mismo tiempo, su ausencia, indicando de qué manera la mujer anónima se queda muda, más allá de la memoria, en la fisura de las diferencias, cuestionando la tolerancia del silencio en las expresiones artísticas.

Para el estudio y la reflexión sobre la expresión audiovisual, como la parte que contextualiza las expresiones de las artistas a las que nos aproximaremos posteriormente, hemos tomado ejemplos de documental y no del cine experimental, ni del audiovisual. Conocer la evolución del lenguaje audiovisual resulta dispensable en esta investigación; en cambio, es importante -además de los discursos artísticos y el desarrollo de sus dispositivos- contextualizarlos en su relación política, económica, social y cultural. Consideramos que el estudio de la transición del documental facilita el reconocimiento de la confusa relación entre tema, contexto social y evolución de los dispositivos de una manera esquemática.

Estudiaremos el caso del documental en Japón. La razón de elegirlo así, además de los motivos personales, no es únicamente la facilidad de la doctoranda para acceder a la información de su país de origen, por su lengua y sus conocimientos de la historia, cultura y política, sino porque el documental japonés muestra una trayectoria del desarrollo documental teórico y práctico basado en la evolución dispositiva con la fusión de los conceptos y las técnicas occidentales. Es decir, en el caso del cine y sobre todo del documental, los movimientos tanto teóricos como prácticos se introducen casi simultáneamente en el país y encuentran su influencia en un desarrollo paralelo al movimiento internacional. Estudiar el documental japonés sería, de esta manera, repasar 
esquemáticamente la evolución internacional sobre el documental y resumir su forma de adaptación en un país no occidental.

Sobre todo, la evolución del vídeo dentro de la expresión documental Private Documentary (documental privado) y Self Documentary (documental sobre sí mismo) nos ofrece un esquema retrospectivo, el cual, a su vez, facilita nuestra aproximación a la relación audiovisual entre expresión y dispositivo, sujeto y objeto, arte y política, ficción y realidad.

La hipótesis que planteamos es que en el ámbito creativo, vinculado con los estudios de género, existe una vertiente en donde confluye la cuestión fundamental enarbolada por el feminismo: "lo personal es político", que ha sido un detonante en el mundo del arte para el planteamiento de asuntos personales cotidianos, con el fin de visibilizar las injustas políticas sociales que tenemos regladas en la sociedad que vivimos, y más específicamente con respecto a la mujer inmigrante. Hablar de la mujer por la mujer, tanto de manera autobiográfica como en forma de autorepresentación, es posible a través de la lectura y la expresión de la historia de otra mujer. Es lo que argumenta Shoshana Felman basándose en el análisis de obras literarias. Nosotros examinaremos su argumento y plantearemos que su posibilidad se puede enriquecer gracias a la expresión audiovisual. Y desde estos parámetros, observaremos que el documental que aborda la subjetividad ha sido un medio y un espacio creativo que ha permitido favorecer la concienciación social, permitiendo crear posicionamientos personales contra todas las formas de violencia y discriminación de cualquier clase con las que convivimos a nivel global. Por otro lado, respecto a los dispositivos técnicos y de edición, la estructura y modo de trabajar con la imagen y el audio en la presentación audiovisual nos va a permitir visibilizar la contradicción y el conflicto existente entre una situación real y su descripción imaginaria.

El objetivo general de nuestra tesis es desarrollar el discurso y profundizar en la reflexión sobre biografía y autobiografía de la mujer en tránsito en la expresión audiovisual contemporánea, analizando las obras seleccionadas para posibilitar una lectura alternativa y basándonos en estudios de la representación audiovisual de la realidad, en relación con la ficción y la subjetividad. 


\section{Objetivos específicos:}

1. Analizar y desarrollar el concepto de la autobiografía de la mujer desde las cuestiones del lenguaje, lo expresable y lo inexpresable de la mujer, aclarando las particularidades de los distintos contextos culturales y temporales.

2. Estudiar conceptos y definiciones de las palabras claves: autobiografía de la mujer, trauma, estetización de la política, poscolonialismo, ficción, lo sublime, deconstrucción, etc.

3. Analizar la posibilidad del arte audiovisual como testigo en relación con el arte contemporáneo después de "la estetización de la política".

4. Analizar en un breve recorrido histórico, basado en las referencias teóricas y prácticas sobre Private Documentary y Self Documentary, los movimientos documentales que abordan el tema de la subjetividad, junto con el estudio de la evolución de los dispositivos que surgieron en la época, para aclarar la relación mutua de la transición del tema y la técnica.

5. Reflexionar sobre la presencia y la voz de la mujer, su incorporación a las expresiones audiovisuales, principalmente en el documental, y contextualizar su expansión a partir de los años setenta.

6. Analizar las obras seleccionadas basadas en el desarrollo del discurso de biografía y autobiografía de la mujer en tránsito, e indicar los aspectos expresados en ellas. Al mismo tiempo, señalar las diversas expresiones artísticas de cada una de las obras y la conciencia que se comparte en ellas.

Con el compromiso de atender los planteamientos mencionados, nuestra investigación ha sido estructurada siguiendo una metodología empírica de análisis comparativo. Para ello hemos tenido que proceder de distinta manera en cada uno de los apartados y conocimientos estudiados y experienciados, como hemos argumentado anteriormente.

Para la selección de los trabajos audiovisuales de las artistas hemos indagado en abundante material próximo al tema de estudio; a saber, hemos buscado los eventos temporales como exposiciones, ciclos de videoarte o del film, talleres de artistas, conferencias, etc. Asimismo, 
hemos visitado instituciones públicas donde nos han permitido acceder a las obras, tales como museos, bibliotecas, mediatecas, videotecas o filmotecas. También hemos encontrado información a través de medios de comunicación alternativos on-line y DVD, y hemos solicitado a galerías o a las propias artistas los trabajos específicos para poder realizar el análisis.

El trabajo de Fiona Tan, gracias a su amable comprensión para con nuestro estudio, nos permitió acceder temporalmente a su obra a través de un sitio web on-line propio. Igualmente, con el fin de encontrar bibliografía específica sobre las artistas, hemos tenido que solicitar información a la organización para que nos facilite la posproducción de los eventos, catálogos y monografías de estudios u otros materiales como subtítulos del film. Por ejemplo, la Cineteca Nacional de México, que ha organizado un ciclo de Trinh T. Minh-Ha, ha mostrado una gran generosidad al facilitar el subtítulo de la traducción en español de la película que analizamos en nuestra investigación.

Para profundizar en la parte teórica, además de consultar libros de texto y publicaciones online, tuvimos la oportunidad de asistir a conferencias y seminarios de Gayatri C. Spivak en CENDEAC (Murcia, 2009) o de Jean-Luc Nancy en distintas instituciones de Valencia durante $2011^{10}$. La consulta bibliográfica ha sido realizada básicamente en tres lenguas: en español, ingles y japonés. No obstante, algunas veces los materiales estaban en francés, alemán y chino. Para las citas realizamos una traducción propia en el caso de no tener la publicación en versión española.

Las obras audiovisuales referenciadas en nuestra investigación son de múltiples idiomas. Además de las lenguas mencionadas, se incluyen: vietnamita, coreana, árabe, italiano, holandés, indonesio, polaco, israelí y ruso. Sin embargo, nos hemos tenido que limitar a mencionar solo los que hemos visto traducido o subtitulado en inglés, francés, japonés o español debido a las limitaciones lingüísticas de la doctoranda. Es decir, no hemos

\footnotetext{
${ }^{10}$ Las figuras madres, jornada en torno al pensamiento de Jean-Luc Nancy realizó con la asistencia del dicho filósofo en varios lugares en Valencia como Facultad de Bellas Artes de Universidad Politécnica de Valencia, Facultad de filosofía de Universidad de Valencia, Instituto Francés y Octubre Centro de Cultura Contemporánea, del 14 al 17 de noviembre del 2011.
} 
referenciado algunos trabajos en otros idiomas si no hemos conseguido acceder a su traducción subtitulada.

La presente tesis doctoral se desarrolla en tres partes. La primera de ellas, la autobiografía de la mujer en distintos contextos culturales, constituye el cuerpo teórico que aborda el tema y el concepto de la autobiografía de la mujer dentro del marco feminista. El discurso que realizamos en ésta, incluye las reflexiones de tres pensadoras que profundizan en sus textos acerca de la mujer desde perspectivas diferenciadas: Shoshana Felman, Gayatri C. Spivak y Drucilla Cornell. A través de sus miradas, también hemos destacado las teorías de Sigmund Freud, Jaques Lacan, Jaques Derrida, Luce Irigaray y Sara Kofman, Kant y Schiller. En los tres capítulos desarrollaremos un análisis de sus textos sobre las cuestiones de la autoexpresión femenina que conforman el corpus fundamental para nuestro desarrollo teórico y son la estructura base de nuestras aproximaciones a las obras audiovisuales.

En el primer capítulo reflexionamos sobre la posibilidad de la autobiografía de la mujer y precisamos el concepto según Shoshana Felman. Nos aproximamos al desarrollo teórico desde la pregunta ¿Puede hablar la mujer con la historia del “otro”?, basándonos en el análisis de su libro What does a woman want?, publicado en 1993. Esta parte nos servirá como un resumen de la trayectoria de la teoría feminista sobre el tema del sujeto mujer en el contexto de la sociedad occidental.

En el segundo capítulo investigaremos el estado de mudez en el que ha permanecido la mujer en la Historia a partir del texto. ¿Puede hablar el ser subalterno? En este caso, la teoría de Gayatri Chakravorty Spivak nos hace reflexionar sobre la posibilidad de habla de la mujer subalterna, en el caso de la mujer no occidental. Ello establece un punto de partida idóneo para especular en torno a la biografía y autobiografía de la mujer contemporánea poscolonial, cuestionando el problema del sujeto femenino no occidental.

En el tercer capítulo, clarificamos la relación del arte femenino como testimonio a partir de la pregunta sobre la posible incorporación de la mujer a la comunidad: ¿Puede hablar la historia con el "otro"? Cornell, en Between Women and Generations, argumenta que la 
relación entre madre e hija constituye la médula teórica y práctica del feminismo. Para ello, Cornell se basa en el análisis de la relación intergeneracional de las mujeres en su propio hogar: su madre, su abuela y la hija que ella ha adoptado en Paraguay. Dentro de su estudio, el testimonio de la mujer y el acto performativo de buscar la voz de la mujer como "otro" se convierten en temas importantes.

En la segunda parte, el arte como testigo: la representación entre realidad, ficción y subjetividad en el documental, iniciamos el análisis de los documentales. Precisamos las cuestiones de la representación artística en el audiovisual contemporáneo. Primero destacamos el tema basándonos en un análisis sobre un documental de Claude Lanzmann según Shoshana Felman. El discurso que realizamos en ésta, además de la argumentación de Shoshana Felman, incluye reflexiones sobre la estetización de la política: Walter Benjamin, Philippe Lacoue-Labarthe y Jean-Luc Nancy. Posteriormente, reflexionamos sobre la cuestión de la subjetividad en el documental, así como sobre la representación de la realidad. Para llegar a hablar en primera persona dentro del ámbito fílmico tomamos el caso del documental japonés. Para nuestro discurso citaremos reflexiones de Michael Renov, Gilles Deleuze y Bill Nichols, y para casos específicos del documental japonés, nos hemos basado en los argumentos de Tadao Sato, Makoto Sato y Tetsuya Mori.

En el cuarto capítulo, el documental sobre testimonios de la memoria traumática, nos aproximaremos a la teoría de Shoshana Felman, quien ilustra la capacidad del arte como testigo. Seguiremos su análisis de la película documental Shoah, realizada por Claude Lanzmann. Como hemos comentado, este capítulo comenzará con una reflexión sobre la relación entre el arte y la política basado en la crítica la estetización de la política, como punto de partida para poder especular sobre la posibilidad del arte audiovisual después de Auschwitz. Concretamente, veremos la posibilidad del arte para traspasar el límite imaginario que divide el mundo. Analizaremos el carácter peculiar de este documental, el cual registra una trayectoria hacia el viaje interior y exterior en Europa, del gueto y del campo de concentración, a través de una serie de entrevistas sobre la memoria del horror. También señalaremos el carácter autobiográfico de este documental que reflexiona sobre la relación entre el autor y su obra. 
En quinto capítulo, la subjetividad en el documental, el camino para llegar a hablar en primera persona, observamos la trayectoria de la subjetividad dentro del ámbito documental japonés. En la parte introductoria profundizaremos en el tema y en la relación entre realidad, ficción y subjetividad, para poder posicionarnos ante los cuatro apartados posteriores. En primer lugar, contextualizamos la historia de documental japonés desde la época del inicio del cine. Proporcionamos un acercamiento a los documentales japoneses relacionados con un enfoque propagandístico, y mencionamos algunos trabajos alrededor de la Segunda Guerra Mundial y hasta los años cincuenta.

En el segundo apartado del mismo capítulo, estudiamos los planteamientos sobre los documentales realizados en la generación de la postguerra en los años sesenta y setenta. Veremos las teorías y prácticas desde la cuestión de la subjetividad en el documental, así como las críticas contra los cineastas y sus trabajos en la vieja generación. Después, observamos los métodos del movimiento documental en los años setenta, concretamente el documental colectivo como modo peculiar de producción y distribución de las películas documentales de aquel momento en Japón. Mencionaremos la corriente Observation Documentary que surgió gracias al desarrollo técnico.

En el tercer apartado, repasaremos las películas independientes con la transformación de los soportes: desde la película de $8 \mathrm{~mm}$ al vídeo de $8 \mathrm{~mm}$, pasando por el vídeo digital en los años ochenta y noventa. Veremos el método Action Documentary de Kazuo Hara, el cual demuestra el estado de confusión de la división entre ficción y realidad/verdad. También observamos un cambio del tema en la aparición de las protagonistas femeninas dentro de las representaciones documentales en los años ochenta. De acuerdo con dicho cambio, estudiaremos algunos documentales de los años noventa difundidos gracias a la cámara digital de tamaño manual, la "Handy Cam", la cual facilita la realización simultánea de los dos métodos opuestos: Observation Documentary y Action Documentary.

El apartado final del quinto capítulo se basa en trabajos seleccionados de mujeres documentalistas. De acuerdo con lo que hemos confirmado sobre la transición documental, 
veremos de nuevo cómo la situación general en las prácticas fílmicas rechazaba a las mujeres. Aprovecharemos la ocasión para referirnos, aun brevemente, a las mujeres excepcionales que han trabajado en el documental. Luego introduciremos referencias a unos documentales de mujeres norteamericanas-japonesas sobre la memoria traumática familiar que cuestionan su identidad en las divisiones nacionales, y posteriormente a unos trabajos de mujeres que tratan de escuchar a los que quedan en el margen de la nación.

En la tercera parte, autobiografía de la mujer en tránsito en la expresión audiovisual contemporánea, realizamos aproximaciones a las obras audiovisuales seleccionadas. Como hemos dicho, vamos a analizar a las obras de siete mujeres artistas: Measures of Distance (1988) de Mona Hatoum, Surname Viet Given Name Nam (1989) de Trinh T. Minh-Ha, Night Cries: A Rural Tragedy (1989) de Tracey Moffatt, May You Live in Interesting Times (1997) de Fiona Tan, A Needle Woman (1999-2001, 2005) de Kimsooja, Les Veuves de Noirmoutire (2004-2005) de Agnès Varda y En memoria de Harue: vida y muerte de una inmigrante japonesa en México, 1929- 1949 (2006-2009) Miki Yokoigawa. Analizaremos cada una de las obras, enfocando hacia la dimensión biográfica y autobiográfica de la mujer en tránsito, de acuerdo con lo que hemos desarrollado en partes anteriores. Destacaremos ciertas características de cada una de las obras, comparando unas con otras, con el fin de aclarar la diversidad de las expresiones a la vez que se determina una conciencia compartida en todas ellas. 
Primera parte:

La autobiografía de la mujer en distintos contextos culturales. 
I. ¿Puede hablar la mujer con la historia del "otro"? según Shoshana Felman. Una aproximación a la teoría de la autobiografía de la mujer. 
Para conocer el tema de autobiografía y biografía en las expresiones de mujeres artistas, como corpus teórico nos vamos a aproximar a la discusión existente sobre la autobiografía de la mujer que argumenta Shoshana Felman ${ }^{1}$. Ella nos comenta lo siguiente acerca de la autobiografía de la mujer:

\section{I will suggest that none of us, as women, has as yet, precisely, an autobiography. ${ }^{2}$}

Felman desarrolla en su obra What does a woman want?, publicada en 1993, su argumento acerca de que nadie ha escrito, hasta ahora, lo que puede llamarse la autobiografía sobre la mujer. En torno a la razón de la imposibilidad de escribir una autobiografía de la mujer, explica lo siguiente:

Trained to see ourselves as objects and to be positioned as the Other, estranged to ourselves, we have a story that by definition cannot be self-present to us, a story that, in other words, is not a story, but must become a story. ${ }^{3}$

En su libro, Felman desarrolla sus ideas y teorías, basadas en las obras autobiográficas de escritoras y pensadoras tales como: Virginia Woolf, Marguerite Duras, Adrienne Rich, Simone de Beauvoir, Sarah Kofman y Luce Irigaray, entre otras. Y aunque no ha ignorado la corriente que opta por hablar sobre lo personal en la literatura, como el estilo de confesión de la mujer bajo la influencia feminista desde los años setenta, Felman considera que el hecho de hablar sobre cosas personales y privadas de la mujer, no se conecta directamente con la autobiografía de la misma.

\footnotetext{
${ }^{1}$ Shoshana Felman es profesora (woodreff profesor) de literatura comparativa y literatura francesa e inglesa en Universidad Emory actualmente, y estuvo dando clase en Universidad Yale durante 1970-2004 en EE.UU. Tiene varias publicaciones con el tema de literatura y psicoanálisis, trauma y testimonio, literatura y filosofía, ley y literatura. http://french.emory.edu/people/felman.html, accedido el 14 de septiembre del 2011.

${ }^{2}$ Felman, Shoshana: What does a woman want?: reading and sexual difference. The Johns Hopkins University Press, 1993, London. p. 14.

Voy a sugerir que ninguna de nosotras, como mujeres, tiene hasta la fecha, con precisión, una autobiografía. [Traducción propia].

${ }^{3}$ Loc. cit.

Entrenadas para vernos a nosotras mismas como objetos y para ser posicionadas como el “otro", alejadas de nosotras mismas, tenemos una historia que, por definición, no puede estar presente para nosotras por sí mismas, una historia que, en otras palabras, no es una historia, sino que debe convertirse en una historia. [Traducción propia].
} 
Reading autobiographically is, however, an activity and a performance far more complex than the mere project -and the mere stylistic trend- of "getting personal." Because as educated women we are all unwittingly possessed by "the male mind that has been implanted in us," because though women we can quite easily and surreptitiously read literature as men, we can just as easily "get personal" with a borrowed voice -and might not even know from whom we borrow that voice. "Getting personal" does not guarantee the story we narrate is wholly ours or that it is narrated in our own voice. ${ }^{4}$

La cuestión de asimilar la autobiografía como manifestación de lo personal-privado, en palabras de Felman, es un tema frecuentemente tratado tanto en el concepto como en la crítica feminista en los últimos años. Felman, en una nota del libro que abordamos, menciona algunas ideas que identifican el estilo de confesión de lo íntimo con la autobiografía, y muestra una referencia de la antología del feminismo de Nancy Miller.

Miller points to the contemporary "outbreak of self-writing," which "(although it is not practiced uniquely by feminists or women) can be seen to develop out of feminist theory's original emphasis on the analysis of the personal: (...) the current proliferation in literary studies of autobiographical or personal criticism," and comments:

The spectacle of a significant number of critics getting personal in their writing, while not, to be sure, on the order of a paradigm shift, is at least the sign of a turning point in the history of critical practices (...) In the face of the visible extremes of racism or misogyny, or the equally violent silences of theoretical discourses from which all traces of embodiment have been carefully abstracted,

\footnotetext{
${ }^{4}$ Ibíd., pp. 13-14.

Leer autobiográficamente es, sin embargo, una actividad y una acción mucho más compleja que el mero proyecto -y la mera tendencia estilística-de "personalizarla". Debido a que somos mujeres cultas, todas estamos poseidas, sin ser conscientes de ello, por "la mentalidad masculina que se nos ha inculcado", porque a pesar de ser mujeres podemos leer fácil y subrepticiamente la literatura igual que los hombres, y con la misma facilidad podemos "personalizarla [la literatura]" con una voz prestada; y tal vez ni siquiera sabemos de quién tomamos prestada esa voz. El hecho de "personalizarla" no garantiza que la historia que narramos sea completamente nuestra, ni que sea narrada por nuestra propia voz. [Traducción propia].
} 
the autobiographical project might seem a frivolous response. How can I propose a reflection about an ethics in criticism ... from these individualistic grounds? But the risk of a limited personalism, I think, is a risk worth taking. ("Preface," Feminist Confessions, ix-x, xiv)

En general, al penetrar en la teoría feminista primordial de los primeros momentos, sea o no sea sobre la cuestión de la mujer, nos encontramos con que este movimiento se manifiesta mediante el acto de escribir, incluso en los textos académicos, donde se supone prima la objetividad. La tendencia de escribir un discurso personal y subjetivo siendo conscientes del riesgo, coincide con la expresión audiovisual y del cine documental que vamos a ver en los capítulos V. Se trata de la preferencia por reflexionar desde la visión subjetiva del mundo personal-privado, dejando de lado su posición objetiva. A pesar de esta fuerte corriente de la época, existe un criterio que nos llama la atención acerca de no aunar directamente la confesión de lo personal y lo privado con la autobiografía tan fácilmente. Felman menciona otra opinión en la misma antología que hemos citado antes:

For a different perspective, which insists on analyzing, on the contrary, the radical gap and consequent differentiation between "the autobiographical" and the illusions of the personal, see (in the same anthology) Shari Benstock's study of Virginia Woolf ("Authorizing Autobiography") and its critique of what might be called the mystique of traditional autobiography ("definitions of autobiography that stress self-disclosure and narrative account"), insofar as this tradition gravitates around the delusion of a coherent (or "organic”) self. In contrast to this mystique, says Benstock, the modern feminine autobiographical project (as embodied by

\footnotetext{
${ }^{5}$ Ibíd., p. 155.

Miller apunta al "foco de autoescritura" contemporáneo, que "(aunque no es practicado únicamente por feministas o mujeres) puede verse derivado del énfasis original de la teoría feminista en el análisis de lo personal: (...) la actual proliferación en los estudios literarios de la crítica autobiográfica o personal", y comenta:

El espectáculo de un número importante de críticos personalizando su escritura, aunque no, desde luego, por orden de un cambio de paradigma, es por lo menos la señal de un punto de inflexión en la historia de la crítica (...) En la cara de los extremos visibles del racismo o de la misoginia, o en la de los igualmente violentos silencios de discursos teóricos de los que todo rastro de personificación han sido cuidadosamente extraídos, el proyecto autobiográfico podría considerarse una respuesta frívola. ¿Cómo puedo proponer una reflexión sobre una ética en la critica (...) a partir de estos argumentos individualistas? Pero el riesgo de un personalismo limitado, en mi opinión, es un riesgo que vale la pena. ("Prefacio", Confesiones Feministas, IX-X, XIV). [Traducción propia].
} 
Virginia Woolf) stresses language as "a principle of separation and division” through which the "self" is at the same time constructed and decentered: "Writing the self' is therefore a process of simultaneous sealing and splitting that can only trace fissures of discontinuity. This process may take place through 'the individual's special, peculiar psychic configuration,' but it is never an act of 'consciousness' pure and simple” (Ibid. 1054, emphasis mine). ${ }^{6}$

A Felman le interesa más la última de estas dos opiniones. El proceso de realizar la autobiografía, escribir sobre sí misma, es el proceso de construirse a sí misma y, de manera paralela, descentralizar a través del lenguaje la identidad, bloqueada en fragmentos. Lo importante para Felman es seguir esta hendidura de la división del proceso. Es decir, no fijarse solo en lo que puede expresarse con palabras y en las características de cada uno de los fragmentos de la mujer, sino observar a través de su fisura, el producto de las rupturas entre el bloqueo y la división en la mujer como el punto más importante que debe tratar la crítica feminista con sinceridad, y ahí es donde se encuentra la posibilidad de la autobiografía de la mujer.

Esta manera de pensar se asemeja a la postura fundamental del arte como testimonio, que analizaremos posteriormente en la película documental Shoah de Claude Lanzmann en el capítulo IV. También superpone la postura de Gilles Deleuze, quien explica la necesidad de traspasar el límite y la línea imaginaria de la división estructurada como deconstrucción (también lo veremos en el capítulo V). Lo importante de la deconstrucción es no quedarse en un solo lado en el interior o en el exterior de Europa, sino atravesar ambos lados y estar

\footnotetext{
${ }^{6}$ Ibíd., pp. 155-156.

Para una perspectiva diferente, que insiste en analizar, por el contrario, el vacío radical y la consiguiente diferenciación entre "lo autobiográfico" y las ilusiones de lo personal, véase (en la misma antología) el estudio de Shari Benstock sobre Virginia Woolf ("Autobiografía autorizada") y su crítica de lo que podría llamarse la mística de la autobiografia tradicional ("definiciones de autobiografia que subrayan la divulgación propia y la descripción narrativa"), en la medida en que esta tradición gravita en torno a la falsa ilusión de un yo coherente (u "orgánico"). En contraste con esta mística, dice Benstock, el proyecto autobiográfico femenino moderno (encarnado por Virginia Woolf) subraya el idioma como "un principio de separación y división" a través del cual el "yo" es, al mismo tiempo, construido y descentrado: “"Escribir acerca de sí mismo» es, por lo tanto, un proceso de cierre y al mismo tiempo de ruptura que solo puede localizar las fisuras de la discontinuidad. Este proceso puede tener lugar a través de «la peculiar configuración psíquica especial de cada individuo», pero nunca es un acto de "conciencia» pura y simple" (Ibíd. 1054, énfasis mío). [Traducción propia].
} 
entre los dos, visibilizar la huella de la separación y la línea imaginaria que marca la división.

Está claro que Felman no niega la importancia de la confesión de la mujer y del discurso sobre lo personal y privado de la misma. Felman intenta examinar el problema de la autobiografía de la mujer con sumo cuidado, evitando el optimismo simple y la idea utópica de la mujer, que supone y espera la aparición del discurso de la mujer de manera inmediata, negando y liberando del discurso el androcentrismo por haberse superado la tradición del logocentrismo ${ }^{7}$, que interviene y es inseparable en la expresión y en la historia del lenguaje de occidente. Felman indica la posibilidad de sacar a la luz la autobiografía de la mujer -que todavía no es una historia en sí misma- a través de la historia del "otro", leyéndola y extrayendo los vínculos de la autobiografía de la mujer, creando así su propia historia.

\begin{abstract}
And it cannot become a story except through the bond of reading, that is, through the story of the Other (the story read by other women, the story of other women, the story of women told by others), insofar as this story of Other, as our own autobiography, has as yet precisely to be owned. ${ }^{8}$
\end{abstract}

Felman busca la posibilidad de la autobiografía de la mujer en el acto de leer: mujeres que lean la historia de los "otros". Entre las mujeres se debe formar un vínculo de lectura, leyendo la historia de otras mujeres. Esa historia se hace una historia a medida que es contada y hablada por otras mujeres. Esta cuestión nos exige repensar el concepto de la autobiografía a gran escala. En esta idea en sí misma encontramos una gran influencia digna de consideración sobre el pensamiento de autobiografía de Paul De Man, la cual fue mencionada en Autobiografías visuales de Ana Maria Guasch que hemos comentado

\footnotetext{
${ }^{7}$ El logocentrismo en el mundo occidental y el machocentrismo como consecuencia, lo aproximaremos en esta parte, con base en la teoría de Luce Irigaray que aplicó el pensamiento de Jaques Derrida junto a la crítica que hiciera Felman sobre Irigaray.

${ }^{8}$ Ibíd., p. 14.

$Y$ esto no se puede convertir en una historia excepto a través del vínculo de la lectura, es decir, a través de la historia del “otro" (la historia leída por otras mujeres, la historia de otras mujeres, la historia de las mujeres contada por otras), en la medida en que esta historia de "otro", como nuestra propia autobiografía, precisamente todavía tiene que ser adueñada. [Traducción propia].
} 
anteriormente en la introducción. Enseguida veremos los detalles del argumento de Felman para comprender su planteamiento. 
I.1. La autobiografía de la mujer como testimonio. 
Antes de destacar el argumento sobre la autobiografía de la mujer de Shoshana Felman, precisaremos su postura dentro del discurso feminista. Sobre todo y cuidadosamente enfocaremos en lo respectivo al uso del "we" (en este caso, nosotras). Porque si es importante formar un vínculo de lectura entre las mujeres para el establecimiento de la autobiografía de la mujer a través de ser contada y hablada por otras mujeres, no podemos ignorar tanto a forma y contenido del relato, como a posición de parlante y dirección de oyente-lector. Por esta razón, aclarar el posicionamiento del sujeto plural en su argumento, supuestamente valdrá la pena en esta ocasión. También aprovecharemos el presente apartado como un breve repaso del desarrollo teórico feminista que nos servirá para precisar el margen del uso de la palabra feminismo a lo largo de nuestras reflexiones. Posteriormente, aproximaremos el argumento de Felman sobre la autobiografía de la mujer que es un testimonio de la vida de la mujer que se diferencia por su confesión.

\section{I.1.1. Nosotras en el discurso feminista.}

Felman intenta explicar el uso de nosotras en su texto del siguiente modo:

I should hasten to explain that by adopting the generic "we" in what I have just written ("I will suggest that none of us, as women, has as yet, precisely, an autobiography"), I am not proposing to speak in the name of women: the "we" is a rhetorical structure of address, not a claim for epistemological authority. I am speaking not for women, but to women. My utterance is meant as a speech act, not as a constative representation; it is a cognitive suggestion, an intuition, but its rhetorical force is primarily performative. The contemporary female autobiographical self-consciousness is a crucially important, innovative theoretical and critical resource, and I do not mean to underestimate or undercut its strategic value. But I do propose here to unsettle the very notion of autobiography, precisely insofar as we have settled into it (I feel) a little too impatiently and self- 
complacently, as though we could be sure that we already have-in culture or in life"a room of our own."

Existe una razón por la cual Felman evita "hablar en representación de la mujer": el discurso de hablar en nombre de y el de hablar para, poniendo a la representada en el dominio o la posesión, en realidad, en lugar de darle la palabra, le obliga a quedarse en el silencio debido al portavoz. Esta indicación de Felman está conectada a la crítica de la teoría de Luce Irigaray $^{2}$, pensadora feminista francesa que introdujo la crítica del logocentrismo de Jaques Derrida ${ }^{3}$ esquemáticamente para el análisis sobre la exclusión de la mujer en el lenguaje del mundo occidental. La aplicación de la crítica de Derrida en la teoría feminista ha logrado proporcionar un esquema claro, que puede servir como base para reflexionar mejor sobre estos temas. Daremos una breve explicación sobre la estrategia y el punto de contradicción en la teoría de Irigaray siguiendo a Felman que comenta lo siguiente:

It is not the material, social, and psychological female condition but rather the very status of womanhood in Western theoretical discourse that concerns Luce Irigaray in her book, Speculum de l'autre femme. ${ }^{4}$

\footnotetext{
${ }^{1}$ Felman, Shoshana, What does a woman want? Reading and sexual difference. London, The Johns Hopkins University Press, 1993, p.14.

Debería apresurarme a explicar que al adoptar el genérico "nosotras" en lo que acabo de escribir ("voy a sugerir que ninguna de nosotras, como mujeres, tiene aún, precisamente, una autobiografía"), no estoy proponiendo hablar en nombre de las mujeres: el "nosotras" es una estructura retórica de tratamiento, no una solicitud de autoridad epistemológica. No estoy hablando por las mujeres, sino a las mujeres. Mi enunciado se entiende como un acto de habla, no como una representación constativa; es una sugerencia cognitiva, una intuición, pero su fuerza retórica es ante todo performativa. En la autobiografía femenina contemporánea la conciencia propia es de crucial importancia, es un recurso innovador para la teoría y la crítica, y no pretendo subestimar o rebajar su valor estratégico. No obstante, en este punto, propongo perturbar la noción misma de autobiografía, precisamente en la medida en que nos hemos establecido en ella (creo) siendo un poco impacientes y autocomplacientes, como si pudiéramos estar seguras de que ya tenemos -en la cultura o en la vida- "una habitación propia". [Traducción propia].

${ }^{2}$ Irigaray, Luce (1930- ), Filósofa feminista y psicoanalista francesa. (...) Con la publicación de «Speculum y Ce Sexe qui n'en est pas un» en 1977, su obra se extiende más allá del psicoanálisis y se adentra en un examen crítico de la filosofía. [VV.AA. Diccionario Akal de Filosofía. Trad. Huberto Marraud y Enrique Alonso, Madrid: Akal, 2004, p. 552.]

${ }^{3}$ Derrida, Jacques (n. 1930), filósofo francés, responsable del deconstruccionismo y una de las figuras que han liderado el movimiento del posmodernismo. [VV.AA. Diccionario Akal de Filosofía. Op.cit., p. 244.]

${ }^{4}$ Ibíd., p. 22.

No es la condición material, social y psicológica femenina, sino más bien el mismo estatus de madurez de las mujeres en el discurso teórico occidental al que se refiere Luce Irigaray en su libro, Speculum de l'autre femme (el espejo del otro mujer). [Traducción propia].
} 
Luce Irigaray ha investigado los textos filosóficos y fundamentales del psicoanálisis escritos por hombres. Como resultado, ha encontrado el concepto de la feminidad en los textos desde diversas perspectivas. Las formas paradigmáticas se encuentran en la discusión de la metáfora de la feminidad del mito de la cueva de Platón, y lo ficcional en la conferencia Sobre la feminidad de Freud. Irigaray, siendo ella misma psicoanalista, utiliza el método psicoanalítico y, al mismo tiempo, introduce la crítica feminista sobre el androcentrismo y el desprecio de la mujer que se encuentra en los textos para su investigación. Durante el proceso de analizar la discusión clásica desde la postura feminista, emplea una reflexión filosófica aplicada en la deconstrucción según Derrida (y otros filósofos a favor de la deconstrucción) para destacar la contradicción y su función de legitimar en sí mismo que se encuentran en la metafísica occidental tradicional de una manera crítica. Para que se aclare bien, seguiremos una explicación de Felman sobre la estructura del logocentrismo de la metafísica occidental y el análisis de Derrida de manera clara y breve, pero concreta.

According to Derrida's radicalization of the Nietzschean and Heideggerian critiques of traditional philosophy, Western metaphysics is based on the totalitarian principle of so-called logocentrism, that is, on the repressive predominance of "logos" over "writing" on the privileged status of the present and the consequent valorization of presence. This presence-to-itself of a center (given the name of Origin, God, Truth, Being, or Reason) centralizes the world through the authority of its self-presence and subordinates to itself, in an agonistic, hierarchical manner, all the other cognizable elements of the same epistemological (or ontological) system. Thus, the metaphysical logic of dichotomous oppositions which dominates philosophical thought (Presence/ Absence, Being/ Nothingness, Truth/ Error, Same/ Other, Identity/ Difference, and so on) is, in fact, a subtle mechanism of hierarchization which assures the unique valorization of the "positive" pole (that is, of a single term) and, consequently, the repressive subordination of all "negativity", the mastery of difference as such. ${ }^{5}$

\footnotetext{
${ }^{5}$ Ibíd., pp. 22-23.
} 
Nos explicaremos brevemente, Derrida realizó la radicalización de la crítica sobre la filosofía tradicional occidental de Nietzsche y Heidegger, y encontró al logocentrismo como la base de la metafísica occidental. El logocentrismo es un principio totalitario: el logos reprime lo escrito, asegurando el valor de la presencia y la prioridad en sí mismo. Es decir, la presencia-de-sí-mismo es el centro del mundo, la cual es la denominación del origen, de Dios, de la Verdad, del Ser, de la Razón... que al mismo tiempo, centralizan el mundo. En el mundo centralizado a través del logocentrismo se genera una jerarquización forzada por medio de su valorización; como consecuencia, se reconoce y juzga sistemáticamente cualquier otro factor como subordinado. Así, la teoría metafísica construye una simétrica oposición dicotómica de diversos tipos tales como Presencia / Ausencia, Ser / Nada, Verdad / Falso, Uno / Otro, Sujeto / Objeto o Identidad / Diferencia donde domina el pensamiento filosófico. Esta estructura en sí funciona como un mecanismo jerárquico que brinda una única valoración al lado positivo. Como resultado, el lado negativo es reprimido y subordinado. De esta manera se establece un mecanismo que controla el sistema de la diferenciación. La crítica de deconstrucción que realizan Derrida y otros pensadores a su favor como Gilles Deleuze, no invierte la relación jerárquica, la estructura del poder que ocasiona la oposición dicotómica entre dominador/dominado. Invertir no implica superar la estructura de estas contradicciones, sino solo subrayar finalmente la estructura como axioma. Deconstrucción es descentralización del logocentrismo que supone esta estructura, es el sistema de la diferenciación. La crítica que la deconstrucción realiza, insta a no pensar permaneciendo en un solo lado de la disparidad, sino subsistiendo en los dos lados al mismo tiempo mientras, a la vez, se considera el movimiento continuo entre ambos lados.

\footnotetext{
Según la radicalización por parte de Derrida de las críticas Heideggeriana y Nietzscheana de la filosofía tradicional, la Metafísica Occidental está basada en el principio totalitario llamado logocentrismo, es decir, en el predominio represivo del "logos" sobre lo "escrito" en la situación privilegiada del presente y la consiguiente valorización de la presencia. Esta presencia-en-sí-misma de un centro (denominado Origen, Dios, Verdad, Ser, o Razón) centraliza el mundo a través de la autoridad de su propia presencia y subordinando a sí mismo, de una manera agonística, jerárquica, a todos los demás elementos reconocibles del mismo sistema epistemológico (u ontológico). Así pues, la lógica metafísica de oposiciones dicotómicas que domina el pensamiento filosófico (Presencia / Ausencia, Ser / Nada, Verdad / Error, Uno / Otro, Identidad / Diferencia, etcétera), es, en realidad, un sutil mecanismo de jerarquización que asegura una única valoración del polo "positivo" (es decir, de un único término) y, en consecuencia, la subordinación represiva de toda "negatividad", el dominio de la diferencia como tal. [Traducción propia].
} 
Dichas propuestas son aproximaciones a la manera reconstructiva de la práctica de realizar y ver películas. En éstas, por ejemplo, la penetración y la violación de los límites -mencionados por Deleuze y que veremos en el primer apartado del capítulo V.- y el viaje entre el interior y el exterior (tal y como lo planteaba el documental Shoah, que vamos a ver en la segunda parte del capítulo IV.), analizan todos los aspectos alrededor del texto, el discurso, el fenómeno social y el estilo del arte, entre otros, desde diversas aproximaciones para aclarar el logocentrismo que existe dentro de ellos. Y además, cuestionan ese sistema disgregador sacudiendo y moviendo su estructura fija, obteniendo así una perspectiva crítica nueva o diferente ante lo tradicional.

En este tipo de análisis se presta mucha atención al discurso y al lenguaje; en este caso, el discurso y el lenguaje no solo con palabras y su expresión lingüística, sino también incorporando cualquier código y expresión que funcione como medio de comunicación entre la sociedad, como por ejemplo el gesto, la expresión física y otros.

Irigaray nos indica, basándose en la teoría de Derrida, que el hombre se ha situado en una posición de supremacía sobre la mujer tanto en la historia como en la tradición de la metafísica occidental, aplicando el sistema de la relación jerárquica de las oposiciones dicotómicas. A través de esta operación de androcentrismo, se ha establecido el sistema de dominio del hombre en el pensamiento occidental. Como consecuencia, la postura de la mujer ha quedado como algo opuesto y diferente, como un objeto, frente al hombre, quien se define como sujeto dominador.

It is by thus examining the mere illusion of duality and the repressive way in which the polarity Masculine/ Feminine functions in Western thought so as to privilege a unique term that Luce Irigaray proceeds to develop her critical argument. Theoretically subordinated to the concept of masculinity, the woman is viewed by the man as his opposite, that is to say, as his other, the negative of the positive, and not, in her own right, different, other, otherness itself. ${ }^{6}$

\footnotetext{
${ }^{6}$ Ibíd., p. 23.
} 
El pensamiento occidental, que valora solo un lado de la disyuntiva, da superioridad a lo masculino frente a lo femenino, considerando que la feminidad es el "otro" y por tanto es el "objeto" para la masculinidad, que actúa como Sujeto. Sin embargo, aunque la mujer en sí no se ha visibilizado como "otro", se ha marginado del sistema de lenguaje, por lo tanto figurando en el pensamiento occidental como un ser invisible.

\begin{abstract}
Throughout the Platonic metaphors that will come to dominate Western discourse and to act as a vehicle for meaning, Luce Irigaray points out a latent design to exclude the woman from the production of speech, since the woman, and the other as such, are philosophically subjugated to the logical principle of Identity -Identity being conceived as a solely masculine sameness, apprehended as male selfpresence and consciousness-to-itself. ${ }^{7}$
\end{abstract}

De esta manera, la observación sobre la feminidad en el pensamiento occidental que hace Irigaray nos menciona las circunstancias de la mujer, que permanece marginada del sistema del lenguaje-significado, es decir, a la mujer se le ha colocado fuera del discurso y del lenguaje en el mundo logocéntrico occidental.

Bajo la teoría de Irigaray, Felman pregunta lo siguiente:

Who is speaking here, and who is asserting the otherness of the woman? If, as Luce Irigaray suggests, the woman's silence, or the repression of her capacity to speak are constitutive of philosophy and of theoretical discourse as such, from what

\footnotetext{
Luce Irigaray procede a desarrollar su argumento crítico por lo tanto, cuando examina la mera ilusión de dualidad y la forma represiva en que la polaridad masculino / femenino funciona en el pensamiento occidental a fin de privilegiar un único término. Teóricamente subordinada al concepto de la masculinidad, el hombre ve a la mujer como su opuesto, es decir, como su "otro", el negativo de lo positivo, y no, en su derecho propio, diferente, otra, la alteridad en sí misma. [Traducción propia].

${ }^{7}$ Loc. cit.

A lo largo de las metáforas platónicas que llegarán a dominar el discurso occidental y a actuar como vehículo de significado, Luce Irigaray señala un patrón latente para excluir a la mujer de la producción de discurso, ya que la mujer, y el "otro" como tal, están filosóficamente subyugados al principio lógico de Identidad: la Identidad se concibe como una sola identidad masculina, comprendida como autopresencia masculina y consciencia de-símisma. [Traducción propia].
} 
theoretical locus is Luce Irigaray herself speaking in order to develop her own theoretical discourse about the woman's exclusion? ${ }^{8}$

Felman nos muestra el punto contradictorio de la teoría de Irigaray, donde se intuye la contradicción que ya hemos mencionamos antes al "hablar para la mujer", "hablar representando a la mujer" y "hablar en nombre de la mujer".

But what does "speaking for women" imply? What is "to speak in the name of the woman"? What, in a general manner, does "speech in the name of" man? It is not a precise repetition of the oppressive gesture of representation, by means of which, throughout the history of logos, man has reduced the woman to the status of a silent and subordinate object, to something inherently spoken for? To "speak in the name of" to "speak for," could thus mean, once again, to appropriate and to silence. ${ }^{9}$

El trabajo de Irigaray nos reveló que la presión ejercida sobre la mujer no solo se da en los mecanismos de la práctica y en los instrumentos de cada sistema de la economía, la sociedad, la medicina y la política, sino que también existe una presión escondida en el logos, la razón y la lógica. Felman aprecia mucho el valor del trabajo de Irigaray; sin embargo, nos indica el punto ciego de su teoría:

This important theoretical question about the status of its own discourse and its own "representation" of woman, with which any feminist thought has to cope, is not

\footnotetext{
${ }^{8}$ Ibid., p. 24.

¿Quién está hablando aquí, y quién afirma la alteridad de la mujer? Si, como sugiere Luce Irigaray, el silencio de la mujer, o la represión de su capacidad de hablar son constitutivos de la filosofía y del discurso teórico como tales, ¿desde qué lugar teórico habla la propia Luce Irigaray para desarrollar su propio discurso teórico sobre la exclusión de la mujer? [Traducción propia].

${ }^{9}$ Loc. cit.

Pero, ¿qué implica "hablar por las mujeres"? ¿Qué es "hablar en nombre de la mujer"? ¿Qué significa, de manera general, "discurso en nombre del" hombre? ¿No se trata de una repetición exacta del gesto opresivo de la representación, por medio de la cual, a lo largo de la historia del logos, el hombre ha reducido a la mujer a la condición de un objeto subordinado y silencioso, a algo que naturalmente se habla en su nombre? Para "hablar en nombre de" a "hablar por", podría por lo tanto significar, una vez más, adueñarse y silenciar. [Traducción propia].
} 
thought out by Luce Irigaray and thus remains the blind spot of her critical undertaking. ${ }^{10}$

Felman opina que Luce Irigaray desarrolla su crítica como representante de la mujer sin declarar bien su posición. Según Felman, se debe ser consciente de la propia posición para proponer una crítica feminista. El uso de "we" (nosotras), en el caso de Irigaray, la posiciona como una representante transparente que no aclara su posicionamiento. Ella habla en nombre de la mujer, pero ella misma no sabe qué posición ocupa dentro de este grupo, solo declara que ella es una portavoz dominante. La función de representante y su discurso frecuentemente le exige el silencio a la vez que hace hablar al grupo que representa. $\mathrm{Su}$ posición y situación de representante transparente es muy cuestionable e Irigaray no presta mucha atención a este aspecto.

Por esta razón, Felman explica la utilización de la palabra "we”, usada para aclarar que ella quiere evitar hablar en nombre de la mujer. La intención del empleo de la palabra nosotras de Felman no significa que hable representando a la mujer, sino que le habla a la mujer. Ella intenta dirigirse a las mujeres. Este tema de hablar dirigiéndose a la mujer lo desarrollaremos más adelante. La cuestión del empleo de la palabra nosotras continúa en la frase del título del último capítulo del libro de Felman: ¿con quién crees que está participando el destino? En este apartado, reflexiona sobre la posibilidad de la autobiografía de la mujer á través del análisis de los trabajos de Adrienne Rich, Simone de Beauvoir y Virginia Woolf como autoras precursoras que han preparado el género privilegiado de la autobiografía. Cuando decimos nosotras, ¿a quién se incluye? Y, ¿a quién no se incluye? Felman no desarrolla esta cuestión y nosotros la dejaremos de momento. Es un tema que debemos desarrollar para reflexionar sobre la tradición de la forma de expresión académica que se nos exige cumplir como requisito mínimo. Tal vez no podamos ignorar este tema si cuestionamos el problema del direccionamiento del habla, de

\footnotetext{
${ }^{10}$ Loc. cit.

Esta importante cuestión teórica acerca de la situación de su propio discurso y de su propia "representación" de la mujer, con la que cualquier pensamiento feminista tiene que hacer frente, no es pensada por Luce Irigaray y, por tanto, sigue siendo el punto ciego de su crítica empresa. [Traducción propia].
} 
quién y a quién hablamos. La idea de Felman sobre la dirección de hablar y el acto de hablar dirigido a alguien es un tema que abordaremos más adelante.

\section{I.1.2. La vida de la mujer con trauma.}

La propuesta de Felman sobre la cuestión de la autobiografía de la mujer, naturalmente, no es un simple análisis de los textos autobiográficos de autoras femeninas dado que dice que nunca ha existido la autobiografía de la mujer. Prácticamente su principal argumento es que solo puede leer la autobiografía de la mujer a través de la historia del "otro", por lo cual ella analiza los textos escritos por hombres, como Balzac y Freud, en el segundo, tercero y cuarto capítulo de su libro. En este análisis aclara que los hombres se turban y se desorientan al enfrentarse a la feminidad, tanto dentro del texto como fuera.

La última parte del primer capítulo contiene una nota: To be continued in chapter 5 (Afterword), que literalmente significa Continuará en el capítulo 5 (Epílogo). Esto quiere decir que el primer y el quinto capítulo son en realidad un mismo artículo dividido. En él desarrolla su idea sobre la autobiografía de la mujer mencionando la reflexión del análisis del texto de Balzac y Freud con los trabajos de las autoras femeninas. Mediante el autoanálisis de su lectura sobre los textos de los autores masculinos explica la importancia del diálogo con el autor masculino, comparando la lectura masculina y la femenina. Y argumenta que el proceso y la huella de lectura serían su posible autobiografía. La teoría y el texto de este libro tienen una estructura complicada. Dejaremos para otra ocasión el mencionar el análisis de las novelas de Balzac, que contiene muchas partes interesantes, sobre todo la observación de la relación de la identidad de la mujer con la memoria de trauma y otros detalles.

Una de las ideas que más nos interesa dentro de su hipótesis sobre la reflexión acerca de la autobiografía de la mujer es "que la vida de toda mujer contiene, de forma explícita o implícita, la historia de un trauma”. Felman menciona dos ejemplos para apoyar su argumento: una mujer noble inglesa, Vita Sackville-West, escribió: “My life [is] a deceitful country" (Mi vida es un país lleno de mentira) en su autobiografía. Como no permitió 
publicarla durante su vida, fue publicada después de su muerte por su hijo. El segundo ejemplo serán las declaraciones de la escritora francesa Marguerite Duras, que comenta que no recuerda nada al escribir su historia autobiográfica. Poniendo estos ejemplos, Felman comenta lo siguiente:

Unlike men, who write autobiographies from memory, women's autobiography is what their memory cannot contain -or hold together as a whole-although their writing inadvertently inscribes it. To the extent that "Pain" is "one of the most important things" in Duras's life, it is, like many stories of profound pain and of traumatization, a story of (partial) amnesia, a story present in the text but whose writing cannot coincide with the writer's consciousness. Indeed, I will suggest -in line with what has recently been claimed by feminist psychiatrists and psychoterapists- that every woman's life contains, explicitly or in implicit ways, the story of a trauma. ${ }^{11}$

Trauma quiere decir una herida, tras lastimarse por alguna causa externa. En general, y más particularmente en nuestro caso, hablamos de trauma mental, que ocasiona estrés mental y puede incluso llegar a desarrollar daño físico. Este es un término que empezó a emplear Freud. Actualmente se emplea la palabra PTSD (Post Traumatic Stress Disorder), o Trastorno de Estrés Postraumático, que se ha generalizado como término psiquiátrico. Cuando una persona sufre traumas, no puede entender bien qué ocurre en ese momento. Enfrentarse a un acontecimiento destructivo y/o mortal inesperada y repentinamente le causa un impacto aplastante que atraviesa su propia protección mental. En el momento en que acontece ese golpe o herida psicológica traumática, uno no puede entender exactamente qué ha pasado en sí mismo y, por esta razón, falla el registro en su memoria.

\footnotetext{
${ }^{11}$ Ibíd., pp. 15-16.

A diferencia de los hombres, que escriben autobiografías desde la memoria, la autobiografía de las mujeres es lo que su memoria no puede contener - o mantener unido como un conjunto-a pesar de que su escritura lo inscribe de forma inadvertida. En la medida en que "el Dolor" es "una de las cosas más importantes" en la vida de Duras, es, como muchas historias de dolor profundo y de traumas, una historia de amnesia (parcial), una historia presente en el texto, pero cuya redacción no puede coincidir con la conciencia del escritor. De hecho, voy a proponer -de acuerdo con lo que recientemente ha sido reclamado por los psiquiatras y psicoterapeutas feministas- que la vida de toda mujer contiene, de forma explícita o implícita, la historia de un trauma. [Traducción propia].
} 
Desde ese instante, únicamente permanece la reacción física, que es la experiencia terrorífica, ante el horror. Como consecuencia, la persona sufre alucinaciones, sensación de miedo y flashback repetitivamente; por ello, el individuo se sume en el pánico y pierde el control. Estos elementos son los síntomas típicos del trauma. El trauma en sí queda en el inconsciente, como la memoria de la cual no se puede rememorar ni hablar. Por intentar no recordar, el consciente y el cuerpo físico reaccionan excesivamente; luego ocasionan inquietud grave y/o la dolencia física.

Felman, siguiendo la indicación de su psicoanalista clínica y forense Laura S. Brown, que examina la definición tradicional de trauma mental, insiste en que no se deben excluir las experiencias de maltrato violento, violación sexual e incesto como experiencias traumáticas. Y comenta con estas palabras los insidious traumata (traumatismos escondidos) surgidos por el dolor psíquico de aquellas mujeres que experimentan estos episodios de forma reiterada en su cotidianidad y que, inconscientemente, transmiten a las siguientes generaciones su experiencia traumática:

Brown refers not only to the great numbers, among women, of abuse, rape, and incest survivors but to the "traumatic stressors" involved in "all those every day, repetitive, interpersonal events that are so often the sources of psychic pain for women" and to the unconscious transmission from generation to those "insidious traumata": "How, then, do we understand the woman whose symptoms of psychic trauma have occurred entirely at second hand, as it were through the mechanism of insidious trauma? Mainstream trauma theory has begun to recognize that posttraumatic symptoms can be intergenerational, as in the case of children of survivors of the Nazi Holocaust; we have yet to admit that it can be spread laterally throughout an oppressed social group (...) for whom insidious trauma is a way of life" (128-29). ${ }^{12}$

\footnotetext{
${ }^{12}$ Ibíd., p. 158.

Brown no solo se refiere a las grandes cifras, entre las mujeres, de supervivientes de abusos, violaciones e incestos, sino a los "estresantes traumáticos" presentes en "todos esos acontecimientos interpersonales, repetitivos y diarios que con tanta frecuencia constituyen las fuentes de dolor psíquico de las mujeres" y a la transmisión inconsciente generacional de estos "traumatismos insidiosos": "¿Cómo, entonces, entendemos a la mujer cuyos síntomas de trauma psíquico se hayan producido completamente de segunda mano, como si fuera a
} 
Según esta indicación, el trauma se transmite como una herida latente a través del inconsciente, traspasando las generaciones y el límite de la consciencia individual. Se puede encontrar el síntoma en la generación posterior de quien ha tenido una experiencia traumática. En otros casos, dentro de un grupo oprimido con un trauma latente se puede mantener el trauma en la misma generación. Es decir, una mujer, aunque no tenga ninguna experiencia traumática en su propia vida, contiene el trauma como herencia de las generaciones precedentes.

Otra posibilidad es que cuando la mujer habla de su vida, surge al mismo tiempo el testimonio de su trauma. Sea cual sea la mujer, en el momento de hablar de su sentimiento y de su experiencia, en el instante en que traslade todo eso en palabras para poder expresarse, siempre se sentirá fracasada. Esta experiencia en sí misma se convierte en un trauma que acarrea miedo y desengaño a la mujer. Por esta razón, Felman argumenta: "la vida de toda mujer contiene, de forma explícita o implícita, la historia de un trauma”.

Puntualizando más en esta forma de ser del trauma, Felman explica que la historia de la vida de una mujer que contiene un trauma no se puede convertir en confesión. Ahí reside la razón de insistir en la imposibilidad de conectar la confesión con la autobiografía de la mujer:

Because trauma cannot be simply remembered, it cannot simply be "confessed": It must be testified to, in a struggle shared between a speaker and a listener to recover something the speaking subject is not-and cannot be-in possession of. Insofar as any feminine existence is in fact a traumatized existence, feminine autobiography cannot be a confession. ${ }^{13}$

\footnotetext{
través del mecanismo del trauma insidioso? La teoría del trauma predominante ha comenzado a reconocer que los síntomas postraumáticos pueden ser intergeneracionales, como en el caso de los niños de los supervivientes del Holocausto nazi; aún tenemos que admitir que se puede propagar lateralmente a través de un grupo social oprimido (...) para el que el trauma insidioso es una forma de vida" (128-29). [Traducción propia]. ${ }^{13}$ Ibid., p. 16.

Porque el trauma no se puede recordar simplemente, no puede simplemente ser "confesado": debe ser testificado, en una lucha compartida entre un hablante y un oyente para recuperar algo de lo cual el sujeto hablante no tiene -y no puede tener- posesión. En la medida en que cualquier existencia femenina es en realidad una existencia traumatizada, la autobiografía femenina no puede ser una confesión. [Traducción propia].
} 
Felman argumenta que la autobiografía de la mujer no puede ser una confesión, insistiendo en la diferencia entre la confesión y el testimonio. El trauma, para quien lo tiene, se pierde y es incontrolable. Tan solo se puede recuperar con tratamiento psicoanalítico a través de un proceso en el cual se fuerza al paciente a hablar con la colaboración del psicoanalista y mediante diversas aproximaciones a la memoria, al sueño, al sentimiento y a la impresión, siendo así capaces de reconocer la causa del trauma. Para poder dar testimonio del trauma es necesaria la colaboración del oyente, además del esfuerzo del hablante: la comprensión mutua es un trabajo necesario para recuperar algo perdido. En este sentido, el diálogo es un factor indispensable para el testimonio de la mujer. Por eso, Felman insiste en la importancia del diálogo a través de la lectura femenina, esperando que se establezca el vínculo propicio entre mujeres para la aparición de la autobiografía de la mujer.

Nos gustaría ampliar un poco la postura de Felman sobre la confesión para evitar un malentendido acerca de la misma. Ella afirma que su intención es no despreciar ni ignorar la importancia de la confesión de la mujer, e insiste en la imposibilidad de que la confesión sea directamente la autobiografía de la mujer, como vemos a continuación:

It is not that women do not have the possibility, or the right, to confess their stories. The critical fashion of autobiographical confession among feminist writers attests to the contrary and has its important critical reasons. But female autobiography, I am suggesting, is not available to a confession and cannot truly and effectively be accessed by this mode, which, in its inadvertent search for absolution (the originary and, in fact, the inescapable desire behind any confession), runs the risk of offering still more masks (idealizing or counter idealizing) for a self conscious feminine identity still unwittingly preoccupied with exorcising female guilt, a perennial exercise that inexorably amounts (no matter how sincere and in good faith) to a false confession (...). ${ }^{14}$

\footnotetext{
${ }^{14}$ Ibíd., p. 158.

No es que las mujeres no tengan la posibilidad, o el derecho, de confesar sus historias. El método crítico de la confesión autobiográfica entre las escritoras feministas demuestra lo contrario y tiene importantes razones críticas. Pero la autobiografía de la mujer, estoy sugiriendo, no está disponible para una confesión y no puede ser acceder a ella verdadera y eficazmente de este modo, que, en su búsqueda inadvertida de la absolución (el originario y, de hecho, el ineludible deseo tras cualquier confesión), corre el riesgo de ofrecer aún más máscaras
} 
Felman está de acuerdo en la importancia de los elementos de la confesión de la mujer para las prácticas de la literatura y la crítica feministas. Pero niega la validez de la confesión como autobiografía de la mujer, porque la confesión es un acto de hablar sobre el pecado de sí mismo para ser perdonado, es reconocer la culpa para rechazarla. Por esta función, la confesión de la mujer solo puede hablar sobre el pecado y la culpa de ser mujer. Dada la educación de la mujer y como consecuencia de mentalizar el verse a sí misma como "lo otro" y "objeto", es inevitable y evidente: la mujer se hace marginalizar y causa el sentimiento que se conecta directamente con la sensación de pecado. Por mucho cuidado y honestidad que tenga, la confesión no se libera del sistema de autocensura, y crea e inventa la culpabilidad de la mujer. Naturalmente, la confesión de la mujer es la historia de la culpa y el perdón por ser mujer. Cualquiera que sea o no sea mujer quiere ser inocente, así que inevitablemente falsea su historia; o, por el contrario, confiesa su pecado inventándolo para ganar el perdón. El resultado sería el mismo, según Felman.

Además de esto, aunque Felman no lo exprese claramente, el sistema le obliga a contar una historia completa, así que podemos considerar que la confesión en su totalidad y la forma de expresión no pueden ser la autobiografía de la mujer. La vida de la mujer con trauma no puede hablar desde la totalidad ni desde la perfección. En su función, el sistema establece una historia con causas y consecuencias perfectas que se aplica en la vida de la mujer. Esa perfección es una falsa imaginación, por lo menos para hablar de la mujer en sí misma. En otras palabras, la confesión en sí y por su acto funciona al completar la falta de la mujer.

Por este motivo, Felman no puede aceptar la confesión como autobiografía de la mujer, ya que la autobiografía debe mostrar la realidad de la mujer. Entonces, naturalmente la autobiografía de la mujer debe ser un testimonio de su vida, no puede ser una historia ideal y total en sí misma. Siguiendo este razonamiento, la autobiografía de la mujer solo puede darse en la forma del testimonio; es la única posibilidad según Felman:

(idealizando o contrarrestando la idealización) para una autoevaluación consciente de la identidad femenina todavía preocupada involuntariamente por exorcizar a las mujeres culpables, un ejercicio perenne que inexorablemente cuenta (no importa cuán sincero y de buena fe sea) como una falsa confesión (...). [Traducción propia]. 
It can only be a testimony: to survival. And like other testimonies to survival, its struggle is to testify at once to life and to the death -the dying- the survival has entailed. ${ }^{15}$

Por otra parte, Felman piensa que el testimonio es la única manera en que la autobiografía de las mujeres que sobreviven la muerte puede ser relatada. Felman cita el comentario de la feminista afroamericana Bell Hooks como ejemplo. Hooks sentía el impulso de asesinar al sujeto sobre el que escribía para poder ser ella misma mientras escribía su propia historia. El intento de escribir sobre la vida de la mujer es un acto violento y contradictorio para la mujer:

"To me," says African American feminist Bell Hooks, "telling the story of my growing up years was intimately connected with the longing to kill the self I was without really having to die. I wanted to kill that self in writing. Once that self was gone-out of my life forever-I could more easily become the me of me." Is not this violent and paradoxical predicament of "writing a woman's death" precisely part of any feminist undertaking of "writing a woman's life?" "The awakening of consciousness," writes American poet Adrienne Rich, "is not like the crossing of a frontier-one step and you are in another country. ",16

Este acto que comenta Adrianne Rich, el cruce de una frontera, es muy inestable para la interpretación. Para Felman, es el cruce del límite que divide la vida y la muerte. Felman también cita otra frase: "When we dead awaken..." (Cuando nosotras morimos nos despertamos...), extraída por Rich del comentario que Bernard Shaw escribiera a raíz de la

\footnotetext{
${ }^{15}$ Ibíd., p. 16.

Esta solo puede ser un testimonio: el de la supervivencia. Y, al igual que otros testimonios de supervivencia, su lucha es atestiguar a la vez la vida y la muerte -la desaparición-que ha supuesto la supervivencia. [Traducción propia].

${ }^{16}$ Ibíd., p. 24.

"Para mí" dice la feminista afroamericana Bell Hooks, "narrar la historia de mi crecimiento estaba íntimamente relacionado con el deseo de matarme a mí misma sin tener que morir realmente. Quería matarme a mí misma escribiendo. Una vez que esa parte de mí se hubiera ido -fuera de mi vida para siempre-, yo podría llegar a ser yo misma más fácilmente". ¿No forma esta situación violenta y paradójica del "escribir sobre la muerte de una mujer" precisamente parte de cualquier empresa feminista de "escribir la vida de una mujer?" "El despertar de la consciencia", escribe la poeta estadounidense Adrienne Rich "no es como el cruce de una frontera, un paso y ya estás en otro país". [Traducción propia].
} 
simpatía por el teatro feminista que Ibsen plantea asumir y reapropiar. Y continúa hablando sobre el tema de la autobiografía de la mujer:

But when we assume and reappropriate, as woman, Ibsen's title and Shaw's comment, when we become, today, the speaking subjects and the autobiographical bearers of the sentence "When we dead awaken..." the sentence is no longer simply sayable, narratable as a simple story but becomes itself, upon each utterance, an enactment, of its own event (its own advent). As a story, "When we dead awaken..." is, however, bound to remain split, and indeed unfinished. ${ }^{17}$

Felman se fija cuidadosamente en la manera en que existe la autobiografía de la mujer, rechazando la confesión como autobiografía y desarrollando la reflexión sobre la autobiografía de la mujer basada en el trauma tras sobrevivir a la muerte. Felman confirma repetitivamente que todavía no existe la autobiografía de la mujer:

This is why I have suggested that "none of us, as women, has as yet, precisely, an autobiography," and that "we have a story that by definition cannot be self-present to us, a story that in not a story but must become a story” (...).

I cannot confess to my autobiography as missing, but I can testify to it.

I cannot write my story (I am not in possession of my own autobiography), but I can read it in the Other. ${ }^{18}$

\footnotetext{
${ }^{17}$ Ibíd., p. 17.

Pero cuando asumimos y nos reapropiamos, como mujeres, del título de Ibsen y del comentario de Shaw, cuando nos convertimos, en la actualidad, en los sujetos hablantes y en los portadores autobiográficos del enunciado: “Cuando nosotras morimos nos despertamos..." la frase ya no es simplemente expresable, narrable como una simple historia, sino que se convierte en sí misma, con cada expresión, en una ley de su propio caso (su llegada). Como un relato, "Cuando nosotras morimos nos despertamos..." está, sin embargo, obligada a permanecer dividida y, de hecho, inacabada. [Traducción propia].

${ }^{18}$ Loc. cit.

Por eso he sugerido que "ninguna de nosotras, como mujeres, tiene aún, precisamente, una autobiografía", y que "nosotras tenemos una historia que, por definición, no puede estar presente por sí misma para nosotras, una historia que no es una historia sino que debe convertirse en una historia” (...).

No puedo confesar a mi autobiografía como desaparecida, pero puedo dar testimonio de ella.

No puedo escribir mi historia (no estoy en posesión de mi propia autobiografía), pero puedo leerla en el "otro". [Traducción propia]
} 
Si no hay ninguna mujer que haya logrado hacer su autobiografía, ¿cómo es posible obtenerla? La manera que Felman plantea en su libro como preparación posible para obtener la solución, es leer la propia autobiografía en la historia del "otro". Como indica Irigaray, basándose en la crítica del logocentrismo de Derrida y otros teóricos feministas, afirma que el pensamiento occidental otorgaba superioridad a la masculinidad sobre la feminidad, distinguiéndolas a lo largo de la historia. Por lo tanto, cualquier análisis e interpretación estaban basados en estos prejuicios del mundo occidental, estructurados en el discurso del favoritismo a la masculinidad, personificada en el hombre. Los textos literarios y teóricos estaban estructurados bajo esta función logocéntrica, y su análisis e interpretación no eran capaces de escapar a esta estructura. Como consecuencia de lo anterior, reafirmaban la estructura misma y su validez. Tras señalar este acontecimiento, Felman critica la lectura logocéntrica que apoya lo masculino. Para ello, relee los textos escritos por autores hombres, basados en la teoría feminista psicoanalítica, e intenta aclarar la perplejidad de los hombres frente a la feminidad y su resistencia.

Por supuesto, Felman evita con sumo cuidado criticar únicamente la lectura del androcentrismo como base para reescribir la superioridad de la feminidad sobre la masculinidad, ya que de esta manera se invierte el sistema de poder que divide al hombre y a la mujer en oposiciones dicotómicas. Si la manera de dar la supremacía a un solo lado es encontrando oposiciones dicotómicas en la obra, solamente se fortalece la estructura de esa división y oposición; aunque la supremacía se traspase de la masculinidad a la feminidad, no tiene mucho sentido para la crítica deconstructiva. La lectura crítica feminista psicoanalista de Felman se basa en la deconstrucción que cuestiona la estructura en sí misma. En este sentido, de ninguna manera se debe fortalecer la estructura. Para Felman, la lectura autobiográfica en la historia del "otro" es un acto para testificar la resistencia femenina en el texto: 
Reading autobiographically is, then, essentially an act of giving testimony: of giving testimony to the unsuspected, unexpected "feminine resistance" in the text (see chapter I). ${ }^{19}$

Felman intenta encontrar la posibilidad de la autobiografía de la mujer en el punto de la vinculación y, al mismo tiempo, de la interrupción en el acto de lectura entre la literatura y la teoría para que nazca la historia de la mujer como recurso indirecto. Su argumento coincide con nuestra intención de encontrar una posibilidad de la autobiografía en la fisura que divide y a la vez vincula arte y teoría. Felman, dada su profesión, se limita a la literatura como una forma de arte. Pero queremos ampliar nuestra interpretación: además de la literatura, también las artes visuales. Por lo menos, el arte audiovisual, porque en el arte audiovisual, sobre todo de tipo documental, el lenguaje es un factor muy importante. Es más, el discurso y el lenguaje no tratan solamente sobre el manejo de la palabra y de la expresión lingüística, sino también de otros tipos de expresión, como el gesto y el código de la comunicación. Este asunto lo consideraremos de forma concreta en los capítulos posteriores, apoyándonos en nuestro trabajo. Felman plantea leer nuestra autobiografía perdida en la historia del "otro", confirmando la resistencia femenina y teniendo como contexto la sociedad y la cultura que nos rodean.

Reading autobiographically cannot, therefore, be merely a question of encroaching, with one's own story, on the feminine resistance in the text. More demandingly and more attentively, it is a question of experiencing this feminine resistance as a joint effect of interaction among literature, autobiography and theory, insofar as all three modes resist, precisely, one another. ${ }^{20}$

A través de la lectura de las obras escritas por hombres, Felman cuestiona repetitivamente qué es la feminidad. Las protagonistas femeninas, trazadas por Felman, muestran su duro

\footnotetext{
${ }^{19}$ Ibíd., p. 133.

Leer autobiográficamente es, pues, esencialmente un acto de dar testimonio: dar testimonio de la insospechada e inesperada "resistencia femenina" en el texto (véase el capítulo I). [Traducción propia].

${ }^{20}$ Loc. cit.

Leer autobiográficamente no puede ser, por lo tanto, una simple cuestión de invadir, con la propia historia de una, la resistencia femenina en el texto. De manera más exigente y atenta, se trata de experimentar esta resistencia femenina como un efecto conjunto de la interacción entre literatura, autobiografía y teoría, en la medida en que los tres modos se resisten, precisamente, unos a otros. [Traducción propia].
} 
destino y su dolorosa vida a través de su resistencia. Ejemplo de ello son una loca superviviente que deja las palabras y se muere por recuperar su consciencia volviendo al mundo del lenguaje y del significado y otra histérica que nunca se recupera y prefiere quedarse callada, rechazando así la palabra que le ofrece el médico. Las mujeres tratadas como objeto frente al sujeto del hombre. Pero ellas resisten, no se convierten en un buen objeto para los protagonistas varones y los escritores: siguen siendo locas y muertas, traicionan amando a otra mujer, son acusadoras a través del silencio. La feminidad que se encuentra en los textos es misteriosa, enigmática y desconocida para los hombres y ellos no saben qué hacer con estas mujeres.

La lectura que Felman plantea es que debemos encontrar el vínculo entre el enigma de la mujer y la resistencia femenina. En el caso del texto de Freud, el enigma de la mujer es el tema principal. Freud es el creador del Psicoanálisis, el primer hombre que observó a la mujer histérica, marginada e ignorada por la sociedad moderna occidental, dominada por el hombre. El concepto y el texto de Freud han sido una gran influencia para el pensamiento y la cultura. Para él, la feminidad es misteriosa, enigmática y desconocida hasta el último momento. A continuación nos aproximaremos con más profundidad a los detalles del análisis de Freud. 
I.2. La resistencia femenina como posible auto expresión. 
Puesto que la autobiografía de la mujer es un testimonio de vida de la mujer que incluye su trauma, el psicoanálisis es un factor importante para hacer posible esta autobiografía, llegando a estar incluso por encima del arte y de la teoría. La práctica de Freud sería considerable que fue uno de los primeros intentos de que un hombre hace a posibilitar que la mujer hable y, al mismo tiempo, que sea escuchada. En presente apartado nos aproximaremos un análisis de Shoshana Felman sobre un texto de Freud como una forma parte de la discusión de la autobiografía de la mujer y posteriormente destacaremos el planteamiento de Felman para el posible autobiografía de la mujer.

\section{I.2.1. Freud y las mujeres histéricas.}

Shoshana Felman analiza el episodio del sueño sobre Irma que tuvo Freud en el tercer capítulo del libro. Freud soñó con Irma, una paciente joven que había interrumpido la sesión psicoanalítica. Este sueño y su autoanálisis ocasionan que Freud escriba $\mathrm{La}$ interpretación de los sueños (1900). Felman observa la resistencia femenina y la perspicacia de Freud en el autoanálisis del sueño sobre Irma, el cual veremos siguiendo la perspectiva de Felman.

En el momento en que Freud vio el sueño de Irma, ellos habían interrumpido la sesión y él escuchó que ella no mejoraba mucho su estado de salud y seguía sufriendo. En ese periodo, Irma era una paciente que había fracasado en su tratamiento psicoanalítico, según Freud. La razón de interrumpir la terapia fue la actitud de Irma, quien no estaba de acuerdo con el tratamiento de Freud y se quedaba en silencio durante la sesión. De esta manera, Irma se resistió al médico. En el sueño que tuvo Freud, Irma le acusaba de su dolor de garganta, pero Freud pensaba que era culpa de ella. Después del autoanálisis, Freud consideró que el sueño se originaba como autodefensa contra la resistencia femenina y fue a partir de entonces cuando empezó a desarrollar la teoría del deseo inconsciente.

Felman valora mucho el reconocimiento de Freud de la resistencia femenina en el análisis del sueño y el establecimiento de la teoría sobre la resistencia femenina como un elemento inolvidable para el psicoanálisis. Se puede decir que el psicoanálisis de Freud parte desde el 
sueño, su autoanálisis y su autointerpretación. Lo más importante para Felman es que el sueño contiene un factor esencial para el descubrimiento del problema de la resistencia femenina, cuya existencia se sospechaba ambiguamente desde hacía tiempo, pero nunca fue buscada ni formalizada. El descubrimiento y la teorización de la resistencia femenina partiendo del psicoanálisis son admirables, aunque Felman considera que el exceso de Freud en torno al sueño es otro asunto aparte.

The genius of Freud's dream is to have recognized, precisely, that; and to have situated both the psychoanalytic lesson of the feminine resistance, and this unspeaking hability of the feminine complaint within his own male dream, this differentially of the female knot of pain with respect to his own theoretical solutions as the very nodal point of his specimen dream and as, indeed, the very navel of his dream of understanding. ${ }^{I}$

Felman interpreta que Freud encuentra la resistencia femenina como la acusación del dolor de Irma. Al mismo tiempo, él reconoce su impotencia frente a esa resistencia y no puede dar explicaciones ni argumentos sobre ella en el sueño. Es una declaración sincera de Freud y su testimonio del límite del lenguaje y la palabra del hombre. Freud aclara el caso de resistencia de su paciente: a la vez que el psicoanalista hace hablar a la paciente dándole la palabra, una parte de la mujer la rechaza con el silencio o la vacilación, mostrándose avergonzada. Ella se resiste a repetir las palabras al médico. El nudo, en este caso, es la causa del dolor y se encuentra en la garganta de Irma en el sueño. A causa de este nudo, ella sufre con el dolor que le oprime y no puede pronunciar las palabras del hombre. Esa mujer se resiste rechazando las palabras ofrecidas por el hombre, pero, mientras tanto, sufre por no poder hablar.

\footnotetext{
${ }^{1}$ Felman, Shoshana: What does a woman want? Reading and sexual difference. London, The Johns Hopkins University Press, 1993, p. 119.

El genio del sueño de Freud es haber reconocido, precisamente, esto; y haber situado ambas la lección psicoanalítica de la resistencia femenina, y esta imposibilidad de hablar de la queja femenina dentro de su propio sueño masculino, esto diferencia el nudo de dolor femenino respecto a las propias soluciones teóricas de lo masculino como el punto nodal de su sueño ejemplar y como muestra, de hecho, el mismísimo ombligo de su sueño masculino de entendimiento. [Traducción propia].
} 
La mujer resiste contra el acto del hombre; al mismo tiempo, la mujer no se satisface ni está contenta al no poder hablar en el sueño de Freud. Si Freud quería exigir la palabra a Irma, era posible y más fácil modificar la situación en el sueño que en la realidad, pero en su sueño tampoco lo consigue y Freud no lo ignora, sino que describe el sueño tal como es. Lo inigualable de Freud y el sueño, según Felman, es la confirmación de que el punto más importante es expresar el límite y la imposibilidad del hombre de dar las palabras a la mujer. El nudo hace sufrir a la mujer y ella le acusa de sufrir dolor, pero él no puede explicar qué es este nudo y tampoco puede quitarlo, así que no puede dar las palabras a la mujer. Freud afirma que existe algo ahí, aunque al mismo tiempo no sabe qué hacer con ello. Felman considera que en el sueño se puede vincular este nudo con el ombligo:

The female knot that constitutes the nodal point of the Irma dream -the dream's knot/navel-is thus prefigured in the initial image of the painful knot -the lump in Irma's throat-which somehow triggers, opens up the self-divided, self-analytic dialogue of Freud's dream. ${ }^{2}$

El ombligo del sueño para Freud es algo insondable e inescrutable.

In the speaking of the navel as "unplumbable" - a knot ("a tangle of dream thoughts") which "cannot be unraveled", the dream interpreter is explicitly suggesting that the navel of the Irma dream, though hinging on the mystery of femininity, is by no means a woman (Mother, Victorian lady, Irma, and so forth) but the cluster of ("comparison between") the women, that is, a structured female knot that cannot be untied, a knot of females differentiated with respect to any given definition; a knot, in other words, which points not to the inexhaustibility, the unaccountability, of female difference: difference that Freud-as man, as doctor, as interpreter-stumbles on experience at first as purely negative resistance, but which

\footnotetext{
${ }^{2}$ Ibid., pp. 117-118.

El nudo femenino que constituye el punto nodal del sueño de Irma-el nudo / ombligo del sueño-es prefigurado de esta manera en la primera imagen del nudo doloroso - el nudo en la garganta de Irma- que de alguna manera desencadena, abre el diálogo dividido y analítico por sí mismo del sueño de Freud. [Traducción propia].
} 
he then insightfully associates with the inexhaustibility, the unaccountability of the very nodal point -the very navel-of the dream. ${ }^{3}$

Felman presta atención a lo que Freud indica sobre el ombligo como la parte impenetrable e inexplicable del sueño y le llama $n u d o$, el enredo del pensamiento. El ombligo del sueño de Irma se vincula con el misterio que llevan, no solo Irma ni otra mujer, sino el grupo de diversas mujeres. Sin embargo, al mismo tiempo, el ombligo no muestra determinación de la identidad de la mujer o de la feminidad. Más bien indica la imposibilidad de explicar la diferencia de la feminidad y su infinidad, aunque estos aspectos tampoco se pueden eliminar. El ombligo es la huella del cordón umbilical que conectaba con la madre, del conducto de abastecimiento que nos vinculaba con ella cuando estábamos en su cuerpo. Era la única parte de unión con la madre. Después del parto, al cortar este cordón, nace un ser físicamente individual, aparte de la madre. Es decir, el ombligo es el punto de vínculo y, al mismo tiempo, es el punto de ruptura.

Según Felman, Freud indica la existencia del ombligo en la interpretación del sueño y en su texto, pero no puede controlar ni saber exactamente su significado. Para comprenderlo, Felman nos plantea que el ombligo es como la entrada para llegar a algo que ni se ha entendido, ni se ha podido encontrar su significado.

The "navel" is, in other word, Freud's discovery -through the Irma dream-that in every theory, interpretation, or conscious meaning there is in disconnection: that in every thought there is the navel of a dream; but also, that in every dream there is the navel of a thought. (...) The visionary thinking power of the dream from which psychoanalysis proceeds resides, however, in the groundbreaking ways in which the

\footnotetext{
${ }^{3}$ Ibíd., p. 115.

En el discurso del ombligo como "insondable" -un nudo ("una maraña de pensamientos de sueño") que "no se pueden descifrar", el intérprete del sueño sugiere explícitamente que el ombligo del sueño de Irma, aunque se vincula con el misterio de la feminidad, de ninguna manera se trata de una mujer (Madre, señorita Victoriana, Irma, etcétera), sino del grupo de ("comparación entre") las mujeres, es decir, un nudo femenino estructurado que no se puede desatar, un nudo de mujeres diferenciado con respecto a cualquier definición dada; un nudo, en otras palabras, que no apunta a lo inagotable, a lo no responsable de la diferencia femenina: la diferencia de que Freud-como hombre, como médico, como intérprete-, tropieza con la experiencia primeramente como resistencia puramente negativa, pero que él luego asocia perspicazmente con lo inagotable, lo no responsable del punto verdaderamente nodal - el verdadero ombligo-del sueño. [Traducción propia].
} 
dream's knot/ navel knots together -for the whole future of psychoanalysis- the question of the navel and the question of the woman as resistance. ${ }^{4}$

En resumen, Felman vincula el establecimiento del psicoanálisis de Freud, basado en el sueño de Irma y su autoanálisis, con un elemento importante de la autobiografía de la mujer, el cual es la lectura de la historia del "otro" como un acto indispensable. Aprecia mucho, en el caso del sueño sobre Irma en La interpretación del sueño, donde Freud descubre la aparición de la resistencia femenina y escribe el descubrimiento del ombligo como punto de interrupción-vinculación y entrada a lo impenetrable. Felman otorga su máximo elogio a Freud porque esta existencia, la del ombligo, nos confirma la realidad de que la feminidad va más allá del ombligo: es inexplicable, inexpresable e insondable con las palabras del hombre.

Por supuesto, Felman no justifica cualquier teoría ni metodología de Freud, pero piensa que atacar a Freud como enemigo de la crítica feminista no sirve; más bien, ignorar la teoría de Freud es una pérdida para el futuro desarrollo de la teoría feminista. Felman rechaza cierto tipo de prejuicios contra Freud, el ataque que suele recibir en la crítica feminista convencional es el que sigue: Freud es androcentrista, un devoto de la superioridad del hombre sobre la mujer, así que su teoría del psicoanálisis está estructurada en el falocentrismo. Felman cita a Juliet Mitchell, que intenta defender a Freud dentro del discurso feminista:

“The greatest part and feminist movement," writes Juliet Mitchell "has identified Freud as the enemy":

It is held that psychoanalysis claims women are inferior and that they can achieve true femininity only as wives and the mother... I would agree that popularized Freudianism must answer to this description, but the argument of this book is that a

\footnotetext{
${ }^{4}$ Ibíd., pp. 119-120.

El "ombligo" es, en otras palabras, el descubrimiento de Freud - a través del sueño de Irma- que existe en desconexión en cada teoría, interpretación o significado consciente: que en todo pensamiento está el ombligo de un sueño; pero también, que en cada sueño está el ombligo de un pensamiento. (...) El poder del pensamiento visionario del sueño a partir del cual procede el psicoanálisis reside, sin embargo, en las innovadoras formas en que el nudo del sueño / ombligo anudan juntas - para todo el futuro del psicoanálisis-la cuestión del ombligo y la cuestión de la mujer como resistencia. [Traducción propia].
} 
rejection of psychoanalysis is fatal for feminism. However it may have been used, psychoanalysis is not a recommendation for patriarchy, but an analysis of one. If we are interested in understanding and challenging the oppression of women, we cannot afford to neglect it. $^{5}$

Mitchell no ignora las características del psicoanálisis que tienen relación y un vínculo profundo con el sistema patriarcal. El discurso de Freud se encuentra frecuentemente arraigado en la idea patriarcal dentro de su texto y su teoría. Por ejemplo, su teoría pragmática: el complejo de Edipo, que margina a la mujer como Sujeto y solo la identifica como madre y esposa. No obstante, la sociedad occidental, en sí, es patriarcal, oprime y margina a la mujer. Y el psicoanálisis, a pesar de analizarla, no escapa de esta realidad, con lo que ese carácter patriarcal no puede extraerse completamente de él. Para saber la manera en que la mujer es oprimida en esta sociedad patriarcal y de esta manera encontrar cómo combatir esa función, el psicoanálisis analiza el sistema patriarcal de diferente manera y desde otro punto de vista fuera de lo convencional; este factor debería beneficiar mucho al feminismo, en opinión de Mitchell. Felman está de acuerdo con esta parte de la opinión de Mitchell:

Like Mitchell, I am concerned with the misguided feminist belief that identifies Freud as the enemy of women: I take this attitude to be a grave misreading that fundamentally misconstrues both psychoanalysis and its as yet unexplored potentialities for a feminist reflection. Like Mitchell, I believe that feminism -the struggle toward a new feminine awareness fighting sex discrimination and redefining male and female sex roles- cannot afford to disregard psychoanalysis. ${ }^{6}$

\footnotetext{
${ }^{5}$ Mitchell, Juliet: Psychoanalysis and Feminism: Freud, Reich, Laing and Women, Vintage books, Nueva York, 1975, Xiii. En: Felman, Shoshan. Op. cit., p. 68.

"La mayor parte y el movimiento feminista", escribe Juliet Mitchell, "ha identificado a Freud como al enemigo": Sosteniendo que el psicoanálisis mantiene que las mujeres son inferiores y que pueden lograr la verdadera feminidad solo como esposas y madres... estoy de acuerdo en que la popularización del Freudianismo responde a esta descripción, pero el argumento de este libro es que un rechazo del psicoanálisis resulta funesto para el feminismo. Sin embargo, a pesar de cómo haya podido ser utilizado, el psicoanálisis no es una recomendación para el patriarcado, sino un análisis de uno. Si estamos interesadas en comprender y desafiar la opresión de las mujeres, no podemos permitirnos descuidarla. [Traducción propia].

${ }^{6}$ Felman, Shoshana. Op. cit., pp. 68-69.

Al igual que Mitchell, me preocupa la creencia equivocada del feminismo que identifica a Freud como el enemigo de las mujeres: tomo esta actitud como una grave malinterpretación que fundamentalmente se forma una idea
} 
Felman les insiste a las feministas que rechazan a Freud, para que reflexionen sobre su actitud. Con este fin, muestra la desventaja que supone para el feminismo, en su desarrollo futuro, la lectura errónea de los textos de Freud. Sin embargo, y de manera simultánea, afirma que la propuesta feminista tiene razón, hecho este sobre el que Mitchell no daba cuenta:

I agree that psychoanalysis is not a recommendation or normative prescription for, but rather an analysis of, the patriarchal symbolic system in which we live (...) I admire and endorse Mitchell's paradoxical position as a feminist advocate of Freud, but I cannot endorse, in theory, the unreachable totality of the advocacy, that is, its implicit theoretical assumption that Freud, because he was the genius that he was, was inherently incapable of error, prejudice, or oversight: that Freud is thus by definition innocent of any feminist critique. ${ }^{7}$

De esta manera, Felman duda de la tendencia dogmática y suprema de Freud en la teoría psicoanalítica, que ignora la propuesta de las feministas. Actualmente, muchas de las feministas, al recapacitar sobre la cuestión de la mujer, modifican su conducta; empiezan a reconocer la importancia y la utilidad del psicoanálisis, aunque no dejen de criticar el falocentrismo del discurso de Freud. En este movimiento de crítica a Freud por parte del feminismo, Luce Irigaray, feminista psicoanalista, es bastante conocida internacionalmente.

Sin embargo, vemos cómo Felman cita a Sarah Kofman en lugar de citar a Luce Irigaray. Kofman es una filósofa francesa de la misma generación que Irigaray; no es psicoanalista, pero introduce la teoría y el método de Freud para la crítica de la filosofía francesa moderna,

equivocada tanto del psicoanálisis como de sus potencialidades aún no exploradas para una reflexión feminista. Al igual que Mitchell, creo que el feminismo -la lucha hacia una nueva concienciación femenina que luche contra la discriminación sexual y que redefina los papeles del sexo femenino y masculino- no puede darse el lujo de hacer caso omiso del psicoanálisis. [Traducción propia].

${ }^{7}$ Ibíd., p. 69.

Estoy de acuerdo en que el psicoanálisis no es una recomendación o prescripción normativa para, sino más bien un análisis del sistema simbólico patriarcal en el que vivimos (...) Admiro y apruebo la posición paradójica de Mitchell como feminista defensora de Freud, pero no puedo aprobar, en teoría, la inalcanzable totalidad de esa defensa, es decir, su supuesto teórico implícito de que Freud, porque ser el genio que fue, fuese intrínsecamente incapaz de errores, prejuicios, o errores: que Freud es pues, por definición, inocente de cualquier crítica feminista. [Traducción propia]. 
como Auguste Comte o Jean-Jacques Rousseau, entre otros. Kofman tiene numerosas publicaciones sobre el pensamiento de Freud. A diferencia de Irigaray, Kofman no declara ser feminista ni haber participado en ningún movimiento. En su libro Enigma de la mujer (1980), hace una dura crítica al androcentrismo y al desprecio de Freud hacia la mujer. Al mismo tiempo, revela los errores en la traducción al francés de los textos de Freud por parte de Irigaray, donde se han omitido algunos términos importantes para su crítica:

No nos parece inocente que la mayoría de las críticas contra Freud se basen en esta «traducción» francesa. Luce Irigaray pretende decir que la traducción minuciosa no habría cambiado gran cosa de la significación de ese discurso «sobre la feminidad» (p. 9, nota 1 de la obra citada). Al menos podemos dudar y preguntarnos por qué Luce Irigaray continúa usando casi siempre una traducción aun sabiendo de sus errores, si no es por las necesidades de «la causa». ¿La de feminidad? No se trata de intentar «salvar» a Freud a toda costa remitiéndose al texto alemán (nosotros no lo «salvaremos» más que ella), simplemente de actuar con una mínima honestidad intelectual consistente en criticar a un autor en función de una crítica, correctamente hecha, más fuerte. Al consultar el texto de Freud nos damos cuenta, por otra parte, de que es mucho más complejo, más heterogéneo de lo que permite apreciar la traducción francesa. ${ }^{8}$

En el mismo libro donde Kofman dice que no tiene ninguna intención de salvar a Freud más que Irigaray, a través del ejemplo del sueño de Irma, nos aclara el sistema y procedimiento del psicoanálisis de Freud: solo al aceptar la palabra del médico-oyente, la mujer que sufre el trauma puede hablar, de lo contrario solo se puede quedar callada. Según Kofman, cuando la mujer habla significa que obedece al amo, repitiendo su palabra en el caso del psicoanálisis de Freud.

\footnotetext{
${ }^{8}$ Kofman, Sarah: El enigma de la Mujer. ¿Con Freud o contra Freud? trad. Estella Ocampo, Barcelona, Gedisa Editorial, 1997, pp. 27-28.
} 
La solución psicoanalítica devuelve a la mujer su palabra para quitársela mejor, para subordinarla mejor a la del señor. ${ }^{9}$

Felman, citando esa frase, pone en el lugar de la feminista airada a Kofman y muestra su inquietud de que Freud se ha condenado como malo en el discurso feminista:

Such rage, unfortunately, is self-blinding. As a woman, I cannot but understand the anger. But as a reader, I cannot but deplore the way in which I see the anger miss its mark; miss its own critical objectives in sliding toward a caricature -both of Freud and of itself. ${ }^{10}$

Aunque tenemos algunas dudas sobre la opinión de Felman en referencia al texto de Kofman, de momento las dejaremos para plantearlas más adelante.

La cuestión más importante que plantea Felman en la lectura sobre Freud es mencionar el punto ciego del texto y la perspicacia de Freud, y tratar de dialogar cada uno. Estos elementos hacen que la discusión en torno al vínculo entre el ombligo del sueño y el texto fructifique con el enigma de la feminidad que ya hemos mencionado.

The dreamer is predicting here, in other words, that femininity -the question of the woman and the woman as a question - is bound to remain unsolved and unresolved in psychoanalytic theory to the extent, precisely, that it is the very navel of psychoanalysis: a nodal point of significant resistance in the text of the ongoing psychoanalytic dream of understanding; a navel that, although "unplumbable," is also positively (to borrow once again Freud's terms) psychoanalysis's "point of contact with the unknown": psychoanalysis's potential for renewal, for a renewed

\footnotetext{
${ }^{9}$ Ibíd., p. 62.

${ }^{10}$ Felman, Shohana. Op. cit., p. 69.

Esa rabia, por desgracia, es auto-ceguera. Como mujer, no puedo dejar de comprender la ira. Pero como lectora, no puedo sino deplorar la forma en que veo que la rabia pierde el norte, pierde sus propios objetivos críticos al deslizarse hacia una caricatura... tanto de Freud como de sí misma. [Traducción propia].
} 
discovery of its own special, revolutionary insight, through its continuing dynamic play-and self-analytic dialogue-with the unconscious of its own self-difference. ${ }^{11}$

De esta manera, Felman concluye la parte sobre la teoría de Freud. Posteriormente, delibera sobre la autobiografía de la mujer, haciendo una reflexión que cambia un poco su opinión:

\begin{abstract}
At the time I wrote the chapter, I wanted to include both men and women in my address. If I destined my ideas and the process of my thinking to, among others, an implicit privileged male reader, it was because my effort then was precisely to include men in the feminist critique of their position. My main concern in the writing was then to elaborate an innovative structure of address that would be specifically inclusive, as opposed to the exclusive structure of address I was deciphering in Freud, and which, I saw as typical of patriarchal utterance, which by definition -if sometime unwittingly-erase women as subjects while maintaining their position as desired objects, always fascinating, sometimes baffling, at moments incomprehensible. $^{12}$
\end{abstract}

Dejamos de lado nuestro juicio acerca del resultado del proyecto de Felman. Muchos pensadores y psicoanalistas afirman claramente que el texto de Freud es una típica expresión patriarcal y su sistema de expresión patriarcal, como resultado, excluye a la

\footnotetext{
${ }^{11}$ Ibíd., p. 120.

Aquí el soñador está prediciendo, en otras palabras, que la feminidad -la cuestión de la mujer y la mujer como una cuestión-se ve obligada a permanecer sin ser solucionada y sin ser resuelta en la teoría psicoanalítica en tal medida, precisamente, que es el mismísimo ombligo del psicoanálisis: un punto nodal de una importante resistencia en el texto del actual sueño psicoanalítico de comprensión; un ombligo que, aunque "insondable", también es positivamente (pidiendo prestados, una vez más, los términos de Freud) el "punto de contacto con lo desconocido" del psicoanálisis: el potencial de renovación del psicoanálisis para un renovado descubrimiento de su propia visión revolucionaria y especial a través de su continua dinámica de juego -y auto-diálogo analíticocon el inconsciente de su propia diferencia. [Traducción propia].

${ }^{12}$ Ibíd., pp. 124-125.

En el momento en que escribí el capítulo, quería incluir tanto a hombres como a mujeres en el trato de mi discurso. Si destinaba mis ideas y el proceso de mi pensamiento, entre otros, a un privilegiado lector masculino implícito, fue porque mi esfuerzo entonces fue precisamente incluir a los hombres en la crítica feminista de su posición. Después, mi principal preocupación en la escritura fue la elaboración de una estructura de tratamiento innovadora que sería específicamente inclusiva, en contraposición a la estructura de tratamiento exclusiva que estaba descifrando en Freud, y que yo veía como la típica expresión patriarcal que, por definición -acaso alguna vez involuntariamente- borra a las mujeres como sujetos mientras mantiene su posición de objetos deseados, siempre fascinantes, a veces desconcertantes, y por momentos incomprensibles. [Traducción propia].
} 
mujer como sujeto hablante; la obra de Kofman lo muestra de manera muy clara, y está basada en una lectura minuciosa del texto de Freud.

I did not want to respond in sort: I did not want to exclude Freud, to erase men as potential addressees, and to repeat the patriarchal structure of exclusion in reverse; I wanted rather to attempt to transform this structure by making its exclusions patent and by performatively demonstrating their lack of integrity (in all senses of the word), by interposing my own voice as a woman reader inside Freud's utterance, and by thus enacting its rhetorical and philosophical explosion from its own inside. $^{13}$

Suponemos que el motivo real de Felman es el de evitar repetir el procedimiento del sistema patriarcal, que oprimía el derecho y el acto de hablar a la mujer; de forma revanchista prescindiendo del hombre. Por eso, Felman no quiere rechazar el diálogo con Freud, aunque tampoco quiere posicionar lo uno por encima de lo otro dividiendo los opuestos -como era el caso de otras feministas-, porque considera que eso solo conservaría la estructura en sí; la única diferencia sería que habría invertido la opresión del hombre hacia la mujer. Por esta razón, ella piensa que no se debe excluir a Freud como interlocutor, aunque hable en tono patriarcal. Nosotras no vemos ningún inconveniente en su opinión.

Sin embargo, si continuamos leyendo su texto, Felman critica a Kofman como si fuera la representante que condena y silencia a Freud, eliminándolo. Siguiendo a Felman, Kofman es una típica feminista que padece autoceguera inducida por la rabia contra el hombre, y así pierde su propia crítica objetiva derivando hacia la caricatura. En estos términos, Felman comunica su reflexión.

\footnotetext{
${ }^{13}$ Ibíd., p. 125.

Yo no quería responder de la misma manera: no quería excluir a Freud, para borrar a los hombres como posibles destinatarios, y repetir la estructura patriarcal de exclusión a la inversa; más bien yo quería tratar de transformar esta estructura haciendo patentes sus exclusiones y demostrando performativamente su falta de integridad (en todos los sentidos de la palabra), mediante la interposición de mi propia voz como mujer lectora dentro de la expresión de Freud y, de este modo, promulgando su explosión retórica y filosófica desde su propio interior. [Traducción propia].
} 
Ahora nosotras analizaremos un poco a Kofman tomando como punto de partida la opinión de Felman. Según Felman, Kofman no propicia ningún lugar para que el hombre participe, pero desde nuestra posición como lectoras, nosotras defendemos que el libro de Kofman no excluye completamente la participación de lectores masculinos, aunque reconocemos que tampoco la facilita demasiado. El estigma de la mujer, al tener un estilo propio, hace una omisión muy particular y emplea una retórica con la que habla por Freud: escribe "yo" en lugar de decir "según Freud" o "la idea de Freud", con lo que da la impresión de ironizar y burlarse del texto de Freud. Sin embargo, como ya comentamos anteriormente, si leemos su texto con perseverancia, se aclara la diferencia entre la definición y la imagen convencional de la mujer basada en el desprecio y la marginación de la tradición metafísica occidental. Y sobre Freud, tras una lectura detallada de su texto original, proporciona una advertencia dura y sincera a Irigaray, quien intenta criticar a Freud como uno de los representantes del androcentrismo y sucesores de la metafísica.

Kofman no tiene la intención de excluir a los lectores masculinos, los hombres como posibles destinatarios, lo cual es evidente y parece una acusación falsa por parte de Felman. Como mencionamos con anterioridad, Kofman nunca pretendió ser feminista ni participó del feminismo en toda su vida. Es una filósofa escritora que reclama la tradición de la filosofía y la metafísica occidentales. No podemos imaginar que ella excluye a las lectoras femeninas; sin embargo, dada la tradición de la filosofía, principalmente supondría a los lectores masculinos. Además, desarrolla su discusión aclarando en qué manera se margina a la mujer mientras visibiliza la diferencia entre el discurso tradicional metafísico y el de Freud.

Como hemos señalado antes Kofman, aunque muestra una lectura e interpretación erróneas por parte de Irigaray, al mismo tiempo no deja de criticar el desprecio hacia la mujer que ha escrito de forma encubierta. Por esta razón, no negamos que Kofman critica puntual y duramente a Freud como padre del psicoanálisis, el sujeto que observa a la mujer como objeto, el médico de la paciente, el sujeto escritor que escribe favoreciéndose a sí mismo sobre el resultado de la observación; en resumen, el padre que ejerce el poder sobre la mujer como esposa e hija, develando la estructura del sistema patriarcal. Sin embargo, es 
demasiado imprudente pensar y juzgar que todos los hombres se acobardan y no se comprometen en la discusión para enfrentarse a esa crítica implacable sobre el carácter patriarcal.

El texto de Kofman muestra una tendencia a la objeción y reclamación, sumada a cierta indignación hacia Freud, y no lo negamos, pero es severo justificar que se trata de rabia a causa de autoceguera. La actitud de Felman hacia Kofman, en este caso, parece la de una mujer sabia y serena que presta poca atención a otra mujer que grita: reconoce en esta voz -que antes era solo un ruido- alguna significación, y piensa que por la misma rabia sufre autoceguera. La que grita es la mujer que ha sido obligada a quedarse en silencio o a repetir únicamente la palabra del amo a lo largo de la historia, de manera legal e ilegal. Además, su voz no llegaba a nadie o, aunque llegara, era solo un ruido sin sentido y excluido. Por lo menos, alguien que se llame feminista a sí misma debería saber escuchar ese ruido, aunque no sepa bien lo que significa. Por rabia, miedo, dolor y otras causas, la mujer histérica que solo sabe gritar y hacer ruido obliga a Freud a crear el psicoanálisis: el tiempo y el espacio de hablar reservados a la mujer ofrecen una ocasión, aunque sea insuficiente, para escucharla y buscar su significado dentro de su voz.

Cuando Felman, durante la discusión para las posibilidades de una autobiografía de la mujer, basa su perspectiva en el psicoanálisis en gran parte, formula su crítica hacia el texto de Kofman diciendo que "pierde su propia crítica objetiva" por el tono de furia, afirmación esta que nos parece un poco injusta.

Sin duda, la atención de Felman es cierta a grandes rasgos y no tenemos intención de negar su opinión. Muchos discursos del feminismo y de las feministas, a la vez que reclaman y proponen alternativas ante la injusticia y la segregación contra la mujer, atacan dejando estallar su ira, y de esta manera caricaturizan no solo al enemigo, sino a sí mismas. Con esto, además de hacer impreciso el quid de la cuestión, resulta dudosa la significación y la importancia de la discusión en sí. Hay innumerables muestras de este tipo de problema: no podemos negar que estos ejemplos caricaturizados han causado un prejuicio sobre la crítica feminista que se ha estancado junto a la premonición del fin del feminismo. Sin embargo, 
es fácil apuntar los defectos, reírse despectivamente con los ejemplos fracasados y afirmar la superioridad de una misma. Lo importante, para nosotras, es estudiar estos ejemplos y cuidarnos de repetirlos; es decir, aclarar cuál es el punto principal de la cuestión y hacer visible la importancia y la significación de la discusión.

Hemos mencionado la exageración de Felman sobre la lectura errónea de Kofman, ya que su lectura no era perfecta ni completa. Sin embargo, no podemos ignorar que el punto de contradicción de lectura de Kofman detectado por Felman es muy agudo:

Kofman's reading does not in effect analyze the dream but paraphrases it incompletely, echoing but one of its many voices. Paradoxically enough, in blaming Freud for his repressive and reductive male appropriation of female speech, what Kofman is precisely doing is (selectively, reductively) appropriating Freud's own words.

But the symmetry, here as elsewhere, is misleading. For in seemingly, reversing Freud's appropriative gesture, Kofman fails to see that the Irma dream is not simply a description of Freud's attempt at mastery; it is a description, a dramatization, of the necessary failure of such an attempt: the Irma dream is, on the contrary, a recognition of the impasse (medical and sexual) inherent in the very impulse to appropriate, to forcefully reduce the otherness of the other. ${ }^{14}$

El método de análisis y la crítica de Kofman siguen la misma metodología de Freud, si se examina bien. Kofman arremete contra Freud empuñando como espada el método psicoanalítico que ha inventado él mismo, pero esa espada es de doble filo y no solo puede emplearse para desmenuzar a la mujer; Kofman muestra este carácter de la teoría de Freud

\footnotetext{
${ }^{14}$ Ibid., p. 90.

Efectivamente, la lectura de Kofman no analiza el sueño, sino que lo parafrasea... de forma incompleta, haciéndose eco de una sola de sus muchas voces. De forma bastante paradójica, cuando culpa a Freud de su apropiación masculina represiva y reductiva del discurso femenino, lo que Kofman está haciendo es precisamente (de manera selectiva, reductiva) es apropiarse de las propias palabras de Freud.

Sin embargo, la simetría, aquí como en otros lugares, es engañosa. Ya que al invertir aparentemente el gesto de apropiación de Freud, Kofman no consigue ver que el sueño de Irma no es simplemente una descripción del intento de Freud de lograr el dominio; es una descripción, una dramatización, del fracaso necesario de tal intento: el sueño de Irma, por el contrario, es un reconocimiento del punto muerto (médico y sexual) inherente al propio impulso de apropiación, para reducir por la fuerza la alteridad del otro. [Traducción nuestra].
} 
en su performance (nos referimos su estilo de expresión propio, que crea una especie de actuación). Esta estrategia es un poco peligrosa. Porque, como indica Felman, nos puede dar la impresión de que ella repite lo mismo que critica acerca de Freud. En cierto modo, podemos juzgar que Kofman lo hace para demostrar la manera de apropiación de Freud, con cierta intención de caricaturizarlo, ya que ese tipo de "performance" demuestra de forma clara y grotesca, en este caso, el proceso de expropiación de Freud. Es como una película de terror de zombis: el cazador intenta resistir al demonio, pero en poco tiempo todo el mundo se vuelve zombi. La escena es muy grotesca, pero es muy fácil de entender la estructura y cómo funciona.

Según Felman, Kofman no se ha dado cuenta y no ha encontrado el carácter del punto muerto sobre el sueño de Irma. Sin embargo, tenemos ciertas dudas al respecto, pero no profundizaremos en este tema dado que la inspiración de Felman, que empieza a reflexionar desde el punto muerto sobre el texto y el sueño sobre Irma de Freud, nos posibilita salir de este círculo cerrado del que no logró salir Kofman, consciente o inconscientemente.

Por otra parte, ésta sería la última duda respecto a Felman en comparación con la lectura de Kofman. Felman dice que durante la lectura y el esfuerzo de diálogo con Freud y su texto, ella espera que ocurra una explosión filosófica. Admiramos más bien poco su actitud, porque en realidad se trata de un asunto filosófico y no debe paliar o disminuir el problema por la retórica literaria. Su expresión es literalmente hermosa y dinámica, pero no se entiende muy bien qué quiere decir en concreto. La forma es muy diferente, pero la aproximación filosófica al texto de Freud que realiza Kofman es más profunda y minuciosa. $\mathrm{Al}$ igual que ocurre con Felman, que posee un amplio conocimiento sobre el texto de Freud, en la bibliografía literaria francesa y la crítica feminista no debería haber este tipo de errores. Pero si la cita sobre el texto de Kofman es desequilibrada y la interpretación parcial, sea o no intencional, dudamos de que Felman confunda el argumento de Kofman con el de Irigaray, principal representante del criterio feminista contra Freud.

Si es así, solo cabe citar unas frases que convengan para la crítica aguda hacia Freud y para caracterizar a Kofman como una representante de la crítica feminista de su generación, 
incluida Irigaray. Felman no puede ocultar la contradicción teórica, y no es honesta su postura con estos prejuicios. Aunque la crítica de Felman contemplaba a Irigaray, condenarla únicamente por alborotarse y pretender la superioridad de la mujer sobre el hombre, no es justo. Es muy parecido al caso de Irigaray, que ha sido injustamente tildada de esencialista en la discusión de la feminidad por muchas feministas en Norteamérica. Sobre este asunto haremos una ampliación posteriormente.

No negamos el trabajo de Felman, lo admiramos y apreciamos mucho; especialmente el énfasis que pone en la imposibilidad de expresar algo integral y único sobre la mujer y la feminidad. Lo consigue mostrando su perspicacia genial y la discusión que busca la posibilidad de la autobiografía de la mujer en el cruce de la literatura, la teoría y el psicoanálisis. Esto abre la viabilidad de considerar las posibilidades de la autobiografía de la mujer en el vínculo y la ruptura entre arte, teoría y psicoanálisis. Su argumento contiene unas cuestiones importantes que debemos desarrollar en el futuro. Con todo, no podemos ignorar un punto que nos preocupa, el cual es, paradójicamente, su capacidad literaria sobresaliente y un manejo retórico maravilloso, que resulta faltar a la honestidad de la discusión. Es decir, nos engaña ocultándonos y haciéndonos invisibles algunos factores. Nos explicaremos a continuación.

\section{I.2.2. El relato de la otra mujer, entre la fisura y la articulación.}

El texto de Felman, debido a la complejidad de la discusión y al abismo del tema, a primera vista es muy denso de leer. Sin embargo, su agudeza y la singularidad de su punto de vista nos dejan abrumadas y nos obligan a centrarnos en su discusión. Además, como dijimos anteriormente, la expresión de su texto es vital, poética y hermosa, muestra el talento literario de la autora, nos convence e hipnotiza. A pesar de ello, esto es en realidad el punto débil de su discurso. Es decir, el texto de Felman no tiene el ombligo que dice Freud; más bien, la mayor parte de la retórica y expresión literaria cubren y hacen invisibles el ombligo del texto. Su explicación, su expresión y su historia son demasiado completas y perfectas. Por esa perfección nos hace sospechar la contradicción de su planteamiento. Es decir, en su texto no se ve el ombligo, no se encuentra la grieta ni la fisura a pesar de su argumento de 
que la autobiografía de la mujer y el testimonio de supervivencia de la mujer solo se lograrían en la grieta y la fisura entre literatura, teoría y psicoanálisis. En el caso de Felman no es que las huellas no existan, sino que están bellamente ocultas.

La retórica literaria cubre y oculta la fisura y su huella, se establece un discurso integral y uniforme. Esta perfección del texto funcionaba y sigue funcionando para ser aprobada en el mundo occidental tradicional, y al mismo tiempo forma parte del establecimiento del mundo legítimo estético-histórico occidental. A la sombra del ejemplo de Felman, nos interesa la función de la retórica y de la técnica que actúan en pro de la perfección estética funcional que tapa y cubre esa hendidura. Ahora nos atreveremos a argumentar que la única manera de la autobiografía de la mujer se da al despojarla de esa retórica fija y visibilizando la fisura y su disputa en la mujer. Y sería indispensable escribir -o por lo menos sugerir-el ombligo, el punto del vínculo y la interrupción de lo desconocido de la feminidad que mencionaba Freud. Paradójicamente, en este sentido, el trabajo de quitar y despegar la retórica fija convencional y desvelar el ombligo, es, justamente, el trabajo artístico, al menos en el sentido del arte contemporáneo.

El carácter del texto de Felman, como hemos mencionado hasta ahora, contiene algunas partes que nos hacen dudar, pero eso no significa que despreciemos su consideración por completo. Por esta razón volveremos a discurrir sobre la última parte de su argumento sobre Freud. Como apuntamos anteriormente, en su lectura de Freud, Felman insistía en hablar de la dirección del hombre. La autora modifica un poco el punto de énfasis en la parte que considera la posibilidad de la autobiografía de la mujer basada en los análisis de los capítulos anteriores junto a la reflexión sobre el diálogo con Freud. Felman emplea la palabra address para discurrir acerca del acto de hablar en cierta dirección. Su discusión desarrolla el cambio de dirección y su importancia para la comunidad de mujeres a la vez que se dirige también al hombre como interlocutor.

The need to speak to women without the intermediary of man, to listen more attentively to women, and to address more urgently the community of women, has imposed itself as a corollary of my growing sense that the feminine predicament of 
"the absence of a story" (or its counterpart, "the presence of too many stories") can be truly grasped, and perhaps remedied, only by the exchange of stories; that only women, can empower women's story only through women's collective perception of themselves. ${ }^{15}$

Felman argumenta que se debe buscar la manera en que la mujer hable por la mujer a través de la lectura: compartir las historias del "otro" leídas por la mujer con las mujeres e intercambiarlas, además de comprender y visibilizar cuál es la falta y la pérdida para la lectura de las mujeres.

Sobre el tema de la comunidad posible de las mujeres, nos aproximaremos a él posteriormente, en la discusión de la comunidad que debe existir entre las mujeres, utilizando para ello el testimonio que ha planteado Drucilla Cornell ${ }^{16}$ tras estudiar la cuestión del feminismo del poscolonialismo con la imposibilidad de hablar del subalterno de Gayatri C. Spivak ${ }^{17}$. Por ahora, manifestamos que estamos de acuerdo en la mayor parte de ese planteamiento y en las pequeñas dudas con respecto al argumento de Felman. Y dichas dudas son: ¿es posible hablar a la comunidad de mujeres sin la intervención del hombre?, eso... ¿no será una propuesta que intenta marginar al otro género por imaginar una idea utópica? Por supuesto, no tenemos ninguna intención de condenar a Felman como exclusivista tomando en consideración solo este punto, ni de acusarla por reducir el feminismo únicamente al problema de la mujer.

Puede resultar un poco repetitivo, pero queremos aclarar nuestra postura sobre la discusión que favorece la inversión en la relación del poder dominante del hombre sobre la mujer y la exclusión del hombre en la teoría feminista. Frente a la realidad de la marginación de la

\footnotetext{
${ }^{15}$ Ibíd., p. 126.

La necesidad de hablar con la mujer sin la intermediación del hombre, de escuchar más atentamente a la mujer, y de dirigirse con más urgencia a la comunidad de las mujeres se ha impuesto a sí misma como un corolario de mi creciente concienciación sobre el hecho de que el aprieto femenino de "ausencia de una historia" (o su contrapartida, "la presencia de demasiadas historias") puede ser verdaderamente comprendido, y tal vez subsanado, solamente intercambiando historias; que solo las mujeres pueden potenciar la historia de las mujeres, y solo a través de la percepción colectiva de las mujeres de ellas mismas. [Traducción propia].

${ }^{16}$ Véase el capítulo III.

${ }^{17}$ Véase el capítulo II.
} 
mujer en la modernidad, se ha establecido el dominio del hombre en el discurso occidental; existe un tipo de discusión que argumenta: para liberar a la mujer se debe excluir al hombre. La idea nos parece poco significativa y efectiva. Si esa idea todavía permanece como la meta del feminismo, no participamos del feminismo ni somos feministas. Nosotras, al igual que Kofman, no creemos que debamos ser feministas, ni pensamos que solo las feministas pueden opinar sobre el discurso y la crítica feminista. Lo que suponemos y entendemos es que la crítica feminista analiza y reprocha la injusticia y el absurdo del sistema androcentrista patriarcal, que es el fundamento masculino establecido en la modernidad occidental. El feminismo es una práctica y una teoría que plantea alternativas contra diversos tipos de segregación, opresión y discriminación bajo la influencia del dominio del fundamentalismo masculino moderno. El punto de partida del movimiento surgió dentro de las cuestiones de la mujer porque se puede observar cierta evidencia en la contradicción del dominio masculino. Pero esto no significa que sea un movimiento de la mujer, por la mujer y para la mujer, eliminando al hombre.

Durante nuestra discusión, el nombre de Luce Irigaray aparece como el pronombre de la feminista a la que se debe criticar. En realidad, la idea sobre la feminidad de Irigaray fue criticada bastante a causa de que su discusión se ha reducido al esencialismo, sobre todo en Norteamérica. Una parte es cierta, su discurso contiene muchos fragmentos que merecen la crítica, por ejemplo el reclamo de Kofman, como hemos visto. Pero al mismo tiempo se ha divulgado su teoría con el malentendido de su argumentación centrada solo en los detalles, y no se ha permitido que las personas interesadas se introduzcan en el motivo real de su planteamiento.

Irigaray plantea el fundamentalismo femenino a la vez que el masculino; a primera vista se ve que solo está planteando invertir el dominio masculino por el femenino, pero no nos apresuremos a juzgar. En la tradición metafísica occidental basada en el fundamentalismo masculino, sobre todo en el sistema androcentrista establecido en la época moderna, para cuestionar y reflexionar acerca del ser humano, se supone un modelo de individuo masculino. Permanece ignorada la parte de las actividades cotidianas repetitivas en el hogar, 
como cocinar y comer, luego lavar la vajilla, coser y lavar la ropa que se lleva por la calle, dar a luz, cuidar de niños, ancianos, enfermos y discapacitados...

Esta visión también da por descontado la función de la continuidad del humano en el tiempo; por ejemplo, la cuestión del alumbramiento. La idea de Irigaray es criticar este esquema que presupone el modelo masculino como individuo moderno, y plantea la reconsideración sobre el ser humano en tanto que no pueden faltar las actividades continuas y los trabajos cotidianos vinculados con la feminidad. Esas actividades estaban a cargo de la mujer, aunque fue ignorada y marginada del sistema de valoración metafísica y capitalista durante mucho tiempo.

En este sentido, una reconsideración basada en el principio femenino nos da otra perspectiva nunca contemplada desde el fundamentalismo masculino. Si comprendemos de esta manera la opinión de Irigaray, no se puede juzgar tan a la ligera como el esencialismo femenino, ni se concluye con la exclusión de los hombres. Al reflexionar sobre el sistema y el ser humano vinculado a la feminidad, se visibilizan los puntos a cuestionar y el nuevo planteamiento alternativo que nunca emergía antes, es decir, la crítica feminista fundamental.

En este momento de reconsideración, no nos parece que sea posible anular ni ignorar la manera y el sistema que ha establecido el fundamentalismo masculino. Tampoco seamos tan optimistas que pensemos que todo se resuelve solo con cambiar del fundamentalismo masculino al femenino. No obstante, la aproximación basada en el principio femenino como método de visibilizar lo invisible y lo ocultado por el dominio masculino moderno, es válida. Además, no se han acabado de plantear las cuestiones y su discusión aún, ésta es la parte que debería desarrollarse más, tanto desde la teoría como en la práctica.

Por esta razón, la manera de considerar el feminismo tan solo como cuestión de la mujer y que únicamente las mujeres puedan reflexionar y tratar sobre el asunto, es una visión estrecha y se pueden perder los puntos esenciales de la discusión. 
La crítica de Felman al feminismo convencional, aunque se deje llevar por una perfección retórica, será una reflexión que muestre la dirección de la postura del feminismo. Se necesita el diálogo y hablar al "otro"; estos nuevos planteamientos se están convirtiendo en la discusión dominante del posfeminismo: buscar una nueva estructura que pueda escaparse del sistema moderno, y suponiendo esto, liberarse de las oposiciones dicotómicas -como el feminismo contra el psicoanálisis y el hombre contra la mujer- procurando dar superioridad a lo uno sobre lo "otro" y así continuar la disputa del ataque mutuo.

Ahora veremos, en resumen, la argumentación de Felman en esa tendencia del posfeminismo, para confirmarla. En la sociedad moderna occidental, basada en el logocentrismo dominado por el hombre, la mujer en sí como un sujeto no podía participar en la comunidad intelectual -filosofía, literatura y arte- y se ha quedado marginada. La mujer para pensar y hablar de sí misma siempre ha tenido una dificultad incorregible, porque a cualquier mujer durante su educación se le capacita para verse a sí misma como “objeto" y se posiciona como el "otro". Así que la mujer no puede hablar de su historia por sí misma y esta historia todavía no existe, está esperando a convertirse en "una". En otras palabras, la comunidad y el vínculo entre mujeres se ha perdido; como consecuencia, el lenguaje, la palabra y la historia como formas de expresión de la mujer en sí misma, se han perdido. Por esta razón, la autobiografía de la mujer está perdida.

El intento de realización de la autobiografía de la mujer ya ha comenzado en manos de escritoras como Virginia Woolf, Simone de Beauvoir y Adrienne Rich, entre otras: todas sus historias perduran como el documento del vínculo y la división entre la teoría, la autobiografía, el psicoanálisis y la literatura (en nuestro caso, digamos, es la forma de arte) en su teoría y en su práctica. Es decir, nunca es una historia unificada coherente, sino que es una historia que presenta la pérdida y la falta, la división y el vínculo perdido en la mujer y entre mujeres.

La autobiografía de la mujer visualiza ese vínculo perdido y se convierte en un lugar que documenta la división y la fisura del sentimiento y la identidad de la mujer dentro de la cultura, la política y la sociedad, como forma de su testimonio. Su autobiografía se puede 
leer solo a través de la historia del "otro", y durante el intento de dialogar con el "otro" y otras mujeres se posibilita el testificar la historia del "otro". Este acto en sí posibilita escribir la autobiografía de la mujer. Como ya hemos nombrado anteriormente, la autobiografía de la mujer nunca es una confesión de sí misma. La autobiografía de la mujer es una historia del "otro", un documento del testimonio de una mujer con trauma, lo cual es un documento del vínculo perdido, la propia división y su hendidura. Esta discusión en sí puede desarrollarse acerca del papel de la autobiografía de la mujer en la recuperación del vínculo de las mujeres.

En último lugar de este apartado sobre la consideración de la autobiografía de la mujer de Felman, veremos una cita de Virginia Woolf que ha sido nombrada por Felman como una de las "founding mothers" (madres fundadoras) junto con Adrienne Rich y Simone de Beauvoir.

I have said that a woman writing thinks back through her mothers. Again if one is a woman one is often surprised by a sudden splitting off of consciousness, then from being the natural inheritor of that civilization, she becomes, on the contrary, outside of it, alien and critical. (A Room of One's Own, 101).

As a corollary to the mixing link in the chain of generations, the "splitting off of consciousness" is thought back through "the dark core" of the mother, through the black hole of her death and of the absence of her story.

(...) an autobiography that is therefore unwritable except through the story of he Other, but that succeeds precisely in inscribing woman's split as groundbreaking: as the groundbreaking process of a woman thinking -thinking back and thinking forward-through her own split. ${ }^{18}$

\footnotetext{
${ }^{18}$ Ibíd., p. 148.

He dicho que una mujer que escribe, piensa respaldada a través de sus madres. De nuevo, si una es una mujer se ve a menudo sorprendida por una repentina escisión de su conciencia, con lo que, tras haber sido la heredera natural de esa civilización, ahora ella se encuentra, por el contrario, fuera de ella, siendo una extraña y crítica. (Una habitación propia, 101). Como corolario del vínculo mixto en la cadena generacional, la "escisión de su conciencia" es el pensamiento que vuelve a través de "la oscuridad básica" de la madre, a través del agujero negro de su muerte y de la ausencia de su historia. ... una autobiografía que es por lo tanto imposible de escribir, excepto a través de la historia del "otro", pero que precisamente tiene éxito cuando inscribe la división de la mujer como pionera: como el proceso revolucionario de una mujer que piensa -pensando hacia atrás y hacia adelante-a través de su propia división. [Traducción propia]
} 
II. .Puede hablar la mujer subalterna? según Gavatri C. Spivak.

Una reflexión sobre el estado mudo de las mujeres en la Historia. 
En esta parte seguiremos abordando el tema de la mujer, específicamente en la construcción del sujeto de la mujer no occidental en la contemporaneidad, como contexto de los trabajos sobre los que reflexionaremos en los próximos capítulos. En el capítulo anterior, analizamos la teoría de Shoshana Felman ${ }^{1}$ acerca de la posibilidad de la autobiografía de la mujer, cuestionando la posibilidad de que la mujer hablara sobre sí misma, dentro del contexto occidental. Ahora veremos, por otra parte, la teoría de Gayatri Chakravorty Spivak $^{2}$ sobre la posibilidad de hablar de la mujer subalterna, en el caso de la mujer no occidental. Esto sería un desarrollo previo para reflexionar en torno a la autobiografíabiografía de la mujer contemporánea, cuestionando el problema del sujeto femenino no occidental.

No hablaremos del sujeto y la cultura solo dentro del grupo étnico no occidental, como antropología, sino que reflexionaremos sobre el sujeto femenino no occidental en la relación con occidente. Esta observación nos aclarará la manera en que funciona el sistema occidental en la construcción del sujeto, que requiere tener al "otro" para justificar y legitimarse a sí mismo.

Muchos han hablado en nombre del "otro" después de la fiebre de los años sesenta a nivel popular con la nostalgia y la admiración a lo folclórico, aunque a nivel académico "otredad" es un término de la filosofía de Derrida. Mieke Bal, en su libro Conceptos viajeros en las Humanidades: Una guia de viaje, comenta lo siguiente:

No hace tanto tiempo que «nosotros» hablábamos en nombre de «otros», inventando términos como «otredad»y «alteridad», junto con calificativos como

\footnotetext{
${ }^{1}$ Véase el capítulo I.

${ }^{2}$ Gayatri C. Spivak es una crítica y activista feminista nacida en 1942 en la India, se ha formado en la India y en EE. UU. y forma parte de la primera generación de intelectuales indios del periodo de la posindependencia. En la actualidad es profesora de la Fundación Avalon de Humanidades en la Universidad de Columbia de EE. UU. Fue foco de la atención de la opinión pública una vez por traducir la obra Gramatología de Jacques Derrida al inglés (Derrida, Jacques, De la grammatologie (1967), Of Grammatology. Trad. Gayatri Chakravorty Spivak (Baltimore: Johns Hopkins University Press, 1976), De la gramatología. Trad. O. del Barco y C. Ceretti (Buenos Aires, Siglo XXI, 1971).) y adjuntar un prefacio largo y denso de la obra. Cuenta con una publicación en Subaltern Studies I y tiene numerosas publicaciones sobre el tema del feminismo poscolonial, además de los trabajos de traducción de poesías y obras literarias del bengala. Participa en varios movimientos sociales y durante los últimos años ha realizado conferencias internacionalmente.
} 
«respeto», «entendimiento», «diálogo»e «igualdad», palabras que nos hacían sentir bien; bien con nosotros mismos. La palabra que se erigió en solitario en lo más alto de ese discurso fue "cultura». ${ }^{3}$

Es cierto lo que comenta Bal, sobre todo en relación con lo que trata de decir sobre la cultura: hubo numerosos reclamaciones por el nombre de "otro" y entonces florecían discursos multiculturales y poscoloniales. Somos conscientes de que hay algunos que ya se aburren de este esquema y lo ven como una mirada irónica a la falacia mezclada con el oportunismo por parte de "nosotros”. Además de eso, en nuestro mundo global, en el que se encuentra tanta mezcolanza, ¿ya no podemos decir “nosotros” ni “otros”? La opinión de Bal es negativa.

Ya no es posible decir «nosotros», ni tampoco «otros», porque la estructura de pensamiento que subyace a esas palabras se encuentra bajo escrutinio. ${ }^{4}$

Pero no llegaremos a juzgar que ya no se puede decir ni "nosotros" ni "otros". Porque en el mundo global contemporáneo, que aplica un transporte más veloz y cuantioso, remarca un nuevo límite de la diferencia entre nosotros y otros. Ya no están tan claras las divisiones entre nosotros y otros como antes, pero eso no significa que hayan desaparecido, sino que su forma se ha transformado, como una red de capas superpuestas de las divisiones.

Ahora bien, nosotros vamos a volver a un ejemplo como arquetipo. El estudio de Spivak sería ideal para considerar ese asunto. Trataremos de aproximarnos a la búsqueda del sujeto en las antiguas colonias de los países occidentales, los que han sido denominados "tercer mundo". De la misma manera, veremos el problema sobre el sujeto de la mujer no occidental desde el punto de vista del feminismo poscolonial.

En este proceso descubriremos cómo se ejecuta el empleo de la violencia para aplicar el sistema de construcción del sujeto sobre cualquier individuo, sin importar lo geopolítico e

\footnotetext{
${ }^{3}$ Bal, Mieke: Conceptos Viajeros en las humanidades. Una guía de viaje. trad. Yaiza Hernández Velázquez, Murcia, CENDEAC, 2009. p. 366.

${ }^{4}$ Ibíd., p. 367.
} 
incluso la propia historia, sobre los denominados "subalternos" del tercer mundo. Posteriormente, trataremos sobre la paradoja del sujeto subalterno sexuado. Para considerar este tema, citaremos el artículo de Spivak: Can the Subaltern Speak? publicado en $1988^{5}$ como guía para tener una perspectiva poscolonial del mundo. Spivak analiza las relaciones entre los discursos occidentales y la posibilidad de hablar de y por la mujer subalterna. Su análisis remarcará el problema contradictorio y la situación paradójica sobre el sujeto de la mujer no occidental. Aunque trate los asuntos particulares del siglo XIX, podemos observar que esa mirada de Spivak es bastante aplicable en el análisis del fenómeno que sucede entre el primer y el tercer mundo hoy en día.

Daremos una breve explicación sobre la palabra subalterno: quiere decir un ser subordinado, marginado y oprimido que permanece en la clase baja de la sociedad. Spivak ha mencionado a Antonio Gramsci ${ }^{6}$ como una referencia de origen de este término en un seminario $^{7}$. Según ella, la definición que da Gramsci sobre este término no es igual que la que propone Spivak actualmente, pero obviamente el origen de la palabra se encuentra en su obra Cuadernos de la prisión ${ }^{8}$.

\footnotetext{
${ }^{5}$ En el año 2009 se ha publicado la edición crítica en castellano: ¿Pueden hablar los subalternos? [escrito por Spivak, Gayatri Chakravorty y traducido por Manuel Asensi Pérez y publicado por el Museu d’Art Contemporani de Barcelona]. Según la explicación del traductor, existen cuatro versiones del texto original, Can the Subaltern Speak?, por parte de la propia Spivak: la primera, la versión del manuscrito del año 1983, que nunca se ha publicado gráficamente; la segunda, de 1985 [Wedge] y la tercera del 1988 [Antología de Nelson y Grossberg]. La cuarta y última versión de 1993 forma una parte de un capítulo, «History», en A critique of poscolonial reason [publicado por Harvard University Press, 1999].

También Spivak comenta en el prefacio de A critique of poscolonial reason [Spivak, Gayatri Chakravorty: Crítica de la razón poscolonial. Hacia una historia del presente evanescente. Trad. Marta Malo de Molina, Madrid, Akal, 2010. p. 8] que ese libro contiene una versión revisada de Can the Subaltern Speak? en el tercer capítulo.

Para la presente observación nos basaremos en la última versión del año 1999 y también en la versión de 1988, porque el tema que nos interesa ya lo había escrito en esta fecha con más claridad y con varias explicaciones para comprender mejor el argumento. En la siguiente parte de nuestro trabajo, vamos a observar la continuidad del interés de Spivak por el tema en Crítica de la razón poscolonial a través de otro episodio sobre la mujer y la importancia de su testimonio entre las mujeres, siguiendo el planteamiento de Durcilla Cornell.

${ }^{6}$ Gramsci, Antonio (1891-1937), ideólogo y político italiano. Hecho prisionero por los fascistas debido a su relación con el Partido Comunista, su encarcelamiento tuvo la consecuencia irónica de apartarle del estalinismo, permitiendo una mejor articulación de lo que es su filosofía política más característica. Robert Audi (ed.): Diccionario Akal de Filosofía, trad. Hubero Marraud y Enrique Alonso, Madrid, 2004, p. 463.

${ }^{7}$ Véase la nota número 14 del presente apartado.

${ }^{8}$ Se encuentra esta publicación en español con el nombre de Cuaderno de la cárcel por Ediciones ERA de México y la Coruña, del 1981 a 2005, siendo en total 6 tomos. En 2009 se encuentra otra publicación en castellano con el mismo título pero con subtítulo distinto por Casa de Juan Pablos de Madrid y Universidad Autónoma Metropolitana de México.
} 
Actualmente, de forma concreta, este término supone expresar a la gente que se la obliga a estar subordinada en el sur de Asia bajo el dominio estatal, imperial, religioso y convencional. La investigación sobre el subalterno ha comenzado a principios de los años ochenta en la India, tras la unión de algunos investigadores de diversas especialidades al proyecto de estudio. Ellos formaron el grupo: Subaltern Studies Group y publicaron la revista Subaltern Studies I en 1982 gracias a Oxford University Press. El artículo que analizaremos, primero fue presentado en la cuarta versión de esa revista en 1985, y fue presentado de nuevo en 1988, como hemos mencionado, tras algunas correcciones y un suplemento.

Spivak utiliza el término de subalterno más ampliamente al mencionar como tal a los seres marginados y reprimidos por el poder dominante, sobre todo al ser desconectados de la inteligencia «episteme».

En 2006, Spivak realizó la conferencia Feminism and Deconstruction ${ }^{9}$ en el Museu D’Art Contemporani de Barcelona, cuya temática estuvo enfocada a las cuestiones de la mujer y el problema occidental del análisis y la crítica de la deconstrucción. Como comentaba ella misma en su conferencia: su discurso y crítica dentro de Europa son más conocidos en Francia y Alemania; sus publicaciones se encuentran traducidas al francés y al alemán, pero no se encuentran frecuentemente traducidas al español. Actualmente tiene dos publicaciones traducidas al castellano: ¿Pueden hablar los subalternos $?^{10}$ y La crítica de la razón poscolonial ${ }^{11}$, que han visto la luz en 2009 y 2010, de entre tantas otras obras suyas. El segundo libro incluye un capítulo que contiene el primer libro. En diciembre de 2009, tras la publicación de la edición crítica de ¿Pueden hablar los subalternos? realizó un seminario en CENDEAC ${ }^{12}$ al que pudimos asistir.

\footnotetext{
${ }^{9}$ La conferencia Feminism and Deconstruction de Spivak se encuentra accesible en la web del Museu D’Art Contemporani de Barcelona.

http://www.macba.cat/controller.php?p_action=show_page\&pagina_id=72\&inst_id=23061, consultado, 23 de mayo del 2009.

${ }^{10}$ Spivak, Gayatri Chakravorty: ¿Pueden hablar los subalternos? trad. Manuel Asensi Pérez, Barcelona, Museu d’Art Contemporani de Barcelona, 2009.

${ }^{11}$ Spivak, Gayatri Chakravorty: Crítica de la razón poscolonial. Hacia una historia del presente evanescente. trad. Marta Malo de Molina, Madrid, Akal, 2010.

${ }^{12}$ El seminario con el título Gayatri Chakravorty Spivak. La cuestión de subalternidad, realizado en el Centro de Documentación y Estudios Avanzados de Arte Contemporáneo, del 1 al 2 de diciembre de 2009.
} 
Para dedicarse al estudio del sujeto femenino, Spivak introduce la teoría de la deconstrucción basada en la Gramatología de Jaques Derrida, la cual hemos observado anteriormente. En especial, analiza el sistema convencional de la autoinmolación de la viuda tras la muerte del marido en la India y su abolición por los británicos como estado protector a principios del siglo XIX. Bajo este análisis, Spivak intenta mencionar una realidad de la mujer que se queda en silencio en la postura del objeto rodeado por la sociedad, la política y la cultura basada en una narrativa histórica normativizada, entre la tensión del imperialismo británico y del nacionalismo patriarcal de la India. Y tampoco deja de denunciar el malentendido y el optimismo de los intelectuales del primer mundo sobre el asunto.

Como Spivak claramente indica, la intención de este estudio del sati, la autoinmolación de las viudas, desde el punto de vista feminista no solo abarca a la mujer como víctima.

\section{El proyecto feminista no consiste simplemente en situar a la mujer como víctima, sino en preguntar: ¿por qué razón el signo «marido» se convierte en el nombre apropiado para la alteridad radical? ¿Por qué «ser» equivale a «ser esposa»? $?^{13}$}

Para Spivak, la aproximación al problema de sati dentro de la dinámica política, social y cultural seria un estudio profundo para aclarar unas cuestiones fundamental planteadas del proyecto feminista como dice arriba, sobre todo ¿por qué «ser» equivale a «ser esposa»? en caso de la mujer. Obviamente, estas cuestiones no son solo de las mujeres subalternas, ni de mujeres sati. Sin embargo, el tema de sati como un caso extremo, nos aclararía la función patriarcal androcentrista con una evidencia, además de la dinámica política del imperialismo y nacionalismo que se legitiman en si mismo cada uno desvalorizando al otro mutuamente. Esta estructura no es nada de la antigüedad, sino que sigue en vigor hoy en día, recodificándose en la expresión más tolerable "género y desarrollo». Esta expresión en sí es un reemplazo del eslogan «la mujer en desarrollo», según Spivak. Entraremos en detalles más adelante en estos apartados próximos.

\footnotetext{
${ }^{13}$ Spivak, Gayatri Chakravorty: ¿Pueden hablar los subalternos? Op.cit. p. 102.
} 
El título del artículo que trataremos ahora, como hemos mencionado, es una pregunta: ¿pueden hablar los subalternos? Si adelantamos la respuesta de Spivak, es que no: los subalternos no pueden hablar. Spivak, durante el desarrollo de su investigación, insiste repetitivamente en la imposibilidad de que los subalternos hablen. En dicho seminario del 2009, Spivak seguía insistiendo en que el subalterno no puede hablar. Durante el seminario daba ejemplos concretos extraídos de su experiencia práctica en el activismo. Ella organizaba unas escuelas y daba clase en varios lugares para la gente que estuviera alienada y desconectada del saber y la educación. Tras muchos años de intentar comunicarse con los subalternos y acceder a ellos, cada vez se encuentra más con la dificultad de que ellos hablen. Y, según dijo, ella misma estaba en el proceso de entenderlos a ellos y no sabía si pudiese llegar a comprenderlos. Es un comentario sincero. En este sentido, podremos decir que los subalternos son “otros” para Spivak también.

$\mathrm{Su}$ afirmación de que los subalternos no pueden hablar no significa que no tengan capacidad de aprender un idioma o que sean impotentes de poder decir, de ninguna manera. Ellos son capaces de dominar una lengua y son inteligentes, como cualquier otro individuo. El problema de no poder hablar ellos mismos no depende de su capacidad personal, sino que es del sistema político, histórico, económico y cultural que les atrapa, no les deja hablar y les obliga a quedarse mudos. A este sistema ella a menudo le llama la "narrativa histórica”. Esta no ha aparecido de una manera inmediata, al contrario, desde hace mucho tiempo se ha construido y sigue reequipándose durante las generaciones a varios niveles: mental y sentimental. En otras palabras, los subalternos han sido alienados del saber a través de una larga historia de discriminación y de marginación, generaciones tras generaciones. Como consecuencia, un ser obligado a quedarse en una posición miserable bajo la violencia absurda discriminatoria y acostumbrarse a ella, una vez que tenga la oportunidad de aprender la lengua y de hablar escoge una expresión: ¡quiero morir!

El motivo de la denuncia de Spivak viene dado por esta situación. Si esa persona solo puede decir quiero morir debido al sufrimiento continuo y al dolor que forman parte de su vida de supervivencia, que nunca da la esperanza del mejoramiento: ¿dejar que muera respetando su voluntad es realmente justo?, ¿lo que dice es realmente lo que quiere decir? El 
argumento de Spivak que dice no pueden hablar los subalternos debemos leerlo en este contexto.

Expresado de otra manera, sí que llega a lograr a hablar esa persona con su propia voz y consciencia, ya no es un subalterno. De la misma forma, Spivak confirmaba la importancia del proceso de des-subalternación en el activismo práctico. A pesar de ello, nos exige que tomemos conciencia de la existencia del subalterno que no puede hablar. Porque existe una violencia consistente en hacer caso omiso de la existencia del subalterno sin voz. Esa ignorancia aliena cada vez más a los subalternos y como consecuencia les obliga más aún a silenciarse. Es un círculo vicioso casi eterno. El argumento de Spivak a lo mejor no aporta la solución completa de escuchar a los subalternos ni enseña la manera de salvarlos desde ese círculo vicioso. Pero tiene un impacto para romper o por lo menos visibilizar ese círculo cerrado. Como hemos mencionado, ella misma todavía no encuentra la manera de comprenderlos. Por eso, durante este apartado seguimos la lectura de Spivak que analiza el sistema que obliga a los subalternos a quedarse mudos, sobre todo a los subalternos sexuados, que se refiere a la mujer subalterna.

Nuestra intención es la misma que la de Spivak; la meta principal de estos apartados son revelar la forma y la violencia de exigir que hable el subalterno sexuado basándonos en el análisis del sistema. De forma concreta, primero veremos el truco de establecer Sujeto como Europa y posteriormente el sujeto falso de la mujer reflejando la ideología patriarcal patriótica establecida por la parte de la comunidad autóctona. Con todo ello aclararemos la relación cómplice entre los poderes de los varones y la situación de las mujeres subalternas que no tienen sitio para hablar. Empezaremos con una crítica aguda sobre la construcción del Sujeto que luego se convierte en un sistema de opresión que obliga a ser mudas a las mujeres subalternas. 
II.1. Occidente como Sujeto. El límite y la violencia epistémica europea. 
Para cuestionar ¿Pueden hablar los subalternos?, Spivak empieza con una crítica de la postura de los intelectuales europeos tales como Michel Foucault ${ }^{1}$ y Gilles Deleuze ${ }^{2}$. Se trata del argumento exhortativo para que el pueblo de la antigua colonia y del tercer mundo reclame, siendo él el sujeto mismo, para enfrentarse contra el poder dominante. En suma, que el subalterno levante su propia voz. No obstante, cuando se habla sobre el sujeto no occidental existe una complicación porque el sujeto mantiene siempre la idea del eurocentrismo. Spivak comenta lo siguiente:

En los años ochenta, parte de la crítica más radical producida en Occidente fue el resultado de un deseo interesado de conservar el sujeto occidental u Occidente como Sujeto. La teoría de unos «efectos-de-sujeto» pluralizados era a menudo una excusa para este sujeto de conocimiento. Aunque la historia de Europa como Sujeto era narrada por la ley, la economía política y la ideología de Occidente, este Sujeto oculto se presentaba como si no tuviera «determinaciones geopolíticas». Por tanto, la crítica más conocida del sujeto soberano inauguró realmente un Sujeto. ${ }^{3}$

Sus teorías «efectos-de-sujeto» a primera vista, dan la impresión de poder profundizar en la cuestión de autoridad del sujeto. Pero en el mayor de los casos ofrecen una vela que esconda al sujeto de conocimiento. Como dice Spivak, para establecer el sujeto, se le supone que tiene una determinación geopolítica. Reflexionar sobre el Sujeto, aunque sea con tono crítico, siempre es hablar de Sujeto occidental o de Occidente como Sujeto. Y esta discusión en sí funciona como un dispositivo que oculta este Sujeto de conocimiento. Así, eternamente se mantiene el sistema del sujeto occidental u Occidente como sujeto. Para defender el argumento planteado, Spivak observa la conversación entre Foucault y Deleuze: Intelectuales y poder, y menciona los dos puntos más importantes, a saber:

\footnotetext{
${ }^{1}$ Foucault, Michel. (1926-1984), filósofo e historiador de las ideas francés. [Audi, Robert (ed.): Diccionario Akal de Filosofía, trad. Huberto Marraud y Enrique Alonso, Madrid: Akal, 2004, p. 433.]

${ }^{2}$ Deleuze, Gilles (1925-1995), filósofo francés. Nació en París, estudió en la Universidad de París, se hizo profesor de la Universidad de París VIII en 1969. (...) Históricamente la filosofía de Deleuze, podría decir que ha avanzado desde la filosofía de la vida después de Bergson. Al punto de dar importancia la manera de estimulación pasiva del pensamiento, su teoría puede identificarse en postestructuralismo, es muy distinta a la de Derrida. [Hiromatsu Wataru (et. ál.): Iwanami Tetsugaku shisou jiten [Diccionario del filosofía pensamiento], Tokyo, Ianami, 1998, p. 1171.] [Traducción propia]

${ }^{3}$ Spivak, Gayatri Chakravorty: ¿Pueden hablar los subalternos? trad. Manuel Asensi Pérez. Barcelona: Museu d’Art Contemporani de Barcelona, 2009, p. 43.
} 
(...) Primero, que las redes del poder/deseo/interés son tan heterogéneas que su reducción a una narrativa coherente es contraproducente, siendo necesaria una crítica continua; y segundo, que los intelectuales deben tratar de revelar y conocer el discurso del «otro» de la sociedad. Sin embargo, los dos ignoran sistemática y sorprendentemente la cuestión de la ideología y sus implicaciones en la historia intelectual y económica. ${ }^{4}$

Ciertamente estamos de acuerdo con la importancia de la crítica persistente y de conocer la característica heterogénea y la misión de estos dos grandes intelectuales. Sin embargo, Spivak menciona la falta de atención sobre su postura. Ellos mismos están implicados por la historia intelectual y la economía europea, que han sido soberanas en los países que otrora fueron antiguas colonias, e ignoran este punto. Spivak indica el problema del estructuralismo y postestructuralismo que, por una parte, ignora la cuestión de la división internacional del trabajo y permite que el tercer mundo sea invisible y por otra el establecimiento del sujeto legal nuevo en la sociedad de capital socializado. Para examinar este asunto citaremos la opinión de Deleuze:

La alusión de Deleuze a la lucha obrera es igualmente problemática; está claro que se trata de una reverencia: «...nada se puede tocar [del poder] en un punto cualquiera de aplicación sin que se halle enfrentado a este conjunto difuso, que desde entonces se ve forzosamente llevado a querer derribar, a partir de la más pequeña reivindicación por mínima que sea. Toda defensa o ataque revolucionarios se unen de este modo a la lucha obrera» (FD 217). La aparente banalidad deja ver una fisura. La afirmación ignora la división internacional del trabajo, gesto este que a menudo caracteriza a la teoría política postestructuralista (.....5

\footnotetext{
${ }^{4}$ Ibíd., p. 45.

Con esto, lo que menciona acerca de los intelectuales Michel Foucault y Gilles Deleuze es, precisamente, la conversación que mantienen entre ambos en: Foucault, Michel y Deleuze, Gilles: Intellectual and Power: A Conversation between Michel Foucault and Gilles Deleuze. [En: Foucault, Michel: Language, Counter-Memory, Practice: Selected Essays and Interviews. trad. Donald F. Bouchard y Sherry Simon, Ithaca, Cornell University Press, 1977.]

${ }^{5}$ Ibíd., p. 47.
} 
Tomando como ejemplo las palabras de Deleuze, Spivak apunta dos puntos problemáticos. Según Deleuze, un obrero cualquiera frente a la función del poder, no puede escapar de reconocer su propia posición oprimida. Así que, natural y conscientemente, surge el deseo de romper con el poder dominador. Como consecuencia, cada uno por su voluntad, a razón de su deseo, realiza las actividades revolucionarias participando en la lucha. Esta opinión obviamente supone la lucha obrera dentro del contexto europeo, pero contiene una falta grave al considerar la división del trabajo como algo internacional e ignorando la realidad del tercer mundo. La división internacional del trabajo funcionaría si la división de los obreros produjera diversos niveles del problema de la explotación y de los conflictos geopolíticos. Pero dentro del discurso de Deleuze no encontramos esta cuestión, este sería el primer problema. El segundo punto sería que este discurso en sí propicia la centralización de Europa y restablece el sujeto legal como capital socializado.

En otras palabras, el tercer mundo como Asia o África ha sido invisible, casi transparente. Significa que el "otro" de Europa se queda marginado otra vez en el discurso y además por el discurso de los mejores profetas sobre la heterogeneidad y la otredad. Basándose en el análisis del problema mencionado, Spivak critica el optimismo de los intelectuales franceses que suponen el sujeto inteligente del subalterno y la posibilidad de reclamar con su propia voz, y la postura que intenta ser transparente solo representando al "otro".

La crítica de la constitución ideológica del sujeto en el seno de las formaciones estatales y de los sistemas de economía política puede ahora ser borrada, del mismo modo que las prácticas activas teóricas de la «transformación de la conciencia». Es patente la banalidad de los listados de autoconocimiento de los intelectuales de izquierdas, subalternos políticamente astutos; representándoles, los intelectuales se representan a sí mismos como transparentes. ${ }^{6}$

Spivak critica la postura de los intelectuales que intentan ser representantes transparentes y se suponen subalternos. Entonces, la cuestión sería cuestionar el carácter y la situación del

\footnotetext{
${ }^{6}$ Ibid., p. 56.
} 
subalterno. Antes de tratar este asunto, Spivak revisa la teoría de Karl Marx ${ }^{7}$ y la de Louis Althusser ${ }^{8}$ y posteriormente indica el problema de la exclusión, al tener en cuenta el factor que supone la familia. Con esta observación, Spivak nos muestra que el marxismo, al igual que otros pensamientos occidentales, forma parte del marco androcentrista, enfatizando la dificultad de suponer la existencia del sujeto de la mujer como subalterna y de esperar su voz propia en el contexto de nuestra sociedad capitalista globalizada.

Sin duda, la exclusión de la familia, aunque se trate de una familia perteneciente a una formación de clase específica, forma parte del marco masculino dentro del cual el marxismo marca su nacimiento. Desde un punto de vista histórico y en la economía global de hoy, el papel de la familia en las relaciones sociales patriarcales es tan heterogéneo y tan cuestionado que la simple sustitución de la familia en este contexto no supone de ningún modo romper ese marco. Tampoco soluciona nada la inclusión positivista de una colectividad monolítica de «mujeres» en el listado de los oprimidos, cuya subjetividad no fracturada les permita hablar por sí mismas contra «un mismo sistema» igualmente monolítico. ${ }^{9}$

Spivak no acepta la idea del establecimiento del sujeto para la mujer oprimida y de esta manera hacer posible un combate contra el sistema monopolítico. Por supuesto, Spivak no niega que haya mujeres interesadas en el feminismo internacional dentro del grupo social gobernado, pero al mismo tiempo insiste en la existencia de mujeres que se quedan en el otro polo, desconectadas de la posibilidad de estrechar lazos solidarios con los demás seres heterogéneos, como: mujeres, prisioneros, soldados reclutados, hospitalizados y homosexuales -como los seres que deben y pueden reclamar su voz propia según Foucault y Deleuze-, en los suburbios de las grandes ciudades y en el tercer mundo. Las mujeres del

\footnotetext{
${ }^{7}$ Marx, Karl (1818-1883), filosofo alemán, teórico de la economía y de la sociedad y autor de algunas de las tesis revolucionarias más influyentes de la historia del pensamiento. [Audi, Robert (ed.): Diccionario Akal de Filosofía. trad. Huberto Marraud y Enrique Alonso, Madrid: Akal, 2004, p. 649.]

${ }^{8}$ Althusser, Louis (1918-1990), filósofo marxista francés. Su publicación en 1965 de dos colecciones de ensayos, Pour Marx (Por Marx) y Lire le Cpital (Para leer «Capital»), hizo de él un fenómeno en los círculos intelectuales franceses y le proporcionó, además, un gran número de lectores en todo el mundo. Las traducciones a otras lenguas de estos textos posteriormente, ayudaron a dar forma al desarrollo del pensamiento marxista en el mundo anglosajón durante la década de 1970. [Audi, Robert (ed.): Diccionario Akal de Filosofía. Op.cit., p. 52.]

${ }^{9}$ Ibíd., p. 61.
} 
subproletariado urbano, además de ser explotadas y alienadas del consumismo, también están bajo control de la sociedad patriarcal en la mayoría de los casos.

En el otro lado de la división internacional del trabajo, el sujeto de la explotación no puede ni saber ni enunciar el texto de la explotación femenina, aunque se llegue al nivel de absurdidad del intelectual no representativo que deja espacio para que ella hable. La mujer está doblemente a la sombra. ${ }^{10}$

Spivak visibiliza una realidad de nuestra sociedad, donde existen personas explotadas que no tienen ni la más remota posibilidad de contrastar su situación, que están desconectadas del razonamiento y atrapadas por el sistema patriarcal, siendo constantemente demandadas para que hablen y reclamen con su propia voz subalterna e invisible, a la manera de Foucault y Deleuze.

La postura de Foucault y Deleuze como intelectuales occidentales siendo transparentes, no son representantes ausentes que permiten hablar al "otro" con voz propia, le parece muy peligrosa a Spivak la manera en que ignoran la economía de ser europeos primermundistas, que al fin y al cabo, pueden participar en ocultar el dominio del imperialismo europeo, incluso neo-imperialismo dirigido por EE.UU., que funciona dominando al tercer mundo. Como hemos mencionado, en realidad muchos seres explotados no tienen el acceso al pensamiento intelectual o están completamente atados con la explicación sobre su realidad y la narrativa histórica. En la circunstancia basada en la división internacional del trabajo, los trabajadores están cada vez más divididos. Además, dentro de ellos existe cierta jerarquía, por la cuestión de despolitización.

Sobre todo, en el caso de la mujer explotada y marginada del saber, que además está bajo el control del sistema patriarcal, la exigencia de que reclame su derecho por su propia voluntad, levantando su voz, no resulta muy eficaz. La vida real de los explotados en el tercer mundo es de supervivencia, y además de estar desconectados de la educación, no es

\footnotetext{
${ }^{10}$ Ibíd., p. 83.

Esta parte se ha omitido en la versión de 1993. Gracias a la edición crítica, el traductor Manuel Asensi Pérez indica la importancia de la frase para reflexionar sobre la mujer subalterna y la recupera en la nota $\mathrm{n}^{\circ} 86$.
} 
tan fácil que reconozcan su propia circunstancia. De esta manera, no reclaman por sí mismos, y esto favorece y brinda el pretexto al poder dominante, para que exista opresión y explotación. De tal manera funcionaría el argumento de los intelectuales franceses para Spivak.

\section{II.1.1. La voz del "otro" en nosotros.}

Por todo lo anterior, Spivak busca una alternativa en la teoría de Jacques Derrida. Ella encuentra una compatibilidad con su teoría, tiene precaución y desconfianza con algún concepto nostálgico del origen de la pérdida como concepto nocivo, para la crítica del imperialismo dentro de la búsqueda de la realidad social. La postura de Derrida es más cuidadosa con el asunto, tanto del nacionalismo o etnocentrismo como con el eurocentrismo, aunque sea solo una reacción contra el imperialismo. Como vimos en la parte anterior, la crítica de Derrida examina muy bien el eurocentrismo. Spivak no olvida tener en consideración la dificultad de leer el texto y diferencia al filósofo de su objeto de estudio (que es la filosofía clásica), dice:

Derrida es difícil de leer, su objeto real de investigación es la filosofía clásica. No obstante, es menos peligroso cuando lo entendemos como un intelectual del primer mundo disfrazado de no-representante ausente que permite que los oprimidos hablen por sí mismos. ${ }^{11}$

Aunque la lectura de Derrida es complicada, si se entiende bien sería útil y mejor que la teoría de Foucault y Deleuze para Spivak. Así que Spivak sintetiza la teoría de Derrida, basada en De la Gramatología, para aplicarla en el análisis sobre el sistema de sacrificios de la viuda para seguir la muerte del marido que se encontraba en cierta región de la India y

\footnotetext{
${ }^{11}$ Spivak, Gayatri Chakravorty: ¿Puede hablar el subalterno? trad. Santiago Giraldo. en Revista Colombiana de Antropología, Vol. 39, enero-diciembre 2003. p. 335.

Esta vez la cita viene de la versión en castellano que se publicó en 2003 en Colombia,

Según Asensi Pérez, esta parte, oprimida en la versión de 1993, en la que Spivak se dedica a defender a Derrida, fue escrita a causa del surgimiento de los ataques de los intelectuales de izquierdas como Terry Eagleton, Perry Anderson y Edward Said, entre otros, contra Derrida en aquellos momentos, alrededor del año 1988. Véase la nota n 92 en Spivak, Gayatri Chakravorty: ¿Pueden hablar los subalternos? Trad. Manuel Asensi Pérez. Barcelona: Museu d'Art Contemporani de Barcelona, 2009, p. 86.
} 
la abolición de esta autoinmolación a mano de los británicos. En este análisis se encuentra el problema y la crisis del sujeto al enfrentar el argumento occidental y no occidental, sobre todo es el caso de la mujer en la comunidad no occidental. Spivak trata de explicar bajo la teoría de Derrida el problema y la dificultad relacionados con el sujeto y la identidad de la mujer no occidental; el problema no es general, sino que es un problema occidental por el eurocentrismo que requiere construir el Sujeto europeo configurando el "otro". No tenemos suficiente espacio para describir los detalles de la teoría, pero nos fijamos en un punto importante para la mirada de Spivak.

Es más importante para mí que, como filósofo europeo, articule la tendencia del Sujeto europeo a constituir al Otro como marginal al etnocentrismo y lo sitúe como el problema de todo logocentrismo y, por ello, de todo esfuerzo gramático (ya que la principal tesis del capítulo es la complicidad entre ambos). No es un problema general, sino un problema europeo. ${ }^{12}$

Para Spivak, lo importante es reconocer el problema de Europa y su pensamiento al requerir siempre la existencia del "otro". Como hemos visto anteriormente, según la explicación de Shoshana Felman, Derrida en el análisis de la historia y el sistema de la metafísica occidental encuentra una función de logocentrismo. Es un tipo de totalitarismo, al poseer un sistema estructurado en la división y que brinda una única supremacía del uno sobre lo otro, como: ser/nada, presencia/ausencia, sujeto/objeto, uno/otro, verdad/falsedad, etc. Con esta estructura jerárquica, da aprobación de la legitimidad y significación de sí mismo contra el "otro", así es como mantiene el poder de dominio. Este sistema de logocentrismo se aplica efectivamente en el eurocentrismo dividiendo a Europa del "otro" y da supremacía y legitimidad a Europa sobre el "otro".

Es el mismo sistema que hemos revisado anteriormente bajo el análisis de Felman, el del androcentrismo que da una única superioridad al hombre sobre la mujer, dividiéndolos. Entonces, mantener el propio sujeto basado en el eurocentrismo y en el proceso de

\footnotetext{
${ }^{12}$ Spivak, Gayatri Chakravorty: ¿Pueden hablar los subalternos? trad. Manuel Asensi Pérez. Op.cit., p. 89. Esta parte también se ha omitido en la versión de 1993, pero se ha recuperado en la nota n $^{\circ} 96$.
} 
construcción del sujeto, fortalece más y más el ismo, manteniendo la misma estructura, y en el esfuerzo de superarlo por el pensamiento lógico, inevitablemente se comete el mismo error. Spivak comenta, siguiendo a Derrida, que el fracaso de superar el sistema logocéntrico, la manera de pensar lógicamente y expresar con cierta retórica, nunca puede escapar del sistema en el texto. El texto siempre lleva esta característica. Esto quiere decir que la teoría menos peligrosa, como Gramatología, tampoco está a salvo de escribir bien. En realidad, solo puede escribir ocultando lo que quiere ignorar, es decir, siempre fracasamos cometiendo errores bajo el control del logocentrismo a la hora de escribir un texto.

No obstante y por esa razón nos fijaremos en la necesidad e importancia de "leer la parte en blanco del texto" siguiendo a Derrida, como posible lectura de encontrar una ruptura del circuito cerrado del logocentrismo. Y centramos la atención en que la modificación del sujeto pensante como transparente, corre el peligro de ocultar el reconocimiento del "otro" por identificarse sin consideración.

Crea el pensamiento o el sujeto pensante transparente o invisible parece, por contraste, esconder el implacable reconocimiento del Otro por asimilación. Es en interés de tales precauciones que Derrida no apela a "permitir al otro(s) hablar por sí mismo" sino que más bien acude a un "recurso" o "llama” al "cuasi-otro" -tout-autre como opuesto al otro auto-consolidante-, a "volver delirante esa voz interior que es la voz del otro en nosotros". 13

De esta manera, evita ser un ventrílocuo que hace hablar a "otro", u obligarle a que reclame con su propia voz. En lugar de eso, escucha la voz del otro en nosotros, que acude a una táctica de volver delirante esa voz interior. Es una manera menos peligrosa, para Derrida y Spivak, en el trabajo intelectual. Y aquí también veremos una posibilidad semejante en el trabajo del arte contemporáneo. Digamos que una obra de arte puede visualizar la voz

\footnotetext{
${ }^{13}$ Spivak, Gayatri Chakravorty: ¿Puede hablar el subalterno? trad. Santiago Girald Op.cit., pp. 337-338. Esta parte ha desaparecido totalmente en la última versión; por esta razón hemos citado la traducción de Santiago Girald, basada en la versión del año 1988. Este argumento tuvo su base en Derrida, Jacques: O fan apocalyptictone recently adapts in philosophy. Trad, John P. Leavy, Jr. Semia: 71.
} 
interior delirante o proporcionar un momento para reflexionar sobre la voz del "otro" en nosotros. Este tema lo desarrollaremos posteriormente.

A propósito, Spivak menciona como posible estrategia para tratar el tema, al asedio de la transferencia, el inconsciente como interrupción ${ }^{14}$ en las primeras partes del capítulo que incluye la última versión de ¿Pueden hablar los subalternos? Por supuesto, el término viene de la teoría psicoanalista freudiana.

Como todo el mundo sabe, la teoría y el argumento de Freud ${ }^{15}$ influyen no solo en el campo de la ciencia médica, sino en muchos campos diversos, sobre todo en el campo del pensamiento fue como un golpe, al exigirle reconsiderarse radicalmente. En relación con el arte, será en el Surrealismo, y a partir de ahí sigue influyendo en la parte práctica de la creación artística tanto como en la parte teórica y en la interpretación sobre el arte.

Para reflexionar sobre el sujeto enmudecido y la posibilidad de encontrar su testimonio debemos fijarnos en la referencia del psicoanálisis. Spivak también consulta el discurso de Freud; igual que Felman, cita y resume la interpretación de Sarah Kofman ${ }^{16}$, quien publica unos artículos que defienden la teoría de Freud mientras critican la mirada discriminada y la función contradictoria de su teoría hacia la mujer, como hemos visto anteriormente.

Sarah Kofman ha sugerido que la profunda ambigüedad en el uso que hace Freud de la mujer como chivo expiatorio puede ser leída como reacción-formación a un deseo inicial y continuo de dar una voz a la histérica, de transformarla en un sujeto

\footnotetext{
${ }^{14}$ Spivak, Gayatri Chakravorty: Crítica de la razón poscolonial. Hacia una historia del presente evanescente. trad. Marta Malo de Molina, Madrid, Akal, 2010. p. 211.

${ }^{15}$ Freud, Sigmund (1856-1939), neurólogo y psicólogo austriaco y fundador del psicoanálisis. Comenzando por el estudio de la histeria en la Viena de finales del siglo XIX, Freud desarrolló una teoría de la mente que ha llagado a dominar el pensamiento contemporáneo. Su noción del inconsciente, la de una mente dividida en contra de sí misma, la importancia de la actividad que carece en apariencia de significado, el desplazamiento y transferencia de los sentimientos, los estados del desarrollo psicosexual, el carácter persuasivo y la importancia de la motivación sexual, así como un gran número de otros temas, han ayudado a conformar la conciencia moderna. [Audi, Robert (ed.): Diccionario Akal de Filosofía, Op.cit., p. 439.]

${ }^{16}$ Sarah Kofman: (1934-1994), nacida en una familia judía en Francia, obtiene el Diploma de Catedrática en Filosofía en 1960. Desde 1970 impartió cátedra de Filosofía en la Universidad de París I, también impartió clase en varias Universidades norteamericanas. Tiene 27 libros publicados; dentro de ellos, ha reflexionado sobre Freud (6 libros), Nietzsche (5 libros), Platón, August Comte, Jean-Jacques Rousseau y Marx, entre otros.
} 
de la histeria. ${ }^{17}$ La formación ideológica masculino-imperialista que transformó ese deseo en «la seducción de la hija» es parte de la misma formación que construye la monolítica «mujer-del-Tercer-Mundo» (...) Así las cosas, nuestros esfuerzos por dar al subalterno una voz en la historia estarán doblemente abiertos a los peligros corridos por el discurso de Freud cuando afronten las preguntas: ¿puede hablar el subalterno? ¿Puede hablar el subalterno (como mujer)? ${ }^{18}$

La teoría y la práctica de Freud contienen una paradoja. Es casi la misma cuestión que examinamos en la parte anterior con la indicación de Kofman. Spivak pone énfasis en el punto preocupante de esa paradoja siguiendo la lectura de Kofman. El psicoanálisis de Freud posibilita que la mujer hable, la mujer histérica. En este sentido Freud es el primer hombre que ha encontrado el sujeto de la mujer histérica. Al mismo tiempo, esa mujer permanece "histérica-enferma" como sujeto que encuentra el psicoanálisis. Es decir, la mujer como sujeto histérico puede hablar, pero una vez que se resiste a obedecer y recibir la palabra de la interpretación de Freud, ya no puede hablar y no hay otra vía más que el silencio. La interpretación de Freud no sale del marco patriarcal, así que la mujer se queda histérica eternamente.

El intento de Spivak de hacer hablar al subalterno, sobre todo, al subalterno como mujer, es lo que puede asimilar el peligro de la construcción y la paradoja que Freud ha realizado. Debemos tener cuidado con estos puntos mencionados: Spivak plantea el análisis del sistema de sacrificio de la viuda en India. Es un ejemplo que muestra la situación difícil de las mujeres en el contexto no occidental. El caso es antiguo, pero la escritura fundamental del poder dominador sobre la mujer subalterna, no ha cambiado mucho hasta el día de hoy. Además, con este análisis nos brinda una comprensión profunda del problema del sistema del colonialismo y nos dará cuenta de que continúa, que no se ha resuelto el problema hasta hoy, aunque cambie la superficie del problema. Spivak intenta visualizar la contradicción

\footnotetext{
${ }^{17}$ Kofman, Sarah: The Enigma of Woman: Woman in Freud's Writing, Trad. Catherine Porter, Itheca, Cornell University Press, 1985. El título original del libro era L`enigma de la femme: La femme dans les textes de Fraude. Paris: Galilée, 1980. La versión española es, El enigma de la mujer. ¿Con Freud o contra Freud? Trad. Estella Ocampo, Barcelona, Editorial Gedisa, 1997.

${ }^{18}$ Spivak Chakravorty, Gayatri: ¿Pueden hablar los subalternos? trad. Manuel Asensi Pérez. Op.cit., pp. 94-95.
} 
sobre el sujeto de la mujer que se queda muda entre la justicia altiva del imperialismo masculino europeo y la narrativa histórica convencional patriarcal.

\section{II.1.2. La protección de la «mujer del Tercer Mundo».}

Uno de los argumentos más importantes que se encuentra en ¿Pueden hablar los subalternos? es que en la antigua colonia la protección de la mujer se convierte en un significante $^{19}$ para establecer una buena sociedad sometida a la operación del poder estatal, como pasaba con los colonos europeos, y al poder de la parte nacionalista, basado este último en el sistema patriarcal tradicional. Significante es un término que ha empleado el lingüista suizo Saussure ${ }^{20}$ junto con la significación para explicar la estructura del signo. Estos términos ya se han introducido en la crítica literaria y en el psicoanálisis, habiendo tenido cierto desarrollo en ambas áreas, y se convierten en un dispositivo indispensable en el discurso estructuralista y postestructuralista.

A continuación, explicaremos brevemente estos términos. El signo puede dividir su función en dos partes: una es el significante, en la superficie, y la significación es la parte interior del signo. Es decir, el significante es su forma de expresión y el significado es el contenido y lo que indica del signo. Por ejemplo, en la palabra estantería, su fonema y lo escrito ("es-t-a-n-t-e-r-í-a") es el significante, y el sentido y lo que quiere decir (mueble sobre el que se pueden dejar objetos) es la significación.

Conforme a Spivak, la protección de la mujer en el tercer mundo se convierte en un significante, es decir, es una forma que en sí misma no tiene sentido y solo sirve como

\footnotetext{
${ }^{19}$ Significante, sonido vocal o símbolo escrito. El concepto debe su formulación moderna al lingüista suizo Saussure. En vez de usar la vieja concepción de signo y referente, Saussure dividió el signo mismo en dos partes interrelacionadas, el significante y el significado [significación]. El significado es el concepto y el significante es un sonido o una inscripción. La relación entre ambos, según Saussure, es completamente arbitraria, porque los significantes tienden a variar en los diferentes lenguajes. Podamos usar o escribir «vache», «vaca» "cow» dependiendo de cuál sea nuestra lengua materna y en todos esos casos tratar con el mismo significado (es decir, concepto). [Audi, Robert (ed.): Diccionario Akal de Filosofía, Op.cit, 2004, p. 892.]

${ }^{20}$ Saussure, Ferdinand de (1857-1913), lingüista suizo, fundador de la escuela de la lingüística estructural. Sus trabajos en lingüística fueron una influencia fundamental para el posterior desarrollo de la filosofía estructuralista francesa y también de la antropología estructuralista, la crítica literaria estructuralista y la semiología moderna. [Audi, Robert (ed.): Diccionario Akal de Filosofía, Op.cit., p. 868.]
} 
dispositivo para indicar algún otro significado. Además, es completamente arbitraria en otro contexto de régimen político, económico y cultural. La protección de la mujer sirve para leer el fundamento de la buena sociedad como significación, pero, en sí, no tiene sentido. De ahí que los hombres manifiesten tanto la protección de la mujer, pero no haya lugar para que ellas mismas hagan sonar su voz. A partir de ahora, nos ocuparemos de los asuntos de protección de la mujer, y más concretamente, del tema de la autoinmolación de la mujer viuda. Nos centraremos en el asunto de la mujer viuda, su derecho y su deseo de vida y de muerte. Pero, a fin de cuentas, no escuchamos ninguna voz de la mujer. El tema central es la protección de la mujer, y la mujer permanece transparente, invisible, como una consciencia en una batalla de las ideologías de los hombres. Y la mujer queda obligada, enmudecida. Para comprender su argumento, observaremos el caso que estudió Spivak.

De forma concreta veremos los dos casos siguientes: el primero, sobre la abolición británica del sacrificio de las viudas en 1829 con la función sistemática de la violación de la ley de la otra sociedad, tratando a la mujer como objeto; el otro, sobre el argumento reaccionario del nacionalismo indio contra la abolición bajo el análisis del Rg-Veda y el Dharmaśâstra. Spivak hace comentarios sobre el texto, que según ella sería el pasado clásico y verídico de la India hindú. Para empezar, veremos la descripción del sacrificio de la viuda y la abolición británica:

La viuda hindú asciende a la pira del marido muerto y se autoinmola en ella. Es el sacrificio de la viuda (la trascripción convencional de la palabra sánscrita que nombra la viuda sería sati. Los primeros colonos británicos la transcribían como suttee). El rito no era una práctica universal ni se limitaba a una casta o a una clase. La abolición de este rito por parte de los británicos ha sido generalmente entendida como un caso de «hombres blancos que salvan a las mujeres de piel morena de los hombres de piel morena». Las mujeres blancas-desde los Registros misioneros británicos del siglo XIX hasta Mary Daly- no han producido una comprensión alternativa de lo mismo. ${ }^{21}$

${ }^{21}$ Ibíd., p. 98. 
Como podemos comprobar, cuando colonizan la India los británicos prohíben la autoinmolación, salvando la vida de la viuda y siguiendo de esta forma el método y la moral occidentales. Los británicos se felicitaron a sí mismos por la abolición. A pesar de que habían ignorado y violado la ley propia del "otro". Con este hecho se puede mostrar la necesidad occidental de educar a los salvajes indios haciéndoles rechazar su propia cultura. De tal manera razona su soberanía en la colonia.

Evidentemente, no estamos en contra de la abolición de la autoinmolación sati: fue admirable en sí al salvar la vida de la viuda que iba a morir a causa de la pérdida de su marido. Sin embargo, Spivak plantea investigar el ardid de la legitimación de la colonización. El concepto de protección de la mujer y la existencia de mujeres que deben ser protegidas se convierte en una razón para la intervención extralegal y la causa para formar una buena sociedad para los gobernadores occidentales. La frase "Los hombres blancos salvan a las mujeres de piel morena" muestra la capacidad y el poder del hombre blanco para ignorar al hombre de piel morena, con lo que se ve la intención de decir realmente: la capacidad depende del color de la piel. Los británicos estaban orgullosos de no intervenir en la cultura de la colonia manteniendo una ley no escrita, si lo comparamos con el dominio español realizado en América. Los británicos se consideraban más civilizados de esta manera.

Sin embargo, el caso de la abolición del sati fue un caso especialmente excepcional. Para marcar el momento en que nace una sociedad no solo civil, sino una buena sociedad, se invocan con frecuencia eventos que infringen el código de la ley para impartir su espíritu: la protección de mujeres por el hombre sería un ejemplo de estos eventos. Spivak comenta esta postura de los británicos citando a J. D. Derrett:

Si recordamos que los británicos se vanagloriaban de su total equidad respecto a la no intrusión de las costumbres/leyes nativas, podemos leer en la siguiente precisión de J. D. M. Derrett una invocación de esta transgresión sancionada de la letra en pro del espíritu: «La primera legislación respecto a la Ley Hindú fue llevada a cabo sin el permiso de un solo hindú». No especifica a qué legislación se refiere. El 
siguiente pasaje, donde la medida sí es nombrada, es igualmente interesante si se considera las implicaciones de la supervivencia de una sociedad «buena» colonialmente establecida tras la descolonización: "La recurrencia del sati en la India independiente es con toda probabilidad una reavivación oscurantista que no puede sobrevivir ni siquiera en los lugares más deprimidos del país». ${ }^{22}$

Sería un ejemplo claro de legitimación de la soberanía por parte de los británicos al poder modificar incluso la ley de otra sociedad sin consultar a nadie de la misma. Spivak no deja de mencionar el punto problemático:

Sea correcta o no esta observación, lo que me interesa es que la protección de la mujer (la «mujer del Tercer Mundo», como se dice hoy) se convierte en el significante que nombra el establecimiento de una sociedad buena (o como ahora se dice, de un planeta bueno) que debe, en tales momentos inauguradores, transgredir la mera legalidad, equidad o conducta legal. En este caso concreto, el proceso permitió también redefinir como crimen lo que había sido tolerado, conocido, o adulado como ritual. En otras palabras: este elemento de la ley hindú saltó por encima de la frontera entre el dominio público y el privado. ${ }^{23}$

Spivak dice que la protección de la mujer se convierte en un significante para una buena sociedad, lo cual quiere decir que se lee y se sabe el significado de la buena sociedad a través de la protección de la mujer; sin embargo la protección de la mujer en sí no se ha leído como algo significativo. Entonces, la protección de la mujer se convierte en una especie de dispositivo que reduce el tema y el problema en simples oposiciones dicotómicas.

En este caso concreto, el discurso de los británicos reduce el problema en oposiciones dicotómicas, como morir la mujer/vivir la mujer, salvar la mujer/abandonar la mujer y liberación de la mujer/opresión de la mujer. En este discurso no hay lugar para cuestionar el

\footnotetext{
22 J. D. M. Derrett: Hindu Law Past and Present: Being an Account of the Controversy Which Preceded the Enactment of the Hindu Code, and Text of the Code as Enacted, and Some Comments Thereon. Calcuta: A. Mukherjee, 1975, p. 46. [En: Spivak Chakravorty, Gayatri. ¿Pueden hablar los subalternos? trad. Manuel Asensi Pérez. Op.cit., p. 99.]

${ }^{23}$ Ibíd., p. 100.
} 
significado de la omisión de la mujer y solo obliga a juzgar dentro de esta estructura jerárquica de oposiciones dicotómicas. Ya hemos visto la manera en que el logocentrismo, al dar soberanía, vivir, salvar y liberar a la mujer se legitima a sí mismo. Para la realización del único valor, en este caso salvar a la mujer, puede y legitima eventualmente un remedio extralegal. Actualmente la mujer del tercer mundo está funcionando como significante -al igual que la mujer que practicaba sati causa y legitima la intervención legal de los británicos en la India- pero actualmente la intervención se convierte incluso en acción militar.

El caso que estamos estudiando es del siglo XIX, pero tenemos que recordar la indicación de Spivak: actualmente encuentra argumentos de afirmación de la guerra o del ataque militar al tercer mundo mediante la protección de la mujer maltratada y para establecer una buena sociedad, destruyendo la otra, que es convencional, subdesarrollada, salvaje, con menos capacidad de resolver el problema por sí misma.

Volviendo al siglo XIX, a partir de esa abolición, una vez que se sucede el sacrificio de la viuda, el acto se torna un crimen. Entonces, la muerte de la mujer con sati que permanecía como un acto privado ritual cambia de sentido: es un acto ilegal. El sati es un acto ritual religioso, que permanecía como asunto privado de la mujer según la explicación de Spivak. La viuda podía elegir libremente a excepción de si tenía un bebé, por ejemplo. Pero para la viuda morir no era una obligación, porque era un asunto privado. La abolición de los británicos también cambió el sentido del sati para la mujer, al convertirlo en un acto público.

El acto privado de la mujer cuando se convierte en acto público es además ilegal, lo que complica más la situación para las mujeres, sobre todo para aquellas que viven habitualmente en su grupo étnico. La parte hindú empieza a reaccionar contra la abolición por los británicos provocando una situación doblemente difícil para la mujer. Veremos los detalles en seguida. 


\section{II.1.3. El sujeto subalterno doblemente mudo.}

La modificación obligada sin hacer caso y sin respeto por la otra cultura, como les pasa a los hindúes a manos de los británicos gobernadores, ha causado una reacción por parte de los primeros. Sobre todo para oponerse a la frase «Hombres blancos salvando a mujeres de piel morena de los hombres de piel morena» aparece otra frase que Spivak describe de esta manera:

Contra ello se han manifestado los indios nativos con una afirmación que es una parodia de la nostalgia por los orígenes: «Las mujeres querían morir», que todavía se mantiene. ${ }^{24}$

Observaremos un tono irónico que también es evidente en la explicación de Spivak sobre dicha frase, que alega la voluntad de autoinmolación de la mujer. Explicaremos la nostalgia por los orígenes perdidos. Cuando hay cierto cambio social, siempre surge una reacción nostálgica que dice "antes era mejor". Esta nostalgia supone un buen origen que existía antes, pero ahora se ha perdido. Pero en realidad la situación no es así. El origen, que era bueno comparado con la situación actual, que es mala, nunca existía; puntualmente, no se sabía que existía. Pero el individuo se convence de la existencia del origen bueno cuando surge el cambio. Es decir, se establece la convención sobre el origen bueno solo en el momento en que se pierde, y solo de esta manera puede ser añorado. En otras palabras, podemos decir que la nostalgia inventa el origen perdido que era bueno en comparación con la situación actual, que presenta problemas. Es una paradoja en la que no se sabe cuál fue primero, si el origen perdido que causa la nostalgia o la nostalgia que inventa el origen perdido.

Siempre existen el descontento, la insatisfacción e inquietud sobre el estado actual y el individuo busca la razón, la causa y la solución a esas intranquilidades. En la historia occidental, sobre todo antes de la época moderna, se solucionaba más fácilmente esta situación gracias a la función religiosa del monoteísmo cristiano, ya que daba la explicación

\footnotetext{
${ }^{24}$ Ibíd. p. 98.
} 
de que todo sucedía por la voluntad de Dios. El mito sostenía la función y la fundación de la sociedad. Después de que Nietzsche ${ }^{25}$ dijera que "Dios ha muerto", ya no se puede contar con él. Ahí surge la nostalgia del origen perdido como una solución para evitar tener que enfrentarse a la cruel realidad actual. Los numerosos cambios que hubo en el esquema mundial prepararon el surgimiento de este tipo de nostalgia: podemos decir que es el tema de la modernidad.

Pero si mencionamos más detalladamente la nostalgia del origen perdido, no es un invento moderno, tiene cierta tradición en la filosofía y la metafísica occidentales. Un ejemplo es el idealismo de Sócrates y Platón, quienes buscaban el origen de toda la verdad en el mundo ideal que no existe en nuestra realidad. Otro ejemplo, el concepto de Jean-Jacques Rousseau ${ }^{26}$ que supone el ser bueno y, por contraposición, el mal y la desgracia proceden de la sociedad. Derrida, cuando desarrolla la crítica, se fija en este punto. Spivak, siguiendo a Derrida, también es escéptica sobre la nostalgia del origen de Martin Heidegger ${ }^{27}$ y, por lo menos para la crítica al imperialismo, es un pensamiento nocivo.

Este artículo está comprometido con la noción de que, tanto en defensa de Derrida como no, una nostalgia por los orígenes perdidos puede estar en detrimento de la exploración de las realidades sociales dentro de la crítica del imperialismo.

En el caso del sati, nunca fue cuestionada la voluntad de la mujer en su práctica, y en el momento de su abolición, como una manera despótica y con el pretexto de la protección de las mujeres, surge la afirmación de la voluntad de la mujer diciendo que «Las mujeres querían morir», suponiendo el origen perdido perfecto en armonía con los hindúes, que los británicos han destrozado. Este argumento solo surge con la intervención del exterior, de

\footnotetext{
${ }^{25}$ Nietzsche, Friedrich Wilhelm (1844-1990), filósofo y crítico de la cultura alemana. [Audi, Robert (ed.): Diccionario Akal de Filosofía, Op.cit., p. 708.]

${ }^{26}$ Rousseau, Jean-Jaques (1712-1778), filósofo, ensayista, novelista y músico francés de origen suizo, conocido sobre todo por sus teorías de la libertad social y los derechos sociales, la educación y la religión. [Audi, Robert (ed.): Diccionario Akal de Filosofía, Op.cit., p. 855.]

${ }^{27}$ Heidegger, Martin (1889-1976), filósofo alemán, caracterizado por su contribución inicial a la fenomenología y al existencialismo (por ejemplo, a través de Sartre) y por haber allanado el camino a la hermenéutica (Gadamer) y al postestructuralismo (Derrida y Foucault) con la ayuda de sus últimas obras. [Audi, Robert (ed.): Diccionario Akal de Filosofía, Op.cit., p. 480.]
} 
otra manera no se hubiera generado la contradicción. Es decir, el argumento de los nativos no es de eurocentrismo, pero repite la misma estructura siendo etnocentrista. Por eso, Spivak comenta que es una parodia de la nostalgia por los orígenes perdidos que permanecía de occidente.

Por otra parte vemos en esta frase un asunto íntimo de la mujer, en tanto que el deseo de la mujer se convierte en asunto público político e ideológico. Podemos imaginar que el sacrificio de la viuda adjunta un valor de rechazo ante el colonialismo imperialista y reclama la autoridad de la India por los nativos a través de su propia tradición, además de ser un acto sagrado religioso. Así el sati se ha convertido en un asunto político ideológico.

A fin de cuentas, aunque los británicos creen proteger la vida de las viudas hindúes mediante la abolición, como consecuencia la mujer queda en una situación paradójica con el énfasis de la voluntad del sacrificio para proteger el honor de la India, de su tierra nativa, como reacción contra la modificación de la ley por parte del poder occidental sobre la colonia.

Spivak menciona la relación entre estos dos argumentos "Hombres blancos salvan a las mujeres de piel morena de los hombres de piel morena" y "Las mujeres querían morir".

En realidad, las dos afirmaciones siguen un largo recorrido para legitimarse la una a la otra. Nunca se encuentra el testimonio de la conciencia de la voz de las mujeres. Dicho testimonio no es que sea ideológico-trascendente o «completamente» subjetivo, por supuesto, pero posee todos los ingredientes para provocar una afirmación contraria. $^{28}$

La mujer, cuando se queda viuda, si no toma la decisión del sacrificio, sería considerada seguidora del imperialismo británico y aquella que abandona la creencia y la cultura propias de los hindúes; además, no le tiene amor a su marido. Si realizara la autoinmolación, se convertiría en una delincuente para los gobernadores. En este caso, la mujer queda

${ }^{28}$ Ibíd., pp. 98-99. 
doblemente marginada de la regla social del poder gobernador y de la norma de la propia comunidad étnica. Por ser viuda, cualquier elección que tome resulta molesta en su sociedad, que mantiene un doublé bind (doble estándar). Y los dos argumentos, aunque se consideran legítimos por sí mismos, en realidad sostienen su legitimidad en el hecho de tenerse el uno al "otro".

Además, la doble función de este sistema le obliga a callarse. En esta estructura de contrafrase, aunque los intelectuales del primer mundo le ofrezcan a la mujer un espacio libre para hablar, este acto no tiene sentido. Porque ella nunca puede liberarse de esta relación ideológica de los dos argumentos, y el espacio libre que suponen los intelectuales del primer mundo se convierte en un campo de batalla ideológico para la mujer no occidental desgarrada por dos culturas distintas. De ahí que la mujer se quede en silencio, nunca podremos oír su voz entre estas contrafrases de los hombres. 
II.2. La paradoja de la libre elección de la mujer. 
A continuación del apartado anterior, seguimos a G. C. Skivak aclarando las dificultades y el paradójico contexto que reproduce seres mudos oprimidos, basándose en el análisis del entorno sati. A consecuencia de dichas contrafrases que hemos visto en el apartado anterior, los británicos utilizan a la mujer como significante de colonización y fundación de la buena sociedad, para legitimar así su intervención política de una manera imperialista. Obviamente, la postura de los británicos trata a la mujer como objeto. Y Spivak pregunta:

\section{La imagen del imperialismo (o de la globalización) como el establecedor de la sociedad ideal viene marcada por la creencia en la mujer como objeto de protección respecto a los de su propio grupo. ¿Cómo debería examinarse este disimulo de la estrategia patriarcal, que aparentemente le garantiza a la mujer una capacidad de libre elección como sujeto? ${ }^{1}$}

La postura imperialista de la primera oración, que impone a la mujer como objeto que debe proteger, desde el punto de vista del feminismo será rechazable. Por otro lado, la segunda frase afirma la posición de la mujer como sujeto que cuenta para tomar una decisión libre sobre su propia vida o muerte: ¿cómo podemos considerarla? La autoinmolación de la viuda ha sido calificada por los hindúes nativos como la consecuencia de una decisión voluntaria de la valiente señora, virtuosa hindú con respeto a la tradición, además de ser el momento de mostrar su profundo amor al marido. Además, es la única ocasión de actuar por su propia iniciativa para las hindúes que viven bajo ese sistema patriarcal estricto, es decir, es el momento de convertirse en sujeto de su propia vida y cuerpo. Si el feminismo reclama la autoridad de la mujer en su propia vida y cuerpo, la elección de la práctica sati podría considerarse como un derecho de la mujer de la India. Con esta consideración superficial, el feminismo podría apoyar la autoinmolación de la mujer, pero esta idea es sumamente contradictoria. Spivak desarrolla la crítica de la conducta de construcción del sujeto femenino, aclarando en este caso la realidad de libre elección de la mujer. A continuación veremos los detalles.

\footnotetext{
${ }^{1}$ Spivak, Gayatri Chakravorty: ¿Pueden hablar los subalternos? trad. Manuel Asensi Pérez. Barcelona, Museu d’Art Contemporani de Barcelona, 2009, p. 103.
} 


\section{II.2.1. Contranarrativa de la mujer.}

Spivak observa que leyendo entre líneas como la parte blanca del texto, basado en el Dharmaśâstra y el $R g$-Veda, puede realizarse una interpretación sospechosamente favorable para la parte del argumento de los hombres hindúes fundamentalistas que analizan el sujeto de la mujer.

Para aproximarme a esta cuestión tendré en cuenta el Dharmaśâstra y el Rg-Veda. Aunque se trata de dos textos muy diferentes, pueden representar «el origen arcaico» en mi homología a partir de Freud. Mis lecturas son un examen interesado e inexperto, por parte de una mujer expatriada, de la fabricación de una represión, de la construcción de una contranarrativa de la conciencia de la mujer, por tanto del ser mujer, del ser una mujer buena, del deseo de una buena mujer, del deseo de la mujer, pues. Paradójicamente, este mismo movimiento nos permite testimoniar el lugar inestable de la mujer como significante en la inscripción del individuo social. ${ }^{2}$

Spivak aclara su posición como lectora exterior, debido al hecho de ser una mujer que vive en el extranjero, fuera de ese sistema, y está interesada en el tema. Pero una parte de esto representa una ventaja para poder testimoniar un sitio inseguro de la mujer como significante durante estos textos, que en el hinduismo ocupan una posición equiparable a la Biblia. Según Spivak, vamos a ver la función de transformarse la mujer como significante dentro del examen sobre la ideología india tanto como hemos visto en el ejemplo anterior de los británicos.

A pesar de que la religión hindú prohíbe estrictamente el suicidio, existe alguna excepción, considerada como un sacrificio para hermanarse a la verdad mediante la superación de la individualidad. Y el sacrificio por muerte de la pareja, solo se lo permite a la mujer.

Este suicidio que no es un suicidio podría ser leído como simulacro tanto del conocimiento-verdadero como de la piedad por un lugar. En el primer caso, es

\footnotetext{
${ }^{2}$ Ibíd., p. 103.
} 
como si en un sujeto el conocimiento de su propia insustancialidad y mera fenomenalidad fuera dramatizado de modo que el marido muerto se convirtiera en el ejemplo exteriorizado y en el lugar del sujeto extinguido y la viuda llegara a ser un (no)agente que «tuviera un mal comportamiento». La consecuencia lógica de situar la agencia en la alteridad es que transforma la ética en un cálculo institucional que supuestamente codifica la intención del agente ausente. En el segundo caso, es como si la metonimia de todos los lugares sagrados fuera ahora la cama de madera en llamas, construida en virtud de un elaborado ritual, en el que el sujeto de la mujer, legalmente desplazada de sí misma, estuviera siendo consumido. Es en los términos de esta profunda ideología del lugar desplazado del sujeto hembra donde se pone en juego esa paradoja de la libre elección. ${ }^{3}$

Spivak supone la lectura del sati -la autoinmolación de la mujer viuda tras la muerte de su marido, que ha calificado como que no es un suicidio- como un simulacro del conocimiento de la verdad como la devoción de lugar. Según lo que nos muestra, nos da a entender que la mujer seguidora e imitadora, tras el esposo muerto, es como un buen ejemplo. La simetría de la pareja del marido y la mujer confirma la relación de sujeto y objeto en este caso. Como consecuencia, esta cuestión de elección se convierte en una cuestión de ética. Dentro de esa noción, evidentemente lleva el concepto de que el sujeto de la mujer es impuro y sucio, así que puede desplazarse de sí misma para llegar al lugar sagrado. Spivak, de esta manera, nos muestra el lugar donde funciona la paradoja de la libre elección de la mujer. El sujeto femenino que toma la elección libre se encuentra en esa narrativa dramatizada: la viuda autoinmolada para seguir al sujeto extinguido o el sujeto de la mujer desplazada de su individualidad. Spivak compara la diferencia del trato sobre el sujeto masculino y femenino en el caso del sacrificio permitido por la religión:

Para el sujeto macho, se trata de la felicidad del suicidio, una felicidad que anulará más que establecerá su estatus como tal. Para el sujeto femenino, una autoinmolación sancionada, aunque arrastre el efecto de una «caída» (pātaka) unida a un suicidio no permitido, comporta el elogio en otro registro por ese acto de

\footnotetext{
${ }^{3}$ Ibíd., p. 105.
} 
elección. Debido a la inexorable producción ideológica del sujeto sexuado, tal muerte puede ser comprendida por el sujeto femenino como un significante excepcional de su propio deseo, que excede la regla general referida a la conducta de la viuda. ${ }^{4}$

En el caso masculino, su acto en sí ya tiene el valor y alegría de forma autónoma, pero en el caso de la mujer solo evita el delito $\mathrm{y}$, para que se justifique como válido, debe fundamentarse en el acto de elección por su voluntad, que viene de otro nivel de operación lingüística. De esta manera se produce inexorablemente el sujeto sexuado y el sujeto femenino se convierte en un significante excepcional de su propio deseo por la función de ir tras la muerte. En estos discursos, escondida, se ve la superioridad del sujeto masculino sobre el sujeto femenino. Además, la construcción del sujeto sexuado es un producto ideológico. Ahí vemos otra vez el sujeto de la mujer como significante, en este caso excepcional de su propio deseo, lo cual quiere decir que el sujeto en sí no se lee, es una agencia para indicar el deseo de la mujer de querer morir en el discurso ideológico. Con esta falsa justificación, los nacionalistas hindúes argumentan que las mujeres realmente querían morir. Este discurso ideológico se extiende y se aprovecha para ejercer la opresión a la mujer.

La autoinmolación, una vez que se establece como un significante excepcional del deseo de la viuda en su contexto, puede generalizarse como una regla. Como ejemplo, nombraremos ciertos periodos y áreas cuya regla excepcional se convirtió en una regla general de una clase específica. A partir del siglo dieciocho y hasta principios del siglo diecinueve, en Bengala fue notable la generalización del sati y hay cierto estudio que explica algunos factores causantes de esa tendencia, desde el control de la población hasta la misoginia comunal religiosa, pero Spivak centra la atención en un factor específico:

Ciertamente su prevalencia aquí en los siglos anteriores se debió a que en Bengala, a diferencia lo que ocurría en el resto de la India, las viudas podían heredar la

\footnotetext{
${ }^{4}$ Ibíd., pp. 105-106.
} 
propiedad. Por tanto, lo que los británicos veían como pobres mujeres victimizadas yendo al matadero era de hecho un campo de batalla ideológico. ${ }^{5}$

Aludiendo al estudio de Asi Nandy ${ }^{6}$, que busca la razón de dicha notable difusión del sati en los siglos XVIII y XIX en esa región a partir del control de la población hasta llegar a la misoginia de la comunidad, Spivak afirma la causa de esa generalización de autoinmolación como una transformación del evento excepcional a la regla habitual, la cual tiene que ver con la cuestión de la lucha económica sobre la herencia del marido fallecido.

Y cita a P. V. Kane, el gran historiador del Dharmaśâstra, como ejemplo de una indicación precisa:

En Bengala, [el hecho de que] la viuda de un miembro sin hijos, incluso en una familia hindú unida, posea prácticamente los mismos derechos sobre la propiedad de la familia que su marido fallecido indujo a los miembros supervivientes a deshacerse de la viuda apelando en los momentos más angustiosos a su devoción y amor por el marido. (HD II.2, 635). ${ }^{7}$

Consideraremos que la indicación de Kane es justa y cierta. El análisis sobre la situación trágica de la viuda por el gran historiador nos muestra el impacto de la mala aplicación del rito convencional sobre la mujer por el interés económico. Es un producto del atropello del derecho de la viuda, y esa transformación del significante excepcional a la regla general sobre la autoinmolación de la mujer se convierte en un dispositivo para eliminar a una posible poseedora de fortuna y permitir que le robaran otros miembros familiares. Como esto causa que la viuda quede obligada a la autoinmolación por tener el derecho de herencia del marido, es paradójico además de injusto.

\footnotetext{
${ }^{5}$ Ibíd., p. 106.

${ }^{6}$ Nandy, Ashis: Sati: a Nineteenth-Century Tale of Woman, Violence and Protest, en Joshi, V. C. (ed.): Rammohun Roy and the Process of Modernization in India. Nueva Delhi: Vicas Publishing House, 1975.

${ }^{7}$ Spivak, Gayatri Chakravorty, Op.cit. p. 106.
} 


\section{II.2.2. Una aporía de contrafrases y el différend.}

A pesar de que Kane, el gran historiador masculino, no comparte el acto de suicidio de la viuda, describe correctamente la situación tan difícil a la que debe enfrentarse y aplaude el valor de la elección libre a morir de la mujer:

La India moderna no justifica la práctica del sati, pero es una mentalidad perversa la que censura a los hindúes modernos por expresar admiración y reverencia por el fantástico y discreto coraje de las mujeres indias por mantener sus ideales de conducta femenina. (HD II.2, 636). ${ }^{8}$

El comentario del gran historiador masculino es contradictorio. De todos modos, aunque se niega la práctica del suicidio en nombre de la India moderna, el autor no oculta la admiración al valor de la elección libre de las mujeres con una buena conducta femenina. De este modo, acepta y afirma la producción del sujeto subalterno sexuado. Y mantiene la estructura de contrafrase diciendo que las mujeres deseaban morir como argumento de la parte india nativa.

Spivak indica que esta admiración patriarcal está en consonancia con la lógica para la práctica e intenta explicar la contradicción de esta contrafrase de ambas partes, indios y británicos, de la siguiente manera:

En contraste, la relación entre la benevolencia británica y dicha lógica es en efecto "un caso de conflicto [...] que nos puede ser equitativamente resulto por una falta de regla de juicio aplicable a ambos argumentos. La legitimidad de una parte no

\footnotetext{
${ }^{8}$ Loc.cit.

Esta parte de la cita de Kane en la versión del año 1988 y la última versión en el tercer capítulo de Crítica de la razón poscolonial incluyen una indicación sobre jauhar, que es una autoinmolación en el grupo de aristócratas rajputs, las viudas de guerreros o de hombres a punto de serlo: La india moderna no justifica la práctica del sati, pero es de mentalidades retorcidas reprender a los indios modernos por expresar admiración y reverencia por el coraje sereno y resuelto de las mujeres indias cuando se convierten en satis o llevan a cabo el jauhar para mantener sus ideales de conducta femenina [HD II.2 636]. [Spivak, Gayatri Chakravorty: Crítica de la razón poscolonial, trad. Marta Malo de Molina. Madrid: Akal, 2010. p. 289.]
} 
implica la falta de legitimidad de la otra». ${ }^{9}$ Por supuesto, históricamente, la legitimidad fue establecida por un poder abstracto institucional. ${ }^{10}$

Citando unas frases del filósofo francés del postmodernismo Jean-François Lyotard ${ }^{11}$, Spivak menciona una aporía de estas contrafrases. Para empezar, no es válido darle una legitimidad a uno de los lados para mostrar la falta de legitimidad del otro lado. Entonces, por esta aporía, mantiene eternamente esta estructura de dicotomía opuesta entre sí: los dos lados reclamarán su legitimidad, cada uno por sus propias razones. Y nunca se puede dar un juicio correcto de la elección debido a la falta de un criterio aplicable a ambos argumentos. Entre esta tensión dinámica, un sujeto al que le es exigida una elección como producto de la ideología implacable, se queda mudo (en este caso, muda). Spivak interpreta esta situación como que el sujeto subalterno sexuado se encuentra en un lugar de différend, del término de Lyotard, y cita lo siguiente:

En el différend, algo «pide» ser expresado en frases, y sufre por la imposibilidad de no poder ser expresado a través de unas frases de una forma correcta. Esto ocurre cuando los seres humanos que piensan que podrían usar el lenguaje como instrumento de comunicación aprenden a través del sentimiento de dolor que acompaña al silencio (y del placer que acompaña la invención de un nuevo idioma), que son reclamados por el lenguaje, no para aumentar en su provecho la cantidad de información comunicable a través de los idiomas existentes, sino para reconocer que lo que queda por ser expresado excede lo que pueden ahora expresar, y que se les debería permitir instituir idiomas que todavía no existen. ${ }^{12}$

\footnotetext{
${ }^{9}$ Lyotard, Jean-François: The Differend: Phrases in Dispute. Trad. De George Van Den Abbeele, Minneapolis, University of Minnesota Press, 1988, p XI; ed. or.: Lyotard, Jean-François. Le différend. París: Minuit, 1983; ed. cast.: La diferencia, Barcelona, Gedisa, 1991, p. 9.

${ }^{10}$ Spivak, Gayatri Chakravorty: ¿Pueden hablar los subalternos? Op.cit. p. 106.

${ }^{11}$ Lyotard, Jean'François (1924-1998), filósofo francés, considerado uno de los más representativos protagonistas del movimiento conocido como post-estructuralismo. De entre principales pensadores postestructuralistas (Gilles Deleuze [1925-1977], Derrida y Foucault), Lyotard es el que se encuentra más intimamente asociado a la posmodernidad. [VV.AA. Diccionario Akal de Filosofía, Op.cit., p. 636.]

${ }^{12}$ Lyotard, Jean-François. The Differend: Phrases in Dispute, trad. De George Van Den Abbeele, Minneapolis: University of Minnesota Press, 1988, p 13; ed. or.: Lyotard, Jean-François. Le différend. París: Minuit, 1983; ed. cast.: La diferencia, Barcelona, Gedisa, 1991, p. 26. En: Spivak, Gayatri Chakravorty: ¿Pueden hablar los subalternos? Op.cit., p. 107.
} 
Sobre el libre albedrío femenino hay dos versiones, interpretada una por los indios nativos y otra por los británicos: la primera es elegir la autoinmolación y la otra, rechazarla. Según Spivak, la viuda puede cambiar de opinión sobre la práctica de la autoinmolación después de tomar su decisión, pero eso produce que reciba un tipo de penitencia por su hecho de transgresión. En cambio, para la policía británica local que supervisa el sati, la suspensión después de tomar la decisión de la autoinmolación es el verdadero libre albedrío de la mujer. La viuda, para mostrar su elección libre, debe elegir morir tras la muerte de su esposo, luego rechazar su práctica y posteriormente recibir la penitencia: es el acto valiente y verdadero de la mujer hindú que suponen los británicos. Con esta estructura de contrafrase, el punto esencial de diagnóstico del libre albedrío femenino es sustituido por otro. Por supuesto, nosotras no estamos a favor de matar a la viuda, al igual que Spivak, punto este que constituye el motivo real de este análisis. Por ello nos explica lo siguiente:

Obviamente no estoy defendiendo la muerte de las viudas. Sugiero que, dentro de estas dos versiones enfrentadas de la libertad, la constitución del sujeto hembra en vida es el lugar de lo différend. En el caso de la autoinmolación de la viuda, el ritual no está siendo redefinido como patriarcal sino como crimen. La gravedad del satí consistía en que era ideológicamente catectizado como «recompensa», de la misma forma que la gravedad del imperialismo estribaba en que era ideológicamente catectizado como «misión social». ${ }^{13}$

La función ideológica contra occidente también repite el esquema imperialista, aunque el contenido manifiesta totalmente lo contrario. Los británicos aprovechaban la protección de la mujer como significante de la buena sociedad y era un cargo ideológico, una "misión social" y con este argumento legitimaban la soberanía en la India. Ahora, para la parte de la India nativa, mediante la autoinmolación el sujeto de la mujer se convierte en significante excepcional de esta estructura. El acto en sí incluye el sentido de una recompensa para la mujer en la narrativa mítica, así que prefiere morir dentro del discurso del hindú nativo. De esta manera, la insistencia del libre albedrío femenino sobre la autoinmolación es una manipulación ideológica peligrosa.

\footnotetext{
${ }^{13}$ Spivak, Gayatri Chakravorty: ¿Pueden hablar los subalternos? Op.cit., p. 108.
} 
Y en la última versión de este texto, Spivak no deja de mencionar la situación actual: la mujer subalterna está entre lo patriarcal y el Desarrollo que dirige organizaciones institucionales basadas en el neo imperialismo, que forma parte de la capitalización global. Un lado argumenta la misión social por la protección de la mujer, el otro lado recompensa con el valor tradicional en la protección de la buena conducta femenina. Como hemos visto, el esquema no ha cambiado nada y su procedimiento cada vez es más complejo y diestro.

\section{II.2.3. La reproducción del subalterno sexuado.}

Para examinar y criticar bien el sujeto femenino que tiene libre elección de autoinmolación, Spivak analiza el efecto asimétrico sobre la formación ideológica del sujeto sexuado. La viuda, por ley general de la doctrina sagrada hindú, debe retroceder a un estado estático sexual, igual que antes del matrimonio, y son bien conocidos los males institucionales por esta ley. A pesar de surgir una gran polémica sobre el sati como destino excepcional del destino de la viuda, no hubo debate sobre este "destino no excepcional de las viudas"14 entre los hombres, ni hindúes ni británicos. Este hecho de no haber discutido sobre el destino no excepcional de la viuda es aún más significativo, según Spivak. Porque no discutir el destino de la viuda no excepcional, sino solo prestar atención a lo excepcional esconde la posibilidad sospechosa de encubrir al sujeto sexuado subalterno una vez formado. Y una vez más, Spivak menciona la asimetría de la mujer como individuo en las reglas religiosas, ya que encuentra la diferencia entre lo masculino y lo femenino.

Esta asimetría legalmente programada en el estatus del sujeto, que efectivamente define a la mujer como objeto de un marido, opera obviamente en interés del estatus del sujeto masculino legalmente simétrico. En consecuencia, la autoinmolación de la viuda se convierte más en un caso extremo de la ley general que en una excepción a ella. ${ }^{15}$

\footnotetext{
${ }^{14}$ Ibíd., p. 111.

${ }^{15}$ Loc.cit.
} 
Aquí el esquema de oposiciones dicotómicas ideológicas del sujeto/objeto, el esposo/esposa, el hombre/mujer y la soberanía del uno sobre el "otro", favorece claramente al hombresujeto. Los hindúes rechazan la soberanía de los británicos porque llevan el esquema del sujeto Británico sobre el objeto India, y al mismo tiempo este esquema ideológico es perceptible en la comprensión de la libre elección femenina.

Basada en esta estructura ideológica, la mujer, como el objeto al perder al esposo como el sujeto, debido a esa muerte elige la autoinmolación. Esa elección es libre naturalmente conforme a la estructura ideológica. Ahí nos fijamos en la transición de la postura de sati del caso excepcional al caso extremo de la ley general. Spivak sigue comentando en tono irónico una parte de la doctrina sagrada hindú que insiste en la recompensa para la viuda, en la expresión de la mujer llena de alegría al seguir a su marido identificándose así en un objeto del hombre-sujeto.

No sorprende leer acerca de las recompensas que el sati obtendrá en el cielo, en donde la cualidad de ser el objeto de un único poseedor queda enfatizado mediante la rivalidad con otras hembras, esas celestes danzarinas en éxtasis, modelos de belleza femenina y placer masculino que cantan su plegaria: "Ella en el cielo, solo dedicada a su marido, y alabada por grupos de apsarās (danzarinas celestes), juega con su marido y con catorce reglas Indras» (HD II.2, 631). ${ }^{16}$

La doctrina hindú le promete a la mujer, atrapada por la mitología, la alegría en el cielo y estar junto con el marido en cierta eternidad. Así funciona la recompensa para el sati, la contradicción y la artimaña de la libre elección de la autoinmolación de la mujer. Sin embargo este elemento se puede empeorar todavía más para la mujer:

La profunda ironía de situar la libre voluntad de la mujer en la autoinmolación se revela una vez más en un verso que acompaña el pasaje anterior: «En la medida en que la mujer [como esposa: stri] no se queme a sí misma en el fuego tras la muerte del marido, nunca se liberará [mucyate] de su cuerpo femenino [strisarir, es decir,

\footnotetext{
${ }^{16}$ Loc.cit.
} 
del ciclo de los nacimientos]». Incluso en el caso de que ello lleve a cabo la más sutil liberación general de la agencia individual, este peculiar suicidio sancionado de la mujer extrae su fuerza ideológica de la identificación de la agencia individual con la supraindividual: mátate a ti misma ahora en la pira del marido y podrás destruir tu cuerpo femenino en el ciclo completo del nacimiento. ${ }^{17}$

El argumento que subyace bajo esta narrativa afirma la condena de ser mujer con el cuerpo de la mujer. A través de la vida y de su cuerpo femenino, la mujer nunca será libre, y este mito-narrativo ideológico puede convertirse en la autoviolencia hacia la mujer.

En otro giro posterior de la paradoja, este énfasis en la libre voluntad establece la peculiar mala suerte de mantener el cuerpo femenino. ${ }^{18}$

De esta manera, y a consecuencia de este concepto, se puede interiorizar y mentalizar la condena del propio cuerpo femenino de la mujer. Una vez que la mujer mentalice este concepto con su narrativa, ser mujer es un infortunio y debería tomar la elección de la autoinmolación en el mismo momento que se le ofrece para así superar la condición de ser mujer. El dispositivo ideológico que produce al sujeto sexuado se establece y funciona de tal manera.

Spivak, después de confirmar esta estructura ideológica dentro del discurso hindú nativo y su función, prosigue el análisis sobre el jauhar, que es la autoinmolación del grupo de mujeres en la guerra contra los musulmanes. En resumen, dentro de la historia hindú, da máxima admiración a las mujeres que se han suicidado para evitar la violencia sexual frente a los enemigos conquistadores. Spivak lee el mensaje ideológico de que la mujer es el objeto del hombre y nunca será libre con su cuerpo femenino en la benévola admiración al jauhar por parte del historiador masculino del siglo veinte. Spivak critica el argumento supuesto para esta admiración de las mujeres que deciden suicidarse frente a los enemigos

\footnotetext{
${ }^{17}$ Ibíd., pp. 111-112.

${ }^{18}$ Ibíd., p.112.
} 
conquistadores y el abuso como el acto heroico femenino contado a las siguientes generaciones.

Aunque jauhar no sea, estrictamente hablando, un acto de sati, y aunque no sea mi intención de hablar de la violencia sexual sancionada de la armada masculina conquistadora, la autoinmolación femenina es ante esto una legitimación de la violación como algo «natural» y funciona, a largo plazo, en interés de una única posesión genital de la hembra. La violación de grupo perpetrado por los conquistadores es una celebración metonímica de la adquisición territorial. Del mismo modo que la ley general para las viudas no se cuestionaba, este acto de heroísmo femenino persiste en los cuentos patrióticos que se cuentan a los niños, operando por ello en el nivel más crudo de la reproducción ideológica. Ello también ha desempeñado un enorme papel, precisamente como significante sobredeterminado, en el reforzamiento del sentimiento hindú de comunidad (Internet produjo una serie de estadísticas espurias en torno al "genocidio» hindú en Bangladesh). De manera simultánea, la cuestión más amplia de la constitución del sujeto sexuado se oculta al subrayar la violencia visible del sati. La tarea de recobrar un sujeto (sexualmente) subalterno se pierde en una textualidad institucional del origen arcaico. $^{19}$

Como muy bien explica Spivak, de un lado da una legitimación al acto de los hombres que realicen violaciones sexuales como premio por ganar la guerra y, de otro lado, a la mujer le recomienda morir como acto heroico para proteger el honor y la sumisión al marido y al bando partidario, en este caso los hindúes.

Existen innumerables ejemplos en que se cuenta la autoinmolación como acto heroico femenino para proteger la fidelidad a su esposo, no solo en la India. Y cada comunidad lo narra con un mensaje ideológico, y la estructura será casi la misma aprovechada como significante para la comunidad. Y esta historia narrada pasa generación tras generación,

\footnotetext{
${ }^{19}$ Ibíd., pp. 112-113.
} 
reproduciendo una conciencia ideológica para la escenificación del comunitarismo, en este caso de sentimiento hindú.

Solo cuenta el caso excepcional, ya que funciona para la reproducción ideológica generación tras generación, ocultando los casos no-excepcionales. Aquí también vemos una contradicción al reflexionar sobre la libre elección de la mujer. En otras palabras, el sujeto de la mujer que elige la libre elección de la autoinmolación se establece durante mucho tiempo, tras generaciones habiendo estado basado en este tipo de historia normativizada por patriotas que la escuchan desde la infancia junto con los mitos religiosos. Estamos tratando del caso específico de la India, pero nos hace imaginar que tendríamos bastante facilidad si quisiéramos aplicar la misma estructura de establecer este tipo del sujeto femenino en otras comunidades de otra parte del mundo.

Antes de llegar a una conclusión, veremos otro origen de la historia del sujeto femenino subalterno en la comunidad india. Como hemos visto más arriba, hubo un momento en Bengala en que la autoinmolación de la viuda fue rigurosamente forzada. En aquel momento coincidió que la viuda podía ser del estatus del sujeto legal. Spivak indica una operación de mala interpretación del texto para legitimar la ejecución por autoinmolación.

Según la explicación de Spivak, se encuentran dos malas interpretaciones en la frase que dice “"Dejad a esas esposas dar un primer paso en la casa» (HD II.2, 634)",20. Primera, la frase como procedencia de la aprobación de la inmolación de la viuda, con una lectura sencilla es evidente que no se refiere a la viuda, sino a las esposas de la casa del hombre muerto, cuyos maridos están vivos. La otra, la primera palabra que empieza en la segunda frase, agré, que quiere decir "primero", algunos la han leído agné: “Oh, fuego". Es decir, que tras una lectura equivocada o una mala interpretación del texto sagrado, surge el ritual de la autoinmolación de la mujer. Esta operación está en diferente orden del origen arcaico que hemos analizado sobre el sujeto femenino subalterno. Estas dos frases no dicen nada sobre quemar a la viuda. Además del cambio de letras en la palabra, adjunta la palabra que relaciona al fuego como una clave del sacrificio sati.

\footnotetext{
${ }^{20}$ Ibíd., p. 113.
} 
He aquí otro escenario del origen de la historia del sujeto subalterno femenino. ¿Se trata de una onirocrítica que debe ser puesta en práctica en relación con una afirmación como esta: "Por consiguiente, debe admitirse que o bien los MSS son corruptos, o Raghunandana cometió un inocente desliz». (HD II.2, 634)? ${ }^{21}$

Por unos corruptos manuscritos o un inocente desliz de un gran maestro de ley, cuántas mujeres se habrán quemado junto con el cadáver de su marido muerto. Por el hecho de normativizar este tipo de interpretación errónea, cuántas mujeres se habrán quedado sin propia voz en la batalla ideológica y cuántas más pasarán por lo mismo todavía. A pesar de encontrarse este error terrible, el gran historiador afirma e intenta buscar el origen del sati en este verso. Y se encuentra una confusión en otros textos que como guía práctica de leyes hindúes afirman el consentimiento del divorcio y nuevo casamiento basado en misma parte del verso que estamos indicando. Obviamente, es totalmente distinta de las otras ideas extraídas del mismo texto. Respecto a esto, Spivak hace mención al chiste del caldero de Freud $^{22}$.

\section{II.2.4. El subalterno sexuado en capas narrativas ideológicas.}

Hemos visto hasta ahora la contranarrativa construida de la conciencia de la mujer, del ser mujer, el que la mujer sea buena, el deseo de la mujer buena y el deseo de la mujer, siguiendo a Spivak. En la última parte, ella se fía del significado de la palabra sati, que es una forma femenina de sat, que es un participio presente del ser, tiene sentido de la Verdad, lo Bueno, lo Justo, y trasciende la noción de género de la masculinidad y asciende no solo a la universalidad humana sino también a la espiritual.

\footnotetext{
${ }^{21}$ Loc.cit.

${ }^{22}$ Cuento o chiste del caldero (Kessel-Logik): un hombre le pidió explicaciones a su vecino porque le prestó un caldero y se lo devolvió roto. Aparece en el segundo capítulo de Interpretación del sueño. Dicho vecino le dio tres explicaciones incompatibles: la primera, que el caldero que le había devuelto no estaba roto; la segunda, que el caldero ya estaba roto cuando se lo había prestado; y la tercera era que no le había prestado nada. Freud indica: aunque las tres explicaciones son incompatibles entre ellas, si solo una pudiera ser aceptada como si fuera razonable, el hombre sería inocente.
} 
Es lo bastante noble como para haber entrado en el discurso más privilegiado de la filosofía moderna occidental: la meditación de Heidegger en torno al Ser. ${ }^{23}$ Sati, el femenino de esta palabra, significa simplemente «buena esposa». ${ }^{24}$

En esta muestra vemos la soberanía de la masculinidad escrita en el lenguaje. Lo superior y lo que significa trascendencia del universo es masculino y en el preciso momento en que se empieza a hablar de afeminado se pierde el gran sentido. En otras palabras, el ser femenino solo contacta con el gran ser registrado como buena esposa. Otra vez vemos la típica operación ideológica androcentrista. Además de esto, la traducción de los británicos cometió el error sobre el sentido de sati.

Ya es hora de descubrir que sati o suttee, como nombre propio del rito de autoinmolación de las viudas, conmemora un error gramatical por parte de los británicos, del mismo modo que la expresión «indio americano» conmemora un error factual por parte de Colón. En las diferentes lenguas de la India la palabra equivale a «la quema del sati» o de la buena esposa, que por ello escapa del éxtasis regresivo de la viuda en brahmacarya. Ello ejemplifica las sobredeterminaciones de la situación por la raza, la clase y el género. Puede quizá ser percibido incluso cuando se uniforma: hombres blancos tratando de salvar a las mujeres de piel morena de los hombres de piel morena, impuesta sobre esas mujeres una enorme construcción ideológica a través de la identificación absoluta, dentro de la práctica discursiva, de la buena esposa y de la autoinmolación en la pira del marido por una ignorante (aunque sancionada) sinécdoque. En el otro lado de esta constitución del objeto, la abolición (o el fin) del cual proporcionará la ocasión para el establecimiento de una buena sociedad, en cuanto diferente de una meramente civil, se encuentra la manipulación hindú de la constitución del sujeto femenino, que he tratado de analizar. ${ }^{25}$

\footnotetext{
${ }^{23}$ Martin Heidegger: An Introduction to Metaphysics, trad. De Ralph Manheim. Nueva York: Doubleday Anchor, 1961, p. 58. Se trata del memorable pasaje en el que Heidegger indaga en la etimología de la palabra «ser». Véase la versión española, Introducción a la metafísica. Barcelona, Gedisa, 2003, pp. 70-73.

${ }^{24}$ Spivak, Gayatri Chakravorty: ¿Pueden hablar los subalternos? Op.cit., p. 115.

${ }^{25}$ Ibíd., pp. 115-116.
} 
De todos modos, los británicos, aprovechando la protección de la mujer como significante para la buena sociedad, razonando así el dominio en la colonia, al mismo tiempo identificaron a la mujer autoinmolada como buena esposa y la obligaron a esta imposición ideológica, tratándola como objeto. Paralelamente, bajo el control y la operación de los británicos sobre la India como su objeto, seguía la operación de construir el sujeto falso femenino basado en la libre voluntad de la mujer por parte de los hindúes, que aprovechaban aquella estructura de dicotomía opuesta tal y como hemos visto hasta ahora. Esta red de ideología e historia normativizada que atrapa a la mujer subalterna está por encima de determinaciones, de la clase, de la raza y del género. Spivak menciona la palabra sati y ahora, hoy en día, en la India se transforma en un nombre Sati para las mujeres. Spivak enfatiza la realidad irónica de llamar a una niña "buena esposa", pero el fundamento de poner este nombre a las chicas tiene otro origen que nos hace mostrar esa tremenda ironía. Según Spivak, este nombre hace referencia a Durga, una figura que aparece en la historia mítica y es la esposa de Siva, el gran dios hindú. El mito cuenta la muerte de SatiDurga y la venganza del marido por la muerte de su mujer. Sati-Durga muere por el conflicto entre su propio padre y el gran esposo. Su cadáver es fragmentado y, allá donde caen sus partes, los terrenos se convierten en tierras santas. Es el mito que explica la fundación de las rutas de peregrinación:

La historia de la mítica Sati, subvirtiendo todo narratema del mito, cumple una función similar: el marido vivo venga la muerte de la esposa, una transacción entre los grandes dioses machos culmina en la destrucción del cuerpo femenino e inscribe, por ello, la tierra como geografía sagrada. ${ }^{26}$

Este sería otro ejemplo normativizado para la constitución del sentimiento de hinduismo, identificando en la tierra sagrada y la imagen de la mujer sacrificada por buena conducta de la hija y la esposa la recompensa de conmemoración de lo sagrado y de la venganza del marido, como una prueba del amor que sigue activo hasta hoy en día. Con esta historia Spivak nos advierte prudentemente para que no incurramos de nuevo en el error de buscar el carácter feminista en la religión hindú.

\footnotetext{
${ }^{26}$ Ibíd., p. 119.
} 
Ver esto como prueba del feminismo del hinduismo clásico o de la cultura de la India como centrada en las diosas y, por ello, feminista, está tan contaminado ideológicamente por el nativismo o el etnocentrismo opuesto como lo estaba el imperialismo al borrar la imagen de la lucha luminosa de la Madre Durga, y revestir el nombre propio Sati únicamente con la significación del ritual de la quema de la viuda indefensa como ofrenda que, en ese caso, puede ser salvada. No hay lugar desde el cual pueda hablar el sujeto subalterno sexuado. ${ }^{27}$

Ante esta situación de las capas narrativas ideológicas amontonadas, ¿cómo podremos contestar a la pregunta sobre si puede hablar la subalterna?

El resultado de este análisis es la respuesta negativa de Spivak: no hay lugar para que el sujeto subalterno sexuado hable.

\section{II.2.5. Una posibilidad de hablar el subalterno en el acto "performativo".}

Llegamos a la misma conclusión que Spivak. Ella pide una revisión del juicio sobre la historia de la sexualidad de Occidente y evita así la aplicación de la teoría

Entre patriarcado e imperialismo, entre la constitución del sujeto y la formación del objeto, la figura de la mujer desaparece, no en una nada limpia, sino en una violenta ida y vuelta que es una figuración desplazada de la «mujer tercermundista» atrapada entre la tradición y la modernización, el culturalismo y el desarrollo. Estas consideraciones revisarían cada detalle de los juicios que parecen válidos para la historia de la sexualidad en Occidente: «Esta sería la propiedad de la represión, la que la distingue de las prohibiciones ejercidas por la simple ley penal: la represión funciona como una afirmación que desaparece, pero también como una incitación al silencio, una afirmación de no existencia; y por consiguiente asegura

\footnotetext{
${ }^{27}$ Loc.cit.

La última oración ("No hay lugar desde el cual pueda hablar el sujeto subalterno sexuado") no aparece en la versión del año 1993, pero se ha recuperado en la nota nº 156 de la edición crítica de Manuel Asensi Pérez.
} 
que de todo esto no hay nada que decir, ver o saber». ${ }^{28}$ El caso del suttee es un ejemplo de que la mujer-bajo-el-imperialismo retaría y deconstruiría esta oposición entre el sujeto (ley) y el objeto-de-conocimiento (represión) e indicaría el lugar de la «desaparición» con algo distinto del silencio y la no existencia, una violenta aporía entre el sujeto y el estatus del objeto. ${ }^{29}$

Citando una frase de Historia de la sexualidad de Foucault, Spivak pide una revisión de la postura de ser reprimido debido al caso que hemos estado viendo hasta ahora. La cuestión ya no solo se concentra en la desvalorización existencial, ni en la invisibilización, ni en la lucha para obtener el sujeto liberándose de la posición del objeto represiva, sino que indica la desaparición con una manera diferente al silencio y a la inexistencia. Y la mujer subalterna se queda en la aporía violenta entre el estatus de sujeto y el de objeto. Para Spivak, en los dos discursos del colonialismo, el británico y el etnocentrista por parte de los nativos, no existe ese lugar que dé cabida a que el sujeto subalterno desarrolle su propia voz, y menos aún a que pueda hablar.

Al final de su texto, Spivak menciona el caso del suicidio de una chica en Calcuta en el año 1926. Ella se llamaba Bhuvaneswari Bhaduri tenía dieciséis o diecisiete años. La causa del suicidio no se supo durante largo tiempo y posteriormente se aclaró la causa diciendo que era consecuencia del rechazo de un encargo de asesinato político. Ella, sabiendo la obligación de su misión, aun así no pudo realizar el asesinato y como consecuencia eligió matarse sí misma. Estuvo en la aporía entre la misión política y la ética humana. Bhuvaneswari, para evitar que sospecharan su pasión ilegítima, se mató, y esperó a ejecutar el suicidio hasta que tuvo la menstruación.

Spivak lee la intención de reescritura no enfática de subalterna del contexto social del sati: es una inversión de la prohibición de inmolación de las viudas durante su periodo menstrual. Y al mismo tiempo, es una reescritura subalterna del discurso sobre la hegemonía de

\footnotetext{
${ }^{28}$ Michel Foucault: History of Sexuality. Nueva York: Vintage Books, vol.1, p. 4. Trad. esp.: Historia de la sexualidad. Buenos Aires: Siglo XXI, 2002, (1 ${ }^{a}$ ed. 1977), 3 vols.

${ }^{29}$ Spivak, Gayatri Chakravorty: ¿Pueden hablar los subalternos? Op.cit., pp. 116-117.
} 
luchadora familiar de Durga. Porque la hegemonía de Durga era bien leída y conocida popularmente dentro del discurso masculino durante el movimiento independentista.

Pero la familia de Bhuvaneswari ignoró su escrito performativo. Y dio una razón falsa muy estereotipada: fue por la neurosis debida a la preocupación de no estar casada, porque sus hermanos se burlaban que ella ya que tenía demasiada edad para no ser ya esposa, o por el fallecimiento de su padre. Es decir, con esta justificación estereotipada, se encubrió lo que quedaba en duda, nunca se cuestionó nada más sobre su muerte y trataron de olvidarla. Además, esta razón falsa que inventó su familia, tan caracterizada en la mujer buena de desear tanto ser esposa o seguir a la muerte al padre, es un resumen de la imagen de la mujer patriarcal. El intento de Bhuvaneswari era totalmente el contrario.

\section{El subalterno como hembra no puede ser ni oído ni leído. ${ }^{30}$}

Finalmente Spivak relata que, al haber una reacción de rechazo a la hora de tratar sobre ella y una confusión en la causa de su muerte a consecuencia del amor ilícito, el intento de reescritura subalterna no tiene rastro.

¡El subalterno no puede hablar! $!^{31}$

Ya para finalizar, Spivak afirma de nuevo la imposibilidad de que el subalterno hable con su propia voz. Mostrando la preocupación sobre el estimulo optimista de ser mujer por Deleuze, como un intelectual que nunca sale del texto y contexto europeo, insiste en la utilidad y práctica de la teoría de Derrida. Hay que reclamar para rescribir desvariar la voz dentro de mí como la voz del "otro" en el interior de mí en cambio del impulso estructurado del utopismo.

Spivak finaliza su artículo afirmando que no se olvide la tarea y con la conciencia de la existencia del subalterno se queda sin su propia voz. La imposibilidad de hablar del

\footnotetext{
${ }^{30}$ Ibid., p. 121.

${ }^{31}$ Ibíd., p. 122.
} 
subalterno no implica que no exista. Y vemos que no funciona el ofrecer un lugar libre para que hable el sujeto subalterno sexuado entre culturas distintas. Han pasado 20 años desde que Spivak escribió este artículo y sigue renovándolo con casos que se han agravado cada vez más con la globalización mundial. La política no ha alcanzado y la legislación, mucho menos, a la velocidad y profundidad de la reproducción del sujeto subalterno.

Spivak niega la postura del representante transparente como Deleuze y Foucault. Al mismo tiempo, niega la posibilidad del subalterno de hablar y de ser escuchado. No negamos su argumento y siempre tenemos la conciencia de haber sido mudos bajo cierta opresión, como hemos visto. Pero no queremos quedarnos en la desesperación total. Así que plantearemos nuestra lectura con un poco de esperanza. Tomamos como ejemplo para ello el suicidio de Bhuvaneswari Bhaduri, caso mencionado finalmente por Spivak.

Ciertamente, como primera interlocutora para ella, no le ha llegado el mensaje a su familia, a pesar del esfuerzo de Bhuvaneswari, que preparó su autoejecución esperando a tener su menstruación. La chica quería mostrar que el suicidio no era resultado del embarazo indeseado, con lo que la familia comprendería que ella estaba escapando de la opresión patriarcal sobre la mujer. Pero a fin de cuentas, la familia no le ha hecho caso, concluye que su suicidio es por apenarse de pasar la edad de casamiento y de un amor ilícito e intenta ocultar y borrar su existencia en la historia de la familia. Así, afirmamos que la voz de Bhuvaneswari no fue escuchada por su familia.

Sin embargo, Spivak ha recibido su mensaje. Nosotras, como lectoras no directas, pero sí a través de la interpretación e intervención de Spivak, aunque sea tan solo un rastro o una huella, hemos visto su mensaje. A lo mejor podríamos ser testigos de su existencia impecable con la voz apagada como lo planteaba Felman. Tal vez, para escuchar la voz se deba tener algo que reverbere dentro de sí mismo y que acude al ejercicio de desvariar la voz dentro de mí como la voz del "otro” en el interior de mí. Y también a la tarea que menciona Spivak: no ser representante transparente, sino ser un mediador. 
Nuestro argumento no es especialmente innovador. En la parte final de la última versión corregida, Spivak comenta como autocrítica de la versión anterior el haber insistido tanto en la frase: “¡no puede hablar el subalterno!”. Este comentario era inapropiado y no era muy recomendable. Sabemos por qué lo ha escrito de este modo, como un grito arrancado de su corazón, gracias a que tenemos este espacio de nuestra lectura y, por lo que hemos visto hasta ahora, es obvio, por la pasión y desesperación de haberla ignorado y malinterpretado quien debía escucharla: su familia y los miembros de generaciones futuras. Además de aclarar su consciencia de que el personaje principal que ha citado, por ejemplo Bhuvaneswari si lo decimos de forma precisa, no es subalterno, Spivak afirma que podemos citar su caso como el de un subalterno que se ve obligado a quedarse mudo con unos contextos y una situación muy limitados, ya que la chica era de clase media y participaba en un movimiento político por la independencia del país. Luego menciona el asunto que indica Abena P. A. Busia:

Busia da una nota positiva para el trabajo futuro cuando señala que, después de todo, yo puedo leer el caso de Bhubaneswari y, por lo tanto, ella ha hablado de alguna manera. Por supuesto que Busia está en lo cierto. Cualquier acto de habla, incluso aquél aparentemente más inmediato, implica un desciframiento a distancia por parte de otro, que constituye, en el mejor de los casos, una interceptación. En eso consiste hablar. ${ }^{32}$

Ya que menciona la sustancia de hablar, es como el fracaso continuo del intento de escribir, según Derrida. A pesar de darle la aprobación de teórica a la opinión de Busia, Spivak no está totalmente de acuerdo con su afirmación optimista. E indica un desenfoque de la lectura del texto de la parte de Busia:

\footnotetext{
${ }^{32}$ Spivak, Gayatri Chakravorty: Crítica de la razón poscolonial. Hacia una historia del presente evanescente trad. Marta Malo de Molina, Madrid: Akal, 2010. p. 302.
} 
"“Can the Subaltern Speak?” de Gayatri Spivak, cuya sección 4 es una explicación forzosa del papel de la desaparición en el caso de las mujeres indias en la historia legal británica.» ${ }^{33}$

Estoy subrayando, más bien, dado el silenciamiento de sus propias nietas más emancipadas, una nueva actitud. ${ }^{34}$

En el seminario que hemos mencionado del año 2009 en Murcia, surgieron preguntas, algunas basadas en la idea de cómo cree Busia que el poder del imperialismo occidental hace callar a la mujer del tercer mundo. Sí, efectivamente, existe este tipo de opresión sobre las mujeres, pero la cuestión más grave es que se resuma el asunto en aquel esquema binario opuesto y que se le siga dando supremacía al uno sobre el otro, igual que hicieron los occidentales imperialistas agresores contra los nativos víctimas. Porque como esta opresión le da el pretexto de activar de alguna manera muy violenta a los nacionalistas fundamentalistas, al mismo tiempo este desarrollo nacionalismo fundamentalista también brinda un pretexto de intervención político-económica a los occidentales. En este esquema da legitimación del uno al otro estructuralmente, como lo que hemos comentado hasta ahora repetitivamente. Si vemos lo que ocurre en Oriente Medio, nos facilitará mucha el comprender la estructura, que no ha cambiado nada; es más, nos parece que está empeorando y forzando más y más su estructura. En este caso, los imperialistas no son los británicos, sino son los estadounidenses y su tropa internacional. Y ahí, las mujeres se quedan silenciadas.

Lo que intenta Spivak citando los casos de personas no precisamente subalternas es una manera forzosa de hablar al subalterno, es aclarar y recordar nuestra complicidad en el mutismo $^{35}$; y piensa que finalmente será más eficaz a largo plazo. En el mundo global, nadie podrá estar a salvo frente a este silenciamiento. A pesar de esto, paradójicamente, y precisamente por eso, debemos fijarnos en esta cuestión y aprender a reconocer cada vez más la forma de la complicidad. Porque como indica correctamente Spivak, teniendo un

\footnotetext{
${ }^{33}$ Abena P. A. Busia: «Silencing Sycorax: On African Colonial Discourse and the Unvoiced Female», en Cultural Critique, $\mathrm{n}^{\circ} 14$ (invierno de 1989-1990), p. 102. En: Spivak, Gayatri Chakravorty: ¿Pueden hablar los subalternos? Op.cit., p. 123.

${ }^{34}$ Spivak, Gayatri Chakravorty: ¿Pueden hablar los subalternos? Op.cit., p. 123.

${ }^{35}$ Loc.cit.
} 
chivo expiatorio no puede tener efecto el trabajo planteado por ella misma. Para seguir trabajando necesitamos optimismo, pero también debemos cuidarnos de confundir el optimismo y la ignorancia porque es peligroso, como hemos visto en la crítica en las primeras partes de este apartado. Spivak comenta después de la indicación de Bucia que acabamos de ver:

Admito este punto teórico, y también admito la importancia práctica, para uno mismo y para otros, de ser optimista acerca del trabajo futuro. Sin embargo, el desciframiento de una incógnita, muchos años después, por parte de otro en una institución académica (un conocimiento de una factoría-de-producción, se quiera o no se quiera) no debe ser demasiado rápidamente identificado con el «hablar» del subalterno. $^{36}$

Recordaremos el comentario de Mieke Bal que hemos visto al comienzo de este capítulo. Tal vez deberíamos encontrar alguna consonancia entre las opiniones de esas señoras. Y esta tarea que plantea Spivak tal vez no es solo para los intelectuales, sino también para los artistas. Una parte de la ventaja del arte es poder expresar o enfocar un valor que todavía no ha sido afirmado, es decir, tener la posibilidad de abrir otra perspectiva y dimensión en su función de la expresión del imaginario creativo. Tal vez puede nacer otro idioma o, por lo memos, una indicación a la posibilidad de la necesidad de otra lengua. Sin embargo, tenemos que concienciarnos de lo que indica Spivak.

Tomando cierta precaución con ilusionar la historia narrativizada que hace silenciar a los subalternos, establecer la ficción del mito o una agitación de caer en la estructura de oposiciones dicotómicas, el arte puede ampliar el acceso al "otro" dentro de sí y el "otro" exterior en nuestra sociedad. Para esto, siempre se necesitará autoreferencia y autocrítica. Y el proceso de la autocrítica, el método que practica Spivak-Derrida, nos guiará a evitar caer en ciertas posturas peligrosas. Y, en la práctica de la creación artística, sería muy significativa la frase la llave para desvariar la voz dentro de mí como la voz del "otro" en

\footnotetext{
${ }^{36}$ Loc.cit.
} 
el interior de mí, sobre todo, para nuestra reflexión sobre las expresiones autobiográfica que incluya los relato del "otro". 
III. ¿Puede hablar la historia con el "otro"? según Drucilla Cornell.

Una consideración sobre la posible comunidad que supone el "otro". 
En esta parte reflexionaremos sobre la posibilidad de un relato de la mujer tras varias generaciones, siguiendo la teoría feminista de Drucilla Cornell ${ }^{1}$, para poner fin a nuestro análisis sobre la cuestión de la autobiografía y biografía de la mujer. Se trata de una parte en la que se encuentra la relación y la articulación con lo visto anteriormente según las ideas de Shoshana Felman y Gayatri C. Spivak. Al mismo tiempo, iniciamos la aproximación del concepto del arte del testimonio en la expresión audiovisual, tema este que desarrollaremos en el siguiente capítulo.

Cornell, en Between Women and Generations ${ }^{2}$, argumenta que la relación entre madre e hija constituye la médula teórica y práctica del feminismo. Para ello, la autora se basa en el análisis de la relación intergeneracional de las mujeres de su propio hogar: su madre, su abuela como la madre de su madre y la hija que Cornell ha adoptado de Paraguay. Dentro de su estudio, el testimonio de la mujer y el acto performativo de buscar la voz de la mujer como "otro" serían temas más importantes, también son recursos indispensables para generar la comunidad que debería establecerse. Con su argumentación, basada en ese estudio, enfocaremos la posibilidad de relatos entre generaciones de la mujer.

Cornell desarrolla su argumento combinando la teoría de la deconstrucción con el conocimiento del derecho. En su planteamiento, sigue a Derrida y aplica la perspectiva psicoanalítica de Freud-Lacan, basándose en la filosofía alemana, específicamente en Kant. En este sentido, Cornell desarrolla su discurso y el criterio muy cercanos a Felman y a Spivak. Dentro de sus propuestas, observaremos principalmente, su planteamiento de pensar una posibilidad para generar una nueva comunidad que pueda formar con el "otro". Tal y como ella misma comenta, el hecho de que su hija sea adoptada y provenga de Paraguay, la ha motivado mucho para reflexionar sobre la cuestión de convivencia con

\footnotetext{
${ }^{1}$ Drucilla Cornell (1950-), doctorada en Derecho por la UCLA (Universidad de California, Los Ángeles), estudió de manera autodidacta la filosofía alemana y con Jacques Derrida profundizó en el conocimiento sobre el postestructuralismo. Actualmente es profesora del Departamento de Política en la Universidad de Rutgers (Rutgers, The University of New Jersey). También es organizadora de un grupo en contra de la guerra, Take back the future, en Nueva York. Cuenta con varias publicaciones sobre Derecho basado en la teoría posestructuralista feminista y existe una publicación traducida al castellano: El corazón de la libertad. Feminismo, sexo e igualdad ${ }^{1}$, Cornell, Drucilla. En el corazón de la libertad. Trad. María Condor. Madrid, 2001. que aborda el derecho a la igualdad política vinculándola con la libertad sexual.

${ }^{2}$ Cornell, Drucilla: Between Women and Generations. Legacies of Dignity, New York, Palgrave, 2002.
} 
"otro" a nivel personal, familiar y social. Es muy consciente del tema de encontrar con cierta dignidad el espacio y tiempo de coexistencia entre seres de distinta cultura; lo veremos durante esta parte de la discusión.

Por ahora solo comentaremos un ejemplo concreto: Cornell aborda el problema de que las mujeres de color e inmigrantes reemplazan a las mujeres profesionales en las tareas domésticas y en el cuidado de los niños al ser mano de obra barata. Esto se debe al desarrollo de la igualdad y la participación social de las mujeres en Estados Unidos, consecuencia directa del feminismo dirigido por las mujeres de la clase media-alta anglosajona. De esta manera, Cornell cuestiona que debe ser el sisterhood (amor fraternal entre mujeres) ${ }^{3}$. Su postura y argumento nos dirigirán hacia una posible dirección para que seamos capaces de reservar el espacio y el tiempo en que la mujer en tránsito pueda hablar y expresarse, además de conocer el esfuerzo y el resultado de las feministas occidentales sobre esta disciplina. Para empezar, veremos una interpretación de Cornell sobre el texto de Spivak para así afirmar la importancia del acto performativo para buscar la voz de la mujer que se queda sin voz.

\footnotetext{
${ }^{3}$ Cornell trata el tema de las labores domésticas encargadas a las mujeres latinas inmigrantes y comenta el motivo, la adaptación internacional, aclarando también su contradicción en: "Cooperation for Dignified Labor: Moving toward Unity”. En: Cornell, Drucilla: Between Women and Generations. Op.cit., pp. 95-120.
} 
III.1. El silencio de las mujeres en La Historia. 
Como preparación teórica, en el tercer capítulo del libro Between Women and Generations, titulado "The Art of Witnessing and the Community of the Ought to Be", , Cornell se basa en el análisis de la discusión sobre la posibilidad de hablar los subalternos sexuados de Spivak que hemos visto en el capítulo anterior. Cornell intenta aproximarla a su argumento afirmando la importancia de su acto performativo, al cual llama dramatic representation, y desarrolla el concepto de la comunidad por el juicio estético, comparándolo con la teoría sobre lo sublime de Kant.

In my reading of her, Spivak dramatically represents the ethical significance of what has been lost, fundamentally misunderstood, in the history of the gendered subaltern. This loss can be summarized as the "valued codings" of the women's lives as they themselves tried to make sense of their responsibilities to themselves and to others. How are we to grasp the feminist significance of this effort at dramatic representation? I interpret Spivak's feminist-inspired historical project through a reading of Immanuel Kant's The Critique of Judgement and Friederich Schiller's interpretation of Kant's idea of the sublime. ${ }^{2}$

Antes de aproximarnos a la interpretación Kantiana sobre el proyecto de Spivak, veremos esquemáticamente la estructura del análisis de Cornell sobre la discusión de Spivak. Como hemos mencionado anteriormente, Spivak presenta en 1988 el texto titulado Can the Subaltern Speak? y vuelve a tratar el mismo tema en el libro publicado en 1999 Crítica de la razón poscolonial ${ }^{3}$, más específicamente en el tercer capítulo, titulado "History". La lectura de Cornell se basa en dicho capítulo. Cornell nos lo explica de la siguiente manera:

\footnotetext{
${ }^{1}$ Cornell, Drucilla: Between Women and Generations. Legacies of Dignity, Nueva York, Palgrave, 2002, pp. 71-94.

${ }^{2}$ Ibíd., pp. 80-81.

En mi lectura de ella, Spivak representa drásticamente la importancia ética de lo que se ha perdido, que fundamentalmente se ha malentendido, en la historia del subalterno sexuado. Esta pérdida puede resumirse como un "valor de codificación" de las vidas de las mujeres de cuando ellas mismas trataron de dar sentido a sus responsabilidades para ellas mismas y para con los demás. ¿Cómo vamos a comprender la importancia feminista de este esfuerzo de representación dramática? Personalmente, interpreto el proyecto histórico de Spivak inspirado en el feminismo a través de una lectura de la Crítica del Juicio de Immanuel Kant y de la interpretación de la idea de lo sublime de Kant por parte de Friedrich Schiller [Traducción propia].

${ }^{3}$ Spivak, Gayatri Chakravorty: Crítica de la razón poscolonial. Hacia una historia del presente evanescente. trad. Marta Malo de Molina. Madrid, Akal, 2010.
} 
When there are stories to remember and pass down, there can be witnesses. As brutal as it is, a story that can be told can be engaged, accepted, or recreated. But what if there are no records and no stories because they have been buried under the legacy of imperialism? What if, when one looks for the story, only the story that the colonizer tells about "them" is found? How does a writer present such silence in order for it to echo? What, then, does it mean to witness? These are just some of the questions that Gayatri Spivak addresses in her extraordinary chapter on history in her book A Critique of Postcolonial Reason. Spivak here returns to the question she asked some years ago in her rightfully well-known essay "Can the Subaltern Speak?",

Nosotras, anteriormente, hemos realizado una lectura enfocada en la manera de ser del subalterno sexuado y en la obligación de quedarse en silencio a través de la crítica de Spivak, a su vez bajo la influencia de la teoría de Derrida. Spivak analizaba "la narrativa histórica" del imperialismo y del nacionalismo-etnocentrista intentando construir una "contranarrativa" que aclarase la existencia del subalterno sexuado, que se encuentra atrapado por varios factores: el tema del sati (la autoinmolación de la viuda tras la muerte de su marido), la colonización y el dominio imperialista eurocentrista, y la reacción de la parte india patriarcal. A Cornell le interesa más el acto de Spivak, que intenta ser una testigo de la voz que ha borrado "la narrativa histórica".

En el artículo del año 1988, Spivak al poner mayor énfasis en criticar vivamente la postura de los intelectuales del primer mundo, como Deleuze y Foucault, que ignoran la situación real del subalterno, por su optimismo. Spivak indica el problema de la construcción del Sujeto europeo juzgando al tercer mundo como lo "otro" y de la relación cómplice de los

\footnotetext{
${ }^{4}$ Ibíd., pp. 71-72.

Cuando hay historias que recordar y transmitir, puede haber testigos. Aunque sea brutal, una historia que puede ser contada puede ser participada, aceptada, o recreada. Pero, ¿qué pasa si no hay registros ni historias porque han sido enterrados bajo el legado del imperialismo? ¿Qué pasa si, cuando uno busca la historia, solo encuentra la historia que los colonizadores que cuentan sobre "ellos”? ¿Cómo hace un escritor para presentar ese silencio de manera que resuene? ¿Qué significa, pues, ser testigo? Estas son solo algunas de las preguntas que Gayatri Spivak aborda en el extraordinario capítulo sobre historia en su libro Crítica de la razón poscolonial. Spivak vuelve aquí a la pregunta que se hizo hace algunos años en su merecidamente reconocido ensayo "¿Pueden hablar los Subalternos?". [Traducción propia].
} 
intelectuales europeos con el sistema eurocentrista. En cambio, en el texto de 1999, Spivak destaca que lo realmente importante es encontrar el silencio dentro de la historia oficial y conseguir el significado en la parte censurada de la historia y de la narrativa, empleando la teoría del psicoanálisis para revelar la relación cómplice entre los dirigentes epistémicos y los native informants [informadores nativos]. Cornell lo interpreta de la siguiente manera:

\begin{abstract}
Spivak uses psychoanalysis to explain how unlisted traces can remain for us as what is missing as we begin to measure silence and pay heed to the significance in the cuts of the threads that should tie together a literary text or a historical narrative. Spivak actually addresses two kinds of silences. ${ }^{5}$
\end{abstract}

Según Cornell, Spivak indica que hay unas huellas, aunque no se vean superficialmente, que quedan dentro de nosotras cuando empezamos a fijarnos en el silencio y el significado de la ruptura de los hilos tejidos en la narrativa histórica y/o en los textos literarios. En cuanto a Spivak, hace referencia a dos tipos de silencios. El primer silencio es el suyo propio, ya que Spivak fracasa en el intento de recuperar la historia de la mujer de su momento. En el texto Crítica de la razón poscolonial, adjunta un análisis sobre un caso que encontró mientras investigaba el sati: una mujer que una vez decidió ser sati y no llevó a cabo esa decisión. Este episodio no aparece en el texto de 1988. La mujer era esposa de un rey de la región de Sirmur (India). No se sabe cuál era su nombre porque no consta en los documentos de los británicos. Solo se sabe que aquella mujer fue llamada Rani, que quiere decir reina. Spivak y Cornell, igualmente, le llaman Rani o Rani de Sirmur.

El otro silencio, en realidad no es un silencio, sino que se trata de una mala interpretación y de una lectura errónea por un prejuicio estereotipado sobre un acto de la mujer. De forma más concreta, indica el asunto del suicidio de Bhubaneswari, que aparecía en la última parte del artículo de 1988, donde la familia de ella se equivoca y malinterpreta la razón de su

\footnotetext{
${ }^{5}$ Ibíd., 2002. p. 72.

Spivak utiliza el psicoanálisis para explicar cómo las huellas no valoradas pueden seguir siendo, para nosotros, lo que falta una vez empezamos a medir el silencio y a prestarle atención a la importancia de los cortes de los hilos que deberían vincular un texto literario o una narrativa histórica. Spivak hace referencia a dos tipos de silencios. [Traducción propia].
} 
muerte. En realidad, Bhubaneswari fue activista de un grupo de liberación nacional y se suicidó por no poder cumplir una misión de asesinato de un político. Pero ella no podía confesarlo y sabía que su muerte sería justificada por una pasión ilegítima. Para rechazar la sospecha de embarazo, esperó al comienzo de su menstruación para realizar su autoinmolación. Spivak interpretó este acto como performativo, como un intento de reescribir el texto social del suicidio sati de una manera intervencionalista, violando la prohibición de sati durante la menstruación. A pesar de su preparación meticulosa para evitar la mala interpretación del estereotipo de la mujer, su familia, sobre todo las mujeres de generaciones posteriores, intentaron esconder su memoria, y malinterpretaron su suicidio como consecuencia de un amor ilícito.

Supe de la vida y muerte de Bhubaneswari a través de conexión familiares. Antes de investigarlas más a fondo, le pedí a una mujer bengalí, filósofa y estudiosa del sánscrito, cuya producción intelectual inicial es casi idéntica a la mía, que iniciara el proceso. Dos fueron las respuestas: (a) ¿por qué te interesa la desventurada Bhubaneswari cuando sus dos hermanas, Saileswari y Rapseswari, llevaron vidas tan plenas y maravillosas?, y (b) le pregunté a sus sobrinas. Parece tratarse de un caso de amor ilícito. ${ }^{6}$

De esta manera, el subalterno sexuado se sitúa alienado y obligado a quedarse en silencio. $\mathrm{Y}$ es un ejemplo muy común de cómo se razonan ciertas cosas que no se quieren ver ni enfrentar, tapándolas con una explicación estereotipada. La tendencia a ignorar la voz que reclama la narrativa histórica ocurre incluso entre las personas más cercanas a esa voz, como sus propios familiares. Desgraciadamente, este es un ejemplo de que no sirve de mucho recuperar este tipo de voz, ya que no cabe esperar demasiado si la que da las respuestas (a) y (b) es una mujer intelectual. La “historia” de Bhubaneswari debe esperar a la llegada de una lectora como Spivak para que escape de esta narrativa histórica basada en la religión y la cultura patriarcal. Lo que distingue a Spivak de la filósofa y estudiosa del sánscrito es la consciencia de la complicidad.

\footnotetext{
${ }^{6}$ Spivak, Gayatri Chakravorty, Op.cit., p. 301.
} 
Para aproximar estos dos silencios, Cornell centra la atención en la palabra "stories". Antes de empezar su discusión, aclara y determina cuidadosamente el carácter de "stories" de la siguiente manera:

But now, let us turn to the "stories". I put "stories" in quotation marks here because Spivak actually writes about what cannot be effectively narrated. In the case of the Rani of Sirmur, her story is about why her history cannot be written. Spivak's representation of the misinterpretation of Bhubaneswari's suicide is an account of how such a dramatic action was trivialized by understanding it as one more story about a woman making the foolish "female mistake" of getting pregnant outside of wedlock. ${ }^{7}$

Cornell explica la razón de poner entrecomillada la palabra "historias", ya que Spivak escribe la "historia" que nunca fue leída, se trata de algo que no se puede contar. En el caso de Rani de Sirmur, Spivak apenas logra escribir por qué no escribieron su historia; en el de Bhubaneswari, narra la manera en que equivocaron la lectura de su acción y cómo la obligaron a quedar silenciada.

El sati, como ya hemos visto anteriormente, es el suicidio que comete la viuda tras la muerte de su marido, y se practicaba en una región de la India. Respecto a esta costumbre, Spivak analiza y critica cada uno de los dos discursos: el imperialista de los británicos, que legitiman su colonización y dominio sobre la colonia prohibiendo el sati y declarándolo un acto ilegal, y el del etnocentrismo de la parte nativa india, que surge como una reacción contra el colonialismo. En el texto de 1999, al igual que en el de 1988, el punto esencial de su análisis no es aclarar el sentimiento, el pensamiento y el hecho de la mujer que practica el sati, sino enfatizar la importancia de desvelar el proceso de construcción de la narrativa

\footnotetext{
${ }^{7}$ Cornell, Drucilla. Op.cit., p. 72.

Pero ahora volvamos a las "historias". En este punto, pongo "historias" entre comillas porque en realidad Spivak escribe sobre lo que de hecho no puede ser narrado. En el caso de la Rani de Sirmur, su historia trata acerca del por qué su historia no puede ser escrita. La representación de Spivak sobre la interpretación errónea del suicidio de Bhubaneswari es un relato de cómo una acción tan dramática fue trivializada al entenderla como una historia más de una mujer cometiendo el estúpido "error femenino" de quedar embarazada fuera del matrimonio.[Traducción propia]
} 
de la mujer con y por el sati dentro de cada discurso. Al mismo tiempo, intenta descubrir cómo en esa narrativa de sati se había borrado y eliminado a la mujer como sujeto y a su significado. Cornell explica la postura de Spivak, que rechaza el sentir pena por las mujeres que fueron sati:

Spivak's intuition is that "the ground level value-codings that write these women's lives elude us. " But of course she wants to test whether she is right about that. In her preliminary challenge to the received story of women who practiced Sati, Spivak refuses them the pity she believes has been evoked by the received Western version of their story, or by the sentimental, purportedly nationalistic response to it. ${ }^{9}$

Así, Spivak trata primero de apartar el sentimiento de compasión por las mujeres sati, ya que sentir lástima por ellas es una consecuencia de la narrativa occidental de los británicos protectores o de la narrativa sentimental nostálgica de los nacionalistas, que tratan a la mujer como objeto. Además, al sentir lástima se repite el proceso de obligar a la mujer a aparecer como víctima muda en estas narrativas. Aunque afirmamos la necesidad y el profundo interés de lo que cuentan mujeres que van al compás del relato del modo de producción, como participantes/resistentes/víctimas ${ }^{10}$, en la medida en que nos concentramos para prestarles atención siguiendo a Spivak. Como ella señala, esas mujeres se convierten en unas figuras esquivas en la narrativa histórica: De hecho, solo a su muerte entran en un relato para nosotros, se hacen representables ${ }^{11}$.

Cornell nos muestra, inspirada por Spivak, que no podemos acceder al código de valores de la vida de una mujer de otro tiempo y cultura. Según Spivak, el relato del “otro" sin cambio

\footnotetext{
${ }^{8}$ Spivak, Gayatri Chakravorty, Op.cit, p. 245.

${ }^{9}$ Cornell, Drucilla, Op.cit., pp. 73-74.

La intuición de Spivak es que "las codificaciones a ras de suelo del valor que escriben las vidas de estas mujeres se nos escapan" Pero, por supuesto, ella quiere comprobar que si tiene razón en eso. En su desafio preliminar sobre la historia popularmente aceptada de las mujeres que practican el sati, Spivak rechaza la lástima que ella cree que ha sido evocada por la versión popularmente aceptada en occidente de su historia [la de ellas], o por la respuesta sentimental, supuestamente nacionalista a la misma. [Traducción propia. Traducción de la cita interna: Spivak, Gayatri Chakravorty, Op.cit. p. 243.]

${ }^{10}$ Spivak, Gayatri Chakravorty. Op.cit, p. 244.

${ }^{11}$ Loc.cit.
} 
del código de valores por su estilo de expresión no es válido para nuestro mundo razonable. Es decir, el código de valores del relato del "otro" incluye un estilo erróneo desde el punto de vista racional de nuestro mundo, donde la razón es el único criterio. Para aclarar esta cuestión, Spivak cita a Rigoberta Menchú, como veremos el apartado siguiente.

\section{III.1.1. “Relato” de Rigoberta Menchú; contradicción de la autobiografía con secreto.}

Algunos tipos de mujeres son las que viven en otra cultura y solo pueden ser representadas de manera incompleta e insuficiente en la narrativa, según Spivak. Como hemos citado anteriormente, Spivak argumenta que las codificaciones a ras de suelo del valor que escriben las vidas de estas mujeres se nos escapan. Existe un estilo que puede dar una medida, es como en el (flujo y reflujo) del modo de la forma total o desplegada ${ }^{12}$, pero este modo es deficiente desde un punto de vista racionalista. Entonces, para poder acceder a ellas como modelos generales de descripción antropológica en una representación escrita racional, siempre deben pagar el coste de transcodificación epistémicamente fracasada. Para completar las explicaciones de esta idea, Spivak se centra en cuatro mujeres. Las dos mujeres de la India, Rani y Bhubaneswari, aparecen en su artículo y además pertenecen a épocas diferentes y alejadas en el tiempo de la propia Spivak. Por otro lado, y aunque solo haga mención de ellas en una nota más extensa de lo normal, Spivak insiste mucho en que es muy importante analizar también a Lily Moya y Rigoberta Menchú. Estas cuatro mujeres permanecen como singulares y con secreto.

Por consiguiente, Naciones Unidas debe racionalizar primero a la «mujer» antes de desarrollarla. Y, sin embargo, la Rani de Sirmur y Bhubaneswari Bhaduri (vide infra), así como, sin duda, Lily Moya y Rigoberta Menchú (véase S. Marks [ed.], Not Either an Experimental Doll. The Separate Lives of Three South African Women, cit., y Rigoberta Menchú, Elisabeth Burgos-Debray, I, Rigoberta Menchú. An Indian Woman in Guatemala ${ }^{13}$, traducción al inglés de A Wright, Lomdores,

\footnotetext{
${ }^{12}$ Loc.cit.

${ }^{13}$ Burgos, Elizabeth, Me llamo Rigoberta Menchú y así me nació la conciencia, México, Siglo XXI, 2000.
} 
Verso, 1984), resultarán instructivas por más que no dejen de ser singulares y secretistas (sobre el «secreto», véase IM XXV). Deben exceder el sistema para llegar hasta nosotros, bajo el modo de lo literario. ${ }^{14}$

Spivak nos menciona la necesidad de superar al sistema mediante el estilo artístico, para que encontremos a las mujeres como "otro" que vive en otra cultura, en diferente tiempo y en diferente espacio, o sea, las que permanecen con otro valor-código. Luego, nos insiste en que prestemos más atención al caso de Menchú:

Pero debemos asimismo prestar atención a Menchú, que se inspira en una táctica colectiva mucho más antigua contra la conquista colonial, leyéndola también a ella a contrapelo de su lenguaje necesariamente inscrito en la política de la identidad: «Pero yo necesito mucho tiempo para contar sobre mi pueblo porque no se entiende así. Claro, aquí, en toda mi narración yo creo que doy una imagen de eso. Pero, sin embargo, todavía sigo ocultando mi identidad como indígena. Sigo ocultando lo que yo considero que nadie sabe, ni siquiera un antropólogo, ni un intelectual, por más que tenga muchos libros, no saben distinguir todos nuestros secretos» (p. 247; ed. cast.: p. 271). Ese texto no está en los libros y el secreto nos guarda a nosotros, no al revés. ${ }^{15}$

Rigoberta Menchú, indígena Maya-Quiché, es una activista de Guatemala que ha organizado el CUC (Comité de Unidad Campesina), desde el cual se manifiesta contra la violación de los derechos humanos de los indígenas por parte del poder estatal que, sojuzgando, está en correlación con el latifundio, así como con la tiranía, la explotación y la confiscación de la tierra a los indígenas en Guatemala. El texto que cita Spivak pertenece a la última parte del libro Me llamo Rigoberta Menchú, escrito y editado por Elizabeth Burgos, quien es una antropóloga venezolana que reside en París. Este libro es el resultado de más de 25 horas de grabación de una entrevista a Menchú en París en 1982.

\footnotetext{
${ }^{14}$ Spivak, Gayatri Chakravorty. Op.cit., p. 244.

${ }^{15}$ Loc.cit.
} 
En este texto, dividido en 32 temas, describe el relato de la vida de Menchú en Guatemala. Podemos decir, en cierta manera, que es una autobiografía, porque es un libro que escribe el testimonio de su supervivencia. Al mismo tiempo, este libro presenta muchos puntos de discusiones y cuestiones sobre varios términos. Es un ejemplo que representa una forma extrema de la imposibilidad y la posibilidad del testimonio de la mujer y la autobiografía de la misma.

En esta ocasión, solo indicaremos dos puntos que pueden captar la indicación justa de Spivak sobre este texto. El primero es que, para Menchú, la lengua materna es el "quiché". Ella ha sufrido daño y desventajas por no saber español en Guatemala, donde es la lengua oficial, y por esta razón fue obligada a pasar su vida humillada por una terrible segregación. Es decir, el español es la lengua del dominador que la oprime a ella y a su comunidad autóctona. Sin embargo, elige y adjudica estratégicamente el español como un recurso de la solidaridad y la lucha para denunciar la injusticia que se realiza sobre ellos, a la vez que denuncia su padecimiento, que tiene como causa no poderse comunicar entre los que están bajo opresión, dada la diferencia de idiomas entre los pequeños grupos indígenas.

En el momento de realizarse la entrevista con Burgos en París, Menchú tenía veintitrés años y solo hacía tres años que aprendía español. Obviamente, su expresión y vocabulario fueron limitados, no podía evitar los errores y las repeticiones dada la falta del ejercicio lingüístico. En otras palabras, desde el punto de vista lingüístico y emotivo, nos facilita imaginar, desde el principio, que el relato salido de su propia boca no es propio: la voz y la manera de expresión son prestadas para ella, ya que ella había perdido su pathos.

Este sería el primer punto; el segundo es el problema de transcribir la entrevista por parte de Burgos, como representante transparente. Aunque Burgos comenta en la introducción del libro que intentó no transformar su relato y no corregir la forma de expresión para respetar la ingenuidad con la que se expresa todo el que acaba de aprender un idioma que 
no es el suyo ${ }^{16}$, la intención del libro es ampliar la comprensión de los lectores sobre el contenido del relato. La división del tema y la colocación de los textos es la edición de Burgos como antropóloga y hablante nativa del español.

De esta manera, el libro nunca está libre de la operación arbitraria. Esta operación es la que indica Spivak como la codificación [el cambio del valor-código]. Burgos emplea el monólogo como estilo de expresión, pues Burgos elimina su propia presencia en el texto, siendo representante transparente invisible. Sin embargo, desde el punto de vista del resultado, el pathos de Menchú ya estaba perdido en mayor parte; digamos que Burgos intentó ocultar esa pérdida.

Por otra parte, ha surgido una polémica sobre los datos erróneos de la fecha y el lugar de la masacre de su familia, que fue asesinada. De esta manera, al incluir algunos errores de la memoria, no se sabe si intencionales o no, se cuestiona la legitimidad legal del testimonio ${ }^{17}$.

Quizá Spivak, suponiendo estos puntos problemáticos, insiste en la importancia del estilo artístico como medio adecuado para podernos encontrar con Menchú en su libro autobiográfico-biográfico. Y como lectores de su libro nos propone una lectura contra el idioma que le es necesario para su identidad-política. Porque Menchú nunca se verá libre de hablar en español, tanto por la misión social que la obliga como por su postura política. Cuanto más se deje llevar ella por la sincera improvisación, sus palabras y acciones no podrán escapar de la dicción y la gramática de la identidad-política. Es obvio. Sin embargo, no estamos diciendo que su testimonio sea mentira o carezca de valor. Menchú nos exige el reconocimiento de ser indígena y su valor es una estrategia para construir una identidad cultural y política visibles como un ser resistente.

Para salir de las circunstancias negativas de ser invisible: reclama el valor de ser indígena y sus derechos, que fueron explotados al ser juzgados, depreciados y obligados a encontrarse

\footnotetext{
${ }^{16}$ Burgos, Elizabeth: Me llamo Rigoberta Menchú y así me nació la conciencia, Op.cit., p. 7.

${ }^{17}$ Desarrollaremos la cuestión entre el testimonio y la memoria traumática en el capítulo IV. siguiendo a Shoshana Felman en su análisis del audiovisual Shoah.
} 
en circunstancias infortunadas como resultado de la explotación. Para que sea visible ante nosotras, que estamos en una perspectiva racional, ella debe cambiar el valor-código. Además, como mencionan Spivak y Cornell, siempre corre el peligro de ser reducida en una narrativa sentimental de la versión occidental, de la narrativa etnocentrista, o de una narrativa trivial con ciertos prejuicios estereotipados.

No obstante, consciente o inconscientemente, Menchú indica que todavía queda el secreto. Es decir, indispensablemente debe mencionar que no es toda su historia, no ha contado todo. Frente a la violencia epistémica occidental, que una vez se apropia del conocimiento del "otro" reduce sistemáticamente su valor y lo sitúa en una posición inferior al suyo, debe reservar un secreto denunciando que no es todo. Digamos que dejar un secreto en la historia de "otro" sería un acto de resistencia. Y asertivamente, Spivak señala que ella no está protegiendo su secreto, sino que quien le protege a ella y a nosotros como lectores es el secreto, no al revés.

Igual que la feminidad era insondable e inexpresable para Freud, quien solo podía vocalizarla con tono patriarcal; el "otro" es insondable e inexpresable para el orador identificado en el Sujeto europeo. Una vez que se introduzca dentro del sistema lingüístico europeo, por la función del logocentrismo, el "otro" será confinado a la subordinación invisible en sí. Como comentan Derrida y Spivak, nuestro proyecto de escribir y leer, hablar y escuchar nunca puede escapar del sistema, lo cual quiere decir que está destinado al fracaso. Realizar el acceso al sistema, y al mismo tiempo escapar de la postura subordinada como "otro" y reclamar el ser de sí mismo, es sumamente difícil y contiene múltiples contradicciones y peligros, como vemos en el ejemplo de Menchú. Así pues, el secreto, en otras palabras, una indicación de lo insondable e inexpresable, apenas cumple el papel de proteger la dignidad del "otro". 
Nosotras, según Shoshana Felman ${ }^{18}$, como lectoras y sabiendo este contexto, al acceder a este tipo de texto debemos leer la fisura de su discurso tanto como el contenido; según Spivak, debemos leer la parte de silencio donde ella no relata y no puede hablar. Aunque fracase al escribir y leer, al hablar y escuchar, tenemos que seguir observando la manera del fracaso, porque únicamente ahí se encuentra una indicación y/o unas huellas de historia del "otro".

\section{III.1.2. El acto performativo para buscar el pathos perdido.}

Volveremos a la historia de Rani para confirmar el acto performativo de Spivak que Cornell llama dramatic representation. Spivak encuentra a una mujer que declaró su voluntad de practicar el sati, pero no lo realizó finalmente, en los documentos de la East India Company (Compañía Británica de las Indias Orientales). Esta mujer era la esposa de un Rey de Sirmur, Karam Prakash, y fue llamada Rani, que significa Reina ${ }^{19}$. Las causas superficiales del sati son: por libertinaje y por ser sifilítico su esposo. Con estas razones, Rani autoriza a su pueblo como tutora de su hijo pequeño, en lugar de su marido, que está bajo vigilancia de los británicos.

A decir verdad, los británicos que llevaban el proyecto de división del territorio de esta región, querían realizarlo a través de la autoridad de Rani, aprovechándose políticamente en beneficio de la East India Company. En ese momento, Rani declaró su voluntad de sati. Los colonos británicos pidieron que interviniera a su voluntad, y la realización de sati por parte

\footnotetext{
${ }^{18}$ Véase el capítulo I.

${ }^{19}$ Spivak hace un comentario sobre el hecho de emplear el término Rani para nombrar a esta mujer: se debe a no haber encontrado su nombre en los archivos ni otro modo de referirse a ella, así que tuvo que adoptar la única forma en que se la designaba, con esa palabra que significa Reina. Pero hace una observación sobre un inconveniente de traducirla por «reina»: puede ser algo precipitado traducir "Rani" por "reina" (no propongo ninguna alternativa), con toda la parafernalia británica o europea que la palabra evoca (véanse las consideraciones sobre la "filosofia" africana en Paulín Hountondji, African Philosophy. Myth and Reality, traducción al inglés de Henri Evans, Londres, Hutchinson, 1983; y el problema de traducir "dharma” como "religión", "nyāya" como "lógica”, etc. Analizado en: B. K. Matilal y G. C. Spivak, Epic and Ethic. Indian Examples, citado en: Spivak, Gayatri Chakravorty, Crítica de la razón poscolonial. Hacia una historia del presente evanescente, Op.cit., p. 204.
} 
de Rani preocupó al gobierno británico, que temía el fracaso del proyecto debido a la muerte de Rani: de forma más concreta, pidieron que se estableciera alguna limitación.

El gobierno británico, en primer lugar, intentó que los sabios y religiosos nativos hindúes convencieran a Rani para que no lo hiciera, porque en aquel momento todavía no se prohibía el sati. Spivak y Cornell comentan que era una época en la que los británicos aún trataban el tema con cierto respeto ante la prevención religiosa de los nativos indígenas. Y por supuesto, la clase dirigente hindú nativa, en este caso los sabios y religiosos, colaboraron con los británicos, que tenían mayor poder efectivo. Pero al final, el gobierno otorgó a un colono británico, el Capitán Birch, una autorización por medio de la cual podía ejercer cualquier fuerza para conseguir que no se llevara a cabo el sati y convencer a Rani de abandonar su voluntad.

El capitán, después de muchas deliberaciones, decidió desplazar el exilio del esposo de Rani a un lugar más lejano, fuera de Sirmur. A partir de la decisión del Capitan Geoffrey Birch, no sabemos nada más del destino del esposo, que desaparece junto al asunto de Rani en los documentos británicos. Spivak intentó aclarar si fue justa o no la interpretación de Birch sobre el deseo de Rani y para ello incluso visitó Nahan, la principal ciudad de Sirmur. Sin embargo, Spivak no pudo encontrar nada sobre Rani; ya que cualquier documento empieza con el reinado de su hijo y lo describe como un rey nativo muy parecido al moderno europeo dentro de los reyes nativos. Con todo lo que hemos leído que supo hasta ese momento, Spivak comenta lo siguiente, indicando la violencia epistémica y negando una ilusión típica romántica:

La imaginamos en su palacio en ruinas, separada de la autoridad de su marido, sin duda patriarcal y disoluto, de repente bajo las órdenes de un joven blanco en su propio hogar. Estos ejemplos deben situarse dentro de la violencia epistémica del mundear de mundos que he descrito antes. Porque también suponen la aparición en el espacio nativo de un agente extranjero de la "verdadera" historia. No hay nada romántico que hallar aquí. Atrapada, pues, entre el patriarcado y el imperialismo, 
la Rani se encuentra en una condición representativa: una mujer cuyo "intercambio", de lo "feudal" a lo "moderno", como agente de su hijo-sujeto, instaurará la historicidad. ${ }^{20}$

De este modo, Spivak nos invita a imaginar la situación política e histórica de Rani, pero no a un nivel abstracto, sino a un nivel físico, con cierta textura del espacio y con indicación de no haber nada romántico. Y describe un viaje a este palacio en que vivía Rani bajo la vigilancia del colono británico y la experiencia que vivió la propia Spivak de poder quedarse una noche en ese mismo palacio. Lo que pasaba es que el palacio, por carecer sus herederos de descendencia directa, estaba en pleito. Pero Spivak, gracias a la buena voluntad de un abogado de una de las partes en litigio, obtuvo permiso para quedarse una noche en el palacio de Rani. Sin embargo, tenía que quedarse encerrada con candados para no permitirle el acceso a todo el castillo y evitar así que su visita sirviera para perjudicar el proceso judicial. Al caer la noche la encerraron con llave. Durante esa estancia corta, que era la quinta y última de los viajes que había realizado, logró quedarse en palacio, pero no pudo acceder al edificio donde había vivido Rani, puesto que estaba cerrado bajo llave permanentemente, y tampoco pudo encontrar nada sobre su escrito ni las huellas de ella.

Cornell interpreta que el acto y escrito de Spivak nos piden imaginar a una mujer encerrada en muchos sentidos:

Spivak cannot even know enough of the Rani's own voice to engage in the transferential relationship the historian Dominick La Capra suggests is a useful fiction in archival work. Using the psychoanalytic metaphor of transference, La Capra's suggestion is that archivist can expand the imagination and hear voice from another imaginary by engaging with the original text as if those voices could talk back to us. This fiction is to help the archivist protect himself against projection of meaning onto someone from another culture and from another time. But as Spivak

\footnotetext{
${ }^{20}$ Spivak, Gayatri Chakravorty, Op.cit., p. 233.
} 
tenderly notes, she does not even have enough of the Rani's voice to imagine her talking back. ${ }^{21}$

A pesar del planteamiento del historiador La Capra, que aplica el método psicoanalítico para poder escuchar la voz que resuena desde el mundo diferente de concepto distinto, Spivak no puede llegar a alcanzar el texto original sobre Rani ni sus huellas. Spivak solo puede describir todo el proceso del viaje de la búsqueda a Rani y su fracaso. Intenta explicar por qué y cómo no pudo lograr encontrar a esa mujer y no pudo escucharla.

Después de todo, Spivak encuentra datos acerca de la muerte de Rani en otro documento: murió en 1837 y se sabe que no era sati por el estilo de sus funerales. No se sabe por qué Rani no hizo el sati y no habrá manera de saberlo de ahora en adelante. Ni Spivak ni Cornell dicen que Rani hubiera debido ser sati. Confirmando la postura opuesta de Spivak contra el sati, Cornell interpreta este asunto de la siguiente manera:

\begin{abstract}
But she wants to change the scene of the ideological battleground to make room for the possibility that the women who practiced Sati cannot be reduced simply to victims. Certainly she knows that she is staging the battleground, but the ethical purpose of that restaging is precisely to preserve the pathos of the burnt widows. If we strip them of their dignity, at least as we imagine it might have been exercised then, their deaths lose their pathos. ${ }^{22}$
\end{abstract}

\footnotetext{
${ }^{21}$ Cornell, Drucilla, Op.cit., pp. 77-78.

Spivak ni siquiera puede saber lo suficiente acerca de la voz propia de la Rani para involucrarse en la relación transferencial que, como sugiere el historiador Dominick La Capra, es una ficción útil en el trabajo de archivo. Usando la metáfora psicoanalítica de la transferencia, la propuesta de La Capra es que ese encargado del archivo puede ampliar la imaginación y escuchar la voz de otro imaginario comprometiéndose con el texto original, como si esas voces nos pudieran responder. Esta ficción consiste en ayudar al encargado del archivo a protegerse a sí mismo de proyectar significado a alguien de otra cultura y de otro tiempo. Pero, como observa Spivak con ternura, ni siquiera cuenta con suficiente voz de la Rani para imaginar su respuesta [Traducción propia].

${ }^{22}$ Ibíd., p. 78.

Pero ella quiere cambiar el escenario de la batalla ideológica para dar cabida a la posibilidad de que las mujeres que practicaron el sati no se pueden ver reducidas simplemente a ser víctimas. Ciertamente, sabe que ella está escenificando el campo de batalla, pero el propósito ético de volver a escenificarlo es, precisamente, preservar el pathos de las viudas quemadas. Si las despojamos de su dignidad, al menos tal y como creemos que podría haber pasado en aquel entonces, sus muertes pierden su pathos. [Traducción propia].
} 
Cornell indica la importancia de prestar atención a la dignidad del "otro" para mantener el pathos del "otro". Sobre la dignidad profundizaremos con más detalle en el siguiente apartado de nuestra investigación, pero por ahora nos fijaremos en la indicación de Cornell sobre el pathos de narrativa. Cornell interpreta que este viaje de Spivak es para construir esta narración como un viaje de "historia" que solo puede terminar igual que un fundido en negro. Según Cornell, Spivak nos pide acompañarla en su viaje hacia Rani y rechaza la anulación del pathos de Rani, que seguramente estaba junto con su vida. De esta manera Spivak no solo presenta lo que no puede narrar con fluidez, sino que nos invita a imaginar el significado de lo que le hizo la Historia legítima de los imperialistas a Rani.

El pathos narrativo de este relato no académico está muy lejos de la práctica austera de la filosofía crítica. $Y$, sin embargo, las contaminaciones diferenciales de la alteridad absoluta (hasta pronunciar las palabras es diferenciarlas de otra cosa, algo que desde luego debería ser imposible) que nos permiten mimetizar la responsabilidad hacia el otro no pueden permitir que se haga desaparecer este pathos con un mero fundido en negro. Al acercarme a su casa tras una larga serie de maniobras detectivescas, estaba mimetizando la ruta de un no saber, de una différance continua, de una "experiencia" de cómo pude no saber de ella. ${ }^{23}$

Spivak nos insiste en que caminemos junto con ella en esta ruta, la ruta de un no saber, de una différance continua, de una "experiencia" de cómo pude no saber de ella, a través de su pathos de intentar narrar esta historia que cuenta la imposibilidad de convertir una historia. Su práctica, que ella misma define como un relato no académico, trata de dejar un espacio para este tipo de brusquedad, espacio que nunca sería completo ni eficaz. Y Cornell se dirige a nosotros para que seamos testigos de su acto performativo, para así llamar la atención en el pathos perdido. En lo que insisten Spivak y Cornell es en que, a pesar de que la voz del "otro" no es accesible, como en el caso que vemos ahora, eso no significa justificar o ignorar su voz. A través de ser testigos de este viaje destinado al fracaso, nos invita a reflexionar acerca del significado de la historia con el pathos perdido.

\footnotetext{
${ }^{23}$ Spivak, Gayatri Chakravorty, Op.cit., p. 240.
} 
III.2. La dignidad y la comunidad posible para el arte del testimonio. 
Drucilla Cornell insiste en la importancia de la dignidad como factor indispensable para un ser testigo de la voz del "otro". La dignidad es un valor absoluto que debe ser reconocido en la particularidad de cada persona como ser humano. Es uno de los conceptos que argumenta Kant. Es una manera de pensar que debe considerar el valor del humano, separando el valor relativo, como el precio dentro del contexto capitalizado, que pone precio a cualquier cosa. Nos explicaremos de forma concreta enseguida.

El sistema capitalista le pone un precio al individuo según la medida del coste por hora de su labor. Este precio varía por la capacidad laboral, la zona geográfica, el contenido de la labor y otras múltiples razones. El precio, como valor numérico, es fácil de comparar y relativizar. En resumen, el capitalismo posibilita comparar la valía de un individuo por su precio. El argumento de Kant sobre la dignidad se basa en que no debe cuantificarse el valor humano con el precio como valor relativo. Por esa razón, cuando Cornell habla de la dignidad del "otro", insiste en estimar el valor único de esa persona como "otro", no el valor comparativo del "otro". Este valor no es un valor intercambiable, es un valor absoluto. Suponiendo esta reflexión, Cornell resume el motivo verdadero del trabajo de Spivak como un intento de oír la voz del "otro" que no se oye y a la vez escribir su acto.

But as the reader, I am nevertheless called by Spivak to witness. In her call to her readers, Spivak is seeking to bring them into being a particular kind of community. That community can best be understood as Kant's sensus communis aestheticus, communis indicating a community that arises in the aesthetic judgment that we are before a sublime or beautiful object or person. Since her focus is loss and fundamental misinterpretation, along with the tragedy of both, Spivak is calling us to judge them as sublime. ${ }^{1}$

\footnotetext{
${ }^{1}$ Cornell, Drucilla, Between Women and Generations. Legacies of Dignity, Nueva York, Palgrave, 2002 , p. 82. Pero como lectora, aún soy llamada por Spivak como testigo. En el llamamiento a sus lectores, Spivak está tratando de que sean parte de un tipo de comunidad particular. Dicha comunidad puede ser entendida mejor como el sensus communis aestheticus (sentido común estético) de Kant: communis (común) señala una comunidad que surge en el juicio estético en que nos encontramos ante un objeto o persona sublime o hermoso. Dado que su enfoque se centra en la pérdida y en la mala interpretación de su fundamento, junto con la tragedia de ambas, Spivak nos invita a juzgarlas como sublime. [Traducción propia].
} 
Para el planteamiento de Cornell sobre la comunidad necesitaremos explicar más conceptos, para complementar la visión sobre el tema. Como vamos a ver en detalle el concepto de la comunidad basada en el sensus communis aestheticus [sentido común estético] de Kant en la siguiente sección, nos explicaremos brevemente. En la Crítica del juicio ${ }^{2}$, Kant indica la posibilidad de abrir una nueva comunidad por el juicio común sobre lo bello. La estética nazi hereda esta idea de Kant, atravesando la interpretación sobre esa idea kantiana de Schiller y el romanticismo alemán, que se ha llamado "estetización de la política". Contra este movimiento nazi y como remedio opuesto, Walter Benjamin propone la "politización de la estética" en su texto La obra de arte en la época de su reproductibilidad técnica ${ }^{3}$. Actualmente, hay muchos análisis y críticas sobre la estética nazi ${ }^{4}$.

Kant ha considerado la comunidad libre, es decir, una comunidad basada en la ética, aparte de la comunidad estética, en su obra Crítica de la razón práctica. Cada comunidad pensada por Kant tiene cierta articulación con las otras, no son independientes ni diferenciadas. Sin embargo, nos da la impresión de que Kant evita conectar directamente el juicio estético con el juicio ético. En realidad, Kant no nos deja su explicación sobre este asunto, por eso no se conocen muy bien sus razones. Lo que podemos imaginar siguiendo la comprensión general dentro de la historia del pensamiento alemán, es que Kant temía que el juicio estético pudiera intervenir en el territorio ético, ya que al estar basado en la función de la imaginación estética, podría llegar fácilmente a tal extremo de poder que ninguna fuerza restrictiva fuera capaz de controlarlo. Si la estética, que carece de principio, ejecuta la ética, es posible que surja un estado de caos que no funcione bajo un control razonable. Es muy peligroso; se puede reducir el problema de la "estetización de la política” en este punto.

\footnotetext{
${ }^{2}$ Tít. orig.: Kritik der Urteilskraft, 1790. En general, llamada tercera crítica por haber sido escrita después de Crítica de la razón práctica y Crítica de la razón pura. En castellano ha sido publicada por distintas editoriales, una de ellas es: Kant, Immanuel. Crítica del juicio. Trad. Manuel García Morente. Madrid: Espasa Calpe, 1977, 2007.

${ }^{3}$ Benjamin, Walter, La obra de arte en la época de su reproductibilidad técnica. Trad. Andrés E. Weikert, México D.F., Editorial Itaca, 2003.

${ }^{4}$ Por ejemplo, El mito nazi, de Philippe Lacoue-Labarthe y Jean-Luc Nancy [Lacoue-Labarthe Philippe y Nancy, Jean-Luc, El mito nazi. Trad. Juan Carlos Moreno Romo. Barcelona, Anthropos Editorial, 2002. es sobresaliente. Trataremos estos temas en el siguiente capítulo IV.
} 
Quizá por esta razón, Kant evita sobreponer exactamente la comunidad estética a la comunidad ética. En cambio, Schiller ${ }^{5}$ y el romanticismo alemán desarrollan en esta dirección la estética de Kant. Por ejemplo, Novalis ${ }^{6}$ y Friedrich Schlegel $^{7}$, que recibieron una fuerte influencia de la interpretación de Schiller sobre la estética de Kant y son del primer periodo del romanticismo alemán, muestran el concepto de la nación artística mítica que convierte a todos los miembros por la estética. El caso extremo es el régimen nacional ideal, como el arte sintético estructurado bajo la dirección de los reyes, con el modelo del rey Federico Guillermo III (Friedrich Wilhelm III), planteado por Novalis ${ }^{8}$. Esa idea ha desarrollado el concepto nacional orgánico en el contexto del romanticismo político que surge y se establece a principios del siglo XIX.

La teoría del estado estético planteada por Schiller y el romanticismo alemán espera el efecto educativo de la estética como resolución de los problemas del individualismo exagerado y de su abuso recuperando el vínculo entre los humanos con la comunidad reconstruida. Sin embargo, la teoría del estado estético extremo avanza con la forma de la estética devorando al individuo, que tiende a anular el principio de libertad que ha obtenido

\footnotetext{
${ }^{5}$ Schlegel, Friedriche Von (1772-1829), crítico literario y filósofo alemán, uno de los principales representantes del romanticismo alemán. [Audi, Robert (ed.): Diccionario Akal de Filosofía, trad. Huberto Marraud y Enrique Alonso, Madrid: Akal, 2004, p. 871.]

${ }^{6}$ NOVALIS, seudónimo de Friedrich von Hardenberg (1772-1801), poeta y filósofo alemán del primer romanticismo alemán. [Audi, Robert (ed.): Diccionario Akal de Filosofía, Op.cit., p. 716.]

${ }^{7}$ Friedrich Schlegel, 1772-1829, crítico alemán de las artes y pensador. Uno de los que impulsan el movimiento del romanticismo del primer periodo. [Hiromatsu Wataru (et. ál.): Iwanami Tetsugaku shisou jiten [Diccionario Iwanami del filosofía pensamiento], Tokio, Iwanamishoten, 1998, p. 758., Traducción propia]

${ }^{8}$ Se ve claramente la idea de un país ideal como obra de arte del rey artista en Fe y amor, obra publicada en 1798. Citamos dos partes de su publicación:

7. Es posible que un país floreciente sea una obra de arte con más realeza que un parque. Un parque construido con buen gusto es un invento inglés. Un país que logre satisfacer al espíritu y al corazón quizá llegue a ser una invención alemana; y el inventor sería entonces el rey de todos los inventores. [Novalis. "Fe y amor", en: Estudios sobre Fichte y otros escritos. Trad. Robert Caner-Liese, Madrid, Akal, 2007, p. 226.]

39. El verdadero príncipe es un artista de artistas; es decir, el director de los artistas. Cada hombre debería ser artista. Todo puede convertirse en una de las bellas artes. El material del príncipe son los artistas; su voluntad es su cincel: es él quien educa, sitúa e instruye al artista, porque solo él percibe desde el lugar justo la imagen en su totalidad, porque no hay nada que tenga más presente que aquella gran idea que debe ser expuesta y ejecutada mediante la unión de todas las fuerzas y todas las ideas. [Novalis: "Fe y amor", en: Estudios sobre Fichte y otros escritos. trad. Robert Caner-Liese, Madrid: Akal, 2007, p. 234.]
} 
la sociedad civil moderna. El intento de desarticular el yo racional por la imaginación estética llega hasta la noción nacional antiliberal que continúa en el nazismo?.

La mirada tabú que hasta hace poco había sobre el romanticismo se originó a causa de esta relación profunda con la noción nacional fascista nazi. En cambio, la teoría de la comunidad de Kant se vuelve a considerar de nuevo, como una nueva posibilidad de solidaridad dentro del marco liberal de hoy en día. La razón de llamar la atención sobre la discusión de la comunidad de Kant es obvia, dado el punto en que se mantiene apartado del concepto extremo romántico. Es decir, la teoría de la comunidad de Kant está abierta a diferentes sentidos por igual: al individualismo de ultranza y al comunismo que se enraíza en el sentido común.

El romanticismo político que ha radicalizado el concepto de la comunidad estética no ha sido tratado ni fue discutido en serio por dos razones principales. Una que ya hemos mencionado, es la tendencia totalitarista en la que la comunidad estética anulaba la libertad del individuo. La otra, a pesar de profesar la universalidad como el gran eslogan de la comunidad, en la discusión reduce de forma concreta el modelo de la comunidad propia que existe históricamente. Es decir, el romanticismo político lleva a una posibilidad de transformar la calidad de la comunidad estética a la comunidad cerrada. Esto es evidente

\footnotetext{
${ }^{9}$ Paul de Man indica la lectura errónea de Schiller a Kant en el capítulo “Kant y Schiller”. Y Josep Goebbels, el ministro de propaganda del Reich, repite esa lectura errónea de Schiller. Citamos un pasaje de Goebbels y el comentario de Paul de Man sobre ese asunto [y véase la nota anterior, que muestra unos textos de Novalis, para compararlos con el de Goebbels]:

El arte es la expresión del sentimiento. El artista se distingue del no artista por el hecho de que puede también expresar lo que siente. Puede hacerlo de varias formas. Algunos a través de imágenes, otros de sonido; otros a través del mármol -o también a través de formas históricas. El hombre-estado es también un artista. La gente es para él lo que la piedra es para escultor. El líder y las masas son por lo menos un problema entre sí del mismo modo que el color es un problema para el pintor. La política es el arte plástico del estado como la pintura es el arte plástico del color. Por ello, la política sin gente o contra la gente no tiene sentido. Transformar la masa en gente y la gente en estado -éste ha sido siempre el sentido más profundo de una tarea política genuina. [Joseph Goebbels, Michael, Ein deutsches Schicksal in Tagebuchblättern, Munich, F. Eber, 1933, pág. 21; citado por Wilkinson y Willoughby, “Introduction”, pág. cxlii. La novela está traducida al inglés por Joachim Neugroschel como Michael, Nueva York, Amok Press, 1987, pág. 14.]

No es del todo irrelevante, no del todo indiferente, que el autor de este pasaje sea -de una novela de-Joseph Goebbels. Wilkinson y Willoughby, quienes citan el pasaje, tienen ciertamente razón al subrayar que se trata de una grave lectura errónea del estado estético de Schiller. Pero el principio de esta lectura errónea no difiere esencialmente de la lectura errónea que Schiller inflige a su propio predecesor -es decir, a Kant. [De Man, Paul, Kant y Schiller, en: La ideología estética. Trad. Manuel Asensi y Mabel Richart, Madrid, Cátedra, 1998, p. 219220.]
} 
con el ejemplo de Novalis: él expone su reflexión considerando la Alemania de aquel momento.

Esta tendencia, la política y el pensamiento bajo la influencia romántica, continúa hasta la época del dominio nazi. Por ejemplo, el caso de Heidegger en El origen de la obra de arte ${ }^{10}$, donde intenta comprender la creación la obra de arte sobreponiendo en el establecimiento de la nación, desde su punto de vista, la aparición de la verdad. Otro ejemplo, la serie del “curso de Hölderlin" desde 1934 encamina una gran meta filosófica de articulación de la metafísica occidental; al mismo tiempo, revela la tendencia del centrismo de la cultura propia que vincula directamente el giro patriota de Hölderlin a la patria alemana real. Como indica Cornell, Spivak muestra que no se puede consentir la nostalgia heideggeriana:

But she is also working against the nostalgia that pretends there were good old days to return to or that indeed could even be recovered. ${ }^{11}$

Por otra parte, Spivak comenta El origen de la obra de arte analizando la metáfora espacial de la idea de Heidegger. Señala la aplicación de la metáfora con la disputa territorial en la obra de arte y compara al artista famoso con un burócrata anónimo, como el encargado de la nueva delimitación del territorio:

Tal como se mencionaba en el capítulo anterior, el mundear de un mundo sobre una tierra sin inscripciones hace alusión a "El origen de la obra de arte”, de Heidegger. Por retomar la argumentación, Heidegger sugiere que el combate entre el mundo que se erige y la tierra que acoge y refugia -se trata de una violenta metáforaconcepto de la violación- se disputa-se desarrolla o se plantea como combate-en la obra de arte como obra. Muchos de los ejemplos de Heidegger en este ensayo son espaciales. Si se utiliza la metáfora-concepto heideggeriana de la tierra y el mundo

\footnotetext{
${ }^{10}$ Heidegger, Martin: Somamichi: Gesamtausgabe. I. Abteilung: Veröffentlichte Schriften 1910-76 Band 5 Holzwege. Trad. Yoshio Kayano y Hes Brockard, Tokyo, Shobunsha, 1988.

${ }^{11}$ Cornell, Drucilla, Between Women and Generations, Op.cit., p. 79.

Pero ella también está trabajando en contra de la nostalgia que finge que hubo buenos tiempos para volver a ellos o que, de hecho, podrían incluso ser recuperados. [Traducción propia].
} 
para describir el proyecto imperialista, lo que surge de la violencia de la fisura (Riss en Heidegger contiene la violenta insinuación de una fractura -’la disputa del combate", "la intimidad de los contendientes"-, en lugar de la connotación relativamente fría de una brecha) es la coseidad [Dinglichkeit] multiforme de un mundo representado sobre un mapa, no meramente la "materialidad del óleo, afirmada y exaltada por derecho propio”, como en una obra maestra de arte europeo, comentada interminablemente por el filósofo y el crítico literario. Los agentes de esta transformación cartográfica en sentido estricto no son sólo grandes nombres como Vincent van Gogh, sino también gente pequeña y poco importante como Geoffrey Birch, así como los responsables de la formulación de las directrices políticas. $^{12}$

Así, Spivak menciona la fuerte relación entre el arte y el deseo imperialista y fascista que se encuentran en la obra de Heidegger: hace que la nueva delimitación del territorio y la construcción del mundo se correspondan de una manera muy violenta a la creación de la obra de arte. Ante este problema y la cuestión de la noción de Heidegger, quien supone una fuerte influencia en el pensamiento y cultura contemporáneos, debemos reflexionar aún más, sobre todo en cuanto a la relación y la metáfora entre la política y el arte. Pero por ahora, solo indicaremos que nosotras también debemos cuidarnos mucho de esta tendencia nostálgica que consigue que caigamos fácilmente en la discusión nacionalista cuando lo que intentamos es resistir frente a la opresión del centrismo occidental.

Como existen ejemplos negativos concretos -el romanticismo político, por ejemplo-, entre los kantianos liberales se ha visto dificultado el debate sobre la comunidad estética de Kant. No obstante, a partir de los años noventa, a raíz de la relectura de Jean-François Lyotard ${ }^{13}$ sobre lo sublime de Kant, los kantianos posmodernos como Cornell empiezan a deliberar

\footnotetext{
${ }^{12}$ Spivak, Gayatri Chakravorty. Crítica de la razón poscolonial. Trad. Marta Malo de Molina, Madrid, Akal, 2010. pp. 213-214

${ }_{13}$ Jean-François Lyotard, 1924-1998, filósofo representativo del pensamiento posmoderno de la filosofía. [Hiromatsu Wataru (et. ál.): Iwanami Tetsugaku shisou jiten [Diccionario Iwanami del filosofía pensamiento], Op.cit., p. 1.667.]
} 
más sobre la posibilidad de la comunidad abierta basada en lo sublime que sobre la comunidad cerrada basada en lo bello. Primero veremos la definición de Kant sobre lo bello y lo sublime.

Lo bello tiene de común con lo sublime que ambos placen por sí mismos. (...) De aquí también que los juicios de esas dos clases sean particulares, y se presenten, sin embargo, como universalmente valederos en consideración del sujeto, aunque no tengan pretensión más que al sentimiento de placer y no a un conocimiento del objeto.

Pero hay también entre ambos diferencias considerables, que están a la vista. Lo bello de la naturaleza se refiere a la forma del objeto, que consiste en su limitación; lo sublime, al contrario, puede encontrarse en un objeto sin forma, en cuanto en él, u ocasionada por él, es representada ilimitación y pensada, sin embargo, una totalidad de la misma, de tal modo que parece tomarse lo bello como la exposición de un concepto indeterminado del entendimiento, y lo sublime como la de un concepto semejante de la razón. (...) También esta última satisfacción es muy diferente de la primera, según la especie, pues aquélla (lo bello) lleva consigo directamente un sentimiento de impulsión a la vida, y, por tanto, puede unirse con el encanto y con una imaginación que juega, y ésta, en cambio (el sentimiento de lo sublime), es un placer que nace sólo indirectamente del modo siguiente: produciéndose por medio del sentimiento de una suspensión momentánea de las facultades vitales, seguida inmediatamente por un desbordamiento tanto más fuerte de las mismas; y así, como emoción, parece ser, no un juego, sino seriedad en la ocupación de la imaginación. De aquí que no pueda unirse con encanto; y siendo el espíritu, no sólo atraído por el objeto, sino sucesivamente también siempre rechazado por él, la satisfacción en lo sublime merece llamarse, no tanto placer positivo como, mejor, admiración o respeto, es decir, placer negativo. ${ }^{14}$

\footnotetext{
${ }^{14}$ Kant, Immanuel. Crítica del juicio. trad. Manuel García Morente. Madrid: Espasa Calpe, 1977, 2007. pp.175177.
} 
En resumen, el juicio que damos nosotros sobre el objeto como bello tiene la forma y ese objeto nos da el sentimiento de encanto agradable directamente; en cambio, el objeto juzgado de lo sublime está pasando del límite de la forma, por el sentimiento de la superación de las facultades vitales indirectamente llega a una satisfacción. En palabras más sencillas, lo bello es indicado hacia la satisfacción positiva como encanto agradable que se basa en la estética comprensible con la forma habitual general; lo sublime, hacia la satisfacción negativa como admiración o respeto en lo que supera la forma, así que es algo incomprensible, exorbitante. Kant pone unos ejemplos en los que se encuentra lo sublime en la naturaleza: masas montañosas que escalan el cielo, abismos profundos donde se precipitan furiosas las aguas, desiertos sombrios que invitan a tristes reflexiones ${ }^{15}$. Cuando nos enfrentamos estos objetos excesivos que superan nuestra capacidad de comprensión cognitiva, nuestra armonía emocional se trastorna y, al mismo tiempo, surge un sentimiento de resistencia contra la fuerza aplastante. Lo sublime no actúa directamente por rutas formadas a partir de la comprensión y el sentimiento, sino que nos acciona indirectamente hacia la satisfacción mediante una manera de desarticular esas rutas.

Lyotard interpreta el problema posmoderno en esa teoría de Kant. Él lee "el límite de la presentación" en "sin forma - sin límite" que es lo esencial de lo sublime. El sentimiento de la forma de lo bello, en otras palabras, surge de la limitación o la restricción. Por eso, el marco del límite determina el objeto y posibilita realizar la presentación ante nosotros. Sin embargo, lo sublime, donde no existen la forma ni el límite para que funcione la presentación, prohíbe hacer la presentación del objeto como objeto. Por lo tanto, lo sublime se compone en la paradoja de que es una representación de lo que no debe ser presentado esencialmente como objeto ante nosotros.

De otra manera, lo que representa lo sublime significa que la limitación y restricción que posibilitan nuestra cognición se ponen a nuestro alcance. Habitualmente, nosotras conocemos el objeto dentro de la limitación y la restricción, así que la marca de la limitación en sí no se conoce. Nosotras hacemos una presentación del objeto en el modo del

\footnotetext{
${ }^{15}$ Ibíd., p.205.
} 
tiempo y espacio; sin embargo, no podemos hacer ninguna presentación del tiempo y del espacio en sí. Solo la representación de lo sublime hace subir a la superficie la condición y el marco invisible de la limitación que nos restringe y que condiciona nuestra capacidad de presentación.

La comunidad formada por lo bello se funda en el vínculo directo de la afectividad. En cambio, la comunidad congregada por lo sublime se dirige por la ley invisible que se encuentra a través de la razón práctica. No es inducida completamente por estímulos emocionales, sino que aspira a la determinación trascendental que está tras la sensibilidad, es decir, el carácter de la comunidad de lo sublime es la orientación hacia la regla ética. Kant señala como un ejemplo de la comunidad de lo sublime la prohibición de la idolatría ${ }^{16}$. Cornell intenta mencionar la posibilidad sobre la dignidad del Otro en lo sublime de Kant.

Según Cornell, el motivo y el objetivo verdadero de Kant durante toda su Crítica del juicio es encontrar el lugar del sujeto y su sentimiento en la filosofía. Es decir, la tercera crítica de Kant es una crítica realizada sobre un juicio de una forma especial, que surge por el sentimiento pero, al mismo tiempo, nunca queda abrumado ni derribado por el sentimiento. Vamos a verlo paso a paso. Cornell indica el error de reducir el sensus communis aestheticus [sentido común estético] de Kant en la estética como sentido común de la comunidad que ya existe:

Some interpreters of Kant have wanted to save him from the subjectivism of the palate. They end up reducing the sensus communis aestheticus to aesthetic conventions materialized in the common sense of an existing community such that one person's judgment of taste can appeal to these conventions to convince others that this or that object is beautiful or sublime. (...) But a communication of aesthetic judgment is possible in Kant not because someone shares the existing

\footnotetext{
${ }^{16}$ Quizá no haya en el libro de la ley de los judios ningún pasaje más sublime que el mandamiento: "No debes hacerte ninguna imagen tallada ni alegoría alguna, ni de lo que hay en el cielo, ni de lo que hay en la tierra, ni de lo que hay debajo de tierra, etc. " [La cita está y se repite frecuentemente en la Biblia, Exod., 20, 4; Deut., 4, 15, 20; Jos., 24, 14 ; Ps., 96, 7. (N. del T.)]. [Kant, Immanuel: Crítica del juicio, Op.cit.]
} 
aesthetic standards of a particular community-this would be a contingent and thus not universal judgment-but because we can imagine that others would join in if we all adopted an enlarged mentality. ${ }^{17}$

Es decir, poder poseer el juicio estético común, no porque ya haya sido compartido el criterio sobre lo bello y la costumbre de la comunidad ya establecida, sino porque el juicio esté basado en la imaginación de que otro también podrá tenerlo como propiedad común. Al lugar que crea esta imaginación, que puede incluir al "otro" y que no existe todavía, Cornell le llama the imaginary domain [la esfera imaginaria]. Según Cornell, cuando Kant argumenta sobre el sensus communis aestheticus [sentido común estético], dirige la comunidad que debe ser y que se funda en esta esfera imaginaria.

The sensus communis aestheticus to which Kant refers always points toward an ought to be of a shared community: the enlarged mentality in which we might articulate to one another the subjective basis of our reflective judgment of the beautiful and the sublime, and find it illuminated through the viewpoint of the other and echoed in the other's attempt to communicate his or her feeling. The futurity of this community of the ought to be remains open as a possibility in the sensus communis aestheticus. The enlarged mentality to which Kant refers, in which we attempt to think from the standpoint of everyone else, does not turn us to everyone in a given community but to anyone who can be included in the idea of humanity. ${ }^{18}$

\footnotetext{
${ }^{17}$ Cornell, Drucilla, Op.cit., p.83

Algunos intérpretes de Kant han querido salvarlo del subjetivismo del gusto. Acaban reduciendo el sensus communis aestheticus (sentido común estético) a convenciones estéticas materializadas en el sentido común de una comunidad existente de manera que la sentencia de gusto de una persona puede apelar a estas convenciones para convencer a otros de que tal o cual objeto es bello o sublime. (...) Sin embargo, en Kant es posible una comunicación del juicio estético no porque alguien comparta los estándares estéticos existentes de una determinada comunidad - este sería un juicio contingente y, por lo tanto, no universal-, sino porque podemos imaginar que otros se nos unirían si todos adoptásemos una mentalidad ampliada. [Traducción propia]

${ }^{18}$ Loc. cit.

El sensus communis aestheticus al que se refiere Kant siempre apunta hacia un debería ser de una comunidad compartida: la mentalidad ampliada desde la cual podríamos articular entre nosotros la base subjetiva de nuestro juicio reflexivo de lo bello y lo sublime, y encontrarla iluminada a través del punto de vista del otro y hecha eco en el intento del otro de comunicar su sentimiento. El porvenir de esta comunidad del debería ser permanece abierto como una posibilidad en el sensus communis aestheticus (sentido común estético). La mentalidad ampliada a la que Kant se refiere, dentro de la cual intentamos pensar desde el punto de vista de todos los demás,
} 
Cornell explica el carácter de este sensus communis aestheticus [sentido común estético] de Kant como la capacidad de obtener la perspectiva del "otro". En este caso, el "otro", no es otro miembro determinado de la comunidad ya establecida, sino que se trata de un individuo que todavía está en el proceso de llegar. Cornell vincula esta idea abierta hacia el futuro como humanidad con la comunidad de lo sublime, suponiendo una indicación de Kant que comprende el nombre del sensus communis aestheticus [sentido común estético] como la idea del sentimiento público, y comenta lo siguiente:

This idea of the public always implies an experiment of the imagination because we are called to imagine all the possible, not just the real, viewpoints of others. Thus, the sensus communis aestheticus always implies a public that awaits us, not one that is actually given to us, nor one that can be given to us, once and for all, in any predetermined public forum. The judgment creates the community, not vice versa: "The judgement of taste exacts agreement from every one; and a person who describes something as beautiful insists that every one ought to give the object in question his approval and follow suit in describing it as beautiful. The ought in aesthetic judgements, therefore, despite an accordance with all the requisite data for passing judgement, is still only pronounced conditionally. ",19

De esta manera, Cornell aclara el significado y la función de la opinión pública de Kant en su tercera crítica e indica la posibilidad de la comunidad abierta que acepta al "otro" independiente de la comunidad existente. Lo importante del sentido público, esta vez, no es que la comunidad ya establecida decida exclusivamente sus reglas, que implican quitarle la

no nos convierte en todos los de una comunidad determinada, sino en cualquiera que pueda ser incluido en la idea de humanidad. [Traducción propia]

${ }^{19}$ Ibíd., p.85

Esta idea del público siempre implica un experimento de la imaginación porque somos llamados a imaginar todos los puntos de vista posibles, no solo los reales, de otros. Así pues, el sensus communis aestheticus (sentido común estético) siempre implica un público que nos espera, no uno que en realidad nos es dado, ni uno que se nos puede dar, de una vez por todas, en cualquier foro público predeterminado. El juicio crea la comunidad, no a la inversa: "El juicio de gusto exige la aprobación de cada cual; y el que declara algo bello quiere que cada cual deba dar su aplauso al objeto presente y deba declararlo igualmente bello. El deber [das Sollen] en el juicio estético no es, pues, según los datos exigidos para el juicio, expresado más que condicionalmente." [la parte de la cita: Kant, Immanuel: Crítica del juicio, Op.cit., pp. 167-168.] 
libertad a un individuo, sino que por el juicio de cada persona, con su libertad y dignidad, se establezca la comunidad por el sensus communis aestheticus [sentido común estético]. El juicio de lo sublime se hace más complicado por incluir la cuestión de la libertad. Cornell da un ejemplo sobre la cuestión de la muerte para entender de un modo más sencillo lo sublime de Kant.

Sublimity in this sense calls forth in us a feeling of respect for who we are as free beings at the same time that it overwhelms us as sensuous creatures.

Death of course is an obvious example of such an overwhelming natural force none of us can escape. ${ }^{20}$

La muerte es una cosa que nos hace sentir respeto, tanto a la muerte en sí como al que muere. Esta función de hacernos sentir respeto también sería un carácter de lo sublime, según Cornell. Sabemos que cualquiera puede morir, pero no podemos presentar a la muerte en sí. La muerte en sí no es comprensible para nosotras. No podemos experimentar la muerte ni testificarla. Cornell dice que la muerte está fuera de nuestro alcance y de la imaginación. En cambio, comenta la posibilidad de testificar la muerte de "otro" y su necesidad. Veremos los detalles enseguida con el ejemplo de su testimonio de la muerte de su madre.

\section{II.2.1. Testificar la muerte de la mujer con dignidad: una biografía de mujeres entre generaciones, como posible autobiografía de la mujer.}

Cornell comenta sobre la decisión de la ejecución de derecho de morir de su propia madre y la importancia de ser su testigo.

\footnotetext{
${ }^{20}$ Ibíd., p.86.

Sublimidad, en este sentido, nos pide un sentimiento de respeto a quienes somos como seres libres, al mismo tiempo que nos abruma como criaturas sensoriales.

La muerte es, por supuesto, un claro ejemplo de tal fuerza natural abrumadora de la cual no puede escapar ninguno de nosotros. [Traducción propia]
} 
I have no adequate words for my mother's bravery as she exercised her right to die, but I can at least write that I was awestruck by her dignity. Yet, my mother, like Spivak's distant relative, depended on a witness to be faithful to the "truth" of her own death-the "truth" of her claiming her own person as the actual means of her death. ${ }^{21}$

La madre de Cornell, tras un tratamiento, al no curarse de su enfermedad y estando sin posibilidad de recuperar la salud, consuma la así llamada muerte digna, la que elige morir por su propia voluntad. En ese momento, la madre pide a su hija Cornell que escriba sobre su muerte digna y el presente libro que estamos estudiando es la respuesta a su petición. Así que el libro en su totalidad lleva en sí mismo un carácter biográfico de su madre; igualmente, habla de la vida y de la muerte de su abuela como la madre de su madre, de Cornell como hija y de la hija adoptada de Cornell: en definitiva, las que no pueden faltar para hablar de la vida de la madre. Es decir, Cornell intenta hablar de la vida y la muerte de su madre basándose en la relación intergeneracional entre abuela-madre-hija. En otras palabras, es la biografía de su madre, su abuela y su hija adoptada, y al mismo tiempo es su propia autobiografía.

Para poder hablar de la historia de estas mujeres necesita la dignidad, e insiste en su importancia repetitivamente, aclarando el sentido y significado de la dignidad durante todo el libro. Por otra parte, reflexiona sobre la vida y la muerte de la mujer, que es imposible de entender y comentar y, por lo mismo, requiere un testigo. Cornell analiza y reconsidera el tema durante el proceso del intento de hablar de la muerte de su propia madre. Al igual que Spivak, y que Felman también en cierto sentido, Cornell se dirige a la nueva comunidad y debe hacerlo a través de la lectura del testimonio de la muerte de su madre, intentando ser testigo, escribiéndola.

\footnotetext{
${ }^{21}$ Ibíd., p.87

No tengo palabras suficientes para el coraje de mi madre cuando ejerció su derecho a morir, pero al menos puedo escribir que yo estaba intimidada por su dignidad. Sin embargo, mi madre, al igual que la pariente lejana de Spivak, dependía de un testigo para que fuera fiel a la "verdad" de su propia muerte: la "verdad" de su reivindicación de su propia persona como el medio de su muerte. [Traducción propia]
} 
My duty was to evoke the sublimity of her death for the reader. I was left with the task of representing the significance of what, on the level of imagination, is unrepresentable: death itself. I was called to this precarious task in my mother's last days. This entire book is my response to her naming me as her witness to her moral freedom. This book, then, also demands that the reader join me in the sensus communis aestheticus through the process of making an aesthetic judgment of my mother's exercise of her right to die as sublime. ${ }^{22}$

De aquí en adelante, Cornell explica por qué requiere al "otro" para convertirse en testigo de la libertad ética y para ello sigue la interpretación de Kant realizada por Schiller. Sin embargo, de todas maneras, no alcanza a superar la contradicción esencial que se encuentra en la filosofía de Kant, ni aunque reinterprete su teoría. Kant trata lo humano como una noción, y no lo capta como sustancia ni sustrato; tampoco hace el trabajo de comparar el sistema de presentación que él mismo fundamenta como hombre occidental en la perspectiva de la universalidad y de la ley invisible. Por esta razón, Cornell indica la necesidad de añadir la perspectiva psicoanalítica para poder ajustar la discusión de Kant en nuestro tiempo contemporáneo.

De esta manera, el argumento de Cornell no es la corriente dominante de la interpretación de la filosofía de Kant y, además, nos parece muy dudoso, sobre el punto de la teoría de la comunidad posible abierta de lo sublime, que ella pueda superar la discusión de la comunidad de libertad basada en la ética de la primera crítica de Kant.

Cabe aclarar que dadas las limitaciones de la presente reflexión no profundizaremos más en este punto. Nos permitimos mencionar algunos nombres de investigadores sobre el asunto para un estudio próximo. Sobre todo, en estos últimos años, nos llama la atención releer la

\footnotetext{
${ }^{22}$ Loc.cit.

Mi deber era evocar la sublimidad de su muerte para el lector. Me quedé con la tarea de representar el significado de lo que, en el nivel de la imaginación, es irrepresentable: la muerte en sí misma. Fui llamada a esta precaria tarea en los últimos días de mi madre. Todo este libro es mi respuesta al hecho de que ella me designara a mí como la testigo de su liberación moral. Este libro, pues, también exige que el lector me acompañe en el sensus communis aestheticus (sentido común estético) a través del proceso de hacer un juicio estético de mi madre en el ejercicio de su derecho a morir como sublime. [Traducción propia].
} 
filosofía de Kant desde el punto de vista psicoanalítico, especialmente en las investigadoras Lacaneanas como Monique David-M'enard ${ }^{23}$, Joan Copjec $^{24}$ y Alenka Zupančič ${ }^{25}$.

Pero, de todos modos, la indicación a la dignidad del "otro" relacionado con la teoría de lo sublime de Kant según Cornell nos da un señal para un posible encuentro del pathos de la voz del "otro":

The respect that dignity demands actually serves as a moral barrier to the translation or the appropriation of the other into our various social and cultural frameworks. It also provides Spivak's history with the ethical force of sublimity, to which we are called to witness. To bear witness to sublimity we have to accept the infinite worth of the other expressed in her dignity. ${ }^{26}$

Para poder evitar la pérdida de pathos a través de la traducción y la violencia epistémica de la apropiación de "otro", el respeto que exige la dignidad serviría como una barrera ética según Cornell. Y también proporciona la fuerza ética que surge de lo sublime a la historia que cuenta Spivak. Su historia está dirigida a nosotras para que seamos el testigo de esta sublimidad y, como responsabilidad de cumplir esta meta de ser testigos, nosotras tenemos que aceptar el valor infinito absoluto del "otro" que se presenta en su dignidad.

En la última parte del libro ¿Pueden hablar los subalternos? aparece una chica, una pariente lejana de Spivak llamada Bhubaneswari. Ella intentó hablar a través del lenguaje de su cuerpo en el momento de su muerte. Cornell interpreta el acto de Spivak, que intenta

\footnotetext{
${ }^{23}$ David-M'enard, Monique, Les constructions de l'universel: Psychanalyse, philosophie. (Las construcciones de lo universal: psicoanálisis, filosofía). Trad. Kawasaki Soichi, Tokyo, Serikashobo, 2001 [Ed. orig.: 1997].

${ }^{24}$ Copjec, Joan, Imaginemos que no existe la mujer: ética y sublimación. Trad. Teresa Arijón, Buenos Aires: Fondo Cultura Económica. 2006 [Ed. orig.: 2002].

${ }^{25}$ Alenka Zupančič. Ethic of real: Kant, Lacan. Trad. Tsuyoshi Togashi, Tokyo, Kawadeshobo, 2003. [Ed. orig.: 2000].

${ }^{26}$ Cornell, Drucilla, Op.cit., p. 93.

El respeto que exige la dignidad sirve en realidad como una barrera moral para la traducción o la apropiación del "otro" a nuestros diferentes marcos sociales y culturales. También le suministra a la historia de Spivak la fuerza ética de la sublimidad, de la cual estamos llamados a ser testigos. Para resistir el ser testigos de la sublimidad tenemos que aceptar el valor infinito del "otro" expresado en su dignidad. [Traducción propia]
} 
hablar sobre Bhubaneswari, encontrando en él una coincidencia con la interpretación de Schiller sobre lo sublime.

Spivak uncovers a story that classically fits Schiller's definition of a sublime object: a physical force that Bhubaneswari feels compelled to resist-colonial oppressionsuffering before her inability to carry out a task she believes is politically necessary, a task that is avoided in a nevertheless ethical way. Only if we "join" Spivak in a sensus communis aestheticus and make the aesthetic judgment about the sublimity of the "stories" she tells us, will the feminist witnessing to which Spivak calls us be brought into being. ${ }^{27}$

Cornell plantea leer el conflicto, el sufrimiento y la muerte de Bhubaneswari, que ha elegido suicidarse al final de una lucha interna entre la necesidad política y el juicio ético como lo sublime, y propone llamarlo testimonio feminista sobre el acto de testificar esta lectura de lo sublime. Los lectores de este testimonio se convierten en testigos en el dominio de la imaginación que pueda obtener la perspectiva del "otro", dirigen con su juicio estético basado en el sensus communis aetheticus [sentido común estético] a la comunidad que debe ser abierta al incluir al "otro".

En el texto de Spivak de 1999, añade un episodio relacionado con Bhubaneswari, donde una de las chicas de la familia de la generación de su biznieta trabaja para el "Nuevo Imperio". Esa chica joven de la India consigue un puesto importante en una empresa internacional en la capital de Estados Unidos; el nuevo imperio administra y controla el mercado internacional globalizado, y la familia está muy orgullosa de su ascenso. Spivak finaliza su texto con este episodio y adjunta su clamor porque el ahorcamiento de Bhubaneswari fue en vano. Como hemos visto en la parte anterior, el acto de habla de

\footnotetext{
${ }^{27}$ Ibíd., p. 90.

Spivak descubre una historia que encaja de modo clásico con la definición de Schiller de un objeto sublime: una fuerza física que Bhubaneswari se siente obligada a resistir-la opresión colonial-, sufriendo ante su incapacidad de llevar a cabo una tarea que ella cree es políticamente necesaria, una tarea que se evita de una forma ética a pesar de todo. Solo si "nos unimos" a Spivak en un sensus communis aestheticus [sentido común estético] y hacemos el juicio estético sobre la sublimidad de las "historias" que nos ella nos cuenta, se creará ese testigo feminista que Spivak nos pide que seamos. [Traducción propia]
} 
Bhubaneswari dentro de su familia solo ha sido leído bajo la representación de la mujer convencional, y se ha rechazado lo sublime de su acto de habla.

Según Cornell, Spivak muestra la tristeza y la vanidad de que no aparezca la comunidad, que debe ser sublime, en la familia de Bhubaneswari, ya que precisamente su familia debería ser el primer lector de su voz. Nosotras, como ya hemos mencionado, no pensamos que su muerte haya sido en vano y que no se haya escuchado su voz totalmente. Porque Spivak la ha oído e intenta ser su testigo y nos exige convertirnos en testigos a nosotras igualmente a través de la lectura. Al mismo tiempo, entendemos muy bien lo que comenta Spivak, porque si reflexionamos sobre la corriente dominadora dentro de su familia y nuestra sociedad globalizada, es absolutamente imposible creer que la voz de Bhubaneswari haya sido revelada. Y no es difícil imaginar que se hayan perdido y que hayan desaparecido las voces de otros tantos casos similares.

Spivak menciona la pérdida de la voz del "otro" en la postura subalterna sexuada y la dificultad de ser oído. Además, defiende que se encontrará una voz que surja en un futuro próximo bajo esa misma dificultad, según la lectura de Cornell. Aún así, Spivak sabe cuál es su postura, en la que debe ser testigo de la voz perdida, y se atreve a repetir el intento difícil y desesperado y escribe abiertamente el proceso del fracaso de su intento. Cornell apunta que el intento de recuperar la voz perdida de la mujer del pasado de Spivak es una procedencia fundamental del feminismo y que es indispensable para considerar la dirección del feminismo.

A feminism that fails to come to terms with our mother's stories loses its soul and disorients us. We fall into the now of advanced capitalism, the quick cure. That Bhubaneswari's suicide was part of her struggle for national liberation is also part of Spivak's own family history and indeed inspires her feminism. The failure to heed 
its significance is part of the feminism of her ancestresses who now work for the "New Empire. "28

Después de poner especial énfasis en la responsabilidad del feminismo actual, Cornell menciona la importancia de reflexionar sobre el mismo no solo en el presente sino en el tiempo continuo. Es decir, debe pensarse en el tiempo continuo como una intergeneración para las mujeres, y éstas deben reconocer la legitimidad de sí mismas.

Who we are can never begin just with the present. In any political position we take, we are constantly working through our own identifications; we are assuming responsibility-or refusing it-for the phantoms that inevitably haunt a patriarchal history that has denied so many women their significance, their voice. The young "emancipated girl” does not know what she is up against, nor how easily her "emancipation" can be co-opted. Spivak calls us toward a "women's time" to remind us not only that what we forget we are fated to repeat, but that we are inseparable from our own reclamation of those obscured by "official history," and that another history can be spun into another story only by respecting another time. $^{29}$

Si seguimos con la metáfora de Cornell, las mujeres, privadas de su significado y su voz, se convierten en fantasmas; siguen aferrándose a la historia patriarcal. Spivak es muy

\footnotetext{
${ }^{28}$ Ibíd., p. 91.

Un feminismo que no logra ponerse de acuerdo con la historias de nuestra madre pierde su alma y nos desorienta. Caemos en el ahora del capitalismo avanzado, la solución rápida. El que el suicidio de Bhubaneswari fuera parte de su lucha por la liberación nacional también forma parte de la propia historia familiar de Spivak y, de hecho, inspira su feminismo. El fracaso de no haber prestado atención a su importancia es parte del feminismo de sus antecesoras, que ahora trabajan para el "Nuevo Imperio". [Traducción propia]

${ }^{29}$ Loc. cit.

Quiénes somos no puede empezar nunca solo a través del presente. En cualquier posición política que tomemos, estamos trabajando constantemente a través de nuestras propias identificaciones; estamos asumiendo la responsabilidad -o rechazándola-de los fantasmas que acechan inevitablemente a una historia patriarcal que le ha negado a tantas mujeres su significado, su voz. La joven "niña emancipada" no sabe a lo que se enfrenta, ni cuan fácilmente puede ser cooptada su "emancipación”. Spivak nos llama a un "tiempo de las mujeres" para recordarnos que no solamente estamos destinadas a repetir lo que olvidamos, sino que somos inseparables de nuestra propia reclamación de aquellas [mujeres] ocultadas por la "historia oficial", y que otra historia puede ser trocada en otro relato solo mediante el respeto de otro tiempo. [Traducción propia]
} 
consciente de ello y asume la responsabilidad buscando el sentido y la voz de ellas. En cambio, las jóvenes descendientes de Bhubaneswari la rechazan y, muy por el contrario, escalan posiciones en el Nuevo Imperio para complacer a su familia. Sin embargo, este es un tema muy delicado, porque la liberación que a primera vista gozan las jóvenes se ha establecido en una inequidad amparada por la historia patriarcal. Es más, igual que muchos subalternos, ellas no saben muy bien cuál es la dificultad a la que se están enfrentando. Lo que no persiste en el consciente y lo que se olvida fácilmente tiende a repetirse con toda certeza. En resumen, olvidar la historia de la opresión en el pasado e ignorar su responsabilidad resultará, paradójicamente, en apoyar esas historias y en ser absorbidas en las mismas otra vez.

Por eso, el trabajo de recuperar lo que es una sombra de la historia es necesario, por lo menos para ser conscientes de la responsabilidad y así evitar ser captadas en esta historia de nuevo. Para este tipo de trabajo, Cornell expone que se necesita el respeto. Ella, que trabaja en la realización del texto testimonial de la mujer, como la biografía de su madre, abuela e hija, y al mismo tiempo de su autobiografía, encuentra el tiempo de la mujer en el testimonio de Spivak.

Women's time is not just about the actual, arduous journey Spivak undertook to find the traces of the Rani of Sirmur. For her journey can be understood as an allegory for how difficult it is not only for historical voices that have been suppressed but also for new voices to find the means of representation to be seen and heard. Women's time is the generational time in which the groundbreaking work of organizing can take place and consolidate the changes it brings about. The tendency to rush in for the quick fix-the one that surpasses the organizing efforts going on throughout our world at the grass-roots level-will once again fail to heed the gendered subaltern. We are called to bear witness to women's suffering under 
injustice and to the silence effectively imposed upon women's stories as a matter of history. ${ }^{30}$

El intento de Spivak, dentro de la tendencia que pide una respuesta inmediata razonable, podría ser justificado como una labor inútil o un esfuerzo en vano. Cornell fomenta la reflexión sobre esta tendencia en la sociedad global capitalista contemporánea de buscar únicamente soluciones inmediatas y juzgar las cosas sin valorar aquello que no concluye al instante. Nosotras, desde el respeto a otros tiempos diferentes, así como al tiempo de la mujer, coincidiremos en que solamente se puede encontrar la autobiografía y biografía de la mujer en el conflicto y la fisura intergeneracional de la mujer como algo que supera el modelo del individuo moderno, limitado solo al presente y desconectado del futuro y del pasado. Como comenta Cornell, para hilar la story [historia] de la mujer, se requiere el respeto y la dignidad que proceden de la comunidad; además, al mismo tiempo estos aspectos posibilitan iniciar una nueva comunidad abierta a los que están en correlación con estos principios.

Por último, citaremos un fragmento de la conclusión de Cornell sobre el texto de Spivak a modo de guía o muestra del trabajo posterior que vamos a desarrollar:

It is one thing to recognize that we cannot know the other's experience and thus validate it in cognitive terms, and another to witness to the gendered subaltern. Often we are called to admit that we cannot know the other in her difference. But the recognition of difference all too easily degenerates into indifference. Instead, Spivak

\footnotetext{
${ }^{30}$ Ibíd., pp. 91-92.

El tiempo de las mujeres no trata solo del viaje arduo, real que realizó Spivak para encontrar las huellas de la Rani de Sirmur. Ya que su viaje puede ser entendido como una alegoría de cuan difícil es, no solo para las voces históricas que han sido suprimidas, sino también para las voces nuevas, encontrar los medios de representación para ser vistas y escuchadas. El tiempo de las mujeres es el tiempo generacional en el que puede tener lugar la labor pionera de la organización y la consolidación de los cambios que trae consigo. La tendencia a precipitarse buscando la solución rápida - esa que supera a los esfuerzos de organización que se dan en todo el mundo a nivel local-fracasará una vez más al dejar de prestar atención al subalterno sexuado. Estamos llamadas a dar testimonio de las mujeres que sufren la injusticia y del silencio que efectivamente se ha impuesto a los relatos de las mujeres como una cuestión de historia. [Traducción propia]
} 
asks us to bear witness to the sublimity of the subaltern and thus to their infinite worth. $^{31}$

${ }^{31}$ Ibíd., p. 94.

Una cosa es reconocer que no podemos conocer la experiencia de la otra y, de esta manera, validarlo en términos cognitivos, y otra es ser testigos del subalterno sexuado. A menudo se nos pide que admitamos que no podemos conocer a la otra en su diferencia. Pero el reconocimiento de la diferencia degenera con demasiada facilidad en la indiferencia. En su lugar, Spivak nos pide dar testimonio de la sublimidad del subalterno y, por tanto, de su valor infinito. [Traducción propia] 
Segunda parte:

El arte como testigo: la representación entre realidad, ficción y subjetividad en el documental. 
IV. El documental audiovisual sobre el testimonio de la memoria traumática. 
En los apartados anteriores hemos especulado sobre la posibilidad de crear la autobiografía de la mujer. En concreto, iniciamos nuestra reflexión desde los estudios teóricos de Shoshana Felman, quien cuestiona que todavía no existe la autobiografía de la mujer propiamente dicha. Una de las razones de su argumentación es que la vida de la mujer incluye un trauma que es esencialmente inconfesable, ya sea consciente o inconscientemente, en consecuencia, no existe todavía ninguna autobiografía escrita por la mujer. Posiblemente, la autobiografía de la mujer podría surgir en el caso de que una mujer hablase sobre otra, convirtiéndose así en testigo de su supervivencia. También, nos centramos en la cuestión relacionada con "ser muda" como subalterno sexuado, según el argumento de G. C. Spivak, quien defiende que es el sistema ideológico de la historia narrativizada, el que deja mudas a las mujeres. Finalmente, con la interpretación kantiana posmoderna de Drucilla Cornell, nos confirma como una posible testificación del "otro", basado en la dignidad del "otro", supone una viable comunidad formada por lo sublime.

Profundizando en estos estudios, nos damos cuenta de que ser testigos y testificar la supervivencia del "otro" son cuestiones céntricas para posibles autobiografías y biografías de la mujer. En el apartado anterior, nos basamos en la teoría del análisis del texto, la escritura y la lingüística. En este apartado, a modo de continuación, observaremos la posibilidad del testimonio de la memoria del trauma en la expresión audiovisual documental. Para ello, no nos referimos a los trabajos de forma global, sino que analizamos un ejemplo de documental audiovisual: Shoah, de Claude Lanzmann (1985). En primer lugar, aclararemos la razón por la cual se elige esta obra para nuestro estudio.

Esta obra, a primera vista, podría incomodar en nuestro proyecto. Shoah no es un documental que reúna testificaciones exclusivamente de mujeres. Tampoco es precisamente una biografía de un individuo, ni un documento audiovisual autobiográfico en el sentido general. Sin embargo, no existe ningún otro ejemplo más relevante de documental audiovisual sobre testimonios de la memoria traumática que el que ampararnos. Esta obra existe aislada de las demás por su propio peso. Su línea argumentativa y su estrategia de expresión la convierten en indispensable al considerar las obras de arte contemporáneo, sobre todo la obra audiovisual de post-Auschwitz. 
Ya el título Shoah sugiere que se trata de un documental sobre el Holocausto. Al mismo tiempo, la obra documenta el viaje del propio autor, el cual intenta recuperar los testimonios entrevistando a las personas que permanecían obstinadamente calladas por el trauma. Esta obra también nos hace comprender la función de la división dicotómica opuesta en la construcción del Sujeto europeo que reproduce la marginación del “otro”. En concreto, la obra visibiliza el sistema antisemita que comprendemos claramente gracias al análisis basado en la deconstrucción ${ }^{1}$ derridiana que realiza Shoshana Felman.

La obra señala el límite que divide lo interior y lo exterior, el Sujeto y el "otro", lo posible y lo imposible, reflejando de este modo la intención del autor: intentar superar el límite imaginario que divide las culturas, los idiomas, los tiempos y espacios indicando la diferencia y su fisura durante el viaje.

Ninguno de los testigos supervivientes de los campos de exterminio habla en primera persona. La memoria del trauma les lleva a testificar eludiendo siempre a un «nosotros», sujeto colectivo representante de millones de muertos inocentes, que no tuvieron derecho a reclamar ni a saber por qué debían morir allí.

El único individuo que habla en primera persona es el autor. Parece que la presente reflexión es un buen preámbulo para el siguiente capítulo, en el cual nos aproximaremos a las corrientes Prívate Documentary y Self Documentary, basadas en documentales surgidos en los años noventa que incluyen el planteamiento de la voz en primera persona, en múltiples temas sociales.

Con el fin de aproximar la aparición de la autobiografía de la mujer (considerando que su vida incluye un trauma y por ello no existe todavía como tal), y plantear la autobiografía de la mujer en una expresión audiovisual capaz de superar los límites del texto, resulta indispensable analizar Shoah como una obra extraordinaria de testimonios con trauma. Nos

\footnotetext{
${ }^{1}$ La deconstrucción es la metodología de la relevación: suele comportar el reconocimiento de pares de oposiciones definidos de forma interdependiente por exclusión mutua, como por ejemplo, lo bueno y lo malo o la verdad y la falsedad, términos que operan todos ellos como fundamento del pensamiento moderno. [Audi, Robert (ed.): Diccionario Akal de Filosofía, trad. Huberto Marraud y Enrique Alonso, Madrid, Akal, 2004, p. 244.]
} 
centraremos en la relación entre arte y testimonio en la obra audiovisual, basándonos para ello de nuevo en la teoría de Shoshana Felman y su reflexión sobre la interpretación de Shoah. Posteriormente, subrayaremos la importancia de comenzar a hablar en primera persona como la esencia del testimonio en esta obra. Mediante este proceso, aclararemos el argumento de Felman: el arte es en sí mismo testimonio.

Estas son las razones principales al elegir esta obra para nuestro análisis. Antes de abordar el análisis, parece imprescindible ofrecer una breve explicación sobre la obra. Shoah, de Claude Lanzmann, es una obra única y peculiar dentro de las numerosas películas que abordan el Holocausto. Este largo documental visibiliza la tragedia de la exterminación judía ejecutada por el Nazismo Alemán. Lanzmann, realizador de la película, es muy conocido por su postura crítica hacia otras obras cinematográficas sobre el Holocausto. Llama la atención, por ejemplo, su crítica mordaz a la película La lista de Schindler (1993), de Steven Spielberg. Lanzmann no solo critica a la película comercial de Hollywood, sino que también muestra su postura crítica frente al documental Nuit et Brouillard (1956) de Alain Resnais $^{2}$, una obra que, no obstante, tuvo un fuerte impacto en el mundo por su representación artística, y que fue admirada por transmitir la miseria del Holocausto.

En contraste con el documental Nuit et Brouillard, el cual contiene bastantes imágenes de archivo del Holocausto, de los judíos de aquel momento y también de los Nazis, Shoah no incluye ninguna imagen histórica. A pesar de tratar el tema de esta carnicería sin precedentes, no contiene ni una sola imagen de los cadáveres. Sí escenifica, sin embargo, los paisajes y lugares donde se situaban los campos de exterminio, si bien solo aparecen las imágenes filmadas en el momento del rodaje, es decir, no muestra ninguna imagen anterior al rodaje.

El documental está dividido en dos partes: primera época y segunda época. La duración del documental depende del país en que se presentó: 613 minutos en Francia, 503 minutos en EE. UU. En el formato DVD está dividido en 4 discos, de 149 minutos, 117 minutos, 142 minutos y 142 minutos de duración respectivamente (un total de 550 minutos, o lo que es

\footnotetext{
${ }^{2}$ Los detalles sobre la crítica de esta obra los explicaremos posteriormente, en el apartado IV.2.2.
} 
lo mismo, casi 10 horas). La película está basada en escenas de entrevistas en múltiples idiomas (inglés, francés, italiano y otros), las cuales tienen lugar en varias zonas de Polonia, Alemania, EE.UU. e incluso Israel. En general, la imagen es en color, pero en algunos momentos de la entrevista se introducen imágenes en blanco y negro. Estas escenas son oscuras, con imágenes borrosas, lo cual sugiere una filmación oculta, como si se tratase de un espía.

La obra no contiene ningún tipo de narración, solo al comienzo de la película unas frases (roll opening credit) introducen la película, pero después no hay ninguna narración explicativa con voz en off. Tampoco tiene música ambiental. Los personajes que aparecen son los testigos, Lanzmann como entrevistador y la intérprete profesional que traduce las preguntas y respuestas simultáneamente. Es decir, no se introduce la técnica del doblaje. Solamente -en función de la necesidad- se ofrece traducción subtitulada. Los subtítulos indican el lugar concreto de la entrevista realizada.

Con esta breve descripción de la obra se verá la diferencia de la típica técnica de expresión documental del reportaje tipo National Geographic. Veremos los detalles en los siguientes apartados. 
IV.1. La relación entre el arte y la política: el arte después de Auschwitz. 
Shoshana Felman afirma que la obra Shoah no es un simple documental histórico. Lo que nos muestra Shoah no es una clara imagen sobre un acontecimiento pasado, sino que nos enseña la visión caótica del presente. En otras palabras, este documental busca en el presente lo que procede del pasado e investiga sobre el testimonio de la catástrofe y sus límites. Este filme tiene mucho que ver con la relación entre arte y testimonio:

\begin{abstract}
(...) Shoah is a film about the relation between art and witnessing, about film as a medium which expands the capacity for witnessing. To understand Shoah, we most explore the question: what are we as spectators made to witness? This expansion of what we in turn can witness is, however, due not simply to the reproduction of events, but to the power of the film as a work of art, to the subtlety of its philosophical and artistic structure and to the complexity of the creative process it engages. ${ }^{l}$
\end{abstract}

Felman comenta que esta densa película sobre testimonios nos obliga a ser testigos observadores, y que es necesario el poder del arte para realmente convertirnos en testigos y poder así testificar en un futuro. El poder del arte, como ella explica, es la capacidad de ampliación de la perspectiva de un individuo hacia la obra. O podemos decir sencillamente: una obra de arte exige una cierta perspectiva de observación.

Pongamos como ejemplo la pintura de Velázquez, Las meninas: el perro pintado en la parte inferior derecha del cuadro, suponemos que está situado enfrente de los otros personajes pintados; la infanta rodeada de las meninas, es quien se encuentra detrás del perro; el pintor está detrás de ellas; un hombre en la puerta pintando casi en el centro derecho del cuadro, se posiciona al fondo alejado del grupo... El cuadro fuerza a reconocer en él esa cognición

\footnotetext{
${ }^{1}$ Felman, Shoshana: The Return of the Voice: Claude Lanzmann's Shoah, en Felman, Shoshana y Laub, Dori, Testimony. Crises of witnessing in literature, psychoanalysis, and history, New York y London, Routledge, 1992, pp. 205-206. “(...) Shoah es una película acerca de la relación entre el arte y el testimonio, acerca de la película como medio amplificador de la capacidad propia del testimonio. Para comprender Shoah, tenemos que preguntarnos: ¿qué aportamos nosotros en calidad de espectadores convertidos en testigos? Esta amplificación al poder convertirnos en testigos a nuestra vez no se debe, sin embargo, solamente a la reproducción de los acontecimientos, sino al poder de la película como obra de arte, a la sutilidad de su estructura filosófica y artística y a la complejidad del proceso de creación que se pone en práctica." [Traducción propia]
} 
espacial. Y, a través del espejo reflejado, la imagen de los reyes al lado izquierdo de la puerta sugiere la conciencia espacial de que los reyes están a nuestro lado frente al cuadro.

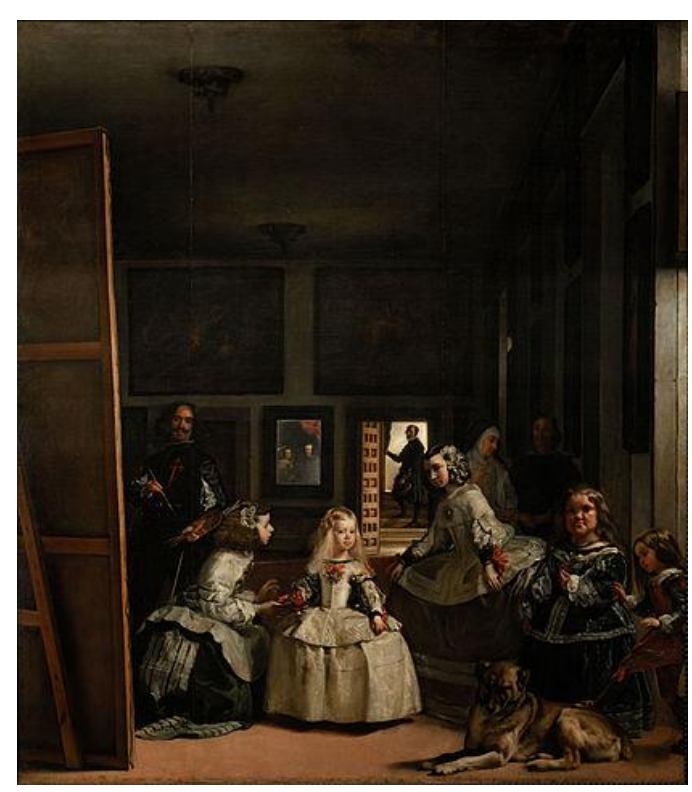

4. Las meninas (1656), Diego Velázquez

Una vez aceptamos ese conocimiento espacial, no dejamos de aplicarlo en nuestra manera de observar. Dicha cognición espacial de perspectiva se encuentra en el punto de fuga, en el centro del cuadro, como fundamento de la perspectiva clásica de la pintura occidental. Y con esta manera de mirar, con la perspectiva como fundamento, fue construido el mundo visual occidental Eurocéntrico, aunque ciertamente no es el único modo posible de observar de los humanos.

Las numerosas obras de arte contemporáneo permiten intentar romper con la perspectiva cerrada del mundo visual occidental, o al menos mostrar otros modos de ver, tal y como aporta el estudio de la historia del arte contemporáneo. Felman alega que Shoah exige otro modo de ver las cosas y nos obliga a reflexionar sobre lo que vemos. Felman rivaliza con Lanzmann (quien, como vimos, critica la ficción cuando ésta sustituye a la representación real del Holocausto). En opinión de Felman, para que la verdad trascienda a través del testimonio, se necesita el arte con apremio: 
"The truth kills the possibility of fiction" said Lanzmann in a journalistic interview.

But the truth does not kill the possibility of art-on the contrary, it requires it for its transmission, for its realization in our consciousness as witnesses. ${ }^{2}$

Para Lanzmann, con la palabra "ficción" se corre el peligro de asociar el arte con la idea de mentira e invento, de relato sin bases en hechos reales. Imaginamos que Lanzmann insiste en que su película no es ficción, ni trata de asuntos ficticios para evitar esa relación con el engaño y la estafa. Es una postura comprensible precisamente por la abundante polémica sobre el tema y la existencia de ciertos argumentos que se esfuerzan por reducir la gravedad del Holocausto. ${ }^{3}$

Felman está de acuerdo con su posicionamiento político, pero no acepta la idea de Lanzmann en relación con el arte. Ella argumenta que el arte es un factor necesario para el documental del testimonio. Por supuesto, el arte conlleva una representación ficticia. En este caso, la ficción no se opone ni rechaza el hecho y/o "lo real", sino que se convierte en un factor para elevar nuestra inteligencia hacia aquello que no se puede expresar directamente. En concreto, lo que no se puede representar directamente es la memoria del trauma. Por otra parte, sabemos que podemos considerar cualquier montaje audiovisual como una representación de ficción ${ }^{4}$; entonces, el argumento de Lanzmann tendría poco poder persuasivo. Suponemos que Felman conoce este punto débil en la argumentación de Lanzmann, y acepta por ello el carácter ficticio como medida preventiva para evitar crear una polémica sobre la división entre la ficción y lo real. Creemos que resulta necesario en este punto realizar un breve repaso de las características del arte y de la relación con su posible consideración como testimonio.

En la teoría de Kant podemos encontrar una reflexión filosófica sobre la posibilidad del arte acerca de lo trascendente. En su tercera crítica, Kant recapacita sobre el carácter

\footnotetext{
${ }^{2}$ Ibíd., p. 206.

"La verdad mata la posibilidad de la ficción", dice Lanzmann en una entrevista periodística. Pero la verdad no mata la posibilidad del arte - por el contrario, lo requiere para su transmisión, para su aceptación en nuestra conciencia como testigos. [Traducción propia]

${ }^{3}$ Trataremos este asunto más profundamente en la siguiente apartado: IV.2.

${ }^{4}$ El tema de la relación entre realidad y ficción lo desarrollamos en la parte introductoria sobre el documental, en la parte introducida del capítulo V.
} 
trascendente de lo bello y lo sublime ${ }^{5}$ : el arte es un posible soporte para generar una comunidad a través de lo trascendente, de lo bello.

Sin embargo, la mayor aplicación y los mayores logros prácticos de la teoría fueron alcanzados por los Nazis. Después de que los Nazis dirigieran la estetización de la vida política $^{6}$, es imposible definir el arte aislado o desconectado de la sociedad y la política aunque se profese «el arte puro»o «el arte por el arte». Ya Walter Benjamin comentaba que «el arte por el arte» puede ser la guerra para la estética fascista.

Tiene puesta su meta en lograr que las masas alcancen su expresión (pero de ningún modo, por supuesto, su derecho). Las masas tienen un derecho a la transformación de las relaciones de propiedad; el fascismo intenta darles una expresión que consista en la conservación de esas relaciones. Es por ello que el fascismo se dirige hacia una estetización de la vida política. Con D'Annunzio, la decadencia hace su entrada en la vida política; con Marinetti, el futurismo, y con Hitler, la tradición de Schwabing ${ }^{7}$ (...)

“Fiat art, pereat mundos”, dice el fascismo, y espera, como la fe de Marinetti, que la guerra sea capaz de ofrecerle una satisfacción artística a la percepción sensorial transformada por la técnica. Este es, al parecer, el momento culminante del “l'art pour l'art”. La humanidad, que fue una vez, en Homero, un objeto de contemplación para los dioses olímpicos, se ha vuelto ahora objeto de contemplación para sí mismo. Su autoenajenación ha alcanzado un grado tal, que le permite vivir su propia aniquilación como un ego estético de primer orden. De esto se trata en la estatización de la política puesta en práctica por el fascismo. El comunismo $^{8}$ le responde con la politización del arte. ${ }^{9}$

\footnotetext{
${ }^{5}$ Sobre el carácter de lo bello y lo sublime que define Kant, véase el apartado III.2.

${ }^{6}$ Benjamin, Walter, La obra de arte en la época de su reproductibilidad técnica, trad. Andrés E. Weikert, México D.F., Editorial Itaca, 2003, p. 96.

${ }^{7}$ Barrio muniqués conocido por su ambiente entre bohemio y maleante [N. del T]

${ }^{8}$ En la primera versión de 1935 (la francesa), en lugar de "comunismo", dice: "Las fuerzas constructivas de la humanidad..."

${ }^{9}$ Benjamin, Walter, Op.cit., pp. 96-99.
} 
Benjamin criticó sobre todo la intervención del arte esteticista en la política y el auge de la politización del arte. Sin embargo, tras enterrar la estrategia artística Nazi, si reflexionamos sobre el pasado vemos que cualquier obra de arte moderno se posiciona a través de dispositivos de operación simbólicos e intervenciones políticas que cambian la manera de mirar y el modo en que un individuo o un ciudadano mantienen la identidad nacional.
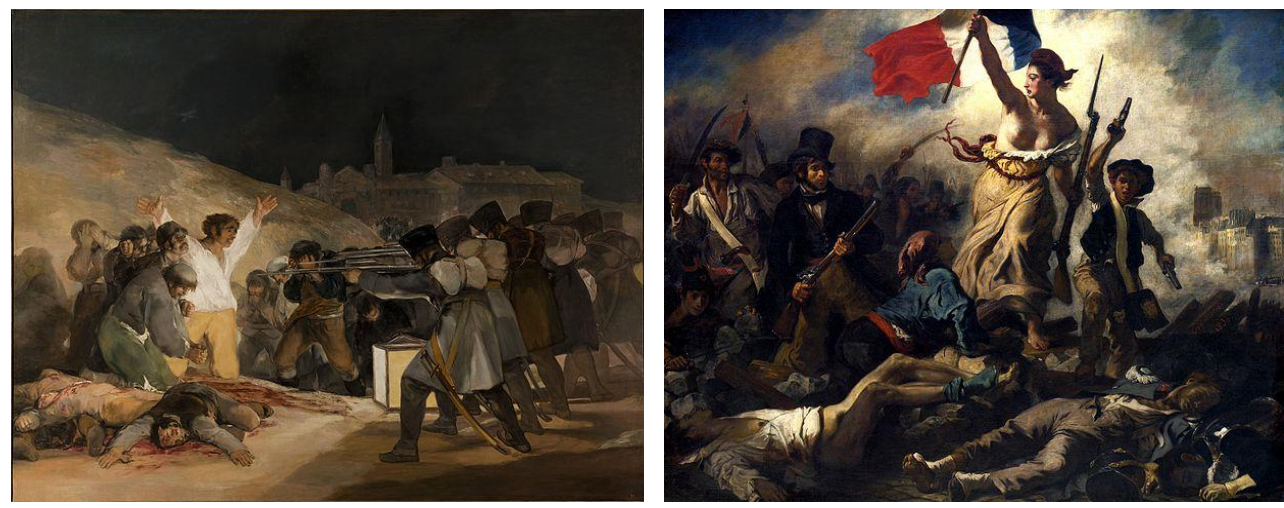

5. El tres de mayo de 1808 en Madrid (1813-1814), Francisco de Goya [izquierda] 6. La Liberté guidant le peuple (1930), Eugène Delacroix [derecha]

La obra El tres de mayo de 1808 en Madrid (1813-1814) de Francisco de Goya, también conocido como Los fusilamientos del tres de mayo, muestra al pueblo indefenso, asustado y asesinado por la milicia francesa. Inspira compasión e indignación, conformando así una identidad española patriótica que resiste contra los franceses despóticos. Por otra parte, en el cuadro La Liberté guidant le peuple (1930) de Eugène Delacroix se observa a la diosa izando la bandera tricolor sobre cadáveres amontonados. Esta imagen produce en los franceses el orgullo de haber conseguido la libertad, igualdad y fraternidad por propia mano de la sociedad civil, aunque con un gran sacrificio como precio.

Existe una estrecha relación, imposible de desestructurar, entre la política basada en la comunidad y los sentimientos que florecen a través de una obra de arte pensada para plasmar la identidad nacional. Como vimos, los Nazis utilizaron esta técnica. Algunos autores que trabajan en la primera línea de la filosofía contemporánea francesa, como 
Philippe Lacoue-Labarthe y Jean-Luc Nancy ${ }^{10}$, indican que los Nazis llegaron a conformar la comunidad «racial» a través del arte con el fin de llegar a convertirse en mito.

El mito nazi, como lo ha mostrado admirablemente Syberberg (sin «Hitler, un film de Alemania», el análisis que hicimos aquí no habría sido posible)*, es la construcción, la formación y la producción del pueblo alemán en, por y como una obra de arte... Lo que debe retenernos es la construcción especifica del mito nazi. Es decir, de eso que no representa el mito de los nazis, sino el nazismo, el propio nacional-socialismo en cuanto mito. La característica central del nazismo (y, muchos respectos, la de fascismo italiano) es la de haber propuesto su propio movimiento, su propia ideología y su propio Estado, como la realización efectiva de un mito, o como un mito vivo. ${ }^{11}$

Sobre la teoría de la politización del arte de Benjamin, su definición y su eficaz resistencia contra la estética de la política Nazi existe todavía espacio para discutir y no se debería simplificar ni descartar. Aún así, podemos alegar que el arte contemporáneo también tuvo inevitablemente que incluir la esfera política en etapas posteriores a la estética Nazi y el arte fascista. La representación artística de nuestro tiempo como reclamo y manifiesto de la disconformidad ante la política estética es un tema clave, y ciertamente fundamental en cuanto se refiere al arte post-Auschwitz. En este contexto, precisamente Shoah es una obra que aborda con seriedad la cuestión sobre la posible obligación o necesidad de incluir lo político en el arte.

\footnotetext{
${ }^{10}$ Philippe Lacoue-Labarthe y Jean-Luc Nancy. Ambos autores ocupan un lugar eminente en la filosofía francesa contemporánea. La Universidad de Ciencias Humanas de Estrasburgo recoge su labor docente y de investigación, y su influencia e incluso liderazgo intelectual. Son los directores, junto con Jacque Derrida y Sarah Kofman, de la colección «Philosophie en Effet» que publica Éditiones Galilée. [presentación en la cubierta del libro, LacoueLabarthe, Philippe y Nancy, Jean-Luc: El mito nazi, trad. Juan Carlos Moreno Romo, Barcelona, Anthropos Editorial, 2002.]

${ }^{11}$ Lacoue-Labarthe, Philippe y Nancy, Jean-Luc: El mito nazi, Op.cit., p. 37-38.

* el título original de la película es: Hitler, ein Film aus Deutschland, realizado en 1977 por Hns-Jürgen Syberberg que tiene duración de 442 mnutos. Recientemente en España, tuvo lugar de presentar en el $12^{\circ}$ Festival Internacional de Cine de Las Palmas de Gran Canaria (1-9 de abril del 2011). http://blog.lpafilmfestival.com/hitler-una-pelicula-de-alemania-en-cuatro-cap, accedido al 20 de noviembre 2011.
} 
La película denuncia el crimen y la matanza sistemática Nazi como consecuencia de una filosofía que se fundamenta en su propio mito y refleja una particular visión del mundo. Muestra la visión del presente como consecuencia de ese tiempo. Añadiremos otro aspecto político propio del documental Shoah: se trata de una reflexión muy consciente de resistencia contra el movimiento del revisionismo histórico del Holocausto, expandido mundialmente, el cual procura generalizar, disminuir y negar la gravedad del suceso a través del uso estratégico de los medios de comunicación y aprovechando la contradicción esencial de este positivismo generalizado que alega la falta de pruebas o la invención de ellas.

Esta consciente muestra política se convierte en la característica artística del arte postAuschwitz de nuestra época. Según Felman, el poder del arte es necesario para poder transmitir el testimonio; es decir, el arte conlleva la posibilidad de resistir contra los "asesinos de la memoria" y el testimonio del acontecimiento catastrófico. Aclararemos los detalles enseguida.

\section{IV.1.1. Arte y testimonio contra el asesinato de la memoria.}

La obra Shoah, además de hacernos capaces de ser testigos como hemos visto, muestra la eficacia del arte como testigo gracias a su poder de representación de los significados del testimonio de nuestra era.

Finally, Shoah embodies the capacity of art not simply to witness, but to take the witness stand: the film takes responsibility for its times by enacting the significance of our era as age of testimony, an age in which witnessing itself has undergone a major trauma. ${ }^{12}$

\footnotetext{
${ }^{12}$ Felman, Shoshana, Op.cit., p. 206.

Finalmente, "Shoah" encarna la capacidad del arte no simplemente como testigo, sino por tomar al testigo de pie: la película se hace responsable de su época mediante la promulgación de la importancia de nuestra época como la era de los testimonios, una época en que los testigos en sí han experimentado un gran trauma. [Traducción propia]
} 
Exactamente en palabras de Felman, Shoah es un documental que registró el testimonio, así como el acto de testificar. El relato de los testigos proviene de la memoria traumática que permaneció durante mucho tiempo en silencio, más allá del olvido, como algo que no se podía contar.

En cierto sentido, para la memoria no pasa el tiempo. Recordar trae a la memoria una representación de la escena que nos rodeaba en aquel momento, y exige revivir la situación una vez más. Un ejemplo muy conocido es la novela En busca del tiempo perdido de Marcel Proust, donde los pasajes recuerdan el olor y el sabor de las madalenas.

No existe ningún inconveniente al revivir recuerdos agradables. En cambio, si se trata de traer a la memoria un suceso catastrófico, horroroso y cruel, recordar significa sentir de nuevo esa catástrofe horrible y cruel. Los supervivientes del despiadado suceso se defienden contra el dolor y la tristeza intentando no recordar, para así poder recuperar la tranquilidad en su vida cotidiana, ocultando y sellando la memoria. Resulta natural y comprensible, de esta manera, la memoria permanece como un trauma sellado del que no se habla.

Sin embargo, de esta forma el agresor y el espectador empiezan a actuar como si no ocurriese nada y nunca hubiera sucedido, aprovechando el silencio de las víctimas. Un ejemplo esquemático que muestra esta consideración lo componen los casos de violación sexual. La víctima de la violencia guarda para sí el trauma. Muchas de las víctimas se quedan calladas, en silencio, para huir del miedo y del dolor del recuerdo.

De este modo, los agresores consiguen esconder su crimen como si nada hubiese ocurrido. El hecho se queda invisible. Si se logra la invisibilización del suceso, se logra la anulación del hecho. Como consecuencia, permite a los agresores, inconscientes en ocasiones de su culpabilidad, reproducir el crimen. Es un círculo vicioso.

En cambio, si la víctima reclama, surge la obligación de testificar y explicar que ocurrió allí. La víctima debe recordar y manifestar los detalles del suceso. Es decir, debe revivir el 
evento exponiéndose al miedo, el dolor y el sufrimiento de aquel momento y debe aclararlo por medio de la palabra haciéndolo público. Sin embargo, no resulta fácil.

La víctima como testigo puede tener dificultades para testificar por alterarse o confundirse en muchas ocasiones. Conseguir que la víctima hable es siempre difícil, y en cierto sentido resulta casi imposible probar todo lo ocurrido desde el punto de vista de la víctima.

Muy al contrario, el agresor generalmente intenta anular su culpa y se aprovecha de esta imposibilidad de denuncia, alegando cualquier razón a su conveniencia: la víctima le provocó, había acuerdo, etcétera, etcétera. Hay miles de pretextos. El razonamiento del agresor es siempre que la víctima tiene la culpa de provocarlo y merece por ello recibir el daño.

El lugar de la acusación se podría convertir en la segunda experiencia traumática para la víctima al exponerse a la intimidación mental del agresor y a la actitud de indiferencia del público ante el estado de la víctima. Otra vez, esto supone un círculo vicioso por el cual la víctima permanece en silencio, invisible, debido al miedo a sufrir un segundo trauma. Para el agresor, el silencio de la víctima anula la visibilidad del suceso -y así también su culpabilidad-, e intentará por todos los medios conseguir silenciar a la víctima.

Quizá podamos decir, que el caso de los revisionistas que procuran reducir y generalizar la gravedad del Holocausto es parecido a este segundo ataque de agresores a la víctima. Y Shoah muestra la resistencia contra este ataque por parte de los agresores. A lo largo del documental Shoah, de casi 10 horas de duración, vimos testimonios en múltiples idiomas, el rechazo a testificar, la angustia ante el acto de testificar. A menudo, se repiten en los testimonios expresiones como: «no se puede decir» «no se puede explicar», etc. El testimonio se ve interrumpido por el sollozo y el silencio, podemos notar cómo el tiempo pesa y el aire incluso resulta doloroso. También se encuentran otros testigos que expresan que «no veían nada» o «no podían verlo»: un gesto de olvido y de amnesia. Las charlas ficticias, infinitas por creerse un falso estereotipo y el silencio bloqueado por ruidos otra vez. En resumen, Shoah muestra el proceso del fracaso de testificar como se conoce 
comúnmente. Cuando los individuos intentan testificar aparece un bloqueo mental, físico y emocional que le impide explicar los sucesos que ha vivido.

\section{IV.1.2. Testificar lo imposible en las diferencias: rupturas e inconexiones.}

Los entrevistados de la película se pueden dividir en tres grupos. El primero, el de los judíos supervivientes que fueron salvados del campo de exterminio, es el grupo de las víctimas. El segundo grupo está formado por los alemanes que participaron reuniendo a los judíos dentro de toda Europa y en su matanza, y en lo relacionado con este proyecto, es el grupo de los agresores. Y el tercer grupo es el de los polacos que vivían alrededor de los campos de concentración, los cuales veían como los judíos eran deportados al campo, éste es el grupo de los espectadores. Según Felman, estos tres tipos de personajes, cada cual por su razón, no pueden ver lo que deben, ni pueden testificar lo que deben.

The Jews see, but they do not understand the purpose and the destination of what they see: overwhelmed by loss and by deception, they are blind to the significance of what they witness. ${ }^{13}$

Felman cita el testimonio de Richard Glazar como un ejemplo de que los judíos no pudieron entender a pesar de haber visto lo que ocurría. Él y los judíos que permanecieron en un vagón de tren en un campo, lograron abrir una ventana y preguntar a un niño de fuera qué estaba ocurriendo por medio de gestos.

Not in words, but in signs, we asked: "what's going on here?" And he made that gesture. Like this. We didn't really pay much attention to him. We couldn't figure out what he meant. $[34]^{14}$

\footnotetext{
${ }^{13}$ Ibíd., p. 208.

Los Judíos ven, pero no entienden el propósito y el destino de lo que ven: abrumados por la pérdida y el engaño, están ciegos ante la trascendencia de lo que son testigos. [Traducción propia]

${ }^{14}$ Loc.cit.

No con palabras, pero con señales, nosotros le preguntamos:” ¿Qué es lo que pasa aqui??” Yél hizo ese gesto. De esta manera. Nosotros realmente no le prestamos mucha atención. No podíamos adivinar lo que eso significaba. [Lanzmann, Claude, Shoah, trad. Federico de Carlos Otto, Madrid, Arena Libros, 2003, p. 42.]
} 


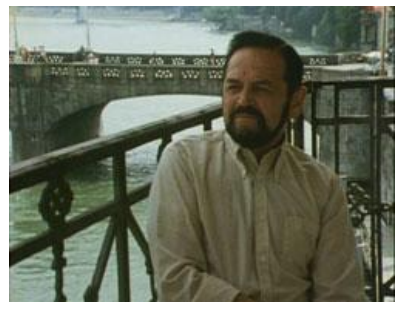

7. Richard Glazar en Shoah (1985), Claude Lanzmann

Según las palabras de Richard Glazar, el niño les contestó moviendo su mano hacia el cuello y desplazándola horizontalmente. Nosotros ahora sabemos cuál fue el destino del tren de judíos, por eso podemos captar la idea de este gesto que quiere decir decapitación o muerte. De hecho, en el contexto de la cultura occidental, este gesto significa la ejecución o la muerte en general. Sin embargo, los judíos no lo entendieron de esta manera, según el testigo comenta sobre aquel momento.

Los testigos polacos y ex-Nazis testifican en el documental, cómo no miraban o no podían ver a pesar de su presencia.

The Poles, unlike the Jews, do see but, as bystanders, they do not quite look, they avoid looking directly, and thus they outlook at once their responsibility and their complicity as witnesses:

You couldn't look there. You couldn't talk to a Jew. Even going by on the road, you couldn't look there.

Did they look anyway?

Yes, vans come and the Jews were moved farther off. You could see them, but on the sly. In sidelong glances. [97-98] ${ }^{15}$

\footnotetext{
${ }^{15}$ Ibíd., pp. 205-206.

Los polacos, a diferencia de los judíos, podían ver pero, como espectadores, no querían mirar, ellos evitaban mirar directamente, y consecuentemente sus perspectivas a la vez que su responsabilidad y su complicidad en calidad de testigos: Shoah, Usted no podía mirar allí. Usted no podía hablar con un judío. Incluso pasando por el camino, usted no podía mirar allí. No se ven de todos modos? Sí, venían furgonetas y los judios eran trasladados afuera más lejos. Se podía ver, pero furtivamente. De reojo.
} 
Según la interpretación de Felman, los espectadores pretenden escapar de su responsabilidad, manifestando que "no podían ver" o que "solo podían ver fragmentos de lo que ocurría". Esta afirmación de no poder ver en la totalidad justifica no hacer nada porque se disculpa de no haber entendido lo que ocurría. Por otro lado, los nazis cuidaban de que no se viera a los judíos, y sobre todo de que su exterminación quedara invisibilizada. El ex-guardia del campo de exterminio de Treblinka, Franz Suchomel testifica:

(...) alambradas con lazos muy tupidos de ramas de árboles, de ramas de pino... Es lo que se llamaba «camuflaje»... Y todo estaba cubierto. Todo, todo. No veían fuera, ni a derecha ni a izquierda. Absolutamente nada... Imposible. ${ }^{16}$

Según Suchomel, el campo estaba organizado de tal manera que la vista quedaba bloqueaba. Es un testimonio que demuestra el esfuerzo de los nazis para que nada fuera visible, para que no hubiera ningún testigo en ese espacio. Además, el espectador tampoco puede ver con claridad a Suchomel testificando en esta escena de Shoah. Durante la entrevista con Lanzmann, de vez en cuando se muestra la imagen del equipo de producción recibiendo la señal desde la cámara oculta, y cuando sale Suchomel la imagen es poco clara y en blanco y negro.

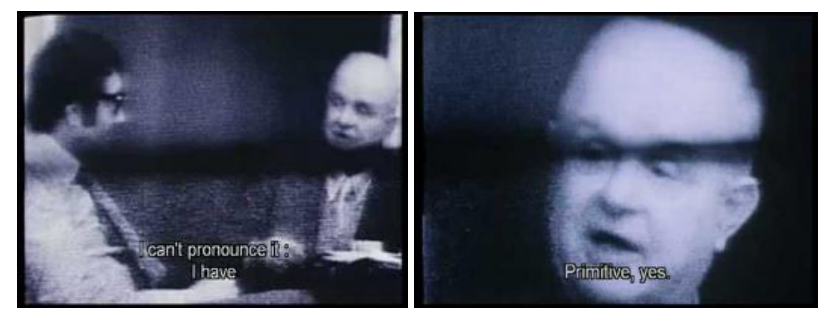

8. Franz Suchomel en Shoah (1985), Claude Lanzmann

Esto no es una casualidad. El testimonio de Suchomel es muy importante, ya que explica de manera global cómo era el campo de Treblinka organizado sistemáticamente por los Nazis. Pero él mismo se presenta muy ambiguo en la imagen, manifiesta que había un acuerdo de no mostrar su nombre para testificar en la entrevista.

\footnotetext{
${ }^{16}$ Lanzmann, Claude, Op.cit., p. 115.
} 
It is not coincidence that as this testimony is unfolding, it is hard for us as viewers of the film to see the witness, who is filmed secretly: as is the case for most of the exNazis, Franz Suchomel agreed to answer Lanzmann's questions, but no to be filmed; he agreed, in other words, to give a testimony, but on the condition that, as witness, he should not be seen ... ${ }^{17}$

Felman indica que podemos conectar este hecho con muchos casos de agresores que evitan ser expuestos para permanecer invisibles. Es difícil acceder a algunos testimonios por parte de los agresores, aunque acepten testificar por determinadas razones, se niegan a testificar en su propio nombre ${ }^{18}$. Esta invisibilidad es la esencia del Holocausto Nazi: hay pocas ocasiones de escuchar testimonios, los cuales además solo aportan imágenes confusas.

$$
\begin{aligned}
& \text { The essence of the Nazi scheme is to make itself-and to make the Jews-essentially } \\
& \text { invisible. To make the Jews invisible not merely by killing them, not merely by } \\
& \text { confining them to "camouflaged," invisible death camps... }{ }^{19}
\end{aligned}
$$

Tal y como afirma Felman, la esencia del crimen nazi es la invisibilización de ellos mismos, como agresores, y de los judíos, como víctimas. La técnica para lograr la invisibilización varía a muchos niveles, desde el nivel físico hasta el simbólico. Veamos solo dos ejemplos que muestran claramente estas técnicas.

\footnotetext{
${ }^{17}$ Felman, Shoshana, Op.cit., pp. 208-209.

No es coincidencia que conforme se desarrolla este testimonio, resulta difícil para nosotros como espectadores de la película ver al testigo, filmado en secreto: como es el caso de la mayoría de los ex-nazis, Franz Suchomel accede a responder a las preguntas de Lanzmann, pero no a ser filmado; está de acuerdo, en otras palabras, a dar un testimonio, pero no a la condición de testigo, él no quiere ser visto... [Traducción propia]

${ }^{18}$ Durante la entrevista, Lanzmann confirma la existencia de un acuerdo para no publicar el nombre de Suchomel, a quien podemos ver exigiendo no citar su nombre; de hecho, vemos en la escena a Lanzmann confirmar el trato de no decir su nombre. Así pues, Lanzmann no cumplió su promesa. Ver a Lanzmann, Claude, Shoah, Op.cit., p. 61.

${ }^{19}$ Felman, Shoshana, Op.cit., pp. 209-210.

La esencia del régimen nazi es hacerse - y hacer a los judios- esencialmente invisibles. Invisibilizar a los Judios no solo asesinándolos, no por el mero hecho de confinarlos "camuflados" a los campos de la muerte invisibles... [Traducción propia]
} 
Uno es la invisibilización del humano asesinado en el manejo del lenguaje (además de eliminar físicamente el cadáver quemando hasta la ceniza). Los Nazis decidieron llamar Figuren al cadáver y exigían a los judíos tratarlos como inhumanos.

The Germans even forbade us to use the word "corpse" or "victim." The dead were blocks of wood, shit. The Germans made us refer to the bodies as figuren, that is, as puppets, as dolls, or as Schmattes, which means "rags." [13]

... a disembodied verbal substitute which signifies abstractly the linguistic law of infinite exchangeability and substitutability. The dead bodies are thus verbally rendered invisible, and voided both of substance and specificity, by being treated, in the Nazi jargon, as figuren: that which, all at one, cannot be seen and can be seen through. $^{20}$

Los nazis prohíben las expresiones como "víctimas" o "cuerpos" referidas a cuerpos humanos muertos o cadáveres. En cambio, utilizan la palabra Figuren. Esta elección de los nazis de usar exclusivamente la palabra Figuren elimina la dignidad en la muerte humana y el valor único de cada persona.

Es esta una operación consciente que se aprovecha de una posibilidad lingüística -la infinita posibilidad de intercambiar expresiones con sus correspondientes consecuencias-, negando de este modo el valor de lo humano. Por lo menos, en el nivel lingüístico el valor es comparable, aunque se hable de seres humanos. Así pues, esta elección consciente al llamar Figuren a un cuerpo humano muerto facilitaba anular el valor humano de los judíos. Esta anulación de lo humano de las víctimas, desde el punto de vista del resultado, anulaba la gravedad del crimen o el crimen en sí.

La expresión Figuren indica que los que allí murieron no tenían valor humano, ni siquiera tenían nombre, ni el carácter personal e individual intrínseco en todas las personas. La

\footnotetext{
${ }^{20}$ Ibíd., p. 210.

[Figuren es] un incorpóreo sustituto verbal que implica en modo abstracto la ley lingüística de la infinita intercambiabilidad y sustituibilidad. Los cadáveres son por lo tanto verbalmente invisibilizados, y anulados ambas la sustancia y la especificidad, por ser tratados, en la jerga nazi, como figuren: palabra que, al mismo tiempo, no nos permite ver pero sí conocer las intenciones... [Traducción propia]
} 
palabra constituye simbólicamente, pues, el punto más grave del crimen Nazi en el Holocausto: la invisibilización de los judíos y su muerte. El término Figuren es un ejemplo de deshumanización, uno de los recursos para anular la individualidad de las víctimas. Paradójicamente, la expresión Figuren -la cual anula lo humano de las víctimas y también el crimen en sí-, ha permanecido como una huella que indica crimen y el carácter esencial de los sucesos.

La otra estrategia de invisibilización es el sistema estructurado para dar muerte a los judíos, es decir, la estricta división del trabajo en lo referente a la exterminación nazi. El transportista de los judíos hacia el campo de exterminio testifica que nunca conoció el destino, ni vio el tren de la muerte ("el tren especial", según la perífrasis Nazi). Precisamente la división del trabajo, permitía que aquel que transportaba a miles de personas hacia su exterminio, no supiera el destino final, lo cual se convertía a su vez en una buena escapatoria para eludir la propia responsabilidad por no saber (o no querer) ver.

El sistema de la división del trabajo facilita ejecutar cualquier acto, sea de la gravedad que sea, sin un juicio humano. Los operadores no saben ni ven lo que ocurre por su operación, solo se concentran en aumentar la eficacia de su trabajo. Este sistema no deja espacio para el juicio humano, como consecuencia, es posible efectivamente transportar a una gran cantidad de personas hacia su exterminio. El sistema de trabajo diseñado también aumenta la gravedad del crimen Nazi y esa ignorancia de lo que han hecho demuestra la esencia del crimen.

Los dos ejemplos de la técnica de invisibilización presentados, muestran la esencia del crimen Nazi, ya sea por la operación lingüística de carácter simbólico o por la técnica de la división del trabajo. Demuestran la alienación de lo humano y fueron útiles para eliminar la compasión. Añadamos un ejemplo más del testimonio antes de cerrar esta parte.

La mujer del profesor Nazi que vivía en Chelmno, donde solo permanecen dos supervivientes del campo de exterminio, contesta a las preguntas de Lanzmann: solo había 
visto la gas $\operatorname{van}^{21}$ (el camión para gasear) que iba y volvía, pero nunca vio a los judíos que estaban dentro del bus, solo veía el bus desde fuera.

Cabe repetir que son numerosos los testigos en este documental que testifican que "no veían"; en otras palabras, ellos son los testigos que demuestran lo difícil que fue ver el interior del Holocausto. En este punto, Felman insiste en la idea de la esencia del Holocausto como suceso imposible de ver:

Thus, the diversity of the testimonial stance of victims, the bystanders and the perpetrators have in common, paradoxically, the incommensurability of their different and particular positions of not seeing... Through the testimonies of its visual witnesses the film make us see concretely -makes us witness -how the Holocaust occurs as the unprecedented, inconceivable historical advent of an event without a witness, an event which historically consists in the scheme of the literal erasure of its witness but which, moreover, philosophically consists in an accidenting of perception $(. . .)^{22}$

De los testigos que aparecen en el documental, ninguno cumpliría los requisitos como testigo, ya que todos afirman que "no veían" y/o que "no podían ver". Cada uno de los tres grupos, de distinta forma y desde perspectivas diferentes, testifica la imposibilidad de ver o conocer la realidad de los sucesos. Felman argumenta que ése es precisamente el testimonio típico del Holocausto (como algo que no se puede testificar), e indica que Shoah muestra cuán imposible es hablar y testificar sobre los hechos en su totalidad con perfección, aclarando las diferencias, rupturas e inconexiones entre los distintos testimonios.

\footnotetext{
${ }^{21}$ Gas van: un camión creado y empleado por los Nazis para asesinar a los judíos durante el transporte. Tenía un sistema que usaba el gas creado por la combustión del motor, que introducía éste al propio vagón.

${ }^{22}$ Ibíd., pp. 210-211.

Por lo tanto, existe diversidad en la posición del testimonio de las víctimas, pero los transeúntes y los autores tienen en común, paradójicamente, la inconmensurabilidad de sus diferentes y particulares maneras de no ver [...] A través de los testimonios de los testigos la película nos hace ver concretamente -nos hace testigos- de cómo el Holocausto ocurre como un advenimiento histórico inconcebible, sin precedentes de un acontecimiento sin testigos, un evento que históricamente consiste en el sistema de la supresión literal de su testigo, pero que, además, filosóficamente consiste en un accidente de percepción (...)[Traducción propia]
} 


\section{IV.1.3. La cuestión de la traducción: el silencio y la aparición de la voz.}

Hasta ahora hemos visto la inconexión entre los testimonios presentados, aún reconociendo las diferentes posturas de los tres grupos. Hemos aclarado el caótico y confuso acto de testificar sobre un suceso traumático, tal y como aparece en Shoah. Pero la confusión en esta obra audiovisual no solo se encuentra a nivel político, sino también a nivel del lenguaje.

Al observar esta obra, escuchamos la voz de la conversación entre Lanzmann, la intérprete profesional y los testigos que hablan en múltiples idiomas; para entenderlo todo, debemos leer los subtítulos.

The incommensurability between different testimonial stances, and the heterogeneous multiplicity of specific cognitive positions of seeing and not seeing, is amplified and duplicated in the film by the multiplicity of languages in which the testimonies are delivered (French, German, Sicillian, English, Hebrew, Yiddish, Polish) [...]

Through the multiplicity of foreign tongues and the prolonged delay incurred by the translation, the splitting of eyewitnessing which the historical event seems to consist of, the incapacity of seeing to translate itself spontaneously and simultaneously into a meaning, is recapitulated on the level of the viewers of the film. ${ }^{23}$

No se utiliza la técnica del doblaje, durante el tiempo que el testigo habla con frecuencia tampoco se incluyen subtítulos, tan solo posteriormente, cuando empieza a hablar la intérprete, se añade el subtítulo. Como indica Felman, la multiplicidad del idioma (francés,

\footnotetext{
${ }^{23}$ Ibíd., p. 211-212.

La inconmensurabilidad entre los diferentes niveles de los testimonios, y la heterogénea multiplicidad de posiciones cognitivas específicas de ver y no ver, es amplificada y duplicada en la película a través de la multiplicidad de lenguas en que los testimonios se reparten (francés, alemán, siciliano, inglés, hebreo, yiddish, polaco) [...] A través de la multiplicidad de lenguas extranjeras y la prolongada demora ocasionada por la traducción, la división de perspectivas en los que el acontecimiento histórico parece consistir, la incapacidad de ver la traducción espontánea y simultánea de un significado, se recapitulan en el nivel de los espectadores de la película. [Traducción propia]
} 
alemán, siciliano, inglés, hebreo, yiddish, polaco) obliga a experimentar la escucha de varios idiomas extranjeros.

En tanto que miramos esta película, escuchamos las palabras vívidas de los testigos y reconocemos en sus gestos, en muchas ocasiones, las palabras que son desconocidas para nosotros. Para saber qué significa debemos esperar la llegada de la voz de la intérprete o las letras de los subtítulos. Esta obra nos hace experimentar repetitivamente el retraso del tiempo entre la palabra original desconocida pronunciada por el testigo y la palabra de la intérprete con sentido o las letras sin sonido. Dicho de otro modo, observamos el momento de testimonio con pathos sin saber qué significa y la llegada retrasada del sentido perdiendo el pathos.

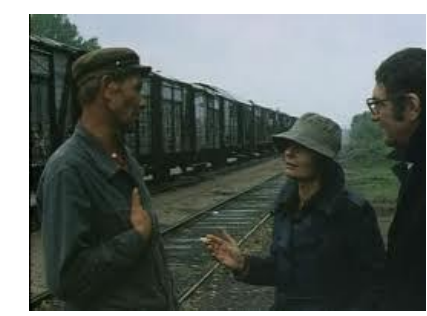

9. Entrevista con el testigo, la intérprete y el autor en Shoah (1985), Claude Lanzmann

Por otra parte, en la escena de la entrevista, algunas veces Lanzmann o el testigo corrigen a la intérprete. La intérprete es transmisora del significado de un idioma desconocido a otro conocido, pero al mismo tiempo, ella puede cometer errores o malentendidos. Sin embargo, no es por culpa de la intérprete en particular, ya que la traducción siempre lleva este tipo de problemas. La escena nos enseña uno de los elementos cruciales que conlleva la traducción: se pueden cometer errores y/o equivocaciones por parte de los intérpretes (es inevitablemente esencial en la traducción el detrimento del sentido o la deficiencia en los significados).

También nos muestra el retraso del tiempo, la diferencia entre los lenguajes, el error y la equivocación que surgen de la traducción como muestra de la desunión y la ruptura inevitable en el momento de escuchar a los testigos. Felman afirma que los testimonios de 
esta obra no se adecúan a un solo lenguaje, y que tampoco resultan perfectamente traducibles, ya que en realidad se trata de una representación de la catástrofe en sí.

El título Shoah simboliza esta catástrofe, o mejor dicho, simboliza la falta de nombre para este tipo de catástrofe. La palabra shoah en hebreo se refiere al Holocausto cuando lleva el artículo determinado, sin el artículo se refiere a catástrofe en general.

(...) Shoah, the Hebrew word which, with the definite article (here missing), designates "The Holocaust" but which, without the article, enigmatically and indefinitely means "catastrophe," here names the very foreignness of languages, the very nameless of a catastrophe which cannot be possessed by any native tongue and which, within the language of translation, can only be name as the untranslatable: that which language cannot witness; that which cannot be articulated without splitting. $^{24}$

Esta obra demuestra, por lo tanto, que no se debe ceñir a un solo lenguaje el testimonio que pretende reflejar una catástrofe. El testimonio incluye necesariamente la diferencia y la desunión de significados y el retraso del tiempo debido a la traducción, además de las contradicciones en los testimonios de los testigos de los tres grupos; cada uno de los cuales "no ve" a su manera. La imposibilidad de los testimonios es un punto de partida en la búsqueda para encontrar la relación entre el testimonio y el arte en Shoah.

Seguramente, la expresión audiovisual es un medio y una forma indispensable para poder mostrar esa imposibilidad y la catástrofe que se encuentran sobre el testimonio. La obra Shoah deja patente lo imposible del acceso directo al Holocausto en una representación del medio audiovisual, separándonos de lo real del Holocausto a través la inconexión entre los testimonios. Pero, al mismo tiempo, nos obliga a reflexionar sobre la necesidad de

\footnotetext{
${ }^{24}$ Ibíd., p. 212-213.

... Shoah, la palabra hebrea que, con el artículo determinado (en este caso inexistente), designa "El Holocausto" pero que, sin el artículo, enigmáticamente e indefinidamente significa "catástrofe", aquí nombres de lenguas extranjeras, el nombre de una catástrofe que no puede ser poseído por ninguna lengua nativa y que, en la jerga de la traducción, solo puede ser calificada como intraducible: aquello que el idioma no puede atestiguar; lo que no puede ser articulado sin dividir. [Traducción propia]
} 
enfrentarnos a ese suceso traumático. De acuerdo con la interpretación psicoanalítica de lo sublime sobre la obra de arte que hemos desarrollado en la primera parte del presente apartado, Shoah es precisamente una obra de arte.

En el próximo apartado, de acuerdo con lo observado hasta ahora, confirmaremos la capacidad de la expresión audiovisual y su carácter artístico para elevarnos a ser testigos de la catástrofe. En consonancia con el argumento de Felman, esta película documenta el viaje de Lanzmann enredado entre las diferencias culturales y políticas. Las múltiples y confusas características del filme nos posibilitan convertirnos en testigos, creando de tal modo una articulación de los fragmentos entre lo dicho y el silencio que nos puede llevar al encuentro con el "otro". 
IV.2. Viaje entre el exterior y el interior como un trayecto autobiográfico. 
En el presente apartado nos aproximamos al carácter de la obra audiovisual Shoah como documento del viaje que posibilita la articulación entre las diferencias de múltiples aspectos culturales, de acuerdo con la observación que hemos realizado en el apartado anterior. También se pretende observar la parte de la trayectoria autobiográfica del autor reflejada en la obra.

El autor de esta obra, Claude Lanzmann, busca y visita a los testigos que se encuentra en este viaje, constituye por ello el primer testigo de la obra.

I would suggest that the impossible position and the testimonial effort of the film as a whole is to be, precisely, neither simply inside nor simply outside, but paradoxically, both inside and outside: to create a connection that did not exist during the war and does not exist today between the inside and the outside -to set them both in motion and in dialogue with one another. ${ }^{I}$

El documental de Lanzmann, es el documental de un doble viaje: por una parte, un viaje personal por el exterior europeo y el interior de Israel (que representa la encarnación de lo judío, relacionado muy profundamente con la historia personal del autor); y por otra parte, un viaje de ida y vuelta hacia el exterior e interior del Holocausto.

Solo mediante el arte, y más concretamente gracias al medio audiovisual, es posible crear una articulación que no existía durante la guerra y que ahora tampoco se presenta entre el exterior y el interior, o crear el tiempo y el espacio que pueda encontrar la relación y la conexión que nunca existió y todavía no existe.

Claude Lanzmann nació en París en 1925 como hijo de inmigrantes judíos de la Europa del este. Durante la Segunda Guerra Mundial participó en la resistencia contra la ocupación

\footnotetext{
${ }^{1}$ Felman, Shoshana: The Return of the Voice: Claude Lanzmann's Shoah. En Felman, Shoshana y Laub, Dori, Testimony. Crises of witnessing in literature, psychoanalysis, and history, Nueva York y Londres, Routledge, 1992, p. 232.

Yo sugeriría que la postura imposible y el esfuerzo testimonial de la película como conjunto se basan, precisamente, en no encontrarse simplemente dentro ni simplemente fuera, pero paradójicamente, tanto dentro como fuera: con el fin de crear una conexión que no existía durante la guerra y no existe hoy entre el interior y el exterior -con el fin de establecer en movimiento y en diálogo uno y otro. [Traducción propia]
} 
Nazi alemana. Al terminar la guerra, retornó al estudio de la filosofía alemana y tras titularse viajó a Berlín para trabajar como profesor de universidad.

Durante su estancia en Berlín, logró entrar en la zona alemana del este y realizar un reportaje, siendo éste el primer reportaje sobre Berlín del Este presentado tras el bloqueo. Después de este trabajo, empieza su carrera como periodista internacional. A partir de 1952 trabaja como director de la revista Le temps modernes, fundada por Jean-Paul Sartre, Simone de Beauvoir y otros más. Desde 1974 se ocupó completamente de la producción de la película Shoah, y tardó once años en perfeccionar este documental.

Observemos uno de los comentarios sobre la carrera y el nacimiento de Lanzmann en la entrevista realizada durante su visita a la universidad de Yale para Fortunoff Video Archive of Holocaust Testimonies en 1986:

Lanzmann, disconnected both from the cultural tradition and from the history of Jews, is educated in French culture and, as a student, specializes in German philosophy. $^{2}$

Es decir, Lanzmann es un francés con conocimientos europeos que no recibe una educación especialmente judía. Tal y como hemos dicho, Lanzmann estudió la carrera de filosofía alemana y enseñó literatura y filosofía francesa en la Universidad Libre de Berlín. Durante la guerra, participó en la resistencia contra la ocupación alemana como un francés patriótico. De todas formas, se pronunció sobre la educación en los hogares de judíos antes de que estallase la guerra en Europa.

"He would ring the bell of the main entrance of the house we lived in," Lanzmann narrates, "in much the same way as the militia or the Gestapo would have done it. Jolted out of sleep, we had to break speed records -which he would time with a chronometer -to put on our clothes and take refuge in an underground hiding place

\footnotetext{
${ }^{2}$ Ibíd., p. 243.

Lanzmann, desconectado tanto de la tradición cultural como de la historia de los judios, es educado en la cultura francesa y, como estudiante, se especializa en filosofía alemana. [Traducción propia]
} 
which he had dug up in the middle of the garden... Thus our father taught us to escape perception and to remain invisible... I was not Jewish by tradition or by education, "but I think that the war as such has made me very much aware of what it is to be a Jew" (Interview). ${ }^{3}$

El padre de Lanzmann les obligaba a él y a sus hermanos a aprender cómo refugiarse dentro de la casa al sonar el timbre de la puerta principal, por supuesto, siempre por su seguridad. Ello demuestra que ni siquiera el propio hogar era un sitio seguro para los judíos de la Europa de aquel momento. No se debía ser visible, ya que al ser visible se ponía la vida en riesgo. La condición de ser judío en Europa era ocultarse en cualquier momento. Él y su familia, así como el resto de judíos, debieron mentalizarse de ello en la guerra. Estas circunstancias crean la identidad judía de Lanzmann y se convierten en el contexto fundamental de su propuesta y su acto expresivo. Por otra parte, él mismo confirma su postura frente a la teoría de Sartre $^{4}$ sobre la cuestión judía.

\begin{abstract}
After the war, Lanzmann is inspired by the philosophical work of his future friend and mentor Jean-Paul Sartre, who, in 1946, publishes his Reflexions sur la question juive. ${ }^{5}$ Lanzmann comments on the impact of this publication: [The] book ... was absolutely crucial for me ... It was something, what the greatest French writer had written ... [on the question of anti-Semitism]. This permitted us to breathe. It was a kind of reconnaissance, of acknowledgment ... The picture of the anti-Semite that Sartre gave is still exemplary today". 6
\end{abstract}

\footnotetext{
${ }^{3}$ Ibíd., p. 243.

"El tocaba el timbre de la entrada principal de la casa en la que vivíamos", narra Lanzmann, "de la misma manera que la milicia o la Gestapo lo habrían hecho. Sacudidos de nuestro sueño, teníamos que batir récords de velocidad -tiempo que él cronometraba-para ponernos la ropa y refugiarnos en un escondite subterráneo que había escavado en medio del jardín... Así pues, nuestro padre nos enseñó a escapar de la percepción y a permanecer invisibles... Yo no era judio por tradición o por educación, "pero creo que la guerra como tal me ha hecho muy consciente de lo que significa ser judio" (Entrevista). [Traducción propia]

${ }^{4}$ Sartre, Jean-Paul (1905-1980): filósofo y escritor francés, principal defensor del existencialismo en los años que siguieron a la Segunda Guerra Mundial. [Audi, Robert (ed.): Diccionario Akal de Filosofía, trad. Huberto Marraud y Enrique Alonso, Madrid, Akal, 2004, p. 865].

${ }^{5}$ El libro de Jean-Paul Sartre al cual se refiere Lanzmann es Reflexión sobre la cuestión judía Seix Barral, 2005. Barcelona.

${ }^{6}$ Felman, Shoshana, Op.cit., p. 244.

Después de la guerra, Lanzmann se inspira en el trabajo filosófico de su futuro amigo y mentor Jean-Paul Sartre, quien en 1946 publica sus Reflexiones sobre la cuestión judía*. Lanzmann comenta sobre el impacto de esta
} 
Analizaremos brevemente el libro de Sartre dadas las limitaciones espaciales para analizar con mayor precisión su obra. Según Sartre, no existe una persona o un cierto grupo de judíos que tenga su carácter específico y esencial, sino que la cultura y el estado nacional de una Europa moderna tan centrada en el cristianismo juzga y establece una imagen del "otro". Se debe excluir lo impuro y lo diferente para justificarse a sí mismo como el "sujeto". Entonces, en términos extremos, los Nazis intentaron distinguir a los judíos para exterminarlos, confiriéndoles toda la culpabilidad del mal y la contradicción del mundo. Sin embargo, en consecuencia fueron quienes realmente fundaron al judío moderno.

Consideramos que este argumento de Sartre está relacionado con el argumento de Simone de Beauvoir $^{7}$ (1908-1986) en El Segundo Sexo: ${ }^{8}$ no se nace mujer, se llega a serlo. Es decir, ser judío o ser mujer no es una particularidad esencial desde el momento en que se nace, sino que se establece mediante la estructura social y la educación. En otras palabras, el judío y la mujer no han decidido su identidad, más bien configuran sus realidades como judío o como miembro perteneciente al sexo femenino debido a condiciones impuestas externamente.

El argumento de Sartre sobre la cuestión judía será posteriormente criticado por Hannah Arendt $^{9}$ y otros autores, pero todavía mantiene un poder persuasivo que nos ayuda a comprender la estructura del antisemitismo y la segregación de los judíos adaptados dentro de Europa (como Lanzmann). La causa por la cual el judío es «invisible» o «no debe ser visible» es porque el antisemita obsesionado los persigue, y la causa de su obsesión no se encuentra en realidad en lo judío. Desde un principio, consideran lo judío como la causa del peligro, pero en verdad esto es un propio invento del antisemitismo.

publicación: [El] libro... fue absolutamente crucial para mí... Fue algo sobre lo que el mejor escritor francés había escrito... [sobre la cuestión del antisemitismo]. Nos permitió respirar. Era una especie de reconocimiento, de conocimiento... La imagen del antisemita ofrecida por Sartre sigue siendo ejemplar hoy todavía”. [Traducción propia]

${ }^{7}$ Simone de Beauvoir (1908-1986): escritora francesa, crítica. [Hiromatsu Wataru (et. ál.): Iwanami Tetsugaku shisou jiten [Diccionario Iwanami del filosofía pensamiento], Tokyo, Ianami, 1998, p. 1471. Traducción propia]

${ }^{8}$ Beauvoir, Simone de, Le Deuxième Sexe (1949), El segundo sexo, Madrid, Cátedra, 2005.

${ }^{9}$ Hannah Arendt (1906-1975): pensadora política nacida en Alemania que desplegó gran actividad en EE.UU. después de la Segunda Guerra Mundial. [Hiromatsu Wataru (et. ál.): Iwanami Tetsugaku shisou jiten [Diccionario Iwanami del filosofía pensamiento], Op.cit., p. 49. Traducción propia] 
Lanzmann piensa que a partir de esta obra de Sartre se descubre la estructura del antisemitismo en Europa, se obtiene el reconocimiento y la visibilidad del problema judío. No obstante, Felman indica que este reconocimiento fue solo desde fuera (por parte de los intelectuales de Europa no judíos).

Via Sartre, the acknowledgment (reconnaissance) of the Jewish question can remain, however, an external -as opposed to an internal -recognition, the acknowledgment from the outside of the reality of anti-Semitism but, by the same token, only of the mythic fictionality of the Jew, of the unreal negativity of Judaism in the anti-Semite's fiction. ${ }^{10}$

A través Sartre, el reconocimiento de la cuestión judía puede permanecer abordado "desde fuera" y no "desde dentro". Es decir, desde la parte del sujeto europeo basado en la ficción negativa que intenta excluir al judío y trata a lo judío como lo "otro". Este raciocinio tiende a crear dos tipos de perspectivas opuestas sobre la cuestión judía de una manera claramente contradictoria.

En primer lugar, el judío es un invento ficticio del antisemitismo, de modo que no existe el judío como tal. Se invisibiliza al judío y a su propia esencialidad. En cierto sentido, la perspectiva incluso se convierte en una negación total de su existencia. En segundo lugar, precisamente esta postura que niega totalmente su identidad provoca la aparición del fundamentalismo radical o del esencialismo exclusivo que pone énfasis en lo particular del judío y en lo propiamente judío.

Este esquema ya lo estudiamos gracias a las indicaciones de Spivak. Su caso se basaba en los británicos dominantes como sujeto y los hindúes como la parte dominada que reclamaba su identidad con una reacción fundamentalista ${ }^{11}$. En el caso analizado por Spivak era aún

\footnotetext{
${ }^{10}$ Felman, Shoshana, Op.cit., p. 244.

A través de Sartre, sin embargo, el reconocimiento (reconnaissance) de la cuestión judía puede permanecer como externo -en contraposición al reconocimiento interno-, el reconocimiento desde el exterior de la realidad del antisemitismo, pero del mismo modo, se reconoce solo la mítica ficción del judío, la negatividad irreal del judaísmo propio de la ficción antisemita. [Traducción propia]

${ }^{11}$ Véase al capítulo II.
} 
más clara la división entre la Europa interior y la India exterior debido a las dimensiones geográficas. Sin embargo, este esquema también es aplicable dentro de Europa en el caso de la cuestión judía y la cuestión antisemita.

Esta función dicotómica -en la que además uno se superpone al "otro"- funciona para buscar un chivo expiatorio. Dicho de otro modo, la idea de Europa no indica en sí algo configurado como una unión sólida, quizá solo simboliza una ilusión de unidad ideal pura que no existe y jamás existirá. Más bien al contrario, se requiere contar con el “otro" para mantener esa ilusión, buscando las diferencias.

El esquema, como veíamos anteriormente, de estas dos ideas divididas en forma dicotómica no presenta espacio para la reconciliación, se perpetuaría así la lucha y el ataque de uno a otro. De este modo, se mantiene la relación combativa y la situación opuesta en la, sin embargo, uno y otro se complementan estructuralmente. Con posterioridad, Lanzmann transmitiría una duda sobre el reconocimiento "desde fuera", la idea de Sartre de que la identidad del judío se construye a consecuencia del invento del sujeto europeo.

Ya vimos que durante su estancia en Berlín Lanzmann presentó un reportaje entrando clandestinamente en el lado Este del bloque alemán. Este trabajo fue su primer trabajo como periodista. En este primer viaje, él encuentra la diferencia decisiva y la comprensión de lo judío gracias a la lectura de Sartre.

I went to Israel for the first time in 1952 and it was a real shock for me to discover that there was a real Jewish world, to discover, let us say, the Jewish positivity ... I had many debates with Israelis, because I say, it according to Sartre, [and thought] that the Jew was a pure creation of the anti-Semite ... I discovered that this was not true ... (Interview) ${ }^{12}$

\footnotetext{
${ }^{12}$ Ibíd., p. 247.

Fui a Israel por primera vez en 1952 y fue un verdadero shock para mí descubrir que existe un verdadero mundo judio, descubrir, digamos, el positivismo judio... Mantuve muchos debates con los israelíes, porque yo digo ly pienso], de acuerdo con Sartre, que el judio fue una pura creación del antisemita... Descubrí que esto no era cierto... (Entrevista). [Traducción propia]
} 
Por su parte, Felman considera que el viaje de Lanzmann desde Francia y Alemania hasta Israel, es el viaje que logra articular lo exterior e interior con su historia personal, lo cual constituye el factor fundamental y definitivo para la producción de Shoah.

After the war, Lanzmann undertakes a series of successive travels, a series of negotiations of the inside and the outside, whose combination constitutes, I would suggest, the itinerary of an existential search whose destination, a priori, is unknown and that will eventually lead him to the inside of the film, and to the film as the locus of a true discovery of the inside. ${ }^{13}$

Lanzmann intentó escribir un reportaje durante los cuatro meses de estancia en Israel, pero fracasó. Felman considera que el fracaso de Lanzmann se debe a que él ya no podía considerarse un "forastero" en Israel, diferente al caso en Alemania y otros sitios donde escribía desde la condición de extraño.

In other words, Lanzmann discovers that he can no longer simply write as an outsider, simply testify from the outside. ${ }^{14}$

Francamente, como forastero que visita el exterior -un mundo mítico y extraño- se puede escribir cualquier cosa, escapando de las responsabilidades de lo que allí ocurre. Así, a Lanzmann le resulta más sencillo escribir sobre el "otro" a la ligera desde el exterior. Sin embargo, una vez se conciencia de encontrarse en el interior, se le hace difícil escribir porque ya no disfruta de la distancia que le protegía y le facilitaba las simples comparaciones, además de que surge una cierta responsabilidad. Lanzmann consideró que el medio del reportaje periodístico no era adecuado para la expresión y comprensión de la cuestión judía. Le pareció que la reflexión sobre lo judío era más bien un tema filosófico,

\footnotetext{
${ }^{13}$ Ibíd., p. 244.

Después de la guerra, Lanzmann emprende una serie de viajes sucesivos, una serie de negociaciones entre lo interior y lo exterior, cuya combinación constituye, me permito sugerir, el itinerario de una búsqueda existencial y cuya destinación, a priori, se desconoce, pero que eventualmente le conduce al interior de la película, y a la película como el lugar de un verdadero descubrimiento del interior. [Traducción propia]

${ }^{14}$ Ibíd., p. 248.

En otras palabras, Lanzmann descubre que ya no puede simplemente escribir como un extraño, simplemente testificar desde el exterior. [Traducción propia]
} 
por ello, comenzó a escribir un libro. No obstante, otra vez fracasó (tras escribir alrededor de cien páginas lo dejó, abandonando el intento de escribir).

Suponemos que Lanzmann no encontró útil el lenguaje escrito en forma de reportaje ni tampoco el lenguaje filosófico a la hora de hablar sobre el encuentro con el interior judío. En este sentido, la escritura que ha aprendido Lanzmann no es adecuada para expresar lo que observa, ni en francés, ni en alemán, quizá tampoco en inglés. Como consecuencia, Lanzmann renuncia a escribir y elige la expresión audiovisual. Esta elección de Lanzmann y la imposibilidad de traducción de la cultura del "otro" a un lenguaje moderno están relacionadas con la codificación que señalaba Spivak $^{15}$. Para mantener el pathos que ha encontrado en el interior, Lanzmann debía evitar la expresión escrita. Felman menciona esa imposibilidad de escribir en su caso, y la posible expresión en medios audiovisuales. Tras veinte años, Lanzmann concluye su primera película. ¿Por qué Israel?

A través del encuentro con lo judío como algo fundamental en Israel, y al adentrarse en un interior de la cuestión judía que no existía para el exterior europeo, Lanzmann percibe la nulidad del reconocimiento desde fuera, así como lo hiciera Sartre ("no existe el judío"). De la misma manera, se dio cuenta de la imposibilidad de escribir sobre el interior desde el exterior.

The impossibility which Israel embodies for Lanzmann, first in the actual impossibility of writing and later in the very possibility of film as a testimony to and an inscription to -that same impossibility, is, I would suggest, the impossibility, on the one hand, of saying the inside from the outside, and, on the other hand, the imperative necessity of speaking from inside to the outside; the contradictory and yet compellingly intransigent necessity of being outside and inside at the same time. $^{16}$

\footnotetext{
${ }^{15}$ Véase al capítulo III., sobre todo el problema de codificación del relato del “otro”, en III.1.1.

${ }^{16}$ Ibíd., p.248-249.

La imposibilidad que encarna Israel para Lanzmann, primero en la evidente imposibilidad de escribir y más adelante en la posibilidad misma de la película como testimonio - y una inscripción- de la misma imposibilidad; es decir, me permito mencionar la imposibilidad, por un lado, de hablar del interior desde el exterior, y, por otro
} 
Tres factores fundamentales establecen el punto de partida de la expresión fílmica de Lanzmann: encontrarse en el exterior y/o en el interior, cumplir con la necesidad de relatar desde el interior hacia el exterior, y la imposibilidad de escribir (con la posibilidad de superación gracias al medio audiovisual). Lanzmann pretende romper con la concepción del judío como una existencia que se refleja solo debido a la ficción antisemita, existencia destinada además a ser excluida por el sujeto europeo. La existencia del "otro", al fin y al cabo, permanecería así negada desde el punto de vista europeo.

No obstante, el intento de hablar desde el interior del "otro" al sujeto europeo exterior conlleva obligaciones confusas y condiciones contradictorias. En un esquema fácilmente comprensible para el sujeto europeo se debería hablar en el lenguaje del sujeto; sin embargo, para poder expresarse desde el interior del "otro" es necesario hablar en su lenguaje propio.

\section{To testify from inside Otherness in thus to bear witness from inside the living pathos}

of tongue which nonetheless is bound to be heard as mere noise. ${ }^{17}$

Así pues, el relato del "otro" que emerge desde su interior difiere del lenguaje y la estructura pensativa del sujeto europeo, tal y como indica Felman. Aunque las palabras pronunciadas se constituyan como un grito del alma, pueden llegar al sujeto como un mero ruido o murmullo, el sujeto no reconocerá su significado. Es necesaria y urgente la intervención de un traductor para que se consiga una comprensión razonable (o alguna otra articulación significativa entre el que pronuncia y el que oye).

En cierto sentido, Lanzmann asume -desde el mismo punto de partida- la importancia del traductor. Adentrarse desde el exterior al interior y mostrar la voz del interior al exterior es significativo. Entonces, debe permanecer en el exterior conociendo su manera de comprender y los significados de las palabras; pero, al mismo tiempo, debe permanecer en

lado, la imperiosa necesidad de hablar desde el interior hacia el exterior, la contradictoria y, sin embargo, intransigente e interesante necesidad de ser exterior e interior al mismo tiempo. [Traducción propia]

${ }^{17}$ Ibíd., p. 231.

Testificar desde el interior de la Otredad, por tanto, ofreciendo testimonio de vida desde el interior del pathos en una lengua que, no obstante, está destinada a ser escuchada como simple ruido. [Traducción propia] 
el interior y reflejar la voz del interior como un mensaje que adquiera significado para el sujeto.

En este proceso se debe considerar un asunto clave: siempre se correrá el riesgo de eliminar aquello que sobrepase la comprensión por parte del sujeto. Como se ha visto en Shoah, la traducción siempre asume una parte de exceso y/o de falta de significado, no se puede negar el carácter contradictorio y la dificultad de la traducción. Y, además, resulta especialmente difícil encontrarse en el exterior y en el interior simultáneamente cuando se trata del Holocausto.

\begin{abstract}
When I started to work on Shoah ... I was like many Jews, I thought I knew: I thought I had this in my blood, which is a stupidity ... When I read Hilberg, for instance, I discovered that in spite of the fact that I had read already many books, I was perfectly ignorant. [Interview, p. 16]

Lanzmann discovers, thus, the way in which the Jews themselves are also mere outsiders to their own history -to their own Holocaust. ${ }^{18}$
\end{abstract}

La conciencia de forastero de Lanzmann se establece al reconocer su ignorancia sobre el interior del Holocausto, aún siendo éste una parte fundamental de su historia como judío. Se conciencia así de su viaje desde el exterior al interior y Shoah empieza a tomar forma.

\title{
IV.2.1. Un viajero como testigo.
}

Anteriormente, hemos afirmado que Lanzmann es única persona que testifica en primera persona y que no hay nadie que cumpla los requisitos para ser testigo en esta obra. Sin embargo, para ser precisos tenemos que corregir esta consideración: existe una persona más que testifica hablando en primera persona, Jan Karski. Él es testigo del momento en que

\footnotetext{
${ }^{18}$ Ibíd., p.252.

Cuando empecé a trabajar en "Shoah"... yo era como muchos judíos, pensaba que sabía: yo pensaba que lo llevaba en mi sangre, lo que es una estupidez... Cuando lei a Hilberg, por ejemplo, descubrí que a pesar de que había leído ya muchos libros, era un completo ignorante. [Entrevista, p. 16] Lanzmann descubre, por lo tanto, la forma en que los judios también son meros extraños a su propia historia -a su propio Holocausto. [Traducción propia]
} 
ocurrían los sucesos. Felman analiza y compara el viaje personal a través de lo judío de Lanzmann (desde Europa como lo exterior, hacia Israel como lo interior) con el viaje de Karski desde el exterior hacia el interior del gueto.

Karski es un hombre polaco que se encargó de informar de la persecución a los judíos debido a sus bases políticas. Él aceptó la petición de un judío, viajó desde el exterior (en este caso, el mundo de los polacos ignorantes de la situación de los judíos) al interior del gueto de los judíos sojuzgados por los Nazis.

Este viaje tenía por objeto presentar públicamente la información y las denuncias recabadas entre los judíos del gueto al exterior, así como transmitirlas a los líderes de los países aliados que procuraban derribar a los Nazis alemanes.

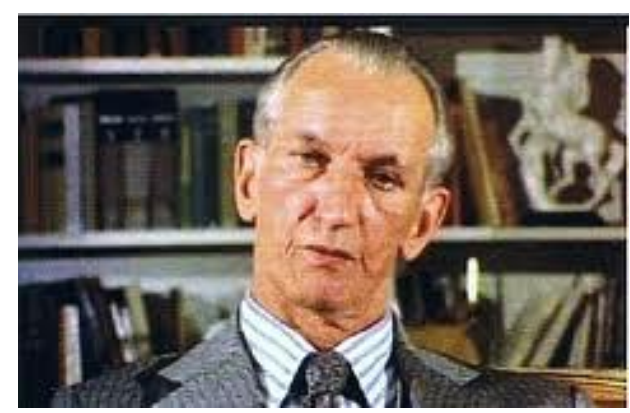

10. Jan Karski en Shoah (1985), Claude Lanzmann

Al principio, él entrevistó a dos líderes judíos y mantuvo una simpatía enorme hacia uno de ellos, «el líder de la Bund ${ }^{19} »$. Karski explica que las razones de esta simpatía eran su gesto como líder, su dignidad aristócrata, su aire de nobleza polaca como caballero culto. Felman apunta a una difícil y contradictoria condición en la amistad con el "otro".

Ironically and paradoxically in a story of the encounter with an Other, Karski gets to like the Bund leader precisely because of his non-Jewish, Polish (aristocratic) air. He can love the Jew because he recognizes in him something humanly familiar

\footnotetext{
${ }^{19}$ Bund: Una asociación de los judíos trabajadores socialistas que se estableció en Rusia en 1897.
} 
("somehow this belong to human relations"), because he sees in him, initially, not the Other but (safely) the Same. In the very movement of his sympathy, Karski can thus take the Jew, ironically, outside of Jewishness and bring him into his own world of the Polish nobleman, as an imaginary double, a companion or a brother. ${ }^{20}$

No dudamos de la voluntad humana de Karski, pero esta simpatía le hace adoptar una dicción variante, en parte debida al carácter de semejanza del noble consigo mismo. En esta relación, el "otro" (el judío) permanece como alguien diferente que no genera simpatía, irónica y paradójicamente. Karski decide acudir al interior del gueto tras la súplica del líder judío que en principio parecía un noble aristócrata polaco, y no un judío. Atravesando un túnel, Karski entra con él al interior del gueto y visualiza la transformación de su acompañante de noble polaco a judío del gueto, y testifica su perplejidad como citamos a continuación:

Debajo del edificio, un túnel. Lo atravesamos sin la menor dificultad. Pero, de repente, jél era otro hombre! El líder del Bund, el aristócrata polaco. Me encuentro a su lado. El está herido, inclinado como un judío del gueto, como si hubiera vivido allí siempre. Aparentemente, ésa era su naturaleza, aquél era su mundo. Así caminamos por las calles... ${ }^{21}$

La persona por la cual él sentía esa simpatía mostró su verdadera naturaleza como el "otro" alejado, solo al atravesar un túnel. Este viaje de dos personas del exterior al interior del gueto nos estremece al límite, pero la línea de demarcación entre lo exterior y lo interior para nosotros y para ellos es en realidad la misma. Lo que vio y testifica Karski trata sobre el mundo del "otro", donde lo humano no tiene cabida:

\footnotetext{
${ }^{20}$ Ibíd., p. 234.

Irónicamente y paradójicamente, en la historia del encuentro con el Otro, a Karski llega a caerle en gracia el líder del Bund precisamente por su aire de no-judío, sino polaco aristócrata. El siente afecto por el judío porque reconoce en él algo humanamente familiar ("de alguna forma esto pertenece a las relaciones humanas"), porque ve en él, inicialmente (y para su seguridad), no al Otro, sino al semejante. (En su simpatía, Karski puede llevar al judio, irónicamente, fuera del judaísmo y traerlo con él a su propio mundo de polacos nobles, como una pareja imaginaria, un compañero o un hermano. [Traducción propia]

${ }^{21}$ Lanzmann, Claude: Shoha, trad. Federico de Carlos Otto, Madrid, Arena Libros, 2003, p. 181. [También en: Felman, Shoshana, Op.cit, p. 235.]
} 
Aquello no era un mundo. Aquello no era la Humanidad. Las calles llenas. Llenas... Los niños horribles... Eso no era la Humanidad. Era una especie de... de infierno. ... Entonces, los alemanes de uniforme, se acercan... iSilencio! Todos paralizados por el miedo a su paso. Los alemanes: ¡desprecio! Evidentemente, aquí están estos sucios infrahumanos. No son seres humanos.

De repente, el pánico. Los judíos huyen de la calle en la que me encuentro. Saltamos a una casa. Él murmura: “iLa puerta! ¡Abre la puerta! ;Abre!” Se abre. Entramos... Él le dice: “¡No tengas miedo, somos judios!” Me empuja hacia la ventana:

“¡Mire, mire!” Estaban ahi dos chicos. Rostros agradables, juventudes hitlerianas, de uniforme. Desfilaban. A cada paso que daban, los judios desaparecían, huían... De golpe, uno de ellos se lleva la mano a su bolsillo, sin pensárselo dos veces. ¡Disparos! Ruido de vasos rotos. El otro le felicita. Ellos regresan. Yo estaba petrificado. Entonces, la mujer judía-indudablemente se había dado cuenta de que yo no era judio- me abrazó: "Márchese, márchese, esto no es para usted. Márchese”. Abandonamos la casa. Abandonamos el gueto. ${ }^{22}$

Los judíos huyen por miedo a los dos chicos de rostros agradables, quienes están orgullosos de sí mismos por amenazarlos violentamente. Frente a esta realidad cotidiana del gueto, no solo Karski se quedará perplejo. Él comprobó que, en el interior, los judíos no eran tratados como humanos. Encerrados en el terror y la humillación, la pobreza y la amenaza violenta -tanto física como mental-, fueron tratados como animales. Felman interpreta la experiencia de Karski como un forastero especial que se encuentra en el interior.

Under the protection - but also in the very skin- of his Jewish alter ego ("we are Jews"), Karski, in observing and recording what it means to be the Other, in effect experience what it means to be inside the Holocaust, as well as what it feels, specifically, to be an inside of the ghetto. It is ironic that it is precisely Jewish empathy that has to send him back outside, back to the relief of the outsider, so as to

\footnotetext{
${ }^{22}$ Ibíd. p. 181. [También en: Felman. Felman, Shoshana, Op.cit. p. 236.]
} 
prevent his torture and to spare him this particular insidedness of its own humiliation. $^{23}$

Según Felman, Karski logra observar lo que significa ser el "otro" en una situación arriesgada en el gueto, con la protección del álter ego del judío líder del Bund. Esta empatía generada sirve para poder negociar con el exterior, y Karski está destinado a testificar en el exterior lo que ha comprobado en el interior. Él sale del gueto como si se tratase del infierno (gracias a la persuasión de una compasiva judía). Sin embargo, su acompañante el líder judío le convence y regresa de nuevo al gueto al día siguiente.

Según la explicación de Felman, esta segunda visita no era necesaria para la misión pública de Karski, ya que la primera visita había sido suficiente para el informe en calidad de testigo. Además, con la primera experiencia, Karski ya era consciente del riesgo que corría en ese cambio entre el exterior y el interior. A pesar de ello, Karski acepta y realiza la segunda visita. Felman compara su segundo viaje con el viaje de Orfeo al otro mundo, buscando la razón en la intimidad de la amistad que Karski ha trabado con su acompañante judío (como el "otro" alejado, pero, al mismo tiempo, como un personaje atractivo). Indica la importancia de este factor para el futuro testimonio de Karski:

I would argue that the most significant element of Karski's testimony is precisely this gratuitous return to the ghetto -this Orphic repetition of spectral visit. Karski is persuaded to accomplish this return from inside the very intimacy of the singular friendship -of the singular companionship of his estranging and compelling host. I would thus suggest that this visit to the ghetto is nothing less, indeed, than the retracing of a journey equal to an oath of love. In repeating his descent to hell ("This was not a world ... It was some ... some hell”), Karski makes a gift to his companion of his fear, of his attention, of his memory, of his emphatic suffering, of

\footnotetext{
${ }^{23}$ Felman, Shoshana, Op.cit., p. 236.

Bajo la protección -pero también en la propia piel- de su álter ego judío ("somos Judíos"), Karski observa y registra lo que significa ser el Otro; en efecto, experimenta lo que significa estar en el interior del Holocausto, asi como lo que se siente, en concreto, al estar en el interior de un gueto. Es irónico que sea precisamente la empatía con un judio la que lo envía de vuelta a fuera, de vuelta a la seguridad de lo exterior, a fin de prevenir su tortura y liberarlo de su particular y propia humillación. [Traducción propia]
} 
his discipleship in trauma, and of the oath of faithfulness precisely to his witness of the pledged promise of his future testimony. ${ }^{24}$

Felman interpreta que la razón de este retorno es la relación afectiva entre los dos hombres. La vuelta al infierno interior es una demostración de su honestidad con lo que ha visto y la promesa de testificación en el futuro. Karski dice que en la segunda visita fue por el mismo camino, y que se acostumbró a la situación un poco más que la primera vez, así que pudo apreciar más cosas. A veces vio, por indicación del acompañante, a los judíos de pie que permanecían inmóviles a punto de morir. El judío acompañante repetía a Karski que mirara, le rogaba no olvidar y transmitir lo que había presenciado al mundo exterior.

\begin{abstract}
(...) ¡Dígalo allá fuera! Usted lo ha visto. « ¡No lo olvide! » Caminamos. iEs macabro! De vez en cuando, él murmuraba: «Recuerde usted todo esto, recuerde todo esto» (...) Muchas veces, yo le preguntaba: «¿Qué les pasa?»Su respuesta: «Se mueren». Y siempre: «Acuérdese, acuérdese». Estuvimos, tal vez, una hora. $Y$ regresamos. Yo ya no podía más. «Sáqueme de aquí» Nunca le he vuelto a ver. Yo estaba enfermo. Yo no (...) Incluso, ahora, no quiero (...) Comprendo lo que usted hace. Yo estoy aquí. No vuelvo a mis recuerdos (...) Y nos marchamos. Él me abrazó. «Buena suerte. -Buena suerte». Nunca más le he vuelto a ver. ${ }^{25}$
\end{abstract}

Tras mostrarle muchos casos de la realidad del interior, el líder sacó de gueto a Karski que ya no aguantaba más, se despidió y volvió al gueto. Karski nunca volvió a verlo y se sintió muy mal. Y esa sensación todavía sigue hasta ahora.

\footnotetext{
${ }^{24}$ Ibíd., pp. 236-237.

Yo diría que el elemento más significativo del testimonio de Karski es precisamente su retorno voluntario al gueto - esta órfica repetición de una visita espectral. Karski se convence de llevar a cabo este regreso desde el mismo interior de la propia intimidad de esa singular amistad -de la singular compañía de su alienado y persuasivo anfitrión-. Por lo tanto, sugiero que esta visita al gueto no es, ni más ni menos, de hecho, el retorno de un viaje equivalente a un juramento de amor. En la repetición de su descenso al infierno ("Este no es un mundo... es algo... algo como el infierno"), Karski regala a su compañero su miedo, su atención, su memoria, su sufrimiento empático, su apoyo en el trauma, y la promesa de la fidelidad precisamente de su testimonio -una promesa garantizada de su futuro testi,monio. [Traducción propia]

${ }^{25}$ Lanzmann, Claude, Op.cit. pp. 185-186. [También en: Felman, Shoshana, Op.cit., p. 237.]
} 
"Comprendo lo que usted hace": esta frase se refiere el trabajo de Lanzmann (filmar el testimonio en la película). El trabajo incluye exigir a Karski que testifique y recuerde la memoria del horror, significa revivir el pasado. Karski dice que entiende la importancia del trabajo, debe testificar sobre el interior del gueto al exterior. Y al decir "Yo estoy aquí. No vuelvo a mis recuerdos...", animándose a sí mismo, intenta seguir testificando. Sin embargo, su testimonio finaliza de repente, inesperadamente, con la pérdida irrecuperable de una parte del relato porque algo le impide concluir su testimonio. Felman indica que comparte el mismo carácter del resto de testimonios de los supervivientes del Holocausto.

Like the testimony of the Holocaust survivors, Karski's testimony ends with the abruptness of an irrecuperable loss ...

This final loss and final sentence is, however, also, at the same time, Karski's indirect way of explaining why, historically, once his mission failed and caught within the paradoxes of his own ongoing history, in the end he had no choice but to

\section{leave the Jew behind.}

We are humans. Do you understand it? Do you understand it? [169]

It was not a world. There was not humanity ... It was not a world. It was not a part of humanity. I was not part of it. [172] ${ }^{26}$

Karski, desde el principio, tenía su papel definido como testigo para el exterior, pero se enfrentó a la siniestra escena del interior del gueto. Él no pudo escoger otra opción más que dejar a los judíos morir. Los judíos murieron en condiciones inhumanas. Él, como humano, volvió al mundo "humano" para testificar. Karski logró salir del interior, llegar a los países aliados y testificar.

\footnotetext{
${ }^{26}$ Felman, Shoshana, Op.cit., pp. 237-238.

Al igual que el testimonio de los supervivientes del Holocausto, el testimonio de Karski termina abruptamente con la pérdida irrecuperable... Esta última pérdida y última frase es, sin embargo, también, al mismo tiempo, la manera indirecta de Karski de explicar por qué, históricamente, una vez su misión fallida y no capturado en las paradojas de su propia historia en curso, al final no tuvo más remedio que dejar al judio atrás. [Traducción propia] Somos humanos. ¿Lo comprende usted? ¿Lo comprende usted? [Lanzmann, Claude, Op.cit., p. 177.] Aquello no era un mundo. Aquello no era la Humanidad ... Eso no era un mundo. Aquello no era la Humanidad. Yo no era de los suyos. No pertenecía a aquello. [Lanzmann, Claude, Op.cit., pp. 182, 186.]
} 
Sin embargo, el testimonio de Karski fue ocultado y negado por los gobiernos de los países aliados. Fue tratado con desconfianza en la esfera pública. Él no pudo obtener la respuesta política que esperaban: fracasó al transmitir el interior del Holocausto, al menos desde un punto de vista político. También constituye un claro ejemplo de asesinato de la memoria traumática. Aquí se demuestra la complicidad de ocultar la realidad del "otro" por parte de las naciones aliadas (aunque acusaban y siguen acusando el crimen Nazi, denunciando su ilegitimidad y sus injusticias, no prestaron la suficiente atención al exterminio). Y Karski, como testigo superviviente del gueto traumático, permanece en silencio.

Felman, citando su testimonio, denuncia esta realidad (el hecho de que Karski se haya quedado en silencio durante muchos años). Él, quien viajó desde el tranquilo exterior hacia el interior traumático y de nuevo al exterior para testificar, atravesando los límites, la línea de demarcación y sus fronteras.

The prisoner of his own oath of speaking, Karski thus becomes, unlike the Jew but also, paradoxically, like him, as yet another bearer of the silence:

Now... Now I go back thirty years. No, I don't go back... In thirty-five years after the war I do not go back. I have been a teacher for twenty-six years. I never mention the Jewish problem to my students. [167] $]^{27}$

En este documental, quien hace romper el silencio de Karski es Lanzmann. Según Felman, la testificación del interior al exterior de Karski fracasó políticamente, pero Lanzmann intenta recuperarla y lo logra a través del arte.

On the other hand, Lanzmann at the same time is himself, like Karski, fundamentally a courier, and perhaps in turn, of necessity, also something like an underground courier: not only the bearer of the silence but, like Karski in this diplomatic mission, the very bearer of a message which he has to bring, precisely, from the very

\footnotetext{
${ }^{27}$ Ibíd., p. 238.

Prisionero de su propio juramento, Karski se convierte así -a diferencia del judío, pero también paradójicamente como él-, en otro portador del silencio: [Traducción propia] Ahora ... yo vuelvo treinta años hacia atrás... No, no vuelvo... En treinta y cinco años dese la guerra no vuelvo hacia atrás... Durante veintiséis años he sido profesor, jamás he hablado del problema judío a mis estudiantes. [Lanzmann, Claude, Op.cit., pp. 174-175.]
} 
voicelessness and silence of the inside to the outside. While Karski failed, however, to communicate effectively the inside outcry of the ghetto to the outside world, Lanzmann hopes, by means of the resources of his art, to have an impact on the outside from the inside, to literally move the viewers and to actually reach the addressees: to make -historically and ethically - a difference. ${ }^{28}$

Lanzmann, al igual que Karski, es un mensajero del interior al exterior, y nos invita al viaje con el objetivo de penetrar los límites. Mediante el poder del arte, él intenta impactar a los espectadores, trasladándoles desde el interior al exterior y viceversa, a través de la escucha y el encuentro con Karski. El esfuerzo de Karski por intentar testificar lo que es tan difícil y dado que ya fracasó, su representación en el medio audiovisual (con la capacidad de transmitir el pathos de la experiencia), al mismo tiempo que la desconexión entre el interior y el exterior, se convirtieron en las paradójicas estrategias de Lanzmann. A nosotros, situados en el exterior del Holocausto, la película nos invita a un viaje al interior y de vuelta al exterior. Somos visitantes ignorantes, como Karski. Lanzmann es el judío acompañante que se refleja en nosotros, nos enseña a ver el interior a través de ese túnel y nos exige que seamos testigos.

Seguramente, la estrategia y el método de Lanzmann no son sencillos. Los que vieron el interior del Holocausto como Karski y otros supervivientes guardan silencio y eso provoca una pérdida en su vida posterior. El interior es un mundo dominado por la muerte y el horror sublime, permanecer en el interior significa estar rodeado de un terror que sobrepasa la imaginación y la comprensión humanas. Para sobrevivir, es necesario convertirse en un ser insensible y quedarse en silencio. Y este silencio es una parte de la realidad del Holocausto.

\footnotetext{
${ }^{28}$ Ibíd., pp. 238-239.

Por otra parte, Lanzmann, al mismo tiempo, es como Karski, básicamente un mensajero, y quizás a su vez, por necesidad, también algo así como un mensajero subterráneo: no solo el portador del silencio, sino, como Karski en su misión diplomática, el portador de un mensaje que tiene que exponer, precisamente, desde la voz mermada y el silencio del interior al exterior. Mientras que Karski no pudo, sin embargo, manifestar de manera efectiva la protesta clamorosa del interior del gueto al mundo exterior, Lanzmann espera, por medio de recursos artísticos, tener un impacto desde el interior al exterior, para conmover literalmente a los espectadores, y llegar a los destinatarios: conseguir-histórica y éticamente- una diferencia. [Traducción propia]
} 
Lanzmann estructura su método basándose en este silencio sobre el Holocausto como el tema principal de la película. Intenta visibilizar el silencio. Es una manera de resistir contra el olvido de la historia. De algún modo, los documentales participan en el olvido al anular este silencio y ocultan así la realidad del Holocausto -para Lanzmann aquí se incluirían todas las representaciones sobre el Holocausto, excepto Shoah-.

\section{IV.2.2. El límite ético de la representación.}

A partir de ahora, nos centraremos en la crítica de Lanzmann sobre las cuestiones de la complicidad con la ignorancia y la ocultación del silencio en la representación del Holocausto. Como hemos visto, silencio e invisibilidad se convierten en partes fundamentales de la realidad del Holocausto. Por esta razón, se deben representar, ya que solo así se puede hacer referencia a esa imposibilidad de conocimiento profundo (poder oír o ver lo que ocurría realmente en el interior), sin ignorar el hecho del Holocausto en sí.

En este sentido, según Lanzmann, Shoah -como obra audiovisual que logra representar el Holocausto- es única. Su argumento se basa en la polémica como cuestión fundamental en cuanto a representación contemporánea. Compararemos los detalles tomando como ejemplo la película Nuit et brouillard, de Alain Resnais ${ }^{29}$, para poder comprender mejor el método de Lanzmann.

Nuestra aproximación toma como punto de partida el uso de las imágenes históricas de archivos; sobre todo, la imagen del cadáver despedazado y las masacres del Holocausto que muestran directamente la muerte humana en la representación audiovisual. Existen algunas críticas y discusiones sobre la «representación del cadáver destrozado» en el documental. Por ejemplo, encontramos un profundo debate sobre la reducción del impacto y el horror.

\footnotetext{
${ }^{29}$ Alain Resnais (1922, Vannes, Francia), se gana una buena reputación con los cortometrajes comerciales: Van Gogh (1948), Gauguin (1950), Guernica (1950), Les statues muerent aussi (1953), Nuit et brouillard (1955) sobre los campos de concentración nazis-, Toute la mémoire du monde (1955). El éxito del movimiento denominado Nouvelle vague le permite pasar al largo con Hiroshima, mi amor (Hiroshima, mon amour, 1959), sobre un bello texto de la novelista Marguerite Duras, donde consigue la perfecta mezcla entre ficción, documental y literatura que busca. [Martínez Torres, Augusto, Diccionario de directores de cine, Madrid: Ediciones del Prado. 1992, p. 225]
} 

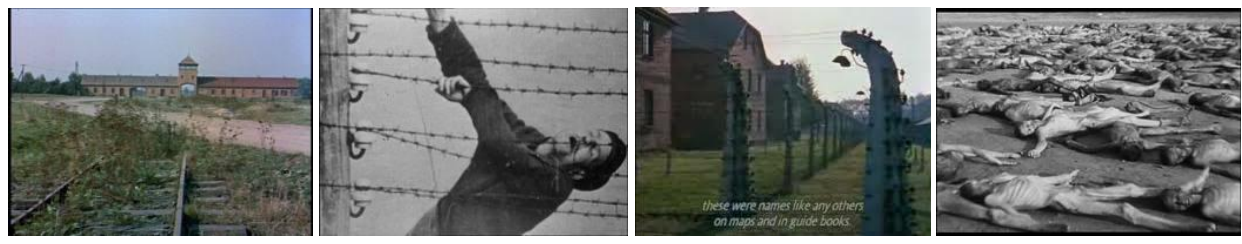

11. Nuit et brouillard (1955), Alain Resnais

En Nuit et brouillard, de Alain Resnais, aparece una imagen de unas cabezas recién cortadas en una vasija, o una escena de miles de cadáveres en los huesos empujados por una retroexcavadora, y otras más que representan miles de cadáveres deshumanizados. Ya resulta impresionante solo el hecho de hablar sobre este tipo de imágenes.

Estas imágenes son bastante chocantes; aun así, la música que ambienta la película y la narración nos ayudan a ver toda la película sin enloquecer y nos permiten reflexionar sobre los acontecimientos y la acusación de los responsables, basándonos para ello en los derechos humanos y la justicia.

Las críticas de la película sobre su representación de tan horribles datos visuales, proviene básicamente de una preocupación: la imagen insoportable de ver, con cierta elaboración, se convierte en una imagen posible de mirar, aunque sea con disgusto. A través de la música y la narración se hace más fácil aceptar las imágenes; como consecuencia, se puede admitir que es posible "diluir" una realidad que es, en principio, inaguantable de mirar.

El contenido del texto de la narración sobre el crimen es muy claro, ingenioso y sugerente. Se centra sobre todo en las funciones de los campos de concentración, con ciertas explicaciones contextuales y una mirada global. En el texto se percibe un objetivo y profundo estudio basado en el análisis de la situación, tanto a través de los archivos escritos, como de las imágenes. Diríamos que Nuit et brouillard ha cumplido perfectamente su papel en el sentido de dar a conocer ampliamente al mundo los sucesos, y posibilitar la reflexión desde la postura del espectador exterior. 
La estrategia audiovisual utilizada tiene mucho éxito, al mostrar las imágenes impactantes (con ciertas explicaciones relativas a archivos históricos) que visualizan una parte importante del Holocausto. Por ejemplo, las imágenes de aquel momento como documento histórico se presentan en blanco y negro, y la ruina de los campos de exterminación, en color. Esta estrategia de montaje nos hace entender el cambio del tiempo entre el momento presente y aquel momento. De esta manera, nos facilita la comprensión del crimen pasado.

Sin embargo, para Lanzmann, el montaje de imágenes y la narración de Nuit et brouillard la convierten en un relato forzado según el modo de conocimiento institucionalizado europeo, que no trata la particularidad de la política de la exterminación del judío, incurriendo otra vez en la anulación de lo "otro".

Lo que muestra Nuit et brouillard es una parte de la catástrofe del pasado -con certeza no es más que una fracción del interior «insoportable» del Holocausto-, elaborada para facilitar su visualización. Pero sobre lo que Lanzmann sí presta atención es la mudez que persiste allí, el silencio y la ruptura, la invisibilización sistemática institucionalizada. Estos aspectos corren el riesgo de no quedar cubiertos en las imágenes de los documentos.

Por otra parte, podemos acostumbrarnos a las imágenes horribles repetitivas; de esta manera, el impacto de la imagen será cada vez más atenuado y reducido. Precisamente según el análisis de Susan Sontag ${ }^{30}$, no se reduce el impacto de la imagen terrorífica, sino

\footnotetext{
${ }^{30}$ Durante todo el libro Ante el dolor de los demás, Sontag reflexiona sobre las imágenes del horror de la guerra y otras cuestiones sobre la transmisión de dichas imágenes. Aunque su discusión se centra en la presentación fotográfica, identifica referencias importantes sobre la imagen audiovisual. Entre ellas, citamos unos fragmentos relevantes para nuestra observación: Por qué no cesó, digamos, la guerra en Bosnia, porque los dirigentes aseguraban que era una situación irremediable, acaso la gente en el extranjero haya apagado las terribles imágenes. Porque no parece que una guerra, cualquier guerra, vaya a poder evitarse, la gente responde en menor medida a sus horrores. La compasión es una emoción inestable. Necesita traducirse en acciones o se marchita. La pregunta es qué hacer con las emociones que han despertado, con el saber que se ha transmitido. Si sentimos que no hay nada que «nosotros» podamos hacer -pero, ¿quién es ese «nosotros»?-y nada que «ellos» puedan hacer tampoco -y, ¿quiénes son «ellos»?-entonces comenzamos a sentirnos aburridos, cínicos y apáticos. ... La gente no se curte ante lo que se le muestra -si acaso ésta es la manera adecuada de describir lo que ocurre-ni por la cantidad de imágenes que se le vuelcan encima. La pasividad es lo que embota los sentimientos. Los estados que se califican como apatía, anestesia moral o emocional, están plenos de sentimientos: los de la rabia y la frustración. Pero si consideramos qué emociones serían deseables resulta demasiado simple optar por la simpatía. ... Siempre que sentimos simpatía, sentimos que no somos cómplices de las causas del sufrimiento. Nuestra simpatía proclama nuestra inocencia así como nuestra ineficacia. En esa medida puede ser una respuesta impertinente, si no inadecuada (a pesar de nuestra buenas intenciones) [pp. 117-119]. La frustración de no poder
} 
que emerge una sensación de impotencia al ver tantas veces esas imágenes chocantes que ocurren al otro lado del mundo mientras no podemos hacer nada al respecto. Como consecuencia, preferimos evitar ver las imágenes del horror y esto nos vuelve cínicos frente a ellas. Además, esas imágenes están en realidad muy lejos de nosotros, esta separación y distancia conlleva la pérdida de interés y nos permite permanecer en una situación de apatía y anestesia moral.

Las imágenes y el texto relatados en Nuit et brouillard, por su impacto, podrían provocar en nosotros varias emociones: la rabia, la frustración e incluso la simpatía. Pero, a su vez, la información narrativa completada con una ilustración impactante también nos convierte en espectadores pasivos. Esta pasividad embota los sentimientos, como indica Sontag. La empatía con los que sufren nos permite proclamar nuestra inocencia, así como nuestra ineficacia, negando nuestra complicidad en el dolor ajeno.

Algunas consideraciones más sobre Nuit et brouillard: es una obra que pone su énfasis en aumentar el conocimiento sobre el Holocausto; en cambio, Shoah no es un documental para saber más sobre él. Lo que nos muestra Shoah sobre cuán ignorantes somos respecto al Holocausto se refiere a lo que no podemos ver y no podemos escuchar. Es decir, esta película exige que cuestionemos la falsedad y el engaño de los sucesos, e incluso del conocimiento y de las conclusiones al ver y escuchar.

To understand Shoah is not to know the Holocaust, but to gain new insights into what not knowing means, to grasp the way in which erasure is itself part of the functioning of our history. ${ }^{31}$

\footnotetext{
hacer algo en relación a lo que muestran las imágenes quizá pueda traducirse en la acusación de que es indec ente el modo en que se difunden: acompañadas, como bien podía ser el caso, de anuncios de emolientes, analgésicos y todoterrenos. Si pudiéramos hacer algo respecto de lo que muestran las imágenes, tal vez estas cuestiones nos importarían mucho menos. [Sontag, Susan, Ante el dolor de los demás, trad. Aulelio Major. Madrid, Santillana Ediciones Generales, 2003, p. 136]

${ }^{31}$ Felman, Shoshana, Op.cit., p. 253.

Entender Shoah es no es conocer el Holocausto, sino obtener nuevos conocimientos sobre lo que significa no saber, para comprender la forma en que la eliminación forma parte del funcionamiento de nuestra historia. [Traducción propia]
} 
De esta manera, Felman explica que Shoah nos hace conocedores del significado de "no saber" para comprender el poder de la eliminación como factor en la construcción de nuestra historia. En Shoah, igual que lo visible, lo que se puede decir y lo que ya se ha dicho, importa (aún más) presentar lo que no se puede decir, como el acontecimiento interior y su pérdida, la imposibilidad de representar el trauma que permanece en una situación de mudez.

How to transmit at once the pathos and the disconnection, the abyssal lostness of the inside, without being either crushed by the abyss or overwhelmed by the pathos, without losing the outside? How to be, thus, at the same time inside and outside? And how to guide the audience into an inside which nonetheless can keep in touch with the outside? It is the complexity of this specific question that defines, I would suggest, Lanzmann's paradoxical attempt to "reach people through their intelligence" precisely in a film that produces an effective and affective shock that resonates, as such, in the whole body of the viewer. If the film succeeds in reaching in the viewer the intelligence of the emotion, the very dumbness of the inside will have been transmitted, and the very shock of the event might generate its own process of historical intelligibility. ${ }^{32}$

El método ascético de Lanzmann en la presentación del audiovisual -sin ilustraciones de imágenes de archivos históricos, ni efectos de audio- proviene de su concepción radical de llegar a la gente a través de su inteligencia. Él no se refiere a una comprensión sobre las causas y los resultados desde una perspectiva europea, sino que lo que pretende es crear una provocación al plasmar en la imaginación algo inimaginable y llegar a comprender algo incomprensible.

\footnotetext{
${ }^{32}$ Ibíd., p. 239.

¿Cómo transmitir a la vez el patetismo y la desconexión, la abismal pérdida del interior, sin que sea aplastada por el abismo o sea abrumada por lo patético, sin perder el exterior? ¿Cómo estar, por lo tanto, al mismo tiempo dentro y fuera? $Y$, ¿cómo orientar a la audiencia hacia un interior que, sin embargo, pueda mantenerse en contacto con el exterior? Es la complejidad de ésta cuestión específica que define, me permito sugerir, el intento paradójico de Lanzmann de "llegar a la gente a través de su inteligencia", precisamente en una película que produce un choque afectivo y efectivo que resuena, como tal, en el conjunto del espectador. Si la película logra alcanzar en el espectador el conocimiento y la emoción, la misma imposibilidad para hablar desde el interior que ha sido trasmitida, y el choque del evento puede generar su propio proceso de inteligibilidad histórica. [Traducción propia]
} 
Suponemos que Lanzmann estaba convencido del audiovisual como medio más adecuado para su concepto. Un testimonio sobrepasa demasiado los límites del lenguaje y afecta mucho la disposición del autor.

La representación audiovisual no se encuentra fuera del propósito del autor. La obra se puede calificar como un tipo de ficción donde la interpretación del autor se refleja a través del montaje y la edición. No obstante, aun constituyéndose como una representación interpretada, el documental tiene la capacidad de ser fiel a la realidad (en otro nivel en comparación con el texto escrito). Existen diferencias fundamentales en las impresiones y el sentido.

Los factores imprescindibles de esta obra son el silencio, la ruptura y la mudez, casi imposibles de representar con palabras sin explicaciones del autor. En tal caso, el audiovisual es favorable para su representación. Por otro lado, documentar y transmitir solo con audio impide conocer exactamente quiénes y con qué gestos se expresaron, incluso aunque se lograse presentar la voz del que atestigua, la voz del intérprete, su tono, la ruptura, el silencio, los momentos mudos y su tiempo real...

Transmitir registrando el gesto del testigo y el contexto que le rodea, el silencio que no permite pronunciar ni una sola palabra, el rostro al titubear y balbucear por su perplejidad, una cara con poca expresión de sentimientos a pesar de testificar cosas impactantes, una pequeña sonrisa del testigo forzado en una situación absurda, y otros más. Estas imágenes alcanzan un mayor impacto en el plano emocional.

Esto nos lleva a pensar: ¿qué ocurrió? y ¿qué ocurre? La provocación exige una reflexión, no solo sobre el pasado, sino también sobre el presente. Aunque parece imposible imaginar, surge la necesidad de imaginar. Sin embargo, es criticable recurrir a la imaginación fácil como estereotipo generalizado y aceptable, que, como vimos, sostiene la vida sosegada alejada de la molestia y la angustia. Lanzmann demuestra que encerrarse en ese lugar seguro es infame y se convierte en una falacia, y se nos impone diciendo: parece imposible imaginar, aun así y precisamente por ello, ve y enfréntate a una realidad que 
sobrepasa la imaginación. El impacto que pretende conseguir esta obra no acepta una simpatía que nos permita ser inocentes. Al llegar a la gente a través de su inteligencia, como dice Lanzmann, se rechazan los sentimientos y emociones que caigan fácilmente en apatía y anestesia moral.

\section{IV.2.3. El arte del testimonio y el poder del audiovisual.}

Entre las numerosas escenas de testimonios en Shoah, una de las más dramáticas y que más nos estremece es la escena frente a la iglesia de Chelmno, en Polonia, donde el testigo Simon Srebnik se queda en silencio.

Srebnik es el testigo más importante de Shoah. Es uno de dos judíos que sobrevivieron de los cuatrocientos mil hombres, mujeres y niños enviados al campo de exterminación de Chelmno.

Él fue uno de los «trabajadores judíos» llamados comando, los que servían para el mantenimiento del campo, quemando cadáveres entre otros trabajos. Srebnik, mientras trabajaba, cantaba y competía con grillos en concursos de salto y velocidad, junto con otros compañeros prisioneros de la SS. Gracias a su talento para el canto y su enorme agilidad, pudo sobrevivir superando la crisis y la muerte. Fue enviado a Chelmno con trece años y medio. Dos días antes de la llegada de las tropas soviéticas, los Nazis ordenaron su ejecución (junto a la de los otros «trabajadores judíos»), pero la bala que penetró su cabeza no alcanzó la parte vital del cerebro y milagrosamente sobrevivió.

La película comienza con la búsqueda de Srebnik para convencerle de regresar a Chelmno con Lanzmann. Su testimonio es importante y, en la mayor parte, crudo; no obstante, habla con una sonrisa tranquila pero inexpresiva, con el fondo de un bello paisaje de las ruinas del campo, del cual no queda nada y permanece cubierto con el verde de la naturaleza. Cuanto más observamos la calma y el silencio, más perplejos nos deja.

Sobre la escena de la iglesia, Felman comenta: 
The church scene is an astounding emblem of the multiplicity and the complexity of layers which unfold between this central silence and the various speeches which proceed from it and encroach upon it. ${ }^{33}$

En una escena Srebnik se queda en silencio, con la habitual sonrisa, después de cantar y testificar en las ruinas del antiguo campo de exterminio. Llega con el equipo de rodaje a la iglesia de la aldea de Chelmno. Como dice Felman, es una escena emblemática que muestra un complejo problema sobre el testimonio del Holocausto. Al mismo tiempo, nos hace reflexionar sobre la imposibilidad del testimonio y la necesidad del arte como posible testimonio de lo real. Para analizar esta escena, la dividiremos en dos partes.

Primero, abordamos la calidad del testimonio en su complejidad y el sentido de los silencios del testigo. En este punto, confirmaremos el poder artístico del audiovisual, el cual nos permite convertirnos en un posible testigo frente a la representación de una escena grotesca, pero también frente al proceso de anulación del testimonio del testigo que ha vuelto donde sucedió la catástrofe pasada. Con esta representación por medios audiovisuales se descubre que la catástrofe no es solo parte del pasado, sino que también es presente.

En la segunda parte, tras lo desarrollado en la primera, estudiaremos la función de la presente obra audiovisual introduciendo la teoría psicoanalítica Lacaniana del encuentro fallido para posibilitar una interpretación artística siguiendo a Felman. Repasaremos brevemente la teoría de lo sublime como función propia del arte según Lacan.

IV.2.3.1. El silencio del testigo en la expresión audiovisual.

En aquella escena frente a la iglesia de Chelmno, en un principio los pueblos que recordaban al niño cantante judío se alegran de saber que está a salvo y le ofrecen sus

\footnotetext{
${ }^{33}$ Ibíd., p. 266.

La escena de la iglesia es un emblema sorprendente de la multiplicidad y la complejidad de las capas que se abren entre este silencio central y los diversos discursos que se desarrollan a partir de él y le invaden. [Traducción propia]
} 
palabras de conmiseración por los judíos exterminados. Los polacos conocían a este niño porque le habían visto encadenado. En aquella época, le hacían cantar en un barco en el río cercano al campo, como representa la escena de la primera parte de la película.

Sin embargo, esta actitud cambia en un momento dado. Lanzmann interroga a los polacos sobre el papel que ejerció la iglesia en la concentración de los judíos. Entonces, ellos empiezan a parlotear de forma locuaz. A primera vista, sus comentarios parecen razonables, pero en realidad se trata de explicaciones estereotipadas que ocultan algo. En otras palabras, se convierten en falsos testimonios formulados.

Los polacos no niegan que conocían la encarcelación de judíos en la iglesia, con un destino seguro a la muerte en el autobús de gas. La conversación, interrumpida por la procesión, termina con un comentario, según el cual en ese momento los judíos invocaban a Jesús y la Virgen María, y maletas llenas de oro de los judíos se encontraban dentro de la iglesia.

Obviamente, existen dos puntos extraños en este comentario: primero, los judíos no invocaban a María ni a Jesús para su salvación. Segundo, ¿cómo podrían conocer el contenido de las maletas? Felman considera la testificación de los polacos como muestra de un prototipo de testimonio desde el exterior.

Like the Nazi teacher's wife (who only "sees things from outsider"; 82) the Poles embody outside witness - present an outside view of the Jewish destiny, but an outside view which nonetheless believes it can account for the inside: in trying to account for the inner meaning of the Jewish outcry from inside the church, and in accounting for the inner, unseen content of the robbed possessions of the Jews inside the confiscated suitcases, the Poles bear in effect false witness. ${ }^{34}$

\footnotetext{
${ }^{34}$ Ibíd., pp. 260-261.

Al igual que la esposa del profesor Nazi (que solo "ve las cosas desde fuera"; 82), los polacos describen a los testigos desde fuera -cercanos a una visión exterior del destino de los judios-, pero testigos exteriores que, no obstante, se consideran capaces de representar el interior: al tratar de relatar el significado del clamor de los judios en el interior de la iglesia, y en la contabilización del contenido oculto de los bienes robados de los judíos en el interior de las maletas confiscadas, los polacos cargan en efecto falso testimonio. [Traducción propia]
} 
Los polacos testifican desde la perspectiva exterior, reflejando una imagen estereotipada de los judíos que se encuentran en el interior. En el primer caso, imaginan empáticamente a los prisioneros dentro de la iglesia, gritando y clamando el nombre de Jesús y María (como si los judíos fuesen cristianos). En el segundo caso, imaginan que había riquezas escondidas en las maletas, accionando así la emoción agresiva y la envidia hostil. Por supuesto, nadie pudo testificar que había visto las maletas con el oro dentro, pero perjuran que los judíos tenían las maletas llenas de oro.

(...) the Poles distort the facts and dream their memory, in exemplifying both their utter failure to imagine Otherness and their simplified negotiation of the inside. It is to their own fantasy, to their own (self-) mystification that the Poles bear witness, in attempting to account for historical reality. Their false witness is itself, however, an objective illustration and concretization of the radically delusional quality of the event. $^{35}$

A los testigos polacos les falta imaginación, por eso solo aplica lo suyo sistemáticamente como cristianos o reflejar sus prejuicios y la envidia que tienen de los judíos. Francamente, están soñando en su memoria y quieren completar la realidad de la historia con su fantasía. Ello simboliza al falso testigo y se concreta en una calidad del suceso radicalmente ficticia. En este caso, Felman juzga la falsedad del testimonio de los polacos.

Para obtener una explicación «razonable» y verosímil, los polacos intentan completar la historia reflejando su ilusión y distorsionando los hechos. Este tipo de testimonio falso difiere un poco de una mentira sencilla, porque ellos creen o intentan creer que están diciendo la verdad, obstinadamente, casi de un modo fanático. Es decir, ellos piensan seriamente lo que dicen e imaginan sobre los judíos, pero sin un ajuste auténtico a la realidad.

\footnotetext{
${ }^{35}$ Ibíd., p. 261.

( ...) Los polacos distorsionan los hechos y sueñan sus memorias, ejemplificando su absoluta falta al imaginar a los Otros así como su simplificación en la negociación interna. De acuerdo con su propia fantasía, con su propio (auto-) enajenamiento, los polacos se convierten en testigos, e intentan dar cuenta de la realidad histórica. Su falso testimonio es en sí mismo, sin embargo, una ilustración objetiva y una concreción de la calidad radicalmente ficticia del evento. [Traducción propia]
} 
En tal caso, ya no les importa si podían ver el contenido de las maletas, ni si podían oír a la invocación a María y Jesús por parte de los judíos. En este grado de incomprensión del "otro" desaparece el espacio de negociación interna. Se confirma la impotencia y la falta de imaginación con el respecto a la diferencia con el "otro", forzando a encuadrarle en una imagen estereotipada.

La entrevista se interrumpe y se reanuda tras el paso de la procesión que sale de la iglesia. En ese momento, la testificación de los polacos se acalora, activando los arquetipos de ficciones negativas relacionadas con el antisemitismo. Aquí, con cierta evidencia, Lanzmann lanza preguntas provocativas, y los polacos responden con una actitud defensiva, volcando la culpa del Holocausto en los judíos.

Facing Lanzmann, the Polish villagers, in turn, exhibit feelings that would normally be hidden, But the silent interviewer and the silent camera urge us not simply to see the testimony, but to see through it: see-throughout the testimony-the deception and the self-deception which it unwittingly displays, and to which it unintentionally testifies.

\section{Why do they think all happened to the Jews?}

Because they were the richest! Many Poles were also exterminated.

Even Priests. ${ }^{36}$

Felman indica la inconsciencia de los testigos polacos que pretenden culpar a los judíos, o al menos creen que los sucesos fueron provocados por ellos mismos, lo cual refleja claramente los estereotipos existentes. Los testigos también argumentan ser inocentes y formar parte de las víctimas cuando mencionan que los polacos y sacerdotes cristianos

\footnotetext{
${ }^{36}$ Ibíd., p. 263.

Frente a Lanzmann, los aldeanos polacos exhiben sentimientos que normalmente ocultarían, pero el entrevistador en silencio y la silenciosa cámara nos instan no solo a ver el testimonio, sino a ver a través de él: observar-a lo largo del testimonio- el engaño y el auto-engaño que inconscientemente muestran, y que involuntariamente testifican. [Traducción propia]

A su juicio, ¿por qué les pasó a los judios toda esta historia?

¡Porque eran ricos!

Hubo no pocos polacos que fueron exterminados, es cierto. Incluso sacerdotes. [Lanzmann, Claude, Op.cit., p. 103.]
} 
fueron víctimas del Holocausto. Así pueden escapar de la responsabilidad y la complicidad. En esta escena vemos una serie de testimonios de campesinos polacos; a través de ellos, vemos su engaño y autoengaño. Felman indica que a la vez constituirían un testimonio involuntario como espectadores del Holocausto, mostrando una faceta engañosa que elude la responsabilidad.

Hasta la testificación del cantante de la iglesia, Kantorowski, el cual entra con ímpetu ante a la cámara, abriéndose paso entre la multitud, exteriorizando un comentario sobre su amigo: un rabino habló frente a los judíos reunidos por los Nazis, y les dijo, estamos pagando por nuestro pecado. Concluye que todo lo que ocurrió era la voluntad de Dios, a final de cuentas. Podría parecer que la matanza más grave del siglo ocurrida ante sus ojos no estuviese relacionada con ellos, o que los campos de exterminio hubiesen sido la voluntad de Dios y de la Biblia.

Sin embargo, Kantorowski testifica sobre esta historia en nombre del rabino que había visto a su amigo, rechazando ser testigo él mismo.

\section{He thinks the Jews expiated the death of Christ?}

He doesn't think so or even that Christ sought revenge. The rabbi said it.

It was God's will, that's all. [100]

In forging, so to speak, the rabbi's signature so as to punctuate his own false witness and to authorize his own false testimony, Kantorowski disavows responsibility for his own discourse (...). The collapse of the materiality of history and of the seduction of a fable, the reduction of a threatening and incomprehensible even to a reassuring mythic, totalizing unity of explanation, is in effect what all interpretive schemes tend to do. Mr. Kantorowski's satisfied and vacuous interpretation stands, however, for the failure of all ready-made cultural discourses both to account for-and to bear witness to- the Holocaust. ${ }^{37}$

\footnotetext{
${ }^{37}$ Ibíd., pp. 265-266.

O sea, ¿piensa que los judios expiaron por la muerte de Cristo? Él no lo piensa ni tampoco cree que Cristo quisiera vengarse. ¿Quien lo ha dicho es el rabino! Era la voluntad de Dios, eso es todo. [Lanzmann, Claude, Op.cit., p. 104.] En la falsificación, por así decirlo, la firma del rabino interrumpe su propio falso testimonio y lo
} 
El falso testimonio de Kantorowski interrumpe el esfuerzo de reflexionar sobre el suceso traumático que permanece en el silencio. Era la voluntad de Dios, eso es todo. Es un enunciado que impide y rechaza el cuestionamiento. Se convierte, precisamente, en una declaración que demuestra el abandono de la reflexión.

Felman interpreta que esta escena muestra la satisfacción y la interpretación vacía de Kantorowski, pero señala el fracaso en el debate sobre las cuestiones culturales relacionadas con las posibilidades de testimonio del Holocausto. La escena realmente nos lleva a cuestionarnos sobre cuál es el sentido del testimonio (sin considerar su calidad), así como su veracidad o falsedad. La grotesca declaración de Kantorowski y esa confianza, casi fanática, nos aportan una sensación aterrorizadora.

Srebnik se encuentra rodeado de los polacos, quienes prosiguen con su falsa testificación en modo charlatán. Él se queda en silencio con una sonrisa tranquila e inexpresiva. Como indica Felman, esta escena muestra claramente cómo surge la falsa testificación y qué es: un relato deformado basado en los prejuicios y la indiferencia que obliga al testigo a permanecer en silencio. De esta manera, de nuevo nos enseña la dificultad y la confusión que existe al testificar sobre el Holocausto. Felman considera que Lanzmann pone énfasis en este silenció y casi le hace hablar:

The film's strategy in not to challenge the false witness, but to make the silence speak from around the false witness: the silence within each of the testimonies; the silence between various silences and various testimonies; the irremediable silence of the dead; church procession; the silence of the ready-made cultural discourses pretending to account for the Holocaust; and above all, in the centre of the film,

autoriza, Kantorowski refuta la responsabilidad de su propio discurso... El colapso de la materialidad en la historia y la seducción de una fábula, la reducción de una amenaza incluso incomprensible para un mito alentador, totalizando la unidad de la explicación, es en efecto lo que todos los sistemas interpretativos tienden a hacer. La interpretación satisfactoria y vacía del señor Kantorowski perdura, a pesar del fracaso de todos los discursos culturales ya hechos, tanto a la hora de tener en cuenta -como de dar testimonio- del Holocausto. [Traducción propia] 
Srebnik's silence in front of the church, in the middle of the talkative, delirious, selfcomplacent Polish crowd. ${ }^{38}$

Esta escena también muestra el proceso del olvido y anulación del testigo. A Srebnik se le envía de nuevo al "silencio de la muerte" a pesar de la intención de volver como testigo en la película. Aunque Srebnik tiene las capacidades fisiológicas para hablar, se queda mudo por el escándalo que hay a su alrededor.
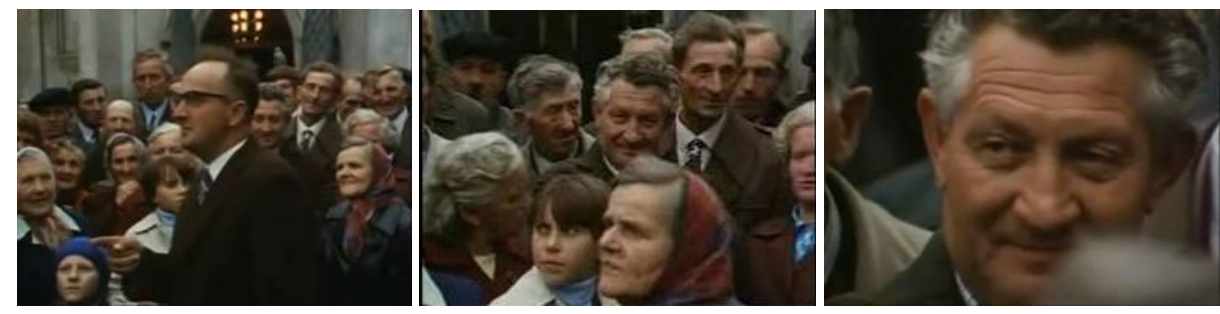

12. Kantorowski y Srebnik frente a la iglesia de Chelmno en Shoah (1985), Claude Lanzmann

La estrategia de la presente obra al mostrar esta escena del silencio con imágenes de la procesión nos lleva a compararla con otra escena del inicio de la película, en la que el testimonio de Srebnik simboliza el silencio que había en aquel momento del Holocausto, del cual él es superviviente. De este modo, Felman argumenta que es el silencio del testigo Srebnik quien revela la falsedad locuaz de los vecinos polacos.

Although Srebnik here personifies the return of the witness -the return of witnessing into the very scene of the event-without-a-witness, what the church scene puts into effect and play out, not in memory but in actual fact (and act), is how the real witness, in returning back to history and life, is once again reduced to silence, struck dead by the crowd ... they are unaware of the precise way in which they

\footnotetext{
${ }^{38}$ Ibíd., p. 266.

La estrategia de la película no es desafiar a los falsos testigos, sino hacer hablar al silencio desde lo que rodea a los falsos testigos: el silencio en cada uno de los testimonios; el silencio entre varios silencios y diversos testimonios; el irremediable silencio de la muerte; la procesión de la iglesia; el silencio de los discursos culturales preparados que pretenden dar cuenta del Holocausto; y sobre todo, en el centro de la película, el silencio de Srebnik frente a la iglesia, en medio de una locuaz, delirante y autocomplaciente multitud polaca. [Traducción propia]
} 
themselves are actually enacting both the Crucifixion and the Holocaust in annihilating Srebnik, in killing once again the witness whom they totally dispose of, and forget. ${ }^{39}$

Precisamente en esta escena se compara la Crucifixión con el Holocausto, filmando otra vez a quien testifica como superviviente de un suceso traumático. Cuando vuelve el superviviente e intenta pronunciar lo que no puede expresar bien ni al completo, al instante -casi automáticamente- se le impide: los ruidos escandalosos de los espectadores y su interpretación estereotipada y endurecida que intenta ignorar y ocultar la realidad hacen que Srebnik calle de nuevo.

Este gesto (escandalizar y cubrir con un relato estereotipado una realidad que no conviene) tiene la misma estructura y función que cuando obligamos a enmudecer a un ser subalterno, tal y como vimos en los apartados anteriores con el análisis de Spivak. Tiene también la misma estructura que la segunda agresión, la de los agresores con cierta complicidad con los espectadores apáticos de una víctima que procura testificar su experiencia traumática (por ejemplo, en el caso de la violación sexual que hemos visto el apartado anterior). Y la confusión, el olvido y el silencio siempre benefician a los agresores.

I would suggest that what the film shows us here, in action, is the very process of the re-forgetting of the Holocaust, in the repeated murder of the witness and in the renewed reduction of the witnessing to silence. ${ }^{40}$

\footnotetext{
${ }^{39}$ Ibíd., p. 267.

Aunque Srebnik aquí personifica el retorno de los testigos -el regreso de los testigos al escenario del suceso sin testigos-, lo que la iglesia pone en escena y en juego (no en la memoria, sino en la realidad y en los hechos) es la forma en que el verdadero testigo, en su regreso a la historia y a la vida, es una vez más es reducido al silencio, sorprendido a la muerte por la multitud ... Ellos no son conscientes de la manera en que ellos mismos están en este momento efectuando tanto la Crucifixión como el Holocausto en la supresión de Srebnik, una vez más matando a los testigos totalmente aniquilados, y olvidados. [Traducción propia]

${ }^{40}$ Loc.cit.

Yo sugeriría que lo que la película muestra aquí, en la acción, es el proceso mismo de re-olvidar el Holocausto, en los reiterados asesinatos a los testigos y en la continua reducción de los testigos hasta el silencio. [Traducción propia]
} 
Felman argumenta que esta obra audiovisual, a pesar de tener la misión de registrar y transmitir los testimonios sobre el Holocausto, en realidad documenta el proceso de la anulación del testimonio y de nuevo el olvido sobre el suceso.

La parte artística mayor lograda en esta obra es la visualización del silencio que apunta a lo que se encuentra más allá del olvido, y se cambia así el significado del silencio. Con frecuencia, el silencio protege a los agresores para anular su crimen y favorece la apatía de los espectadores, quienes configuran de este modo una relación cómplice con los agresores. En el plano legal y político todavía persiste este esquema. Sin embargo, la presente obra nos hace comprender que el único sentido del silencio no es el que reconocemos habitualmente. El silencio que se encuentra en esta escena -así como muchos otros silencios que encontramos durante toda la obra- no protege en absoluto a los agresores ni a los espectadores. Enseguida veremos la parte artística de esta escena.

\section{IV.2.3.2. La representación del encuentro fallido.}

Felman interpreta la escena frente a la iglesia utilizando un término importante: el encuentro fallido, relativo al psicoanálisis de Jaques Lacan ${ }^{41}$.

What the church scene dramatizes is the only possible encounter with the Holocaust, in the only possible from of a missed encounter. ${ }^{42}$

Srebnik se queda en silencio, rodeado de gente que habla escandalosamente: de nuevo se convierte en un testigo eliminado, un fantasma con sonrisa serena. Como hemos visto, esta escena nos enseña, qué actitud fue tomada en el pasado y cómo es retomada por los espectadores del Holocausto, esta vez incluso con un testigo que ha regresado. Los vecinos polacos siguen sin oír su voz a pesar de encontrarse muy cerca de un testigo superviviente.

\footnotetext{
${ }^{41}$ Lacan, Jacques (1901-1981), teórico y psicoanalista francés. Lacan desarrolló y transformó la teoría y la praxis propuesta por Freud tomando como base la lingüistica estructuralista desarrollada por Saussure. (...) Lacan ha sido particularmente influyente sobre los teóricos de la literatura y sobre filósofos posestructuralistas como Foucault, Derrida y Deleuze. [Audi, Robert (ed.): Diccionario Akal de Filosofía, Op.cit., p. 587.]

${ }^{42}$ Ibid., pp. 267-268.

Lo que la escena de la iglesia dramatiza es el único encuentro posible con el Holocausto, en la única forma posible a partir de un encuentro fallido. [Traducción propia]
} 
Ellos interpretan el Holocausto, pues, desde la perspectiva exterior, haciendo callar al testigo que ha vuelto desde el interior. Es decir, ellos se encontraron plantados frente al testigo, no obstante, no pudieron considerarlo como tal. Al mismo tiempo, Srebnik tampoco encuentra a quien le escuche, así que la única vía es permanecer en silencio.

Al fin y al cabo, para ser testigos de lo "otro" debemos quedarnos en ambos lados, exterior e interior. Lo que tanto Lanzmann como Felman plantean es que nos convertimos en testigos del encuentro fallido al observar esta escena. Una consideración más estricta desde la postura del psicoanálisis incluiría que lo perdido en la escena es el encuentro en sí. Deberíamos decir que se pierde la posibilidad de llegar a conocer lo que Srebnik no puede decir. Incluyéndonos como espectadores, nos concienciamos de esa pérdida.

El encuentro fallido, en términos de Lacan, digamos rigurosamente que supone la pérdida del encuentro entre un sujeto y lo real. Lo real ${ }^{43}$ se convierte en uno de los tres conceptos fundamentales de la teoría de Lacan: es algo que no se puede expresar con el lenguaje, está fuera del él, es indecible. Al mismo tiempo, lo real permanece siempre, pero nos damos cuenta de su presencia solo después. Es algo que está continuamente junto a nosotros, pero no nos damos cuenta cuando nos acompaña. Solo podemos reconocer su huella retroactivamente. En general, lo que presenta lo real es la muerte y la memoria o el estado no recuperable que precede al comienzo de las actividades lingüísticas.

En la interpretación psicoanalítica, el arte es un producto de lo sublime que hace aparecer lo real en el mundo sensible. Al mismo tiempo, lo sublime no aparece como real en sí, sino como lo que nos separa de lo real. Un ejemplo más comprensible lo encontramos si comparamos lo real con la muerte: siempre existe para nosotros, no obstante, es imposible de expresar con el lenguaje. Es decir, la muerte se encuentra fuera del sistema lingüístico.

\footnotetext{
${ }^{43}$ Real: lo real es aquello que lo simbólico nunca puede captar por el medio de sus diferencias binarias. No es la <realidad>> de los objetos y las personas de todos los días, sino aquello que queda por fuera de estas identificaciones familiares. Para el sujeto, es lo interior y exterior que resisten inconscientemente las diferencias impuestas y lo dejan con un problemático exceso de goce. [Wright, Elizabeth: Lacan y el posfeminismo, trad. Gabriela Ubaldini, Barcelona, Editorial Gedisa, 2004, p. 83]
} 
El arte puede conseguir que la muerte sea representada en el mundo sensible, sin embargo y al mismo tiempo, la hace aparecer como algo que nos separa de ella. Supongamos que un cuadro representa a la muerte en nuestro mundo sensible. Al mismo tiempo, esta pintura grabada en el cuadro existe aquí y ahora, y así aparece como la que nos consigue separar de la muerte en sí. Es decir, una obra de arte es una ventana que muestra a través de lo sublime lo real, lo cual siempre existe pero no se puede conocer en el mundo sensible sin la ayuda del arte. Al mismo tiempo, por esta ventana se aparta lo real de nuestro contexto inmediato, de nuestra realidad.

Según la interpretación de Felman, la obra Shoah cumple este papel de ventana: nos hace reconocer la existencia de lo que no se puede expresar en el lenguaje, mientras nos separa de lo que no se puede expresar.

En la escena de la iglesia, se puede reconocer cómo la experiencia seguida, la actitud y las palabras de los vecinos polacos intentan reducir evasivamente una historia estereotipada al enfrentarse al acontecimiento catastrófico pasado. Es una postura que debe ser criticada en el contexto de Shoah y nos aproxima al suceso de una manera grotesca.

En general, nosotros realizamos la misma operación casi cotidianamente, cubriendo lo real con una tapa para poder estabilizar nuestro mundo. En cambio, la realidad que experimentó Srebnik - la verdad del Holocausto- no se puede expresar a través del lenguaje. Además, nosotros no podemos reconocerla como percepción ni experiencia repetida. En el contexto psicoanalítico, el interior del Holocausto es lo real y se incluiría a los supervivientes. Y Shoah como obra artística cumple el papel de esa ventana que nos permite entrever el interior del Holocausto pero que, al mismo tiempo, aparta el Holocausto de nosotros.

No solo es esta escena de la iglesia: en todo el documental Shoah, nos aterroriza cuestionarnos qué era el Holocausto si lo aproximamos a lo real; no obstante, esta obra nos separa de lo que no se puede expresar, solo nos hace reconocer desde lejos que aquello existió. Este reconocimiento es posible gracias a la función psicoanalítica de lo sublime. Suponemos que esto es precisamente el poder del arte: observar el testimonio a través de él, 
según argumenta Felman. El proceso para llegar al lugar del encuentro fallido, o para encontrar y buscar lo invisible y hacerlo visible, demuestran el poder del arte.

\section{IV.2.4. Hablar en primera persona: el principio de la obra de arte como testimonio.}

La obra Shoah comienza cuando Lanzmann encuentra a Srebnik. Este encuentro aparece como un momento que ofrece a Lanzmann el lugar y el tiempo adecuados para empezar a hablar desde el yo en primera persona. La película empieza con un escrito sin voz con explicaciones sobre el Holocausto en Chelmno y las circunstancias de la supervivencia de Srebnik, y dice:

Le he encontrado en Israel. He convencido al niño cantor para que volviera conmigo a Chelmno. ${ }^{44}$

A diferencia del cantante polaco, Lanzmann testifica en primera persona. Este encuentro es el punto de partida de la película; al mismo tiempo, es un punto de llegada del viaje personal de Lanzmann desde el exterior al interior y el punto de repartida del interior al exterior.

I would suggest that the artistic power of the film proceeds, precisely, from this finding: the event of Shoah is an event of finding. ${ }^{45}$

Según Felman, la intención de esta obra es buscar e investigar los diferentes niveles en el encuentro. Ella lo explica dividiendo en cinco niveles la búsqueda de los significados en el encuentro:

\section{The finding, first and foremost, is the finding of Simon Srebnik, the astonishing} winning Survivor (...)

\footnotetext{
${ }^{44}$ Lanzmann, Claude, Op.cit., p. 17. [También en: Felman, Shoshana, Op.cit., p. 253.]

${ }^{45}$ Felman, Shoshana, Op.cit., p. 253.

Yo diría que la potencia artística de la película procede, precisamente, del siguiente hallazgo: el caso de "Shoah" es un caso de búsqueda. [Traducción propia]
} 
2. The finding is thus also, at the same time, the finding of a site of entering, the discovery of the unique significance of a place: (...)

3. The finding is the finding of testimony -of its singular significance and functioning as the story of an irreplaceable historical performance, a narrative performance which no statement (no report and no description) can replace and whose unique enactment by the living witness is itself part of a process of realization of historic truth (...)

4. Israel became the place from which Lanzmann can himself, for the first time, testify from the inside (as both an inside and an outside witness), the place, in other words, in which Lanzmann for the first time finds a voice with which he can say "I" and with which he can articulate his own testimony: "I found him in Israel" and persuaded that one-time boy singer to return with me” (...)

5. Finally, the finding is the finding of the film itself: Shoah rethinks, as well, the meaning and the implications of the advent (of the event) of its own finding. To find a new possibility of sight, a possibility not just of vision -but of re-vision (...) ${ }^{46}$

Las explicaciones de Felman nos aclaran los distintos niveles del encuentro en esta obra. Son las condiciones indispensables para poder establecer la obra Shoah como una obra de arte sobre el testimonio. En las frases se acentúa la necesitad y la importancia de Israel como un lugar que posibilita el encuentro, y así precisamente posibilita el testimonio. El posible encuentro con un testigo tan extraordinario como Srebnik seguramente sería más difícil en otro territorio. El encuentro -como una posible intervención por parte de los supervivientes judíos, expulsados de Europa por los ataques pogrom y el Holocausto-, solo

\footnotetext{
${ }^{46}$ Ibíd., pp. 254-255.

1. El encuentro, en primer lugar, es el hallazgo de Simón Srebnik, el sorprendente superviviente ganador (...) 2. El encuentro es, por tanto, también al mismo tiempo el hallazgo de un sitio de llegada, el descubrimiento de la singular importancia de un lugar: (...) 3. El encuentro es el hallazgo de testimonios -de su singular importancia y funcionamiento como narración de una operación histórica fuera de lo común, una actuación narrada a la cual ninguna declaración (sin informes ni descripciones) puede sustituir y cuya única validación por los testigos con vida es su propia vida como parte de un proceso de reconocimiento de la verdad histórica (...) 4. Israel se convirtió en el lugar donde Lanzmann puede expresarse, por primera vez, desde el interior (tanto como testigo del interior como del exterior), el lugar, en otras palabras, en el que Lanzmann por primera vez encuentra una voz con la que el puede decir "yo" y con la que puede articular su propio testimonio: "Lo encontré en Israel y convencí al niño que una vez fuere cantor para volver conmigo..." (...) 5. Por último, el encuentro es la conclusión de la película en sí: "Shoah" repiensa, también, el significado y las implicaciones de la llegada (de la existencia) de su propia conclusión. Para encontrar una nueva posibilidad de visión, no solo una posibilidad de visión, sino de revisión (...) [Traducción propia]
} 
sería posible en Israel. De la misma manera, es el lugar de intervención de Lanzmann como alguien que llega desde el exterior y se enfrenta a la realidad del judío, reconsiderando así la imagen del "otro" producida por el antisemitismo en un Israel acondicionado y creado por la historia.

En este punto, debemos realizar una sutil objeción y disentir con Felman y Lanzmann. Desde el principio, Shoah se basa en un concepto estratégico y una estructura que se opone y supera el revisionismo que rechaza e intenta reducir la gravedad del Holocausto. Esto complica aún más el asunto. Lanzmann pone demasiado énfasis en lo judío y en Israel como el único interior que reúne y condensa lo judío. Por ello, no podemos negar que la obra da la impresión de favorecer y sostener el nacionalismo israelí y la ideología judía exclusivista.

Hasta ahora, hemos utilizado la palabra Holocausto para referirnos a la matanza sistemática por motivos religiosos en los campos de exterminio Nazi durante la Segunda Guerra Mundial. Sin embargo, la palabra Holocausto originalmente se refiere a las ceremonias religiosas en que se ofrece un sacrificio - quemar un cordero hasta la ceniza, por ejemplo-. El uso de este término nos hace reflexionar sobre una operación ideológica, según la cual estos sucesos serían un gran sacrificio que se ofrece a Dios para la fundación del país de Israel. En este sentido, habría que cuidar el significado de la palabra, pues incluye una operación simbólica para sostener y apoyar el mito de la fundación del país: Dios les concedió el país a cambio del grave sacrificio del "Holocausto". Además, no hay que olvidar que entre las víctimas de esta masacre Nazi se encuentran no pocos roma (gitanos rumanos), homosexuales y criminales políticos que fueron también objeto de exterminio.

La palabra genocidio podría ser un antecedente para designar el suceso dado el sentido que tiene de exterminación sistemática de un grupo. Pero el término actualmente incluye la adopción coactiva por parte de la intervención estatal y la violación sexual con el objetivo de aniquilar una etnia. En este sentido, no podemos decir que la palabra genocidio sea la más adecuada para referirse a la masacre en los campos de exterminación Nazi durante la Segunda Guerra Mundial. 
Este suceso es tan controvertido que resulta incluso polémico designarlo con un sustantivo adecuado, ello demuestra la confusión a nivel simbólico en el lenguaje, a lo cual sigue el problema de la traducción. Con ello, el lenguaje en sí acarrea un problema de falta y/o exceso de significado. Tal vez debido a la conciencia que lo religioso adquiere en la palabra Holocausto, Lanzmann haya decidido titular su documental con el nombre de Shoah.

Sin embargo, la palabra en hebreo no nos permite comprehender el contexto (donde este idioma funcionó solo como lenguaje religioso durante muchos años, hasta el momento de la fundación de Israel, cuando se modernizó y resucitó). Felman lo interpreta de otra manera, pero nos convence poco. Si Lanzmann crea la imagen de Israel como la tierra renacida, representa en Shoah la historia judía de la separación y el padecimiento, retrotrayéndose como el mito de la fundación del país. Nos hace recordar y volver a reflexionar sobre el mito Nazi y la teoría sobre la cuestión judía de Sartre.

Por otra parte, en la interpretación de Felman -desarrollada a consecuencia de la conciencia sionista y nacionalista de Lanzmann-, la agregación de Israel como único lugar de encarnación de lo judío se encuentra con una incompatibilidad e incoherencia en el discurso que ella misma desarrolla. Es decir, si consideramos a Shoah como una obra para encontrar la articulación entre exterior e interior, y permanecemos en ambas partes, encontramos una contradicción que se manifiesta en nuestra manera de ver cómo Israel es el interior (identificado con el gueto dentro de Europa), y/pero los judíos siguen siendo las víctimas unilaterales. Dividiría así el exterior -la Europa de los perseguidores- y el interior -el Israel de las víctimas-, manteniendo esta estructura de mutua oposición.

Esto nos obliga a juzgarla como un fracaso de decontracción ${ }^{47}$ que intenta comprender críticamente ésta estructura de dualidad opuesta por articular y transportar entre ambos lados, sobre la necesidad e importancia en las que Felman insistía de estar en el exterior y en el interior al mismo tiempo. El análisis de esta obra en el artículo de Felman se basa en la decontracción.

\footnotetext{
${ }^{47}$ decontracción: término que inventó Jaques Derrida. En los Estados Unidos, la escuela de Yale desarrolló un método de análisis basado en este término, dirigida por Paul de Man, principalmente en el ámbito de la literatura comparada.
} 
Es razonable y legítima la resistencia y la crítica ante el revisionismo que generaliza y reduce la particularidad y la gravedad del Holocausto. Sin embargo, si lo único y particular del testimonio que nos muestra Shoah es la identificación particular con Israel (como el interior perjudicado) exclusivamente hasta el final, no podemos estar de acuerdo con esta idea.

Superando la instancia de la postura política y crítica del autor, honestamente lo que observamos en esta obra es el fracaso del viaje de Karski del interior al exterior del gueto, el silencio de Srebnik con su sonrisa calmada, el encuentro fallido con lo real (aunque además tal encuentro solo podamos captarlo y reconocerlo posteriormente). Registros que solo podrán comprender quienes vivan posteriormente y se conviertan en testigos. Todo esto nos obliga a reflexionar sobre el valor y el significado de este encuentro.

La obra Shoah nos conciencia del valor de hallar lo que fue ocultado, visibilizar lo invisible. La consideración y la reflexión que exige Shoah -respetando las particularidades del Holocausto- en sí solo nos lleva ver una franja de Gaza envuelta entre paredes como si fuese un gueto, así como los pequeños interiores colonizados por el imperialismo europeo. Nos exigirá llegar a oír la voz olvidada, respetando lo único y particular de cada quien.

Contradictoriamente, la obra Shoah tiene el poder de sacudir las creencias hasta la autoconciencia. Este poder es un elemento importante del arte si tratamos de comprender su meta. Shoah muestra el poder estatal israelí y el de los espectadores externos al problema de Palestina. Espectadores que por su parte designan «al problema de dos mil años de religión» con evasivas estereotipadas como parodias de mal gusto. Por miedo a malhumorarnos con tanto absurdo o a que tantas catástrofes se repitan, cerramos los ojos, lo cual nos recuerda al silencio de Srebnik con su sonrisa calmada. Tras ver Shoah, no podemos dejar de reconocerlo. Esta es, consideramos, la consecuencia de la intervención artística que aporta al individuo otras perspectivas, abriendo nuevas posibilidades.

Añadimos una explicación sobre nuestra comprensión de la teoría de Felman. Por supuesto, no pretendemos negar al completo su opinión. De hecho, estamos muy de acuerdo en 
introducir su teoría como base fundamental de análisis en nuestra obra posteriormente, en especial lo concerniente a la importancia de buscar y encontrar la función artística en el arte. Tampoco tenemos ninguna intención de juzgar la esencia de Israel, ni ponemos ningún reparo sobre el impacto que el país causa en Lanzmann, o sobre sus diferencias con Sartre en relación a la cuestión judía. Además, el análisis de Felman sobre la obra, su contextualización y la explicación de los motivos de Lanzmann para producirla, nos parece que forman parte de un trabajo admirable que nos inspira y proporciona claridad.

Buscar al sujeto que ha permanecido en la ignorancia, encontrarse con el "otro", prestar atención a sus particularidades, ser conscientes de la división entre el exterior y el interior, poder viajar a través de ellos, encontrar su articulación para crear un lugar de intervención y hablar en primera persona desde ahí... Son elementos que hemos estudiado tras el análisis de Shoah y la aplicación de la interpretación del arte psicoanalítico de Felman. Este es indudablemente un momento importante para el desarrollo posterior de nuestro trabajo.

El comentario que realizamos arriba pretende ser una aclaración ante una posibilidad peligrosa: tratar la intervención artística y política que cuestiona la manera de ser de un individuo, como si estuviera enraizado en una etnia y una tierra determinada o en un Estado específico, pone el énfasis en lo único. No hace falta decir que nuestra obra intenta ser una intervención artística cuyo objetivo es seguir penetrando y transportándonos hasta los límites, superando así la línea formada por operaciones simbólicas, desmantelando y oponiéndonos al totalitarismo basado en el nacionalismo y el racismo. 
$\underline{\text { V. El camino para llegar a hablar en primera persona en el documental japonés: }}$ cuestiones de subjetividad, ficción y realidad. 
En esta sección estudiaremos los temas de ficción y subjetividad en el documental, basándonos tanto en la teoría como en su evolución técnica y práctica.

En el ámbito de los teóricos y de los realizadores del documental, existe un amplio debate sobre la división entre ficción y documental, entre subjetividad y objetividad en la expresión. La cuestión sobre el tratamiento de la subjetividad en el documental es una cuestión muy importante en dicho debate, desde los comienzos de su historia. Michael Renov, profesor de la Universidad de California del Sur y especialista en cine y televisión, comenta sobre la situación:

Within the community of documentary practitioners and critics, "subjectivity" has frequently been constructed as a kind of contamination, to be expected but minimized. ${ }^{1}$

Según Renov, la subjetividad en el documental siempre está presente, pero se debe procurar reducir y/o eliminar. Pero, como ya sabemos, en los años noventa en diversas versiones del documental -sobre todo en ciertas corrientes como el Self Documentary o el Private Documentary-, la subjetividad se convierte en un factor indispensable para la expresión audiovisual. Renov indica que el cambio comenzó en los años setenta, cambio que sin embargo ya se puede encontrar germinado en los años sesenta.

El Cinéma-vérité ${ }^{2}$ y el Direct Cinema (cine directo) ${ }^{3}$ de los años sesenta se convirtieron en el centro de una corriente que comienza a cuestionar la subjetividad y la objetividad en la

\footnotetext{
1 Renov, Michael: New subjectivities: Documentary and Self-Representation in the Post-Vérité Age. Transformations in Film as Reality (Part Three) Documentary Box \#7. http://www.yidff.jp/docbox/7/box7-1e.html, accedido el 5 diciembre del 2008.

Dentro de la comunidad de los profesionales y de los teóricos del documental, "la subjetividad" ha sido frecuentemente conceptualizada como un tipo de contaminación que es de esperar, pero que debe ser minimizada. [Traducción propia]

${ }^{2}$ Cinéma-vérité: el término significa «cine-verdad» en francés y se aplica a una serie de películas documentales que se esfuerzan por resultar inmediatas, espontáneas y auténticas por medio de un equipamiento portátil y discreto y el rechazo de cualquier línea o concepto narrativos preconcebidos en relación con el material. Cinéma-vérité fue el término empleado por Jean Rouch para describir la película que filmó con Edgar Morín, Chronique d'un été (Crónica del verano, 1960), considerada como la primera de estas obras. La teoría y la práctica del Cinéma-vérité seguían hasta cierto punto al pionero del cine ruso Dziga Vertov, quien también empleó el término «cine verdad» (Kino-pravda) para referirse a una serie de noticiarios, y, en menor grado,
} 
expresión audiovisual. Ambos movimientos documentalistas surgieron casi simultáneamente, cada uno en diferente lugar (Francia y EE.UU.). Supusieron un cambio radical tanto en la teoría como en la práctica de la expresión cinematográfica. Para su surgimiento, fue indispensable la aparición de la cámara de hombro y el empleo del magnetófono sincrónico. A lo largo del presente capítulo trataremos de abordar los detalles y las referencias de estos dos movimientos cinematográficos basándonos en su evolución técnica.

Fuera del ámbito del Cinéma-vérité y del Direct Cinema, Renov examina desde la perspectiva de la subjetividad el documental de Jonas Mekas como obra conmemorativa de los años setenta. El gran trabajo de Mekas ha sido considerado como su diario personal en un soporte cinematográfico. Hoy en día, se encuentran muchas referencias que analizan los trabajos de Mekas, Chantal Akerman y otros más como los orígenes del Private Documentary (relatos sobre asuntos privados e íntimos). Renov mantiene una opinión al respecto un tanto diferente: considera que los tipos de trabajo como el de Mekas y el de Akerman son una representación de lo privado, pero no son separables de la esfera pública por varias razones.

(...) the maker's subjectivity is explicitly aligned with social affiliations. (...) but in these instances autobiographical discourse is conditional, contingent on its location within an explicit social matrix. A particularly rich example of this phenomenon occurs with work of that explore exilic identity, films such as Joans Mekas's Lost, Lost, Lost (1975), Chantal Akerman's News from Home (1975) (...)

Although Mekas's magisterial film has most frequently been categorized as an autobiographical work of the American avant-garde, in fact it charts at least three

también las del pionero americano del documental Robert Flaherty. [Konigsberg, Ira: Diccionario técnico Akal del cine, trad. Enrique Herrando Pérez y Francisco López Martín, Madrid 2004, p. 114]

${ }^{3}$ Cine directo: tipo de documental que surgió en América durante la década de los sesenta. El cineasta Albert Maysles lo bautizó con ese nombre para sugerir su acercamiento directo, inmediato y auténtico al tema tratado. En él se evita plantear tanto la narración como la perspectiva desde la que se abordará al sujeto, lo que no puede decirse de la mayoría de los documentales anteriores. Los acontecimientos parecen filmados exactamente tal y como sucedieron, sin ensayos previos y con el montaje mínimo. (...) Este tipo de cine se desarrolló inicialmente sobre todo a través de los documentales realizados para la televisión por Robert Drew y Richard Leacock, cuyo primer trabajo fue Primary (Primarias, 1960), sobre la lucha en las primeras elecciones celebradas en Wisconsin entre Hubert Humphrey y John F. Kennedy. [Konigsberg, Ira: Diccionario técnico Akal del cine, Op.cit. p. 99] 
histories over a fourteen year period (1949-1963) -that of the Lithuanian exiles, the "ban the bomb" social protest movement of the late 1950s/early 1960s and the emergent underground film scent of the same period. This filmic documentation takes as its pivot Mekas's own history and experience but envelopes it in layers of historical documentation. Mekas's subjectivity is eloquently performed across decades of real time, three hours of film time, but his is an identity constituted, as Aronowitz has argued, by multiple and specific relations to institutions and significant others, all of whom are in motion. ${ }^{4}$

El trabajo de Mekas se ha considerado como un diario personal llevado al formato de película de $16 \mathrm{~mm}$. Las escenas filmadas tratan sobre su vida cotidiana, y sobre su intimidad relacionada con los lituanos exiliados en Estados Unidos, así como con el movimiento social contra las bombas atómicas y la corriente artística underground film de aquel momento. Renov no niega que los trabajos abordan los asuntos privados de los autores, pero enfocarse solo en lo privado separándolo de lo público no nos permite una interpretación completa. Renov argumenta que esta obra es un documental histórico, pero cuyo eje es la subjetividad de Mekas.

Es decir, el trabajo de Mekas constituye una expresión en forma de diario autobiográfico, en el cual nos relata su vida privada, explorando su identidad con los registros audiovisuales. Al mismo tiempo, sin embargo, es una representación de la historia

\footnotetext{
${ }^{4}$ Renov, Michael: New subjectivities: Documentary and Self-Representation in the Post- Vérité Age. Transformations in Film as Reality (Pat Three) Documentary Box \#7. http://www.yidff.jp/docbox/7/box7-1-e.html, accedido el 11 de febrero del 2009.

(...) la subjetividad del creador está explícitamente en línea con sus afiliaciones sociales... Pero en estos casos, el discurso autobiográfico es condicional, supeditado a su ubicación dentro de una matriz social explícita. Un ejemplo particularmente representativo de este fenómeno lo constituye el trabajo sobre el exilio que explora la identidad, con películas como las de Jonas Mekas "Lost, Lost, Lost” (1975) o la de Chantal Akerman "Noticias desde el Hogar" (1975) (...)

A pesar de que la magistral película de Mekas ha sido más frecuentemente categorizada como una obra autobiográfica de la vanguardia americana, en realidad representa, al menos, tres historias en un período de catorce años (1949-1963) - la del exilio lituano, la de la campaña para el desarme nuclear como movimiento social de protesta a finales de los 1950 y comienzos de los 60, y la del incipiente cine underground en el mismo período. La documentación fílmica toma como eje la propia historia y experiencia de Mekas, pero se encuentra envuelta en capas de documentación histórica. La subjetividad de Mekas se percibe de manera elocuente a través de décadas en el tiempo real (y de tres horas en la película), pero su identidad, como Aronowitz ha argumentado, está constituida por múltiples y específicas relaciones con instituciones y otras personas importantes, todos ellos en movimiento.[Traducción propia]
} 
enmarcada en un contexto social, político y cultural. Su trabajo también muestra una realidad en la cual la historia privada y autobiográfica solo puede ser contada dentro de unas relaciones sociales y culturales. Su trabajo recoge unas imágenes audiovisuales que simbolizan su vida cotidiana inevitablemente encuadrada en una red política, social y cultural (en su actividad contra la bomba atómica, como exiliado lituano y en lo relativo al género underground).

Renov basa su argumento en la teoría de Annette Kuhn, quien ilustra la dificultad a la hora de dividir lo público y lo personal/privado en la imagen.

The images are both "private" (family photographs) and "public" (film, news, photographs, a painting): though, as far as memory at least is concerned, private and public turn out in practice less readily separable than conventional wisdom would have us believe... [If] the memories are one individual's, their associations extend far beyond the personal. They spread into an extended network of meaning that bring together the personal with the familial, the cultural, the economic, the social, and the historical. Memory work makes it possible to explore connections between "public" historical events, structures of feeling, family dramas, relation of class, national identity and gender, and "personal" memory. In these cases, histories outer and inner, social and personal, historical and psychical coalesce; and the web of interconnections that binds them together is made visible. ${ }^{5}$

La conciencia de la relación inseparable entre lo privado y lo público, y la continuidad entre el interior y el exterior de la historia, se convierten en conceptos fundamentales de las obras del Private Documentary y del Self Documentary, ambos como Self-Representation. Renov

\footnotetext{
${ }^{5}$ Kuhn, Annette, Familiy Secrets: Acts of Memory and Imagination, London Verso, 1995, p. 4 [citado en en Renov, Michael, Op.cit.] Las imágenes son a la vez "privadas" (fotografías familiares) y "públicas" (cine, noticias, fotografías, una pintura): sin embargo, al menos en lo que respecta a la memoria, la esfera pública y la privada en la práctica son menos fácilmente separables de lo que la sabiduría mundial convencional nos hace creer... [Si] los recuerdos son de una persona, las asociaciones se extienden más allá de lo personal. Se propagan en una red amplia de significados que unen lo personal con lo familiar, lo cultural, lo económico, lo social, y lo histórico. El trabajo con la memoria hace posible explorar las conexiones entre lo "público" de los acontecimientos históricos y las estructuras de los sentimientos, los dramas familiares, las relaciones de clase, género e identidad nacional, y la memoria "personal". En estos casos, se unen las historias interiores y exteriores, sociales y personales, históricas y psíquicas, y esa red de interconexiones se hace visible. [Traducción propia]
} 
afirma que este concepto surge bajo una gran influencia del feminismo que argumentaba que "lo personal es lo político".

En relación con la expresión documental y la posible división entre ficción y realidad, subjetividad y objetividad, destacaremos en este momento otra cuestión importante, según Gilles Deleuze ${ }^{6}$. Este filósofo francés reflexionó sobre las películas de un cierto modo global. En su obra Imagen-tiempo, Estudio del cine $2^{7}$, Deleuze analiza a algunos documentalistas y sus trabajos, tales como Jean Rouch $^{8}$ (Cinéma-vérité) y Pierre Perrault ${ }^{9}$ (“Cine de lo vivido”). Ellos filmaron la realidad frente a la cámara, es decir, intentaron evidenciar ante el espectador la presencia de la cámara que filma a las personas objetivo del rodaje.

\begin{abstract}
La evolución de los dos autores sería difícil de explicar si nos limitamos a invocar la imposibilidad de alcanzar un real bruto; todo el mundo supo siempre que la cámara ejerce una acción sobre las situaciones, y que los personajes reaccionan ante la presencia de la cámara, y esto no perturbaba a Flaherty ${ }^{10}$ ni a Leacock ${ }^{11}$, quienes no veían en ello más que un falso problema. ${ }^{12}$
\end{abstract}

\footnotetext{
${ }^{6}$ Gilles Deleuze: uno de los más influyentes filósofos franceses de su generación. Es autor del mencionado libro La imagen-tiempo, el segundo volumen de Estudio sobre cine. También, entre otros muchos libros, escribe Foucault, El anti-Edipo (con Félix Guattari), Lógica del sentido o El pliegue. [cubierta de Deleuze, Gilles: La imagen-tiempo. Estudio sobre cine 2, Trad. Irene Agoff, Barcelona: Paidós, 1986]

${ }^{7}$ Deleuze, Gilles: La imagen-tiempo. Estudio sobre cine 2, trad. Irene Agoff, Barcelona, Paidós, 1986. Fue publicado en 1985 en París, como el Segundo tomo del Estudio sobre cine, escrito por Deleuze, Gilles en 1983 [ $L a$ imagen-movimiento. Estudio sobre cine 1, trad. Irene Agoff, Barcelona, Paidós, 1984.] Estas obras comienzan a tratar el cine como factor indispensable a considerar en la filosofía sobre la percepción contemporánea.

${ }^{8}$ Jean Rouch (1917-2004), antropólogo y cineasta francés, reconocido principalmente como autor de la Nouvelle vague (Nueva ola.)

${ }^{9}$ Pierre Perrault (1927- 1999), cineasta, poeta, dramaturgo y realizador de radio de Quebec. Su filmografía y biografía se encuentran en la web NFB.ca, la cual facilita las películas producidas por la National Film Board of Canada: http://www.onf.ca/selections/denys-desjardins/loeuvre-de-pierre-perrault/, accedido el 02 de diciembre de 2010 .

${ }^{10}$ Robert Flaherty (1884-1951), autor de la obra clásica Nanuk, el esquimal (1922), Moana (1926), Hombre de Arán (1934), Louisiana Story (1948) y otras. Fue pionero de la película documental.

${ }^{11}$ Richard Leacock (1921- ), uno de realizadores importantes de Direct Cinema. Empezó su carrera en el cine como operador de la cámara con Flaherty en 1946. Fue el director de la facultad de cine del Instituto Tecnológico de Massachusetts en 1969, permaneció en el mismo instituto hasta 1988. La web oficial es: http://www.richardleacock.com/index.20031205142621.html, accedido el 5 de abril del 2009.

${ }^{12}$ Deleuze, Gilles: La imagen-tiempo. Estudio sobre cine 2, Op.cit., p. 203.
} 
Según Deleuze, el Cinéma-vérité o "cine-realidad" aparta a un lado el problema de la imposibilidad de filmar una cruda realidad como si no existiese la cámara. Pero eso no significa ocultar la presencia de la cámara en la expresión documental, sino todo lo contrario: se visibiliza como medio provocador que filma el fenómeno que ocurre frente a ella. Deleuze juzga que todo el mundo conoce esta realidad acerca del documental: la cámara provoca, filma y representa.

Sin embargo, no será tan fácil en la realidad. Existe una preocupación por que el documental sea una representación objetiva e imparcial que capte el hecho tal y como es. La referencia de Renov también indica esta tendencia a considerar que el documental debería ser objetivo. Principalmente en los medios de comunicación, los documentales se interpretan de este modo. Por ejemplo, en Japón esta idea prevalece para los reportajes periodísticos y los documentales científicos emitidos en televisión. La mayoría de espectadores accede a los documentales solo por vía televisiva, y pueden así tener la impresión de que el documental es la verdad y la ficción es falsa.

Suponemos que esta reclamación vendría dada por la tendencia de que el documental debe ser verdad. Sin embargo, este esquema tan sencillo no siempre funciona. Deleuze afirma la nulidad del esquema: "documental = verdad = realidad", $y$ "ficción $=$ falso $=$ invento", ni tampoco, "documental = objetividad" y "ficción = subjetividad".

Nos interesa considerar un aspecto de este nuevo tipo de relato tal como aparece en cualquier otro ámbito. Si pensamos en las formas que desde mucho antes venían recusando la ficción, comprobamos que el cine de realidad reclamaba unas veces hacer ver objetivamente medios, situaciones y personajes reales, y otras mostrar subjetivamente las maneras de ver de estos mismos personajes, la manera en que ellos mismos veían su situación, su medio, sus proclamas. Sumariamente, estaban el polo documental o etnográfico y el polo encuesta o reportaje. Estos dos polos inspiraron obras maestras, y se mezclaron de distintas formas (Flaherty por un lado 
y por otro lado Grierson ${ }^{13}$ y Leacock). Pero, al recusar la ficción, si bien este cine descubría nuevos caminos, conservaba y sublimaba una idea de verdad «que dependía de la propia ficción cinematográfica»: estaba lo que ve la cámara, lo que ve el personaje, el antagonismo posible y la resolución necesaria de los dos. ${ }^{14}$

Según el análisis de Deleuze, incluso en el ámbito del Cinéma-vérité y en su recuse de la ficción, existen dos polos: el documental etnográfico con mayor apariencia objetiva y el reportaje, más subjetivo.

Pone como ejemplo a Flaherty, quien se encontraría en el polo etnográfico-objetivo en su realización de Nanuk, el esquimal, una obra maestra del documental clásico. En Nanuk fueron grabadas unas escenas sobre la supervivencia salvaje de los esquimales, filmando algunas costumbres que ya habían perdido, con personajes que estaban abandonando alguna de sus tradiciones en sus estilos de vida ${ }^{15}$. Se encuentran algunas construcciones de la escena al momento de filmar limitadas por dificultades técnicas del rodaje. No estaban basadas en la ficción ni en la historia inventada. Su obra intenta representar la vida de las personas habituadas a tierras primitivas, inexploradas por la civilización occidental. Por eso, se pone el énfasis en la mirada de la cámara observadora-objetiva sobre los motivos.

En el otro polo, en el reportaje subjetivo, encontraríamos a Grierson (en ocasiones reconocido como fundador del documentalismo inglés), quien manifestó que el documental debe servir como arma para mejorar la sociedad y denunciar la injusticia, mientras se iluminan las sombras de la sociedad. En este sentido, a través de la revelación de la injusticia por medio del documental, el mensaje debería llegar a los espectadores. Por ello,

\footnotetext{
${ }^{13}$ John Grierson dirigía durante las décadas de 1920 y 1930 el movimiento documental inglés (junto con Paul Rotha), el cual tenía por objeto cambiar el mundo a través de efectos educativos y propagandísticos.

${ }^{14}$ Ibíd., p. 201.

${ }^{15}$ A este respecto, en Nanuk, el esquimal se encuentran unas referencias típicas del Documental de ficción. Existe cierta polémica sobre esta película en cuanto a su simple consideración como "documental". Sin embargo, aunque haya controversia sobre el estilo en la dirección de su trabajo, Flaherty sigue siendo reconocido como el padre del documental hasta hoy en día. Una referencia sobre Nanuk, el esquimal: por ejemplo, Augusto M. Torres comenta en la parte que presenta a: Robert Flaherty (1884, Iron Mountain; 1951, Dummerston, Estados Unidos): (...) Entre 1913 y 1914 rueda un documental sobre los esquimales, pero un incendio destruye el negativo. Vuelve en 1919, financiado por los peleteros Révillon, para pasar quince meses entre los esquimales y rodar su primer largometraje Nanuk, el esquimal (Nanook of the North, 1922), un documental personal de ficción. [Martínez Torres, Augusto, Diccionario de directores de cine, Madrid: Ediciones del Prado, 1998, pp. 105-106]
} 
la obra contiene ya desde el principio una marcada subjetividad que se refleja en la mirada de la cámara sobre los motivos.

No obstante, ninguno de los dos realizadores dudaba que su película registrase la realidad y la verdad frente a la cámara. La imagen de supervivencia de los esquimales en la lucha continua contra las amenazas de una naturaleza siempre sorprendente y de su convivencia con la misma no es una falsa ilusión. La imagen de la dura labor de los obreros y de la situación pobre, humilde y socialmente injusta tampoco era una fantasía. Trátese bien del estilo etnográfico-documental o bien de la encuesta-reportaje, ambos trabajos piden a sus espectadores ser observados como un registro de hechos reales y una historia verdadera.

Claro está que la expresión documental con imágenes obtenidas de la realidad, con personajes reales, con vidas reales, ha obtenido distintos efectos en el cine de ficción. Sin embargo, Deleuze indica que el relato de la película está basado en una idea de verdad «que dependía de la propia ficción cinematográfica». Para comprender su argumento debemos comprender la función de relato cinematográfico.

Deleuze desarrolla su argumento en el contexto del relato como la tercera instancia en el cine, más allá de la descripción y de la narración. Basándose en el proceso del montaje de las imágenes, Deleuze explica esquemáticamente la función de la imagen subjetiva ${ }^{16} \mathrm{y}$ objetiva, luego determina el relato en este caso:

(...) el relato concierne en general a la relación sujeto-objeto, y al desarrollo de esta relación (mientras que narración concernía al desarrollo del esquema sensoriomotor). El modo de verdad encuentra, entonces, su plena expresión no ya en la conexión sensoriomotriz, sino en la «adecuación» del sujeto y el objeto. No obstante, hay que precisar qué son el objeto y el sujeto en las condiciones del cine. Por convención, se llama objetivo a lo que «ve» la cámara, y subjetivo a lo que ve el

\footnotetext{
${ }^{16}$ Cámara subjetiva. uso de la cámara por el que se produce una focalización interna, es decir, la cámara se identifica con uno de personajes diegéticos y nos ofrece una visión y una escucha subjetivas, el audioespectador ve y escucha lo mismo que el personaje. [Cuéllar Alejandro, Carlos A., Vocabulario Básico del audiovisual, Valencia: Ediciones de la Filmoteca IVAC, 2004, p. 24.]
} 
personaje. Esta convención solo rige en el cine, no en el teatro. Ahora bien, es preciso a su vez que la cámara vea al personaje: el mismo personaje unas veces ve y otras es visto. Pero además la propia cámara trae al personaje visto y lo que el personaje ve. Podemos considerar entonces que el relato es el desarrollo de los dos tipos de imágenes, objetivas y subjetivas, su compleja relación, que pueda llegar incluso al antagonismo pero que debe resolverse en una identidad del tipo Yo=Yo: identidad de personaje visto y que ve, pero también identidad del cineasta-cámara, que ve al personaje y lo que el personaje ve. ${ }^{17}$

El relato en la expresión cinematográfica es una relación entre sujeto y objeto. La imagen subjetiva es la que el personaje ve, mientras que la imagen objetiva es la imagen de este personaje que la cámara ve sin personalizarla. Las dos imágenes son captadas por la misma cámara y serán proyectadas en la misma pantalla tras el montaje. Para que el espectador entienda el relato, tendrá que suponer la veracidad de la imagen subjetiva. Es decir, debe creer en la imagen que ve el personaje, aunque sea captada por la cámara. En otras palabras, exige que el espectador se identifique con este personaje, aceptando que la imagen mostrada es la misma que el sujeto vio. Al mismo tiempo, alguien está mirándolo a él para sustentar ese mundo, donde existen la primera y la segunda persona, pero se necesita una tercera mirada, desde donde se vean esos dos personajes. Esta es precisamente la función del relato de ficción. Entonces, Deleuze llama «veneración» a esta postura en la que el espectador se identifica e identifica a cada personaje de manera coherente, según la distinción de las imágenes subjetiva y objetiva.

A Deleuze le llama la atención esta función de construcción y conservación de la identidad en el relato cinematográfico, función según la cual se mantienen las identidades por operaciones propias de la ficción. Así pues, la relación entre ficción y documental es complicada, especialmente en lo concerniente a la idea de la verdad. En los trabajos de escenas clásicas, era muy importante poder captar o descubrir una realidad que se encontraba fuera de la escenificación interpretada por los actores profesionales y otras preparaciones previas. A pesar de rehuir de la ficción, el documental cinematográfico no

\footnotetext{
${ }^{17}$ Ibíd., pp.198-199.
} 
escapa de ella. Deleuze se refiere a Nietzsche ${ }^{18}$ con el fin de aclarar esta relación entre la ficción, lo real y la verdad:

\section{(...) Era muy importante recusar las ficciones preestablecidas en provecho de una} realidad que el cine podía captar o descubrir. Pero se abandonaba la ficción en provecho de lo real, al mismo tiempo que se conserva un modelo de verdad que suponía a la ficción y emanaba de ella. Eso que había mostrado Nietzsche ${ }^{19}$, que la idea de lo verdadero era la ficción más profunda en el corazón de lo real, el cine todavía no lo había descubierto. La veracidad del relato seguía fundándose en la ficción. Muchas cosas cambiaban cuando se aplicaba la idea o el modelo de lo verdadero a lo real, pues la cámara se dirigía a un real preexistente pero, en otro sentido, las condiciones del relato no habían cambiado en nada, lo objetivo y lo subjetivo quedaban desplazados pero no transformados; las identidades se definían de otra manera pero se definían; el relato resultaba veraz, realmente-veraz, en lugar de ficticiamente-veraz. Solo que la veracidad del relato no había dejado de ser ficción. ${ }^{20}$

Según Deleuze, aunque la película trate sobre asuntos reales con personajes, situaciones y medios reales, con los registros de su imagen, el relato en sí no deja de basarse en la ficción. Cuanto más se construyen y conservan las identidades como un personaje unido integral en el relato, más veraz resulta. Según Deleuze, existen dos tipos de veracidad, uno que es

\footnotetext{
${ }^{18}$ Nietzsche, Friedrich Wilhelm (1844-1900): filósofo y crítico de la cultura alemán. [Audi, Robert (ed.): Diccionario Akal de Filosofía, Op.cit., p. 708]

${ }^{19} \mathrm{La}$ idea de Nietzsche sobre la verdad es muy distinta de la comprensión convencional. Aquí citaremos una explicación contenida en el diccionario filosófico: (...) para Nietzsche no hay «verdad» en el sentido de correspondencia de lo que pensamos o decimos con el «ser» y a fortiori, no hay «verdadero mundo del ser» con respecto al cual imaginar siquiera sea correspondencia. (...) Nuestra comprehensión puede limitarse al modo en que la vida y el mundo se presentan e intervienen en nuestra experiencia. Pero si son el único tipo de realidad, no hay ya ninguna razón para disociar de ella las nociones de verdad, de conocimiento y de valor. La cuestión pasa a ser entonces cuál es el mejor modo de interpretar y evaluar lo que encontramos cuando exploramos la vida y el mundo. (...) Al hablar de la muerte de Dios, Nietzsche está pensando no solo en el abandono de la hipótesis de Dios (que él consideraba completamente «indigna de creencia», deudora en cuanto su origen y atractivo de la ingenuidad, el error, la necesidad demasiado humano y la ulterior motivación), sino también el rechazo de todo sustituto metafísico. Asimismo, criticó y rechazó los postulados relacionados de «almas» substanciales y «cosas» autocontenidas, considerando que las dos cosas son ficciones ontológicas que se limitan a reflejar abreviaturas lingüístico-conceptuales convenientes (aunque oportunas) para productos, procesos y conjuntos de la relaciones funcionalmente unitarios [Audi, Robert (ed.): Diccionario Akal de Filosofía, Op.cit, p. 710.]

${ }^{20}$ Ibíd., p. 201.
} 
ficticiamente-veraz y que corresponde al cine de ficción, y otro que es realmente-veraz y corresponde al documental. En el caso de la película de ficción, a través del montaje de las imágenes, de las miradas, la cámara subjetiva de personaje ficticio, la imagen del mismo y la cámara que construye su identidad, resulta una veracidad ficticia. A su vez, la película de realidad capta las imágenes de las escenas reales, pero hace la misma operación de montaje de las miradas y genera el relato cinematográfico, se conservan las identidades como cineasta documentalista y como personajes reales, resultando así una veracidad real. De cualquier modo, la veracidad del relato no puede excluir el carácter de ficción, y así la película documental no está libre de ser ficción.

Si es verdad lo que dice Deleuze sobre Nietzsche, la idea de lo verdadero era la ficción más profunda en el corazón de lo real, la ficción y lo real no se pueden dividir. La idea de la verdad está en sí basada en una ficción, tanto la idea de ser verdadero como la del mundo verdadero son ficción. Entonces, ¿resulta en vano cuestionarse si son verdad los asuntos en una representación documental? Deleuze comenta que el cine todavía no había descubierto esta cuestión. Seguramente los cineastas pioneros tenían confianza en que representaban una verdad basada en la realidad. Hasta cierto momento, el cine en general (también el cine documental) no cuestionaba la calidad de la verdad ni el relato verdadero. Por eso persistía el debate sobre la división entre ficción y realidad en la expresión cinematográfica, y sobre todo en el documental. Sin embargo, ciertos movimientos cinematográficos -al igual que el documental a partir de los años sesenta-, empiezan a cuestionar la calidad de la verdad en relación a la ficción.

La ruptura no está entre la ficción y la realidad, sino en el nuevo modo de relato que las afecta a ambas (...).

Por ejemplo, Perrault critica toda clase de ficción, lo hace en el sentido de que ella forma un modelo de verdad preestablecido que expresa necesariamente las ideas dominantes o el punto de vista del colonizador, incluso quien la forja es el autor del 
film. La ficción es inseparable de una «veneración» que la presenta como verdadera, en la religión, en la sociedad, en el cine, en los sistemas de imágenes. ${ }^{21}$

Entonces, la crítica a la ficción no solo implica su separación de la realidad. Lo que plantea Deleuze citando a Pierre Perrault es que, en caso de criticar a la ficción, se debe criticar la complicidad entre la ficción y una «veneración» que siempre refleja las ideas dominantescolonizadoras basadas en el modelo de verdad.

Lo que indica Deleuze es muy importante porque, sobre todo en el cine, en las expresiones documentales (desde la época de Flaherty captando las imágenes del "otro") esta idea de los colonizadores que oprimen al "otro" nunca dejaba de estar presente. Miles de ejemplos de películas sobre viajes a sitios lejanos sin civilización occidental mantienen una mirada desde el exotismo, con una mezcla compleja de sentimientos de desprecio hacia lo salvaje y de adoración nostálgica a lo primitivo. En estos ejemplos podemos encontrar la función del Orientalismo $^{22}$ planteada por Edward W. Said ${ }^{23}$. Es decir, esa mirada hacia el "otro" sirve para aumentar el valor y la autoridad de Occidente, magnificándose a sí mismo por su capacidad de querer y poder conocer al "otro". La mirada justifica la dominación occidental en cualquier sitio; al mismo tiempo, construye la imagen mística de Oriente. Hasta los años sesenta, cuando aparecen el cine directo de Cassavetes y de Shirley, el «cine de lo vivido» de Pierre Perrault y el «cine-verdad» de Jean Rouch, no surge esta crítica contra la complicidad entre la ficción y la idea de dominación-colonización.

En este contexto, Deleuze argumenta la importancia de la liberación de la ficción desde un modelo de verdad. Lo que Deleuze llama «ficción de fabulación» en varios trabajos sobre Perrault es en realidad, una teoría que aprehende del mismo Nietzsche.

\footnotetext{
${ }^{21}$ Ibíd., p. 202.

${ }^{22}$ Said, Edward W., Orientalismo, Trad. María Luisa Fuentes, Barcelona: Roandom House Mondadori/ Debolsillo, 2009.

${ }^{23}$ Edward W. Said (1935-2003) nació en Jerusalén y pasó parte de su juventud en el Líbano y El Cairo. Se educó en el Victoria College de El Cairo, en el Mount Hermon School de Massachusetts y en las universidades de Princeton y Harvard. En esta última ejerció la docencia durante breves períodos, así como en las universidades de Yale y Johns Hopkins, pero fue en la Universidad de Colombia donde desarrolló casi toda su carrera investigadora como catedrático de literatura inglesa y comparativa [Said, Edward W. Orientalismo, Op.cit., p. 4.]
} 
Nadie entendió tanto como Perrault la consigna de Nietzsche: «suprimid vuestras veneraciones». Cuando Perrault se dirige a sus personajes reales de Quebec, no es solamente para eliminar la ficción sino para liberarla del modelo de verdad que la penetra, y encontrar en cambio la pura y simple «ficción de fabulación» que se opone a este modelo. Lo que se opone a la ficción no es lo real, no es la verdad, que siempre es la de los amos o los colonizadores, sino la ficción fabuladora de los pobres, que da a lo falso la potencia que lo convierte en una memoria, una leyenda, un monstruo. $^{24}$

Deleuze presenta dos niveles de ficción. En primer lugar, la ficción como veneración que sostiene la verdad de los amos colonizadores y que se representa como verdad en el cine. Este tipo de ficción sostiene el relato y la veracidad. Por supuesto, para Deleuze este tipo de ficción es un medio del poder autoritario del amo colonizador que debe ser vencido y superado. Y, en segundo lugar, el otro tipo de ficción es la de los pobres, «ficción de fabulación», la cual potencia a lo falso para llegar a convertirlo en una memoria, una leyenda, un monstruo.

La verdad es siempre la de los amos colonizadores; entonces, a los pobres dominados solo les queda lo falso. En este punto, Deleuze utiliza las palabras "el amo colonizador" y "el pobre", lo cual nos hace reflexionar sobre el esquema de dominio del colonialismo y la relación económica entre el dominador y el dominado. La idea de Deleuze es un concepto fundamental del poscolonialismo. El amo, el sujeto europeo, produce la verdad y su justicia con el poder de aplicarlos sobre todos los que están bajo su dominio. Como consecuencia, los demás permanecerán como el "otro" contrario al sujeto y solo acarrearán lo falso y la injusticia.

Como hemos visto en el capítulo anterior, Spivak indica la existencia de un ser mudo rechazado. Ambos -colonizador y colonizado- le niegan la oportunidad de hablar al subalterno sexuado sobre sí con voz propia, exigiéndole que se pronuncie solo sobre la verdad del sujeto colonizador o sobre el deseo de la parte etnocentrista patriarcal. También

\footnotetext{
${ }^{24}$ Loc. cit.
} 
vimos el argumento de Felman que insistía en la imposibilidad en el habla de la mujer y en el testimonio del "otro". Sin embargo, ni el argumento de Spivak ni el de Felman favorecen a que los marginados pobres no permanezcan mudos. Lo que plantea Deleuze no es que ellos mismos hablen sobre su verdad, sino que los pobres fabulen para visibilizar la realidad y el engaño de la veracidad. Nos parece que la intención de Deleuze es compatible con los argumentos feministas anteriores.

Imaginamos que Deleuze confía en la posibilidad de exteriorizar el problema a través de la representación ficticia en la expresión cinematográfica. Fijémonos, pues, en esa capacidad del dispositivo audiovisual que nos permite representar la relación entre verdad, ficción y realidad en varios niveles de auto-referencia. Quizás el empleo del término "autoreferencia" pudiere resultar excesivo, pero seguramente aquí se encuentre un indicio del arte contemporáneo audiovisual que incluye una auto-referencia en sí. Lo observaremos durante el presente capítulo. Posiblemente podamos decir que esa «ficción de fabulación», con cierta potencia para hacer temblar al modelo de verdad, puede revelar la complicidad entre la idea de verdad y de «veneración», basadas en la visión de la parte dominante Nos parece que Deleuze pretende desarticular la ficción y ello serviría para romper y superar el modelo de verdad convencional.

Lo que el cine debe captar no es la identidad de un personaje, real o ficticio, a través de sus aspectos objetivos y subjetivos. Sino el devenir del personaje real cuando él mismo se pone a «ficcionar», cuando entra «en flagrante delito de leyenda», y contribuye así a la invención de su pueblo. No se puede separar al personaje de un antes y un después, pero él los reúne en el tránsito de un estado al otro. Él mismo pasa a ser otro, cuando se pone a fabular sin ser nunca ficticio. Y el cineasta, por su lado, se hace otro cuando «se intercede» así personajes reales que reemplazan en bloque sus propias ficciones por sus propias fabulaciones. Ambos se comunican en la invención de un pueblo. ${ }^{25}$

${ }^{25}$ Loc.cit. 
La identidad bien establecida de un personaje en una película siempre necesita tanto de esta veracidad como de un relato de ficción. Según Deleuze, en el cine -sea de ficción o real- lo más importante no es la identidad del personaje basado en el modelo de verdad, sino el devenir del personaje real. Ese devenir es la creación que merece ser llamado arte. Seguramente, la invención de un pueblo es el resultado del trabajo artístico. Pero, ¿cómo es ese devenir del personaje real? Deleuze lo explica citando las obras maestras de Rouch, como Les maîtres fous, Moi un Noir, Jaguar y Cocorico monsieur Poulet, de la siguiente manera:

Si nos limitamos a estas obras maestras, advertimos en primer lugar que el personaje ha dejado de ser real o ficticio, en la misma medida en que ha dejado de ser visto objetivamente o de ver él subjetivamente: es un personaje que atraviesa pasos y fronteras porque se dedica a inventar como personaje real, y se hace tanto más real cuando más inventado. ${ }^{26}$

El personaje cuenta e inventa una ficción de fabulación. De este modo, se percibe mejor su posición real y nos permite centrar la mirada en sus aspectos reales o ficticios. Es un personaje que traspasa el límite imaginario que divide realidad y ficción, imagen objetiva y subjetiva en la representación audiovisual. La identidad de un personaje desplazado de un modelo de verdad; al mismo tiempo, es desarticulado por la ficción de fabulación. Deleuze confirma este punto en su comentario sobre Dionisos, la gran síntesis de Rouch:

Es preciso que el personaje sea primero real para que afirme la ficción como una potencia y no como un modelo: es preciso que se ponga a fabular para afirmarse tanto más como real y no como ficticio. El personaje no cesa de hacerse otro, y ya no es separable de ese devenir que se confunde con un pueblo. ${ }^{27}$

Deleuze insiste mucho en que el personaje sea el "otro" y participe en la creación de su pueblo. La idea de que el cine debe crear a su pueblo es uno de los argumentos

\footnotetext{
${ }^{26}$ Ibíd., p. 204.

${ }^{27}$ Loc.cit.
} 
fundamentales en su libro sobre el cine, en el cual realiza una clasificación de la imagen y su signo. El cine como arte crea a su pueblo que todavía no existe. Esta idea nos lleva a recordar la teoría sobre la transcendencia del poder del arte, o sobre la posibilidad de formar una nueva comunidad a través de una obra de arte, las cuales mencionara Kant en su Crítica del juicio (1970). Lo explicamos en el primer capítulo; por ello, citaremos solo brevemente una parte de su argumento:

En ningún juicio en donde declaramos algo bello permitimos a alguien que sea de otra opinión, sin fundar, sin embargo, nuestro juicio en conceptos, sino solo en nuestro sentimiento, que ponemos a su base, no como un sentimiento privado, sino como un común. Ahora bien: ese sentido común, para ello, no puede fundarse en la experiencia, pues quiere justificar juicios que encierran un deber (ein Sollen); no dice que cada cual estará conforme con nuestro juicio, sino que deberá estar de acuerdo. Así, pues, el sentido común, de cuyo juicio presento aquí, como ejemplo, mi juicio de gusto, a quien, por tanto, he añadido una validez ejemplar, es una manera forma ideal que, una vez supuesta, permite que de un juicio que concuerde en ella, y esto sobre la misma ya expresada satisfacción en un objeto, se haga, con derecho, una regla para cada uno, porque el principio, si bien solo subjetivo, sin embargo, tomado como subjetivo-universal (una idea necesaria a cada cual), en lo que se refiere a la unanimidad de varios que juzgan, podría, como un principio objetivo, exigir aprobación universal, con tal de que se esté seguro de haberlo subsumido correctamente. ${ }^{28}$

Según Kant, el juicio del gusto es universal. Este juicio no se basa en el principio de la razón, sino en el sentimiento. Pero no se juzga por experiencias personales previas, sino que el juicio estético se basa en el sentido común. Por esta razón, un juicio del gusto siempre exigirá una aprobación del sentido común. Además, a pesar de que ese juicio es subjetivo, al mismo tiempo es un principio universal que exige una aprobación objetiva. Es decir, el juicio del gusto exige la aprobación de los demás. Es una exigencia absoluta: no simplemente se presupone que los demás puedan tener el mismo juicio que nosotros, sino

\footnotetext{
${ }^{28}$ Kant, Immanuel, Crítica del juicio, Madrid, Espasa Calpe, 1977, p. 170.
} 
que deben tenerlo por sentido común. De esta manera, fundamentalmente, no se permite mantener otra opinión sobre el juicio de lo bello. En el capítulo anterior, indicábamos los peligros en la aplicación de este principio del juicio estético en la política práctica. Kant insiste cuidadosamente en que el sentido común no se extrae de un concepto como una manera forma ideal.

Kant vuelve a insistir en que ese sentido común es una forma ideal. Sin embargo, no abandona el proyecto de desarrollar la reflexión sobre el juicio estético. Tras añadir una validez representativa del juicio estético como ejemplo del juicio de sentido común, Kant argumenta la superioridad del juicio del gusto sobre el intelectual. Y define que el gusto es una facultad del juicio que posibilita la comunicación del sentimiento a través de una representación.

Vuelvo a coger el hilo abandonado por este episodio, y digo que el gusto puede ser llamado sensus communis con más derechos que entendimiento sano, y que el Juicio estético puede llevar el nombre de sentido común mejor que el intelectual, si se quiere emplear la palabra sentido para un efecto de la manera reflexión sobre espíritu, pues entonces, por sentido se entiende el sentimiento del placer. Podríase incluso definir el gusto como facultad de juzgar aquello que hace universalmente comunicable nuestro sentimiento en una representación dada, sin intervención de un concepto. $^{29}$

Resumiendo las palabras de Kant, se puede entender que el Juicio estético supera al juicio intelectual. Con la exigencia de aprobación, podemos comunicarnos universalmente a través de una obra de arte. Su observación nos hace imaginar la posibilidad de establecer una nueva comunidad basada en el Juicio estético.

Kant solo menciona el carácter del Juicio estético y sus posibilidades de realización. Sin embargo, esta idea se desarrollaría en el Romanticismo alemán con otros factores añadidos, ya propuestos por Kant en su obra, como la admiración por la naturaleza, la identificación

${ }^{29}$ Ibíd., p. 236. 
del artista como un genio, el respeto al sentimiento, etc. Posteriormente, la discusión acerca de la trascendencia del arte y su posibilidad para crear una nueva comunidad fue utilizada por los Nazis para formar una nación, tal y como se ha indicado en el capítulo anterior. ${ }^{30}$

Con todo, solo mencionaremos que el cine sí tiene como antecedente su uso para la formación de una nación, basándonos en el hecho de la aplicación de los Nazis y en sus miles de películas propagandísticas ${ }^{31}$. Deleuze es muy consciente de este peligro, así que subraya la importancia de distinguir entre pueblo y nación ${ }^{32}$.

\begin{abstract}
Ya no es Nacimiento de una nación, sino construcción o reconstrucción de un pueblo, donde el cineasta y sus personajes se hacen otros juntos y el uno por el otro, colectividad que se extiende cada vez más, de lugar en lugar, de persona en persona, de intercesor en intercesor...

El devenir del cineasta y de su personaje pertenecen a un pueblo, a una comunidad, a una minoría cuya expresión ellos practican y libran (el discurso indirecto libre). ${ }^{33}$
\end{abstract}

\footnotetext{
${ }^{30}$ Hemos desarrollado este tema basándonos en el razonamiento de Benjamín sobre la reflexión y crítica de la estetización de la política, con las indicaciones de Lacoue-Labarthe y Nancy en el apartado I.2.1. También se ha estudiado la posibilidad de formar una nueva comunidad a través del arte en el apartado I.1.3., en la cual abordábamos el asunto desde las teorías feministas de de Spivak y Cornell.

31 Concretamente, el tema de la propaganda en el cine Nazi está resumido en Suplemento. La propaganda y los films de guerra nazi, en Kracauer, Siegfried: De Caligari a Hitler: una historia psicología del cine alemán, trad. Héctor Grossi, Barcelona, Paidós, 1985, pp. 255-290.

${ }^{32}$ Por supuesto, el concepto "Nacimiento de una nación" proviene de la película clásica norteamericana de Griffith que analizó Deleuze en La imagen-movimiento. Sin embargo, parece que no nos desviamos de la verdadera intención de Deleuze. Además de alarmar contra el peligro del fascismo durante los tomos 1 y 2 del Estudio del cine, se encuentran unas indicaciones precisas. Por ejemplo, se compara el trabajo de Griffith con las películas de la Unión Soviética (principalmente de Eisenstein) desde un punto de vista histórico. Deleuze indica el carácter de ambos trabajos como la gran forma. En los últimos pasajes del libro, Deleuze comenta sobre Romm, realizador de Unión Soviética, de la siguiente manera: Romm es discípulo de Pudovkin mucho más de lo que cree (en una generación para la cual la gran forma, a menudo, no es más que una supervivencia o una obligación impuesta de Stalin.)(...) Lo que él quería en Obyknovennie fashizm era un montaje de documentos capaz de evitar una historia del fascismo o una reconstrucción de grandes acontecimientos... [Deleuze, Gilles: La imagenmovimiento. Estudio sobre cine 1, trad. Irene Agoff, Barcelona, Paidós, 1984, p. 253]. Es decir, no son pocas las ocasiones en que la gran forma, como reconstrucción de grandes acontecimientos, y una historia fascista se encuentran en una relación paralela en la expresión cinematográfica. La crítica positiva de Romm [quien introduce el montaje de los documentos para evitar la gran forma], concuerda con nuestra opinión. Si adjuntamos dos comentarios de Deleuze, nuestras indicaciones podrán quedar completadas (sobre Leni Riefenstahl, representante realizador del cine nazi). Deleuze señala el vínculo esencial entre imagen-movimiento y el fascismo. Véanse la página 220 y 349-350 en Deleuze, Gilles: La imagen-tiempo. Estudio sobre cine 2, Op.cit.

${ }^{33}$ Deleuze, Gilles, La imagen-tiempo. Estudio sobre cine 2, Op.cit., p. 206.
} 
El pueblo que espera Deleuze sería totalmente diferente a la nación uniforme establecida por el poder estatal. Su pueblo es de los "otros", el de las minorías que permanecerían eliminadas dentro de la nación uniforme. Observamos la importancia que tiene ser el "otro" en la teoría de Deleuze, no solamente como personaje en el cine, sino que incluso el realizador debe ser "otro".

Así pues, según Deleuze, los autores del documental también deben ser "otros”. Deleuze compara a Rouch y Perrault: ambos empezaron su carera de cineastas con la cámara de hombro y el magnetófono, pero con grandes diferencias de postura no solo cinematográficas y formales, sino también personales.

Para Perrault, se trata de pertenecer a su pueblo dominado y de recobrar una identidad colectiva perdida, reprimida. Para Rouch, se trata de salir de su civilización dominante y de alcanzar las premisas de otra identidad. ${ }^{34}$

Es decir, en el caso de Perrault, permaneciendo pobre en su pueblo, como el "otro", intenta recuperar una identidad colectiva que había sido rechazada y destruida por el sujeto dominante, el amo colonizador. Rouch, en cambio, llega a ser el "otro" abandonando su posición como Sujeto en la civilización dominante. Entonces, ambos tienen la meta de ser el "otro", pero desde diferentes puntos de partida. De todas maneras, Deleuze insiste nuevamente en la necesidad de convertirse en el "otro", la misma necesidad que para los personajes. Y critica una declaración del Cinéma-vérité:

(Perrault y Rouch) los dos autores deben hacerse otros, con sus personajes, al mismo tiempo, que sus personajes deben hacerse otro también. La célebre fórmula: «lo cómodo del documental es que uno sabe quién es y a quién filma», pierde validez. La forma de identidad Yo = Yo (o su forma degenerada, ellos = ellos) cesa de valer para los personajes y para el cineasta, en lo real tanto como en la ficción. Lo que se deja adivinar es más bien, en grados profundos, el «Yo es otro» de Rimbaud. ${ }^{35}$

\footnotetext{
${ }^{34}$ Ibíd., p. 205.

${ }^{35}$ Loc.cit.
} 
De esta forma, para Deleuze no tiene mucho sentido dividir del género cinematográfico en ficción y realidad. Lo importante es poder superar la creencia de la verdad mediante la ficción en la representación cinematográfica, captando el devenir del personaje real que se convierte en el "otro"; y al mismo tiempo, los realizadores deben hacerse "otros". Ya en 1985, Deleuze se refirió a la posibilidad y la importancia artística del cine en el cual el yo es otro, como dijo Rimbaud al analizar el Cinéma-vérité.

En este caso, Deleuze argumenta el vacío en la división entre ficción y realidad en la expresión cinematográfica. Entonces, específicamente en la película documental, ¿tampoco deberíamos dividir ficción y realidad? Para reflexionar sobre esta cuestión citaremos a Makoto Sato ${ }^{36}$, un documentalista japonés, también conocido como teórico del documental. Sato fue profesor en Eigabigakko (Film School of Tokyo) y en la Universidad de Artes y Diseño de Kyoto en los últimos años.

\begin{abstract}
El documental es una ficción. Aunque la película trate sobre una realidad cruda, una vez construida, se convierte en "una realidad que conviene al autor", está alejada de la realidad. Por eso, el documental no sería más que una figura semejante a la realidad. ${ }^{37}$
\end{abstract}

La cita es de El Documental también es ficción, ensayo que se ha convertido en un escrito póstumo de Sato. En su pequeño ensayo explica sus razones para argumentar que el

\footnotetext{
${ }^{36}$ Sato, Makoto (1957-2007): Estudió filosofía en la Universidad de Tokio. En 1981 participó como ayudante de dirección de Aotaka Katori en la película Muko naru umi (The Innocent Sea). Fue asimismo ayudante de dirección de Shinske Ogawa en un episodio de Sennen Nizami no hidokei: Magino-mura monogatari (Sundrial Carved by a Thousand Years of Notches: The magino Village Story/1987). En 1988 se embarcó en la que sería su primera película como director. A lo largo de tres años convivió con su equipo, conformado por siete personas, en las montañas de Niigata. El resultado, Aga ni ikiru (Living on the River Agano), estrenado en 1992, se convirtió bien pronto en un título clásico del cine documental japonés contemporáneo. Ganó numerosos premios por todo el mundo (...). Otros títulos de Makoto Sato son Mahiruno hoshi (Artist in Wonderland/1998), Hanako (2001), Agano kioku (Memories of Aga/2004), y Out of Place. Memories of Edward Said (2005). Makoto Sato es, además, ensayista cinematográfico y profesor en la Film School of Tokyo y en la Kyoto University of Art and Design. Está considerado como uno de los cineastas más elegantes del panorama cinematográfico japonés. Alejado de las corrientes del llamado cine privado, Sato es un heredero consciente de Ogawa y Tsuchimoto, pero con un gran afán experimental que se manifiesta en cada uno de sus nuevos proyectos. [Muguiro, Carlos (et. ál.): El cine de los miles de años: una aproximación histórica y estética al cine documental japonés (1945-2005), Navarra, Festival Internacional de Cine Documental de Navarra, Navarra Dirección General de la Comunicación, 2006, p. 225.]

${ }^{37}$ Sato, Makoto, Documentary mo Ficcion de aru (El documental también es ficción) citada en VV.AA. Gendaishiso. Revue de la pensée d'aujourd'hui (El pensamiento contemporáneo), Documentary Vol.53-13. Seidocha, Tokio, 2007, p. 8. [La traducción propia del texto original en japonés]
} 
documental es ficción, sobre todo en el caso del documental con personas. Hay dos razones principales. Una es la dificultad para captar la naturalidad del fenómeno mediante la cámara, especialmente para filmar las escenas de vidas cotidianas de los personajes como si no estuviese la cámara. Otra razón es la necesaria arbitrariedad del realizador en el montaje y la edición.

El argumento de Sato nos recuerda a Bill Nichols, gran teórico e investigador del cine y la cultura en Estados Unidos, que defendía las mismas ideas en su conocido libro La representación de la realidad.

Los documentales son una ficción con tramas, personajes, sucesos como cualquier otra. $^{38}$

El comentario de Nichols apoya al argumento de Sato. Pero Nichols es más cuidadoso e indica la diferencia entre la ficción y el documental. Sato no explica exhaustivamente cuál es la diferencia, de modo que continuaremos con la comparación de Nichols.

La diferencia entre la dirección hacia el mundo y un mundo se puede iluminar imaginándonos en relación con una habitación. En la ficción, miramos una habitación bien iluminada, oyendo y viendo lo que ocurre en su interior, aparentemente sin que lo sepan sus ocupantes. (...)

En el documental, miramos hacia el exterior desde una habitación escasamente iluminada, oyendo y viendo lo que ocurre en el mundo que nos rodea. ${ }^{39}$

Esta analogía explica muy bien la diferencia entre la perspectiva de la película de ficción y la del documental. En cualquier modo, es el realizador quien nos indica a través de qué ventana, cuánto tiempo y cómo mirar la película.

\footnotetext{
${ }^{38}$ Nichols, Bill, La representación de la realidad. Cuestiones y conceptos sobre el documental, Barcelona, Paidós, 1997, p. 149.

${ }^{39}$ Ibíd., p. 155.
} 
En una obra de ficción, el rodaje y el equipo de los personajes pueden modificarse dentro de la habitación con cierta conciencia; es decir, desde el principio tendrán la visión total sobre lo que se va a mostrar en esta habitación. Desde esta conciencia se filma, monta y representa. Los espectadores también la mirarán, pero sabiendo que la representación no sale de esa habitación y que los espectadores que están en el exterior pueden alejarse de allí con facilidad.

Al contrario, en el caso del documental se filma desde el interior de la habitación: la mirada desde el interior hacia el exterior que le rodea dificulta una visión global. Podrá existir una visión previa para captar ciertas escenas que parecen interesantes e importantes, pero a veces no se podrá captar la escena tal como se esperaba. De este modo, el control sobre el objeto del filme es menor, así como la flexibilidad (en comparación con la película de ficción). Además, los espectadores observarán suponiendo que lo que se representa ocurre alrededor de ellos, en el entorno real.

El documental comparte muchas características con el cine de ficción pero sigue presentando importantes diferencias con respecto a la ficción. Las cuestiones del control del realizador sobre lo que filma y de la ética de la filmación de actores sociales cuyas vidas, aunque están representadas en la película, se extienden mucho más allá del ámbito de ésta; las cuestiones de la estructura del texto así como las de actividad y las expectativas del espectador ---estos tres ángulos desde los que parten definiciones del documental (realizador, texto, espectador)--- también sugieren que, en diversos sentidos importantes, el documental es una ficción en nada semejante a cualquier otra. ${ }^{40}$

Según Nichols, si se compara el documental con la obra de ficción existen paralelismos, pero el carácter ficticio será muy diferente en cuanto a la ética, el control de la filmación y los actores sociales. La dimensión ética es relevante es cuanto a varios aspectos. Por ejemplo, en la obra audiovisual de ficción, se representan escenas de asesinatos o

\footnotetext{
${ }^{40}$ Loc. cit.
} 
violaciones sexuales con cierta frecuencia. En cambio, si en el caso del documental se exhibieran estas imágenes se podría crear una gran polémica.

Otro ejemplo: en la obra de ficción se puede inventar cualquier trama con escenas suponiendo que el espectador sabe que se trata de una obra de ficción. En el caso del documental, existe cierto acuerdo con los espectadores para representar lo real. Por esta razón, los realizadores serán mucho más cuidadosos, ya que su ética será cuestionada si se incluyen escenas imaginarias "no reales".

El control sobre la filmación que analizábamos anteriormente a través de la analogía de la habitación (captar el exterior desde el interior de la habitación) simbolizaba la inflexibilidad al filmar desde dentro de la habitación. Un factor aún más importante que distingue el documental como ficción es la relación y la estructura entre el realizador, el texto y el espectador según Nichols.

El documental nos dirige hacia el mundo de la realidad brutal al mismo tiempo que intenta interpretarlo, y la expectativa de que lo vaya a hacer supone una intensa diferencia con respecto a la ficción.

Los documentales nos dirigen hacia el mundo pero también siguen siendo texto. Por tanto comparten todas las implicaciones concomitantes del estatus construido, formal e ideológicamente modulado, de la ficción. El documental se diferencia, sin embargo, en que nos pide que lo consideremos como una representación del mundo histórico en vez de cómo semejanza o imitación del mismo. ${ }^{41}$

Este carácter del documental como texto que interpreta la realidad constituiría la segunda razón del argumento de Sato: es la ficción la que incluye la retórica, la metáfora y la perspectiva de cada realizador. Entonces, podemos confirmar el concepto de veracidad del relato cinematográfico que ha indicado Deleuze. Tal vez, para mantener "la verdad" -o por lo menos una impresión de "la verdad"- en la expresión cinematográfica se necesite esa

\footnotetext{
${ }^{41}$ Ibíd., p.153.
} 
ficción. Así pues, para abordar la posible ficción presente en el documental tendremos que considerar la retórica, la metáfora y la perspectiva del realizador en la obra.

Sin embargo, dice Nichols, el documental nos exige considerar que es una representación del mundo real histórico, en vez de una imitación o semejanza del mismo como ficción. Dicho de otro modo, el documental representa la realidad captando escenas del espacio y el tiempo de nuestro mundo real, pero al mismo tiempo contiene obligatoriamente una estructura interpretativa a través de la cual se manifiesta la perspectiva del autor. Se trata, pues, de una representación del mundo real según el punto de vista del autor.

En resumen, el documental nos ofrece representaciones o similitudes fotográficas y audiovisuales del mundo. El documental representa los putos de vista de individuos, grupos o entes que van desde un realizador solitario como Flaherty hasta el gobierno del Estado pasando por la cadena $C B S^{42}$

Sato también está de acuerdo con estas características que diferencian al documental del cine de ficción, sobre todo en cuanto a la metáfora de la habitación y al método de filmación:

Sin embargo, el documental no es una transcripción de "la realidad". Aunque la película capte un suceso fortuito sin ninguna previsión, apenas se reconstruyen esos fragmentos de "la realidad", se alejan de "la realidad". Esa película obligatoriamente se convierte en una "creación convenida" del autor. Esta es mi modesta opinión, real y sincera, con la experiencia que me ha aportado producir películas documentales ${ }^{43}$.

Por su propia experiencia de rodaje, Sato añade otro comentario sobre la filmación del mundo real. Él insiste en lo difícil que es captar la escena en un ambiente cotidiano en el que él podría participar personalmente sin una cámara. En general, la gente se pone

\footnotetext{
${ }^{42}$ Ibíd., p. 154.

${ }^{43}$ Sato, Makoto, Op.cit., p. 8. [Traducción propia]
} 
nerviosa frente a la cámara. Aunque previamente el equipo de rodaje pida a la gente que actúen con naturalidad, que hagan "lo de siempre", ellos se visten mejor o limpian su lugar al saber que llegará el equipo de rodaje. Basándose en su experiencia de rodaje documental, Sato insiste en ello, enfatizando la dificultad de filmar escenas reales como si no hubiese cámara y la imposibilidad de captar una realidad ordinaria. Esta puntualización sobre la presencia de la cámara es un cuestionamiento frecuente en el Cinéma-vérité.

Si nos adelantamos un poco en el tiempo, la situación cambia drásticamente por la aparición de la cámara "Handy Cam" como soporte de registro del audiovisual de los años noventa. En el siguiente apartado nos aproximaremos a la corriente transicional hasta la llegada del cambio drástico de los años noventa.

A partir de la próxima sección, comenzaremos a estudiar el movimiento documental en Japón desde sus comienzos hasta los años noventa, tratando de aportar ciertas explicaciones en lo referente al tema de la subjetividad. 
V.1. El movimiento documental como proceso paralelo de occidentalización del país. 
En este apartado estudiaremos el movimiento del documental en Japón desde el inicio de la introducción cinematografía al país, atravesando la Segunda Guerra Mundial y hasta la década de los años cincuenta. Para comenzar, podemos decir que la historia cinematográfica de Japón coincide con el proceso del desarrollo de modernización y occidentalización del país. Es decir, al repasar la historia del cine y documental se percibe claramente una postura cultural y política que se encuentra bajo la presión de la modernización y occidentalización del país. Esta hipótesis nos servirá a la vez para comprender esquemáticamente el proceso de modernización y adaptación del estilo occidental a un lugar no occidental, y su complejo resultado en cuanto a la identidad cultural creada. En esta parte nos apoyaremos en unos conocimientos esenciales para poder contextualizar los enfoques que estudiaremos más adelante.

Por ello, investigar el proceso de la evolución del documental en Japón inevitablemente conlleva repasar la trayectoria ideológica del país bajo la influencia internacional. $\mathrm{Al}$ mismo tiempo, en este estudio nos aproximaremos al desarrollo del dispositivo y la técnica que posibilita una nueva forma de expresión audiovisual. A continuación, abordaremos estos asuntos refiriéndonos a las obras y a los movimientos documentales que se convirtieron en un viraje decisivo en la trayectoria del documental.

\section{V.1.1. El inicio de la imagen en movimiento y su forma de presentación.}

En general, la historia del cine comienza gracias al invento de los hermanos Lumière, cuyo cinematógrafo $^{1}$ fue presentado en el año 1895 en París. Tan solo 2 años después, en 1897, ya se empieza a proyectar en Osaka, Japón. El cinematógrafo fue introducido en el país por un japonés, Katsutaro Inabata ${ }^{2}$, quien estudió junto a Lumière en París. A Inabata le pareció

\footnotetext{
${ }^{1}$ Cinematógrafo: cámara y proyector, al principio unidos en un mismo aparato, inventado en Francia por los Hermanos Augste y Louis Lumière (1862-1954; 1864-1948). (...) El 28 de diciembre 1895, los hermanos Lumière exhibieron una serie de cortometrajes, cada uno de 1 minuto o 2 de duración, ante un público de pago en un café de París. (...) Sus películas más notables consisten en breves registros de la realidad (llamados actualités); por ejemplo, la salida de los trabajadores de la fábrica Lumière o la entrada de un tren en la estación de París. [Konigsberg, Ira: Diccionario técnico Akal del cine, Trad. Enrique Herrando Pérez y Francisco López Martín, Madrid, 2004, p. 113].

${ }^{2}$ Katsutaro Inabata: empresario de la industria textil que estudió la técnica de la tintura en Francia. Tenía un profundo conocimiento de la cultura francesa, y se esforzó en establecer el Instituto franco-japonés de Kansai: $L o s$ hermanos Lumière realizaron la primera proyección cinematográfica en París en 1985 (en el período meiji 28).
} 
oportuno transportar la máquina y la película para que la población japonesa conociera el contexto europeo a través de la imagen en movimiento. De este modo, desde un principio el cinematógrafo cumplió la misión de instruir sobre aspectos relacionados con el extranjero, y de hecho fue considerado como el mejor medio para representar la cultura occidental en Japón (aún más que la fotografía). No obstante, esta intención de mostrar la imagen extranjera no es exclusivamente la idea de un japonés.
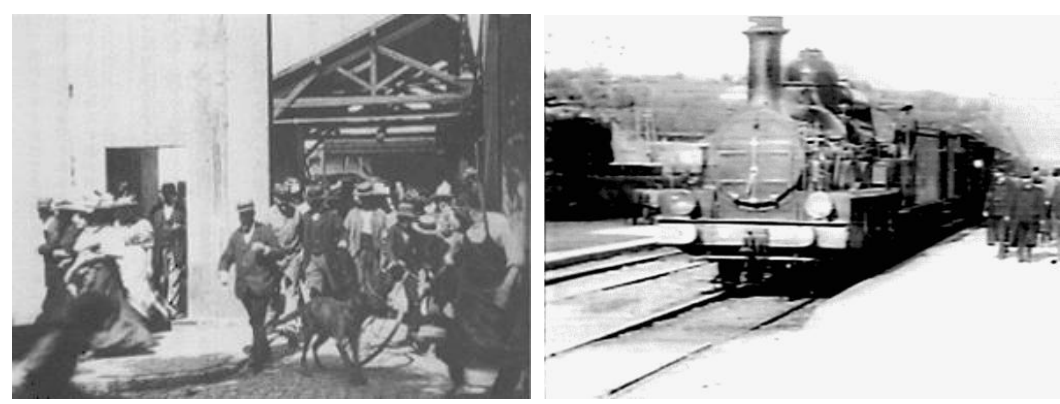

13. La salida de la fábrica (1895) y La llegada del tren (1897), los hermanos Lumière

Al año siguiente, en 1898, llegan a Japón dos operadores del cinematógrafo de la empresa de Lumière para filmar en el país. El crítico del cine japonés Tadao Sato indica al inicio de la serie de libros Documental Japonés ${ }^{3}$ que estos operadores mantenían un interés por el folklore. Así pues, estos dos operadores franceses del cinematógrafo se quedaron en Japón y viajaron hasta al norte del país para filmar el Ainu, una raza y cultura minoritarias. Las películas de aquel momento todavía se conservan en la empresa. Nos parece interesante las indicaciones de Tadao Sato, que asegura el valor antropológico y documental de las imágenes filmadas por los operadores de Lumière.

En Japón, dos años después (período meiji 30, año 1897), tuvo lugar la primera representación cinematográfica en la ciudad de Osaka. El importador fue Katsutaro Inabata, quien había estudiado con los hermanos Lumière durante su estancia en París. Matsumoto, Kengo: Academia del Cinema, vol. 35 , http://archive.mag2.com/0000208600/20080114000000000.html, accedido el 10 de febrero 2009. [Traducción propia del texto original en japonés]

${ }^{3}$ Sato, Tadao (et. ál.), Nihonno dokymentary I, Dokyumentary no miryoku [El documental japonés I, El atractivo del documental], Tokio, Iwanamishoten, 2009. 
Por ejemplo, fue filmada [por los operadores franceses] una escena rural con un campesino caminando en una noria ${ }^{4}$. La imagen tiene un sentido folclórico (aunque fue filmado por curiosidad), ya que aparece ese agricultor desnudo. Para los agricultores y pescadores, era muy común en aquel momento trabajar desnudos. Pero, al mismo tiempo, tenían prohibido por la policía trabajar de esa manera, y la razón era que los extranjeros lo calificaban como algo salvaje. ${ }^{5}$

Trabajar desnudo en los pueblos agrícolas y pesqueros es una costumbre que ya se ha perdido en todo el país nipón. Incluso nos sorprende encontrar esa prueba en forma de imagen filmada de aquel momento. La palabra "extranjeros", en este caso, se refiere a los extranjeros occidentales, quienes consideran a Japón como un país salvaje. La intención y la curiosidad por filmar "la imagen salvaje" desde la perspectiva occidental, así como el esfuerzo por "corregir" u "ocultar" la imagen "salvaje" de la parte no occidental, contribuyen a la identificación de la mirada de los extranjeros, y nos obliga a reflexionar sobre ello como un ejemplo típico del conflicto en una zona "subdesarrollada", inmersa en un proceso de modernización-occidentalización.

En dicha visita de los operadores de Lumière, se instruye a unos operadores japoneses. Tadao Sato supone que las primeras imágenes filmadas por los japoneses se realizaron en ese momento. Las imágenes que los japoneses filmaron se encuentran junto con las imágenes filmadas por los franceses, conservadas en la empresa.

... son imágenes principalmente de la zona comercial de Tokio y Kyoto, da la impresión de que se trata de una fotografía turística. Quizá a los japoneses de aquel momento les pareciera que debían filmarlas por ser las que valdrían la pena. ${ }^{6}$

Uno de los operadores japoneses del cinematógrafo que aprendieron con la visita del equipo de Lumière del año 1898, viaja en 1900 a China para filmar un suceso. Se inicia así el

\footnotetext{
${ }^{4}$ La noria japonesa llamado Suisha. Es un dispositivo para echar riego hacia arrozal. Se instara en reguera y se hace girar pisando.

${ }^{5}$ Sato, Tadao, Op.cit., pp. 7-8. [Traducción propia del texto original en japonés]

${ }^{6}$ Ibíd., p. 8. [Traducción propia del texto original en japonés]
} 
documental como tipo de reportaje noticiario: en la guerra entre Rusia y Japón, se filma en Manchuria, compitiendo así con los operadores internacionales.

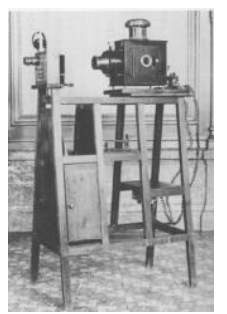

14. Cinematógrafo de Lumière
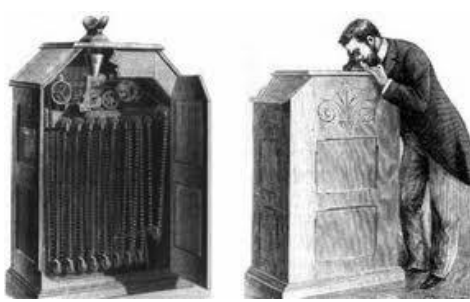

15. Cinematoscopio y Black Maria de Edison y W.K.L. Dickson.

Ya un año antes de la llegada del cinematógrafo de Lumière, se había presentado una imagen en movimiento de kinescopio de los laboratorios de T. Edison en Japón. Por lo general, se encuentran más referencias a Edison como el inventor del cine en EE.UU. porque el cinematógrafo es una máquina creada mediante la unión de kinetógrafo y kinetoscopio $^{7}$, inventados por el laboratorio de Edison en colaboración con W.K.L. Dickson. La primera exhibición en público fue en 1893. Entre las imágenes en movimiento filmadas por Edison se encuentra una escena de baile de Maiko filmado en 1894. La descripción de Tadao Sato es la siguiente:

En realidad, esta película fue filmada en 1894, invitándoles a un estudio específico de rodaje instalado por Edison, en el siguiente año de la Expo Mundial. En este estudio entra la luz del sol desde el techo, lo que contribuye a que el giro dependa

\footnotetext{
${ }^{7}$ Kinetógrafo: cámara desarrollada en los laboratorios de Edison para hacer tiras cortas de película para máquina de visionado individual, llamada kinetoscopio. (...) El kinetoscopio se exhibió públicamente en 1983. (...) El kinetógrafo, a pesar de ser poco manejable, tenía varias características que pasarían a ser estándar en cámaras posteriores, a saber, la película de $35 \mathrm{~mm}$ con cuatro perforaciones a los lados de cada fotograma y el mecanismo de ruedas dentadas que enganchaba las perforaciones para mover la película. [Konigsberg, Ira: Diccionario técnico Akal del cine, Op.cit., pp. 282-283.]
} 
del ángulo de cambio del sol. Fue llamado "Black Maria”" por su aspecto, era parecida al coche celular. ${ }^{9}$

Esta imagen fílmica muestra un baile de tres chicas vestidas con kimono al estilo Maiko (señorita bailarina de Kioto-Guion con unas cintas anchas blancas). La película fue divulgada como un espectáculo proyectado en la Expo Mundial (International Exhibition) en Chicago, el mismo año de la exhibición pública del kinetoscopio. Si comparamos el interés inicial por la técnica de imágenes en movimiento, a Edison y a Dickson les interesaba la presentación del espectáculo mediante un equipo fijo que permitiese ver las imágenes individualmente; a los hermanos Lumière, un registro folklórico con el equipo compacto transportable y su proyección abierta a la pantalla. Las técnicas del kinetógrafo y del kinetoscopio fueron mejoradas por los hermanos Lumière mediante el cinematógrafo, una máquina más transportable que logra tener mayor éxito de proyección para un público numeroso. Con el inicio del cine, se estandariza el formato de la película de $35 \mathrm{~mm}$ con la velocidad de 16 fotogramas por segundo. En Japón igualmente se introduce como formato estándar del cine.

De esta manera, las películas importadas de Europa y de Norteamérica se exhibieron con bastante prontitud en Japón. Y a la vez se inicia la producción de películas nacionales siguiendo la técnica importada. Para el desarrollo del cine japonés, sobre todo en el caso del documental, no se puede ignorar la influencia del vanguardismo ruso y la alianza política y cultural con el cine alemán. Antes de destacar algunos trabajos documentales, indicaremos una peculiaridad en la representación cinematográfica de Japón.

Una característica peculiar de la proyección cinematográfica en Japón se basa en el acompañamiento del Benshi (presentador) ${ }^{10}$, quien hablaba junto con una melodía sobre la

\footnotetext{
${ }^{8}$ Black María: se refiere al pequeño estudio junto a los laboratorios de Edison en West Orange, Nueva Jersey. Diseñado por W.K.L. Dickson y acabado de fabricar en 1893, se utilizó para la filmación de las tres películas utilizadas por los cinematoscopios de Edison. (...) Un enorme cinematógrafo filmaba a los intérpretes contra un fondo negro iluminado por la luz del sol que entraba a través del techo movible. Toda la estructura podía girar siguiendo el movimiento del sol, aunque la mayor parte de los rodajes se realizaba a medio día. [Konigsberg, Ira: Diccionario técnico Akal del cine, Op.cit, p. 55.]

${ }^{9}$ Sato, Tadao: Qué y cómo se ha filmado el documental, en El documental japonés I, El atractivo de documental, Op.cit, p. 6. [Traducción propia del texto original en japonés]
} 
imagen del cine mudo. En Estados Unidos hasta el año 1910 existía el Lecturer (lector), quien explicaba la imagen, pero desapareció inmediatamente. En Japón, hacia 1930 había más de seis mil presentadores Benshis (momento en que llegaron los filmes con el audio talkie). Este presentador era un narrador de la imagen; no solo interpretaba la historia de la película, sino que también actuaba como actor o actriz, cambiando el tono de la voz cuando era necesario. Una razón para tal cantidad de Benshis incluso una vez habían aparecido las películas talkie era la dificultad de la traducción de los idiomas en las películas importadas. Sin embargo, el fenómeno no se explica exclusivamente por esa razón, ya que en aquel momento existían las películas de producción nacional. La segunda razón sería, pues, la falta de equipamiento audio en los cines. Pero tampoco esta segunda razón explica al completo el fenómeno por el cual más personas preferían una función cinematográfica con Benshi que con talkie en aquel momento.
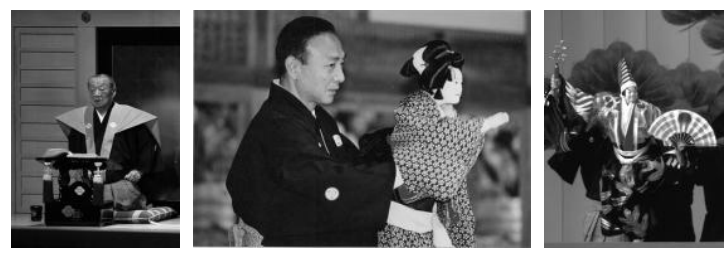

16. Cantante-narrador y los operadores de Ningyoujoururi con su marioneta en el teatro.

En resumen, según un estudio de Inuhiko Yomota ${ }^{11}$ sobre los Benshis relativo al tema de la desincronización entre el sonido y la imagen, el público aceptó al Benshi como la manera de conservar la tradición de los espectáculos narrativos como Ningyoujoururi ${ }^{12}$, Koudan, o Rakugo $^{13}$, así como sus flexibilidades en la improvisación. Sobre todo la de Ningyoujoururi,

\footnotetext{
${ }^{10}$ Sobre el estudio del Benshi encontramos mucha información gracias al estudio de Fujioka y a la presentación de la investigación Katsudoushashin to gunshu (Cinematografía y muchedumbre) de Kuniyuki Terada en las jornadas: El límite de «la teoría» de la imagen: entre el logos y el mythos, celebrado en la Universidad de Kioto el 1 de marzo en 2008, a las cuales la doctoranda tuvo la oportunidad de asistir.

${ }^{11}$ Inuhiko Yomota: profesor catedrático de la Universidad de Meiji, imparte clases de historia del cine. Son numerosas sus publicaciones sobre amplios temas, desde el Manga (caricatura japonesa), la literatura comparativa o la gastronomía, hasta la cultura y la política asiáticas.

${ }^{12}$ El Ningyoujoururi es un teatro de marionetas con el cantante Guitaiu, quien canta y relata la historia haciendo uso del Shimisen (instrumento musical japonés de tres cuerdas). También llamado Bunraku.

${ }^{13}$ Koudan es un tipo de relato sobre historias con cierta interpretación general sobre los temas bélicos, la historia y algunos asuntos políticos. Ya en la década de 1820 se estableció tal como es ahora. Se encuentran muchas historias que se han traspasado del Koudan al teatro Kabuki y a Bunraku. El Rakugo es también otro tipo de relato, la narración es más amplia que en el Koudan y en general trata sobre la vida cotidiana de la gente en la ciudad. En
} 
espectáculo basado en un conjunto de imágenes en movimiento de marionetas y la narración de un cantante, pero en el cual se podía disfrutar de cada uno de los elementos por separado. Es decir, se trataba de un espectáculo en el que colaboraban la canciónnarración y el baile-movimiento de la marioneta. De esta manera, el público japonés no sentía la necesidad de una sincronización exacta de la imagen con el audio.

El proceso de la aceptación del cine se encuentra en la línea extendida del arte popular que se supone de la separación entre la imagen (la figura) y el sonido como "Ningyoujoururi" (...) [Por esa razón] fue posible el surgimiento de un performance refinado y complicado como el de Benshi; luego, maduró el gusto del público que, no obstante, no le dejó de apoyar. ${ }^{14}$

Por otra parte, algunos de los investigadores y productores de cine alegaron que la imagen cinematográfica debía ser independiente, sin ninguna intervención, seguramente influidos por el concepto de Cine Puro y la teoría del montaje ${ }^{15}$ de Eisenstein ${ }^{16}$, del cine de la vanguardia rusa. Así criticaban el performance del Benshi. La polémica persistió dentro del ámbito cinematográfico; sin embargo, hacia finales de los años treinta el número de Benshis fue diezmado a 338 sin alcanzar ninguna conclusión teórica. Esta reducción se debió a que el poder estatal japonés de entonces comenzó a examinar la autorización de los Benshis; es decir, introdujo un sistema de control.

\footnotetext{
estos dos tipos artísticos del relato, habla sólo una persona que maneja la historia, interpretando a todos los personajes que salen en la misma.

${ }^{14}$ Yomota, Inuhiko: Eigashi eno shoutai [La invitación de la historia del cine], Tokio, Iwanamishoten, 1998, pp. 137-138. [Traducción propia del texto original japonés]

${ }^{15}$ Véanse los ensayos de la teoría del montaje de Eisenstein. 5. Eisenstein y la teoría del montaje, en: Romaguera I Rámio, Joaquín y Alsina Thevente, Homero (eds.): Textos y Manifiestos del Cine, Estética. Escuela. Movimientos. Disciplinas. Innovaciones, Madrid: Ediciones Cátedra, 1989, pp. 71-87.

${ }^{16}$ Sergei Mijailovich Eisenstein (1898, Riga, Letonia; Moscú, Unión Soviética: (...) Recibe el encargo de hacer una película conmemorativa del veinte aniversario del primer intento revolucionario en 1905, que es origen de su obra maestra El acorazado Potemkin (Bronenosets Potiomkin, 1925). (...) Mientras escribe sus primeros ensayos sobre el montaje de atracción, realiza la genial Octubre (Oktiabre, 1927), reconstruido críticos acontecimientos de 1917, basada en la obra de John Reed Diez días que conmovieron al mundo, y perfecta aplicación de sus teorías, pero tiene graves problemas de censura por su visión de los acontecimiento. [Konigsberg, Ira: Diccionario técnico Akal del cine, Op.cit., p. 97.]
} 
Durante cierto período, en Japón el Benshi requería la autorización como una muestra de patriotismo, de fidelidad y de rendición de servicio a su patria, a sus pueblos. $^{17}$

Así describe Yomota a los métodos de control del gobierno que inferían un servicio a los Benshis como educadores con el objetivo de que creciese una nación uniformada a través del cine, la diversión y el arte popular. Siguiendo a Yomota, Atsuhiro Fujioka, investigador de cine en el campo del espacio público japonés, añade una indicación según la cual por una nueva operación del poder estatal aumentó el número de Benshis.

\begin{abstract}
Precisamente en el año 1931, cuando Japón provocó la guerra de Manchuria y comenzó la guerra de la invasión, aumentó el número de los presentadores [Benshi]. Este es un problema que no debería quedar como una sola coincidencia. ${ }^{18}$
\end{abstract}

Posteriormente, debido a la reducción de los Benshis, el poder estatal exige ese servicio al cine solamente como parte de la educación, instigando la guerra e interviniendo ${ }^{19}$ cada vez más. Como indican estos ejemplos, la industria del cine se encuentra bajo el control estatal ya antes de la guerra.

La película documental no fue una excepción. Tanto el documental japonés, como su técnica e industria se desarrollaron con rapidez en aquella época. Antes de la guerra, el cine documental en Japón se llamaba Bunkaeiga o película cultural ${ }^{20}$ (a diferencia de Gekieiga o

\footnotetext{
${ }^{17}$ Ibíd., p. 140. [Traducción propia del texto original japonés]

${ }^{18}$ Fujioka, Astuhiro: La renovación y la modernización de la técnica en la década de 1930 y su representación filmica, en: CinemaganiNet! No. 6 de 2002, Online Research Journal of Cinema, http://www.cmn.hs.h.kyotou.ac.jp/CMN6/fujioka.html, accedido el 10 de febrero del 2009. [Traducción propia del texto original japonés]

${ }^{19}$ La censura por parte de la policía se inicia ya en 1917, en todas las clases de película en Japón: 1917, Ordenanza de la Jefatura Superior de Policía número 12: Reglamento de control sobre el espectáculo cinematográfico. [Sato, Tadao (et al.): Nihonno dokymentary II, Seiji, Shakai hen. [El documental japonés II, El volumen de la política social], Tokio: Iwanamishoten, 2010, p. 11.]

${ }^{20}$ El término Bunkaeiga (película cultural) procede de bunkaeigaron (teoría de película cultural), título de la traducción japonesa del Documentary de Paul Rosa traducida por Taka Atsugi. A pesar de no haber importado ninguna película de Paul Rotha y John Grierson, sus teorías eran muy conocidas en el círculo de cineastas japoneses. La razón para adoptar de ese término es la siguiente, según la explicación de Tadao Sato: La razón por la cual Atsuko Takagui tradujo "documentary", escrito por Paul Rosa como manifiesto del movimiento documentalista, a "bunkaeigaron" (teoría de la película cultural) como el título del libro es porque en aquel momento existían muchos cortometrajes alemanes que abordaban temas científicos y se les llamaba "bunkaeiga"
} 
película teatral $^{21}$ que es la película de evasión). Actualmente, la palabra mayormente difundida es la de documentary (documental). Sin embargo, esta palabra no se empieza a utilizar hasta la posguerra. Enseguida veremos el carácter contradictorio de la película cultural, en constante tensión política, económica y cultural.

\title{
V.1.2. La contradicción en el desarrollo del documental como propaganda.
}

Makoto Sato, realizador de documentales y crítico, explica las circunstancias de los documentales japoneses, llamados "películas culturales" en el contexto previo a la guerra en Japón y durante la misma.

\begin{abstract}
En el contexto anterior a la guerra en Japón, en el cual el documental se llamaba "película cultural”, se percibe claramente un dogmatismo deforme impaciente por alcanzar a las potencias occidentales en el proceso de modernización. En aquel momento en Japón, la cultura pretendía simbolizar a un "Occidente Moderno". ${ }^{22}$
\end{abstract}

Esto es importante para comprender el establecimiento de la cultura japonesa moderna. Podemos decir que el arte encarnaba al arte occidental en un contexto de modernización del país. Es un ejemplo que muestra la complejidad ante el Occidente de aquella época. La meta de modernización del país se comprueba no solo en su admiración e imitación del estilo occidental, sino también en su introducción para poder competir con las potencias occidentales. Por supuesto, este espíritu de búsqueda de competición con los países

(película cultural). Más tarde, el término “bunkaeiga” se ha adoptado para referirse a un cortometraje que debía acompañar a cada sesión de cine obligatoriamente según la Ley de 1940. [Sato, Tadao (et. ál.): Nihonno dokymentary I, Dokyumentary no miryoku [El documental japonés I, El atractivo de documental], Op.cit., p. 40.] Es decir, en Japón el uso del término encuentra su conexión con los cortometrajes alemanes. Estos cortometrajes son Kulturfilme de Ufa, coincide una indicación de Kracauer: (...) Las películas documentales: los Kulturfilme, como se llamaba en Alemania (...). A causa de su minuciosidad científica y competente fotografía, los Kulturfilme de Ufa se convirtieron en una especialidad alemana de gran demanda en el mercado internacional. [Kracauer, Siegfried: De Caligari a Hitler: una historia psicológica del cine alemán, trad. Héctor Grossi, Barcelona: Paidós, 1985, pp. 136-137.] Ya que en aquel momento, no se podía ver las películas del documentalismo inglés en Japón, para referirse a la película de no ficción, esta traductora escogió el ejemplo de películas alemanas.

${ }^{21}$ En Japón, se denomina Gekieiga (película teatral) a las películas de ficción para distinguirlas del documental. Las Gekieiga no son necesariamente filmadas en el teatro, sino que puede ser cualquier tipo de película en la que los actores interpreten bajo la dirección del realizador. La mayor parte de Gekieiga eran películas de evasión.

${ }^{22}$ Sato, Makoto: Documentary no shujigaku (La retórica del documental), Tokio, Misuzushobo, 2006 , p. 6. [Traducción propia del texto original japonés] 
occidentales resulta en la participación, en el colonialismo, y dirige al país hacia la política de fortalecimiento económico y militar.

En la invasión de Manchuria ${ }^{23}$, el Imperio japonés declara su oposición de intereses contra Inglaterra, principalmente. Como consecuencia, en 1937 se inicia la guerra entre Japón y China que se extiende a la Guerra del Pacífico. Al comienzo de la guerra, la industria del cine permanece bajo el control total del $\operatorname{poder}^{24}$ y empiezan a producirse Kokusakueiga (película de política nacional) como parte de la propaganda nacionalista.

Makoto Sato presta atención al primer período de la película cultural, cuando algunos trabajos visibilizaban la parte oscura de la sociedad y denunciaban las injusticias. En este período, la película cultural se encuentra bajo la influencia del iluminismo de la escuela inglesa (representada principalmente por Paul Rotha y John Grierson ${ }^{25}$ ), la cual considera al cine como el alma de la reforma social. Sin embargo, incluso aquellos que defendían esta

\footnotetext{
${ }^{23}$ Manchuria: región que hasta 1932 pertenece al nordeste en China, pero en 1934 Puyi vuelve a ser emperador de Gran Imperio Manchukuo y la región se convierte una nación marioneta del Imperio japonés. No se pudo obtener la aprobación internacional. Por esta razón, Japón y Manchuria se separan de la Liga de Naciones en 1933.

${ }^{24}$ Como hemos visto, la censura por parte de la policía sobre las películas se inicia en el año 1917. Pero encontramos movimientos independientes con los cineastas amateurs de los años veinte que preparan el próximo desarrollo del documental japonés. Por ejemplo, la así llamada Prokino, o Nihon Puroretaria Eiga Doumei [Proletarian Film League of Japan/ Liga de películas proletarias de Japón], se inicia con una película documental de 1928 sobre una huelga en la fábrica de salsa de soja (filmada por Genju Sasa, un joven amateur izquierdista). A partir de ese momento, Prokino invita a Akira Iwasaki como diligente teórico y se organiza un movimiento de documental independiente que se proyecta en todo el país. Taka Atsugi, quien tradujo la teoría del documental de Paul Rotha al japonés, también se involucra en este movimiento. Sin embargo, debido a la inclinación hacia el militarismo de la sociedad japonesa y la represión del pensamiento izquierdista, el movimiento es derrotado a principio de los años treinta. Prokino finalizó por la detención de todos los miembros que quedaban en 1934. Una de las características del movimiento es el empleo de la película de 9,5 mm (Pathé Baby) con la cámara de juguete. Ciertos teóricos lo señalan como el origen del video-activismo con la cámara Handy-cam. El movimiento izquierdista fue derrotado por el control de la policía, pero la teoría y la práctica propagandística desarrollada por Prokino fueron introducidas como modelos en la "película cultural", logrando un cambio en los temas de la propaganda militarista. Este carácter propagandístico del documental japonés constituye un punto de partida para nuestra disertación. [para más detalles véanse Sato, Tadao (et. ál.): Nihonno dokymentary I, Dokyumentary no miryoku [El documental japonés I, El atractivo del documental], Op.cit., p. 17 y pp. 45-46, Gerow, Aron, Dokyumentary to seiji-riron [El documental: política y teoría], en Sato, Tadao (et. ál.): Nihonno dokymentary II, Seiji, Shakai hen [El documental japonés II, El volumen de la política social], Op.cit., pp. 47-52 y "The Cooptaion of Prokino de Abé Merk Nornes, en su libro, Japanese Documentary Film: The Meiji Era through Hiroshima, Minneapolis: University of Minnesota Press, 2003, pp. 66-69].

${ }^{25}$ Paul Rotha (1907- 1984) y John Grierson (1898-1972): realizadores y organizadores del cine documental y personalidades principales del movimiento del documental inglés iniciado en la década de 1930.
} 
teoría del documentalismo con cierta influencia del realismo socialista ${ }^{26}$, empiezan a producir películas culturales según las políticas nacionales durante la guerra.

No obstante, el iluminismo propio de la "película cultural" se traslada a una película de propaganda de la política nacional cuando Japón se torna al fascismo. La nación se levanta como un solo hombre y avanza hacia el camino militarista. $Y$ en ese momento influye poderosamente la estrategia del Ministerio de Propaganda de la Alemania Nazi que reevaluaba en el cine su potencial propagandístico como país aliado ${ }^{27}$. Debido a la mayor atención al documental como pilar de propaganda para la realización de la política nacional, el gobierno fortalece la censura en la película teatral ${ }^{28}$ y obliga a exhibir la "película cultural" en todas las proyecciones cinematográficas según la "Ley del cine de 1939". ${ }^{29}$

Cualquier proyección en el cine debía realizarse mediante la película cultural hasta el fin de la guerra en Japón. Bajo la protección y el control del gobierno y la milicia imperial se producen las películas de propaganda nacional, llamadas películas culturales. Al comenzar la invasión y la colonización en el este-sudeste asiático, el cine se establece como medio de manipulación de la identidad nacional bajo influencia del poder imperial: se favorece la protección de Asia contra las potencias occidentales y se afirma la legitimidad de la guerra. Tadao Sato se pronuncia en cuanto a la relación entre documental y guerra. No disponemos de espacio suficiente para profundizar en la relación entre guerra y cine, o en la polémica del documental como propaganda. Solo fijaremos nuestra atención a la siguiente síntesis:

Sean ficciones o documentales, las películas producidas en Japón hasta su derrota en 1945 representan solo la justicia del país y el vigor del ejército japonés. La única

\footnotetext{
${ }^{26}$ Váyase a la nota 24. No pocos jóvenes que participaba en Prokino se dedicaron a producir películas culturales en aquella época. [Sato, Tadao(et al.): Nihonno dokymentary I, Dokyumentary no miryoku [El documental japonés I, El atractivo de documental], Op.cit., pp. 45].

${ }^{27}$ Japón sella un pacto de alianza con Alemania e Italia en 1940. Son tres países fascistas.

${ }^{28}$ Váyase a la nota 21.

${ }^{29}$ Sato, Makoto, Op.cit., p. 7. [Traducción propia del texto original japonés]
} 
excepción es una serie de documentales de Fumio Kamei ${ }^{30}$, con una oculta intención antibélica en el momento de la guerra de China contra Japón ${ }^{31}$.

En general, esta situación se explica por la estricta censura del gobierno y del ejército. Forma parte de la realidad: la censura realizada por el Departamento de Policía Nacional a partir de 1917 en el país elimina todas las imágenes que reflejan cadáveres, sin distinción de amigos o enemigos en el campo de la batalla, tanto en documentales como en reportajes. Como resultado, hasta la derrota la guerra fue expresada pastoralmente en los noticiarios, incluso en el medio documental. ${ }^{32}$

Las películas documentales de aquella época eliminaban las imágenes para evitar que los espectadores se inquietasen y reflexionasen. Fueron ocultadas las imágenes de cadáveres, de refugiados, de la miseria producida por la guerra. La narración justificaba las razones y agitaba al público sin dejar espacio para el cuestionamiento. Se trataba de propagandas precisas que ofrecían una información parcial. Se aprovechaban las imágenes captadas

\footnotetext{
${ }^{30}$ Fumio Kamei (1908-1987): estudió cinematografía en la Unión Soviética (durante 1928-31). En 1933 ingresó en la productora P.C.L. (Photography Chemical Laboratory), donde sentó las bases del cine documental japonés dirigiendo "Doto wo kette, Shanghai" (1928) y "Kobayashi issa" (1941). Su pelicula Tatakau heitai (Fighting Soldiers) provocó la ira de la clase militar, que logró su encarcelamiento aplicando la represiva legislación de la época. Tras la guerra, se convirtió en uno de los líderes de la lucha sindical en la productora Toho al tiempo que dirigió dramas como "Senso to Heiwa" (War and Peace /1947), "Onna no issho" (A Woman's Life /1949), "Onna hitori daichi wo yuku" (Woman Walking Alone in the Earth 11953). Se consagró como gran documentalista con "Nihon no higeki" (A Japanese Tragedy /1946), "Kichi no ko-tachi" (Children of Base /1953), "Ikite ite yokatta"(Still It's Good to Live /1956), "Ryuketsu no kiroku” (Record of Blood: Sunagawa /1956) y "Sekai wa kyofu suru" (The World is Terrified: The Reality of the Ash of Death 1957). En 1960, tras dirigir "Ningen mina kyoudai" (Men are all Brothers), abandonó el cine y pasó a regentar durante algún tiempo un negocio de antigüedades. Regresó al cine en 1984 con "Minna ikinakereba naranai” (All Must Live) y en 1986 firmó un ensayo cinematográfico de dos horas y 36 minutos de duración "Seibutsu mina tomodachi" (All Living Things are Friends). Falleció unos días después de terminar el montaje de esta película. Para muchos historiadores y cineastas, Fumio Kamei es el documentalista más representativo de Japón, una figura que equivaldría a Flaherty, Jennings y Vertov [Muguilo, Carlos (et. ál.): El cine de los mil años: una aproximación histórica y estética al cine documental japonés (1945-2005), Navarra, Colección punto de vista, Festival Internacional del Cine Documental de Navarra, 2006, p. 105].

${ }^{31}$ Según el análisis de Tadao Sato, ya en Doto wo kette, Shanghai (1928) se percibe la intención antibélica de Kamei. La película señala la tristeza y el dolor de la guerra. Nunca antes se habían reflejado tanto estos sentimientos en el documental japonés. Los críticos de aquel momento aceptaron que el documental puede tener carácter artístico gracias a esta obra, pero nadie comentó el sentido antibélico de la producción. Sato supone que los críticos también se cuidaban de la censura. La obra de Kamei o él mismo nunca anunciaron sus intenciones antibélicas, sino que sólo insinúan una realidad según la cual el ejército japonés no fue bienvenido por parte de los chinos (contrariamente a lo que aseguraban los medios de comunicación con entusiasmo). Hasta aquel momento, en el caso de documental, el realizador sólo hacía indicaciones al operador de la cámara para la filmación y sólo viajaban los operadores de audio y cámara. Después, con los materiales filmados realizaban el montaje sin saber donde habían sido grabados [Sato, Tadao (et. ál.): Nihonno dokymentary II, Seiji, Shakai hen. [El documental japonés II, El volumen de la política social], Op.cit., pp. 23-24].

${ }^{32}$ Sato, Tadao: Cómo se ha documentado la guerra, en Nihonno dokymentary II, Seiji, Shakai hen. [El documental japonés II, El volumen de la política social], Op.cit., p. 11. [Traducción propia del texto original japonés]
} 
frente a la cámara, las cuales sí constituían una serie de imágenes reales. Sin embargo, no podemos decir que este tipo de películas expresara la realidad de la guerra. En este contexto, Tadao Sato comenta que para reflexionar sobre las películas de aquella época es muy importante fijarnos en qué se describe, pero al mismo tiempo qué deja de ser descrito. Es decir, se requiere cierto tipo de lectura crítica de los documentales para poder imaginar lo que no se dice, de la misma manera incluso con lo que sí se dice.

Facilita el análisis de este tipo de películas el hecho de contextualizarla en años posteriores. Sin embargo, en realidad en ese preciso momento resultaba sumamente difícil poder imaginar lo que no se decía. Actualmente, tanto por el desarrollo técnico del montaje como por el retoque de la imagen y el audio, de nuevo es cada vez más difícil de juzgar. Más adelante abordaremos las cuestiones de censura y lectura de la información documental, cuando nos aproximemos a los documentales de los años noventa.

La película cultural, tal y como se denomina en Japón a los documentales, quedó bajo el control político. Podemos así afirmar que esta época supuso un tiempo difícil para la libre expresión -desde las diversas disciplinas, hasta los mismos sentimientos íntimos-. Y el cine no fue una excepción. En este tiempo el documental japonés no goza de una autonomía expresiva; sin embargo, irónicamente se desarrollan tanto la técnica como la teoría, y se establece una base de industrialización muy competente.

Si tuviésemos que elegir un documental perteneciente a este período, sería Tatakau Heitai (Fighting Soldiers) $^{33}$, película de 66 minutos, en blanco y negro, de $16 \mathrm{~mm}$, realizada en el

\footnotetext{
${ }^{33}$ Tatakau heitai (Fighting Soldiers/ 1939): Aunque Kamei ha repetido numerosas veces que éste no era un film antibélico, en libros, ensayos y reseñas periodísticas siempre es descrito como el ejemplo más representativo del cine antibélico. (...) Como la película no pasó la censura militar, su exhibición fue prohibida y la copia se ocultó en un almacén. "Tatakau heitai" fue olvidada y considerada como una obra perdida durante muchos años. Sin embargo, el equipo de Nippon Eigasha, cuando estaba trabajando en los preparativos de la serie de Showa Document para Asahi Broadecasting en 1976, descubrió accidentalmente una copia de la película, oculta tras la pantalla en un estudio de sonido. Sin narración y a través exclusivamente de imágenes, sonidos, música e intertítulos, la película es una obra esencial de la historia del cine documental, a pesar de que Kamei siempre advirtió que en la copia estrenada faltaban importantes escenas. [Yoshio Yasui: Extracto de Kamei Fumio, Yamagata International Documentary Film Festival 2001, en: Muguilo, Carlos (et. ál.): El cine de los mil años: una aproximación histórica y estética al cine documental japonés (1945-2005), Op.cit., p. 22]. Para la realización de esta película, Kamei también viajó al campo de batalla siguiendo al ejército japonés. En un lugar de esa filmación, Kamei sujeta a un niño chino que intentó escapar de los japoneses y le obligó al operador de la cámara
} 
año 1939 por Fumio Kamei. Como dice Tadao Sato, Kamei es un realizador único, cuyos documentales ofrecían resistencia a la política nacional de aquel momento. Pertenece a la corriente marxista. Él estudió el método y la técnica del montaje de cine en Leningrado (San Petersburgo) al principio de los años 30. Es decir, aprendió la teoría del montaje en el inicio de la vanguardia rusa en la Unión Soviética.
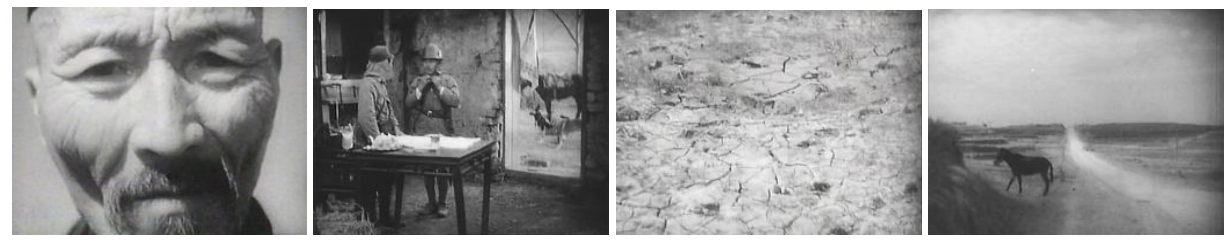

17. Tatakau Heitai (Fighting Soldiers, 1939), Fumio Kamei

La película representa las actividades de un dispositivo militar japonés que avanzaba en China durante la guerra contra este país, lo que causó la participación de Japón en la Segunda Guerra Mundial. Kamei fue exigente con la estructura y el método de montaje, no impuso narración a la película y solo adjuntó algunos títulos, como frases ambiguas que se podían entender como afirmaciones o negaciones sobre la guerra. En algunos fragmentos también se intenta mostrar la rivalidad entre imagen y audio: con la imagen del hospital en el campo de batalla se adjunta el sonido de un cañonazo.

El comentario de Makoto Sato sobre esta película es el siguiente:

En esta película, las letras del título sacuden el ánimo de lucha invocando a la guerra sagrada, en realidad una guerra de invasión japonesa. A pesar de esto, el montaje de Kamei extrae el sentido fuera de las frases, mediante palabras contrarias a las imágenes de agotamiento de los soldados en la batalla y los rasgos extenuados de los agricultores chinos. Es decir, la película posee una doble

que filmara el gesto de niño aterrorizado. Shigeru Miki, el operador de la cámara, se negó [Jun-ichi Segawa, quien fuere asistente de la cámara, testifica sobre este hecho en varias ocasiones. Se puede escuchar su entrevista en la película documental Rupe: Cameraman, Segawa Junichi nome [Lupa, el ojo del Cameraman Junichi Segawa.], 16mm., 90min., realizada en 1996 por Shinichi Ise: http://www2.odn.ne.jp/ise-film/works/lupe/lupe.html, visualizada el 30 de noviembre del 2010]. Debido a esta oposición entre el realizador y el operador de la cámara, posteriormente crece una polémica llamada Ruupe-Ronsou [polémica de lupa] en la revista de investigación del cine cultural [Bunka Eiga Kenkyu] en 1940 [Sato,Tadao(et. ál.), Nihonno dokymentary I, Dokyumentary no miryoku [El documental japonés I, El atractivo del documental], Op.cit., p. 25. 
estructura en la palabra y en la imagen. Las autoridades militares seguían engañando a los pueblos, afirmando que obtenían una serie de victorias cuando la realidad era una derrota tras otra. Juzgan a esta película como antibélica y prohíben su proyección. Kamei fue el único cineasta detenido en la cárcel por transgredir la Ley para el mantenimiento del orden público. ${ }^{34}$

A primera vista, si leemos el guión de los títulos de la obra de Kamei, no percibimos un sentimiento antibélico. Sin embargo, con las imágenes (aunque no son excesivas) se deja un espacio para cuestionar lo que ocurre en el campo de batalla. Este espacio que permite una reflexión sobre el tema -a través las contradicciones entre la expresión audiovisual y el texto- fue creado como un acto de resistencia. De este modo, el planteamiento de este espacio distingue al documental de otros cientos de películas propagandísticas de aquella época.

La indicación de Makoto Sato sobre la detención de Kamei discretamente critica a los documentalistas que producían las películas propagandísticas de aquel momento. Otro autor crítico del cine con el mismo apellido, Tadao Sato, se refiere a las películas de propaganda ${ }^{35}$ como obras maestras porque suponen el inicio de la historia del documental japonés. Pero Makoto Sato no ofrece ninguna referencia sobre las películas de propaganda. Podemos imaginar que para Makoto Sato, el documental sin autonomía expresiva no vale la pena como referencia documental. La obra de Kamei expresa una parte de la realidad de la guerra que la autoridad imperial japonesa prohibía representar. Makoto Sato presta atención a la estrategia de la película con su doble estructura en la palabra y la imagen. Porque

\footnotetext{
${ }^{34}$ Sato, Makoto, Op.cit., p. 7. [Traducción propia del texto original japonés]

${ }^{35}$ Tadao Sato indica una relación cómplice entre el público, el cineasta y la autoridad militarista japonés en cuanto a la guerra: Entonces, ¿estos antiguos documentales [sobre la guerra, los cuales sólo contemporizaban los prejuicios de un público que justificaba la guerra del ejército japonés y admiraba su valentía] no tiene valor? No, no es eso. Porque queda registrada la manera de pensar de los japoneses en aquel momento, quienes intentaban comprender la guerra de ese modo. La mayoría del público nacional pensaba lo mismo, no sólo debido a la imposición por parte del poder estatal. Si hubiese habido muchas personas que no lo creyesen así, hubiese existido algún movimiento de inquietud, aunque no llegara a convertirse en rebelión [Sato, Tadao (et al.), Nihonno dokymentary II, Seiji, Shakai hen. [El documental japonés II, El volumen de la política social], Op.cit., pp. 7-8.] Esta reflexión es muy importante porque encontramos una tendencia que reduce la culpabilidad de los diligentes militaristas en la guerra, a la vez que finge que las víctimas son engañadas en mayoría de la gente posguerra. Desgraciadamente, en el plano popular se ha enterrado este asunto sin una reflexión suficiente. Por lo tanto, se remite a las propuestas de los documentales de posguerra. A lo largo de esta sección veremos unas obras esenciales en este tema.
} 
precisamente esto se convierte en la retórica del filme: con el fin de mantener la autoridad expresiva, se niega a ser un portavoz más de la política nacional. No tenemos ninguna objeción con esta reflexión de Makoto Sato, y si pudiésemos añadir nuestra opinión, diríamos que esa retórica potencia nuestra capacidad de imaginación y de cuestionamiento de la realidad. Seguramente esta obra, conmemorativa de la época del inicio del documental japonés, es una muestra de autonomía en la expresión documental anterior a la derrota en la guerra.

\section{V.1.3. El nuevo documental de la posguerra: de observación de intervención dinámica.}

En el caso de Japón, el concepto de posguerra se aplica a partir de 1945, año en que finalizó la guerra con las dos bombas atómicas en Hiroshima y Nagasaki. A partir de la posguerra, el documental japonés fue liberado de la política nacional imperialista del país. Sin embargo, fue dominado por otra potencia política: la tropa norteamericana que dirige la democratización de Japón durante unos años (GHQ) ${ }^{36}$.

En relación a las políticas en la industria del cine documental, el $\mathrm{GHQ}^{37}$ fomentó la difusión de películas educativas a través de la proyección en las escuelas (aparte de las proyecciones en las salas de cine). Surge una división entre la proyección de las películas comerciales Gekieiga (película teatral) en las salas de cine ${ }^{38}$ y la proyección de los documentales en lugares alternativos, por ejemplo, en las escuelas. De esta manera, se prepara el terreno para que crezcan las semillas del cine documental japonés. Tras la derrota en la guerra, el pueblo japonés se da cuenta de la mentira y la falsedad en las películas culturales.

Liberada de la censura por parte del gobierno y de la policía, los realizadores del cine empiezan a producir con dinamismo. Los productores de documentales producen también

\footnotetext{
${ }^{36}$ La ocupación de la tropa norteamericana como GHQ en Japón continúa hasta 1952.

${ }^{37}$ General Headquarters, the Supreme Commander for the Allied Powers, comúnmente denominado GHQ en Japón.

${ }^{38}$ Según la cronología, en 1950 la producción alcanza la cifra de 215 largometrajes. Japón tiene en estas fechas 3.734 salas [Muguilo, Carlos (et. ál.): El cine de los mil años: una aproximación histórica y estética al cine documental japonés (1945-2005), Op.cit., p. 25.]
} 
películas educativas basadas en ideas de paz y de elogio a la democracia. La población nipona, que hasta entonces solo recibía una información limitada por la política nacional, absorbe inmediatamente las diversas exhibiciones.

Aunque estas películas tenían un gran dogmatismo, para los japoneses que tenían vendados los ojos por las noticias falsas, fueron recibidas como un espejo del mundo verdadero con un sentimiento de libertad. Sin embargo, aquí, el iluminismo que anida en el documental japonés de la posguerra, enseguida se adecúa al realismo social oficial. En todas las partes del movimiento popular de Japón influian profundamente los fantasmas del estalinismo. (...)

Los mismos realizadores que contribuían a las películas de propaganda, durante la posguerra cambian completamente sus posiciones y producen un documental que profesa la revolución democrática. ${ }^{39}$

Makoto Sato, igual que Tadao Sato, indica que los cineastas (excepto Fumio Kamei) filmaban las películas según la política nacional, glorificando la lucha sagrada del imperio japonés a lo largo de la guerra. Pero con la derrota inmediatamente empezaron a crear obras que rechazan la guerra y ensalzan la democracia. De este modo, encontramos en la postura del documentalista y su obra una conformidad con ser mero portavoz del patrocinador. En tal caso, no importa si se favorece a la política nacional o a la democracia. Una crítica radical hacia esta postura de los cineastas y un debate sobre el estilo estético en la expresión documental deberán esperar hasta los años sesenta, cuando surge la nueva generación de la posguerra. Veremos los detalles en los apartados próximos.

Para finalizar con nuestra aproximación a los inicios de documental japonés, debemos reflexionar sobre dos películas muy significativas de la década de los cincuenta, las cuales se podrían considerar como obras conmemorativas en la historia del documental japonés. Como hemos mencionado, hasta los años sesenta los documentalistas no empiezan a reflexionar sobre la responsabilidad política y social del documental. Así, la aparición de estas dos películas prepara la evolución del documental de las siguientes décadas. Una es

\footnotetext{
${ }^{39}$ Ibíd., pp. 7-8. [Traducción propia del texto original japonés]
} 
Kyoshitsu no kodomotachi (Niños en clase) ${ }^{40}$ de 29 minutos, en blanco y negro, producida en el año 1956 por Susumu Hani. Otra es Ikiteite Yokatta (¡Qué bien por vivir!) de 52 minutos, en blanco y negro, filmada en el año 1956 por Fumio Kamei. Las dos son muy distintas en cuanto al tema, el estilo y el método de realización. Veamos, pues, cada documental con algunos comentarios sobre la parte técnica, manteniendo nuestro enfoque en los aspectos que influirán en los trabajos posteriores del documental japonés.

El trabajo de Susumu Hani surge dentro de empresa Iwanami Eiga (Cine Iwanami) para una productora de Iwanami. Esta sociedad de producción fue establecida por la Iwanamishoten (Editorial Iwanami), reconocida por su reflexión y sensatez. La sociedad se funda como una producción especializada en las películas educativas y de publicidad a petición de las empresas y otros.

La productora Iwanami establece una corriente importante para la renovación de la película documental japonesa de la posguerra. Posteriormente, esta sociedad impulsa a varios autores excelentes en el documental japonés. De hecho, el método que eligió Iwanami fue emplear a jóvenes sin previa experiencia en la producción y la realización del cine en el contexto anterior a la guerra: hizo que estos jóvenes produjesen las películas de no ficción desde cero; es decir, les obligó a considerar e incluso inventar las técnicas de producción de una película documental.

Kyoshitsu no kodomotachi (Niños en clase) es una película educativa patrocinada por el Ministerio Nacional del nuevo régimen japonés. La obra representa a los niños de segundo año de Primaria en Tokio. Se cuestionan los métodos del profesor para administrar la clase con el fin de que los niños puedan participar en ella y aprender libremente. Muestra el

\footnotetext{
${ }^{40}$ En los años cincuenta, cuando trabajaba en la compañía Iwanami, Susumu Hani dirigió documentales didácticos para el Ministerio de Sanidad y de Educación. Sus primeros cortos documentales "Niños en clase" y "Niños dibujando [Eo kaku kodomotachi: 38min., b/n, 1956]" tenían el objetivo de dar fe de los nuevos sistemas educativos del país. Los protagonistas eran los niños que habían nacido tras la guerra y, por lo tanto, pertenecían a la primera generación del Japón democrático. Sin embargo, el propósito pedagógico-propagandístico del gobierno quedaba superado por la mirada transparente y libre de Hani. La cámara se disolvía en el grupo infantil y nadie reparaba en ella, anticipando intuitivamente las ideas del llamado "Direct Cinema" [Muguilo, Carlos (et. ál.): El cine de los mil años. Una aproximación histórica y estética al cine Documental japonés (1945-2005), Op.cit., p. 27.]
} 
estado de aulas hacinadas con demasiados niños y un profesor estricto que no consigue mantener el orden porque carece de un don de mando.

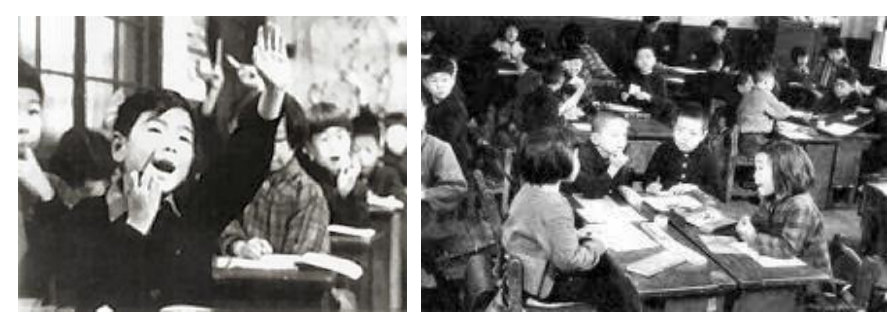

18. Kyoshitsu no kodomotachi (Niños en clase, 1956), Susumu Hani

La película en sí tiene cierto mensaje; sin embargo, son las imágenes de los personajes principales con una naturalidad libre las que superan una expresión muy formal y de esta manera se desvía del documental del duro realismo socialista, el cual ofrecía demasiada prioridad al mensaje.

La técnica y la imagen de esta película son increíbles en comparación a lo que se podía encontrar anteriormente en el documental japonés. Por ejemplo, a pesar de ser un cortometraje, se filmaron unos cuantos miles de metros de película aunque solo se emplearon ochocientos metros ${ }^{41}$. Es decir, se filmó el estado de los niños durante un largo tiempo y posteriormente se seleccionaron las escenas más interesantes. En aquel momento, esto supuso una técnica de realización documental muy revolucionaria. Podemos decir que el germen del Direct Cinema se encuentra en este modo de hacer documental. Efectivamente, es el inicio del documental de observación, ya que posteriormente aumentan las obras de este tipo y se establece como método gracias a un avance técnico del dispositivo.

Según los comentarios de los participantes en el rodaje de la película ${ }^{42}$, los niños como sujetos frente a la cámara en un principio se desorientan. Pero después se acostumbran a la

\footnotetext{
${ }^{41}$ Sato, Sato (et. ál.): Nihonno dokymentary II, Seiji, Shakai hen [El documental japonés II, El volumen de la política social], Op.cit., 2010, p.53.

${ }^{42}$ Varios textos describen el estado del rodaje en aquel momento. Tadao Sato cita el libro del realizador Susumu Hani: Enguishinai shuyautachi: kirokueigasakushanomeara [Los personajes principales sin actuación desde la percepción de un documentalista] Tokio, Chuokoronsha, 1958: Y sin cumplirse ni dos días, el interés [de los
} 
presencia de la cámara en clase, así como a las personas del equipo de rodaje. Ellos se quedan más tranquilos y actúan naturalmente, lo cual mejora la calidad de filmación.

En realidad, la posibilidad de filmar estas escenas tan naturales y vívidas se explica gracias a la parte técnica, en este caso, a la portabilidad y la flexibilidad de la cámara. Esta película fue filmada con cámara Arriflex, una cámara producida en Alemania (la cual según dicen fue inventada para el registro de la batalla). Veamos cómo lo explica Tadao Sato $^{43}$ a continuación.

Hasta aquel momento, generalmente las películas profesionales en Japón se filmaban mediante las cámaras estadounidenses Mitchell, con las que se podía filmar con una excelente calidad ${ }^{44}$. Pero eran difíciles de transportar por su peso y existían problemas de discrepancia entre la imagen del visor y de la película filmada. Es decir, para poder filmar bien con esta cámara se debía decidir cierto encuadre de antemano, contando con la distancia entre la cámara y el objetivo. Al emplear las cámaras Mitchell en el documental se podía filmar al personaje en un sitio fijo o mover el orden dependiendo del cálculo de la distancia. Es decir, el movimiento del objeto se limitaba en la filmación y era imposible de grabar sin una previsión de dicho movimiento.

En cambio, la cámara Arriflex era capaz de corresponder con cierta flexibilidad a los movimientos libres de los niños. Aún así, no se podía prever exactamente cuándo y quién actuaría de manera interesante. Para poder captar las escenas atractivas, de todos modos se

niños por el equipo de rodaje] había desaparecido totalmente. (...) Durante la clase, nosotros [el equipo de rodaje] permanecimos ignorados como los más discretos de sus amigos, como unos diagramas gráficos en la pared o una pizarra [Traducción propia del texto original en japonés], en: Sato, Tadao (et. ál.): Nihonno dokymentary I, Dokyumentary no miryoku [El documental japonés I, El atractivo del documental], Op.cit., p. 54. También en una entrevista de Sumiko Haneda a Mitsuru Kudou, la ayudante y el productor de la película, se comenta que la curiosidad de los niños no duraba mucho tiempo. Según ellos, la curiosidad apenas duraba unos minutos para cada tarea, para el equipo de rodaje, la lámpara o la cámara. Al mismo tiempo, el equipo se las ingeniaba para mantener el estado natural de los niños y del ambiente de la clase [Tadao Sato (et. ál.): Nihonno dokymentary III, Seikatsu, Bunka hen. [El documental japonés III, El volumen de la vida y la cultura], Tokio: Iwanamishoten, 2010, pp. 178-188].

${ }^{43}$ Tadao Sato (et al.), Nihonno dokymentary I, Dokyumentary no miryoku [El documental japonés I, El atractivo del documental], Op.cit., pp. 54-55.

${ }^{44}$ En la sección de la cámara en el Diccionario técnico Akal del cine, se ofrece una breve explicación sobre la relación entre las cámaras Mitchell y Arriflex: La vieja Mitchell BNC de 35mm, durante mucho tiempo el caballo de batalla para el rodaje en estudio, (...) las pequeñas cámaras portátiles, como la clásica Arriflex $352 C$, se emplean para el trabajo de campo (...) [Konigsberg, Ira: Diccionario técnico Akal del cine, Op.cit., p. 67.] 
debía fijar la imagen en una persona y esperar a su acción espontánea mediante un rodaje por largo tiempo.

Éste es un buen ejemplo que nos ilustra la relación entre la portabilidad del soporte fílmico y su posible representación en audiovisual. A pesar de que este documental logró filmar las imágenes vividas, un audio que represente las experiencias deberá esperar todavía más (hasta que aparezcan las cintas de bajo precio).

La técnica utilizada por Hani se convirtió prácticamente en un mito del documental japonés. No obstante, resulta demasiado romántico creer que este mismo método funciona en la actualidad. De acuerdo con Tatsuya Mori ${ }^{45}$, documentalista japonés, hoy en día no tiene sentido repetir la técnica de Hani. Todos, incluso los niños que comienzan tener capacidad de entendimiento, nos encontramos rodeados de imágenes: nos hemos acostumbrado demasiado a las imágenes de la TV, del ordenador, del móvil, etc. Aunque no es fácil de explicar teóricamente, siempre percibimos de una manera inmediata lo que ocurre frente a la cámara.

Dicho de otro modo, hoy en día nadie puede actuar libremente y con naturalidad frente a la cámara porque entiende que va a permanecer como una imagen audiovisual que puede distribuirse en la red con la misma rapidez y facilidad que cualquier otro dato. Esta manera de comprensión por parte de los individuos contemporáneos constituiría una parte de la interiorización de la educación a través de la imagen. Se trata de un asunto que tiene diversos enfoques y en el cual debe profundizarse más. No obstante, en este momento solo indicaremos que por su relevancia es uno de los temas a desarrollar en un futuro próximo.

En cualquier caso, la película de Hani fue una obra revolucionaria. Su objetivo de superar el dogma formalista relativo al realismo social del documental japonés fue logrado en esta obra. Asimismo, las tres tipologías (película cultural, película política nacional y película

\footnotetext{
${ }^{45}$ Tatsuya Mori (1956- ), director independiente de programas televisivos y presentador de la película documental: A (1998) y A2 (2001). Ha escrito varias publicaciones sobre los medios de comunicación, el documental y otros asuntos sociales. El detalle de su trabajo lo analizamos en V.3.3.2. http://moriweb.web.fc2.com/mori_t/index.html, accedido el 30 de marzo 2009.
} 
iluminista) sustentadas por los productores profesionales y por los teóricos fueron superadas por un joven sin educación profesional previa en la época inicial del documental de la posguerra japonesa. Gracias a este éxito en la producción de una obra conmemorativa se inicia un nuevo estilo en el documental japonés. De esta forma, Iwanami Eiga demostró su acierto al emplear a productores de cine que antes de la guerra eran básicamente inexpertos. A partir de este momento, son varios los nuevos talentos de película documental japonesa los que aparecen desde dicha empresa.

El documental de la posguerra de Fumio Kamei Ikiteite Yokatta (Still, It's Good to Live) aborda el desastre de la bomba atómica. Durante la ocupación de la tropa norteamericana que se prolonga hasta el año 1952, la información sobre las bombas y sus consecuencias no estaban disponibles para una exhibición en público ${ }^{46}$. Debido a esta situación, la voz de las víctimas no era fácil de escuchar ${ }^{47}$. Como consecuencia de la falta de la información sobre los daños provocados por el ataque nuclear, las víctimas incluso sufrieron segregación social. Kamei intenta denunciar la injusta discriminación de estas personas recogiendo la voz de las víctimas y presentando el movimiento social contra la bomba atómica.

La película está dividida en tres partes, "Morir es duro", "Vivir es duro" "Pero, iqué bueno es vivir!". Muestra los efectos de la bomba entrevistando a los supervivientes y montando imágenes documentadas. Luego señala el dolor físico y mental de las víctimas y sus

\footnotetext{
${ }^{46}$ A finales de agosto de 1945, Nihon Eigasha publica el noticiario de cine Nihon News, para el cual envía a un equipo de 30 personas (incluyendo el operador de la cámara Shiger Miki) a Hiroshima y Nagasaki con el fin de filmar los estragos de la bomba. Sin embargo, en octubre fueron detenidos por la tropa norteamericana y se prohibió el rodaje. Más tarde, emplea al equipo de Nihon Eigasha y realiza The Effect of the Atomic Bomb in Hiroshima and Nagasaki en secreto para enviarla a EE. UU. GHQ se pronunciaba oficialmente a favor de la libertad de expresión, pero en realidad realizaban una censura estricta de las publicaciones y los medios de comunicación, incluido el cine. En particular, las informaciones sobre los efectos de la bomba atómica eran secreto militar y fueron tratadas como asunto confidencial. Tadao Sato supone que GHQ se precavía de generar un sentimiento anti-norteamericano al restringir las informaciones de los daños de la bomba atómica. Los detalles se encuentran en Tadao Sato (et al.): Nihonno dokymentary II, Seiji, Shakai hen. [El documental japonés II, El volumen de la política social], Tokio: Iwanamishoten, 2010, pp. 84-85. Como excepción, existe un cortometraje para la educación infantil, Nagasaki no ko (Los niños de Nagasaki), de Genichiro Higuchi (1949). El documental está basado en las notas de los niños de Primaria en el lugar que sufrió el ataque nuclear y fue producido en una manera independiente. Posteriormente, Higuchi será el primer personaje del documental científico educativo por el rodaje del microscopio.

${ }^{47}$ En el ámbito de las películas de ficción, Kaneto Shindo realiza su primera obra de producción independiente en 1952 abordando el tema de bomba atómica: Con el fin de la ocupación, vuelven los temas prohibidos a las pantallas. En ese nuevo contexto, Kaneto Shindo realiza Genbaku no ko (Children of Hiroshima) sobre un tema tabú, la hecatombe de las bombas [Muguilo, Carlos (et. ál.): El cine de los mil años. Una aproximación histórica y estética al cine Documental japonés (1945-2005), Op.cit., p. 28.]
} 
familias, evidenciando la difícil supervivencia social y económica en que se encuentran. El mensaje de esta película es muy claro: persigue que se ofrezca cierta ayuda a las víctimas y a sus familiares que todavía sufren secuelas y que se comprenda ampliamente los daños ocasionados por el ataque nuclear. Denuncia la injusticia de la bomba atómica y lo justo del movimiento social contra la bomba atómica. El estilo expositivo de este documental ofrece una clara explicación de la situación. La intención de mostrar el mensaje político se realiza de forma muy precisa en esta película, y también se observan algunos aspectos del dogmatismo propio del realismo socialista.

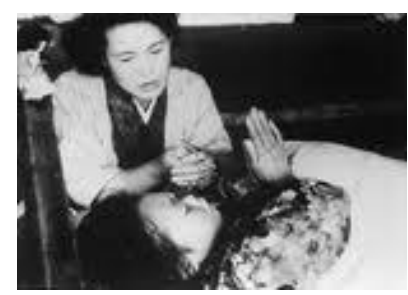

19. Ikiteite Yokatta (Still, It's Good to Live, 1952)

A pesar de ello, esta película tiene un carácter innovador para el documental japonés. Se nota claramente en una escena en la que Kamei, el realizador mismo, sale en la imagen con otro personaje entre sus brazos: una chica, víctima de la bomba, la cual se quedaba en una habitación encerrada en casa, casi perdiendo la esperanza de vivir y sin poder caminar por las secuelas. Kamei realiza una entrevista a la chica y la anima a salir de la casa. La chica quería reconocer una ciudad que nunca había vuelto a ver tras su salida del hospital. El equipo de rodaje pide un coche a la organización Contra la Bomba Atómica ${ }^{48}$ y realiza la visita de la ciudad en el coche. Kamei lleva a la chica en sus brazos para que ella vea el paisaje y aspire el aire de la ciudad.

Esta escena es solo un breve momento en la película y no se percibe ninguna insistencia por parte del autor para aparecer en la obra. Sin embargo, aun así resulta sorprendente. Según Tadao Sato, el personal del rodaje no había aparecido nunca en la imagen del documental

\footnotetext{
${ }^{48}$ The Japan Council against Atmic and Hydrogen Bombs: http://www.antiatom.org/, accedido el 28 marzo 2011.
} 
japonés hasta esta película. De hecho, existía una clara separación entre ambos lados al filmar y ser filmado. Él indica la importancia de la escena de la siguiente manera:

No parece nada peculiar, pero es muy importante. El documental [japonés] estaba hasta aquel momento mayormente patrocinado por grandes empresas $u$ organizaciones nacionales. De ahí que no pocas veces se escuche más bien una narración insípida con la voz de la empresa o del gobierno que la propia voz del autor. En cambio, en esta obra, a pesar de que Kamei no habla, muestra su cara y deja claro que se queda al lado de la chica víctima del bombardeo atómico. Con ello, [Kamei] declara que él mismo es responsable de lo que describe y manifiesta en la película. La primera vez que vi la película, sentí que esto le aportaba una gran energía. $^{49}$

Observamos claramente la postura del autor del documental que deja ser un simple portavoz del patrocinador. En la tradición documental, uno de los aspectos más importantes es conseguir una representación objetiva. Por eso, hasta entonces el equipo de rodaje debía ser únicamente observador para conseguir un registro real y objetivo. En el caso de la película de propaganda, la objetividad aseguraba el "realismo" de la obra al lanzar un mensaje político mediante imágenes reales, aunque como hemos visto existía una manipulación irrazonable de imágenes o informaciones.

Ahora, el acto de Kamei en este documental -sea consciente o inconscientemente- hace temblar la tradición que ligaba la objetividad con la realidad. Siguiendo los comentarios de Tadao Sato, la potencialidad de la película viene dada por una manifestación abierta de la responsabilidad del autor como individuo. La subjetividad del autor y su opinión personal en la expresión documental llegan al corazón del espectador.

Podemos considerar que en esta obra se encuentra el germen de un movimiento cinematográfico que se esforzará por establecer la responsabilidad y la subjetividad del

\footnotetext{
${ }^{49}$ Sato, Tadao (et. ál.): Nihonno dokymentary I, Dokyumentary no miryoku [El documental japonés I, El atractivo de documental], Op.cit., pp. 58-59. [Traducción propia del texto original japonés]
} 
autor en su expresión. Tadao Sato describe esta película como un trabajo que inicia un nuevo rumbo en el documental japonés:

Se puede decir que esta obra abrió un nuevo rumbo en el que el documental no se queda solo como noticia, sino que crea los eventos y planea y dirige el asunto sobre el que se debe informar. ${ }^{50}$

En este nuevo rumbo en que se crea y se planea el evento, vemos el mismo intento de visibilizar lo invisible. A su vez, en el evento del documental y en la obra documental en sí se encuentra un acto performativo por recuperar la esperanza de la vida a pesar de los horrores que acaecen en nuestro mundo.

Por último, debemos añadir que esta película fue significativa por su distribución y producción independiente. Tras la derrota en la guerra, debido a la supresión de la proyección de la película cultural, eran muy limitados los lugares donde proyectar públicamente los cortometrajes documentales. Concretamente, esta película fue proyectada en el miniteatre (sala pequeña del cine) Namikiza en Ginza, Tokio. Con ello, se inauguró el recorrido de la proyección de cortometrajes documentales independientes ${ }^{51}$.

\footnotetext{
${ }^{50}$ Sato, Tadao (et. ál.): Nihonno dokymentary II, Seiji, Shakai hen. [El documental japonés II, El volumen de la política social], Op.cit., p. 86. [Traducción propia del texto original japonés]

${ }^{51}$ Ibíd., p. 87.
} 
V.2. La subjetividad en el documental de los años sesenta y setenta. 
En el presente apartado destacaremos un movimiento de producción y proyección del documental independiente aparecido en Japón de la década de los sesenta y setenta. Este movimiento se convierte en el resultado radical de los planteamientos de posguerra en torno al documental japonés.

Los años sesenta fueron muy significativos en varios aspectos para el movimiento cinematográfico y el arte audiovisual en general. Por ejemplo, Kaneto Shindo realizó la película Hadaka no shima (The Naked Island) en 1960, considerada como una película que abrió el camino de la producción del film independiente ${ }^{1}$ con un equipo reducido. En el momento de su presentación, la obra fue prácticamente ignorada por los distribuidores nacionales. Sin embargo, al ganar premios y distribuciones internacionales se logró recuperar económicamente.
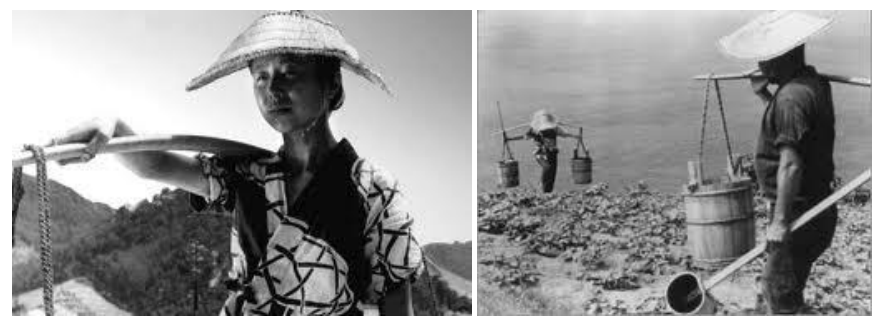

20. Hadaka no shima (The Naked Island 1960), Kaneto Shindo

La película fue realizada por un equipo de 13 personas, incluyendo a dos actores profesionales, durante un mes de rodaje. El presupuesto equivaldría a una décima parte de lo normal en aquel momento. El sistema establecido en esta película fue que: todo el rodaje fué en el exterior, concentrando a todos los personajes durante el rodaje y participación de todo el personal en mesas redondas. Influye notablemente en las producciones de películas independientes, sobre todo. Vamos a ver una radicalización de su método en el movimiento del documental independiente de la siguiente década.

\footnotetext{
${ }^{1}$ La producción llega a las 547 películas. Sobresale Hadaka no shima (The Naked Island), de Kaneto Shindo, primer premio en Moscú. El filme, producido por la propia compañía de Shindo (Kindai Eiga Kyokai), abre las puertas a un tipo de producción más pequeña y autónoma [Muguilo, Carlos (et. ál.): El cine de los mil años. Una aproximación histórica y estética al cine Documental japonés (1945-2005), Navarra, Festival Internacional de Cine Documental de Navarra, Navarra Dirección General de la Comunicación, 2006, p. 33].
} 
También aparecieron en esta década la cámara portátil de $16 \mathrm{~mm}$ con la función de grabación del sonido sincronizado y la grabadora de vídeo portátil Portapak de Sony. Muchas referencias del videoarte las encontramos en esta década. Destacaremos asuntos relacionados con el videoarte en otra sección, pero por ahora seguiremos con el tema del documental.

Para empezar, vamos a ver una crítica de Toshio Matsumoto ${ }^{2}$ y sus jóvenes colegas realizadores del documental japonés contra la vieja generación de cineastas. Aclararemos el contexto para la aparición del sujeto del autor en el documental japonés. Luego comentaremos unos documentales de Nagisa Oshima ${ }^{3}$ y de Shohei Imamura, considerados como realizadores de la nueva ola japonesa, como ejemplos de la aparición del autor como sujeto. Como parte final de esta década, repasaremos el Cinéma-vérité y el Direct Cinema como los movimientos internacionales que provocaron una renovación radical de la teoría y la práctica del documental.

Posteriormente, nos fijaremos el movimiento de la producción documental de "comuna" que apareció en la mitad de los años sesenta y que duró una década con un intenso trabajo centrado en el contexto social. En relación a estos trabajos, nos referiremos a un documental producido por Makoto Sato en el que se aplica el estilo de producción de esa década, si bien aparece durante los últimos años de la década de los ochenta.

\footnotetext{
${ }^{2}$ Matsumoto Toshio (1932- ): Matsumoto es uno de los pioneros del documental vanguardista, aunque ha trabajado también dentro del cine experimental, la videocreación y el arte multimedia. Se graduó en la Universidad de Tokio en 1955. Tras dirigir su primera película para Iwanami (Senkan/ The Bends- 1956), Matsumoto se pasó al cine independiente, buscando siempre nuevas formas de expresión. Sus escritos, desde “Eizo no hallen" (1963) a "Eizo no tankyu” (1992), conforman una de las fuentes de estímulo, provocación y reflexión más importantes del cine japonés de los últimos cincuenta años. Además de algunos cortos esenciales dentro de la historia de no ficción japonesa, como "Nishijin" (1961) e "Ishi no uta" (The song of Stones/ 1963), Matsumoto ha dirigido obra experimental de ficción de gran repercusión internacional, como "Bara no soretsu" (Funeral of Roses/ 1969) y Dogra Magra. Imparte clases en Facultad de Arte de la Universidad de Arte y Diseño de Kioto [Muguilo, Carlos (et. ál.): El cine de los mil años. Una aproximación histórica y estética al cine Documental japonés (1945-2005), Navarra, Festival Internacional de Cine Documental de Navarra, Navarra Dirección General de la Comunicación, 2006, p. 118].

${ }^{3}$ Nagisa Oshima (1932- ), realizador de películas. Le llamaban el abanderado de la Nueva ola de Shouchiku. Tiene numerosos trabajos, Nihonno yoruto kiri (La noche y niebla de Japón 1960), Koushukei (Pena de muerte por estrangulación /1968), Imperio de los sentidos (1977), Feliz Navidad, Mr. Lawrence (1983), Taboo (Tabú /1999).
} 
Para finalizar el presente apartado, comentaremos algunos documentales que se centran más en los asuntos personales y privados, abriendo así camino hacia los Private Documentary y Self Documentary. Los trabajos que vamos a mencionar serían unas excepciones que se quedaron fuera de la tendencia principal del documental japonés de aquella décadas de los sesenta y setenta, los cuales reclamaban justicia y exaltaban la solidaridad social en la resistencia contra el poder político y económico, junto al movimiento estudiantil. Sin embargo, paradójicamente, estos trabajos excepcionales a su vez indican un cierto límite con los documentales de la corriente principal de aquella época. En esta sección, como en la anterior, seguimos la interpretación de Tadao Sato y Makoto Sato. Con todo, nuestra intención es contextualizar la parte del documental fílmico que abre el camino hacia la aparición del Private Documentary y del Self Documentary en los años noventa. Y éste nos servirá para una mejor comprensión del criterio de Makoto Sato sobre los Private Documentary y Self Documentary, los cuales alcanzan su mayor auge en el documental de los años noventa.

\section{V.2.1. El autor como sujeto en el documental y la nueva ola japonesa.}

A partir de la derrota de la guerra de 1945 y hasta los años 50, el documental se había liberado de la censura del gobierno militarista y se disfruta de libre expresión, al menos en teoría ${ }^{4}$. En general, la sensación de los espectadores del documental, en el nuevo régimen político, fue como si se hubiese conseguido quitar la venda del totalitarismo fascista, venda que les ocultaba las informaciones durante la guerra. La mayoría de los documentales ahora se realizan con la forma y el estilo propagandístico del realismo socialista, alabando el nuevo régimen democrático.

Los mismos realizadores de documental, que a lo largo de la guerra producían películas de propaganda con la máxima y ciega admiración a la guerra y al ejército del imperio japonés, por el cambio del patrocinador, producen películas que aplauden el fin de guerra y la

\footnotetext{
${ }^{4}$ El cuartel general de los países Aliados llamada GHQ en Japón, fomentó la libre expresión como el proceso de la democratización del país. Sin embargo, por otra parte, realizó el control en ciertos asuntos inconvenientes para la administración de gobierno. Por ejemplo. los estragos del ataque nuclear eran materia reservada hasta 1952, al fin de la ocupación por las tropas aliadas. Para los detalles váyase a V.1.3.
} 
revolución democrática. No se ha encontrado una auto-reflexión por parte del cine ni de los cineastas, sobre su participación en la guerra. En este contexto, las generaciones de cineastas que se estrenan en la posguerra, como Toshio Matsumoto, se plantean cuestionar la responsabilidad de los documentalistas que producían las películas de política nacional y participaban así en la guerra. Makoto Sato explica la crítica de Matsumoto y sus compañías del siguiente modo:

Se critica la ausencia del sujeto del realizador: solo se inscriben en la corriente dominante en cada momento y únicamente alaban al objeto del rodaje. Esto supuso una declaración que abriría el camino hacia la vanguardia de la presentación, estableciendo el sujeto del autor de la película contra la corriente política vulgar abanderada del realismo socialista. ${ }^{5}$

Durante el período anterior a la guerra se habían producido películas de propaganda que enaltecían la lucha, por orden del gobierno del Imperio japonés. En la posguerra se realizaron películas que alababan a la democracia, según indicaciones del cuartel general de la tropa norteamericana que ocupaba Japón. Una vez las tropas se habían marchado, la tendencia expresiva en el documental japonés seguía el mismo esquema, cambiando los patrocinadores (ya fuese el gobierno o grandes empresas en numerosos casos).

Sarcásticamente, el mismo autor podía decir absolutamente lo contrario dependiendo del patrocinador. Para Matsumoto y su compañía, el estilo realista de los documentalistas de la vieja generación es falso. Este tipo de documental se convirtió en portavoz audiovisual del poder político. Siendo portavoz se elude la responsabilidad sobre lo que se dice. En este momento, no existe aún el sujeto del realizador en su producción y expresión.

Con todo, Matsumoto y sus colegas llegan a la conclusión de que es necesario construir el sujeto del autor en la expresión documental a nivel teórico-práctico. Como indica Abe

\footnotetext{
${ }^{5}$ Sato, Makoto: Documentary no shujigaku [La retórica del documental], Tokio, Misuzushobo, 2006, p. 8. [Traducción propia del texto original en japonés]
} 
Mark Nornes ${ }^{6}$, este cuestionamiento sobre la subjetividad del autor ya se encuentra escrito por el consejo editorial de Kiroku Eiga (película documental) en 1960:

\begin{abstract}
El consejo editorial de Kiroku Eiga anunció en 1960 que a partir de entonces sus esfuerzos tomarían una nueva dirección, poniendo un énfasis especial en tres asuntos interconectados: (1) el cuestionamiento (ronrika) de la relación que se establecía entre el ambiente o entorno y la subjetividad del director, (2) el cuestionamiento de la representación y la subjetividad del director (sujeto), y finalmente (3) el cuestionamiento de la relación que se establecía entre la posición del sujeto en esa realidad o entorno y la representación subjetiva de esa realidad. ${ }^{7}$
\end{abstract}

Los cineastas de la nueva generación que surge en los años sesenta, debido a esa conciencia sobre la responsabilidad en la participación en la guerra, llegan a cuestionar el sujeto del autor y la subjetividad expresiva. A partir de la iniciativa de estos jóvenes cineastas, el documental japonés empieza a cuestionarse el sujeto del autor como una contestación crítica a la responsabilidad del cine y su participación en la guerra.

Encontramos otros autores (aparte de Matsumoto) que procuran establecer el sujeto del autor en el documental de los años sesenta. Por ejemplo, Kazuo Kuroki ${ }^{8}$ seguía produciendo películas de publicidad que apenas anunciaban nada, solo intentaban presentar al sujeto del autor cuando trabajaba en Iwanami (la productora especializada en películas educativas y de publicidad de empresas). A consecuencia, continuamente tenía problemas con los clientes. Por esta razón comenzó a limitar la presencia del autor en el documental y empezó a producir películas teatrales renunciando a Iwanami.

\footnotetext{
${ }^{6}$ Abé Mark Nornes, profesor de la Universidad de Michigan en EE. UU., investigador de cine y documental japonés, en http://www.lsa.umich.edu/sac/faculty staff/nornes.html, accedido el 15 de enero de 2011.

${ }_{7}^{7}$ Abé Nornes, Mark: El rastro del cine documental japonés de posguerra: a tientas en la oscuridad, en Muguilo, Carlos (et. ál.): El cine de los mil años. Una aproximación histórica y estética al cine Documental japonés (19452005), Op.cit., p. 64].

${ }^{8}$ Kazuo Kuroki (1930-2006), realizador de películas japonés. Empieza a rodar documentales en Iwanami Eiga Seisaku Gaisha (sociedad de producción de Iwamami) y después de retirarse produce numerosas películas de ficción.
} 
No solo los jóvenes se presentan como las grandes influencias en este momento de renovación. Es el caso de Toshio Yanaguisawa ${ }^{9}$, quien producía documentales desde la antes de la guerra hasta el final de los años sesenta. Él rehusó todas las técnicas de la película publicitaria, y se dedicó a producir documentales independientes sobre los servicios de asistencia social.

Al considerar el desarrollo del documental japonés no podemos ignorar los trabajos en la Televisión. En los años sesenta los realizadores con esta conciencia del sujeto del autor tuvieron graves conflictos con los grandes estudios y productoras, los cuales buscan beneficios económicos y evitan el conflicto político. Además, debido a la decadencia de la industria del cine, no son pocos los realizadores que empiezan a trabajar en la Televisión que se encontraba en un proceso de desarrollo.

Por ejemplo, Nagisa Oshima realizaba películas como representante de la nueva ola japonesa en Shochiku (gran empresa del cine y el espectáculo). No obstante, en las primeras etapas de la Televisión, en la década de los sesenta, produjo unos trabajos de documental experimental. Entre los documentales más importantes de Oshima, Wasurerareta kougun (El ejército de emperador olvidado $)^{10}$ es una obra conmemorable de esta década del documental japonés.

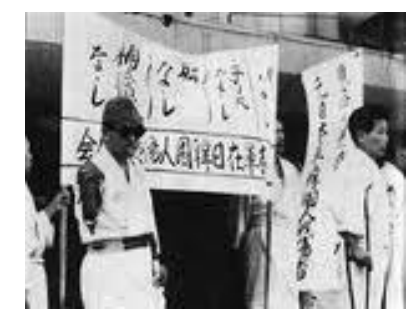

21. Wasurerareta kougun (El ejército de emperador olvidado, 1963), Nagisa Oshima

\footnotetext{
${ }^{9}$ Toshio Yanaguisawa (1916-1999), realizador de películas documentales. Estuvo en Shouchiku (la sociedad de producción Shochiku) que es una gran empresa del teatro y otros medios de espectáculo. Después, concentra su trabajo en la observación de la vida diaria de los incapacitados.

${ }^{10}$ Wasurerareta kougun (El ejército de emperador olvidado): 26minutos, en color, Non Fiction Gekijo (teatro de no ficción), Nihon Televi (Nippon Television). Dirigida en 1963 por Nagisa Oshima y producida por Junichi Ushiyama. Se puede ver la obra en The Broadcast Library de Yokohama, en Japón. http://www.bpcj.or.jp/english/, visualizada el 3 de febrero 2011.
} 
En este trabajo, Oshima retrata a los coreanos mutilados de guerra que permanecían en Japón. Antes de la derrota de la Segunda Guerra Mundial, Corea permaneció como un territorio japonés. Por esta razón, los coreanos sufren daños por participar en el ejército del emperador japonés. Al final de la guerra, Corea se independiza y el gobierno japonés anula la nacionalidad a los coreanos que permanecían en Japón: como resultado, estos coreanos incapacitados se quedaron sin pensión. En este documental, se muestra el estado miserable e irremediable de estos coreanos debido al rechazo del gobierno japonés, la falta de interés del gobierno coreano y la ignorancia del público japonés. Este documental finaliza con una frase: “¡Japoneses, nosotros!, ¿está bien así?”, escrita por Oshima cuestionando el sentimiento humano y la responsabilidad de todos los japoneses frente a esta gente herida, tanto física como psicológicamente. Tadao Sato comenta sobre esta obra de la siguiente manera:

Oshima llega al grito de “JJaponeses, nosotros!, ¿está bien así?” Es su voz interior indignada. Podemos decir, de esta manera, que declara en voz alta que es posible que el documental manifieste la posición de un autor, basada en sus convicciones personales: se supera así el marco de ser un simple reportero de una noticia objetiva. ${ }^{11}$

La narración de este documental de Oshima es un reflejo de sus propios sentimientos. También las imágenes y los estados que se muestran crean una sensación bastante violenta y se mantiene una tensión entre el objetivo del rodaje y la perspectiva del sujeto-autor. Es notable la intención del autor de querer mostrar la herida grotesca de esas personas. Y a través del impacto, Oshima espera que espectador llegue a cuestionarse por qué ocurre esto y como puede dejarse así. Siguiendo la interpretación de Tadao Sato, en el trabajo de Oshima se encuentra una apropiación del tema y de las imágenes captadas del "otro", marginado e invisible en la sociedad.

\footnotetext{
${ }^{11}$ Sato, Tadao (et. ál.): Nihonno dokymentary I, Dokyumentary no miryoku [El documental japonés I, El atractivo de documental], Tokio: Iwanamishoten, 2009, p. 62. [Traducción propia del texto original en japonés]
} 
Nagisa Oshima también fue uno de los más importantes teóricos sobre la realización del trabajo fílmico. Sobre todo la tesis que propuso para el documental tuvo una gran influencia en los documentalistas de la generación siguiente, tal y como resume Makoto Sato:

Oshima propone la tesis general del rodaje en los documentales: "el amor hacia el motivo u objeto del documental" y "la reunión de materiales por un largo tiempo". Así, surge la corriente del cine documental japonés que establece la política del autor ${ }^{12}$ mediante el intercambio de los autores del cine, atravesando el género de cine teatral o cine experimental y otros más. ${ }^{13}$

Su método se genera como los estándares que se deben cumplir en el documental japonés. La tesis planteada por Oshima se fue radicalizado en la siguiente generación: surge un fenómeno peculiar de producción del documental en comunas, al que vamos a referirnos en la siguiente sección.

En comparación con el trabajo de Oshima, Ningen johatsu (A Man Vanishes/ Desaparición de un hombre) de Shohei Imaura ${ }^{14}$ de 1967, tiene distinto aspecto y muestra un nuevo carácter del documental japonés. La película fue rodada para Imamura Productions, fundada por Imamura mismo en 1965. Imamura, también trabajó durante años en el gran estudio del cine Shochiku y Nikkatsu como ayudante de grandes maestros de cine como

\footnotetext{
${ }^{12}$ La política del autor: cada obra de arte, pintura, música, literatura y otros más poseen un sujeto de presentación (el pintor, músico, escritor, etc). Igualmente, en el cine el realizador debería ser el sujeto de presentación. Es la política del autor la que manifiesta el cine como un medio de presentación del realizador e incluye la estrategia de su realización. El concepto "la política de autor" procede de Ali Baba et la "Politique des Auteurs" (Ali Baba y "La política del autor") en la revista Les Cahiers du cinéma, febrero 1995, de François Roland Truffaut (realizador de cine de la nueva ola francesa bajo influencias de André Bazin, el primer director de la revista mencionada). También de Naissance d'une nouvelle avant-garde: la caméra-stylo (Nacimiento de una nueva vanguardia: la cámara-pluma) en la revista L'Écran Français, 1948, de Alexandre Astruc, escritor de ensayos sobre cine y realizador dentro de la nueva ola del cine francés.

${ }^{13}$ Sato, Makoto, Op.cit., pp. 8-9. [Traducción propia del texto original en japonés]

${ }^{14}$ Shohei Imamura. Tokio (Japón), 1926. Imamura es unos de los grandes maestros del cine emergido con la llamada Nueva Ola japonesa de los años sesenta. Fue ayudante de dirección de Yasujiro Ozu, Masaki Kobayashi y Yuzo Kawashima, a quien siempre consideró su maestro. Debutó en 1958 con Nusumareta Yokujo (Deseo robado) y a partir de Ningen Johatsu (Desaparecer un hombre) presta una gran atención al documental, en donde se refugiará especialmente entre 1970 y 1979. En 1983 ganó la Palma de Oro en Cannes por Narayama Bushiko (La Balada del Narayama), premio que volvió a recibir en 1997 por Unagui (La Anguila). Ha dirigido también Kanzo sensei (Dr.Agaki/1998), Akai hashi no shitano nurui mizu (Warm Water Under a Red Bridge/2001), y ha participado en la película colectiva 11-09-01(2002) [Muguilo, Carlos (et. ál.): El cine de los mil años. Una aproximación histórica y estética al cine documental japonés (1945-2005), Op.cit., p. 131]
} 
Ozu, Kawashima y otros más. Posteriormente se independiza, formando su propia productora.

Este documental comienza con la búsqueda de un desaparecido que había dejado a su prometida. Se realizan entrevistas a los conocidos del desaparecido. Dentro del proceso de investigación, Imamura piensa que la causa de la desaparición del hombre es su intención de huir del matrimonio prometido, y empieza a sospechar que la hermana de la prometida tenía una relación secreta con el desaparecido. De esta manera, el tema principal es la búsqueda de un posible triángulo amoroso, aunque no se sabe muy bien hasta el final. Entonces, Imamura les hace a las hermanas enfrentarse en el plató y finaliza declarando que este documental es bastante ficticio.
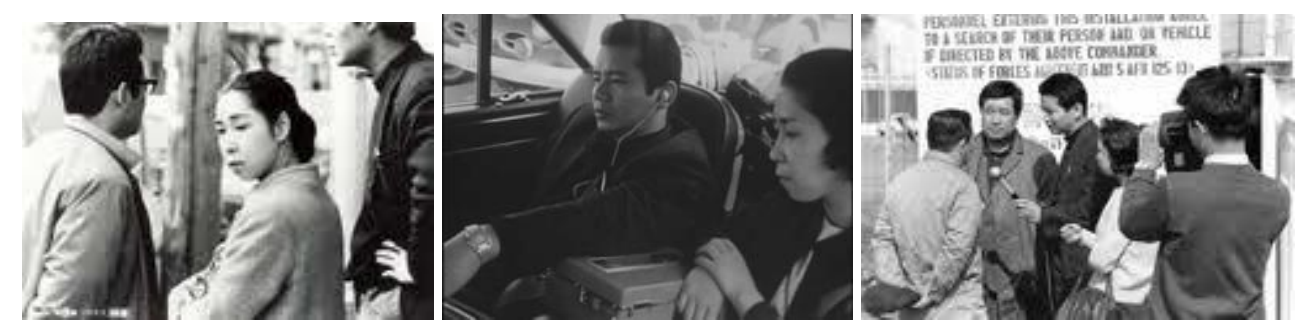

22. Ningen johatsu (A Man Vanishes/ Desaparición de un hombre,1967) Shohei Imaura

Según Imamura, la prometida del desaparecido fue contratada para el rodaje de esta película ${ }^{15}$. Al mismo tiempo, ella misma dio su consentimiento explícito para ser filmada. De acuerdo con esto, en el proceso de la búsqueda le acompaña un actor profesional y los dos entran en un estado amoroso. En el documental se muestran unas imágenes de cámara oculta. En otra parte, Imamura empieza a perseguir a la hermana de la prometida, hasta inventa un personaje para que la hermana confiese lo que Imamura espera escuchar. Y nos muestra todo el proceso de dirección y planificación de la película, en la cual él mismo cumple un papel de actor importante. Tadao Sato comenta sobre esta obra comparándola con la de Oshima:

\footnotetext{
${ }^{15}$ Váyase a Los caminos de la experimentación. El refugio documental. Shohei Imamura entrevistada por Toichi Nakata, en: Muguilo, Carlos (et. ál.): El cine de los mil años. Una aproximación histórica y estética al cine documental japonés (1945-2005), Op.cit., 2006, p. 126.
} 
En el caso de esta obra, el director aparece como un personaje principal más que el personaje, y además no declara como en el caso de Oshima en Wasurerateta kougun (El ejército del emperador olvidado.) sino que habla del fracaso. Y cuestiona qué puede aprender de este fracaso. El documental se ha transformado de tal modo que posibilita incluso este cuestionamiento. ${ }^{16}$

Como dice Tadao Sato, Imamura no consiguió encontrar "la verdad" de lo que suponía él en su documental. En términos precisos, resulta polémico calificar a esta película como documental por muchas de sus partes. Sin embargo, si observamos el proceso del fracaso de la búsqueda de Imamura como autor de la obra, es bastante aceptable como documental. Al mismo tiempo, en este trabajo se cuestiona cuál es el límite entre la realidad y la ficción. Solamente hablando del estado amoroso entre la prometida y el actor profesional, aunque los dos fueron contratados para el rodaje y eran conscientes de la filmación, no sabemos muy bien si su amor fue algo que atrajo la atención de la cámara o no. La estrategia que ha planteado Imamura se radicaliza en el trabajo de Kazuo Hara, al cual nos vamos a referir en adelante.

\section{V.2.2. La renovación radical: Cinéma-vérité y Direct Cinema.}

De este modo, en la década de 1960 surge una declaración y el movimiento de renovación documental en Japón; igualmente, a nivel mundial, se encuentra una innovación en el mundo del documental, llamado Cinéma-vérité en Francia y, Direct Cinema en Estados Unidos.

En la historia del cine surgen dos grandes movimientos simultáneamente en Estados Unidos de América y en Francia. En Estados Unidos le llaman Direct Cinema y Cinéma-vérité en Francia. Ambos Direct Cinema y Cinéma-vérité se constituyen como cine de observación. ${ }^{17}$

\footnotetext{
${ }^{16}$ Sato, Tadao (et. ál.): Nihonno dokymentary I, Dokyumentary no miryoku [El documental japonés I, El atractivo de documental], Op.cit, p. 64. [Traducción propia del texto original en japonés]

${ }^{17}$ Sato, Makoto, Op.cit., p. 52. [Traducción propia del texto original en japonés]
} 
Estas dos corrientes del cine de la observación no surgieron hasta los años sesenta por dos restricciones principales: la limitación ideológica y las limitaciones de tipo técnico. El documental permanecía bajo el poder de las ideologías dominantes hasta ese momento. El caso de la historia del documental japonés es un ejemplo notable, aunque no es un caso excepcional a nivel mundial. En la expresión documental se manifestaba claramente un mensaje a través de la narración por medio de palabras que buscaban la comprensión y/o agitación del público. Era el modo general de representación. Una visión radical afirmaría que los documentales hasta ese momento no tienen un mensaje político social ni manifiestan su ideología; por lo tanto, no pueden ser calificados como un documental serio.

Las limitaciones técnicas se suavizan, ya que en ese momento los documentalistas pudieron obtener la grabadora simultánea de audio. En el rodaje de estudio, ya desde las décadas los años treinta y cuarenta, se podía realizar la grabación simultánea por el sistema de grabación óptica, pero la máquina era muy grande y pesada, prácticamente no transportable.

Como hemos visto anteriormente, el documental Tatakau heitai, de Fumio Kamei, tiene una parte de grabación simultánea; transportando la máquina al lugar de rodaje con la ayuda de una carreta. Pero es una excepción. En general no es fácil llevar transportar tanta máquina, de modo que se guardaba la imagen en la cámara y el audio en grabadora, cada uno por separado. Era técnicamente difícil sincronizar la imagen y el audio en el momento de la edición. Ello dificultaba la producción del cine de observación.

En el caso de Kyoushitsu no kodomotachi de Susumu Hani, también visto anteriormente, al nivel de la imagen se logra captar las imágenes del tipo del cine de observación. Sin embargo, no tiene audio sincronizado y es la narración la que explica la situación de la imagen.

En 1959 se perfeccionó un sistema de Synchronous Communications (Comunicaciones sincrónicas) para grabar el audio y la imagen sincronizada con un magnetófono Nagra, de la empresa Nagra de Suiza, y una cámara sencilla de 16mm Éclair, de la empresa Éclair de Francia. 
Cuando los autores del audiovisual tuvieron los equipos de cámara con sistemas de grabación simultánea de audio, ¿qué quisieron hacer?: intentaron representar el acontecimiento que ocurre frente al ojo, grabándolo tal como es, alejándose de las restricciones ideológicas. Es el punto de partida más importante del "Direct Cinema”, movimiento cinematográfico que reforma los documentales anteriores. ${ }^{18}$
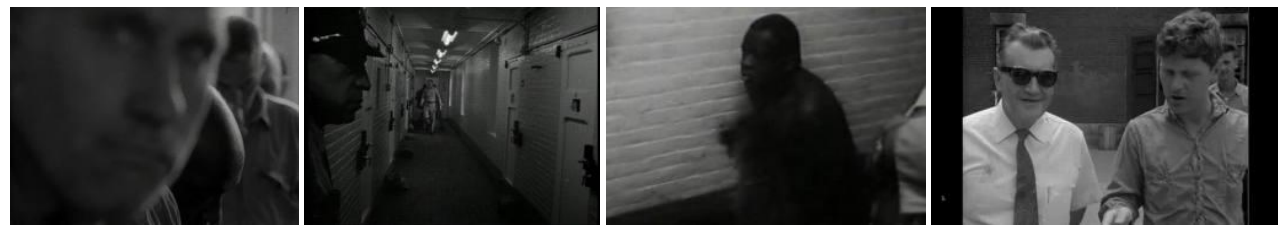

23. Titicut Follies (1967), Frederick Wisman

Makoto Sato explica la situación de este modo. Una de las obras más importantes del Direct Cinema es Primary (Primaria), de 60min., realizada en 1960 por D. A. Pennebaker y el operador Richard Leacock, donde se filmaron las elecciones primarias presidenciales de John F. Kennedy. También es notoria Titicut Follies, de 84min., en blanco y negro, producida en 1967 por Frederick Wisman ${ }^{19}$. Representaba la vida cotidiana en la prisión pública del estado de Massachusetts en los años sesenta. Las obras conmemorables del Cinema-vérité son Chronique d'un été (Crónica de un verano), de 86min., en blanco y negro, de Jean Rouch $(1960)^{20}$ y Le joli mai (El bonito mayo), de Chris Marker, 163 min., producida en 1962.
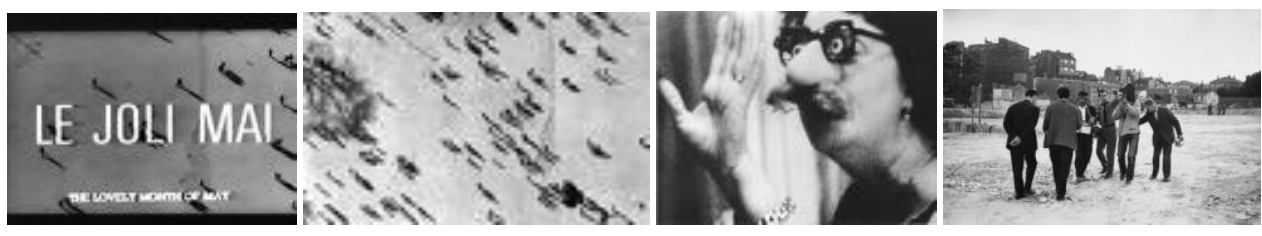

24. Le Joli mai (El bonito mayo,1962 ), Chris Marker

\footnotetext{
${ }_{18}^{18}$ Ibíd., p. 56. [Traducción propia del texto original en japonés]

${ }^{19}$ Wiseman, Frederick (1930- ), realizador de cine documental norteamericano. Es un autor representante del movimiento Direct Cinema, ha producido más de 30 documentales. Al mismo tiempo, es un realizador peculiar dentro del movimiento. Según Sato, su estilo de montaje abandona el método de construir un eje temporal como punto importante de la "dramaturgie" en la película, excluyendo la narración y la música ambiental. Su estilo aséptico al observar a los objetivos y eliminar los elementos explicativos y del mensaje, consiguen un impacto fuerte sobre los espectadores exigiendo que cada quien considere los asuntos por su cuenta.

${ }^{20}$ Rouch, Jean (1917- 2004): antropólogo y realizador de cine documental francés.
} 
Sato comenta sobre Primary de Richard Leacock y Chronique d'un été de Jean Rouch, ambos producidos en el año 1960, para explicar la diferencia entre el Direct Cinema y el Cinéma-vérité.

Las dos han sido calificadas como obras conmemorativas del Direct Cinema y del Cinema-vérité. El núcleo del cambio del Direct Cinema es que los productores tratan de que la cámara sea transparente, es decir, intentan ser fieles como observadores. En cambio, el Cinéma-vérité tiene un matiz diferente: desarrolla el camino de la conciencia sobre la existencia de la cámara como provocadora frente al objeto. $^{21}$

Estas dos direcciones, de alguna manera contrarias en su tratamiento de la cámara en el documental, se desarrollan más en el Private Documentary y Self Documentary de los años noventa. En este punto, solo confirmamos que se planta el germen del método de la película de observación a raíz del desarrollo de la técnica de grabación simultánea del audio con la cámara portátil.

Volvemos a la corriente del documental japonés. En los años sesenta se abre un nuevo campo peculiar del documental de observación en Japón: la película científica, sobre todo la que emplea la cámara rápida con el microscopio. Un ejemplo paradigmático es Marine Snow, Sekiyu no kigen (Nieve marina. El origen del petróleo $)^{22}$ de $20 \mathrm{~min}$, en color, $35 \mathrm{~mm}$, producida en 1960 por Shinkichi Noda.
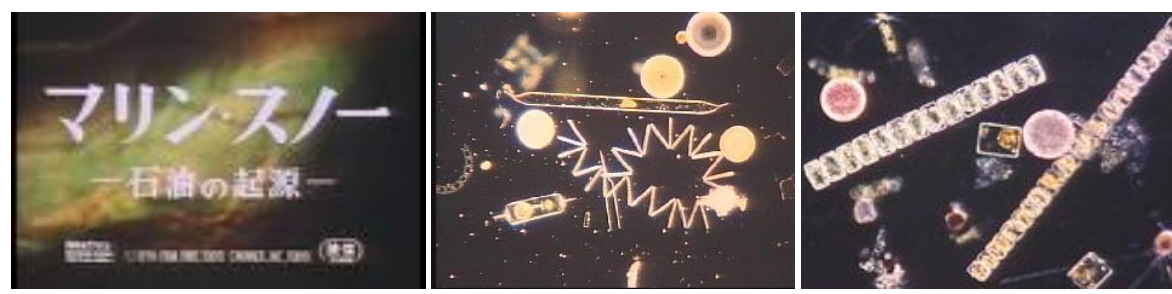

25. Marine Snow, Sekiyu no kiguen (Nieve marina. El origen del petróleo, 1960), Shinkicho Noda

\footnotetext{
${ }^{21}$ Ibíd., p. 56. [Traducción propia del texto original en japonés]

${ }^{22}$ Se puede ver esta obra en el WEB TEPIA Video Library de The Machine Industry Memorial Foundation http://www.stream.tepia.jp/small_play.html, o por el menú de los vídeos:

http://www.stream.tepia.jp/bunrui_contents.html?cateClass3=20701, accedido el 15 julio de 2009.
} 
Se trata de una película de publicidad para una empresa de petróleo. Se visualiza la teoría del génesis del petróleo desde el plancton marino y por momentos se olvida su carácter publicitario. La imagen dentro del microscopio parece una pintura abstracta, la película construye un mundo audiovisual poético propio, se podría decir que observamos una convergencia entre ciencia y arte.

\section{V.2.3. El documental en la colectividad.}

Un método peculiar de la realización del documental en Japón imposible de ignorar es el rodaje del grupo colectivo surgido en la década entre 1968 a 1978. Como hemos comentado anteriormente, la producción independiente de Kaneto Shindo, con un equipo de rodaje de 13 personas, ya se constituye como un grupo reducido en 1960. Cuando se generaliza el uso de la cámara de $16 \mathrm{~mm}$, se reduce más el equipo mínimo de rodaje por cuestiones técnicas.

En este sentido, el rodaje por un grupo colectivo parece normal. Sin embargo, el estilo que aproximaremos ahora, sobre todo el método que ha realizado Ogawa Production dirigido por Shinsuke Ogawa ${ }^{23}$, es un caso muy especial: el personal que se dedica al rodaje mantiene una vida colectiva en una comuna, tanto las personas objeto de la filmación como las que producen el documental. Es decir, se alquila una casa en el lugar de rodaje y conviven durante años como vecinos de las personas objeto del rodaje.

Podríamos considerar que el estilo de rodaje de Ogawa Production es el final de la radicalización del método de producción independiente de Kaneto Shindo de concentración del personal durante el rodaje, así como de la tesis de Nagisa Oshima: el amor hacia el

\footnotetext{
${ }^{23}$ Shinsuke Ogawa (1935-1992): Tras estudiar cine en la Universidad de Kokugakuin, Ogawa trabajó como ayudante de dirección en numerosos documentales publicitarios para "Iwanami Production", entre los cuales destaca la película de Kazuo Kuroki "Waga ai Hokkaido" (My love, Hokkaido / 1962). Nunca dirigió una película en Iwanami pero formó parte activa de El Grupo Azul, que renovó las formas del documental en los sesenta. A partir de "Seinen no umi" (Sea of Youth /1966), Ogawa comenzó a realizar películas de forma independiente conformando una carrera que se suele dividir en tres etapas. Las películas del movimiento estudiantil (19651968); la serie de Sanrizuka (1968-1974); y la historia de Magino (1975-1992). "Ogawa Production", la productora que ensayó nuevas formas de producción, distribución y exhibición colectivizada, fue formada en 1968 y se disolvió tras la muerte de su fundador. Ogawa creó además el Festival Internacional de Cine Documental de Yamagata [Muguilo, Carlos (et. ál.): El cine de los mil años: una aproximación histórica y estética al cine documental japonés (1945-2005), Op.cit., p. 170.]
} 
motivo y el objeto del documental y la reunión de materiales por un largo tiempo. En la misma línea, Noriaki Tsuchimoto ${ }^{24}$ también demostró una práctica de la tesis de Oshima en su serie de documentales visitando a propósito el lugar y realizando una observación de un tema en concreto. Enseguida veremos el resumen de Makoto Sato sobre estos dos grandes documentalistas, representantes de la década de los setenta del documental japonés, también llamada edad de oro.

\begin{abstract}
Noriaki Tsuchimoto y Shinsuke Ogawa fueron precursores del documental japonés de la década de los años setenta. Ambos son realizadores que acumularon experiencia en "Cine Iwanami” y se convirtieron en los catalizadores de esta época. Cada uno empezó a producir una serie de películas con temáticas diferentes, estableciendo sus propias sociedades de producción alejadas del Cine Iwanami. Tsuchimoto inicia en 1971 una serie de 13 películas sobre Minamata con "Minamata- Kanjasan to sono sekai" (Minamata: los pacientes y su mundo), producida por Seirinsha (la productora Seirin). Por otra parte, Ogawa produjo 7 películas como la serie de Sanrizuka: empieza en 1968 con "Nihonkaihousensen Sanrizuka no natsu” (Frente de liberación japonés, el verano de Sanrizuka), viviendo en comuna con el personal del rodaje. ${ }^{25}$
\end{abstract}

Como menciona Sato, Tsuchimoto y Ogawa son dos realizadores representativos del documental independiente de los años setenta. Los dos autores ya eran muy conscientes de la manifestación del sujeto del autor en el documental. Pero la temática de las series de sus documentales continúa siendo social.

\footnotetext{
${ }^{24}$ Noriaki Tsuchimoto (1928-2008): Estudió en la Universidad de Waseda, posteriormente se incorporó al estudio Iwanami, donde trabajó como ayudante de dirección en películas como "Furyo shonen" (Bad Boys / 1960) de Susumu Hani. Fue uno de los líderes del movimiento por un nuevo cine documental llamado "Ao no kai" (El Grupo Azul), del que formaban parte también Kazuo Kuroki, Yoichi Higashi y Shinsuke Ogawa. Debutó como director en el cine independiente con "Aru Kikan joshi” (An Engenieer's Assistant / 1962). Su monumental trabajo documentando las consecuencias del envenenamiento con mercurio en Minamata, que comenzó en 1971 con "Kanja-san to sono sekai" (Minamata: The victims and Their World), ha continuado hasta el día de hoy. Por su trabajo obsesivo sobre una materia y por su estilo, Tsuchimoto es, junto con Ogawa, una de las referencias de "la edad de oro" de cine documental de los años sesenta y setenta [Muguilo, Carlos (et. ál.): El cine de los mil años: una aproximación histórica y estética al cine documental japonés (1945-2005), Op.cit., p. 105.] Tsuchimoto ha realizado también un proyecto de recolección de retratos de las víctimas todavía en vida, visitando casa por casa. El resultado fueron 500 fotografías presentadas en la exposición de Minamata-Tokio en el Museo de Fotografía de Tokio en el año 2000.

${ }^{25}$ Ibíd., p. 9. [Traducción propia del texto original en japonés]
} 

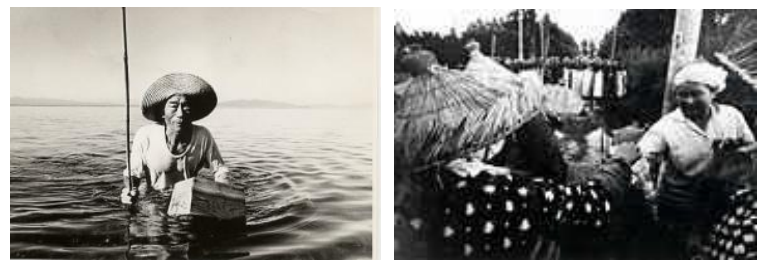

26. Minamata- Kanjasan to sono sekai (Minamata: los pacientes y su mundo, 1971), Noriaki Tsuchimoto

[izquierda]

27. Nihonkaihousensen. Sanrizuka no natsu (Frente de liberación japonés, el verano de Sanrizuka, 1968),

Shinsuke Ogawa [derecha]

La serie de documentales de Noriaki Tsuchimoto abordan la enfermedad de Minamata, una pandemia sufrida por los habitantes cercanos al río y al puerto de Minamata, en la prefectura de Kumamoto al sudoeste de Japón, un lugar contaminado con mercurio por las aguas residuales de la industria química de $\mathrm{Chisso}^{26}$. Los documentales tratan sobre los daños físicos, así como los graves perjuicios sociales que sufrieron sus habitantes ${ }^{27}$.

Ya desde 1940 se avanzaban algunos presagios de los daños, y en la década de 1950 se empezó a encontrar una relación causal entre las enfermedades de los habitantes y las aguas residuales de la fábrica. A pesar de ello, tanto el gobierno como la empresa ignoraron la grave situación y continuaron sin tomar medidas. Como consecuencia, se extendió la contaminación y empeoró gravemente la situación de las víctimas. Aún más, comenzó a darse una fuerte segregación de las víctimas y sus familias. Desde finales de los años sesenta hasta la década de los setenta la disputa se acaloró, con un activismo que exigía a los juzgados alegato e indemnización por los daños y perjuicios, así como su prevención.

\footnotetext{
${ }^{26}$ Chisso Corporation: gran empresa de la industria química de Japón. En su fábrica de Minamata producía fertilizante químico que causó la contaminación ambiental. La empresa permanece hasta hoy y sigue produciendo fertilizantes y otros productos agrícolas y ampliando el negocio con biotecnología y partes electrónicas como cristal líquido. Actualmente, la empresa se encuentra en un proceso de disgregación en dos empresas, Chisso Corporation y UNC. Existen críticas sobre este proyecto porque se sospecha que se está intentando que el nombre desaparezca y de esta manera también la responsabilidad de la empresa sobre los daños que ha provocado. http://www.chisso.co.jp/english/index.asp, accedido el 14 de febrero de 2009. http://www.houseofjapan.com/local/chissos-spin-off-plan-ok, accedido el 01 de febrero de 2011.

${ }^{27}$ Se encuentra la tesis doctoral de Albert Ruda en la que se estudia la responsabilidad en el caso Minamata de Japón: http://www.tesisenxarxa.net/TDX-0630106-114151/index.html , accedido el 01 de febrero de 2011.
} 
El suceso de Minamata fue reconocido mundialmente gracias al ensayo fotográfico de W. Eugene Smith, presentado primero en la revista Life y posteriormente como la publicación Minamata en 1972. El agravio del gobierno y la gran empresa hacia las víctimas de esa enfermedad no se reduce exclusivamente a ellos. Aquellos que apoyaron a las víctimas sufrieron muchas presiones, tanto legales como ilegales. Un ejemplo: Smith acompañaba a la protesta de las víctimas y sus familiares junto a otros periodistas. El fotografo fue atacado por mafiosos contratados por la empresa, resultando gravemente herido y perdiendo la vista en un ojo.
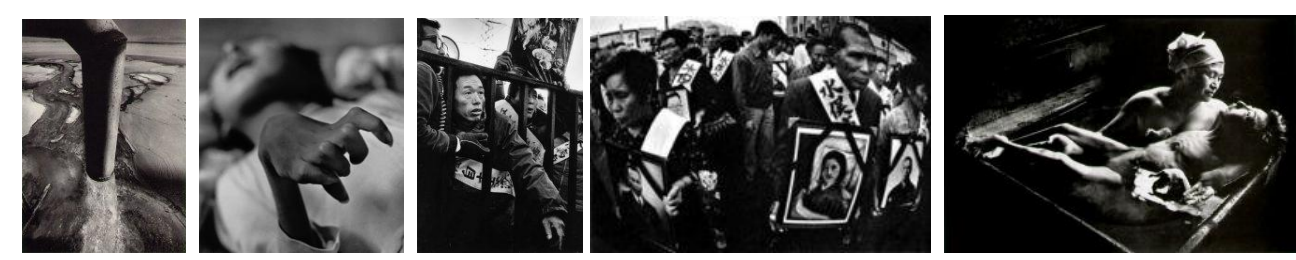

28. Fotografía de la serie Minamata y Tomoko Uemura in her Bath (1972), William Eugene Smith

El documental de Ogawa aborda el combate de Sanrizuka, también llamado el combate de Narita en algunos casos. Es un movimiento de agricultores por la defensa de sus tierras. Surge cuando el gobierno determina la compra coactiva de las fincas para construir un aeropuerto, sin ningún previo aviso ni negociación con las personas que vivían en el lugar. Al principio, el movimiento empleó la estrategia de Hitotsubo baishu undo (El movimiento de compra de 3.306 metros cuadrados): varias personas compraron $3.306 \mathrm{~m}^{2}$ para sufragar la protección del campo agrícola y dificultar la compra por parte del gobierno. Se realizaban actividades en grupos activos de niños, jóvenes, mujeres, ancianos o familias, y se reconoció como una campaña general del pueblo.

La campaña coincidió con el movimiento estudiantil, ya que varios grupos de estudiantes manifestaron su solidaridad y se reunieron en Sanrizuka. De esta manera se intensificó el combate. El gobierno no dejó de mantener una postura enfervorizada y envió a la policía y a los antidisturbios. Debido a este uso de la fuerza hubo numerosos heridos y muertos. Como consecuencia, el enfrentamiento entre los manifestantes y las autoridades se agudizó; no obstante, finalmente se inauguró el aeropuerto de Tokio Narita en 1978. El movimiento 
de resistencia declinó por el ocaso del movimiento estudiantil con algunos conflictos internos y desuniones dentro del grupo de los estudiantes.

Tanto Tsuchimoto como Ogawa producen documentales en donde las injusticias ocurren por culpa del poder político y económico (el gobierno y las grandes empresas). Apoyan de este modo la lucha contra dicho poder, contextualizando las actividades del movimiento social y estudiantil. Sato opina sobre los dos documentales:

La enfermedad de Minamata, por su escala y gravedad en cuanto a los daños y perjuicios causados por la contaminación ambiental producida por una fábrica, se volvió un suceso deplorable para Japón. Asimismo, la lucha de los agricultores de Sanrizuka recorrió el mundo como el combate en contra del aeropuerto Narita. Podemos decir que los dos documentales filmados por Tsuchimoto y Ogawa observan con atención a partes de Japón donde no ha llegado la luz, zonas de un país entusiasmado con el alto desarrollo económico. Además, debido a la alta calidad documental y su grandeza por la influencia sobre el movimiento de proyección independiente, Tsuchimoto y Ogawa se han convertido en las dos grandes figuras del documental japonés. ${ }^{28}$

Makoto Sato compara los trabajos de Tsuchimoto y Ogawa con el movimiento de la escuela inglesa de documentalismo que procura iluminar la parte oscura de la sociedad capitalista. Es un tipo de iluminismo propagandístico que espera corregir la injusticia a través de la denuncia pública en el medio fílmico. Se mantiene una confianza en los autores e incluso en los espectadores basada en el reconocimiento de los sucesos reales que se están filmando. Es decir, el motivo de evidenciar ese suceso proviene de la buena voluntad de los autores al declarar su apoyo y empatía con las personas objetivo de la filmación. Sin embargo, al mismo tiempo, se espera un cierto objetivismo de los que filman y transmiten las ideas a través de los documentales, ya que el suceso es real. En este caso, se enfatiza en la conceptualización de aquello que se identifica, en una realidad objetiva de la verdad.

\footnotetext{
${ }^{28}$ Ibíd., p. 10. [Traducción propia del texto original en japonés]
} 
El contexto social gracias al cual fue posible realizar producciones y proyectar los documentales independientes fue el movimiento estudiantil activo mundialmente -bajo la influencia de les événements de Mai de 1968 en Francia-, así como el movimiento político y social contra la guerra de Vietnam, finalizada en 1975.

Sea de una manera directa o indirecta, el hecho de que Estados Unidos interviniera en la guerra desde 1955 enviando tropas a Vietnam desde la base en las islas de Okinawa ${ }^{29}$ involucró a Japón profundamente en el conflicto. Los estudiantes, principalmente a través de diversas organizaciones del movimiento formadas en todo el país, se manifestaron en contra de la guerra y/o la revolución socialista. Paralelamente, se sostenían organizaciones de proyección voluntaria para los documentales independientes de Ogawa y Tsuchimoto. Sin embargo, estos movimientos pronto se debilitarían en los años ochenta.

Ya ha pasado "la época de la política", denunciada principalmente por los movimientos estudiantiles. Ahora se empieza a infestar la idolatría al dinero sin hacer caso de sus formas de "destrucción de la villa”, negando asi secretamente la historia y la tradición en las municipalidades japonesas. ${ }^{30}$

"Destruir la villa", como comenta Sato, simboliza el derrumbamiento de la comunidad por la destrucción de los espacios comunes y los edificios convencionales a causa de la urbanización, sus grandes esquemas y la reventa de la tierra con la subsiguiente devaluación económica. Los miles de proyectos especulativos empiezan a cambiar completamente el paisaje rural y las formas de vida tanto individual como de la comunidad.

Podríamos decir que el documental de Ogawa es un registro de la nueva comunidad que pretende proteger a la comunidad antigua: muestra la lucha por salvaguardar la tierra como condición indispensable para seguir manteniendo la comunidad de agricultores. Los

\footnotetext{
${ }^{29}$ Las islas de Okinawa fueron el campo de batalla en el último momento de la Segunda Guerra Mundial y permanecieron bajo la política administrativa hasta 1952. Hasta 1972 no se restituye el derecho de la política administrativa a Japón, dejando las bases militares norteamericanas con extraterritorialidad. En Okinawa se encuentra una concentración de 74 por ciento de militares norteamericanos que permanecen en Japón hasta la actualidad.

${ }^{30}$ Ibíd., p. 11. [Traducción propia del texto original en japonés]
} 
estudiantes les apoyan contra un poder capitalista que intenta destruir la comunidad anteponiendo sus beneficios.

El grupo de producción de Ogawa representaría, pues, a la nueva comunidad y también a las organizaciones que apoyaban la proyección de su película. En un sentido más amplio, podemos entender que a través del cine participaba a mantener la comunidad del pueblo. No obstante, esta comunidad se empieza a derrumbar, digamos más bien que comienza el desplome de la fantasía comunitaria, ya que la antigua comunidad de agricultores empezaba a decaer en manos de la modernización técnica agrícola. Sato comenta citando un libro de Katsuhiko Fukuda ${ }^{31}$, un importante mediador que dirigía a los ayudantes de dirección de Ogawa Production:

Katsuhiko Fukuda, en "Sanrizuka Andosoi" (Heigensha, 2001), editada como
escritos póstumos, muestra que él mismo captaba claramente el síntoma de
derrumbamiento de la comunidad rural. Fukuda explica este fenómeno: la
individualización del trabajo agrícola, causada por la modernización de la
agricultura, ya no necesita el trabajo colectivo y solidario como "Yui". ${ }^{32}$

Los agricultores ya no trabajaban conjuntamente dada la modernización del proceso de trabajo. A través de la maquinaria se individualizaron las labores, y deja de existir la colectividad solidaria que se congregaba en el lugar de trabajo. Ogawa, en calidad de observador de la antigua comunidad, formaba a la vez parte de la nueva comunidad y era protector de la comunidad antigua: daba cuenta de ese fenómeno y sugería un cambio.

A partir de 1975, Ogawa y su personal de rodaje se trasladan a una aldea de Yamagata al nordeste de Japón, alejándose del lugar de la lucha. Ellos empiezan a labrar el arrozal y a aislarse en el pequeño mundo de la experiencia agrícola. Podemos imaginar que sintieron dudas o contradicciones al enfrentarse al derrumbamiento de la comunidad, y parece que su acto intenta superar la separación entre sujeto y objeto, a saber: filman a los agricultores

\footnotetext{
${ }^{31}$ Váyase a V.3.

${ }^{32}$ Ibíd., p. 20. [Traducción propia del texto original en japonés]
} 
como objeto, siendo a la vez sujeto de la película su experiencia como agricultores (aunque llevaban una vida colectiva).

Tsuchimoto empieza a rodar documentales sobre otros temas. Sin embargo, de vez en cuando vuelve a Minamata y continuamente produce documentales sobre el tema. En cambio, Ogawa nunca volvió a rodar sobre Sanrizuka.

\section{V.2.4. Encuentro con el "otro" interior, para enfrentarse al "otro" exterior.}

Hasta ahora nos hemos dedicado comentar el movimiento documental japonés fijándonos en la serie de Sanrizuka de Shinsuke Ogawa en Ogawa Production y en la serie de Minamata de Noriaki Tsuchimoto en Seirinsha de la década de los sesenta. Ahora nos permitimos comentar un documental de Makoto Sato producido en 1992 porque todavía se utiliza el método de Ogawa Production con el tema de la segunda enfermedad de Minamata. Makoto Sato mismo, comenta que es la última película en que se ha aplicado el estilo de Ogawa Production.

La segunda enfermedad de Minamata también ha sido denominada la enfermedad de Minamata en Nigata. Es decir, el mismo suceso de Minamata (en la prefectura de Kumamoto, situada en el centro de Kyushu, la isla más sur de las cuatro islas principales), ocurre en la cuenca del río Agano de la prefectura de Nigata, localizada en el centro norte de Honshu, la isla central más grande en la costa del mar japonés. En general, se ha comprendido que si el gobierno hubiera tomado ciertas medidas responsables sobre el caso de la enfermedad de Minamata que tuvo lugar del 1953 a 1959, habría podido evitarse el suceso de Nigata de 1964. La fábrica de Showa Denko en Nigata producía el mismo producto que Chisso y se encontraron los mismos síntomas que en los enfermos de Minamata. La empresa Showa Denko, culpable del suceso, destruyó los datos para ocultar las pruebas. Por ello, nunca saldrán a la luz todos los aspectos del asunto. En este contexto, Makoto Sato realiza un documental sobre la vida cotidiana de la gente que vive en el pueblo de la cuenca del río Agano. 


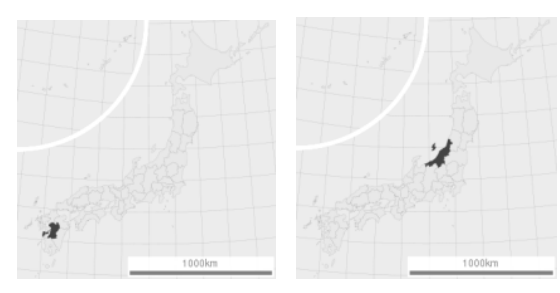

29. El plano de Kumamoto y Nigata, Japón

Agani ikiru (Vivir en Aga) es la primera película de Sato como realizador. Para su producción aplicó el método del grupo colectivo al estilo Ogawa Production, llevando un estilo de vida comunitario con el personal de rodaje: alquilan una casa en Aga (Nigata) desde 1989 y permanecen allí durante 3 años, describiendo en el documental la experiencia y su valor como rodaje colectivo.

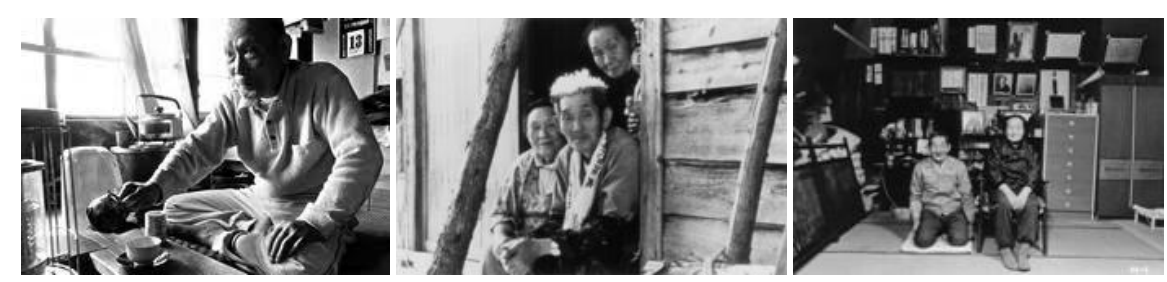

30. Agani ikiru (Vivir en Aga 1992), Makoto Sato

Por su propia experiencia de rodaje colectivo en comuna, Makoto Sato explica la ventaja de este estilo de la siguiente manera:

El fundamento del documental es encontrar al "otro". ¿Cómo enfrentar al objeto del rodaje como un "otro" exterior? Al final de una compleja colaboración con el personal como un "otro" interior. $Y$, ¿cómo podemos aproximarnos a su forma más profunda, aunque sea por un momento? El "gain line" del documental dependería de la voluntad adquirida por la cadena humana constituida por el personal, aunque les faltara cohesión y capacidad de juicio instantáneo, de ataque al objeto intimidándolo a través de la energía ciega y excesiva del equipo, encontrando el espacio oportuno de acción. ${ }^{33}$

\footnotetext{
${ }^{33}$ Ibíd., p. 48. [Traducción propia del texto original en japonés]
} 
Sato insiste en la importancia de contar con la complejidad dentro del grupo. Es decir, las personas del rodaje deben discutir hábilmente dentro del mismo grupo, basándose en esa complejidad, para así obtener una conciencia común, aclarar el problema principal y acatar un enfoque común. Un equipo en cierto desacuerdo, al enfrentarse a lo objetivo con el "otro" exterior, agudizará los sentidos ávidamente aproximando la energía que se ha generado en la discusión y proyectará las contradicciones. Su postura y práctica está basada en la colectividad, pero su intención profunda está alejada de la armonía preestablecida. La posición fundamental de Makoto Sato hacia el documental proviene de su experiencia en la comuna durante su primera producción. Su postura se convierte en la base esencial del concepto para la crítica del Private Documentary y del Self Documentary, donde el rodaje y el montaje se pueden realizar por una sola persona.

Por otra parte, el estilo del rodaje en una comuna, alcanza cierto límite porque en aquel momento algunos participantes comienzan a sospechar que ya se alcanzaba su límite. Sato aporta un comentario basándose en un artículo sobre Noriaki Tsuchimoto del libro Gamenno tanyou (El nacimiento de la imagen) Misuzushobo, por Kazushi Suzuki que cita una referencia de Shiro Otsu, el operador con la cámara.

Según las propias palabras de Otsu, "llegábamos a una época que el objeto no se perfilaba si no actuábamos por nuestra parte”. Es decir, comenzaba inevitablemente a no funcionar la concepción objetivista según la cual la verdad afloraría espontáneamente si uno se aproximaba sinceramente hacia ella, porque existía en algún lugar indudablemente.

Dicho de otro modo, esto significa la llegada del período del subjetivismo y el relativismo, donde existirían varias verdades según las distintas perspectivas. Otsu dice que encontró el síntoma evidente de ese cambio en el año 1974-75. ${ }^{34}$

La conciencia sobre el tema del documental se traslada de la objetividad a la subjetividad: se cuestiona la representación de las circunstancia del acontecimiento en sí, ¿por qué importa representar cómo ve el sujeto de la producción lo que ocurre frente a él? Cuando

\footnotetext{
${ }^{34}$ Ibíd., p. 20. [Traducción propia del texto original en japonés]
} 
subrayamos esta subjetividad de "lo privado y lo personal", no es posible escapar de un sentido trascendental.

En los años setenta los documentales de grupos colectivos eran muy activos, como vimos hasta ahora. Sin embargo, aparece un documental que se concentra en lo privado y lo personal como tema principal: Kyokushiteki erosu, Renka 1974 (Eros privado extremo, canción de amor 1974) de Kazuo Hara ${ }^{35}$. Este es un realizador muy particular que profesa la Action Documentary. Hará que se capten escenas en que las personas filmadas están actuando por su propia voluntad. La manera de evidenciar la presencia de la cámara ante la persona filmada es más radical que en el Cinéma-vérité.

La presente obra de Hara sobre lo íntimo y lo privado, fue revolucionaria en aquel momento. Sin embargo, al mismo tiempo, el concepto y la manera de mirar a los motivos y objetivos de su película tienen cierta conciencia política. Se percibe claramente la influencia del feminismo, y nos recuerda al eslogan "lo privado es político" por la elección del tema y de las escenas de la obra. Por ejemplo, en una entrevista, contestando a una pregunta sobre el tema de masculinidad en Japón, Hara comenta sobre una escena en la que él mismo llora.

Por tradición, los hombres en Japón no lloran. Por lo tanto, muchas veces ni siquiera existe la posibilidad de considerar la opción de que los hombres lloren en pantalla. El movimiento estudiantil en los setenta coincidió con el movimiento feminista y hubo voces que reclamaron que, si las mujeres podían ser libres, entonces también se debía permitir a los hombres expresar sus sentimientos: se reivindicó el que los hombres pudiesen llorar. "Cuando lloré en Kyokushiteki erosu: Renka 1974, yo no estaba actuando. Estaba tratando de formar parte, de la

\footnotetext{
${ }^{35}$ En España, fue presentada los trabajos se Kazuo Hara en Festival Internacional de cine de las Palmas de Gran Canaria del 2011. Tenía charla con realizador con funciones de cuatro documentales del 2 al 6 de Abril. http://lpafilmfestival.com/events/charla-con-kazuo-hara?locale=es, accedido el 25 de noviembre del 2011.
} 
mejor forma posible, de ese nuevo modo de vida. Mis lágrimas reflejaban ese deseo". ${ }^{36}$

Hara admite que la idea de presentar la escena de él mismo llorando, como un hombre expresando un sentimiento libre, reflejaba su deseo. Esta acción equivale y se conecta con la liberación de la mujer. Es decir, para que la mujer pueda ser libre, el hombre también debe liberarse a sí mismo, rompiendo la imagen del hombre convencional. El movimiento estudiantil que coincidía con el movimiento feminista ha recibido una profunda influencia de este autor.

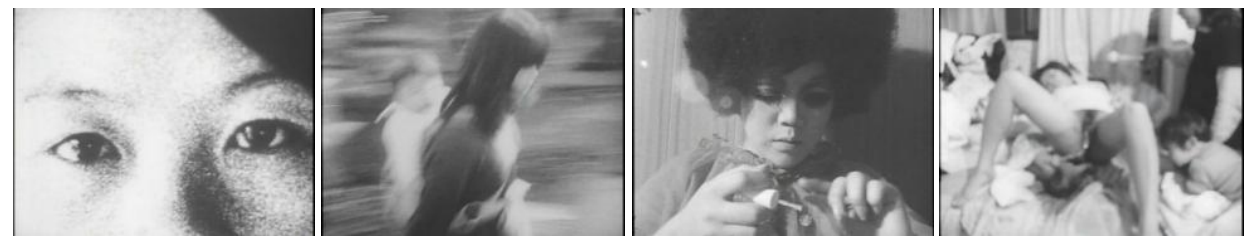

31. Kyokushiteki erosu, Renka1974 (Eros privado extremo, canción de amor 1974), Kazuo Hara

Kyokushiteki erosu: Renka 1974 es un documental de Hara donde se filma a Miyuki Takeda, su ex-mujer, con la colaboración de Sachiko Kobayashi, su mujer actual. La película es de $16 \mathrm{~mm}$. Por regla general, Hara opera con la cámara y Kobayashi con el magnetófono. Hara y Kobayashi permanecen al lado del sujeto de rodaje y Takeda es el objeto de la filmación. Sin embargo, la relación entre el sujeto y el objeto no está tan clara, de vez en cuando se invierten sus posiciones. La interpretación de Sato sobre esta película es muy acertada:

Por lo menos, en los documentales hasta "Kyokushiteki erosu: Renka 1974 (Eros privado extremo, canción de amor/ 1974)" siempre se podía establecer una división rigurosa entre el objeto y el personal del rodaje. Las dos tesis "la reunión de materiales por un largo tiempo" y "el amor hacia el motivo y el objeto del documental", establecidas por Nagisa Oshima en los años sesenta, cuestionaban la postura de aproximación del personal del

\footnotetext{
${ }^{36}$ MacDonald, Scott, El miedo y la intimidad. Kazuo Hara habla de las películas que cambiaron los límites de lo filmable. Una entrevista de Scott MacDonald en Memoria y conciencia, en Muguilo, Carlos (et. ál.): El cine de los mil años: una aproximación histórica y estética al cine documental japonés (1945-2005), Op.cit., p. 177.
} 
rodaje como unos meros extraños y se plantea cómo construir una relación íntima de confianza con el objeto.

Sin embargo, Kazuo Hara no solo pone a su "ex-mujer" que representa a "lo p€rivado" como protagonista principal, sino que destina la cámara a Hara y a "la nueva novia" Sachiko Kobayashi que maneja el magnetófono. Es decir, empieza a violar la línea imaginaria que habría existido indiscutiblemente entre los lados al rodar y al ser rodado. Como resultado, logra una descripción de la relación vivida entre hombre y mujer como un enredo de la relación matrimonial establecida.

Se puede decir que es un giro copernicano donde se ha invertido el punto de vista de la cámara que estaba fija, sobre la línea que divide al sujeto que filma y del sujeto que es filmado. $^{37}$

Sato indica que en el trabajo de Hara se logró traspasar el límite imaginario entre el sujeto y el objeto de rodaje. Reflexionar sobre este acto nos demuestra el límite que marcaba la forma dentro del documental. La obra tiene un fuerte impacto que nos hace deliberar sobre los límites divisorios que se suponen de la relación entre el hombre y la mujer, la masculinidad y la feminidad. Esto nos lleva a reflexionar sobre una realidad sujeta al matrimonio institucional y sobre una costumbre de pensar la relación entre hombre y mujer basada en el sistema.

Se encuentran muchos aspectos comunes entre Makoto Sato y Kazuo Hara: comparten un mismo contexto social e ideológico como autores que produjeron documentales independientes y también impartieron clase a jóvenes ${ }^{38}$. Sin embargo, en cuanto al método educativo y al estilo fílmico de cada uno, Hara y Sato son completamente distintos. Lo comprobamos por el hecho de que Sato ha realizado el documental Agani ikiru (Vivir en Aga) con el equipo colectivo al estilo Ogawa Production en los últimos años de la década de los ochenta. En él, Sato muestra la experiencia positiva del rodaje en grupo colectivo. Hara produce de manera individual, grabando con la cámara él mismo. Además, Sato

\footnotetext{
${ }^{37}$ Sato, Makoto, Op.cit., p. 22. [Traducción propia del texto original en japonés]

${ }^{38}$ Hara fundó la academia preparatoria Cinema juku en Osaka para formar autores del documental, actualmente imparte clases en la Universidad de Artes de Osaka. Igualmente, Sato enseñó en la Eiga bigakko (Escuela estética del cine) e impartió clases en la Universidad de Artes y Diseño de Kioto, hasta su muerte.
} 
demuestra una simpatía por el Observation Documentary de Frederick Wiseman que trata de ocultar la apariencia de la cámara frente a los objetos en su trabajo, mientras que Hara es la misma encarnación del Action Documentary que persigue una clara apariencia de la cámara.

Cronológicamente, la realización de Tanabe buraku (Poblado Tanabe), la mejor película de la serie de Sanrizuka de Shinsuke Ogawa, tuvo lugar en el año 1973. Por otra parte, Shiranuikai (Mar Shiranui) e Igakutoshiteno Minamatabyo- sanbusaku (la trilogía Enferma de Minamata desde la perspectiva médica), de la serie de Minamata de Noriaki Tsuchimoto, se realizaron en 1975. El año de realización de Kyokushiteki erosu- renka 1974 (Eros privado extremo, canción de amor/ 1974) de Hara se encuentra en medio de aquellas dos obras maestras. Se acababa de producir una película centrada en la privacidad y en lo personal de la relación triangulo con dos mujeres. Los gastos del equipo y del rodaje de la película de $16 \mathrm{~mm}$ fueron muy elevados; sin embargo, Hara sentía la necesidad de mostrar una encarnación de "lo colectivo a lo privado" dentro de la corriente del documental japonés.

Gracias a la aparición de un documental que gira en torno a lo privado y lo personal con el tema principal del triángulo amoroso del autor, nos damos cuenta de su peculiaridad, por contraste con los documentales anteriores que estaban siempre justificados ideológicamente según lo público.

En la siguiente sección, nos aproximaremos al desarrollo del tema de lo privado en el documental japonés en los años ochenta y noventa. Igualmente, nos referiremos al cambio del medio y dispositivo, ya que se amplía la posibilidad de representación de la obra audiovisual de Private Documentary y Self Documentary. 
V.3. El flujo entre ficción y realidad en: Private Documentary y Self Documentary. 
Durante el presente apartado, a pesar de centrar nuestra atención en la transición temática hacia lo privado y lo personal en el documental japonés, abordaremos las indicaciones de Michael Renov y Annette Kuhn mencionadas anteriormente, donde se demuestra que en la imagen filmada es imposible separar lo privado y lo público. Concretamente, nos aproximaremos a unos trabajos seleccionados que son emblemáticos de los años ochenta y que abren el camino hacia expresiones del audiovisual con el tema de la subjetividad. Y posteriormente, trataremos el tema del Private Documentary y Self Documentary que se expande en el campo documental de los años noventa.

Para empezar, ofreceremos una breve explicación del contexto social en Japón en esta época y analizaremos una obra de Katsuhiko Fukuda ${ }^{1}$, representativa de la transición temática que oscila de la colectividad a la individualidad. Más tarde, nos referiremos a su desarrollo técnico y aproximaremos una obra audiovisual de Yukiko Eguchi basada en el tema de lo privado y personal que también representa el cambio temático y de soporte en esta década. Junto con la obra de Fukuda, la obra de Eguchi se convierte en otra de las dos miradas distintas basadas en el relato de la mujer.

Luego, reflexionaremos sobre un documental de Kazuo Hara que impacta fuertemente en la sociedad japonesa. Esta obra se basa en una temática social, pero la manera de abordar el tema desde una mirada muy personalizada, convierte el tratamiento del tema social en algo subjetivo. Este trabajo, conmemorativo del documental japonés de esta década, nos obliga a reflexionar sobre la transición en el tema y en el modo de retratar la realidad en el documental. Al mismo tiempo, nos lleva a considerar la manera de traspasar los límites de la ficción y de la realidad.

Posteriormente, analizaremos los documentales japoneses basados en temas privados y personales, así como el cambio de la técnica y el soporte que hubo desde la película hacia el video digital en los años noventa, siguiendo la crítica de Makoto Sato. Después de contextualizar bien el ámbito documental, social y político de esta década, destacaremos

\footnotetext{
${ }^{1}$ Katsuhiko Fukuda (1943-1998): realizador de película documental independiente. Fue ayudante de dirección de la serie de Sanrizuka de Ogawa Production. A partir del año 1978 se convierte en cineasta independiente y vuelve a Sanrizuka. Ha producido trabajos con película de $8 \mathrm{~mm}$.
} 
dos documentales que abordan el tema de la familia de dos autores que se han basado en la técnica y el soporte del video digital con la cámara Handy-Cam. Son dos trabajos de la segunda mitad de los años noventa que representan, en el documental japonés, el tema del conflicto familiar. Casualmente, al mismo tiempo, son historias que simbolizan la crisis del mismo autor y la ausencia paternal en su familia. Las referencias de la presente sección a estas dos obras de realizadores jóvenes japoneses, servirán como material de comparación para otra obra que aborda el tema familiar bajo la mirada del multiculturalismo.

Nuestra aproximación a la definición del Self Documentary se fundamenta en las ideas de Tatsuya Mori, quien argumenta que la objetividad del documental es ineficaz basándose en una crítica a los medios de comunicación y reflexionando sobre dos documentales que abordan temas sociales, según la mirada de la cámara Handy-Cam.

Finalmente, realizaremos un análisis comparativo de obras basadas en temas familiares. Son tres obras de jóvenes documentalistas que han realizado sus trabajos en Japón con el tema familiar cuestionando la propia identidad del autor.

\section{V.3.1. El relato de la mujer en la transición del tema y del soporte.}

En la década de los años ochenta se genera una falta de interés por los asuntos políticos, como reacción a los años setenta. Por la anterior ebullición del movimiento estudiantil, se forma el siguiente esquema: movimiento=combate=violencia . Por otra parte, se difunde una idolatría hacia el dinero en todo el país, a consecuencia de la burbuja financiera e inmobiliaria. En este contexto, se provoca un fenómeno reaccionario, parecido a un tipo de alergia juvenil al debate sobre la utopía colectiva y el mundo político.

Entre los jóvenes japoneses se genera un fenómeno cultural llamado Otaku (persona insociable entregada a su hobby), donde se siente mayor simpatía por el mundo imaginario como el video juego y/o los dibujos animados que por el mundo real. Otras generaciones mayores, revolucionarias en los años setenta, entran en los años ochenta empezando a disfrutar de la vida consumista y tratando de ignorar las contradicciones sociales. Además, 
permanecen inmersos en la nostalgia de la juventud, abandonando también la realidad actual, al igual que los jóvenes. Se empujan los problemas sociales que se combatían en los años setenta, hacia lo lejos, hacia el olvido. Cuando vuelven a la memoria, son sepultados y ya no se reflexiona sobre ellos (excepto unas pocas personas interesadas y algunos pocos activistas).

Si analizamos los años ochenta, lo más importante fue la caída del muro de Berlín: la opinión pública se ocupó de juzgar la disolución de la Unión Soviética, como el fracaso del régimen político y económico del socialismo y el comunismo. La crítica sobre la sociedad capitalista, el debate político o la opinión basada en ideologías se quedan anticuados. Con esta situación, en Japón, el partido comunista se debilitó y se redujo, también el partido socialista acabó desmembrado. Algunos diputados socialistas ex-directivos, establecen un partido opuesto al que ocupa la administración de aquel momento, aunando fuerzas con miembros del partido conservador en el poder, del cual se han emancipado. De esta manera, se percibe la ambigüedad ideológica en la esfera política. Sato comenta esta circunstancia:

\begin{abstract}
La transformación de "lo colectivo a lo individual" empieza a aparecer en la superficie, lo que solo avanzaba bajo el agua en los años setenta. Aunque a paso lento, se puede captar el comienzo del cambio en la manera de elegir el tema o en el objeto del problema social que se permuta al universo privado. ${ }^{2}$
\end{abstract}

Con este trasfondo, Katsuhiko Fukuda, quien trabajaba en los años setenta en la productrora de Ogawa Production, presenta en 1988 Kusatori zoshi (El libro de escarda), de 16mm (el original de $8 \mathrm{~mm}$ ), $82 \mathrm{~min}$. de duración ${ }^{3}$, color, en un contexto en el que la comunidad ya se encuentra debilitada en el lugar de lucha de Sanrizuka. La obra, representa la vida cotidiana de una anciana que vive en soledad y fue rodada como una película individual. Fukuda se

\footnotetext{
${ }^{2}$ Sato, Makoto: Documentary no shujigaku [La retórica del documental], Tokio, Misuzushobo, 2006, p. 23. [Traducción propia del texto original en japonés]

${ }^{3}$ Se encuentra unas indicaciones sobre el año de producción de esta obra en 1985, por ejemplo en una lista de producción de Katsuhiko Fukuda en una página de Nagoya Cinémathèque: http://cineaste.jp/1/960.htm, accedido el 31 de marzo del 2009. Sin embargo, la mayoría de registros concuerdan en que 1988 fue el año de la presentación pública. Suponemos que 1985 se había presentado la obra en $8 \mathrm{~mm}$ y luego en 1988 se presentó en 16mm.
} 
quedaba solo en Sanrizuka tras independizarse de Ogawa Production que se mudó a Yamagata. Él seguía filmando con la cámara de $8 \mathrm{~mm}$ y presentó esta obra.

El documental está estructurado en 13 cuentos que retratan al personaje principal, doña Katsu Someya y a su familia, que narra un sueño extraño que tuvo la noche anterior, otra historia contaba su viaje a Sanrizuka como explotadora agrícola. También se incluye una narración sobre la obsesión que tenía en su infancia a causa de la pobreza, y otros relatos más. Las imágenes representan su vida cotidiana trabajando en el campo. A través de esta obra se muestra la realidad, sus memorias y sus sueños, como lamentación o lección de vida.
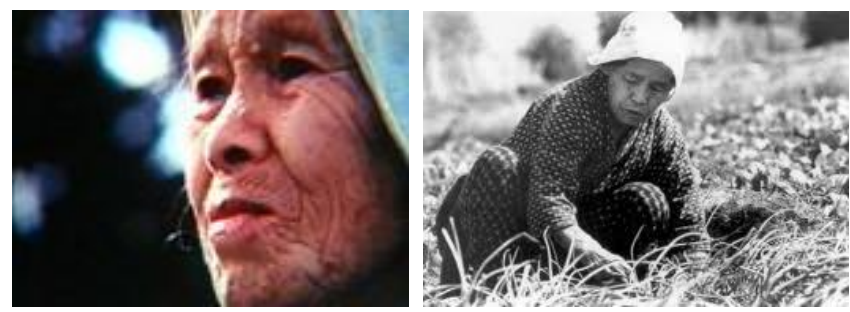

32. Kusatori zoshi (“A Grasscutter's Tale”, El libro de escarda, 1985), Katsuhiko Fukuda

Una escritora japonesa, Mayumi Mori, comenta sobre esta obra, en comparación con los documentales sobre problemáticas sociales que habían florecido en la década anterior:

Aunque haya muchos trabajos en que se trata el tema de los problemas sociales como los de Sunagawa o de Minamata, muchas veces se me enfría el entusiasmo por la demasiada demostración de la lucha por el poder (o contra el poder) al que se ataca de frente. ¿Y qué? Me hace cuestionar sobre las mujeres, los niños y los ancianos que no están en la imagen. Cuando rara vez salen las mujeres [en la imagen], son del grupo de distribuidoras de comida vestidas de Kappougi (delantal con mangas para kimono), limitadas a los papeles femeninos. Por esta razón, me sentí refrescada por este audiovisual de Kusatori zoshi. Proyecta a una anciana Katsu Someya que vive en Narita y su continua escarda que parece sin fin. La mano de doña Katsu se mueve rítmica sin tardanza, mientras, su boca, también. Las 
pequeñas historias sobre lo que sucede hace muchos años, del hijo que vendió el terreno a la corporación del aeropuerto sin permiso, del marido inútil y de cuando murió ese marido, como si el asunto no tuviera nada que ver con ella. Cada vez que repite cambia lo que contaba antes y surge una carcajada en el público. La energía de esa anciana que vive solo escardando en un pueblo inhabitado, nos recupera el ánimo. Y [nos hace pensar] ise puede vivir de esta manera! o más bien, ise puede seguir arraigándose en la tierra! ${ }^{4}$

Bien sea sobre Sunagawa ${ }^{5}$, donde existía el conflicto contra la confiscación del terreno por el proyecto de ampliación de la base militar en Tatekawa (Tokio) en 1955-1957, o sobre Minamata, donde la enfermedad fue provocada por la contaminación de la fábrica; los documentales basados en temas de lucha social, con imágenes del combate hasta los años setenta, casi siempre representaban un tipo de heroísmo varonil. En estas expresiones las mujeres, los niños y los ancianos no aparecían o se quedaban al margen.

Como indica Mayumi Mori, las mujeres siempre eran representadas cumpliendo el papel femenino estereotipado: como cocinera, limpiadora, cuidadora del hogar y de los niños, de los ancianos o los enfermos, etc. Las pocas veces que salían en la imagen siempre estaban relacionadas con el cumplimiento del rol femenino. Es decir, en dichos documentales sobre el combate heroico, los varones fueron representados como personajes principales y los demás no se representaron y/o se quedaron como actores secundarios, a pesar de que ellos también compartían los problemas sociales -sufriendo lo mismo- y participaban de la lucha de resistencia.

En este contexto, comprendemos perfectamente la frustración que sentía Mayumi Mori y su abolición que indica con la expresión refrescada por ver a esta anciana como el personaje principal del documental, en medio del conflicto contra la confiscación del terreno para la

\footnotetext{
${ }^{4}$ Mori, Mayumi, Choushiteki documentary hourouki [Una nota errante en privado sobre los documentales], en Sato, Tadao (et. ál.): Nihonno dokymentary I, Dokyumentary no miryoku [El documental japonés I, El atractivo de documental], Tokio: Iwanamishoten, 2009, p. 96. [Traducción propia del texto original en japonés]

${ }^{5}$ Por la ampliación de la base militar de las tropas estadounidenses, surge un conflicto entre la policía y los habitantes oponentes a la confiscación de terreno. El documental de Kamei, Fumio (Ryuketsu no kiroku: Sunagawa-Record of Blood: Sunakawa/ 1956) trata sobre esta lucha que trata de impedir la medición del terreno para el proyecto.
} 
construcción del aeropuerto internacional de Narita, problema que también hemos mencionado en la sección anterior.

Los familiares hombres que describe íntimamente esta anciana, no son héroes ni mucho menos. La anciana, no realiza ni una manifestación política, ni un discurso exagerado. Habla solo de lo que recuerda mientras trabaja. Además, sus relatos no cuentan con una coherencia exacta, el documental presenta unas imágenes desordenadas de los personajes y de los asuntos según su comprensión. Se muestra la ruptura y la inconexión de unos relatos repetitivos. Esta manera de relatar, por parte de la anciana, nos hace recordar la indicación de Shoshana Felman, la cual nos posibilitaba una lectura de la mujer encontrando un punto de ruptura y la conexión con el relato femenino.

Este documental, quizá simplemente por estar basado en el relato de una anciana, nos facilita visibilizar el punto de ruptura y su conexión con la historia de la vida de la mujer. Posiblemente, ese punto de ruptura y conexión dentro de su relato, fuere también el punto en el que se dividen y a la vez se comunican la realidad y la ficción, lo privado y lo público, lo personal y lo social.

Por otra parte, la imagen de la anciana y de los personajes que aparecen en sus relatos, está muy lejos del heroísmo romántico. Ella nunca muestra gestos del combate en el documental, sino que las imágenes solo representan el gesto de su labor cotidiana como campesina. Paradójicamente, eso nos impacta en mayor medida y nos lleva a reflexionar sobre el contexto social que la rodea. Es decir, nos hace imaginar más allá de lo que representa la imagen. En otras palabras, nos lleva a pensar su contexto, y nos damos cuenta de que ella es la única persona que resiste contra el poder político y económico que, había expulsado a la gente del pueblo, como si de quitar malas hierbas se tratase.

La imagen de esta anciana en un pueblo inhabitado, también nos recuerda al acto de Fukuda, el autor de este documental, quien se quedó solo en Sanrizuka después de que la comuna de Ogawa Production se trasladase a otro lugar. Tal vez, no estamos tan equivocados en esta interpretación, pudo ser que Fukuda mirase y escuchase a esa anciana a través de la cámara 
reflejando una imagen de sí mismo. De hecho, en su obra se representa el acto de dejar de hablar para escuchar a la anciana, él mismo se convirtió en el primer testigo del relato. Este documental nos invita a escucharla y conocerla, formando una posible lectura de autobiografía de la mujer. Quizás, Fukuda -aún siendo hombre- logra de alguna manera, participar en la posible lectura de la autobiografía de la mujer con esta obra, gracias a su postura crítica sobre el heroísmo masculino en el documental.

En resumen, esta obra se diferencia de los documentales anteriores -incluso de las series excelentes de trabajos de los grandes maestros hasta los años sesenta, basadas en los problemas sociales- en dos puntos principalmente, a saber: se libera del dogmatismo del realismo socialista alejado del heroísmo romántico, y se enfoca en una sola persona, anciana, sin enfatizar el papel estereotipado femenino. La aparición de este documental dentro del contexto del conflicto de Narita, además, la convierte en una obra que se encuentra sobre una línea prolongada de Ogawa Production, pero al mismo tiempo, es una producción de una sola persona, Katsuhiko Fukuda, quien decidió quedarse solo en Sanrizuka Narita. Todo ello, nos indica una notable transición en el documental japonés.

Esta corriente que transforma el centro de atención de lo colectivo a lo individual no influye tan solo en el documental, sino que provoca un nuevo movimiento general en el cine independiente. Dicha corriente se sostiene, sobre todo, en la innovación técnica del equipo audiovisual como la simplificación de la operación, y la bajada del coste por el cambio de la cámara y el soporte de almacenamiento de los datos audiovisuales.

\section{...Y también en la segunda mitad de los años setenta, las películas de $8 \mathrm{~mm}$ producidas a nivel individual empiezan a formar notablemente una gran corriente en el cine independiente, basada en el progreso técnico. ${ }^{6}$}

Como menciona Makoto Sato, comienzan a producirse de manera muy activa películas rodadas individualmente. Gracias a la cámara con película de $8 \mathrm{~mm}$ aumentó el número de

\footnotetext{
${ }^{6}$ Sato, Makoto, Op.cit., p. 23. [Traducción propia del texto original en japonés]
} 
productores, ya que era fácil operar. El mismo eslogan publicitario "quien quiera puede filmar", lo demostraba.

El vídeo de 8mm, aparecido en los años ochenta, contribuyó aún más a multiplicar el interés por captar el mundo privado. Desde la película de $8 \mathrm{~mm}$ "quien quiera puede filmar", hasta el vídeo de $8 \mathrm{~mm}$ "todo el mundo ha filmado ya”, se inauguró un gran cambio en el entorno técnico audiovisual.

Si los años setenta supusieron el inicio del cambio de una producción colectiva a la película individual, en el campo de producción del cine los años ochenta serían un período de cambio del problema social al universo privado como tema y objeto. ${ }^{7}$

Este cambio técnico de la película de $8 \mathrm{~mm}$ al vídeo de $8 \mathrm{~mm}$ contribuye decisivamente en la representación audiovisual. En 1986 Yukiko Eguchi produjo MaMa, de 8mm, a color, de 49min. de duración. Fue un documental muy comentado por su temática privada e íntima. Es primordial el tema de la identidad de la autora: ella busca las causas de sus diferencias en la relación con su madre desde un punto de vista psicológico. Luego, reconoce que su madre a la vez sufría con la figura su propia madre (la abuela de la autora). Se representan las dificultades vitales en la relación abuela - madre - hija por medio del odio y del amor.

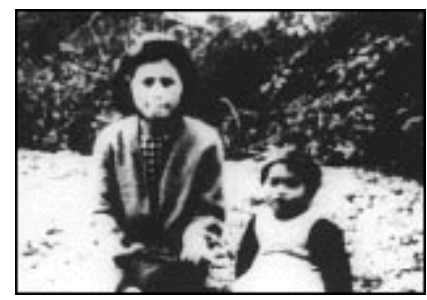

33. MaMa (1987), Yukiko Eguchi

En la película, se confiesa el origen familiar de la comunidad coreana ${ }^{8}$ y la dificultad narrativa de dos mujeres, la madre y la hija. Finaliza con la entrevista directa a la madre.

\footnotetext{
${ }^{7}$ Ibíd., p. 23. [Traducción propia del texto original en japonés]

${ }^{8}$ Por la invasión del imperio japonés, desde el año 1904 Japón ha asumido el mando de la política interior y exterior de Corea. En el año 1910, mediante el tratado de anexión Japón-Corea, Japón incluye la península coreana a su territorio. Antes y después de esta anexión y hasta la derrota de la Segunda Guerra Mundial (1945), numerosos coreanos se han trasladado por diversas razones: por coacción del poder japonés, como refugiados para
} 
Citaremos aquí la sinopsis de la película que se presentó en el Festival Internacional de Cine Documental de Yamagata en 1987:

In this private documentary produced as a graduate project at the Tama Art University, Eguchi Yukiko searches for her own identity. The film begins with her wondering whether her mother might somehow be the cause of her own obsessive cleanliness. It then goes on to tell of her mother's life with a voice-over narration as the camera tracks the places she had lived, from Miyazaki to Yokohama. Next, the facts of her mother's marriage and Yukiko's birth are exposed. Because her mother was Korean, she was unable to register her daughter's birth and thus Yukiko was born illegitimate. Her mother went from man to man, and moved from place to place, giving birth to three children, each with different fathers. Yukiko's memories of the past and her mother's recollections alternate, gradually building up into a story. As a child, Yukiko was unable to warm to her stepfather. Her mother sensed this, but was unable to resolve the situation. Now she is afflicted with obsessive cleanliness and self-hatred. She begins to feel troubled by being told she has come to resemble her mother, and at this point, the large role of her maternal grandmother becomes evident. In the process of learning how greatly her mother was affected by her grandmother's disorderly life, Yukiko seems to arrive at a new understanding of her mother. A question she asks her mother, just by chance, enables her to see her

evitar el conflicto entre las potencias que luchan por el dominio de colonización, o por buscar mejores posibilidades económicas para sobrevivir, entre otras razones. Tras la derrota en la guerra, y debido a la independencia de Corea, el poder japonés despoja a los coreanos que viven en Japón de la nacionalidad japonesa. Desde entonces, los coreanos que permanecieron en Japón no tienen ni la nacionalidad japonesa ni el derecho de voto, hasta hoy en día. Según las leyes japonesas, no es suficiente con nacer en Japón para obtener la nacionalidad, sino que es necesario tener padres japoneses. De este modo, los hijos de coreanos que nacen en Japón no obtienen el derecho a la nacionalidad. Y dentro de la comunidad coreana, por la Guerra de Corea (1950- armisticio de 1953), se encuentra una fuerte división entre el norte y el sur, opuesta política e ideológicamente, con una problemática muy compleja. Además, por culpa de una profunda discriminación, existe la tendencia de ocultar su pertenencia coreana no solo a las personas que les rodean, sino incluso a los hijos. Como consecuencia, es notable la falta de información sobre la historia y la cultura de la tercera y cuarta generación de los coreanos afincados en Japón. Es frecuente el caso de jóvenes de tercera o cuarta generación que mantienen la nacionalidad coreana, pero no la japonesa. La discriminación hacia los coreanos nacidos en Japón existe en relación a ciertos asuntos legales: para obtención de trabajo, el matrimonio, etc. Los problemas en la vida social y cotidiana todavía son graves y profundos en muchas ocasiones. Si comparamos la miseria que sufren con la pobreza causada por la segregación, la gravedad se ha reducido poco a poco; sin embargo, no se ha resuelto el problema esencial de la discriminación. Actualmente, debido a la inestabilidad de la política en la península coreana y a la manipulación emocional nacionalista, a menudo sufren la discriminación indebida como chivo expiatorio. 
mother's life from a fresh perspective. The film does not, however, draw definite conclusions about the relationship between mother and daughter. ${ }^{9}$

Desde el punto de vista personal, en esta obra se indaga y se profundiza en el tema de las relaciones familiares, sobre todo entre madre e hija. El tema es muy privado e íntimo. La obsesión por la limpieza y la repugnancia hacia sí misma, representan el dolor de no poder aceptarse. El hecho de auto-calificarse como sucia, le obliga inevitablemente a reflexionar sobre su identidad. Tras narrar un asunto privado e íntimo, se descubre la subjetividad de la autora. En el último momento, cuando aparece la madre, de nuevo se establece la subjetividad de la autora, ya que se da una diferente perspectiva sobre el asunto, iniciando una posible comunicación entre las dos.

La línea imaginaria que divide sujeto y objeto, que Kazuo Hara ya atravesara en los años setenta, traspasó la línea imaginaria que divide lo íntimo y la realidad, la ficción y el documental, la memoria y el contexto. Lo mismo ocurre por la introducción de la narración de Eguchi como autora y objeto de la película. La confesión de sus memorias de la niñez, se convierte en una descripción de la realidad vivida. Al mismo tiempo, inevitablemente

\footnotetext{
${ }^{9}$ Yamagata International Documentary Film Festival (YIDFF): http://www.yidff.jp/97/cat091/97c102-3.html, accedido el 31 de marzo del 2009. En este documental de producción privada, como proyecto de posgrado para la Universidad de Arte de Tama, Eguchi Yukiko busca su propia identidad. La película comienza con una pregunta sobre si su madre podría ser de alguna manera la causa de su obsesión por la limpieza. A continuación, pasa a hablar de la vida de su madre con una voz en off en una narración ante la cámara que realiza un seguimiento de los lugares en que habían vivido, desde Yokohama a Miyazaki. Después, expone los hechos relacionados con el matrimonio de su madre y el nacimiento de Yukiko. Como su madre era coreana*, no pudo registrar el nacimiento de su hija y, por tanto, Yukiko nació ilegítima. Su madre pasó de un hombre a otro y se trasladó de un lugar a otro, dando a luz a tres niños, cada uno de diferentes padres. La memoria del pasado de Yukiko y los recuerdos de su madre consolidaron progresivamente su historia. Cuando era una niña, Yukiko no fue capaz de sentir simpatía por su padrastro. Su madre lo consideraba deplorable, pero no pudo resolver la situación. Ahora ella se ve afectada por una obsesión por la limpieza y auto-desprecio. Ella comienza a preocuparse cuando le dicen que ha llegado a parecerse a su madre, y en ese punto, el gran papel de su abuela materna se hace evidente. En el proceso de conocer de qué manera la vida de su madre se había visto afectada por la vida desordenada de su abuela, Yukiko parece llegar a una nueva comprensión sobre su madre. Una pregunta que hace a su madre solo por casualidad le permite ver la vida de su madre desde una nueva perspectiva. La película, sin embargo, no extrae conclusiones definitivas acerca de la relación entre madre e hija. [Traducción propia] *. En esta parte en el texto en japonés no se sabe exactamente quién es de Corea, y por ello para la traducción he seguido el texto en inglés. Según Nada Hisayoshi, investigador del cine vanguardista y de la película personal, la madre de Eguchi no es coreana, sino que tan solo su marido y su padre eran coreanos; es decir, el padre y el abuelo materno de Eguchi son de Corea: The director was born in an ethnic Korean environment (both her father and her mother's father are of Korean descent). La directora nació en un ambiente étnico coreano (tanto su padre como el padre de su madre son de ascendencia coreana) en Hisayoshi, Nada: Self-Documentary: Its Origins and Present State, en la revista sobre documentales Documentary Box, vol. 26 (oct. 2005), http://www.yidff.jp/docbox/26/box26-2-e.html, accedido el 31 de marzo del 2009. [Traducción propia]
} 
aparecen elementos de ficción al relatar el recuerdo, y al recordar. El fundamento del relato es descubrir el trauma y tener así la posibilidad de hablarlo, pero el trauma siempre es algo que no se puede contar como hemos visto en el primer capítulo. De esta manera, solo se puede describir lo que rodea al trauma en sí, relatando la situación y los sentimientos.

Eguchi habla de su situación y lo que ha ocurrido con sus emociones. Naturalmente, ella no puede hablar objetivamente de sí misma, como consecuencia, ella se relata con subjetividad. Desde este punto, se nos plantea una cuestión: ¿podría existir un relato del trauma objetivo? Estas cuestiones sobre la memoria y el relato del trauma que no escapa de convertirse en ficción, las hemos desarrollado con la ayuda del trabajo de Shoshana Felman. Si seguimos sus ideas, el trabajo de Eguchi nos plantea escuchar lo que no se puede decir y que nosotros sigamos hablando de ellas como testigos de ese relato imposible.

\section{V.3.2. Los límites en el documental: ética social, ficción y privacidad.}

Nunca ha desaparecido completamente la presentación audiovisual basada en temas sociales y públicos. Sin embargo, podemos decir que la aparición del vídeo de $8 \mathrm{~mm}$, más económico y fácil de manejar que la película de $8 \mathrm{~mm}$, evidentemente, facilita que la elección del tema sea también lo privado.

(...) [el documental japonés] Yuki Yukite shingun (The Emperor's Naked Army Marches On, 1987) de Kazuo Hara, retrata a un ex combatiente «desquiciado» de la guerra del Pacífico, cuya misión de vida es la denuncia de los crímenes de guerra japoneses desde un camión con altavoces con el cual recorre el país, visitando importunamente a sus oficiales superiores de antaño, exigiéndoles que pidan perdón por sus crímenes, como los asesinatos de prisioneros estadounidenses en Filipinas, los cuales ordenaron o condonaron. ${ }^{10}$

\footnotetext{
${ }^{10}$ Sontag, Susan: Ante el dolor de los demás, trad. Aurelio Major, Madrid: Santillana Ediciones Generales, 2003, p. 143 .
} 
Kazuo Hara había lanzado una película documental independiente con el tema del individuo y la privacidad en los años setenta. En 1987 realizó Yukiyukite shingun (El ejército de Dios sigue marchando/ Camina el ejército desnudo del emperador) ${ }^{11}$, a color, de $16 \mathrm{~mm}$. y 122min. de duración. En este trabajo Hara muestra la quintaesencia del Action Documentary; a saber, su manera de aproximación al objeto filmado dejando clara la presencia de la cámara, y aceptando la violencia de la cámara como desafío. Esta obra única de Hara, filma el acto provocador y desviado del personaje principal Kenzo Okuzaki ${ }^{12}$, un ex-soldado japonés que exige las responsabilidades de la Guerra del Pacífico.

Con plena conciencia de enfrentarse a la cámara, la actitud de Okuzaki cada vez se vuelve más violenta, llegando incluso a un episodio de intento de asesinato fuera de la película documental. Makoto Sato resume esta impresionante obra que dio un gran golpe al Japón de aquel momento.

\begin{abstract}
"Yukiyukite shingun (El ejército de Dios sigue marchando/ Camina el ejército desnudo del emperador)" es la obra paradigmática de Hara que profesa el "Action Documentary”. Es un documental que persigue representar la acción desviada de lo normal. Una energía terrible y una violencia espantosa han provocado un impacto agudo sobre la falsedad fantástica de un Japón atontado por la pasividad. ${ }^{13}$
\end{abstract}

En los años ochenta, en Japón, se establece una pequeña sociedad burguesa que disfruta de la vida consumista conseguida gracias al desarrollo económico y su estabilidad, ignorando el conflicto y la pobreza del país. Dentro de este ambiente, la figura del soldado que fue

\footnotetext{
${ }^{11}$ Durante nuestro trabajo utilizaremos la traducción El ejército de Dios sigue marchando, respetando la opinión del autor: en Japón el título es "Yuki tukite shingun", pero el título inglés (The Emperor's Naked Army Marches On / El ejército desnudo del Emperador sigue marchando) no fue una buena traducción. Sería mejor llamar God's Army Marche On (El ejército de Dios sigue marchando) [MacDonald, Scott: El miedo y la intimidad. Kazuo Hara habla de las películas que cambiaron los límites de lo filmable. Una entrevista de Scott MacDonald en Memoria y conciencia, en Muguilo, Carlos (et. ál.): El cine de los mil años: una aproximación histórica y estética al cine documental japonés (1945-2005), Navarra, Festival Internacional de Cine Documental de Navarra, Navarra Dirección General de la Comunicación, 2006, p. 187]. En Festival internacional de cine Las Palmas de Gran Canaria traducía como Camina el ejército desnudo del emperador. [http://lpafilmfestival.com/events/yukiyukite-shingun--2?locale=es, accedido al 10 de noviembre del 2011.]

${ }^{12}$ Kenzo Okuzaki, personaje principal de de película Yukiyukite shingun (El ejército de Dios sigue marchando), estuvo en prisión cumpliendo su condena desde 1983 hasta 1997, período que incluye el estreno de la película.

${ }^{13}$ Sato, Makoto, Op.cit., pp. 11-12. [Traducción propia del texto original en japonés]
} 
expuesto a la violencia de la guerra y que sobrevivió, aproxima otra vez esta violencia a los que intentan evitarla y escapan de la responsabilidad como hizo el emperador, el primer ministro y los superiores militares. De esta manera, se descubre el velo engañoso de un Japón convertido en nación moderna, gracias a la sociedad civil contemporánea que ha arrinconado los sucesos de la horrible guerra de invasión al Sureste asiático.
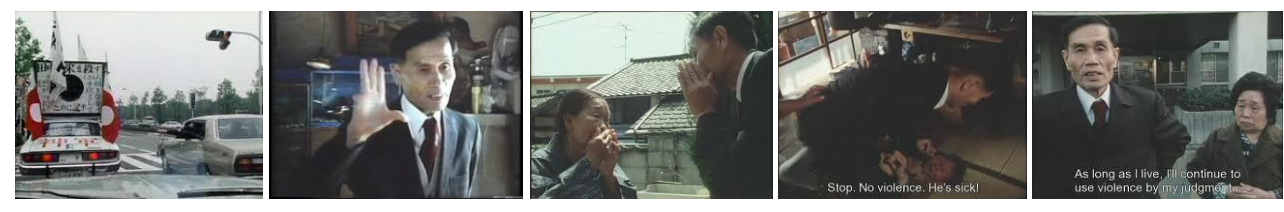

34. Yukiyukite shingun (The Emperor's Naked Army Marches On, 1987), Kazuo Hara

Una característica del trabajo de Hara, es que filma provocando al objeto para que actúe instintivamente frente a la cámara. Es decir, Hara obliga al objeto rodado a que sea consciente de la presencia de la cámara, y filma el proceso en el que se intensifica su actuación. Quizás el objeto rodado que está actuando, nunca podría actuar igual sin la cámara que tiene enfrente. Si bien Okuzaki tiene una personalidad fuerte, que sin la presencia de la cámara no habría sido tan violenta. Hara le obliga a encontrarse en una situación de confusión frente a la cámara, la persona en sí no sabe si su conducta parece natural y filma esta situación confusa que se encuentra entre la ficción y la realidad. El punto más relevante del documental de Hara, es que no se omite ni el deseo o la aspiración de manipular al objeto rodado, ni su proceso de realización de dicha manipulación (como parte sospechosa y confusa interna de la película documental). Si una de las razones que justifican las obras de arte contemporáneas es, ser críticos y proponer una reflexión, el trabajo de Hara cumplirá ampliamente los requisitos.

Llegados a este punto, nos surge una pregunta: si los protagonistas frente a la cámara también actúan por el deseo y la demanda directa o indirecta del director, ¿cuál es la diferencia entre la película documental y la de ficción? Entonces, ¿cuáles son las divergencias entre el documental y la película de ficción? La relación de poder que separa al sujeto del objeto (el esquema del sujeto que maneja y el objeto que es manejado), en la película de Hara, gradualmente se va desdibujando. 
Por ejemplo, en Yukiyukite shingun (El ejército de Dios sigue marchando/ Camina el ejército desnudo del emperador) hay algunas escenas en que Okuzaki interroga al exsuperior del ejército para esclarecer la verdad sobre el fusilamiento de su subordinado, ocurrido justo después de la finalización de la guerra. Para el interrogatorio, Okuzaki inicialmente aparecía con los familiares del difunto. Pero cuando pierde la colaboración de la familia que rechaza el acto violento de Okuzaki, opta por llevar familiares falsos sin ninguna relación real. Obviamente, se trata de un acto estratégico de Okuzaki, presionando a los ex-superiores del ejército para conseguir el testimonio y el perdón. No podemos justificar inmediatamente este acto, aunque gracias a él la película resulte más atractiva. Sin embargo, la preparación y la dirección de Okuzaki se intensificaban cada vez más según avanzaba el rodaje. Al principio, Okuzaki solo actúa contestando a la provocación de Hara, pero poco a poco arrecia su actitud y finalmente empieza a asumir la dirección.

"En la película de Hara, el objeto contraataca a la cámara” (Aaron Gerow ${ }^{14}$ ). Es exactamente lo que dice Gerow, la obra de Hara, por su intercambio violento, más que por ser objeto de violencia, potencia la fuerza de la película. ${ }^{15}$

Hidenori Okada, en calidad de investigador de cine, elije esta obra de entre los mejores documentales japoneses incluidos para programa especial sobre documental en una revista en 2007. Insiste en la importancia de la posición de Hara en la historia del documental japonés, argumentando que la historia del documental japonés se puede dividir en dos fases: antes de Hara y después de Hara. Precisamente, esto se debe a la lucha cuerpo a cuerpo en lo que se refiere a rodar y ser rodado. Es indiscutible que la obra de Hara y su postura, al aferrarse a la producción individual y al tema de lo privado y lo personal, abrió el camino para el Private Documentary y Self Documentary, los cuales forman una gran corriente en el campo del documental o, más bien, de la representación audiovisual.

\footnotetext{
${ }^{14}$ Aaron Gerow, ex-editor de la revista electrónica Documentary box que publica Yamagata International Documentary Film Festival (YIDFF), especialista en cine japonés y profesor asociado de la Universidad de Yale en Estados Unidos de América.

${ }^{15}$ Okada, Hidenori: Nihon no documentary (El documental de Japón), en VV.AA. Gendaishisou. Vol.35-13, Documentary (El pensamiento de hoy, Vol.35-13, El documental.), Tokio, Seido-sha, 2007, p. 285. [Traducción propia del texto original en japonés]
} 
Fukuda, Eguchi y Hara son los autores emblemáticos del Private Documentary y del Self Documentary, estilos documentales que se mueven entre la ficción y la realidad. La línea imaginaria que divide la ficción y el documental, el sujeto que rueda y el objeto que es rodado, la narración subjetiva y la narración objetiva, nos van aproximando a los ejemplos concretos de nuestro enfoque investigador sobre el tema del documental, como contexto histórico, social, plástico y audiovisual. Con esta base, enseguida veremos el movimiento del Private Documentary de los años noventa.

\section{V.3.3. El video digital en los años noventa.}

En los años noventa la temática de lo privado y lo personal se extiende en el documental japonés. Como vimos en el apartado anterior, la representación de los movimientos sociales y de la resistencia política, en los años ochenta, disminuye notablemente en el documental de producción independiente. La tendencia a disfrutar de la vida consumista, dado el buen estado de la burbuja financiera e inmobiliaria en Japón, propicia una apatía bajo la influencia del fin de la guerra fría.

La caída del muro de Berlín en 1989 y la disolución de la Unión Soviética en 1991 se constituyeron como expresiones del fracaso del comunismo y el socialismo. Posteriormente, surge una confusión ideológica en la práctica política que atenúa la ineficacia del antagonismo político y se propaga un ambiente de indiferencia política. Un ejemplo concreto en Japón se observa en el partido socialista, el cual mantenía sus convicciones con cierta resolución, a pesar de permanecer en territorio capitalista bajo un fuerte control estadounidense, pero finalmente se fragmenta: algunos diputados y ex-directivos socialistas forman un nuevo partido de oposición con miembros de un grupo conservador escindido del partido de la administración regente. Es decir, los grupos que se oponían ideológicamente tanto de derecha como de izquierda establecieron un tercer partido político simplemente aunando el número de diputados.

Bajo esta situación, puede decirse que la discusión sobre el tema político en sí sería un acto analógico contra la marcha del tiempo. Ya no existe nada más que hablar 
sobre mí, ni lo político ni lo social. De este modo, se ha generado el fundamento social, politico y técnico del "Private Documentary" de los años noventa. ${ }^{16}$

Exactamente ocurre lo que comenta Makoto Sato: aumenta la cantidad de producción de documentales con el tema de lo privado y lo personal en los años noventa en Japón. Asimismo, se generaliza la presentación de las películas documentales en las salas de los cines comerciales del tipo complex, consiguiendo que algunas obras llamen poderosamente la atención de los espectadores y con el consecuente éxito financiero.

Makoto Sato, realiza una lista de once documentales del tipo Private Documentary sobre los cuales se discutió acaloradamente en los años noventa. Todos ellos se centran en el tema de lo privado y las relaciones familiares de los autores:

Quiero enumerar cronológicamente los documentales privados que han llamado la atención por su presentación pública en el cine. "Kazokushashin” (La fotografia familiar), producida por Yoshiharu Tezuka en 1989, "Ni tsutsumarete” (En cubierta)” de Naomi Kawase (1993), “Tsuma wa filipina” (Mi mujer es filipina), de Yasunori Terada (1994), “Bokuha ikareru kiiro94- Nijino álbum” (Soy el amarillo furioso 94/ El álbum de arco iris) ${ }^{17}$ de Kidlat Tahimik (1994), "Hyakudai no kakyaku” (El viajero en la eternidad) de Masato Hara (1995), "Osaka Story” (Historia de Osaka) de Toichi Nakata (1996), "Yumika” de Katsuyuki Hirano (1997), “Añ̃yon Kimuchi” de Testsuaki Matsue (1999), "Fatherless” (Sin padre) de Masaya Muraishi y Yoshiya Shigeno (1999), "Shiro- The White” (Blanco/ The White)" de Katsuyuki Hirano (1999), "Home” (Hogar) de Takahiro Kobayashi $(2002) .^{18}$

Todos estos documentales fueron proyectados en el cine comercial. Las condiciones de la proyección del documental cambió a partir de los años noventa y se generalizó, cada vez

\footnotetext{
${ }^{16}$ Ibíd., p. 24. [Traducción propia del texto original en japonés]

${ }^{17}$ El título original en inglés: Bakit Dilaw Aug Gitana Ng Bahag-Hari? I am Furious Yellow '94; Why is Yellow Middle of Rainbow?

${ }^{18}$ Loc.cit. [Traducción propia del texto original en japonés]
} 
más, su presentación en salas de cines comerciales. Hasta los años ochenta rara vez se encontraba la proyección de un documental en una sala comercial. Llama la atención el éxito de las presentaciones públicas de los documentales basados en lo privado y lo personal, producidos de manera independiente.

Este fenómeno nos hace pesar en la distancia del tiempo y compararlo de nuevo con los documentales y las proyecciones independientes de los años setenta. En aquel momento, la proyección en sí, tenía un valor de resistencia ante el capitalismo excesivo en el cine: era un medio contra el capitalismo y el consumismo de la industria cinematográfica.

Según el análisis de Makoto Sato, cambia completamente el estado de la producción documental a partir de la segunda mitad de los años noventa. Hasta Tsuma wa filipina (Mi mujer es filipina) y Bokuha ikareru kiiro94- nijino album (Soy el amarillo furioso 94/ El álbum del arcoiris) de 1994, todas las obras se producían en película de 16mm. Por ejemplo, Kazokushashin (La fotografía familiar) de 1989 se produjo bajo la teoría convencional de la película documental, junto con un presupuesto minucioso realizado por Tezuka, quien estudiaba en el colegio de cine de Inglaterra. Esta es una obra que presenta lo ocurrido durante su fugaz viaje a Japón con su mujer inglesa.

En cambio, Ni tsutsumarete (En cubierta), producida por Naomi Kawase en 1993 y realizada con película de $8 \mathrm{~mm}$, se convirtió al formato de $16 \mathrm{~mm}$ tras un gran éxito para ser presentada en el cine. "Bokuha ikareru kiiro94- Nijino album (Soy el amarillo furioso 94/ El álbum del arcoiris)”, de Kidlat Tahimik, es una recopilación del álbum familiar que fue rodada durante veinte años en película de 16mm. "Tsuma wa filipina (Mi mujer es filipina)", de Yasunori Terada, fue planteada y producida como película de $16 \mathrm{~mm}$. Sin embargo, a partir de 1995 se encuentran más obras realizadas por medio del vídeo digital que con película tradicional.

Las dimensiones de la cámara de video digital se han reducido más que las de la cámara de vídeo de $8 \mathrm{~mm}$. La Handy-Cam dominó rápidamente el mercado en la década de los años noventa. A pesar de su tamaño, mejora la calidad de la imagen. Graba la imagen y el audio 
en cinta de mini DV. Como soporte de grabación audiovisual, se redujeron sus dimensiones al igual que la cámara. Esta cámara y las económicas cintas, se han divulgado internacionalmente y no existe comparación posible con la cámara y la película de $16 \mathrm{~mm}$ desde el punto de vista presupuestario. Esta ventaja de bajo presupuesto de la Handy-Cam y el mini DV, ha posibilitado a los jóvenes autores sus diversas expresiones. Lo más importante es que esta superación técnica del dispositivo y del soporte, propicia el rodaje durante largo tiempo. Enseguida analizaremos dos obras que surgieron en la segunda mitad de los años noventa, las cuales introdujeron la Handy-Cam como dispositivo indispensable para su expresión.

\title{
V.3.3.1. El Private Documentary con el tema familiar y la Digital Handy-Cam.
}

Makoto Sato comenta los dos trabajos documentales surgidos en la segunda mitad de los años noventa, basándose en la situación de la digitalización de la cámara y del soporte:

\begin{abstract}
Especialmente, "Fatherless" y "Home" no se hubieran podido realizar sin el vídeo digital, ya que el movimiento de la cámara en mano del realizador representa al problema familiar y de la tierra natal que permanecen como un trauma. Aunque se trate del mundo privado y personal, surgiría una reacción diferente por parte de la familia, que acepta la presencia de la "digital handy cam” frente a una cámara de $16 \mathrm{~mm}^{19}$
\end{abstract}

Fatherless $^{20}$ es un documental que se produjo con el equipo de compañeros de clase de la Escuela de $\operatorname{cine}^{21}$, siendo el personaje principal Masaya Muraishi, realizador y uno de los alumnos de la misma escuela. Al inicio de la película se muestra el carácter y la vida cotidiana destrozada de Muraishi: no va a la escuela ni al trabajo, esporádicamente

\footnotetext{
${ }^{19}$ Ibíd., p. 26. [Traducción propia del texto original en japonés]

${ }^{20}$ La versión para graduación de la escuela fue producido en 1997, color, video, 53 mis. La versión para presentación general, 1999, color, VTR, 78min. El director es Yoshita Shigeno es compañero de la protagonista principal, Masaya Muraishi, en la clase de la escuela de cine. El proyecto fue presentada por Muraishi, junto con Shigeno y su equipo de los compañeros de misma clase realizaron este documental.

${ }^{21}$ Nihon Eiga Gakkou (Japan Academy of moving images) que ha fundido por Shouhei Imamura desde el $1975 \mathrm{y}$ se establece una Universidad: Nihon Eiga Daigaku, a partir del 2011.
} 
mantiene relaciones sexuales con hombres desconocidos y se lastima a sí mismo una y otra vez. Se fundamentan las causas de esta actitud en sus relaciones familiares desde la niñez. Muraishi regresa a su pueblo y manifiesta ese resentimiento acumulado durante su niñez y su adolescencia contra sus padres, y la cámara registra lo que allí ocurre.

El padre abandonó a Muraishi y a su madre (que era noctámbula), y el padrastro aumenta la separación entre hijo y madre. Muraishi tiembla de miedo por el desplome familiar, pero se atreve a observar fijamente la parte oscura de sí mismo y de su familia. Al contar con un equipo de rodaje con los compañeros de la escuela, utiliza unas cuantas Handy-Cam; pero para la parte del diálogo con la madre y el padrastro, el mismo Muraishi opera una sola cámara. El objeto filmado es consciente de la cámara, y unas veces le trata con cariño y otras se pone furioso durante la conversación a solas con el hijo o el hijastro. En el documental se logran registrar unas escenas muy íntimas y personales con la cámara pequeña.
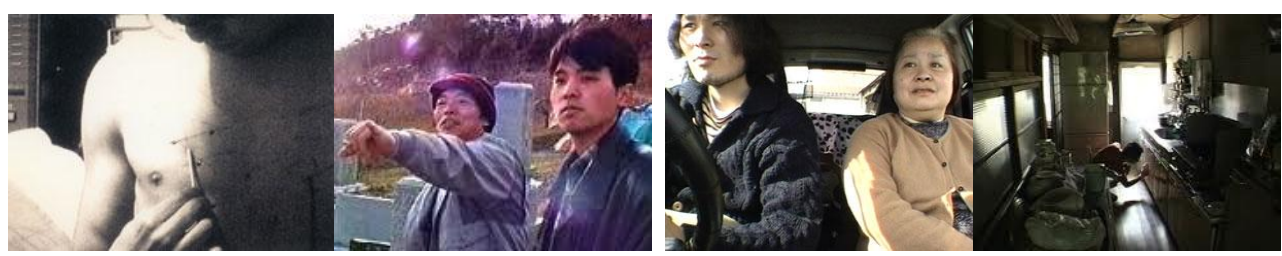

35. Fatherless (1999), Yoshiya Shigeno y Masaya Muraishi, 36. Home (2001) Takahiro Kobayashi

Por otra parte, Home es un documental, color, video, 64min de duración, producido por Takahiro Kobayashi en la que él mismo capta la esencia "del hogar" en ruinas. Kobayashi, al igual que Muraishi, es un estudiante de la Escuela de cine. El protagonista principal de la obra es su hermano mayor que se queda encerrado en casa durante siete años. Kobayashi filma a los personajes: el hermano mayor que rechaza violentamente al hermano menor que regresa con la cámara, la madre que pide ayuda llorando, él mismo que se conmueve y no puede enfrentarse ni al hermano ni a la madre, y el padre que vive lejos de la casa y no se mueve ni hace nada aunque le pidan ayuda. 
En un momento dado, el realizador deja la cámara a su hermano que es el personaje principal. A partir de entonces, el hermano mayor -que solo podía actuar violentamente frente a la familia- empieza a confesar ante la cámara. Podríamos decir que la Handy-Cam del vídeo digital funciona como medio de comunicación para enfrentarse a uno mismo. A través del vídeo, el hermano mayor, hasta entonces enclaustrado en su mundo, encuentra la herramienta para expresar sus sentimientos y posteriormente empieza a intentar comunicarse con el mundo exterior. La obra documenta todo este proceso.

En estas dos obras se encuentran algunas coincidencias en cuanto al tema y al contenido de la trama, y también en cuanto a la metodología y la técnica del rodaje. En lo que se refiere al contenido, ambos realizadores son estudiantes de la Escuela del cine que tienen la necesidad de filmar una obra para graduarse. Ambos eligen el tema de la familia, en el que se suponen con un mayor dominio. En realidad, durante el rodaje también ambos realizadores descubren lo que no sabían sobre su familia.

Los jóvenes protagonistas, como hijos de familia, sienten cierta angustia y eso se revela gracias a la presencia de la cámara: la cámara registra el sufrimiento de estos jóvenes, el ahogo de la madre y la ausencia del padre. En comparación con la postura de los documentalistas de los años sesenta, quienes tramaban una rebelión contra la generación de sus padres reclamando responsabilidades por su participación en la guerra, estos jóvenes cineastas guardan ciertas frustraciones porque no tienen a quien atacar y porque el padre está ausente, tanto a nivel práctico como simbólico.

Otra coincidencia técnica en estos dos documentales es el importante papel que cumple la cámara y la postura de los jóvenes en el tratamiento de la misma. Los dos autores intentan afrontar su inquietud y la parte negativa de sí mismos, filmando la realidad de la familia para poder transitar por la vida cotidiana con mayor tranquilidad. Ellos intentan comunicarse a través de sus propias familias. Gracias a esta pequeña máquina que puede pasar inadvertida, posible de manejar por todo aquel con conocimientos básicos, se puede repetir inmediatamente una y otra vez lo que ya ha sido captado. Mediante el uso de esta cámara se busca la manera de comunicarse consigo mismos y con la familia. 
Aquí se encuentra una práctica del rodaje que traspasa las dos técnicas de rodaje opuestas: la del Action Documentary (de la cual Kazuo Hara es representativo), que provoca a un objeto que no puede evitar actuar frente a la cámara, y la del Observation Documentary que intenta documentar reduciendo la presencia de la cámara.

Como contexto, se halla una realidad familiar donde solo existe una comunicación superficial que tiene como fin mantener esta pequeña comunidad social. Padre, madre e hijo: cada individuo se queda encerrado en su posición y se interrumpe esa relación íntima. En esta situación, el realizador coloca una cámara como medio de comunicación. Observa fijamente la realidad familiar y lo que ocurre durante su intento de comunicación. La cámara funciona como eje de la comunicación, y el autor registra con cierta provocación, como en el Action Documentary. Sin embargo, capta las escenas de la familia cotidiana a la manera del Observation Documentary, aprovechando las ventajas principales de la HandyCam, como su reducido tamaño y el largo tiempo de grabación.

\section{V.3.3.2. Self Documentary con temas sociales.}

En otro de sus ensayos, Makoto Sato se refiere a dos documentales independientes japoneses de los años noventa que deben ser observados: $A(A)$, producida por Tatsuya Mori $^{22}$ en 1999, y Atarashii Kamisama (El nuevo Dios), producida por Yutaka Tsuchiya en 1999. Los dos trabajos representan problemas sociales como tema principal. $A$ investiga a la secta religiosa “Aum Shinrikyo". Atarashi kamisama (El nuevo Dios), estudia el régimen imperial japonés y la agrupación de derechas.

A partir de entonces, surge una duda: ya que abordan una temática social, ¿podemos categorizar a estos dos documentales como Self Documentary? En la obra de Tsuchiya se representa lo privado que ha sido captado por la cámara. En la obra de Mori aparece el problema del sujeto que surge cuando el realizador opera la cámara. A través del concepto

\footnotetext{
${ }^{22}$ Tatsuya Mori (1956- ), fue director independiente de programas televisivos y presenta la película documental: $A$ (1998) y A2 (2001). Tiene varias publicaciones sobre los medios de comunicación, documental y otros asuntos sociales, http://moriweb.web.fc2.com/mori_t/index.html, accedido el 30 de marzo del 2009.
} 
del sujeto, Mori justifica por qué su trabajo es Self Documentary, desarrollaremos este aspecto más adelante. Consideramos, en conclusión, que ambos se constituyen como Self Documentary porque representan la subjetividad de los autores. Veamos las razones de Makoto Sato que ayudaron a desarrollar su teoría a Tatsuya Mori.

Atarashii Kamisama (El nuevo Dios) es un documental donde se persigue a Karin Amemiya, vocalista de un grupo de punk-rock de extrema derecha que en su actuación grita cientos de veces "viva el emperador". La escena es filmada por el realizador Tsuchiya, izquierdista, que tiene un pensamiento opuesto al régimen imperialista.

Yutaka Tsuchiya empieza a producir obras audiovisuales en 1990, y a partir de 1998 organiza el proyecto de Video $A c t^{23}$ para la distribución regular de los vídeos independientes. El concepto del proyecto está basado en el activismo que pretende cambiar el mundo y utiliza el vídeo para acercarse a los problemas sociales y conseguir una libre distribución. La difusión y el desarrollo del video digital y de Internet evidentemente han posibilitado que el pueblo recupere la expresión y la información bajo el dominio del poder estatal y la industria comercial.

Los medios de comunicación que se supone aseguran el derecho a la libre expresión en los países democráticos, en realidad se encuentran controlados de manera invisible por el poder político-económico. De esta manera, el movimiento del video-activismo y su evolución mundial es muy importante para la difusión de las noticias. A pesar de estar de acuerdo con la importancia del video-activismo, Makoto Sato es escéptico frente a las producciones documentales de los grupos de video-activistas. En su comentario, critica la tendencia demasiado dogmática de sus obras, causada por el intento de aumentar la pureza del mensaje:

\footnotetext{
${ }^{23}$ Video Act: proyecto dirigido por Yutaka Tsuchiya que pretende ofrecer una plataforma de distribución libre para los vídeos. A través de la plataforma se publica y distribuye un catálogo de video independiente con temas sociales como la guerra, la globalización, el trabajo, la pobreza, la ecología, etc. Al mismo tiempo, se organizan los eventos para presentar los vídeos. El motivo principal para el establecimiento de este proyecto es estudiar la situación de los autores del audiovisual independiente en Nueva York. En 1998 se distribuye gratis del primer catálogo de los vídeos. Desde el año 2004 se empiezan a distribuir audiovisuales activistas en AcTV: http://www.videoact.jp/actv, accedido el 31 de marzo del 2009. http://www.youtube.com/group/VIDEOACT?gl=JP\&hl=ja, visualizado el 31 de marzo del 2009. La Web principal es: http://www.videoact.jp/, accedida el 31 de marzo de 2009.
} 
Es decir, hay demasiados trabajos que exponen desde el principio el tema, se puede saber qué quieren decir aún antes de mirarlos. Como obra audiovisual para la discusión, debate o reunión política, es un medio eficaz sin duda; sin embargo, si es así, sería igual a la propaganda de izquierda democrática de la posguerra. ${ }^{24}$

Para Makoto Sato, el documental de posguerra japonés debe al menos mantener la política del autor, es decir, se debe representar una postura crítica sobre la responsabilidad de los autores. La película de propaganda que solo aplaude a los objetos -sean del imperialismo o sean de la democracia- están lejos del concepto de documental que tiene Makoto Sato. Él explica sus prejuicios frente a los trabajos del video-activismo y se cuestiona si se constituirían como un tipo de propaganda. No obstante, Sato aprecia el trabajo de Tsuchiya después de ver Atarashii Kamisama (El nuevo Dios), donde se comprueba el antagonismo ideológico mediante el video-activismo. Sobre todo, menciona el papel importante de la cámara digital en su documental.

El punto que mayor admiración me causa es la clara estrategia de introducción de lo privado y lo íntimo, como cualidades al utilizar la cámara digital en su trabajo. ${ }^{25}$

La obra representa la relación y los sentimientos entre Tsuchiya y Amemiya, los cuales gradualmente sienten una atracción mutua a pesar de tener ideas opuestas. Al principio, la comunicación es torpe dada la diferencia ideológica entre las dos personas.

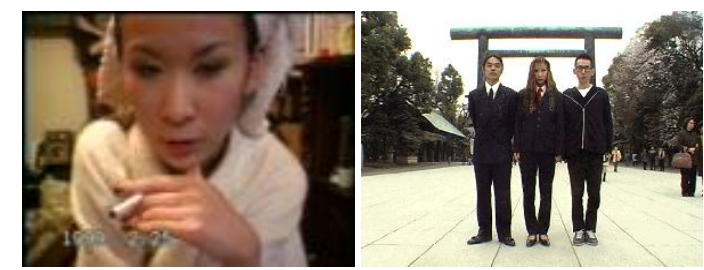

37. Atarashi Kamisama (El nuevo Dios, 1999), Yutaka Tsuchiya

\footnotetext{
${ }^{24}$ Ibíd., p. 32. [Traducción propia del texto original en japonés]

${ }^{25}$ Ibíd., pp. 32-33. [Traducción propia del texto original en japonés]
} 
El realizador Tsuchiya le da una cámara digital a la protagonista principal Amemiya y ella filma sus actividades y sentimientos. Posteriormente, flaquea y empieza a confesar poco a poco frente a la cámara. Luego, el grupo de punk-rock en el que participa Amemiya no solo va a las reuniones derechistas, sino que también viajan a Corea del Norte, el último país comunista que no tiene relación diplomática con Japón para, según ella, “indagar al enemigo". Estos vídeos filmados por Amemiya presentan un acto humorístico donde un exrepresentante del Nihon Sekigun (Ejército Rojo Japonés) ${ }^{26}$, exiliado en Corea del Norte, cosecha boniato en la montaña. También se registran las actuaciones espontáneas de los activistas derechistas japoneses. Makoto Sato comenta sobre el vídeo rodado por Amemiya y el uso estratégico de Tsuchiya al introducir esta escena.

\begin{abstract}
Amemiya, mientras filma el video digital, no tiene ninguna mala intención. Más aún, ella habría rodado de manera positiva y respetuosa. Pero por la astucia de Tsuchiya que introduce el vídeo privado de Amemiya en su obra se posibilita una lectura crítica. Cada vez más, Amemiya y el grupo de punk-rock hablan exageradamente sobre los asuntos políticos. Así, lo privado y lo íntimo de ellos es captado por el vídeo digital describiendo la inquietud y soledad de su existencia. Me ha parecido que aquí se presenta una nueva perspectiva de captación de la privacidad. $^{27}$
\end{abstract}

Podemos interpretar que en este caso, el vídeo digital ha captado una parte de la inconsciencia de los jóvenes que recurren al "pensamiento" o a la ideología radical para desviar sus inquietudes y su razón de ser, y poder así evadirse. La estrategia de Tsuchiya al utilizar el vídeo privado de Amemiya, presenta una nueva perspectiva de lo privado y la intimidad de una joven.

El caso contrario lo vemos en A, producida por Tatsuya Mori en 1999, donde se filma como personaje principal a un joven encargado de la información pública de Aum Shinrikyo, una secta que en 1995 perpetró un ataque con gas químico de Sarín en el metro de Tokio con

\footnotetext{
${ }^{26}$ Nueve jóvenes japoneses miembros de este grupo realizaron un secuestro de un Yodogo (vuelo de Japan Airlines) el 31 de marzo del 1970 y después se exiliaron en Corea del Norte.

${ }^{27}$ Ibíd., p. 34.[Traducción propia del texto original en japonés]
} 
más de cinco mil víctimas. Al principio, esta obra se empezó a rodar como un documental televisivo. Posteriormente, a causa de que le confiscaron el equipo, Mori siguió filmando con la cámara digital, y la presentó públicamente como un documental.

Es тиу probable que los jóvenes japoneses sean atraídos por nuevas sectas religiosas como "Aum Shinrikyo”, por inquietudes existenciales y porque no acaban de encontrar sus propios fundamentos. "A” de Tatsuya Mori, presentada en 1998, es un documental que describe la presión invisible que comprime fuertemente a la sociedad japonesa, lenta pero constantemente, criticando con rigor a los medios de comunicación, en su mayor parte, a través de un joven encargado de la sección de información pública de "Aum Shinrikyo". ${ }^{28}$

Tatsuya Mori produce varios documentales como programas de televisión. Sin duda, conoce muy bien los entresijos de la producción televisiva. Con esta base, Tatsuya Mori ofrece una mirada crítica y aguda de los medios de comunicación masivos como la televisión, la cual se ha vuelto un gran medio con cierto poder que concede preferencias a los grandes capitales y al mercado consumista.

Por otro lado, se nos plantea la cuestión: ¿por qué numerosos jóvenes que han crecido con una educación que valora la personalidad y la individualidad en la sociedad actual, con el desarrollo económico y la vida consumista comienzan a participar en la vida colectiva de una secta religiosa fundamentalista? El tema de este documental es básicamente social.

Técnicamente, Tatsuya Mori no se había planteado filmar con la Handy-Cam, ni había pensado en aprovechar las posibilidades de esa cámara pequeña. Ello es un resultado no planificado a raíz de la privación del equipo de rodaje televisivo. Él presentó el documental como resultado de la eliminación de otras opciones por el fuerte rechazo que tuvo por parte de la televisión, ya que ninguno de los canales televisivos aceptó su trabajo.

\footnotetext{
${ }^{28}$ Ibíd., p. 13. [Traducción propia del texto original en japonés]
} 
En aquel momento, justo después de que ocurriera el ataque en el metro por Aum Shinrikyo, inundaron las noticias y reportajes sobre el asunto, pero tenían la misma tendencia a emitir la información estereotipada de la secta. Mori empezó a realizar entrevistas directas a los jóvenes, entrando al lugar de su comuna, y sus informaciones no coincidían con las imágenes estereotipadas reproducidas por los medios de comunicación. Los directivos televisivos juzgaron como peligroso al vídeo de Mori y le presionaron para la suspensión del rodaje.

En el medio televisivo comercializado existe un discurso de que "el documental debe ser objetivo" y que "no se debe introducir el sentimiento en el documental", según los conceptos de neutralidad e imparcialidad. Mori lo aceptaba: igual que los demás, producía sus documentales en trabajos completamente divididos según cada especialista y cada proceso con cierta evidencia.

Sin embargo, después de que se fuera el equipo de rodaje y él empezase a filmar con la Handy-Cam sin expectativas de presentar el documental al medio que se lo ha encargado, surgen preguntas inevitables: ¿por qué se filma? ¿Quién soy yo, el que está rodando? ¿Qué relación tengo con el objeto del rodaje? ¿Cómo actuaría yo como el sujeto de rodaje frente al objeto? Son cuestiones fundamentales sobre la relación del sujeto y el objeto en el documental. Mori comenta la experiencia en el momento de coger la cámara digital en el proceso del rodaje de $A$ en una entrevista:

En el proceso del rodaje de “A” por haberme quitado mi ENG (equipo de rodaje), no había otro modo de rodar sino siendo yo mismo. Ahí, por primera vez, me he dado cuenta de que "la imagen es sujeto" (...). He notado que el sujeto de la imagen soy yo mismo operando el encuadre, manejando el pan y el zoom. Quizá he empezado a observar que "la objetividad, la neutralidad y la imparcialidad no son otra cosa más que una ilusión,"29

\footnotetext{
${ }^{29}$ Mori, Tatsuya, El horizonte del documental: texto fúnebre para Sato Makoto, en VV.AA. Gendaishiso. Revue de la pensée d'aujourd hui (El pensamiento contemporáneo, revista del pensamiento de hoy en día), Documentary, Op.cit., p. 34. [Traducción propia del texto original en japonés]
} 
Como una ley no escrita en la producción del documental televisivo, la misión de los medios masivos es informar sobre los problemas y asuntos sociales captando la realidad con objetividad, neutralidad e imparcialidad. Los productores del audiovisual televisivo deben cumplir esta meta. Mori lo cumplía sin ninguna reflexión; sin embargo, por el hecho de trabajar sin equipo y sin personal técnico, cambió su modo de pensar sobre el sujeto y la subjetividad de la presentación audiovisual y esto se convirtió en el nuevo sostén de su trabajo.

Mori plantea la categorización del Self Documentary por la aparición del sujeto en la obra en $A$ y en su continuación $A 2$ :

\begin{abstract}
El documental "A" y "A2" también son "Self Documentary". ¿Si se filma a su propia familia es "Self Documentary"? No, no es así. Pero si se filma siendo consciente del yo como sujeto, si sería "Self Documentary" [aunque se traten temas sociales ${ }^{30}$
\end{abstract}

La justificación del Self Documentary es para Mori la presencia del yo como sujeto de rodaje en la obra audiovisual. Aunque se aborden temas sociales, si se percibe la existencia del yo como sujeto en la obra, se convierte en Self Documentary. En el caso de su documental, describe el pensamiento, el acto, la duda y el conflicto de Mori como sujeto de rodaje al enfrentarse a los jóvenes de Aum Shimrikyo como objetos.

Por el contrario, aunque se traten asuntos familiares, si el sujeto que narra el asunto no queda establecido en la obra, no sería Self Documentary. Cuando se filma a su propia familia, es difícil no hablar de sí mismo; como consecuencia, fácilmente se convierte en Self Documentary de manera natural.

Mori amplia la interpretación sobre Self Documentary para los trabajos de Shinsuke Ogawa o de Noriaki Tsuchimoto (que hemos visto en los apartados anteriores). Según él, son películas rodadas por estos autores al estilo de Self Documentary. Es decir, en sus trabajos

\footnotetext{
${ }^{30}$ Loc.cit. [Traducción propia del texto original en japonés]
} 
se encuentra el establecimiento del yo como el sujeto de rodaje y se describe la relación entre los objetos. En este caso, también se indica la importancia de la relación íntima entre el realizador y el operador de la cámara.

Antes, estaba el operador de la cámara que se encargaba de la imagen. Por eso era muy importante la relación entre el operador y el realizador. En los casos del Sr. Shinsuke Ogawa y del Sr. Noriaki Tsuchimoto, también era así. Un ejemplo excepcional es del Sr. Kazuo Hara. El documental del Sr. Hara evidentemente pertenece al Self Documentary. Dentro de este género de "Self Documentary", en ocasiones hay unos que filman a su alrededor. Hay otros que han filmado cómo se enfrentan a una secta religiosa que planeó una matanza, y también hay otro que siguió filmando al señor Kenzo Okuzaki que es un ser extraño, agresivo y ofensivo siendo estrujado por él. ${ }^{31}$

Lo que Mori quiere decir es que si en la obra se nota la presencia del sujeto que rueda y se muestra la relación entre el sujeto y el objeto, se puede calificar como Self Documentary. Por lo menos, en los trabajos de Sinsuke Ogawa y Noriaki Tsuchimoto se encuentra el establecimiento del sujeto y se refleja el pensamiento y el conflicto del autor al enfrentarse a los problemas de los objetos. En este caso, el término que utiliza Mori, Self Documentary, podemos aplicarlo al documental privado e íntimo, como hemos visto anteriormente, porque se encuentra en el punto de partida del sujeto en los documentales que hemos considerado y que vamos a analizar.

La política del autor, que tanto importaba a Makoto Sato, puede coincidir con el planteamiento de Mori. Teóricamente, hoy en día se empieza a universalizar la posibilidad de ser distribuidor de imágenes audiovisuales: puede hacerlo quien quiera en el mundo, simplemente con una cámara pequeña y potente. Ante esta situación, en el documental de lo privado y lo personal cada vez importa más el criterio sobre la manera en que se establece el yo como sujeto en la obra audiovisual.

\footnotetext{
${ }^{31}$ Loc.cit. [Traducción propia del texto original en japonés]
} 
V.3.3.3 La auto-búsqueda en el Private Documentary.

Para finalizar el presente apartado, nos hemos aproximado a diversos trabajos de Private Documentary y Self-documentary de los años noventa, contextualizando bien el cambio que hubo en los años ochenta con los trabajos emblemáticos de la transición del tema y el soporte, queremos adjuntar una comparación de documentales de los jóvenes documentalistas. Primero nos aproximaremos a Osaka Story, de Toichi Nakata, un documental que cuestiona la identidad de su familia de inmigrantes coreanos.

La migración japonesa moderna tiene ciertas contradicciones. Como hemos mencionado, tras la ocupación japonesa de la península coreana y la anexión del país, muchos coreanos emigran a Japón con la nacionalidad japonesa. Tras la derrota de la Segunda Guerra Mundial, Corea se independiza y el gobierno japonés anula la nacionalidad a los coreanos que permanecen en Japón, incluso a los hijos de estos coreanos nacidos en Japón. Hoy en día, algunas personas dentro de la tercera o la cuarta generación de migrantes coreanos ya han logrado adquirir la nacionalidad japonesa.

Sin embargo, es obvia la contradicción que exige a los hijos de los "coreanos" (cuyos padres ya nacieron en Japón) realizar el trámite para obtener la nacionalidad. Es una contradicción basada en el concepto de Ius sanguinis, el cual no solo se encuentra en el derecho legal. En muchas ocasiones, uno puede llegar a cuestionar su propia identidad y surgen así conflictos íntimos. Se aborda continuamente el tema de la problemática social y personal de los coreanos japoneses en el documental japonés, como hemos comprobado en la excelente obra de Naguisa Oshima o en el Private Documentary de Tetsuaki Matsue. Dentro de esta serie de documentales, es notable que desde los años ochenta empiezan a aparecer de forma muy activa trabajos auto-reflexivos realizados por estos "nietos de los inmigrantes coreanos”, como hemos señalado en la obra de Yukiko Eguchi anteriormente.

Según la argumentación de Tatsuya Mori, hemos descubierto que los Self Documentaries, en amplios términos, no solo tratan de temas familiares y relaciones privadas, sino que se refiere también a los trabajos donde la relación entre sujeto y objeto queda patente a través 
de la presencia de la cámara y del montaje. Lo importante, tanto en los Private Documentaries como en los Self Documentaries, es presentar al sujeto y su manera de construir la relación entre el acontecimiento y las personas objeto. En otras palabras, el sujeto relata el asunto como primera persona en la obra. Es decir, el documental privado es una representación en el mundo audiovisual construido por un sujeto, y al mismo tiempo, a través de la creación de su mundo documental privado se reconstruye al sujeto.

El papel que cumplen los dispositivos fue muy importante para el desarrollo de los documentales privados de los años noventa. Sobre todo, el desarrollo de la técnica de la cámara digital pequeña que puede filmar por largo tiempo. Ello posibilitó un nuevo y mayor acceso al mundo documental. Como resultado, la línea imaginaria que dividía sujeto y objeto, y su relación parcial en el documental, empiezan a ponerse en tela de juicio. Este aspecto nos obliga a reconsiderar el campo documental, incluso nos lleva a reconsiderar la relación entre documental y ficción. Es decir, debido a la aparición de los Private Documentaries ya no funciona el sencillo esquema donde la ficción es subjetiva y el documental es objetivo.

Esta tendencia a centrarse en el mundo privado en el documental, se encuentra no solo en Japón, sino en todo el mundo.

La prosperidad del "Private Documentary" no se da solo en Japón. No se puede negar la tendencia de que el ámbito privado se convierte en el campo principal de batalla para los autores asiáticos y para los documentalistas en diversos países occidentales. Esto es consecuencia del fin de la Historia grandiosa como el socialismo y la difusión de la cámara de vídeo digital como contexto técnico. ${ }^{32}$

En esta prosperidad mundial del Private Documentary es notable la tendencia de introspección en las obras de autores japoneses. Es decir, su interés por el tema, la mirada hacia su interior y la expresión, tienen una forma de círculo cerrado. Según la opinión de

\footnotetext{
${ }^{32}$ Sato, Makoto, Op.cit., p. 49. [Traducción propia del texto original en japonés]
} 
Makoto Sato, esta tendencia de los jóvenes autores japoneses contrasta con la de la misma generación de los autores de Asia.

Todas estas obras ${ }^{33}$ se enfocan en sus padres, su familia, su mujer, su amigo y su etnia; se orientan a superar la temática del cine político corriente, relatando en primera persona pase lo que pase. Evidentemente, ofrecen una fresca simpatía al despiezar el estereotipo de la figura de joven o de coreano residente en Japón. Sin embargo, contienen una parte frágil que se queda en una opinión personal poco esmerada en el producto final. Comparándolas con las obras de "auto-búsqueda" de artistas jóvenes del audiovisual de China y Taiwán que se enfrentan al problema del Estado o del sistema de reclutamiento, se nota un contraste en la fragilidad y la debilidad de los jóvenes japoneses que no alcanzan a descubrir al adversario contra el que deben luchar. ${ }^{34}$

Como vimos, durante la década de los ochenta las oportunidades de proyección documental no televisiva se encuentran en declive, pero la anterior anotación se refiere a los documentales de jóvenes japoneses que sí llamaron la atención durante los noventa en Japón. La opinión de Makoto Sato es negativa, se lamenta del carácter débil y frágil del Private Documentary japonés. Descubrimos su deseo fundamental de que el documental se convierta en un arma para el cambio social. Este concepto es una tradición que proviene del documentalismo inglés desde sus primeras etapas.

El documental debería iluminar la parte negativa y oscura de la sociedad, dejando al descubierto la injusticia y las contradicciones. Está al encargo de ofrecer acusaciones para que sirvan en el combate, y así poder cambiar el mundo. En torno a esta conceptualización del documental, el contenido debería ser sólido con el fin de servir como arma. Esta idea es un estigma de la generación de Makoto Sato, estudiante a finales de los años sesenta y a

\footnotetext{
${ }^{33}$ Las obras indicadas son las siguientes: Ni tsutsumarete (En cubierta), realizada en 1993 por Naomi Kawase, Tsumaha filipina (Mi mujer es filipina), de 1994 por Yasunori Terada, Osaka story (Historia de Osaka/ 1996), de Toichi Tanaka, Anñyon Kimuchi, (Fatherless-Sin padre/ 1999) de Testuaki Matsue, Masaya Muraishi de Ryouya Nomo en 1999, Atarashii kamisama (El nuevo Dios), realizada por Yutaka Tsuchiya en 1999.

${ }^{34}$ Ibíd., p. 13. [Traducción propia del texto original en japonés]
} 
principio de los años setenta, conocedor del movimiento estudiantil bajo la fuerte influencia de los documentales independientes de Shinsuke Ogawa y Noriaki Tsuchimoto.

Nosotros respetamos y coincidimos en la mayor parte con su opinión. Sin embargo, objetamos con las ideas de Makoto Sato sobre los Private Documentary en lo que se refiere a la consideración de la identidad personal en relación con la etnia, la sociedad y el Estado. De hecho, para reflexionar sobre la identidad personal y familiar en nuestra sociedad posmoderna se enfatiza la importancia del problema de las identidades híbridas en contextos multiculturales y transnacionales; creemos que esta reflexión ya se convierte en un planteamiento social.

Por ejemplo, Osaka Story de Toichi Nakata ${ }^{35}$ describe la mezcla y la ruptura de la identidad étnica, religiosa, cultural y de género en su propia familia. El padre de este joven realizador es un coreano afincado en Japón y la madre es japonesa. La pareja mantiene una vida matrimonial en común, pero no está registrada legalmente, así que Nakata es el apellido materno.

Osaka Story es el documental de un viaje de Nakata, quien estudió en National Film \& Televisión School de Beaconsfield en Reino Unido y regresó a Japón después de tres años de ausencia. El padre había logrado crear una sociedad financiera y conseguir cierta fortuna gracias a un negocio, pero él siente una gran antipatía hacia el primer hijo que regresa con un pequeño equipo de rodaje.

La madre crió a siete hijos, ayudando a la vez a su pareja en este negocio de salón de juego con máquinas Pachinko ${ }^{36}$. Ella obligaba a Toichi a casarse pronto y a dedicarse al negocio

\footnotetext{
${ }^{35}$ Toichi Nakata: de padre coreano y madre japonesa, Toichi nació en Osaka (Japón). Estudió en la National Film \& Television School de Beacondfield, en el Reino Unido, donde realizó su primera película, "Munoru \& Me”. En 1994 irrumpió en la escena documental japonesa con "Osaka Story”, una película que describía el regreso de Toichi Nakata a Osaka en un interno de recomponer el legado japonés-coreano de su familia. Fue celebrado como uno de los mejores ejemplos del documental japonés privado de la década. [Traducción propia del texto original en japonés], en Muguilo, Carlos (et. ál.): El cine de los mil años: una aproximación histórica y estética al cine documental japonés (1945-2005), Op.cit., p. 131.

${ }^{36}$ Pachinko: máquina de juego con fichas. Es un juego de azar. Habitualmente, se trata de negocios dirigidos por coreanos afincados en Japón.
} 
familiar siguiendo los pasos del padre. Pero ya su hermana mayor se convirtió en médica y se casó con un japonés, alejándose de la familia; es decir, se independizó prácticamente perdiendo los vínculos familiares.

Las demás personas que trabajan en el negocio familiar están muy unidas. Un hermano menor que se volvió creyente de la "Iglesia de la Unificación" (grupo religioso fundado por un coreano cristiano) se casó con otra creyente siguiendo las indicaciones de esta secta. El padre es el jefe dictador de la familia y del negocio. Con todo esto, el sudor, el sufrimiento y las preocupaciones de la madre nunca se terminan.

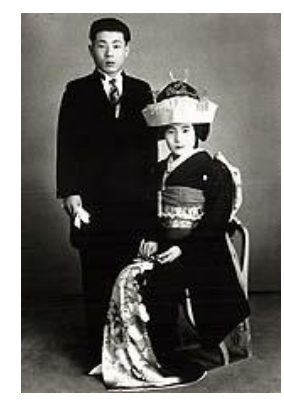

38. Osaka Story (1994), Toichi Nakata

Por otra parte, Toichi es consciente de su identidad homosexual. Busca la oportunidad de confesarlo y pretende declarar su negativa a continuar con el negocio del padre para poder dedicarse al cine durante su estancia en Japón.

En la última parte de la película, Toichi viaja a Corea con su padre. Allí se descubre que el padre tiene otro matrimonio efectuado con boda solemne y aceptada por los parientes en Corea. Éste es un secreto dentro de la familia japonesa, en la cual el problema se convierte en un tabú y nadie comenta nada. La madre de Toichi espera ser enterrada junto con el marido en la misma tumba en Japón, a pesar de sus sentimientos contradictorios. Aún a sabiendas de ello, el padre visita Corea cada vez con mayor frecuencia. Finaliza la película con una voz en off que confiesa que tuvo lugar una fuerte disputa entre el padre y el hijo sobre este asunto. 
Esta película fue filmada en formato de $16 \mathrm{~mm}$. por Simon Atkins, quien en la actualidad trabaja como productor y operador de cámara del documental. Toichi Nakata aparece pocas veces en la imagen con los protagonistas. El estilo de encuadre y filme es del Observation Documentary: se captan escenas de la vida cotidiana de la familia tanto en la casa como en el negocio. Al mismo tiempo, contiene la narración propia de este tipo de documental, con la voz en off de Nakata que explica el contexto o los propios sentimientos.

Las personas que aparecen en la imagen, por sus gestos, denotan la tensión y los nervios frente a la cámara. Se encuentran pocas escenas crudas, en comparación con otros trabajos como Fatheless o Home filmados con la cámara digital pequeña. Por ejemplo, no se muestra la imagen de la escena en la que el autor confiesa su homosexualidad a la madre, ni la disputa con el padre. Tan solo se adjunta su narración.

En esta obra se describe una situación confusa de la que cada uno de los miembros de la familia tiene múltiples identidades enredadas desde un punto de vista étnico, religioso, sexual y transnacional. A pesar de tratar un asunto grave, el autor mantiene el ritmo del documental con cierta agilidad gracias a la narración. En toda la película se conserva el sentido del humor; con ello, inspira simpatía. Sin embargo, al mismo tiempo, se observa desde un punto de vista crítico a la familia desde el interior. No se insiste en la coherencia ni en la armonía familiar, tampoco se presenta en un sentido patético, ni se manifiesta un trauma por la pérdida de la unidad familiar. Este filme ha recibido halagos afanosos por parte de los intelectuales liberales, sobre todo, de los partidarios del multiculturalismo en Japón. Citaremos como ejemplo el comentario de unos investigadores japoneses desde la corriente de Cultural Studies:

Lo sobresaliente de "Osaka Story" es su descripción de las identidades contradictorias, creadas por una relación confusa entre etnicidad y género. Al describir positivamente la historia -ya que si no fuere así se aumentaría la gravedad y la seriedad de la misma- toda la película está plagada de extraña alegría y humor. Aunque dentro de estas diferencias culturales se encuentra una amarga tensión entre el amor y el odio, la relación particular genera una confianza que transcurre 
a lo largo de todo el filme y se convierte en la característica más peculiar de éste. Entonces, nos damos cuenta de que la identidad compleja que Nakata describe es más rica y atractiva que la identidad homogénea tal como habitualmente se concibe, y que su existencia es consecuencia de la manipulación artificial. ${ }^{37}$

En cambio, también tuvo lugar cierta crítica negativa. Nakata escribe una presentación sobre esta obra para el festival de "One Corea", pero recibió críticas y quejas por parte de los coreanos residentes en Japón por no presentar ni el nombre coreano de su padre, ni el suyo, por no aceptar la etnia coreana como su propia identidad y por carencias en el mensaje étnico.

En estos últimos días he oído varias quejas de los espectadores coreanos afincados en Japón sobre mi película "Osaka Story”: «usted no ha llevado la carga de su etnia», «me desesperé porque usted no utiliza ni el nombre ni el apellido coreano de su padre», «no comprendo para nada lo que quería decir en esta película», etcétera. ${ }^{38}$

Nakata acepta y coincide con estas críticas y opiniones, pero explica su idea personal confirmando la diferencia con ellos. El autor insiste en la negatividad de aferrarse a la etnicidad y a una conciencia racial: al final, de esta manera fácilmente se cae en un exclusivismo que, según Nakata, se convierte en una injusticia social. Por su propia experiencia al residir más de diez años en Estados Unidos e Inglaterra, él siente que arrastrar el contexto cultural étnico japonés, coreano u oriental es solo un estorbo:

Si tuviese que elegir solo un lado, diría claramente que prefiero ser parte de los no nacionalistas, pero esto provocaría múltiples problemas. Al haber tenido la experiencia de vivir durante 10 años en Occidente, quisiera o no al principio me

\footnotetext{
${ }^{37}$ Toshiya Ueno y Yositaka Mori, Cultural Studies nyumon [Introducción a los Estudios Culturales], Tokio, Chikumashoten, 2000, p. 171. [Traducción propia del texto original en japonés]

${ }^{38}$ http://hana.wwonekorea.com/history/hist/12th96/es-nakataTou.html, accedido el 31 de marzo del 2009.

[Traducción propia del texto original en japonés]
} 
costó mucho sentirme responsable y representante de Japón o de Oriente. Ser coreano y japonés no amplía mis posibilidades, solo las ha limitado.

Por desgracia, cuando uno se sitúa como individuo en nuevas tierras, en la mayoría de los casos, entorpece aquello que se arrastra del contexto cultural étnico de la tierra natal. Por mi experiencia digo que los que se aferran a la ilusión nacionalista tienen una fuerte intención intrínseca de segregación del "otro". La historia humana demuestra que muchos conflictos se provocaron por la formación de una nación de comunidad étnica. ${ }^{39}$

Quien en mayor medida se siente sujeto a la conciencia étnica, más excluyente es y más tiende a la marginación. Cuando se reflexiona sobre la Historia, se observa que numerosas discordias y conflictos han sido provocados por la intención de establecer un Estado basado en la comunidad étnica. De este modo, Nakata es muy cuidadoso en su declaración sobre la conciencia étnica y en su afirmación extrema sobre la identidad étnica homogénea convencional. Por otra parte, confiesa que no produjo su documental para lanzar un mensaje personal ni para formular unas emociones calculadas. Como resultado, si los espectadores asistieron al cine esperando recibir un mensaje étnico o un elogio a la comunidad étnica, seguramente se sintieron desesperados con esta obra. A través de esta postura entendemos que su producción y él mismo mantuvieron conscientemente una cierta distancia de la publicidad y de la agitación política.

En otras palabras, la intención de la película no es comunicar ningún mensaje propiamente dicho. Por eso, las impresiones sobre la película son realmente diversas. Estoy seguro de que los que fueron al cine esperando la representación de la etnia-nación quedaron insatisfechos. Sin embargo, a través de la misma realización, esta película me ha revelado el profundo abismo de cuarenta y cinco años entre el concepto de etnia-nación en relación con mi padre como hombre, y con mi madre como mujer. Me hizo concebir la tristeza del sentimiento de etnia-

\footnotetext{
39 http://hana.wwonekorea.com/history/hist/12th96/es-nakataTou.html, accedido el 31 de marzo del 2009. [Traducción propia del texto original en japonés]
} 
nación en las almas de aquellos que, cada vez más, con los años vuelven a Corea y a Japón. ${ }^{40}$

Así pues, en su documental no encontramos un análisis del nacionalismo. Su mirada hacia la unidad familiar y las relaciones familiares se desarrolla con un conocimiento profundo y cierto afecto; al mismo tiempo, no pierde la ocasión de determinar con serenidad la identidad híbrida y compleja de cada miembro en la familia.

Este documental muestra la tristeza y el dolor de aquellos que se sienten atraídos hacia diferentes sentidos: uno hacia Corea (el padre) y otra hacia Japón (la madre), según Nakata sentimientos estos cada vez más agudos a medida que envejecían. Los sentimientos de los propios padres están repartidos entre Corea y Japón. El padre se siente desgarrado entre su vida y su familia japonesa y la de Corea. La madre también siente una gran separación entre un marido que quiere volver a su tierra natal, Corea, y los hijos nacidos en Japón.

En la situación sobre la identidad que vemos aquí, no sería suficiente la expresión del hibridismo o de las identidades múltiples, sino que además es necesario representar que cada uno de ellos es un ser desgarrado por dichas identidades. Sus heridas y cicatrices muestran sus propias identidades de una manera contradictoria.

Si la comparamos con las obras de jóvenes japoneses autores y a la vez protagonistas del documental Fatherless y Home, las cuales albergan una sensación sofocante de angustia y malestar por su situación familiar y como individuos, Osaka Story transmite una sensación casi de libertad y alegría.

¿Por qué en esas dos obras de jóvenes japoneses se respira un aire tan trágico? Ante estas grandes diferencias se nos ocurre la idea de que tanto Fatherless como Home mantienen escondida la premisa principal sobre la propia identidad: representan a unos individuos

\footnotetext{
${ }^{40}$ http://hana.wwonekorea.com/history/hist/12th96/es-nakataTou.html, accedido el 31 de marzo del 2009. [Traducción propia del texto original en japonés]
} 
"perfectos" y una familia feliz reunida, a pesar de describir la inquietud de los jóvenes y el desplome de la familia como temas principales.

En el caso de estos jóvenes japoneses protagonistas, la comparación entre un modelo ideal de sí mismos y de la familia con su propia realidad -de inestabilidad, inseguridad, imperfección y desunión- solo puede ocasionar un complejo de inferioridad que genera ansiedad. Si se mantuviese la suposición de que el resultado en la comparación entre estos modelos ideales y la realidad, es la infelicidad, su relato solo podría convertirse en una tragedia.

No tenemos intención de juzgar la superioridad de uno frente al otro. Tal y como muestran Fatherless y Home, describir la realidad de la angustia de una familia que sufre por la presión del modelo ideal y convertir al documental en un relato trágico del conflicto tiene sentido como reclamo y crítica. Es decir, son muchas las contradicciones que existen al aplicar el modelo ideal inventado por la sociedad moderna a la realidad. La muestra del dolor y del malestar que se generan por la comparación de la propia identidad con este modelo ideal, en algún sentido, se convierte en una forma de crítica del modelo y los regímenes que lo sostienen.

En contraste, en el caso de Osaka Story, donde cada miembro de la familia soporta los problemas de sus relaciones familiares y de su identidad, no se cuestiona la diferencia y la distancia entre el modelo ideal y la infelicidad causada por dicho modelo. El vigor de la escenificación, el cual aporta cierta alegría al documental, describe positivamente la identidad compleja, abrazándose tanto al amor como al odio a sí mismos y a la familia. Representa la firme voluntad del autor de aceptar abiertamente la realidad, sin prejuicios. Aquí no solo vemos que el modelo ideal del individuo y de la familia no funciona como un valor absoluto, sino que además se abre una perspectiva de la identidad híbrida basada en múltiples culturas.

El comentario de Makoto Sato mencionado anteriormente sobre la sensación de estancamiento, fragilidad y debilidad del documental japonés es aplicable a Fatherless y 
Home. Ciertamente, en Osaka Story tampoco se describen las circunstancias históricas o políticas de la comunidad coreana afincada en Japón; no obstante, consideramos que al menos el contenido que afirma la identidad basada en las multiplicidades étnicas, de género y nacionalidad, debería quedar fuera de su crítica negativa.

En el siguiente apartado veremos algunos documentales privados de autoras japonesas afincadas en Estados Unidos, que abordan el tema de lo privado en relación a la identidad del individuo y la familia. Su planteamiento establece un nuevo sujeto con los diversos contextos sociales y culturales en el documental. 
V.4 La voz de las mujeres en el documental. Articulación entre lo público y lo privado. 
A lo largo del presente capítulo reflexionamos sobre los documentales con el tema de la subjetividad, tomando los ejemplos de la transición en Japón bajo la influencia internacional. Básicamente, a partir de los años setenta, el movimiento del documental independiente traspasa el tema y su modo de producción de lo colectivo a lo privado. Y cada vez enfatiza en mayor medida el problema de la identidad individual. Esta tendencia corre en paralelo al movimiento social y político: por ejemplo, a la reivindicación de los derechos civiles y a los movimientos antibélicos y estudiantiles, los cuales transfirieron el documental a la política de la identidad. En este cambio, el feminismo será un protagonista importante.

Dentro del movimiento social de la década de los sesenta, para renovar y reconstruir la política nacional, los jóvenes reclamaron y lucharon contra la autoridad parental, pero menospreciaron la cuestión de la discriminación sexual y de genero. Por esta razón, la propuesta que realizan las feministas, sirvió para prestar atención a ciertos temas, a saber: los problemas relacionados con las mujeres, la comunicación directa entre los individuos, la consideración de la importancia tanto del producto final como del proceso de configuración, el sistema de libre participación en la toma de decisiones, la responsabilidad compartida sobre asuntos familiares y del hogar y otros más. Estos aspectos condujeron a la politización de los asuntos privados, la raza, el género, el origen étnico. Aún más, hoy en día seguirán siendo importantes los conceptos de la identidad fluida y múltiple, así como la crítica a la identidad "esencialista” para la conservación de un grupo social.

Para concluir su artículo, Michael Renov argumenta (New Subjectivities. Documentary and Self-Representation in the Post-Vérité Age):

How can we account for the dramatic even explosive appearance of new subjectivities on film and tape as the century comes to a close? Julia Watson has written about the historical conditions in which women have voiced their "unspeakable differences" through autobiographical discourses. "For the immigrant or multicultural daughter, naming the unspeakable is at once a transgressive act that knowingly seeks to expose and speak the boundaries on which the organization 
of cultural knowledge depends and a discursive strategy that, while unverifiable, allows a vital Emaking sense' of her own multiple differences. "I Such a statement well summarizes the circumstances in which this latest phase of documentary exposition has arisen. During the direct cinema period, self-reference was shunned. But far from a sign of self-effacement, this was the symptomatic silence of the empowered who sought no forum for self-justification or display. And why would they need one? These white male professionals had assumed the mantle of filmic representation with the ease and self-assurance of a birthright. Not so the current generation of performative documentarists. In more ways than one, their selfenactments are transgressive. Through their explorations of the (social) self, they are speaking the lives and desires of the many who have lived outside "the boundaries of cultural knowledge. ${ }^{2}$

Debemos fijar nuestra atención en su indicación sobre el silencio sintomático. Desde el principio de nuestra argumentación, nos hemos aproximado a un tipo de silencio de la mujer o del "otro" y hemos desarrollado la idea de la existencia de una posición femenina oprimida. Éste es un silencio, un estado de mudez, que precede a las "diferencias indecibles", según indicaba Julia Watson. Sin embargo, el silencio criticado por Renov ahora se convierte en un gesto del poderoso, quien no necesita ceñirse a unas reglas preestablecidas ni ofrecer "auto-referencias". Apoyamos la corrección de las indicaciones

\footnotetext{
${ }^{1}$ Watson, Julia: Unspeakable Differences: The Politics of Gender in Lesbian and Heterosexual Women's Autobiographies, en Watson, Julia y Smith, Sidonie: De/Colonizing the Subject: The Politics of Gender in Women's Autobiography, Minneapolis, University of Minnesota Press, 1992, p. 140.

${ }^{2}$ Renov, Michael, New Subjectivities. Documentary and Self-Representation in the Post-Vérite Age, en http://www.yidff.jp/docbox/7/box7-1-e.html, accedido el 9 de marzo del 2011.

¿Cómo podemos darnos cuenta de la dramática aparición, incluso explosiva, de las nuevas subjetividades en las películas y las cintas [de vídeo] en el siglo que llega a su fin? Julia Watson ha escrito sobre las condiciones históricas en que las mujeres han expresado sus "diferencias indecibles" a través de discursos autobiográficos. Para la hija inmigrante o multicultural, nombrar lo innombrable es a la vez un acto transgresor que, a sabiendas, busca exponer y hablar de los límites en los que la organización depende del conocimiento cultural y una estrategia discursiva que, si bien no es verificable, permite un sentido Emaking vital" de sus propias y múltiples diferencias" Esta declaración resume así las circunstancias en que ha surgido esta última fase de la exposición documental. Durante el período del cine directo, la auto-referencia fue rechazada. Pero lejos de ser un signo de humildad, era éste el silencio sintomático de la facultad de quien no busca ningún foro para la au to-justificación o la auto-promoción. ¿Y por qué iban a necesitarlo? Estos profesionales, varones blancos, habían asumido el manto de la representación cinematográfica con facilidad y seguridad, como un derecho de nacimiento. No así la actual generación de documentalistas performativos. En más de un sentido, sus actos son transgresores. A través de sus auto-exploraciones de su yo (lo social), están hablando de la vida y de los deseos de los muchos que han vivido fuera de "los límites del conocimiento cultural".
} 
de Renov: sobre aquellos que se encuentran en una posición de poder, como hombres blancos, a quienes no les surgirá la idea de insistir en el derecho naturalmente obtenido y/o en la confianza sobre sí mismos. Si profundizamos un poco más en la idea de Renov, sospechamos que estos hombres suponían un conocimiento común en ciertos lenguajes y en las posibilidades de la expresión audiovisual. Según sus explicaciones, si lo viera alguien que comparte esos conocimientos, podría comprenderlo sin una explicación específica. La mayoría de las veces, este tipo de conocimiento común está reservado para la parte poderosa, se reproduce repetitivamente en las expresiones que lo afirma, se reconstruye y se fortalece más y más.

A pesar de ello, y paradójicamente debido a ello, los documentalistas performativos de hoy en día, empiezan a intentar romper el silencio y/o visibilizar el silencio en sus obras, tras la crítica sobre las cuestiones de género desde la perspectiva del poder, y una comprensión común que sostienen mutuamente. Según Renov, ellos se dirigen más allá de los confines y comienzan a expresar el conocimiento fuera de los límites a través de la expresión audiovisual.

Añadiremos que para completar su discurso - en cuanto a la expresión audiovisual-, es necesario fijarse en el desarrollo de los dispositivos que posibilitan la obtención y el acceso a la imagen en movimiento, además del contexto ideológico. De hecho, en más de la mitad de la historia del cine se ha excluido técnica y sistemáticamente a las mujeres como productoras. Son pocas las excepciones en que se les ha posibilitado el acceso a la obtención de imágenes en movimiento. Todo lo que hemos visto en las secciones anteriores, como repaso de la historia documental con el tema de la subjetividad, principalmente en Japón hasta los años ochenta, es un periodo que carece de mujeres autoras y de sus trabajos. A los que hemos hecho referencia eran vídeo o película de $16 \mathrm{~mm}$. En este contexto, el caso de Sumiko Haneda (1926- ), mujer y documentalista, será una excepción, pues lleva una carrera de más de cincuenta años en la producción de documentales. Ella misma comenta sobre esta situación: 
Actualmente, se puede conseguir fácilmente la imagen en movimiento gracias a la cámara de vídeo pequeña. Ha aumentado el número de realizadoras de audiovisual. Sin embargo, hace cincuenta años no era nada fácil obtener la imagen en movimiento. Se necesitaba mover las máquinas, los materiales pesados y grandes, y a un gran personal. También era indispensable un largo tiempo en entrenamiento. No obstante, la sección creativa de las empresas de cine que cumplían estas condiciones cerraba las puertas a las mujeres. A quien le hayan ofrecido la ocasión de dirigir una película, como a Kinuyo Tanaka, ha sido privilegiada por tratos especiales debido a ser una gran estrella de la actuación. A pesar de ello, dentro del campo del documental y de la película científica antes de la Guerra (1941-1945), se formaban excepcionalmente a muy pocas mujeres ${ }^{3}$

Como comenta Haneda, obtener la imagen en movimiento en sí era difícil y dentro de la industria del cine existía una exclusión de las mujeres. Curiosamente en el campo del documental en Japón se encontraban mujeres que participaban en la producción, pero eran muy pocas ${ }^{4}$. Hace unos cincuenta años, ellas ni se imaginaban poder expresarse en el audiovisual. La reducción del tamaño y del presupuesto de los soportes audiovisuales abrió la posibilidad de la obtención de imágenes en movimiento prácticamente para todos, y por supuesto esto incluyó a las mujeres.

Tenemos el ejemplo de Taka Atsugi, quien tradujo el documentalismo de Paul Rotha y participó con Kinopro en los años treinta ${ }^{5}$, trabajó como guionista de Aru hobo no kiroku

\footnotetext{
${ }^{3}$ Haneda, Sumiko: Naze watashiwa kirokueigao... [Por qué yo, documental...] en VV.AA. Gendaishisho, Revue de la pensée d'aujourdhui [El pensamiento contemporáneo, Revista del pensamiento de hoy en día], Documentary Vol.53-13, , Tokio, Seidosha, 2007, p. 48. [Traducción propia del texto original en japonés]

${ }^{4}$ En el ámbito del documental japonés se encuentran muy pocas mujeres que participaban como guionistas, montadoras, productoras y realizadoras, aparte de narradoras. Como realizadora, además de Haneda, se encuentran Tosie Tokieda (1929- ), quien produjo varios documentales en Iwanami Eiga como: Machi no seiji: benkyousuru okasan (La política del barrio: madres que estudian/1957), de 16mm., en b/n, de 32min. de duración y Yoake no kuni (El país amanecido/ 1967), de 35mm., a color, de 110min.). También encontramos a Tomoko Fujiwara (1932- ) que inició su carrera con Orang-utan no chie (La inteligencia del orangután/ 1960), de 35mm., en b/n, de 39min., la cual sigue trabajando independientemente. Un caso peculiar en el ámbito del cine japonés es la realizadora Sachi Hamano (1948- ), la cual ha presentado más de trescientos películas pornográficas independientes (llamado Pink eiga) y tres películas sobre la relación entre la mujer y la sexualidad. Ahora se presenta la cuarta película (no cine porno) por Tantansha (productor de Hamano): http://www.h3.dion.ne.jp/ tantan-s/, accedido el 21 marzo de 2011.

${ }^{5}$ Sobre la traducción de libro de Paul Rotha y el movimiento de Prokino, váyase a V.1.2.
} 
(Documento de una maestra de guardería), dirigida por Souya Mizuki en 1942. Este documental aborda el tema de la problemática laboral de las mujeres. El crítico del cine japonés Tadao Sato comenta sobre el trabajo de Taka Atsugi como guionista:

Por ejemplo, el trabajo de Taka Atsugi como guionista, “Aru hobo no kiroku” (Documento de una profesora de guardería), dirigido por Souya Mizuki en 1942, es una obra que marca un hito en la historia como documental que aborda el problema laboral de la mujer. Taka Atsugi y Souya Mizuki, hasta el final de la guerra, realizaron "Watashitachi ha konnani hataraiteiru” (Nosotras trabajamos tanto/ 1945). Éste es un registro de la intensa labor, prácticamente increíble, de las chicas estudiantes voluntarias en la fábrica de municiones. Nos enseña a una parte de los japoneses en la guerra que trabajaban con entusiasmo confiando en la victoria. ${ }^{6}$

Este último comentario de Tadao Sato, nos obliga a reflexionar sobre el carácter del documental como registro histórico. Como vimos, el trabajo que se realiza durante la guerra constituye un tipo de propaganda para el control total del gobierno y del ejecutivo militar del imperio japonés, con el fin de motivar la continuación de la guerra. Además, la mayoría de los japoneses estaban entusiasmados con la guerra, si bien tras la derrota trataron de esconderlo y borrarlo como si no tuvieran ninguna responsabilidad. De tal modo, que estos documentales serían un testimonio de la consciencia de la época, por lo menos, registran el aspecto político de ese momento.

Como hemos comentado, también es un caso excepcional la participación de Hanada desde el inicio del "nuevo documental" japonés por la producción de Iwanami, que hemos visto en el apartado V.1. Después de producir tantos documentales por dicha producción y posteriormente en la producción independiente, en 2008, ella presenta un documental: $A h$, Manmoukaitakudan (Ah! El equipo de explotación de Manchuria), basada en la emigración japonesa hacia Manchuria, que centraremos nuestra atención después.

\footnotetext{
${ }^{6}$ Sato, Tadao (et. ál.): Nihonno dokymentary I, Dokyumentary no miryoku [El documental japonés I, El atractivo de documental], Tokio, Iwanamishoten, 2009, p. 46. [Traducción propia del texto original en japonés]
} 
En el presente apartado aproximaremos trabajos de mujeres realizadoras, con el tema acerca de la migración japonesa con el estilo Private Documentary y Self-documentary, realizados a partir de los años noventa, de acuerdo con lo que hemos desarrollado en la parte teórica documental, y también como la teoría feminista. Consideramos que nuestra aproximación a estos documentales de las autoras con el tema de la migración, contextualiza nuestras reflexiones sobre las diversas expresiones audiovisuales con el tema de la autobiografía de la mujer en tránsito que se encuentran en el campo de las artes visuales.

\section{V.4.1. El testimonio de la memoria traumática por las autoras norteamericano- japonesas.}

Como hemos dicho, nos aproximaremos a unos documentales de autoras americanojaponesas, siguiendo a Efrén Cuevas Álvarez y su artículo La crónica histórica a través de la mirada autobiográfica. Las huellas de la II Guerra Mundial de los japonesesamericanos $^{7}$.

Hoy en día se encuentran más de ciento veinte mil habitantes de familias japonesas en Estados Unidos, ocupando un 0.4 por ciento del total de sus habitantes. Constituye el tercer grupo étnico asiático más numeroso, siguiendo al chino y al filipino. Antes de tratar los documentales, daremos un breve repaso sobre migración hacia EE. UU como contexto histórico.

La cuestión de la migración japonesa está profundamente relacionada con el dominio de las potencias europeas sobre Asia del Este, así como con su independencia tras las dos grandes Guerras Mundiales. También tiene una relación estrecha con la rápida y violenta imposición del régimen capitalista de la zona a finales del siglo XIX y hasta el siglo XX. Al reflexionar sobre las cuestiones migratorias, en el Japón de aquella época, podemos ver una relación representativa entre modernización, capitalismo y guerra. Diríamos que el análisis

\footnotetext{
${ }^{7}$ Cuevas Álvarez, Efrén: La crónica histórica a través de la mirada autobiográfica. Las huellas de la II Guerra Mundial en los japoneses-americanos, en: Muguilo, Carlos (et. ál.), El cine de los mil años: una aproximación histórica y estética al cine documental japonés (1945-2005), Navarra, Festival Internacional de Cine Documental de Navarra, Navarra Dirección General de la Comunicación, 2006, pp. 193-199.
} 
sobre el caso migratorio de Japón del siglo XX, se convierte en un resumen paradigmático del período de transición hacia la modernización y la capitalización, el cual también surge en otras partes del mundo.

En Japón, desde el siglo XVIII hasta finales del siglo XIX, es un país permanece cerrado: el poder estatal prohibía viajar al extranjero, razón por la cual no se encuentra migración internacional. En cambio, al establecerse el nuevo régimen moderno, se inicia la migración internacional por directivas gubernamentales. Debemos reconocer, en toda su amplitud, la cuestión migratoria del siglo XX y su diversa problemática como asuntos surgidos inevitablemente por la imposición del capitalismo en nombre de la modernización. En este punto, citaremos un comentario de la tesis de Kenichiro Shoda, un investigador japones sobre la emigración del país.

[Shoda] capta la cuestión migratoria como el problema agudizado que Japón debía enfrentar en el proceso de participación en el régimen capitalista mundial, el cual ha resultado en la fricción y el antagonismo entre naciones. Por esta razón, argumenta que se pueden vincular estrechamente la emigración hacia América y la emigración hacia Manchuria ${ }^{8}$.

A continuación, veremos la relación inequívoca entre el proceso de participación en el régimen capitalista y la cuestión de la emigración hacia América y Manchuria (Asia). La sociedad capitalista, por su función y naturaleza, requiere para su extensión la mano de obra barata. Los nuevos mercados que se abren buscan a estos trabajadores y les convierten a su vez en consumidores. Es un sistema que persigue su amplificación absoluta; de lo contrario, fracasaría y no podría seguir manteniéndose. Una de las condiciones indispensables para la extensión del capitalismo es la abolición del régimen de bienestar social. En resumen, la sociedad capitalista debe realizar un intercambio mutuo por medio del valor monetario, y la división de las clases sociales limita ese intercambio. Es decir, en la extensión capitalista no conviene mantener esa devoción por el desarrollo social.

\footnotetext{
${ }^{8}$ VV.AA: Emigration and Immigration Studies in Japan: Survery and Biliography I, the Maiji era -Sept. 1992, Tokio, Akashishoten, 2007, p. 16. [Traducción propia del texto original en japonés]
} 
Japón, en el momento de su modernización, tomó el modelo británico para introducir el régimen político de la monarquía constitucional, concediendo a una parte de la clase privilegiada el estatus de nobleza. Eliminó las clases sociales que se dividían escasamente en un periodo de régimen feudal, convirtiendo el pueblo en llano. Por otra parte, en la sociedad moderna, el ciudadano obtiene derechos y libertades, pero al mismo tiempo se homogeniza la mano de obra: se debilita el sistema de las profesiones heredadas (el hijo de agricultores se convierte en agricultor; el hijo de carpintero, en carpintero; el hijo de comerciante, en comerciante) y se establece el capitalismo moderno.

Tras eliminar las rígidas divisiones de clases sociales, Japón promueve la industrialización por medio directivas gubernamentales. Se cambian completamente las condiciones laborales y se inicia el flujo de la fuerza laboral desde las provincias a las grandes ciudades industrializadas. Al mismo tiempo, debido al desarrollo de la economía monetaria, fracasan y se agotan las comunidades agrícolas de subsistema que hasta entonces se autoabastecían con el trueque a pequeña escala. El movimiento de los trabajadores no se limita al interior del país. Seguramente, todo esto se convierte en la base para la emigración internacional.

La emigración internacional tenía dos direcciones: una corriente hacia América, y otra hacia Asia de oriente-sur. La observación de los dos sentidos de la emigración nos esclarecerá la postura arbitraria de Japón sobre sus políticas migratorias.

La primera emigración dirigida por el gobierno japonés tomo rumbo hacía Chiapas, México, en 1897. El proyecto de continuar enviando masas de trabajadores resulta un fracaso, pero aún así supone el inicio de la emigración internacional japonesa, también conocida como Enomoto-Imindan ${ }^{9}$.

Posteriormente, el destino principal de los emigrantes japoneses será Hawái y Estados Unidos. A partir de la Restauración de Meiji, que fue el inicio del gobierno del Imperio

\footnotetext{
${ }^{9}$ Enomoto Imindan, Primer grupo organizado de emigración del gobierno japonés. El grupo, instado por Takeaki Enomoto (ex-ministro de Asuntos Exteriores y el fundador de la asociación de emigración) estaba formado por treinta y cinco japoneses que emigraron a Chiapas en 1897.

The Ministry of Foreign Affairs of Japan: http://www.mofa.go.jp/mofaj/press/pr/wakaru/topics/vol28/index.html, accedido, el 15 de junio del 2009.
} 
Japonés, el número de habitantes prolifera. Ni las zonas agrícolas, ni las ciudades contaban con suficientes lugares para aceptarlos. Como consecuencia emigran a Hawái y a Estados Unidos donde se presentan como mano de obra de bajo precio. Durante muchos años EE. UU. es el país que recibe mayor número de inmigrantes japoneses, hasta el año $1908^{10}$, a causa del pacto de caballeros entre Japón y Estados Unidos, que limita la migración japonesa.

Posteriormente se inicia la emigración hacia Brasil ${ }^{11}$. El primer grupo de emigrantes, formado por setecientas noventa y una personas, llega a Santos, Brasil, en el barco Kasadomaru el día 18 de junio de 1908. En el década de 1920, la mayor parte de la emigración hacia América se afinca en Brasil y, claramente, una de las razones para no elegir como destino de emigración los Estados Unidos fue el movimiento anti-japonés. Sobre todo, en la zona de California era donde había una mayor intensidad del movimiento anti-japonés fundado en el terror amarillo, surgido a finales del siglo XIX y a principios del siglo XX en Europa y Estados Unidos.

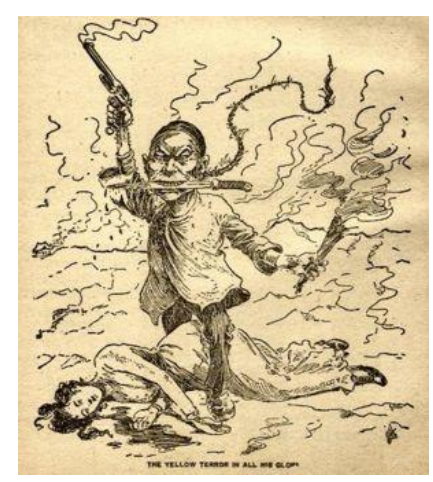

39. Caricatura editorial de The Yellow Terror In All His Glory (1899)

Yellow peril, tal y como se llamó en inglés, es un sentimiento de terror y de odio contra los chinos, principalmente, pero también se aplica al resto de "los amarillos". No somos

\footnotetext{
${ }^{10}$ Tabla cronológica de la historia de inmigración japonesa en Estados Unidos de América: Wakayama shimin toshokan imin shiryoushitu: en http://www.lib.city.wakayama.wakayama.jp/wkclib_doc/sub13.htm, accedida el 6 de junio del 2009.

${ }^{11}$ Tabla cronológica de la historia de inmigración japonesa en Brasil: Wakayama shimin toshokan imin shiryoushitu: en http://www.lib.city.wakayama.wakayama.jp/wkclib_doc/sub19.htm, accedida el 6 de junio del 2009.
} 
capaces de definir exactamente a quiénes se aplica y a quiénes no, pero sabemos que por lo menos se incluye a los japoneses. Podemos considerar que este sentimiento anti-japonés fue profundizado por el conflicto entre Rusia y Japón. Este terror imaginario y la conciencia racista concluyen con la concentración de japoneses durante la Segunda Guerra Mundial, que es el tema principal de los documentales de las norteamericano japonesas que vemos ahora.

En este contexto, en 1941, a consecuencia del ataque sorpresa a Pearl Harbor, efectuado por la marina del Imperio japonés, comienza la Guerra del Pacífico entre EE. UU. y Japón. En 1942, el gobierno estadounidense reunió coactivamente a los habitantes japoneses en campos de concentración bajo el pretexto de protegerlos. Los japoneses, incluso aquellos que tenían ciudadanía norteamericana, debían evacuar sus residencias e ingresar en los campos. En algunos casos, los refugiados fueron "acogidos" en establos porque la construcción de las viviendas en campos de concentración se retrasaba. Pero en otros casos, el campo de concentración se situaba en terrenos baldíos y tuvieron que autoabastecerse, sin libertad fuera del mismo. Estos japoneses no fueron liberados hasta el fin de la guerra en 1945, tras la derrota de Japón.

Durante la concentración, los sentimientos de estrés, descontento e insatisfacción de los japoneses se acentuaban cada vez más. Sucedieron varios delitos, robos, incluso homicidios. Tuvieron lugar casos de violencia doméstica y también sexual hacia las mujeres y niñas, en la actualidad existen algunas acusaciones realizadas por las víctimas ${ }^{12}$. De acuerdo con este contexto analizaremos dos obras que abordan el tema familiar desde la memoria traumática.

\footnotetext{
${ }^{12}$ Janic Mirikitani, poeta y activista de la tercera generación de familias japonesas inmigrantes. Tiene algunas publicaciones de poesía y ensayos sobre su propia experiencia en el campo de concentración y sobre su trauma como víctima de la violencia doméstica sexual. Actualmente desarrolla varios programas sobre los problemas de la pobreza y de la violencia doméstica. Es la directora ejecutiva de la iglesia Glide de San Francisco. Al mismo tiempo, realiza actividades de denuncia al gobierno de los Estados Unidos sobre la violación de los derechos de musulmanes y árabes en el país tras la declaración de lucha contra el terrorismo.
} 
V.4.1.1. La contradicción de la identidad y la imagen del inmigrante ejemplar en el cine.
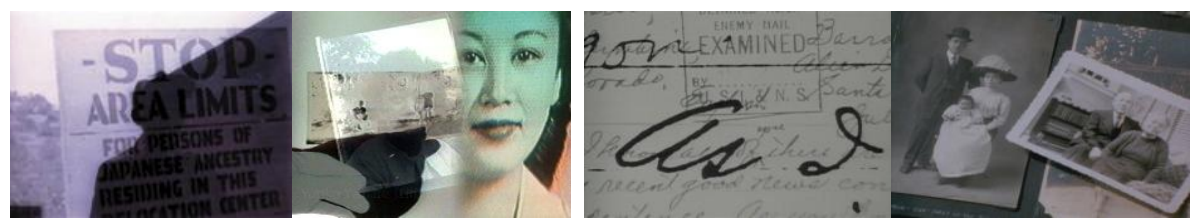

40. Who's Going to Pay for These Donuts, Anyway? (1992), Janice Tanaka

41. Family Gathering (1988), Lise Yasui

Cuevas analiza cuatro documentales de las autoras japonesa americanas: Rabbit in the Moon (1999), dirigida por Emiko Omori y co-producida por ella y su hermana Chizuko Omori; Who's Going to Pay for These Donuts, Anyway? (1992), de Janice Tanaka; History and Memory (1991), de Rea Tajiri; y Family Gathering (1988), de Lise Yasui. Estos documentales son producidos por autoras pertenecientes al "Nisei" (segunda generación de origen japonés) o al "Sansei" (tercera generación) desde una mirada histórica de las memorias de sus familiares cercanos: el padre, la madre, los abuelos y ellas mismas. El contexto común en estos trabajos es la familia, y en las autoras es su historia y la memoria de aquellos campos.

Al estallar la guerra entre EE. UU. y Japón, tras el ataque a Pearl Harbor en diciembre de 1941, los prejuicios raciales y la historia social provocada por la amenaza bélica confluyeron en uno de los episodios más oscuros de la historia de los derechos civiles en Estados Unidos durante el siglo XX: la encarcelación de 120.000 personas de origen japonés en su mayoría inmigrantes de primera, segunda o tercera generación, en campos de concentración repartidos por todo el país. Esta situación, que se mantuvo entre tres y cuatro años, resulta aún más paradójica si se tiene en cuenta que dos tercios eran ciudadanos estadounidenses. ${ }^{13}$

A partir de los años sesenta, con el movimiento de los derechos civiles, se activó el debate sobre los sucesos referentes a la concentración de japoneses en EE. UU. Aún más cruel resulta que afectase solo a los japoneses y se dejase aparte a los italianos y alemanes,

\footnotetext{
${ }^{13}$ Cuevas Álvarez, Efrén, Op.cit. p. 193.
} 
aunque también ambos eran de países enemigos. Esta política fue duramente criticada, denunciando la agresión racista y el desprecio hacia los asiáticos. En 1988, gracias a cierta recuperación del honor y de los derechos de los americano-japoneses, se consigue una disculpa oficial por parte del presidente del país ${ }^{14}$.

Se han producido numerosos documentales de cine y televisión en relación al tema de los campos de concentración de estos americano-japoneses. A partir de la disculpa oficial de 1988, se fundó el Japanese American National Museum ${ }^{15}$, el cual promueve actividades de difusión educativa. Dentro de sus iniciativas, llama la atención la película Days of Waiting: The Life \& Art of Estelle Ishigo ${ }^{16}$, producida en 1990 por Steven Okazaki ${ }^{17}$, quien recibió un premio Oscar de la Academia en 1991 al mejor cortometraje documental.

Este asunto constituye uno de los más importantes dentro de la historia del movimiento de los derechos civiles en los EE. UU. Hoy en día se promueve la reflexión sobre este suceso. Se ha generalizado en el país un clima de consentimiento de las infracciones estatales a los derechos humanos contra musulmanes y árabes por cuestiones religiosas, etnicidad y raza, a partir del 11-S. De hecho, esta tendencia al beneplácito de las transgresiones de los Derechos Humanos en aras de garantizar la seguridad pública, se ha generalizado en todo el mundo bajo el eslogan de "lucha contra el terrorismo".

Por otra parte, el suceso no permanece tan solo en la Historia y en la memoria pública, sino que se queda en la historia y en la memoria privada del individuo y de su familia. En muchas de estas memorias, en lo que respecta a la comunidad japonesa-americana, existen cicatrices en la formación de la identidad individual y familiar, traumas que no pueden relatarse por medio de las palabras. Actualmente, a causa del envejecimiento de la generación que experimentó la vida en los campos de concentración y también de los que

\footnotetext{
${ }_{15}^{14}$ http://www.civics-online.org/library/formatted/texts/civilact1988.html, accedido el 18 noviembre del 2008.

15 Japanese American National Museum: http://www.janm.org/, accedido el 20 noviembre del 2007.

${ }^{16}$ Days of Waiting: The Life \& Art of Estelle Ishigo: documental sobre Estelle Ishigo, quien rechazó ser separada de su marido japonés-americano y prefirió vivir reclutada en el campo de concentración. http://www.farfilm.com/web/title dow.htm, accedido el 20 diciembre del 2008.

${ }^{17}$ Steven Okazaki: documentalista americano-japonés de tercera generación. En los últimos años se ha dedicado a producir documentales sobre la bomba atómica en Japón, tales como White Light/ Black Rain. Este documental fue seleccionado como mejor dentro de la especialidad de no ficción de los premios Emmy en 2008.
} 
allí nacieron, existe una ruptura entre las generaciones y la consiguiente preocupación de que la memoria de los sucesos se vea interrumpida. Preocupa observar un presagio que nos está llevando a repetir este mismo suceso irracional en nuestros tiempos, no podemos asumir que el pasado es un hecho histórico finalizado y alejado de nosotros.

¿Cuál es el significado de la memoria y del trauma de los campos de concentración para la comunidad y la familia? ¿Qué representan para un japonés-americano? Los documentales exteriorizan estas cuestiones y descubren los dilemas de identidad, explorando la manera de establecer al sujeto de las autoras en la expresión audiovisual. Nos aproximaremos a los documentales según los conceptos de identidades individuales y familiares desgarradas por la memoria y el olvido, por dos patrias y dos generaciones ideológicas, por la injusticia y las contradicciones que se derraman entre las frases escritas en la historia pública.

Después de la Segunda Guerra Mundial, en los EE. UU. influyeron poderosamente los sucesos del batallón 442 (442nd Regimental Combat Team), formado por voluntarios americanos japoneses que se reunieron al empezar la Guerra contra Japón para recuperar el honor y los derechos en el país norteamericano. Combatieron ferozmente en Europa, y entre soldados muertos y heridos sumaron más de nueve mil personas. Es muy conocido el rescate del batallón de Texas que se encontraba rodeado de enemigos en Italia: para salvar a un grupo de doscientas personas, murieron o quedaron heridos más de ochocientas del batallón 442. En Alemania, el batallón 442 participó en la liberación de personas en el campo de concentración de Dachau ${ }^{18}$. Como comenta Cuevas, la situación era muy paradójica:

\section{(...) Una paradoja que aumentó aún más cuando el ejército de ese país formó un batallón, el famoso 442, con americanos japoneses, y llegó incluso a organizar una campaña activa de reclutamiento entre los internados en aquellos campamentos. ${ }^{19}$}

\footnotetext{
${ }^{18}$ Campo de concentración de Dachau: el campo concentraba a los criminales políticos, fue construido por los Nazis como escuela de violencia para las SS. Se internaron más de 200.0000 personas provenientes de toda Europa y más de 43.000 personas fueron ejecutadas. Las personas fueron liberadas por las tropas estadounidenses y el campo se cerró en 1945: http://www.kz-gedenkstaette-dachau.de/timeline/1933-1945.html, accedido el 6 diciembre del 2008.

${ }^{19}$ Cuevas Álvarez, Efrén Op.cit., p. 193.
} 
El batallón 442, pagando con un gran sacrificio, se convirtió en un símbolo que mostraba el sentimiento patriótico y de fidelidad hacia los EE. UU. por parte de los americanosjaponeses. En 1960, algunos militares retirados llegan a la Cámara Alta y Baja como senadores, de esta manera se comienza a recuperar el honor y los derechos de los japoneses-americanos como potencia política efectiva.

Dado el notable desempeño del batallón 442, la comunidad japonesa de los EE. UU. se asegura una posición social como minoría ejemplar por sus servicios a la patria norteamericana, a pesar de ser originarios de un país enemigo. Existen varias películas de ficción y documentales que instruyen sobre estos sucesos. Por ejemplo, la película de ficción Go for Broke! ${ }^{20}$, producida por Robert Pirosh en Hollywood, blanco y negro, 92 min. de duración, en 1951 (cuando todavía no había sido recuperada la ciudadanía para los americanos-japoneses), describe actividades del batallón 442 con su capitán blanco, el único no asiático del batallón, como protagonista principal.
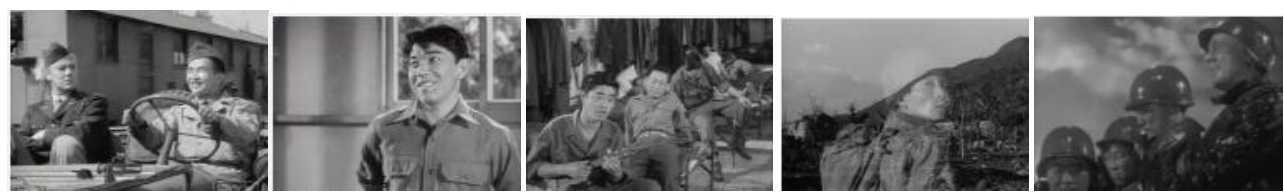

42. Go for Broke! (1951) de Robert Pirosh

El batallón 442 de la sección 100 estaba formado por japoneses-americanos de Hawai, anexionada a los EE.UU. en 1898, donde se situaba Pearl Harbor. En esta isla, los japoneses ocupaban el sesenta por ciento de toda la población, pero solo setecientas personas fueron internadas en campos de concentración. La proporción de jóvenes voluntarios americanos-japoneses en la isla fue muy alta.

\footnotetext{
${ }^{20}$ Go for Broke!: dirigida por Robert Pirosh en 1951, en blanco y negro. Go for broke es una mala traducción en la lengua inglesa, ya que proviene del dicho japonés Atatte kudakero que quiere decir "realizar algo sin saber si se logra o no y manteniendo la disposición de aceptar el fracaso". Originalmente, los inmigrantes japoneses en Hawai decían esta frase para apostar. Los voluntarios americanos-japoneses de Hawai utilizaban esa frase frente a la batalla encarnizada, desafiando a la muerte.
} 
Por otra parte, en tierra firme también se desplegaron reclutamientos de voluntarios en los campos de concentración, pero fueron menos los presentados en comparación con Hawai. La razón, como indica Cuevas, es que los jóvenes americanos-japoneses con ciudadanía estadounidense se encontraban en una situación paradójica: al ser transportados a los campos, se les había quitado la ciudadanía, pero también su derecho y honor; al mismo tiempo, se les exigía servir a la patria alistándose como voluntarios. Muchos de ellos albergaban un mejor trato del Estado, por eso algunos se quedaron en los campos, pero otros fueron al frente de batalla. Algunos de los que se quedaron hicieron huelgas y se sublevaron reclamando justicia e igualdad.

V.4.1.2. La identidad, la memoria y la historia, desde el campo de concentración.
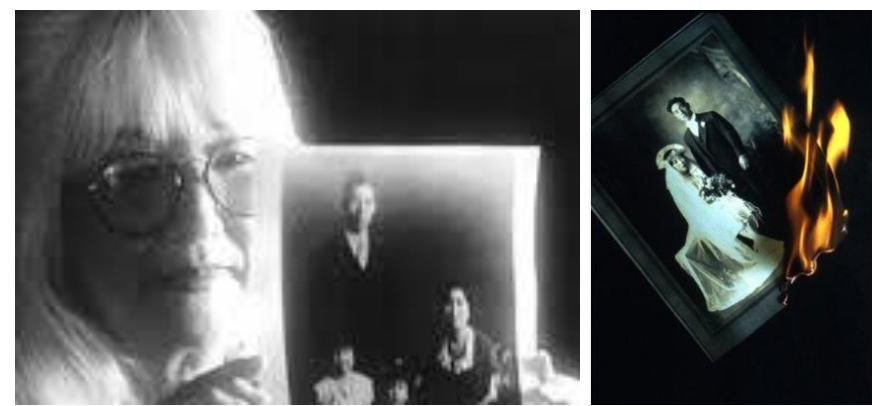

43. Rabbit in the Moon (1999), Emiko Omori

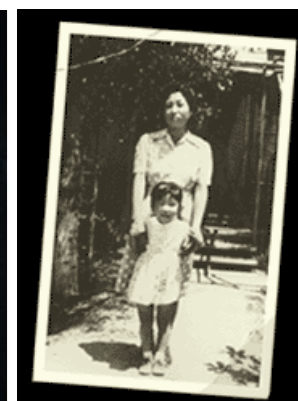

Rabbit in the Moon, producida por Emiko Omori y coproducida por su hermana Chizuko Omori, se centró en el tema del reclutamiento de los americanos-japoneses en los campos de concentración, y también en la disgregación y discordia dentro de la comunidad japonesa entre los que fueron a la guerra y los que no. Representa las cicatrices ocasionadas por el gobierno norteamericano y la guerra. En este documental se visualiza en mayor medida el contexto histórico, ya que se introducen datos y documentos tales como imágenes de noticiarios y fotos de archivo con un estilo documental histórico-expositivo.

Sin embargo, la película se aleja de la típica narración omnisciente, para anclarse en la perspectiva de las hermanas Omori, que fueron protagonistas de aquellos 
sucesos, pues fueron trasladadas, junto con sus padres, a uno de los campos de concentración cuando Emiko tenía un año y Chizuko once. ${ }^{21}$

Las hermanas Omori intentan relatar su propia experiencia de vida en el campo de concentración, poniendo énfasis en la experiencia personal como punto de origen del relato. Pretenden narrar la historia de su familia a través de sus vivencias, no la Historia objetiva ni la historia del movimiento del derecho civil.

Esta perspectiva autobiográfica resulta explícita desde el comienzo, especialmente a través de la voz en off de Emiko, que servirá como guía para el espectador, dotando a la crónica histórica de un tono personal muy claro. ${ }^{22}$

De este modo, aclarando su postura basada en la propia experiencia autobiográfica, muestran los sucesos que ocurrieron allí por medio de la entrevista a los testigos por parte de Chizuko, hermana y coproductora de la autora. Cuevas indica la importancia de las fotografías familiares en esta obra.

La fuente histórica de carácter visual más significativa en "Rabbit in the Moon" son las fotografías familiares, de la familia Omori y de las familias de otros entrevistados. Su importancia no reside tanto en el tiempo de pantalla que ocupan, que no es mucho, como en su carácter de "leitmotiv" visual en el filme, pues hacen visible el choque entre un pasado traumático y su reevaluación desde el presente. La cineasta recrea esa relación colocando con frecuencia las fotografías en entornos frágiles: con el cristal del marco roto y/o tiradas en el suelo del hipotético campo, lo que las distancia claramente del ámbito doméstico en el que inicialmente estuvieron. De este modo, Emiko ofrece una adecuada metáfora visual, que arranca del registro factual -la fotografía- pero va más allá, reflejando visualmente el

\footnotetext{
${ }^{21}$ Ibíd., p. 194.

${ }^{22}$ Loc.cit.
} 
sentimiento de ruptura que aquellos años supusieron en la vida cotidiana de las familias retratadas en las fotografías. ${ }^{23}$

Durante largo tiempo, los contenidos de muchos de los documentales se basaron solo en imágenes de fotografía como documento histórico. Todavía hoy en día numerosos noticiarios y documentales educativos mantienen esta tendencia. En cambio, el uso de la fotografía como leitmotiv en el documental privado, surge de la intención de visualizar la relación entre la imagen y el individuo que mira, entre la memoria y su evocación. El tema principal es el conflicto del individuo. En el caso de que la memoria que pretende recordar contenga un trauma, una experiencia dolorosa y patética, inevitablemente conduce a un choque fuerte y a un sentimiento de rechazo contra la fotografía como instrumento evocativo.

Además de ello, la fotografía es un leitmotiv para reflexionar sobre la continuidad en el tiempo. En particular, la fotografía familiar muestra de manera más perceptible esta característica. La fotografía capta la imagen del tiempo momentáneamente y la conserva. Al mirarla con posterioridad, la persona que aparece ha envejecido o incluso ha fallecido, el aspecto del entorno ha cambiado o ya ha desaparecido. Volver a mirar las fotos de los familiares cuando todavía eran jóvenes o estaban vivos significa reflexionar y confirmar la prolongación del tiempo dentro de la familia. A través de este aspecto podemos decir que tomar una fotografía familiar se convierte en un acto de confirmación sobre la continuidad temporal de la familia en el futuro. Cuevas comenta que existe una fotografía que merece una mención especial dentro de las numerosas fotografías familiares que aparecen en este documental.

Además, entre esas fotografías, la película singulariza una especialmente, que muestra a Emiko y su madre en el campo de concentración. Es la primera foto que se le hizo a Emiko y la última en la que aparece su madre, que moriría al poco de salir de aquel campo. Esta circunstancia, explicada en off, hace de esta fotografía un símbolo de todo el filme, al condensar en esa instantánea la fractura provocada

\footnotetext{
${ }^{23}$ Ibíd., pp. 194-195.
} 
en la historia familiar de esa generación por la II Guerra Mundial y el internamiento en los campos. ${ }^{24}$

Este documental describe desde una perspectiva crítica el mito de los japoneses-americanos como la minoría ejemplar que jura fidelidad a los EE. UU. Se subraya la ínfima minoría que sigue mostrando resistencia dentro de la comunidad tras la Segunda Guerra Mundial. Una comunidad que debía demostrar su fidelidad absoluta aún en el campo de concentración; en otras palabras, un grupo obediente que resultaba favorable y conveniente para el gobierno. Sin embargo, el documental tampoco favorece el chauvinismo japonés ni describe a Japón como la gran tierra perdida que evoca a la nostalgia.

Chizuko y Emiko pertenecen a la tercera generación de japonesas-americanas: sus padres ya habían nacido en EE. UU., su lengua materna es el inglés y su tierra natal es Norteamérica. Aún así, su vida como asiáticas en los EE. UU. tropieza con muchos obstáculos, incluso después de recuperar los derechos civiles. Sus dificultades no solo se manifiestan exteriormente, sino que también se encuentran en su intimidad. En la obra se relatan sus crisis de identidad y el fuerte rechazo que sienten por sus raíces japonesasasiáticas.

La voz en off de Emiko contiene escasas referencias explícitas a dicha crisis, dejando que los testimonios de los entrevistados y su contextualización histórica nos la muestren. No obstante, Emiko arranca su narración en off con una reflexión que apunta directamente a esta cuestión y que de algún modo encuadra todo el filme: sobre unas imágenes domésticas de niños con rostros orientales, ella se interroga sobre un hipotético hijo suyo: "Como yo, mi hijo sería un americano atrapado en el cuerpo de una raza extranjera no querida. ¿Podría esconder a mi hijo mi deseo de que él o ella fueran más blancos, para así no sufrir el rechazo que yo sufrí tan solo por culpa de mi rostro? ${ }^{25}$

\footnotetext{
${ }^{24}$ Ibíd., p. 195.

${ }^{25}$ Loc.cit.
} 
Existe una tendencia según la cual las víctimas de sucesos o accidentes graves tienden a estabilizar su dolor físico y mental a la vez que interiorizan un cierto sentido de culpabilidad. Al enfrentarse al absurdo, al incidente desgraciado que les ha ocurrido, con frecuencia razonan estos sucesos y tratan de establecer un mundo coherente de causa y efecto alrededor de sí mismas. Es la única forma de sobrevivir al episodio traumático.

En resumen, en estos casos se encuentra una tendencia a adoptar la idea de que el castigo es merecido porque se acepta una supuesta inferioridad como parte de la dinámica de causa y efecto, en la que además como decimos se interioriza un sentido de culpabilidad. El color de la piel, los rasgos faciales y la complexión corporal asiáticos son causas de dificultad y adversidad en la vida cotidiana: al menos, si fuese blanco, nadie le otorgaría ese dolor y esa angustia. Emiko no cree que esto sea justo. Como prueba de ello, Emiko relata que ese deseo íntimo de borrar su "inferioridad" física es una idea que debe esconder a sus hijos. Tampoco esto es justo de ninguna manera, y ella lo sabe, pero relata que el deseo de ser blanco es un deseo que no puede abandonar. Ahí se expande el conflicto entre el cuerpo real, que es su cuerpo japonés, y el cuerpo ideal, que es el cuerpo blanco.

El modelo que idealiza al cuerpo blanco es evidentemente consecuencia del imperialismo y el colonialismo de Europa, donde se establece un esquema de los grupos europeos blancos como superiores que ocupan también una posición dominante en cuanto a la cultura. Es un resultado de la modernización, basado en el centralismo de Europa en el caso de Estados Unidos, hablando en término extremo, marcando la superioridad de los de anglosajones se generan la posición dominante los euro-norteamericanos y se distingue con los de color que son de fuera de Europa.

Actualmente, el esquema de dominador y dominado ya no se divide geográficamente entre Europa y Norteamérica como primer mundo y las antiguas colonias como tercer mundo, sino que la colonia está dentro de Europa o en Norteamérica misma. Es decir, los habitantes de los antiguos países colonizados se sitúan ampliamente en el primer mundo como mano de obra barata. Al mismo tiempo, las antiguas colonias, después de conseguir su independencia, no han podido superar la estructura política, económica y cultural, y siguen 
formando un tercer mundo como fuente de suministro de mano de obra barata, a excepción de unas pocas personas pertenecientes a la clase dominante. La obra de Emiko contiene este cuestionamiento sobre la identidad del individuo migrante frente a la crisis y el complejo de inferioridad ante los blancos, por ello resulta necesario entender el contexto postcolonial.

El complejo por no ser blanco de la autora Emiko proviene en gran parte de la experiencia en el campo de concentración:

"Salimos de los campos como nuevos inmigrantes (...) y entramos en un país extraño para nosotros. ¿Quiénes éramos? ¿Cual era nuestro lugar en esta gran familia americana? (...) El Gobierno logró borrar buena parte de mi pasado cultural. Logró alienarme de mí misma, del rostro con que yo me veo". ${ }^{26}$

A partir de esta narración, comprendemos cómo el campo de concentración ha logrado enraizar un complejo en los americanos-japoneses, lo cual es exactamente lo que el Estado pretendía. Solo se recuerda el hecho de que dejaron libres a italianos y alemanes y castigaron a los japoneses, como evidente menosprecio a los asiáticos en los EE. UU., y surgen contradicciones mentales. Sin embargo, Cuevas descubre una esperanza en la obra.

No obstante, la imagen final, con Emiko en pantalla por primera vez, sujetando una foto familiar anterior a la guerra, mantiene en primer plano esa sugerente combinación de recuerdos personales y sufrimientos colectivos, al tiempo que parece dejar la cuestión de la fractura identidad con una nota final de esperanza. ${ }^{27}$
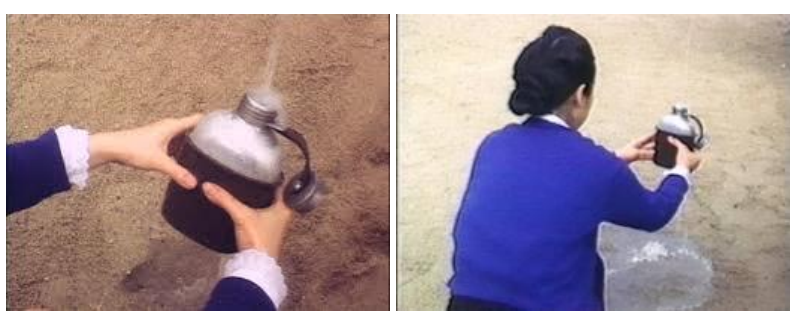

44. History and Memory (1991), Rea Tajiri

\footnotetext{
${ }^{26}$ Loc.cit.

${ }^{27}$ Ibíd., pp. 195-196.
} 
Por otra parte, el documental History and Memory de Rea Tajiri aborda un tema y contexto similar al de Rabbit in the Moon pero de manera diferente.

En este filme, Tajiri explora las consecuencias del internamiento en la vida de su madre y en su propia vida, con un formato que está a medio camino entre el documental y el cine experimental. ${ }^{28}$

El trabajo de las hermanas Omori es más estudiado, contiene mayor información sobre la historia pública y su estilo es más didáctico; en cambio, el trabajo de Tajiri muestra características del cine experimental. No obstante, el origen del motivo de la película es muy similar al de Omori: la crisis de la identidad.

Una influencia que ella explora como parte de una búsqueda personal, como afirma en la voz en off: "Empecé buscando porque me sentía perdida, desarraigada, como un fantasma que flota sobre la tierra, observando a otros vivir su vidas sin tener yo una vida para mi.", 29

Las hermanas Omori construyen su obra enfocando en lo que queda de la memoria y los documentos; por contraste, Tajiri, se fija en la falta de memoria. Para reconstruir su identidad individual, basada en la historia, y en la memoria de su familia, se remonta al pasado y se topa con los sucesos del campo de concentración que se convierten en el tema principal. Al investigar el pasado, se enfrenta a un problema: lo ocurrido no se recuerda muy bien o prefiere no ser recordado.

Al intentar reconstruir su identidad personal, en el contexto de su historia familiar, Tajiri busca nuevos modos de abordar aquellos acontecimientos del pasado, dada la escasa ayuda de su madre, que como muchas otras de su generación, no recuerda bien aquellos años o prefiere borrarlos de sus recuerdos personales. ${ }^{30}$

\footnotetext{
${ }^{28}$ Ibid., p. 197.

${ }^{29}$ Loc.cit.

${ }^{30}$ Loc.cit.
} 
Los supervivientes de situaciones difíciles a menudo sufren el síntoma de la amnesia. Sin embargo, la memoria es atemporal: cuando recordamos, en todo su sentido, la visión, el sonido, la temperatura del momento en el que se tuvo aquella experiencia, llegan a envolver a quien recuerda. El sufrimiento que sienten las víctimas en los flashbacks de sucesos difíciles es un ejemplo. Rememorar una situación dura y absurda, obliga a repetir la misma experiencia con el mismo dolor, pena, humillación y angustia.

En el rechazo a repetir el pasado terrible se procura no recordar, se trata de olvidar. Recordar y testificar sobre el grave suceso siempre supone una terrible carga para las víctimas. Este tema ya lo hemos desarrollado en los apartados I.2., según la teoría de Shoshana Felman y el análisis del documental Shoah de Claude Lanzmann. Entonces, ¿cómo representar un suceso que no se quiere recordar? El caso de la obra de Tajiri, gracias a la memoria perdida de su madre. Tajiri experimenta una aventura como artista audiovisual para poder concluir la obra.

Tajiri supera esa limitación recreando aquellos tiempos en torno a un suceso que le persigue en su memoria: su madre rellenando una cantimplora en el paisaje de desierto del campo de concentración. Tajiri se aleja de la factualidad de la imagen documental, introduciendo varias veces esta escena recreada que marca su memoria de las historias maternas. ${ }^{31}$

En la propia narración de Tajiri, ella comenta:

"Durante años he vivido con esta imagen sin una historia, sintiendo un fuerte dolor, sin saber cómo encajan juntas." 32

Esta obra genera un espacio de encuentro para el olvido de la madre y los recuerdos traumáticos de la hija, al introducir alternativamente la representación de las imágenes que representan el fuerte dolor de la hija y la secuencia de entrevistas a la madre que no se

\footnotetext{
${ }^{31}$ Loc.cit.

${ }^{32}$ Loc.cit.
} 
acuerda. El documental propone una comunicación torpe entre madre e hija a través del intercambio de la falta de memoria de la madre y la repetición de los recuerdos de la hija. La autora crea de esta forma un audiovisual en el que los hechos y la ficción se entrecruzan. Es el resultado de la recomposición de imágenes que ella guardaba en su interior, la cuales no sabía muy bien dónde colocar, y para ello encontró un lugar en esta obra que se sitúa entre el documental y la ficción, entre la memoria y la amnesia. Frente a esto, Cuevas comenta:

La realización de esa película le ayuda por fin a encontrar un marco narrativo para esa imagen, "a conectar la imagen con la historia", como ella dice, asumiendo la comprensión narrativa de la identidad como el catalizador de su impulso creativo. ${ }^{33}$

La imagen que aparecía repetitivamente en el interior del individuo, una imagen traumática que no se podía relatar, se conecta con la historia familiar y la Historia que la rodea. Esto nos ayuda a comprender lo que quería decir la autora sobre sí misma y su familia.

Esta nueva comprensión le ayuda también a salvar el espacio que le separaba de su madre, pues de este modo, como dice hacia al final, "pude perdonar a mi madre su falta de memoria y pude construir esta imagen para ella”. Esta pauta final impregna de hecho todo el filme, pues este no busca una explicación lineal de la historia del internamiento de los japoneses americanos, sino que pretende más bien completar aquellos vacíos en la memoria familiar que estaban condicionando la historia de los suyos. ${ }^{34}$

De esta manera, estos Private Documentary de americanos-japonesas en los años noventa parten de la memoria, de la historia y del trauma ante el suceso por el cual la familia y su grupo étnico al completo pasaron, al ser confinados en campos de concentración, para abordar el tema de la identidad individual y familiar, como base para la construcción de la identidad.

\footnotetext{
${ }^{33}$ Loc.cit.

${ }^{34}$ Loc. cit.
} 
Estos documentales muestran otro nivel en el conflicto de la identidad, en comparación con los trabajos japoneses que hemos visto anteriormente. Por una parte, encontrábamos el conflicto de la identidad del individuo y la familia comparados con el modelo estándar “japonés”; por otra parte, se representaba el conflicto al aceptar identidades múltiples. Lo que aquí se representa es la identidad cultural totalmente negada y destruida por la vida en campos de concentración, y el conflicto del individuo desgarrado entre dos culturas (la mentalidad norteamericana, por haber nacido y crecido en el país, y las rarezas del propio cuerpo asiático en EE. UU.).

Sin embargo, en el trasfondo de todas las obras se puede leer una búsqueda de la propia identidad y el intento de relatar reflexivamente sobre la familia y su historia en primera persona. Para poder responder a la cuestión de ¿quién soy yo?, uno debe re-observar y retratar a su familia, su historia y su memoria, desde el punto de vista subjetivo. Y, ¿cómo construir el sujeto en el mudo audiovisual? ¿Cómo el sujeto a su vez construye el mundo audiovisual? Estas relaciones mutuas y complementarias constituyen un profundo tema de estudio.

Los Private Documentary de los años noventa que hemos visto, abordan el tema de la identidad. No escapan de la influencia de los planteamientos del feminismo. Las obras han mostrado, cada una a su manera, las variedades de las identidades contemporáneas y la crítica de la identidad homogénea a la que el grupo se siente socialmente subyugado.

\section{V.4.2. La historia y la memoria de los migrantes contados por la mujer.}

Hasta ahora hemos analizado unos trabajos de Private Documentary de los años noventa, acerca de la familia inmigrante y multicultural de los autores japoneses. Estos autores, hijos o nietos de inmigrantes, cuestionaban en el documental su identidad y la memoria traumática de la familia. Para finalizar el presente capítulo, de acuerdo con los trabajos anteriores, ofrecemos algunas referencias sobre documentales de mujeres realizadoras. Ellas no provienen de familias de migrantes, pero les acompañan con la cámara y muestran un reflejo de su autobiografía en el documental. Igual que la primera parte, haremos una 
breve explicación sobre el contexto histórico para facilitar nuestra aproximación a los documentales.

El rumbo del inmigrante japonés tras su rechazo, tanto a nivel popular como político legal en EE.UU., empieza a fomentar la emigración hacia Brasil que es el país que actualmente ostenta el mayor número de japoneses. Brasil hasta 1969 había recibido 247.312 inmigrantes japoneses, según el informe ${ }^{35}$ de la embajada en Japón. Se conforma así la diáspora japonesa más grande del mundo. Los japoneses emigraron a toda América; además de los países ya mencionados, emigran hacia Perú, Canadá, Argentina, Cuba, Paraguay, etc. Los inmigrantes japoneses sirvieron como mano de obra barata para el país receptor, mientras que para el país emisor contribuyeron a la adquisición de divisas y a la reducción del exceso de población y de mano de obra.
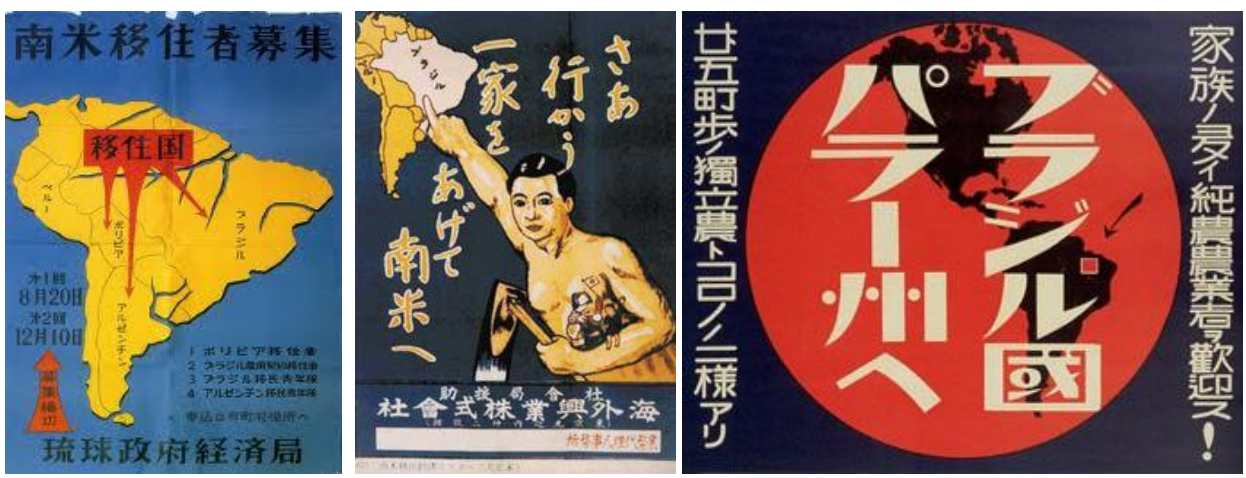

45. Póster de la demanda de emigración a Brasil

Sin embargo, hay ciertas dudas y contradicciones, sobre todo en cuanto a la reducción de la población activa. A pesar del envío de emigrantes japoneses hacia América, Japón recibe inmigrantes de Asia del Este (sobre todo de la península coreana y algunas partes de China como mano de obra barata). Este hecho está relacionado con la gestión de la colonia de Japón en la zona de Asia del Sureste. Lo explicaremos brevemente.

\footnotetext{
35 Asunto sobre la raza en la población brasileña, en http://www.brasemb.or.jp/info/people_race.php, accedida el 15 de julio del 2009.
} 
Por medio de amenazas militares, en 1876 Japón obligó a Corea a ratificar un tratado ${ }^{36}$ desigual (exigido también por potencias como Gran Bretaña, Estados Unidos y otras más), cambiando la posición a una más favorable para Japón. Tras este tratado, otras potencias como Estados Unidos, Gran Bretaña, Alemania, el Imperio Ruso y Francia también impusieron tratados desiguales y desventajosos para Corea.

De esta manera, la península inevitablemente se inició en el régimen capitalista moderno. Los agricultores se rebelaron contra la invasión y contra el régimen feudal en $1894{ }^{37}$. Con el pretexto de reprimir esta rebelión, el Imperio Chino de Gran Qing y el Imperio japonés intervinieron militarmente, dando lugar a la guerra entre China y Japón. El Imperio japonés venció en esta guerra y procedió a la colonización de algunas partes de China y de la península coreana, en una competición a la par que las grandes potencias occidentales.

El Imperio japonés se alió con Gran Bretaña en $1902^{38}$ y desde $1904^{39}$ se empezó a intervenir y se anexionó a Corea en 1910, tras ganar la guerra contra el Imperio Ruso, la cual había surgido por excluir la intervención rusa en Corea en 1905. En 1914 Japón declara la guerra contra Alemania, de esta manera participó en la Primera Guerra Mundial. Japón competía con las grandes potencias occidentales en la colonización por medio de invasiones militares, pero al final se quedó aislado del mundo al establecer el Estado de Manchuria (1932-1934), luego el Gran Imperio Manchukúo(1934-1945), el Estado títere de Japón $^{40}$.

\footnotetext{
${ }^{36}$ El tratado comercial entre Japón y Corea de 1876, archivado por National Archives of Japan en http://www.archives.go.jp/ayumi/kobetsu/m09_1876_01.html, accedido el 15 agosto del 2009.

${ }_{37}$ Donghak Peasant Revolution in 1894 (Kougo nouminn sensou), citada por la enciclopedia Mypedia: http://kotobank.jp/word/\%E7\%94\%B2\%E5\%8D\%88\%E8\%BE\%B2\%E6\%B0\%91\%E6\%88\%A6\%E4\%BA\%89, accedido el 15 de julio del 2009.

${ }^{38}$ Nichieidoumeikyouyaku (Alianza Anglo-japonesa), en Nihongaikounenpyou-narabini-shuyoubunsho, joukan. Ministerio de Asuntos Exteriores de Japón, Tokio, pp. 203-205, en la base de datos El mundo y Japón, base de datos: la política japonesa y relación internacional del laboratorio de Akihiko Tanaka del Instituto de la cultura oriental de la Universidad de Tokio: http://www.ioc.u-tokyo.ac.jp/ worldipn/documents/texts/pw/19020130.T1J.html, accedido el 15 de julio del 2009. ${ }^{39}$ Nikkan-seigou (Anexión de Corea a Japón) en 1904, Diccionario electrónico Koujien vol. 5, Iwanamishoten, Tokio, 1998.

${ }^{40}$ Manshukoku (Manchuria, Manchugúo o Manchukúo) se había fundado en 1932 y se extinguió en 1945 por la derrota del imperio japonés en la Segunda Guerra Mundial, en Diccionario electrónico Koujien vol. 5, Iwanamishoten, Tokio, 1998.
} 
Durante este tiempo, la península coreana avanzó en la imposición del capitalismo y la colonización de la sociedad, de una manera mucho más exagerada que Japón, invadiendo este país y otras grandes potencias occidentales. Cambió de régimen político, el país quedó devastado tras las rebeliones contra la colonización y dando lugar a las dos guerras de Japón-China y Japón-Rusia. Antes de la anexión de 1904, los coreanos emigraron a Japón como mano de obra de menor precio que la japonesa (es decir, mal pagados). También suponemos que llegaron como refugiados por el estado de guerra. Debido a la invasión y colonización asiática por parte de Japón, el gobierno igualmente envió emigrantes (diferentes a los emigrantes de América) que unos se asumieron como colonizadores y otros se dedican labores agrícolas en la zona. Esta emigración también tenía el sentido de remarcar el territorio del imperio japonés por el hecho de aumentar la población japonesa en la zona.

Dentro del grupo de emigrantes japoneses Manmou-kaitakudan que partieron hacia Manchuria a partir de 1932, fueron enviados agricultores con instrucción militar para las zonas rurales extremamente empobrecidas. Surge la crisis de la economía japonesa Showakyoko de $1930^{41}$, bajo la influencia de la crisis mundial de 1929. Además fue limitada la emigración hacia Norteamérica.

Sustancialmente, la colonización despojó del campo a los agricultores nativos por medio de la amenaza militar. A pesar de esta invasión, Japón y Manchuria ejercían una resistencia armónica colaborando con los cinco pueblos raciales asiáticos (de etnia han, mongoles, manchúes, coreanos y japonés), incluso el pueblo japonés reaccionó contra el imperialismo británico occidental y el norteamericano. La nación protegía la autodeterminación muy superficialmente.

Desde luego, la invasión con ayuda de la fuerza militar en la zona asiática de aquel momento no se justifica mediante el lema de resistencia contra las potencias occidentales.

\footnotetext{
${ }^{41}$ Shouwa-kyokou: la crisis que pasó Japón n 1930 por la influencia de la crisis mundial de finales de 1929. Causó un gran daño a la economía y empeoró la atención social y el nivel de vida. A partir de 1932 se recupera la situación económica; sin embargo, la zona rural ha continuado empobreciéndose. Diccionario electrónico Koujien vol. 5, Iwanamishoten, Tokio, 1998.
} 
Aunque los japoneses sufrían cierta opresión por parte de las potencias occidentales, la opresión que los vecinos asiáticos sufrieron no es justificable de ninguna manera.

Con todo lo que hemos visto hasta ahora, la política de migración japonesa se estableció de diferentes maneras en América y Asia. La emigración japonesa hacia América estaba formada por mano de obra barata y, como hemos visto, mejoró la adquisición de divisas. Es decir, fueron enviados por intereses coloniales. Muchos fueron a estudiar a Estados Unidos para acelerar la modernización de Japón -postura similar a la de los estudiantes de otras colonias- para el aprendizaje del conocimiento y la técnica del Estado protector.

Por supuesto, también hubo emigración por razones de exilio intelectual, político o religioso. De todos modos, lo que sí mantiene coherencia entre la migración japonesa hacia América y la migración japonesa hacia Asia es que el gobierno Imperial Japonés las dirige como política nacional. A partir de cierto momento, el "negocio" fue encargado a empresas particulares de emigración, pero no cabe duda de que fuera fomentado por el gobierno. La emigración a Manchuria se realizó por medio del negocio nacional.

Entre estos negocios, la educación ideológica nacional y las relaciones internacionales, dentro de los migrantes en tránsito y sus familias se encuentra una mezcla. Es fácil identificar la ruptura, la pérdida y la separación en las historias traumáticas.

V.4.2.1. Las mujeres documentalistas que escuchan los murmullos del "otro".

Como hemos mencionado, la política del Imperio japonés en Asia era muy contradictoria: se comportaba como Estado protector de la zona, criticando al colonialismo de las potencias occidentales; pero al mismo tiempo enviaba al ejército y después a emigrantes para ocupar los territorios. A la vez, recibía a inmigrantes de esas zonas como la mano de obra más barata.

La invasión japonesa de Asia, sobre todo de China y Corea, implicó la violación de los Derechos Humanos por parte de los militares japoneses, por ejemplo plasmada en el problema de Jugun-ianfu (también llamado Comfort women o Sex Slave). El problema 
Jugun-ianfu consistió en que se trasladó a mujeres para ejercer la prostitución como medio para evitar las violaciones sexuales por parte de los soldados japoneses en las zonas ocupadas de Asia. Las mujeres eran de diversas nacionalidades: japonesas, coreanas, chinas, filipinas, holandesas... Dentro de este grupo, muchas mujeres fueron engañadas o forzadas a ejercer la prostitución. Las mujeres vivían en condiciones difíciles y permanecieron en un estado de esclavitud sexual a favor de los soldados japoneses. Este problema salió a la luz en $1992^{42}$; hasta ese momento casi nunca se había tratado el tema públicamente.
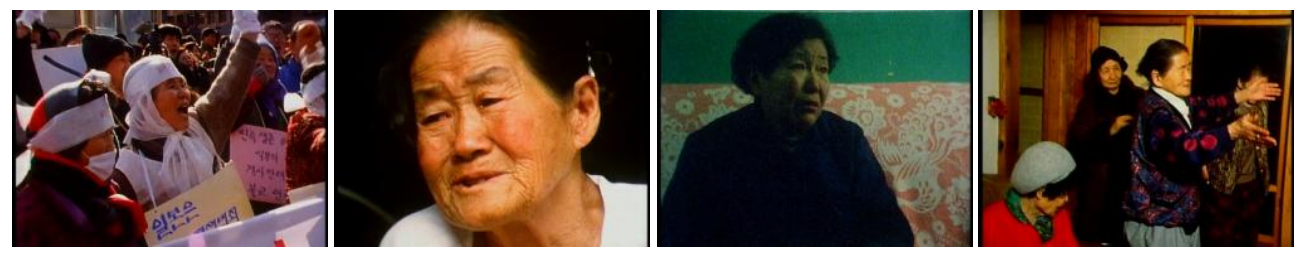

46. The Mrunuring (1995) Young-joo Byun

Las mujeres Ianfu ocultaron y callaron su experiencia para no sentir la pena y el miedo del aislamiento y la segregación dentro de sus comunidades. Ahora hay algunas mujeres que testifican y reclaman indemnizaciones por los daños sufridos. Existe un excelente documental de Young-joo Byun sobre el tema de las Ianfu, precisamente su serie de tres obras: The Mrunuring (1995), a color, de 98min. de duración; Habitual Sadness (1997), a color, de 56min. de duración; y My Own Breathing (1999), a color, de 77min. de duración. Son documentales sobre mujeres coreanas ex-ianfu ya ancianas que viven juntas en una

\footnotetext{
${ }^{42}$ Esxiste algunas aproximaciones sobre el problema de Jugun-ianfu contextualizando en el trafico personal especializada a las mujeres, llamado Karayuki (las que iban a trabajar al sur extrengera) que se encontraba desde la primera etapa de la emigración moderna japonesa. En la última etapa de era Meiji(1868-1912), se encontraba el fomento social de Karayuki llamando Nippon joushi gun (el ejercito de chica japonesa) como un medio de obtener divisas. En sociedad japonesa ignoraba Karayuki como la parte vergonzosa de la preguerra y en los años setenta se empieza a conocer ampliamente por una publicación de Tomoko Yamazaki: Sandakan hachibanshoukan: teihen joseishi joshou (Sandakan prostíbulo No.8: Historia de la mujer en la capa más baja de la sociedad), Tokio, Chikumashoten/ Bungeishunju, 1972. En 1974 adaptaron este libro al cine de ficción: Sandakan No.8 por Kei Kumai, color, duración de $121 \mathrm{~min}$.

[una reseña sobre esta película de New York times por Janet Maslin publicada el 8 de agosto 1977: http://movies.nytimes.com/movie/review?_r=1\&res=9C00E2D6113FE334BC4053DFBE66838C669EDE\&oref=s login, accedido el 30 de marzo del 2011.] Citaremos una indicación de la investigación sobre el tema: Tras se ha aclarado el problema de Jugun-ianfu en 1992, el tema de Karayuki se asume en el problema de ianfu. Dentro de esta tendencia, Meiko Yamada [1992] considera Karayuki como un punto de partida de Jugun-Ianfu.Sugako Niikura: 3.Karayuki en The Association for Immigration Studies (ed.): Emigration and Immigration Studies in Japan Survery and Biliography II, Oct. 1992 - Sept. 2005, Tokio: Akashishoten, 2007, p. 129.
} 
casa llamada $\mathrm{Nanumu}^{43}$. El testimonio de estas mujeres que viven aisladas dentro de la sociedad y que han sobrevivido a la esclavitud sexual se convierte realmente en el testimonio del subalterno sexual. Al igual que los testigos de Shoah, su testimonio muestra la memoria traumática de la violencia sufrida con una sensación llena de amargura y angustia.

El discurso de los revisionistas que niegan la existencia del problema y tratan de reducir lo más esencial del mismo alegan que ellas eran prostitutas. Sobre el papel, se insiste en la justificación de este suceso y en las ventajas de haber reducido la cantidad de violencia sexual de los soldados japoneses en la zona ocupada. De esta forma, muchos habitantes de Japón todavía siguen ignorando la importancia de los Derechos Humanos de estas mujeres $^{44}$. El olvido de su historia se fundamenta básicamente en la falta de interés de la generación de los jóvenes. Spivak nos alerta sobre el peligro de provocar una repetición de la misma catástrofe.

El destino final de los que emigraron a Asia fue ciertamente miserable. Justo antes del final de la Segunda Guerra Mundial existieron casos de suicidios colectivos de japoneses para evitar ser prisioneros, ya que habían sido abandonados por el ejército japonés y se sentían indefensos en un país extranjero (en este caso, China). Otros fueron asesinados por venganzas y por la confiscación forzada del terreno y otros asuntos. También se encontraban numerosos muertos de fío y de inanición durante el viaje hacia Japón. Por la intervención militar de la Unión Soviética se encarcelaron numerosas personas que fueron desterradas a Siberia para cumplir con trabajos forzados en circunstancias funestas.

El grupo Manmou-kaitakudan que emigró a Machuria estaba formado por trescientas mil personas. Muchos de ellos, cerca de ochenta mil personas, murieron al final de la guerra y

\footnotetext{
${ }^{43}$ Nanum House: http://www.nanum.org/, accedido el 18 de junio del 2009.

${ }^{44}$ Por supuesto, existe cierto movimiento de apoyo a estas ianfu de Japón que reclama el derecho de la mujer. Por ejemplo, Video-Juku es un grupo de mujeres que produce video-documentales contra la violencia de género y para la protección de sus derechos. En estos videos se recogen testimonios de Jugun-ianfu en amplias zonas de Asia. Algunas de sus obras son: We Shall Always Remember: Tribut to KANG Deuk-Kyoung Halmoni (1997), de 16min. de duración, Breaking the History of Silence: The Women's International War Crimes Tribunal of Japan's Military Sexual Slavery (2001), de 68min. de duración: en http://www.jca.apc.org/video-juku/English.html, accedido el 15 de marzo del 2011.
} 
durante su regreso a Japón. En aquel momento, en un contexto de confusión y peligro durante la retirada de China, muchos niños murieron o fueron abandonados y solo algunos consiguieron ser adoptados.

Entre los gobiernos de la República China y de Japón no se mantuvieron relaciones diplomáticas hasta el año 1972. Los problemas fueron postergados durante mucho tiempo, ya que hasta 1981 no se empieza la investigación para la identificación de los niños y su regreso a Japón. La mayoría de los que permanecieron en China trabajaron desde su infancia y disfrutaron de muy escasa atención educativa, sufriendo además numerosos problemas causados por la acusada discriminación hacia los japoneses. Algunos de ellos regresaron a Japón, pero tras haber vivido durante más de treinta y cinco años en China también permanecen alienados en la sociedad japonesa, en su propio país, debido básicamente a diferencias culturales y la dificultad del idioma.

Sumiko Haneda ${ }^{45}$ (1926- ) ha trabajado en la película documental de Iwanami, la cual construye la nueva historia del documental japonés con el realizador Susumu Hani. ${ }^{46}$ Haneda cuestiona e intenta recuperar la voz desaparecida en la narrativa histórica a través de su documental Ah, Manmou-kaitakudan (2008), a color, de 120 min. de duración.
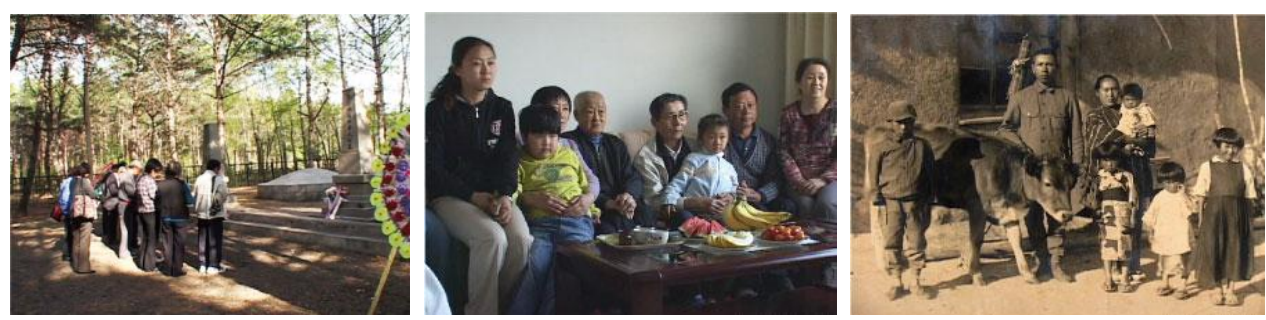

47. Ah, Manmou-kaitakudan (2008), Sumiko Haneda

El trabajo se basa en entrevistas realizadas durante siete años a los ancianos supervivientes y a sus familiares que permanecieron en China, situaciones muy lejos del conocimiento de

\footnotetext{
${ }^{45}$ Haneda Sumiko (1926- ), documentalista nacido en Dairen, Manchuria. En 1950 entra en Iwanamieiga seisakusho y se dedica a dirigir documentales. A partir de 1981 trabaja independientemente en la productora Jiyukobo que crea su marido Mitsuru Kudo: http://www.jiyu-kobo.com/, accedido el 25 marzo del 2011.

${ }^{46}$ Vease al apartado V.1.3.
} 
Haneda que no sabía nada sobre las personas que se quedaron en la zona de Manchuria (a pesar de que ella nace en el continente chino como hija de inmigrantes japoneses y de su regreso a Japón en 1948).

Actualmente, los inmigrantes asiáticos que llegaron a Japón antes de la guerra están en proceso de mejorar su nivel económico y su calidad de vida, consiguiendo salir de la miseria, la pobreza y la segregación. Por ejemplo, en la comunidad coreana crecen la tercera y cuarta generación, cuyos padres ya nacieron en Japón y cuya lengua materna es el idioma japonés. Es posible encontrar ciertos movimientos que buscan la reconciliación entre las divisiones del norte y del sur dentro de la comunidad. Como señalábamos en las secciones del documental japonés en las décadas de los años ochenta y noventa, se encuentran algunas obras que pretenden recuperar su voz como seres humanos, aún bajo la sombra de la narrativa histórica nacionalista desde la parte de la comunidad coreana.

Después del final de la Segunda Guerra Mundial, resurge la emigración hacia América con el fin de resolver la situación catastrófica del país que tenía una grave escasez de alimentos. También se encuentran algunos casos de exiliados que fueron a América del Sur como refugiados o expulsados por el gobierno japonés.

Tras lograr el levantamiento de la economía japonesa, existe una tendencia de "reimportación" de la mano de obra de la segunda o tercera generación de la colonia japonesa que por aquel entonces residía en diversos países de América. En los años noventa el gobierno japonés decide concederles el visado de trabajo con el fin de resolver la escasez de mano de obra para las tareas sencillas en las fábricas. Sin embargo, se detectó cierta discriminación en cuanto a las condiciones laborales, el sueldo y la educación, así como conflictos por diferencias lingüísticas, costumbres de vida o prejuicios raciales.

Resulta paradigmático el documental que aborda este tema, Un senhor do Brasil. Visitando brasileiros no Japão ${ }^{47}$ (2008), producida por Nanako Kurihara ${ }^{48}$, de 59 min. de duración. El

\footnotetext{
${ }^{47}$ http://amky.org/senhordobrasil/story.html, accedido el 21 marzo del 2011.

${ }_{48}$ Naoko Kurihara. http://www.wmm.com/filmcatalog/makers/fm38.shtml, accedido el 21 marzo del 2011.
} 
personaje principal de este documental es un anciano japonés de 92 años de edad llamado Kenichi Konno, quien había emigrado a Brasil en 1931 a consecuencia de las políticas de fomento de la emigración del gobierno japonés. El documental le sigue en sus viajes a Japón de cada año para visitar a los brasileños que trabajan en Japón. A través del relato de la vida personal del protagonista y de sus viajes, se aclara la actitud contradictoria de Japón: en períodos de estrechez económica, envía a los emigrantes, arguyendo que es en pro de la nación y para el desarrollo del país, pero mientras, se aprovecha de ellos como mano de obra de menor precio y los discrimina.

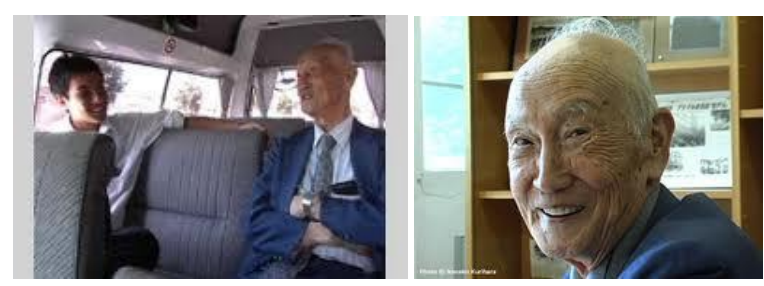

48. Un senhor do Brasil. Visitando brasileiros no Japão (2008), Nanako Kurihara

Durante la actual crisis, las primeras personas que han perdido el trabajo son ellos, pero el gobierno continúa profesando "la ayuda y el apoyo económico para regresar a su país", mientras condiciona la prohibición temporal de la vuelta a Japón. Este trato para con los brasileños (muchos de ellos, de descendencia japonesa) no es nada más que la consideración de los trabajadores como algo desechable, que cuando no se necesita se puede tirar como basura.

En otros casos, en Japón se explota a los extranjeros asiáticos y sudamericanos bajo el pretexto de la práctica profesional. Ésta es la otra cara del sistema japonés que no recibe inmigración y que se aprovecha de la mano de obra barata temporal “de usar y tirar".

Añadiremos otro caso que se ha vuelto muy común, precisamente el de la inmigración matrimonial de mujeres asiáticas hacia áreas pobres y rurales de Japón causada por la inexistencia de candidatas japonesas que quieran casarse en las comunidades de las zonas agrícolas, donde se mantienen bastante las costumbres patriarcales. En este caso, se debería reconsiderar la importancia de la libre elección de esas mujeres al contraer un matrimonio 
internacional con un campesino japonés que exigirá a su mujer cumplir el papel de la señora campesina al cuidado de los niños y de los ancianos que realizan las tareas domésticas, y que a la vez trabaja junto con el marido en la temporada de cosecha, bajo la presión de sus diferencias a nivel económico. Esta es la manera en que la sociedad japonesa se sigue beneficiando de la migración. En el ejemplo de la mujer inmigrante queda claro el sistema patriarcal que oprime a la mujer.

Por otra parte, se olvida fácilmente a los emigrantes que fueron expulsados. Resulta algo peculiar el caso de The Cat of Mirikitani ${ }^{49}$ (2009), producida por Linda Hattendorf, de 74min. de duración. Hattendorf trabaja en la edición documental en Nueva York. Tenía la intención de realizar un documental que representase qué signfican las cuatro estaciones para la gente sin techo. Y entonces encuentra a Jimmy Mirikitani como protagonista de su documental. Él tiene 85 años, vive en la calle dibujando y dando comida a los gatos. La autora inicia la filmación en enero de 2001, pero el once de septiembre ocurre el desgraciado ataque a las Torres Gemelas. Debido a este suceso, Hattendorf lleva a Mirikitani a su piso y cambia totalmente el proyecto de su documental.

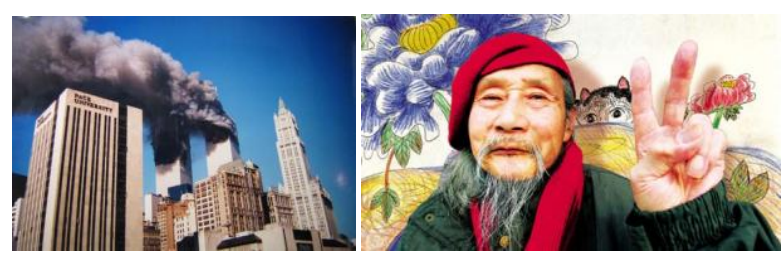

49. The Cat of Mirikitani (2009), Linda Hattendorf

La vida de Mirikitani era algo sorprendente para Hattendorf. Él era un japonés nacido en Sacramento y criado en Hiroshima desde los 3 años, vuelve a EE.UU. para estudiar pintura. Igual que otros japoneses afincados en EE.UU., durante la Segunda Guerra Mundial estuvo internado en un campo de concentración y por culpa de una confusión, en un escrito, renuncia oficialmente al derecho civil estadounidense. Su familia en Hiroshima falleció a causa del ataque nuclear. Después de salir del campo de concentración, se quedó sin

\footnotetext{
${ }^{49}$ The Cats of Mirikitani (Los gatos de Mirikitani), realizada por Linda Hattendorf en 2006 en EE.UU. El documental es a color y dura $74 \mathrm{~min}$. La realizadora se interesa por la vida de un artista japonés anciano y sin techo, a quien da abrigo cuando caen las torres gemelas. Mientras le ofrece su ayuda descubre una historia sorprendente, en http://www.cinememoria.org/edoc.php?c=390, accedido el 21 marzo 2001.
} 
ciudadanía. Nunca le llegó ningún aviso de rehabilitación, quizás por haberse trasladado tantas veces. Al final, él se quedó sin techo. Mientras aclara la difícil vida y el trauma de Mirikitani, Hattendorf busca una posibilidad para recuperar sus derechos y sus memorias.

Gracias al seguimiento de la autora con la cámara, este documental registra su comportamiento frente al protagonista y nos obliga a reflexionar sobre la historia y la política, el proceso de recuperación de la memoria, los derechos y los instintos humanos de un anciano desgarrado entre varias culturas. Al mismo tiempo, analiza la sociedad estadounidense a través de la vida de Mirikitani, y se observa también la intolerancia después del 11-S.

En estos documentales de realizadoras que abordan el tema acerca de la migración japonesa, encontramos aspectos distintos a los que hemos visto con anterioridad. Ellas, de repente, y muchas veces por casualidad, encuentran a personas con problemas y sienten una motivación por realizar el documental, engendrado en la ignorancia sobre sus propias historias. El caso de Haneda es un buen ejemplo de ello: incluso experimentando el regreso a Japón desde Manchuria al final de la guerra, no conocía lo que ocurría con las personas que se quedaban allí. Después de un largo tiempo, realizó una búsqueda para reencontrarse con la historia a través del relato de los inmigrantes en el documental.

En el caso de Nanako Kurihara, Linda Hattendorf y Young-joo Byun, existe una gran diferencia de generación entre los personajes objetivos. Sus relatos no comparten los tiempos en lo que ellas se fijan, si bien la mayoría de los casos son de hace mucho tiempo. Se podría considerar como algo que ya se encuentra en el pasado y no tiene mucho que ver con ellas. Sin embargo, las obras y lo que ellas representan no son algo del pasado, sino que tienen como objetivo reflexionar sobre lo que ocurre en el presente, como consecuencia del pasado. Todas las realizadoras son muy conscientes de la actualidad de los problemas. Los personajes de estos trabajos son casi todos ancianos y algunos ya han fallecido, pero los documentales siguen y seguirán siempre relatando sus vidas. Una vez les hemos escuchado, ya no podemos ignorarlos, y seguiremos hablando sobre lo que hemos oído con la experiencia de ser testigos de su vida a través de los documentales. 
Y también, como argumentaba Tetsuya Mori, estas realizadoras tratando los temas del "otro", se construye un sujeto que se enfrenta a aquellos sucesos de los personajes y empiezan a hablar en primera persona. Una de ellas trata de ser como un testigo de los murmullos de las ancianas supervivientes de la esclavitud sexual, otra intenta recoger memorias e historias olvidadas a través de la realización de los documentales. Son las expresiones de Self-documentary, al mismo tiempo, serian los registros del proceso de dessubalternización que comentaba Spivak. Y también es una obtención de la voz de sí misma, para empezar a relatar en primera persona, siendo las mujeres las expresiones audiovisuales.

En último lugar, citaremos una frase de un artículo que Michael Renov escribió para la revista Documentary Box como conmemoración del centenario del cine, en la cual reflexiona sobre la subjetividad en los documentales:

But what makes this "new subjectivity" new? Perhaps the answer lies in part in the
extent to which current documentary self-inscription enacts identities -fluid, multiple,
even contradictory - while remaining fully embroiled with public discourses. ${ }^{50}$

${ }^{50}$ Renov, Michael, Op.cit.

“Pero qué hace que esta "nueva subjetividad" sea nueva? Quizás la respuesta está en parte en la autoinscripción de los actuales documentales promulga la libre actuación del representa a identidades -fluida, múltiple, incluso contradictoria - mientras permanecen totalmente implicados en discursos públicos." [Traducción propia] 
Tercera parte:

Autobiografía de la mujer en tránsito en la expresión audiovisual contemporánea. 
VI. La autobiografía de la mujer en tránsito en el campo de las artes audiovisuales. 
En el presente capítulo, analizaremos diversas expresiones audiovisuales de artistas que trabajan sobre la cuestión de la identidad de la mujer que se encuentra en tránsito entre culturas, políticas y generaciones, introduciendo los estudios que hemos desarrollado hasta este momento.

En concreto, nos aproximaremos a los trabajos audiovisuales de Mona Hatoum, Trinh T. Minh-ha, Tracey Moffatt, Fiona Tan, Kimsooja, y Agnès Varda, finalmente haremos referencia a un vídeo-documental de la doctoranda. Las obras que analizaremos se producen entre la década de los ochenta y los comienzos del presente siglo. Presentan una gran variedad en la expresión, técnica, soporte y medios de representación audiovisual. Al mismo tiempo, expondremos como todas ellas muestran aspectos autobiográficos de la mujer en transito. A excepción de Tracey Moffatt y Agnès Varda, las demás artistas trabajan en el "extranjero"; o dicho a la inversa, ellas son extranjeras en el país de filmación. En los trabajos que hemos seleccionado se percibe el reflejo de sus propias experiencias vividas como extranjeras o exiliadas. Sus trabajos nos parecen muy adecuados para exponer nuestras aproximaciones sobre la expresión autobiográfica audiovisual de la "mujer en tránsito".

En el caso de Moffatt, ella trabaja en Australia, su país de nacimiento, pero en su trabajo cuestiona su identidad como una hija aborigen adoptada por una familia colonizadora. Con el fin de reflexionar sobre la identidad de la mujer que se encuentra en tránsito cultural en su propio país, el análisis de su trabajo resulta más que adecuado. El caso de Agnès Varda presenta, a primera vista, dudas sobre la conveniencia de su inclusión en el presente estudio, sin embargo, tal y como hemos argumentado hasta ahora siguiendo a Shoshana Felman, que argumenta que para que aparezca la autobiografía de la mujer, es preciso convertirnos en testigos del relato femenino para poder seguir hablando sobre ella. Así pues, el trabajo que destacaremos de Varda es extraordinario desde el punto de vista del tránsito, del tiempo y del rol de la mujer. 
Antes de comenzar el análisis de cada una de las obras seleccionadas, ofreceremos un breve repaso entorno al contexto artístico del videoarte, el documental o la influencia cinematográfica en el arte y la instalación, que provocaron cambios e incidieron en los discursos artísticos del momento. Como hemos visto anteriormente, el cambio radical en la expresión -tanto teórica como práctica- del documental de los años sesenta y setenta, se debe a la emancipación ideológica y también al desarrollo técnico del soporte. Este cambio se generalizó a nivel mundial, tanto en el campo documental como en el ámbito del cine. También, fuera de la industria cinematográfica, las diversas expresiones audiovisuales se inician en estas décadas, tales como el videoarte y el performance. Anna Maria Guasch explica una tendencia que se encuentra el inicio de videoarte siguiendo a John G. Hanhardt:

De hecho, tal como afirma John G. Hanhardt, la incorporación del vídeo a la praxis artística hay que entenderla como oposición a la televisión comercial, pero también como consecuencia de la búsqueda de prácticas intertextuales por parte de artistas del assemblage, del happening, del fluxus, etc., que rechazaban la noción de arte existencial derivada del expresionismo abstracto y cuestionaban la noción de arte elevado. ${ }^{l}$
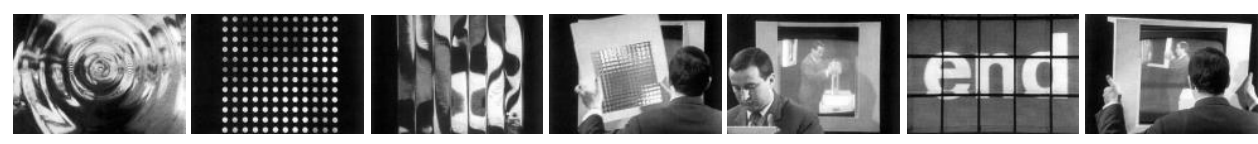

50. Auto-Vision (1964), Karl Gerstner

En el comienzo de los años sesenta los artistas como Tom Wesselmann, Gunther Uecker, Isidore Isou y Karl Gerstner comienzan a introducir la TV como material en su expresión; es decir, utilizan imagen simbólica y aparato físico de la televisión en sus obras. Y W. Vostell y N. J. Paik que son pioneros del videoarte, también comienza introducir el monitor televisivo en su trabajo.

\footnotetext{
${ }^{1}$ Guasch, Anna Maria, El arte último del siglo XX. Del posminimalismo a lo multicultural, Madrid, Alianza Editorial, 2000, p. 441.
} 
Implicados desde principios de los años sesenta en el movimiento fluxus y críticos respecto al papel social y cultural de las instituciones, en torno 1960 W. Vostell y N.J.Paik empezaron a utilizar monitores de televisión, que presentaban a la manera de esculturas en exposiciones de arte, como iconos de la nueva cultura de masas. ${ }^{2}$

En 1963, Wolf Vostell presenta Wolf Vostll \& Television Décollage Posters \& Comestible Décollage en la Smolin Gallery de Nueva York. El concepto de décollage fue acuñado por Vostell en 1950 que sería como antítesis del concepto artístico collage, el cual designaba a las creaciones por medio de capas. El artista presentó decollage televisivo dentro de la exposición mencionada. Es una aplicación del principio de decollage en televisor: seis televisores expuestos de distintos programas televisivos con imágenes que habían sido perturbadas. Sylvia Martín comenta sobre la postura de Vostell comparándolo con Paik:

Si Paik, en sentido constructivo, se aprovecha de las posibilidades que ofrecía la transferencia electrónica de datos y su aparición operativa, Wolf Vostell representaba con el llamado décollage televisivo, un contenido claramente crítico de la incipiente hegemonía de la televisión. ${ }^{3}$
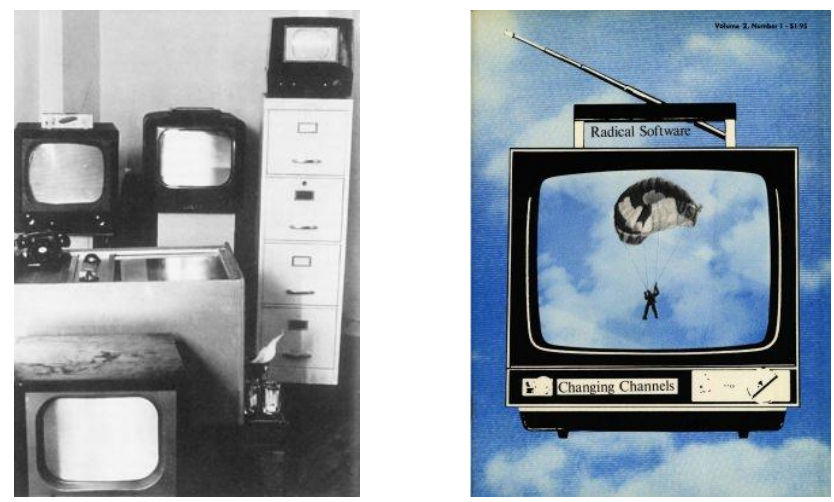

51. Television Décollage (1963), Wolf Vostell [izquierda] 52. Radical Software, Volume II, Number 1(Winter 1972), Changing Channels [derecha]

\footnotetext{
${ }^{2}$ Ibíd., p. 442.

${ }^{3}$ Martín, Sylvia: Videoarte Colonia: Taschen Gmbh, 2006. p. 8.
} 
Esta conciencia de los videoartistas continúa gracias a Guerrilla TV, un grupo de vídeoactivismo de Estados Unidos que presenta su propia declaración en 1971. Paralelo a este movimiento sobre la TV, se encontraba la corriente cinematográfica underground que también tenía un carácter de oposición a la corriente televisiva dominante. Como pilar de esta corriente encontramos la revista Radical Software ${ }^{4}$, que funcionaba como matriz de los conceptos teóricos y reafirmaba las posibilidades de libertad de expresión del vídeo y la película de la cámara portátil, criticando el autoritarismo televisivo. En este contexto, se originan casi todas las monografías de videoarte a partir de esta década, con trabajos de artistas principalmente estadounidenses.

En los años setenta, como indicaba Michael Renov que hemos referido en el capítulo anterior, la influencia del feminismo se hace más visible en la expresión audiovisual. Muchas mujeres artistas presentan trabajos audiovisuales memorables en esta década. Por ejemplo, Jonan Jonas, una artista pionera que practicaba performance, grabó en vídeo su acción en 1970, Jonas Bach Piece, realizada en Jones Beach (Long Island). Martín describe su método de trabajo con el vídeo, distinguiéndola de otros videoartistas. Citamos sus palabras:

Jonan Jonas, pionera en el arte de la "performance", utiliza el vídeo en sus acciones como medio de expresión complejo y, en la década de 1970, marca claramente una diferencia con el uso reducido que hacen del medio artistas como Bruce Nauman o Vito Acconci. Según sus palabras: "El vídeo es un mecanismo que extiende las fronteras de mi diálogo interior para incluir al público. La percepción es una doble realidad: mi persona como imagen y como intérprete. Creo en el trabajo en términos de poesía imaginista; elementos dispares yuxtapuestos [...] alquimia.» ${ }^{5}$

\footnotetext{
${ }^{4}$ Radical Software http://www.radicalsoftware.org/e/index.html, accedido el 15 de julio del 2009

${ }^{5}$ Martín, Sylvia, Op.cit., p. 62.
} 

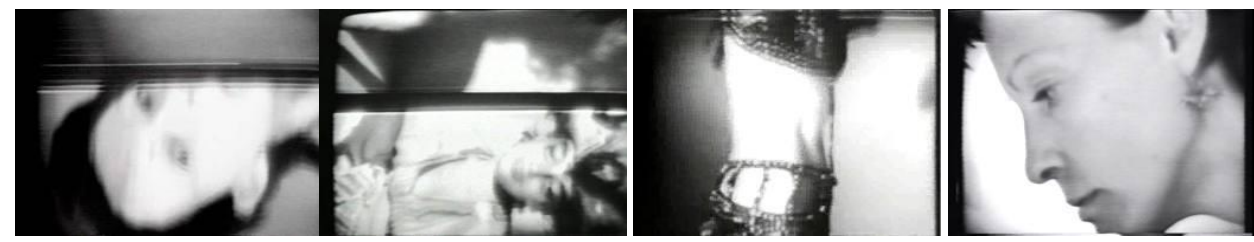

53. Vertical Roll (1972), Joan Jonas

En Japón, en 1971-1972 Fujiko Nakaya ${ }^{6}$ realiza Minamatabyoo kokuhatsusurukai, Tentomura video-nikki (El grupo de denuncia de Minamatabyou: vídeo-diario del grupo de la tienda de campaña). Presenta en la primera exposición de videoarte en Japón, Video Communication: Do it yourself kit (1972). Es un vídeo-diario que registra unas actividades de apoyo a las víctimas de la enfermedad de Minamata $^{7}$ estableciendo un campamento frente a la oficina principal de Chizzo, la empresa causante de ese desastre ecológico (en Tokio). Dentro de unas imágenes impactantes de los altercados con los guardias o de las miradas frías y deprimentes de los empleados desde los edificios, nos llama la atención unas escenas en las que graban sus propias actividades a través del vídeo, filmado por Nakaya o su acompañante Hakudou Kobayashi en un monitor pequeño. Hiroaki Sato, videoartista e investigador japonés de la imagen en movimiento, comenta sobre la obra:

\begin{abstract}
Dentro del vídeo-movimiento, al proyectar la imagen de los participantes o los interesados que acaba de ser grabada y ser vista inmediatamente en el monitor, el "feedback" es extraordinariamente efectivo. Ésto ya había sido demostrado en el primer período del vídeo-movimiento en EE.UU., nos sugiere que Nakaya fue animado a participar en estas actividades del grupo. Nakaya comenta sobre esta obra: «ya que el vídeo es verdaderamente eficaz como herramienta de
\end{abstract}

\footnotetext{
${ }^{6}$ Fujiko Nakaya: actualmente presenta obras de tipo Landscape Art con instalaciones de niebla artificial. Su padre Ukichi Nakaya es investigador especialista de nieve y colaboró en la realización del documental Yuki no kesshou (El cristal de nieve, 1939) y ello ocasiona la creación de la productora Iwanami Eiga. La web oficial de la artista es: http://processart.jp/nakaya/e/profile_e.html, accedido el 20 marzo del 2011.

${ }^{7}$ Enfermedad de Minamata: enfermedad ocasionada por la contaminación de vertidos industriales de la fábrica de abono químico de Chizzo en Minamata, Kumamoto (Japón). Para más detalles véase el V.2.
} 
comunicación, simplemente pensé en probarlo en el lugar donde ahora mismo ocurre la des-comunicación.» ${ }^{8}$

Ésta es una muestra del interés de la artista en la interactividad del vídeo como herramienta de comunicación desde el período inicial del vídeo-movimiento en Japón. A la vez, este comentario también nos enseña que, en el contexto del primer período de las artes audiovisuales en Japón, no se encontraba una división clara entre el vídeo-documental y el videoarte.
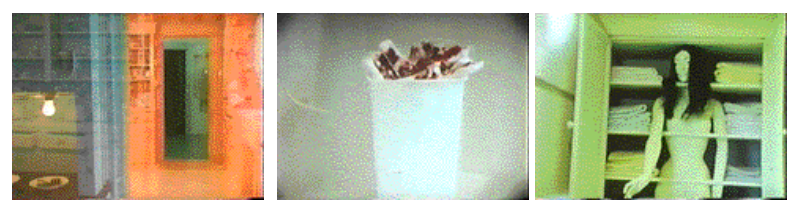

54. Woman's House (1972), Mako Idemitsu [izquierda]

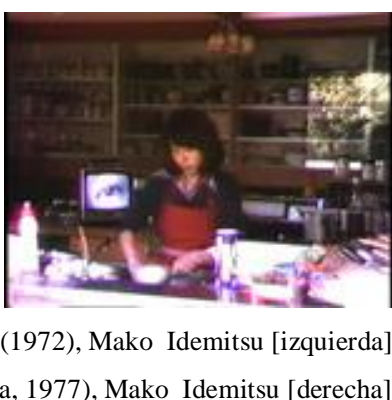

55. Shuhu no itinichi (Un día de ama de casa, 1977), Mako Idemitsu [derecha]

En distinto contexto en Japón, Mako Idemitsu9 (1940- ) presenta en 1977 la obra de vídeo Shuhu no ichinichi (Un día como ama de casa) ${ }^{10}$. Es un vídeo a color, de 9 min. $40 \mathrm{seg}$. (la versión inglesa, 9min. 50seg.) de duración ${ }^{11}$. Idemitsu se traslada a Los Ángeles, California, para contraer matrimonio con Sam Francis, un pintor estadounidense. Después, se divorcian, y ella regresa a Japón. Durante su estancia en Los Ángeles realizó su primera película de 16mm., Woman's House, presentada en 1972, a color, de 13min.40seg. de duración. En ella registra la casa monumental del arte feminista creada por el proyecto de Judy Chicago,

\footnotetext{
${ }^{8}$ Sato, Hiroaki: Shiminvideo, Art to documentary no aidade [El vídeo del ciudadano: entre el arte y el documental], en VV.AA: Gendaishiso. Revue de la pensée d'aujourd hui [El pensamiento contemporáneo, Revista del pensamiento de hoy en día], Documentary, Vol.53-13, Tokio: Seidocha, 2007, p. 129. [Traducción propia por original japonés]

${ }^{9}$ Mako Idemitsu, su web oficial es http://www.makoidemitsu.com/www/home_j.html, accedido el 20 marzo 2011.

${ }^{10}$ Este trabajo está en la corrección de la MoMa, el Museo arte moderno de Nueva York. Esta archivada como Another Day of Housewife (1977-1987) video, color y sonido, 18 minutos de duración en web de MoMa PS1: http://www.moma.org/collection/browse_results.php?object_id=118191, accedido el 1 de abril del 2011. Los datos de la obra es distinto con loas que tiene en el WEB oficial de la artista. Nosotros seguimos con los datos según el web de la artista, los enlaces mira a nota 7 y 9.

${ }^{11}$ http://www.makoidemitsu.com/www/video-j.html, (http://www.makoidemitsu.com/www/video.html), accedidos el 23 de marzo 2011.
} 
Miriam Schapiro y sus estudiantes. Volviendo a Shuhu no ichinichi, este vídeo muestra un largo día de un ama de casa con hastío. En cada escena aparece una TV que contiene la imagen de un ojo como si estuviera observando la labor de la mujer. Esta introducción de la imagen del monitor con el ojo dentro de la obra, también llamada Mako Style, recibe una fama internacional.

Martha Rosler (1943- ) trabajaba en performance y fotografía con la técnica del collage. Presentó su trabajo de vídeo Semiotics of the Kitchen en 1975. Caricaturizando el papel de la mujer en el hogar con cierta ironía y visibilizando la violenta frustración del ama de casa como una parodia de programa de TV, que ofrece una imagen estereotipada del modelo ideal de ama de casa. Martín describe esta obra de la siguiente manera:

La actriz [Rosler] empieza a nombrar los utensilios de cocina de forma alfabética de la A hasta la Z; los objetos se muestran al público con gestos agresivos o frustrados, de manera que sea innegablemente perceptible el carácter neurótico de la «perfecta ama de casa televisiva», hasta que Rosler empieza a lanzar un cuchillo al aire y volver a agarrarlo. ${ }^{12}$
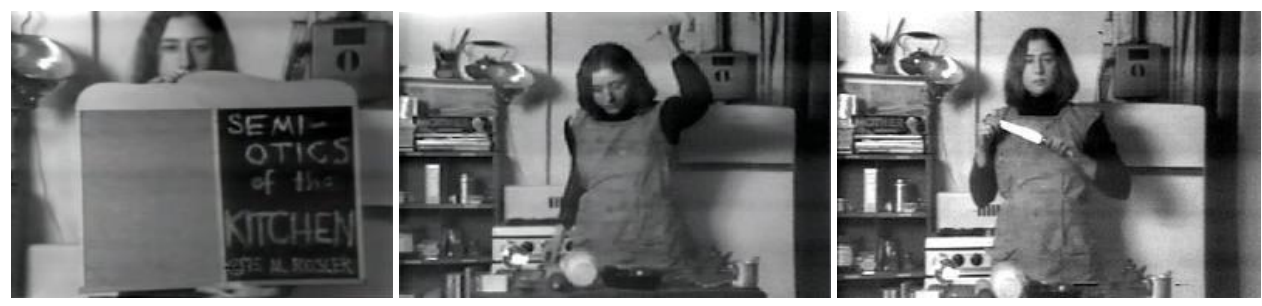

56. Semiotics of the Kitchen (1975), Martha Rosler

Los temas del hogar, las críticas a los estereotipos y la reclamación sobre las aplicaciones de la imagen femenina, obtienen en este período un reconocimiento a nivel mundial gracias a la actividad de las artistas a través de ciertas expresiones audiovisuales en el videoarte, al igual que en otros medios.

\footnotetext{
${ }^{12}$ Martín, Sylvia, Op.cit., p. 82.
} 
Al final de los años setenta, Dara Birnbaum presenta Technology/ Transformation: Wonder Woman (1978/1979, en vídeo, de 5min. 16seg. de duración). Es una obra que aprovecha las escenas de un programa televisivo sobre heroínas llamado Wonder Woman (La Mujer Maravilla), creado como versión antagónica de Superman.

La artista alinea secuencias de su transformación mágica y con ello abre la discusión sobre la imagen de la mujer en la sociedad y en los medios. ${ }^{13}$
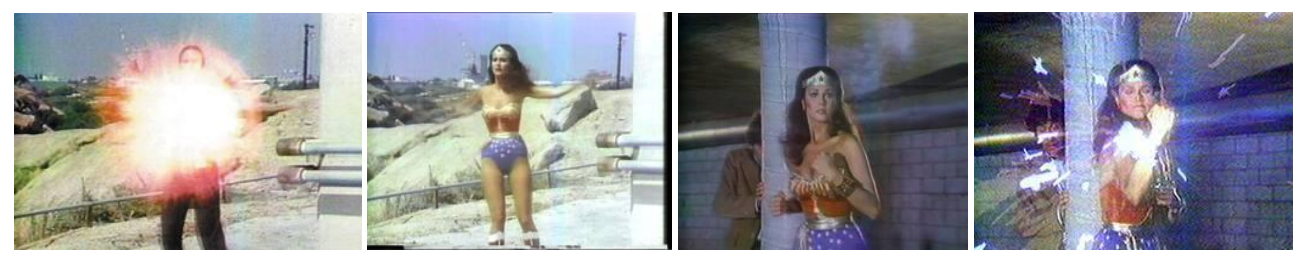

57. Technology/ Transformation: Wonder Woman (1978/1979), Dara Birnbaum

Ya mediante este trabajo, el videoarte utiliza las imágenes de un programa de TV con ciertas modificaciones, mostrando las diferentes maneras de interpretar las imágenes y criticando el tratamiento de la mujer en la imagen televisiva. Se descubre que la estructura de la figura de la "mujer maravilla" se confina a las obligaciones impuestas por la sociedad y a lo que de ella se espera.

También nos gustaría añadir una referencia sobre unas obras audiovisuales de esta década que coinciden con el tema de la mujer y el reclamo a la sociedad patriarcal. Niki de Saint Phall realiza en 1973 la película $\operatorname{Daddy}^{14}$ (Papi, a color, de 90min.) en colaboración con Peter Whitehead. En un folleto de un ciclo retrospectivo de Whitehead en Buenos Aires $9^{\circ}$ Festival de Cine Independiente se ofreció una descripción sobre la película:

\footnotetext{
13 Ibíd., 2006, p. 15.

${ }^{14}$ En marzo del 2007 se presenta la película en formato Digibeta de Peter Whitehead en Buenos Aires $9^{\circ}$ Festival Internacional de Cine Independiente, presentada por Contemporary Films: http://www.contemporaryfilms.com/, accedido el 22 marzo del 2011.
} 
Lo que comenzó como un documental acerca de la escultora francesa Niki de Saint Phalle terminó como una fantasía - en colaboración entre la propia De Saint Phalle y Whitehead-sobre los intentos de una mujer por exorcizar la influencia de su abusadora figura paterna. Alternativamente góticas y surrealistas, De St. Phalle y Mia Martín son protagonistas de esta suerte de Molestando a papá en tono de charada, exteriorizando sus fantasía sobre un pobre y desafortunado patriarca, ... ${ }^{15}$

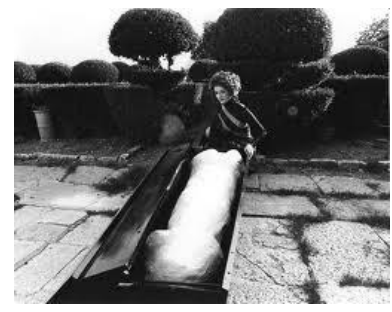

58. Daddy (1973), Niki de Saint Phalle y Peter Whitehead

En las obras de la primera etapa de Niki de Saint Phalle son muy notables los temas de la mujer y de la relación compleja entre el amor y el odio en la familia patriarcal. En esta película -concebida con un carácter entre documental, experimental y fantasía- podemos encontrar una síntesis de su pensamiento y las motivaciones para su creación artística.

Para finalizar la recapitulación de las actividades de las artistas feministas del videoarte en los setenta, Sylvia Martín comenta que Dara Birnbaum junto con Valie Export, Lynn Hershman, Nancy Holt, Ulrike Rosenbach, Martha Rosler, Rosemarie Trockel y Friederike Pezold pertenecen a la primera generación de artistas feministas que introducen el vídeo a su trabajo con el fin de cuestionar la posición y la imagen de la mujer dentro de la sociedad mediática ordenada hacia el patriarcado ${ }^{16}$.

En la siguiente década, parece que tiene lugar una reacción a la dura transgresión de las primeras artistas feministas, ya que aparecen unas artistas que muestran con mayor sutileza

\footnotetext{
15 http://www.thestickingplace.com/wp-content/uploads/2009/01/retro_whitehead11.pdf, accedido el 15 de noviembre del 2009.

${ }^{16}$ Martín, Sylvia, Op.cit. p. 15.
} 
y un coqueteo estratégico la obviedad femenina en sus trabajos. Martín lo comenta del siguiente modo:

El ídolo del pop Madonna ejemplifica el concepto aparecido en la década de 1980 de «obviedad femenina», que muestra un trato infantil a través de roles cada vez más debilitados. Artistas como Pipilotti Rist, Andrea Frazer, Mona Hatoum, Sam Taylor-Wood o Venessa Beecroft, combinan composiciones conceptuales, documentales y escenificadoras sin transición. Conceptos como la ficción y la realidad o la parodia y la autenticidad se entrelazan y extraen el carácter dogmático y emancipador de los años anteriores del tema principal. ${ }^{17}$

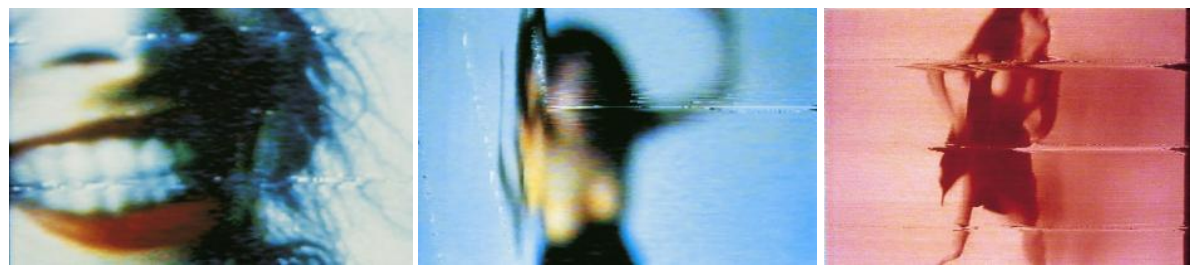

59. I Am Not The Girl Who Misses Much (1988), Pipilotti Rist

En los años ochenta, se podría decir que, a gran escala, ocurre algo similar a los casos de documental japonés. La importancia de la resistencia contra el poder político cultural se debilitaba. En el caso del arte feminista, el fuerte reclamo sobre lo patriarcal, el intento de destruir la imagen femenina creada por los varones y el manifiesto de la igualdad de la mujer se perciben cada vez menos en los trabajos de las artistas de la siguiente generación.

Aparentemente, se podría juzgar que en los trabajos de las artistas de la década de los ochenta se percibe cierta connotación infantil y la obviedad femenina. Sin embargo, nosotros ahora diríamos, más bien, que las artistas de la siguiente década comienzan a centrar más la atención en lo íntimo-personal y a cuestionar la feminidad en sí.

\footnotetext{
${ }^{17}$ Loc.cit.
} 
Gracias a las artistas feministas de las primeras generaciones se ha visibilizado bastante la imagen femenina construida por el sistema patriarcal y el androcentrismo. A través de la acusación de su incómoda posición como mujer, se trata de superar dicha posición. Pero en muchas ocasiones las expresiones de las primeras etapas del arte feminista solo hablan de su pena como víctimas y sobre su condena por ser mujer.

Seguramente, también ello es un aspecto fundamental que debe abordarse en la expresión femenina debido a la existencia de tan diversas realidades de tantas mujeres oprimidas y despreciadas en nuestro mundo. Puede ser que sea necesario seguir visibilizándolo, no obstante, una vez que se afirma la legitimidad de este aspecto en la disciplina artística, se convierte en un dogma o en un requisito indispensable que se debe cumplir en las obras artísticas. En este sentido, es bastante comprensible que haya cierta reacción contra este dogmatismo en las siguientes generaciones.

En los siguientes apartados iniciaremos el análisis de los trabajos de artistas en tránsito, centrados en el tema de la autobiografía de la mujer. 
VI.1. Measures of Distance (1988), Mona Hatoum: la representación de las discrepancias entre los sentimientos de una madre y su hija. 
En la presente sección comenzaremos con el análisis de la obra Measures of Distance ${ }^{l}$ de Mona Hatoum, presentada en 1988 y basada en el tema de la autobiografía de la mujer en tránsito. Este análisis supone el inicio de nuestras aproximaciones a los trabajos audiovisuales seleccionados en torno al tema.

Tal y como hemos visto en la parte introductoria del presente capítulo, la artista es considerada como una de las exponentes de la segunda generación dentro de la dinámica del arte feminista en el videoarte. En concreto, esta artista presentó en los años ochenta unos trabajos en vídeo, mientras realizó a la vez performance e instalaciones.

Mona Hatoum $^{2}$ es ya una artista muy reconocida internacionalmente. Trabaja con múltiples medios y materiales, y presenta su obra principalmente en escultura, vídeo, instalaciones y vídeo-instalaciones. Ha participado en exposiciones internacionales, tanto en la Documenta XI de Kassel (2002) como en la Bienal de Venecia (1995 y 2005). De hecho, algunas de sus obras forman parte de colecciones públicas, como por ejemplo la del Centro Pompidou de París, en el MoMa de Nueva York o la Tate Modern de Londres, entre otras ${ }^{3}$.

En España, su exposición individual contaba con algunas obras recientes de escultura e instalación: Mona Hatoum: Le grand mond ${ }^{4}$ fue exhibida en la Fundación Botín en Santander desde octubre del 2010 hasta enero del 2011. En el año en curso ha ganado también el premio Joan Miró, y actualmente prepara una exposición para la Fundación Joan Miró de Barcelona para el próximo año 2012. Un comentario de los jurados ${ }^{5}$ sobre la artista subraya la importancia de su contribución y el gran significado de sus trabajos en el ámbito artístico:

\footnotetext{
${ }^{1}$ Para el presente análisis hemos accedido a su obra archivada en UBUWEB: Measures of Distance (1988), vídeo de $15^{\prime 2} 26^{\prime \prime}$ de duración, PAL, son, a color. En: http://www.ubu.com/film/hatoum_measures.html, visualizado el 13 de mayo de 2011.

${ }^{2}$ http://www.rtve.es/alacarta/videos/programa/metropolis-mona-hatum/1071615/, visualizado el 10 de junio de 2011.

${ }^{3}$ http://www.whitecube.com/artists/hatoum/, accedido el 20 de junio de 2011.

${ }^{4}$ http://virtual.fundacionbotin.org/visita mona/index.html, accedido el 15 de mayo de 2011.

5 Alfred Pacquement (director del Centro Georges Pompidou), Vicente Todolí (ex director de la Tate Modern), Paul Erik Tojner (director del museo de Arte Moderno de Luisiana) y Rosa María Malet (directora de la Fundación Miró), en: http://www.fundaciomiro-bcn.org/premijurat.php?idioma=4, accedido el 9 de mayo de 2011.
} 
"[Mona Hatoum] ha sido pionera a la hora de vincular las prácticas artísticas a realidades no occidentales, mostrando las conexiones que se establecen entre la cultura occidental y los acontecimientos culturales y políticos transnacionales. A partir de Hatoum, el mundo del arte se ha vuelto un lugar más abierto y menos centrado en sí mismo"t6

Asimismo, esta crítica asegura nuestro acierto al iniciar la presente aproximación a su trabajo. Partimos desde la perspectiva analítica de las expresiones audiovisuales de las artistas en tránsito, y nos basamos en lo que hemos desarrollado hasta el momento en relación a las cuestiones de realidad e identidad no occidental. Continuamos explorando la interrupción y la articulación entre culturas diferentes.

Antes de comenzar a analizar su obra, explicaremos brevemente la trayectoria de la artista. Mona Hatoum nace en Beirut, Líbano, como hija de una familia palestina exiliada. En 1975 parte a Londres y toma la decisión de permanecer en este país con el fin de huir de la guerra civil libanesa. Mientras, se inicia en el estudio del arte. Stéphanie Moisdon, crítica, comisaria independiente y cofundadora de The BDV (Bureau des vidéos) comienza a escribir un texto sobre la obra a la que nos vamos a aproximar?

En quittant le Liban, Mona Hatoum a laissé derrière elle sa famille palestinienne, et en particulier sa mère. «Measures of Distance» relit la douleur de cette rupture. ${ }^{8}$

Su condición como exiliada no solo es palpable en su vida real, sino que se convierte en un tema importante en su expresión. En este sentido, podemos calificar a Mona Hatoum como una artista exiliada, al igual que a otras artistas a las que nos referiremos en adelante.

\footnotetext{
${ }^{6}$ Serra, Catalina: Mona Hatoum logra el III Premio Joan Miró en el periódico El País, Barcelona, 07/02/2011: http://www.elpais.com/articulo/cultura/Mona/Hatoum/logra/III/Premio/Joan/Miro/elpepucul/20110207elpepucul_9 /Tes, accedido el 9 de mayo de 2011.

${ }^{7}$ Encyclopedie Noveaux Media, en: http://www.newmedia-art.org/index.htm, accedido el 13 de junio de 2009.

${ }^{8}$ Moisdon, Stéphanie: Measures of Distance en Vidéo et après. La collection vidéo du Musée National d'Art Modern Centre Pompidou, París; Édition Carré, 1992, pp. 152 [http://www.newmedia-art.org/cgi-bin/showoeu.asp?ID=I0150238\&lg=FRA, accedido el 13 junio 2009]: Al dejar el Líbano, Mona Hatoum ha dejado tras de sí a su familia palestina, y en particular a su madre. "Measures of Distance" está unida al dolor de esta ruptura. [Traducción y transcripción propia]
} 
Durante el primer período de su carrera, en los años ochenta, Hatoum trabaja intensamente el tema político en performance y vídeo. En el año 1989 la artista presenta The Light at the End como su primera gran obra escultórica y, a partir de entonces, durante los años noventa, comienza a presentar activamente trabajos escultóricos e instalaciones. Anteriormente había presentado en 1988 Measures of Distance, una obra que puede ser considerada como un punto de inflexión y divergencia en su trayectoria artística.

\section{VI.1.1. La expresión audiovisual de la autobiografía de la mujer.}

La obra Measures of Distance es un trabajo audiovisual conmemorativo y significativo tanto de la artista como de la representación audiovisual autobiográfica, clave en nuestra investigación. La calificaríamos como autobiografía de la mujer según la argumentación de Shoshana Felman que hemos desarrollado en el primer capítulo ${ }^{9}$. Según Felman, la autobiografía de la mujer conlleva algunas paradojas fundamentales. Una de las paradojas se refería al tabú del trauma. Con el fin de recordar los conceptos fundamentales de la autobiografía femenina, según la argumentación de Felman, vamos a repasarlos brevemente.

En resumen, incluso la escritura de una autobiografía femenina -a pesar de ser escrita por una mujer- se realiza desde la perspectiva masculina debido a la educación, las tradiciones y los modos de escritura anclados en la Historia del Hombre. Dicho de otro modo, al escribir sobre la vida de la mujer no se puede evitar una cierta opresión porque la escritura masculina limita la expresión e interviene para que ésta sea entendible. Es decir, la parte diferente, lo que es propiamente de la mujer, quedaría fuera de la comprensión. En este sentido, la vida de una mujer expresada mediante la escritura-lenguaje del hombre nunca puede ser completa: siempre quedará una parte indecible, que es precisamente la parte propiamente femenina. Con esta opresión, por parte de la escritura-lenguaje masculino, la mujer sufre por no poder expresarse plenamente sobre sí misma o por no tener palabras propias.

\footnotetext{
${ }^{9}$ Váyase al capítulo I.
} 
Además, Felman sintetiza esta situación en la expresión de la mujer de la siguiente manera: la vida de la mujer, sea consciente o inconscientemente, incluye un trauma. El trauma es algo indecible, aprisionado por la conciencia y que hace sufrir a quien lo ha vivido. En general, el trauma se encuentra escondido; pero, en un momento dado, se manifiesta a través de los síntomas. Para que la memoria y la experiencia traumática puedan ser pronunciadas, se necesita un proceso psicoanalítico.

Así, Felman considera que la autobiografía femenina es la expresión de la vida de una mujer que incluye un trauma, para diferenciarla de la confesión; esto es, de una confesión en una narración que se enfoca en la culpabilidad personal, se corre el peligro de esconder lo indecible. Esta indicación de Felman no desvaloriza la importancia de diversas expresiones de confesión y de soliloquio de la mujer. Sin embargo, la expresión autobiográfica femenina que nosotros consideramos en nuestro discurso -basado en la argumentación de Felman- no concuerda al completo con la naturaleza de las confesiones y su representación audiovisual.

Hemos comentado la necesidad del proceso psicoanalítico en la creación de la autobiografía de la mujer, pero también reflexionamos sobre el problema del psicoanálisis en nuestras aproximaciones a la teoría de Felman. Sobre todo, en relación a la dinámica de poder entre psicoanalista-hombre-Freud y paciente-mujer-histérica, según la crítica Sara Kofman ${ }^{10}$. Kofman y Felman concuerdan en que Freud podría ser considerado como el primer hombre que quiso conceder la palabra a la mujer, descubriendo su parte propiamente indecible. Pero, al mismo tiempo, él le obliga a auto-calificarse como "histérica". Parece que aquella opresión del lenguaje masculino, el cual limitaba la expresión de la mujer, hace que la mujer solo consiga un lugar como "parlante histérico" -a pesar de las posibles buenas intenciones de Freud para que la mujer participe en el mundo como parlante-. En este contexto, Felman señala una resistencia femenina contra la opresión masculina, en la lectura del caso de Irma $^{11}$ la que resistió a Freud permaneciendo en silencio.

\footnotetext{
${ }^{10}$ Váyase a I.2.1.

${ }^{11}$ Irma es una paciente de Freud, el psicoanálisis de sus sueños le inspira escribir La interpretación de los sueños (1900). Los detalles se pueden ver en los apartados del I.2.
} 
Con estas paradójicas circunstancias, en torno a la autobiografía de la mujer, Felman plantea una lectura entre mujeres como posible solución. Al mismo tiempo, indica que la posible autobiografía de la mujer se convertiría en el testimonio de la supervivencia de la misma.

Entonces, para que la vida de la mujer y su trauma sean expresables, sí que es necesario un cierto dialogo psicoanalítico en el que se realice un proceso que permita expresar la experiencia traumática. A través del proceso de escucha de los relatos de las mujeres y del "habla", como testigos del relato que incluye lo indecible, se estaría preparando la posible autobiografía de la mujer.

Con todo, en la expresión autobiográfica femenina es importante aquello que es expresable sobre la vida de la mujer; al mismo tiempo, es indispensable que existan indicaciones sobre lo indecible, donde se señale la ruptura y la conexión que se encuentra en los relatos y en las lecturas de las mujeres. Y la obra Measures of Distance, igual que los otros trabajos seleccionados en el presente capítulo, puede sobradamente ser considerada como una representación autobiográfica femenina en esta línea, como veremos. Además, esta expresión audiovisual nos facilitaría la aproximación a la posible autobiografía de la mujer. Lo averigüemos durante nuestro análisis de ahora en adelante.

\section{VI.1.2. Mi querida Mona. Cartas de la madre.}

Antes de comenzar a fijarnos en los detalles, ofreceremos una breve descripción del trabajo Measures of Distance. Éste es un vídeo a color de 15minutos 26 segundos de duración. El vídeo empieza con el fondo de una imagen de una fotografía no muy definida. La imagen está cubierta con letras árabes escritas a mano en una superficie enrejada. Tras un breve instante, comienza el audio de una conversación en árabe de dos mujeres. Luego entra una voz en off en inglés que narra: es la de la autora que traduce la carta de su madre. En el momento en que cambia la imagen, la caligrafía bajo la superficie enrejada también cambia. Tras el paso de varias imágenes (algunas veces, aparecen imágenes de una cabeza, y luego 
el torso de una mujer desnuda a contra luz), se reconoce que son partes del cuerpo de una mujer. Moisdon lo describe de modo siguiente:

Derrière une surface quadrillée par des mots écrits en arabe, des formes abstraites se dessinent. Ce voile, cette paroi opaque posée comme un deuxième écran entre notre regard et l'image, est la matière même d'une lettre de la mère à l'artiste. ${ }^{12}$

La narración de la voz en off traducida al inglés, y la superficie opaca puesta como una segunda pantalla (según Moisdon) de las letras árabes que cubre la imagen, son dos detalles que nos señalan la introducción de la carta de la madre de la artista.

Después de la segunda mitad del vídeo, una vez se oscurece y desaparece la imagen, aparece otra, rectangular, alargada, en medio del fondo negro. La imagen es del torso de la mujer desnuda a contraluz e incluye las letras árabes que cubren la imagen. Tras un tiempo, esa imagen rectangular alargada se funde con una imagen de la parte del cuerpo de la mujer en todo el encuadre, igualmente junto a las letras árabes, como un malla fina enrejada.

Hay ciertos momentos en que se encuentran estas dos imágenes superpuestas: una es un rectángulo alargado del torso de la mujer desnuda, la otra de partes del cuerpo a tamaño de la pantalla. Luego, una desaparece fundida, alternativamente, deja la otra y vuelve a aparecer. Finalmente, al comienzo de la narración de la voz en off de la última carta, desaparecen totalmente, tanto la imagen, como el audio de las conversaciones de las mujeres. Con esta descripción, ya es posible reconocer que en esta obra se juega y se cuestiona la relación entre aparición y desaparición, continuación y ruptura, imagen y texto, relato y cuerpo, escritura y lectura, lectura y traducción. Todos ellos relacionados con la mujer.

\footnotetext{
${ }^{12}$ Moisdon, Stéphanie: Measures Of Distance en Vidéo et après. La collection vidéo du Musée national d'art modern Centre Pompidou, Paris; Édition Carré, 1992, pp. 152. El mismo texto se encuantra en: http://www.newmedia-art.org/cgi-bin/show-oeu.asp?ID=I0150238\&lg=FRA, accedido el 13 junio 2009.

Detrás de una superficie llena de palabras escritas en árabe, formas abstractas se dibujan. Este velo, esta superficie opaca puesta como una segunda pantalla entre nuestra mirada y la imagen, es la materia misma de una carta de su madre a la artista. [Traducción propia]
} 
En concreto, a lo largo de la obra la parte narrativa de la voz en off recita el contenido de cinco cartas que la madre escribe a la artista, su hija, que vive lejos de ella. Comienzan siempre con una frase: Mi querida Mona. Las cartas relatan el amor de la madre hacia su hija, expresan su adoración por ella y su lamento por el hecho de estar separadas. Aparte de ello, la madre se pronuncia como subdominante bajo el sistema patriarcal. Dentro de la tensión de los relatos, la madre expresa su alegría y el placer que siente al construir una nueva relación de amistad con su hija -la cual se encuentra en proceso de hacerse mujer- y al compartir un secreto común frente al esposo-padre. También observamos la perplejidad de la madre ante las preguntas de una hija que se enfrenta a una crisis dentro de una cultura totalmente distinta a la que ha conocido durante su vida antes de partir a Inglaterra.

La artista nunca habla en primera persona, sino que relata a través de las cartas de su madre. Es decir, quien habla en primera persona es realmente la madre. No obstante, las cartas ilustran cuestiones de identidad y sexualidad que se encuentran muy relacionadas con la condición de la artista como exiliada. Madre e hija comparten su existencia como mujeres y sus circunstancias como exiliadas, además del contexto familiar palestino bastante patriarcal. Coinciden en algunas cuestiones esenciales de sus identidades, pero, al mismo tiempo, existen importantes diferencias entre ellas. El título de la obra, Medir la distancia, justificaría estos varios niveles de distanciamiento: de geografía política y cultural, geografía física, tiempo físico y generacional, intimidad. Lo que se está midiendo es la distancia entre madre e hija. A través del relato de las cinco cartas de la madre se construye la imagen de la misma, mientras se configura la imagen de la artista y se mide la distancia entre ambas. Aunque la artista no se pronuncie directamente a modo de soliloquio, en los márgenes entre imagen-frase-audio comprensible e incomprensible aparecen y desaparecen las diferencias, el desacuerdo y las discrepancias en la relación entre madre e hija. En este sentido, dentro de la presente obra, podemos encontrar un abismo en el que, paradójicamente, es posible la comunicación. De entre los aspectos más interesantes de la obra, la función de la traducción es clave en nuestra aproximación a la misma. 


\section{VI.1.3. La traducción en la dinámica de los códigos culturales: occidental, y no occidental.}

La expresión audiovisual del presente trabajo nos muestra diferentes niveles de fragmentación, diferencia y discrepancia. Por ejemplo, como hemos indicado, las imágenes corresponden a partes del cuerpo de una mujer (el propio cuerpo desnudo de la madre de la artista), la imagen está cubierta con una capa de letras que, a su vez, es un fragmento de las cartas de la madre escritas en árabe. La narración de la voz en off es la traducción de algunas partes de las cartas, y el audio que se escucha de fondo son partes fragmentadas de la conversación en árabe.

Cada uno de estos aspectos es indispensable para el presente trabajo, pero, sobre todo, la narración de la artista se constituye como el elemento fundamental, una especie de bisagra que permite construir estas diferentes capas de imagen y audio. Si centramos nuestra atención en esa narración, no podemos -obviamente- ignorar la función de la traducción. Además, en el presente caso, fijarnos en ella nos facilitará aclarar la estructura de la obra. Ahora lo veremos.

Como estudiamos en el capítulo IV, donde nos aproximamos al análisis de Shoshana Felman del documental $S h o a h^{13}$, lo que rompe el límite del medio es la interposición de la voz. Únicamente a través de la traducción podemos entender la expresión del original de otra lengua; sin embargo, éste es un proceso de interpretación, minimización y tergiversación que deforma su significado y sentido original. Ya vimos que en esa película documental, que duraba más de 9 horas y estaba formada solo por las escenas de entrevistas, los testigos hablaban en su lengua: polaco, alemán, inglés y hebreo, entre otros. Luego, el intérprete traducía lo que había querido decir el testigo con cierto retraso (a modo de interpretación consecutiva). En el medio audiovisual es posible oír la voz original del testigo con su gesto visual, aunque no se entienda lo que se dice, y escuchar con cierto retraso el significado, la traducción. Es más, este "retraso visibilizado" era un aspecto muy

\footnotetext{
${ }^{13}$ Shoah (1985) es una película documental de Claude Lanzmann que dura más de 9 horas. Esta obra trata sobre el proyecto de exterminio de los judíos realizado por los nazis durante la Segunda Guerra Mundial y cuestiona la imposibilidad de representación y de testimonio.
} 
importante en la obra, e incluso se mostraban algunas escenas en las que el mismo autor corregía al intérprete con el fin de indicar los riesgos de la traducción.

Igualmente recordamos la indicación según Gayatry C. Spivak ${ }^{14}$ sobre el intento de escribir sobre mujeres en diferentes culturas que se encuentran fuera del modo de producción dominante.

Estamos avanzando, pues, a partir de la tesis de que las mujeres fuera del relato del modo de producción marcan los puntos de fundido en la escritura de la historia disciplinaria en el mismo momento en que mimetizan «la escritura como tal», huellas del relato (¿de alguien?, ¿algo? -nos vemos erróneamente obligados a preguntar-) que se borra a medida que éstas se revelan. ${ }^{15}$

Spivak intentaba escribir sobre la mujer subalterna que se encuentra fuera del modo de producción dominante, una red de códigos político-económico-histórico-culturales. Pero estas mujeres no estarían suficientemente representadas. Spivak comenta que en esta situación es posible etiquetarlas, pero que no se les puede captar al completo. Ilustra sus dificultades para escribir sobre estas mujeres:

Así pues, por repetir una intuición anterior, las codificaciones a ras de suelo del valor que escriben las vidas de estas mujeres se nos escapan. Estos códigos solo son mesurables en el (flujo y reflujo del) modo de la forma total o desplegada, que es «deficiente» desde un punto de vista racionalista. ${ }^{16}$

En este contexto, Spivak se refería a 4 mujeres como modelo notable, entre ellas se encontraba Rigoberta Menchú. En su caso, por el afán tanto de proteger a su pueblo indígena bajo la opresión como de protestar contra la injusticia basándose en la denuncia de la violación de los Derechos Humanos, elige pronunciarse en el idioma del opresor. El

\footnotetext{
${ }^{14}$ Hemos desarrollado la lectura sobre el trabajo de Spivak en los apartados de capítulo II. y en algunos fragmentos del capítulo III. del presente trabajo.

${ }^{15}$ Spivak, Gayatri Chakravorty: Crítica de la razón poscolonial. Hacia una historia del presente evanescente, trad. Marta Malo de Molina, Madrid, Akal, 2010, p. 243.

${ }^{16}$ Ibíd., pp. 243-244.
} 
relato de Menchú, su traducción y transcripción incluyen un problema fundamental relacionado con el cambio del código cultural. Durante el proceso de hacer comprensible su relato se realizan modificaciones en las que se omiten las diferencias y se aplica lo que es más parecido. Pero aún más, si nos fijásemos en las lenguas no occidentales y occidentales, la diferencia sería aún más notable. Como consecuencia, las modificaciones serían más drásticas. Sin embargo, si se escapara de ese proceso facultativo de la traducción por el cual inevitablemente se modifica, el relato no se comprendería ni se oiría como una voz, sino que permanecería como un ruido cualquiera. Esto es, realmente, una situación bastante paradójica.

En esta situación, las codificaciones a red de suelo del valor que se escriben de estas mujeres se nos escapan; del mismo modo, el relato de las mujeres con diferencias culturales se nos aparece como una forma disgregada o sobrepasada. De todas maneras, no nos posibilita precisar su ser. Spivak indicaba dos cuestiones para una posible comunicación con cierta calidad en cuanto al respeto. Una la podemos encontrar dentro de la misma frase que comentaba: mesurable en el (flujo y reflujo del) modo de la forma total o desplegada, que es «deficiente» desde un punto de vista racionalista. Es decir, aunque no se adecua a la forma considerada más razonable, sería interesante respetar los modos de expresión originales. En este caso, el relato tendría el flujo y reflujo del modo de la forma total o desplegada. En concreto, nos daría la impresión de un conjunto de repeticiones insistentes, una expresión de superabundancia o alguna falta decisiva para la comprensión global. Spivak nos indica que hay ciertas cosas que solo se pueden encontrar dentro de esa forma de expresión.

La segunda cuestión es el empleo estratégico de la función del secreto. Ya hemos confirmado su argumento en el tercer capítulo ${ }^{17}$; por ello, solo lo repasaremos brevemente. En algunas ocasiones, para representar los relatos y sus indecibles diferencias se confiesa la existencia de un secreto. Frente a la violencia epistémica ${ }^{18}$ que funciona como una potencia dominadora y "poseedora" de otra cultura, los que reclaman desde la postura de su

\footnotetext{
${ }^{17}$ Léase sobre el relato de otra cultura en III.1.1. del presente trabajo.

${ }^{18}$ Léase sobre la violencia epistémica en II.1. del presente trabajo.
} 
"protección" intentan demostrarlo explicando bien los argumentos para evitar una interpretación equívoca y/o un malentendido, al mismo tiempo dejan algunas partes como un secreto.

En concreto, en el caso de Menchú citado por Spivak, que vimos anteriormente, se declara que no se ha mostrado todo sobre su cultura y que se está ocultando su identidad como indígena para guardar el secreto ${ }^{19}$ con el fin de que no sea apropiado por los demás. Esto es un gesto de resistencia contra el dominio intelectual sobre su cultura. A pesar de que Menchú declaraba la protección del secreto para la conservación de su cultura, Spivak interpreta que el secreto la protegía a ella y a su cultura, y no al revés. Es decir, el secreto y la indicación de su existencia reservan el momento para una reflexión delicada sobre la identidad de otra cultura. Esta insistencia en la declaración sobre el secreto anula las posibilidades de ser analizado (limitando la consecuencia de integración en el sistema occidental racionalista), lo cual aplaza y desplaza al ser consumido, y permite resistir contra el dominio epistémico occidental.

Ahora bien, volviendo al tema de la traducción, nos parece que con el medio audiovisual, aprovechando sus características, sería posible mantener visible la función y el proceso de traducción-cambio del código en algunas partes. Y seguramente el trabajo Measures of Distance de Mona Hatoum nos muestra un buen ejemplo de su aplicación en la expresión de la mujer no occidental que está fuera del sistema productivo. Al mismo tiempo, nos valdremos de las teorías de Felman y Spivak ya que nos facilitará una lectura más alternativa del presente trabajo.

\section{VI.1.4. La relación entre madre e hija bajo la sombra del padre.}

Para aproximarnos a algunos detalles de la obra la vamos a dividir en tres partes, según el cambio del estilo, en la representación. La primera parte es la parte introductoria, desde el comienzo del vídeo hasta la primera pausa de las imágenes. Se presentan tres cartas mediante la narración de la voz en off. Tras la pausa, la segunda parte muestra las imágenes

\footnotetext{
${ }^{19}$ Sigo ocultando lo que yo considero que nadie sabe, ni siquiera un antropólogo, ni un intelectual, por más que tenga muchos libros, no saben distinguir todos nuestros secretos. [Brugos, Elizabeth: Me llamo Rigoberta Menchú y así me nació la conciencia, México D.F., Siglo XXI, 2000, p. 271.]
} 
fundidas mientras se presenta la cuarta carta. La tercera parte solo presenta la narración de la voz en off de la quinta carta sin imagen ni audio de la conversación de fondo. Este fragmento dura menos de dos minutos, pero nos parece interesante analizarla, separándola de otras, las dos partes anteriores. Como hemos comentado, la narración en voz en off de la traducción de la carta de la madre para la artista es una bisagra en el presente trabajo. Empecemos, pues, a analizar la obra según su narración-traducción ${ }^{20}$.
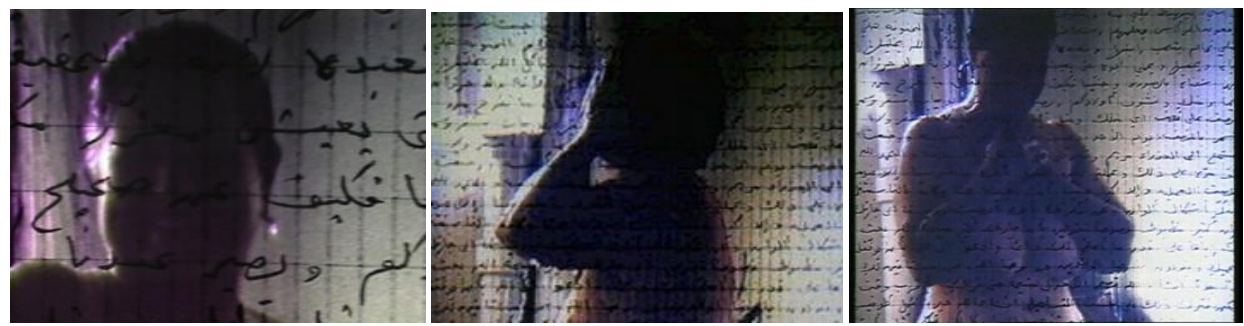

60. Measures of Distance (1988), Mona Hatoum

Tras el título, la obra comienza con la pantalla en negro. Primero, aparece poco a poco una imagen de fotografía poco clara, con la malla de las letras árabes, cada ciertos segundos cambia fundiéndose a otra imagen de fotografía igualmente no muy clara con el mismo tipo de letras. Esta transición de imágenes sin audio, dura casi veinte segundos. Después, se empiezan a oír voces de mujeres conversando en árabe, con la transmisión de las imágenes junto con la superficie de las letras. Esto dura casi un minuto, al fondo de la conversación se oye algún ruido de bocinas de autos, cerca y lejos, como un ruido cualquiera que se escucharía desde cualquier vivienda en la ciudad. Las voces de las mujeres -a pesar de que no se entiende el contenido de la conversación- no transmiten ninguna tensión. En ocasiones se escucha una ligera risa. Luego, comienza la narración de la primera carta:

My dear Mona, the apple of my eyes, how I miss you an along too fess my eyes on your beautiful face that brightens of my days. ${ }^{21}$

\footnotetext{
${ }^{20}$ Para la transcripción de la narración de la presente obra hemos conseguido la colaboración de Sabrina Molinari Tato, doctoranda de la Facultad de Bellas Artes de la Universidad Politécnica de Valencia. Como ya comentamos, hemos accedido a la obra por UBUWEB, en: http://www.ubu.com/film/hatoum measures.html, visualizado el 13 de mayo de 2011.

${ }^{21}$ Mi querida Mona, mi favorita. Como te extraño, y añoro posar mis ojos en tu hermosa cara que alumbra mis días. [Traducción propia]
} 
La narración empieza con una expresión de adoración por la hija. La carta señala que la artista estuvo durante una visita en la casa y ahora que se ha marchado, la casa ha perdido su alma. La ausencia que inunda el lugar no solo es por la ausencia de la artista, sino por todas las hijas que no están. Una sentencia alude a this bloody wall como si no permitiese el regreso de las hijas; la madre espera que esta sangrienta pared desaparezca pronto y sus hijas puedan volver, siente nostalgia de los viejos tiempos en los que estaban juntos. El siguiente comentario muestra que la madre ha disfrutado de las conversaciones con la hija artista y se ha generado una nueva y amistosa relación:

Why don't you come back and live here? And we can make all first drafts and tapes you want. $^{22}$

Aquí empieza una referencia acerca de un proyecto del trabajo audiovisual de la artista hablando del borrador del guión y de la cinta magnetofónica. El siguiente asunto que aparece se refiere a la autoridad sobre el uso de las fotografías del desnudo. Con estas indicaciones nos hace imaginar la conexión entre la presente obra con las fotografías y las cintas que se habían realizado durante la visita anterior de la artista a la casa de la madre. Es decir, dichas indicaciones funcionan como auto-referencia al presente trabajo, casi obligándonos a que nos imaginemos que la imagen de fotografía y la voz de la conversación son de la madre, al igual que las cartas. Como respuesta a la pregunta de la hija, la madre le permite utilizarlas con una condición: que no se entere su marido, el padre de la artista. Se describe la situación en la que la artista tomó las fotos: la madre posa prácticamente desnuda en la ducha durante el tiempo de la siesta vespertina; el marido las ve, pero prosiguen tomando fotos, ignorándole. En ese momento la madre ríe, pero el padre permanece serio y enfadado. La presiona con comentarios incisivos como si ellas estuvieran haciendo algo que solo le pertenece a él. Después, se comenta que la madre disfrutó de las sesiones fotográficas porque se sentía compenetrada con la artista, sin nada que ocultar entre ellas, compartiendo su intimidad femenina. Y, de nuevo, insiste en que puede utilizar las fotografías siempre que el padre no se entere de ello:

\footnotetext{
${ }^{22}$ ¿Por qué no regresas y vives aquí? Y podemos hacer todos los primeros borradores y cintas que quieras. [Traducción propia]
} 
Any way whatever you do with the picture, for God sake, don't tell your father or you never hear the end of the story. ${ }^{23}$

Con esta frase termina la primera carta. El contenido de la misma nos señala tres aspectos fundamentales que configuran la imagen de la madre en la presente obra. En primer lugar, ella es una madre repleta de amor hacia su hija, que añora su compañía, y se queja de su ausencia, con una expresión casi excesiva de adoración. En segundo lugar, es una madreesposa bajo el dominio del padre-esposo. Tercero, es una madre que necesita generar una nueva amistad con su hija, compartiendo secretos frente al comportamiento dictatorial del padre-esposo.

La segunda carta empieza igualmente con una expresión de adoración por la hija que no está a su lado, con cierto tono de lamento porque se siente abandonada por ella:

$$
\begin{aligned}
& \text { My dear Mona, you will never know how much I miss you } \\
& \text { and long for you to come and visit again soon } \\
& \text { I only hope that we don't have to wait another four years to see you again, my little } \\
& \text { one. }^{24}
\end{aligned}
$$

La narración de la voz en off sigue, esta vez con una observación de la madre que se sorprende porque la hija recuerda cada palabra de un comentario que la madre le hizo hace veinte años. Se refiere al momento en el que la hija tuvo la primera menstruación, la señal de que era ya una mujer (una situación que provocó una crisis de identidad a la artista).

Maybe it doesn't make any sense to you know and I must say, I'm surprised that you still remember every word I said to you on that afternoon.

When you think of it, it was over twenty years ago now.

If you are still thinking about it and analyzing it.

\footnotetext{
${ }^{23}$ De cualquier manera, hagas lo que hagas con las fotografías, por el amor de Dios, no le digas nada a tu padre o nunca escucharás el final de la historia. [Traducción propia]

${ }^{24}$ Mi querida Mona, nunca sabrás cuánto te extraño. Y cuánto deseo que vengas a visitarnos pronto de nuevo. Solo espero que no tengamos que esperar otros cuatro años para verte de nuevo, mi pequeña. [Traducción propia]
} 
Well I supposed is a very important instant in every girl's life and it seems to have created, an identity crisis for you. ${ }^{25}$

Después, la madre comenta que su hija se convirtió de una "pequeña diablito", a una joven mujer, por medio de la menstruación. Describe que su niña estaba alterada debido a la sangre y no paraba de llorar. En esos momentos, dice, su intención era poder consolarla. Es por ello que lo que pronunció aquella tarde no era realmente importante, sino que solo pretendía animar a la hija. En cambio, la hija no piensa en absoluto lo mismo, aunque no se dice claramente. Podemos leer esa diferencia de opinión al margen de las frases. Por ejemplo, cuanto más insiste la madre que era por el bien de la hija, más suena como una excusa.

If I remember well, I said you should consider yourself very lucky to be a woman

If you could only think about it once a month.

Whereas men have to show every day.

I supposed thinking about it now is a strange way to described the difference

between men and women.

I was only trying too cheer you up.

I make you feel good about being a woman. ${ }^{26}$

Sigamos con la tercera carta. Como de costumbre, empieza con el afecto por su hija y las quejas por su ausencia. Igual que la primera carta, ésta también alude a la sangrienta pared que las separa en cuatro esquinas del mundo, reclamando que es una realidad injusta.

My dear Mona I hope to see you my little one.

You're so close to my heart and so far away from me.

\footnotetext{
${ }^{25}$ Tal vez no tenga sentido para ti ahora, y debo decir que me sorprende que sigas recordando cada palabra que te dije aquella tarde. Si lo piensas, ya hace veinte años de eso. Si sigues pensando y lo analizas. Bueno, supongo que es un momento importante en la vida de toda niña. Parece que te creó una auténtica crisis. [Traducción propia]

${ }^{26}$ Si recuerdo bien te dije que debías considerarte muy afortunada por ser mujer, ya que solo debes de pensar en ello una vez al mes, mientras que los hombres tienen que demostrarlo todos los días.

Supongo que pensar en ello ahora es una extraña manera de describir la diferencia entre hombres y mujeres.

Yo solo trataba de animarte, y de hacerte sentir bien por ser mujer. [Traducción propia]
} 
It is not fair that this bloody wall should take all my daughters away from me to the four corners of the world. ${ }^{27}$

Y después de la reclamación, una lamentación en la carta nos señala un momento de cambio en la madre, en cuanto a su manera de pensar y de sentir a través de la correspondencia con la hija, además de una alegría por sus comunicaciones. Nos parece que aquí sería una auto-referencia de la correspondencia en sí. Es decir, dentro de la carta, nos explica la función de la comunicación para la protagonista madre.

I've been enjoying your letters enormously and now enjoy answering your questions.

Although they are sometimes weird and too proving for my liking.

So they make me think about myself in a way that I haven't looked up before and for a moment they take my mind away from this terrible wall that seems to go forever. ${ }^{28}$

Estos pensamientos, ocasionados por las preguntas de la hija, llevan a la madre a imaginar cosas que nunca había pensado antes, transportan su mente fuera de esa terrible pared. Esto nos hace pensar sobre el estado de la madre como oprimida y víctima de la política y de la dura realidad de la guerra. Es decir, sus circunstancias en tanto que oprimida siempre están presentes en su vida cotidiana e incluso ocupan su mente. Desgraciadamente, la sensación que tiene de la pared no es muy positiva, le parece que permanecerá para siempre. Esto nos hace imaginar su desesperación y la continuidad de la opresión que ella siente, también nos señala la división de la familia, que sigue sin saber hasta cuándo se prolongará.

La carta continúa. Ahora, el tema que aborda es el de la sexualidad bajo el control del marido-padre. En realidad no habla de su propia sexualidad libremente, sino que describe las imposiciones del marido sobre las emociones de su mujer, desvalorizando sus intereses

\footnotetext{
27 Mi querida Mona. Espero verte, mi pequeña. Estás tan cerca de mi corazón y tan lejos de mí. No es justo que esta sangrada pared se lleve todas mis hijas lejos de mí, a todos los rincones del mundo. [Traducción propia]

${ }^{28}$ He disfrutado tus cartas enormemente y ahora disfruto al contestar a tus preguntas, aunque a veces son raras y provocativas para mi gusto. Así que me hacen pensar en mí en un modo en que no había pensado antes y, por un momento, estos pensamientos transportan mi mente fuera de esta terrible pared que parece que permanecerá para siempre. [Traducción propia]
} 
sexuales y sus manifestaciones, calificándolas como women non sense (tonterías de mujeres).

La carta insiste sobre la figura del padre como dominador de la sexualidad y de los asuntos privados de la familia; al mismo tiempo, lo representa como una persona celosa por no conseguir el mismo trato que el de la hija hacia la madre. De nuevo, los comentarios señalan que la madre se siente feliz por tener una relación muy íntima, cariñosa y amistosa con su hija. Supondríamos que esa relación íntima profundizaría más al compartir un secreto frente al marido-padre. Sin embargo, en esta ocasión, la carta acusa a la hija: ¿por qué no se comunica con él de misma manera? Argumenta que, después de todo, siempre será la hija de su padre. Estas exigencias nos parecen contradictorias, ya que ahora es la madre la que procura ser sub-dominante, cumplir el papel de buena madre y buena esposa, y en ello se visualizaría una actitud de doble moral.

Luego, en la carta se repite el mismo tema que se vimos en la primera: la prohibición del padre a mostrar las imágenes del desnudo de la madre, quizás como consecuencia de sus complejos y del sentimiento de que están violando su propiedad.

I supposed he still can't forgive you, for taking does pictures of me in the shower.

It's as if you had trespass on his property and now he feels that there's some weird exchanges going on between us from which he is excluded.

He calls it women non sense. ${ }^{29}$

En cambio, la última parte de esta carta describe el placer del sexo por parte de la mujer:

Your last letter made me laugh a lot

I can't understand this expression, lay back in think of England

It means they believe that women are not supposed to enjoyed sex?

Well my answer to that it's of course we do as much as men, if not more.

\footnotetext{
${ }^{29}$ Supongo que no puede perdonarte por tomar esas fotografías de mí en la ducha.

Como si hubieras traspasado su propiedad y ahora él siente que hay ciertos intercambios raros entre nosotras de los cuales él está excluido. Él los llama tonterías de mujeres. [Traducción propia]
} 
Why do you think I keep telling you should get married?

After all, life is not worth living if it's all hard work and no fun. ${ }^{30}$

La carta, con cierto sentido del humor, rechaza la idea estereotipada de que la mujer no tiene placer sexual. Pero se encuentra también una extraña conexión entre el placer del sexo, el matrimonio y la diversión fuera del trabajo. No negamos cada una de estas ideas: la mujer puede tener el mismo placer en el sexo (a lo mejor más que el hombre) y la vida no valdría la pena si solo trabajásemos duramente, sin disfrutar de alguna diversión. Sin embargo, quizás el matrimonio que la madre recomienda a la hija, no sería una condición indispensable. Además, con lo que hemos visto en las cartas en torno a la incómoda relación con el marido-dominante-poseedor nos surge la pregunta: ¿cuál es la razón por la que recomienda a su hija que contraiga matrimonio? Es una pregunta que permanecerá abierta, ya que ni la artista ni la madre la contestan.

Después de la narración de voz en off de estas frases, desaparece la imagen, se funde y la pantalla oscurece. Pero continúa la voz en off de la conversación como audio de fondo.

VI.1.4.1. La distancia entre la nostalgia y la realidad.

Después de desaparecer la imagen de la primera parte, tras una pausa de diez segundos aproximadamente, aparece fundida una imagen fragmentada de una fotografía vertical del cuerpo desnudo. Como hemos mencionado, esta imagen también está cubierta de la malla cuadrada con las letras árabes. En comparación con la que se mostraba en la primara parte, se percibe mejor la totalidad del cuerpo. Durante unos 15 segundos se muestra solo esta imagen vertical, entonces se empieza a fundir otra imagen de una parte del cuerpo del mismo tipo que se veía en la primera parte, e igualmente cubierta de las letras árabes. Durante algunos segundos se mantienen estas imágenes dobladas. Desaparece la imagen vertical 15 segundos después de que haya aparecido la imagen horizontal. Luego aparece la

\footnotetext{
${ }^{30}$ Tu última carta me hizo reír mucho. No puedo entender esta expresión tal y como la piensan allá en Inglaterra. ¿Quiere decir que ellos creen que las mujeres no podemos disfrutar del sexo? Bueno, pues mi respuesta es que por supuesto que nosotras disfrutamos tanto como los hombres, si no más. ¿Por qué crees que sigo diciéndote que deberías casarte? Después de todo, la vida no vale la pena si solamente consta de trabajo duro y no hay diversión. [Traducción propia]
} 
imagen vertical otra vez, se mantiene la doble imagen, luego desaparece la imagen horizontal. Es decir, la imagen vertical que se pone en el centro de la pantalla y la imagen horizontal del tamaño de la pantalla aparecen y desaparecen alternativamente durante toda esta parte que corresponde a la narración de la voz en off de la cuarta carta. Mientras, se escucha la voz de la conversación de las mujeres en árabe.

La narración de la carta empieza con la expresión del amor hacia la hija y de la tristeza debida a su ausencia, igual que en las otras cartas:

My dear Mona, the love of my heart.

how I miss you and long to hold you in my arms even if only is for one minute. ${ }^{31}$

No obstante, esta carta es distinta a las otras. Empieza hablando sobre la distancia entre madre e hija. La madre expresa que no entiende lo que la hija comenta sobre la distancia.

I don't know what you mean when you talk about the gap between us. $^{32}$

Según la carta, la hija no puede recordar un sitio de cuando era niña. Suponemos que se refiere al lugar donde vivía la familia. Al parecer, la hija, es la única que no tiene recuerdos de la tierra natal de la familia, a diferencia de sus hermanas. La carta describe con mucha nostalgia que la familia vivía en tierras propias en un pueblo pequeño, rodeada de familias y de amigos dispuestos a ayudarse mutuamente.

We felt happy and secure and it was paradise comparing to where we are now.

So if I seemed to be all as irritable and impatient

It's because life was very hard when we first left Palestine. ${ }^{33}$

\footnotetext{
${ }^{31}$ Mi querida Mona, el amor de mi corazón, cómo te extraño y anhelo tenerte en mis brazos, aunque fuera por un minuto. [Traducción propia]

${ }^{32}$ No sé qué quisiste decir cuando hablaste acerca de la distancia entre nosotras. [Traducción propia]

${ }^{33}$ Nos sentíamos felices y seguros y era el paraíso comparado a donde estamos ahora.

Así que si parezco estar irritable e impaciente es porque la vida era muy dura cuando salimos de Palestina. [Traducción propia]
} 
Se compara, casi exageradamente, a la tierra natal que se ha perdido con el paraíso. Siguiendo algunas indicaciones de capítulos anteriores, esto responde a la función de la nostalgia: crea un lugar de origen perfecto tras sufrir su pérdida. Nos permitimos ser escépticos, sobre lo que comenta de lo maravilloso de su pueblo natal. Sin embargo, entendemos que este sentimiento nostálgico crea una utopía provocada por las circunstancias terribles de pérdida total en un momento dado. La carta lamenta su situación, la condición de exilio y los duros comienzos.

Can you imagine us having to separate from all our loved ones

living everything behind and starting again from scratch

Our family is scattered all over the world some of our relative we 'll never saw again to this day.

I personally felt as if I've been strict linking of my very soul

And I'm not just talking about the land and property we left behind

But with that our identity and our sense of pride, in who we are went out the window. ${ }^{34}$

La opinión personal de la madre relata como perdió no solo sus propiedades materiales y su tierra, sino que el exilio le ha desgarrado la identidad y el orgullo de ser quién es. Es decir, tras esta pérdida siente que, de alguna manera, su dignidad ha sido violada. Y luego comenta la influencia que ello puede haber tenido sobre la hija, la cual ha nacido ya en el exilio.

Yes of course, I supposed this must have affected you as well.

Because been born in exile in a country which does not want you is not fun at all. ${ }^{35}$

\footnotetext{
${ }^{34}$ Puedes imaginarnos separados de todos nuestros seres queridos, dejando todo atrás y empezando de nuevo de la nada. Nuestra familia está dispersa por todo el mundo, algunos de nuestros parientes no los volveremos a ver de hoy en adelante.

Personalmente, siento como si fuese el punto débil de mi alma, y no estoy hablando solamente de la tierra y las propiedades que dejamos, sino también de nuestra identidad y nuestro sentido de orgullo de ser quienes somos, que se escapa por la ventana. [Traducción propia]

${ }^{35}$ Sí, por supuesto, supongo que esto también te afectó a ti, ya que habiendo nacido en el exilio en un país en el que no eres bienvenido no es en absoluto divertido. [Traducción propia]
} 
Según la carta, al exiliarse, dejando atrás todas sus propiedades y separándose de la familia y amigos, se siente un peligro que acecha a la identidad y a la dignidad. Frente a este peligro, la madre podrá abstraerse en la memoria y la añoranza nostálgica de su "paraíso perdido". Sin embargo, los que nacen en el exilio no podrán tener la memoria de "su tierra", por lo que no pueden compartir esa nostalgia.

Now that you and your sisters have left Lebanon.

Your are again living in another exile an in a country that is totally different to your own.

So when you talk about the feeling of fragmentation and not knowing were you really belong.

Well this has been a painful reality of all our people ${ }^{36}$

La condición de la madre como exiliada, que sigue en Líbano, y de las hijas, en países totalmente diferentes, hace que el sentimiento de fragmentación y de no saber realmente a dónde se pertenece sea muy profundo. Este sentimiento aparecerá constantemente en las obras que analizaremos en adelante. Como comenta la carta, ésta es una realidad dolorosa de los exiliados y el dolor sufrido, no permite que se deje de cuestionar la propia identidad en un intento de recuperar la dignidad. Y, tal vez, aunque las crisis de identidad no correspondan exclusivamente a aquellos que viven en exilio, los que se encuentran desgarrados de su cultura o se enfrentan a diferencias abismales en el plano políticoeconómico-histórico-cultural, sufran más notablemente un estado sofocante en la aporía.

Cuando termina la narración de la voz en off que relata esta dolorosa realidad, desaparece la imagen del tamaño de la pantalla, fundiéndose y dejando paso a otra imagen vertical. Todavía se escucha la conversación en árabe de la voz en off como audio de fondo, la cual dura unos doce segundos después de la desaparición de la imagen horizontal de una parte del cuerpo y de la narración en inglés.

\footnotetext{
${ }^{36}$ Ahora que tus hermanas y tú habéis dejado el Líbano, tú estás de nuevo viviendo en otro exilio y en otro país que es totalmente diferente al tuyo. Así que, cuando hablas de un sentimiento de fragmentación y de no saber a dónde perteneces realmente, bueno, ha sido una realidad dolorosa para nuestra gente. [Traducción propia]
} 
VI.1.4.2. My dear Mona, etcetera, etcetera. La distancia desde el sentido del humor.

La última carta comienza con la imagen de la fotografía vertical del cuerpo desnudo, pero solo dura cinco o seis segundos y después seguirá hasta el último momento sin imagen y sin el sonido de la conversación en árabe que sonaba como audio de fondo. Es decir, durante todo el tiempo en esta parte solo se escucha la narración de la traducción en inglés de la quinta y última carta de la voz en off con la pantalla negra.

Tras cinco segundos desde la desaparición del sonido de la conversación, comienza la narración con la frase My dear Mona, como de costumbre:

My dear Mona, etcetera, etcetera.

Esta vez omite las expresiones de amor y de añoranza por su hija. En esta narración no habla sobre la intimidad ni la distancia en la relación amorosa entre ambas, ni sobre los celos del padre, sino que describe la difícil situación de la correspondencia. Narra que el ataque de un coche bomba a la oficina local de correos realmente está dificultando el mantenimiento de la correspondencia. La carta ha podido llegar a su destinataria porque la madre se la han enviado, a través de un primo que viajó a otra ciudad.

En ella se describe el estado de tensión tras el ataque, lo cual obstaculiza el tránsito cotidiano, además de otros problemas que dificultan la correspondencia: los misiles caen en el camino que lleva a la oficina de correo más cercana. Comenta:

Even going to your ants place around the corner for the afternoon coffee seems to be quite an adventure these days. ${ }^{37}$

La descripción en la carta nos hace imaginar la proximidad de la violencia, de los ataques que invaden las calles. La imagen en la que se combina esta violencia con el café de la

\footnotetext{
${ }^{37}$ Incluso ir a casa de tu tía a la vuelta de la esquina para el café de la tarde parece ser toda una aventura estos días. [Traducción propia]
} 
tarde con la tía que vive a la vuelta de la esquina nos confirma la violencia insistente de la guerra, la cual no solo se limita a las batallas en el desierto o en el bosque donde únicamente están los soldados, tal y como suele aparecer en las películas.

Luego añade un comentario sobre la interrupción de la visita a algunos familiares con el fin de evitar cruzar la línea verde, y se lamenta sobre la imposibilidad de la comunicación a través del correo.

And now even the must basic dealing of communicating with you by letter is been denied to us. ${ }^{38}$

Y termina pidiendo a su hija que intente hacer una llamada telefónica, aunque es un medio de comunicación que exige mucha paciencia y tampoco es seguro conseguir la comunicación, ya que depende mucho de la suerte.

I know it's extremely difficult for you to get a line to pay a rute and you have to dial for days before you can get thorough if you are lucky.

But it looks like this would be the only way to get your news from now on. ${ }^{39}$

Esta última parte dura apenas tres minutos, sin imagen, en el silencio. Comparando las características de la imagen y el sonido con las otras secciones, o solo comparando los contenidos de las cartas, aquí cabe menos interpretación ya que se trata de una expresión monótona que deja menos lugar a la exageración retórica y sentimental.

Durante toda la obra el tono de la voz de la narración en inglés mantiene la calma y se escucha monótono. Por el contrario, el contenido de las cartas y las descripciones de la madre son una manifestación de sus sentimientos volátiles e inestables: el cariño, la alegría, la risa, el miedo, la perplejidad y la tristeza. Es casi seguro que la traducción de las cartas

\footnotetext{
${ }^{38}$ Y ahora incluso la forma más básica para comunicarnos contigo por carta nos está siendo negada. [Traducción propia]

${ }^{39}$ Sé que es extremadamente difícil para ti poder conseguir una línea para llamar.

Tienes que llamar durante días antes de que puedas contactarnos y tener suerte, pero parece que es la única manera de tener noticias tuyas de ahora en adelante. [Traducción propia]
} 
está sintetizada, inevitablemente, y son fragmentos solo de algunas partes de la correspondencia. Pero la voz de la conversación que acompaña a esta narración, aún sin entender lo que se dice, nos hace escuchar las huellas de pathos de cuando el sentimiento sale por el corazón a través de la boca.

Las imágenes imprecisas de fotografías fragmentadas que se solapan y las letras árabes con una malla cuadriculada que hemos descrito provocan que sea necesario agudizar la vista y luego agudizar la inteligencia buscando alguna conexión entre el sonido, el texto y la imagen.

Por otra parte, estas imágenes cubiertas con unas líneas finas enrejadas nos hacen compararlas a sus trabajos de instalaciones que encontramos en su obra posterior. Una serie de trabajos que nos da la impresión de una jaula que los atrapa, detiene y "protege" de alguna manera y los divide de nosotros. Nos aporta una sensación de sofoco. Una imagen carcelaria que, al mismo tiempo, deja un espacio que fuerza a evitar un juicio absoluto. Es decir, no solo aporta una sensación dura, trágica, facilitando una incitación emocional. Parece que la presente obra también tiene ese carácter ambivalente.

Y la última parte, por la omisión de la imagen y del audio de la conversación, hace que nos concentremos en escuchar la narración. Luego, frente a la pantalla negra, al escuchar la proximidad de la violencia física entorno a la madre y el aviso de la interrupción de la correspondencia nos hace pensar más sobre el contexto. Es decir, no nos enseña visualmente ni una sola ilustración o fotografía como imagen de la violencia; sin embargo y quizás por eso aun más, provoca a nuestra imaginación. Al mismo tiempo, la omisión del audio de la conversación que generaba un ambiente más íntimo nos hace reflexionar realmente sobre la distancia desde el lugar de procedencia de la carta.

Merve Unsal ${ }^{40}$, artista y crítica de arte de origen truco, comenta sobre este carácter de los trabajos de Hatoum, comparándolos con los de Shirin Neshat ${ }^{41}$ en un texto que forma parte

\footnotetext{
${ }^{40}$ http://www.linkedin.com/in/merveunsal, http://www.boltartarsiv.net/merve-unsal-airports-2010/, accedido el 10 de junio de 2011.

${ }^{41}$ Shirin Neshat (1957, Quzvin, Irán), vive y trabaja en EE.UU. desde 1974. Ha realizado exposiciones individuales en centros de arte y museos como el Museo de Arte Moderno de México DF, el Contemporary Arts
} 
de la presentación de la presente obra en Uubweb. Neshat ${ }^{42}$ también es una artista reconocida internacionalmente, de origen iraní y exiliada en EE. UU. Su trabajo se basa en el tema de la mujer en el mundo árabe mediante la fotografía y el formato audiovisual. Algunos conceptos que trabaja en su obra tienen una similitud con el trabajo de Hatoum; por ejemplo, la introducción de letras y el cuerpo femenino a través de algunas expresiones del sometimiento femenino dentro del patriarcado. El comentario de Unsal es siguiente:

It is impossible not to think about Shirin Neshat's images, with provocative, posed portraits of women, juxtaposed with Persian script. I believe that Hatoum's work is visually in dialogue with Neshat's work and yet there is something about Hatoum's work that troubles me and attracts me in a way that Neshat's work does not. The immaculate aesthetic of Neshat's images does not leave room for me. Hatoum's work, on the other hand, turns the mirror to me, showing me what I think and believe through secretly sharing the intimate world between herself and her mother. There is something timeless, universal and beautiful about this gesture and I cannot help but think that the video becomes a means to close the distances, between Hatoum and her mother and between me and the work, rather than measuring those distances. $^{43}$

Unsal se fija en un espacio dentro del trabajo de Hatoum que permite proyectar el sentimiento de cada uno de los espectadores. Según Unsal, la obra de Neshat es impecable, casi tanto que no deja espacio para que los demás vean en ella un reflejo de sí mismos. En

\footnotetext{
Museum de Houston, el Walker Art Center de Minneapolis, el Espoo Museum of Modern Art (Finlandia), el Castello di Rivoli en Turín, el Dallas Museum of Art, el Wexner Center de Columbia, el Art Institute of Chicago, la Serpentine Gallery de Londres, el MUSAC de León o el Hamburger Bahnhof de Berlín. Neshat también ha participado en la Documenta XI (2002), la Bienal de Whitney (2000) y en 1999 ganó la XLVIII Bienal de Venecia. http://www.phedigital.com/index.php?sec=noticia\&id=340, accedido el 21 de junio 2011.

42 http://www.musac.es/index.php?ref=3500, http://www.rtve.es/television/20100329/shirin-neshat/325756.shtml, visualizado el 10 de junio de 2011.

${ }^{43}$ http://www.ubu.com/film/hatoum_measures.html, accedido el 6 de junio del 2011. Es imposible no pensar en la provocación de las imágenes de Shirin Neshat que plantean los retratos de las mujeres, se yuxtaponen con la escritura persa. Creo que el trabajo de Hatoum es visualmente un diálogo con el trabajo de Neshat y, sin embargo hay algo en el trabajo de Hatoum que me preocupa y me atrae de una manera que el trabajo de Neshat, no. En la estética impecable de imágenes Neshat no deja espacio para mí. El trabajo de Hatoum, por el contrario, se vuelve un espejo de mi misma, mostrándome lo que pienso y creo en secreto a través del hecho de compartir el mundo íntimo entre ella y su madre. Hay algo atemporal, universal y hermoso en este gesto y no puedo dejar de pensar que el vídeo se convierte en un medio para cerrar las distancias, entre Hatoum y su madre, y entre yo y mi trabajo, en lugar de medir las distancias. [Traducción propia]
} 
cambio, la de Hatoum nos deja un espacio, funciona como un espejo. Lo que Unsal comenta es que el espacio que nos deja nos permite proyectar a cada quien lo suyo. Es decir, podríamos entender la visualización de la obra como un momento de reflexión. Hatoum hace que sea posible reconocer nuestras vivencias a través de lo que ella muestra. Esto se debe probablemente tanto a la calidad de la imagen como al sentido de humor de su trabajo, y tal vez nos permite interactuar precisamente por ese carácter ambivalente de la obra.

Nos parece que los trabajos de Neshat tienen una mayor tendencia a la dramatización, tendencia que se basa en una estética de la imagen impecable. Ya desde que trabajaba en la fotografía mostraba esa tendencia, y al mudar a la expresión audiovisual se empezó a percibir más. Últimamente, con su película titulada Mujeres sin hombre ${ }^{44}$ ha llegado a un cierto clímax en su carácter dramático. En una expresión extrema, podríamos decir que su obra es absolutamente bella por su impecable imagen que sigue el código estético que nos hace sentir el abismo de su mundo estético, nos abruma; en otras palabras, no nos permite cuestionar ni reflexionar sobre su veracidad. ${ }^{45}$ Como hemos comentado en algunas ocasiones durante el primer capítulo, el juicio de lo bello nunca nos permite ninguna alternativa, es universal según el sentido común que nos indicaba Kant. ${ }^{46}$

En cuanto al tema abordado por Neshat sobre la mujer en el mundo árabe, muchos aspectos conceptuales y formales son compartidos en la obra de Hatoum. Sin embargo, el trabajo de Hatoum, por su carácter ambivalente y sus toques de humor, nos provoca una cierta distancia. Por ejemplo, si nos referimos a las palabras de la madre, presentadas en forma de carta: aunque sea una expresión del amor o del dolor, no podemos negar totalmente lo que se expresa: sus sentimientos; pero, al mismo tiempo, nos hace pensar en lo que no se dice.

\footnotetext{
${ }^{44}$ En 2009 ganó el Premio León de Plata del Festival de Venecia por su película Women without Men. También ha recibido reconocimientos como el Hiroshima Freedom Prize y el Lillian Gish Prize. En 2008, su exposición individual Mujeres sin Hombres inauguró el Aros Kunstmuseum en Dinamarca, viajó a la Galería Nacional de Arte Contemporáneo en Atenas y abrió el Kulturhuset Stockholm en otoño de ese mismo año. http://www.phedigital.com/index.php?sec=noticia\&id=340, accedodo el 21 de junio de 2011.

${ }^{45}$ La cuestión de lo veraz, sobre todo en la relación entre lo político, la veracidad y el poder que Deleuze critica lo hemos visto en el capítulo V. del presente trabajo.

${ }^{46}$ El riesgo de esta tendencia con las prácticas del cine-audiovisual lo hemos estudiado en IV.1.1., y nos hemos aproximado también a la teoría de Kant en III.2. y V.
} 
Es decir, nos permite una lectura al margen del texto. Incluso la omisión de las frases de expresión amorosa de la quinta carta (My dear Mona, etcetera, etcetera) nos obligan a imaginar, quizás con cierto humor, el aburrimiento de la hija que recibe tantas muestras de amor. No se nos muestra ni un rechazo ni una actitud escéptica hacia el amor de la madre, pero sí se nos indica una sensación de saturación, por las atenciones en demasía. Cierto es también que la repetición resulta por la anulación del sentido de los significados reales.

No obstante, el sentido del humor no tiene como consecuencia la caricaturización de la dura situación y de la realidad dolorosa de que rodea a los personajes de esta obra. Se crea cierta tensión con lo que se describe en la carta, también entre la imagen y el audio. Pero nos parece que su trabajo evita una actitud dramática de la emoción a través de la perfección de su historia de una manera unilateral. Más bien, nos señala una historia que nunca se perfecciona, indicándonos los puntos en que se conecta y se divide y enfatizando en las diferencias, la discrepancia y la distancia entre madre e hija. Stéphanie Moisdon concluye del siguiente modo:

\begin{abstract}
Mona Hatoum construit une stratification des niveaux de lecture et de représentation, une esthétique ambivalente qui inclut à la fois la distance et la proximité. La membrane épistolaire fait office de troisième corps, de lieu d'intersection, et matérialise en même temps les frontières qui écartent le regard de l'artiste et tout ce qui la rattache à ses origines. ${ }^{47}$
\end{abstract}

En esta obra, la artista construye y al mismo tiempo deconstruye la imagen sintética de la madre desde el punto de vista de la hija. La imagen de su cuerpo desnudo fragmentado, la voz de la conversación que nos hace oír directamente, el pathos, la narración de la carta traducida al inglés, que nos hace comprender su situación y las relaciones personalessociales... Cada uno de estos aspectos, nos ayudan a configurar la obra y a deconstruirla. Estos aspectos se enredan mutuamente y se completan uno a otro, para construir una

\footnotetext{
${ }^{47}$ Moisdon, Stéphanie, Op.cit., pp. 152.

Mona Hatoum construye una estratificación de niveles de lectura y de representación, una estética ambivalente que incluye a la vez la distancia y la proximidad. La membrana epistolar hace la labor de tercer cuerpo, de lugar de intersección, y materializa al mismo tiempo las fronteras que separan la mirada del artista y todo aquello que la une a sus orígenes. [Traducción propia]
} 
imagen de la madre; pero, al mismo tiempo, no dejan de indicarnos una fisura. Obviamente, esta imagen de la madre no deja de ser una construcción por parte de la artista como hija, seguramente en ella esté reflejada una versión de su mirada hacia la madre. Aunque las palabras de la hija no llegan a ser pronunciadas, recibimos ciertas señales y se abre un espacio a la imaginación para reflexionar sobre esas cuestiones.

La configuración de la imagen de la madre, a través de la correspondencia en la expresión audiovisual, nos recuerda a la obra MaMa de Yukiko Eguchi ${ }^{48}$, producida el año 1987. La coincidencia en la cercanía de fechas de estas obras con temas similares pero en distinto contextos culturales nos hace reflexionar sobre la contemporaneidad ${ }^{49}$.

Recordamos el argumento de Felman sobre la autobiografía de la mujer como testimonio de supervivencia de la mujer a través de la lectura, de la expresión por la mujer y sobre la mujer, siendo testigos del relato. También recordamos la indicación de Durcilla Cornell ${ }^{50}$. Diríamos, pues, que la expresión de Mona Hatoum en la presente obra nos posibilita reservar cierto espacio de reflexión sobre las autobiografías de la mujer. Lo curioso del trabajo de Hatoum es que sin una expresión extremadamente dramatizada logra reservar una postura con un respeto a la dignidad y a la cultura del "otro", mostrando un dilema y un estado contradictorio en la comunicación. Nos parece que es un trabajo que nos lleva más allá de la teoría de Cornell, en la que se ponía el énfasis en la dramatización en la realidad de las mujeres.

Seguramente, la multiplicidad en las expresiones de la mujer es posible y nuestra intención no es negar ningún tipo de expresión. De ahí que la dramatización sea un modo de expresión muy útil y su introducción estratégica pueda resultar muy positiva dependiendo

\footnotetext{
${ }^{48}$ Váyase a V.3. Todos los detalles del trabajo MaMa de Yukiko Eguchi.

${ }^{49}$ No se ciñe exactamente a nuestro tema, pero adjuntamos una referencia de la correspondencia en vídeo entre Shuji Terayama y Shuntaro Tanigawa (un poeta japonés) fechado en 1982-1983. Terayama fue un gran innovador en el amplio campo de la expresión artística de la posguerra japonesa desde Haiku (poesía tradicional japonesa) hasta la expresión audiovisual como película. Para más detalles váyase a Uubweb, en: http://www.ubu.com/film/terayama.html, accedido el 10 de junio de 2011. También en el mismo sitio se puede ver el vídeo Video Letters, 1932-1983, 75' NTSC, a color: http://www.ubu.com/film/terayama_video-letter.html, visualizado el 10 de junio de 2011.

${ }^{50}$ Se remite al capítulo III., sobre todo al apartado III.2.1. del presente trabajo.
} 
del contexto. Esta cuestión la dejamos abierta para la siguiente sección en la que vamos a considerar la provocativa obra de Trinh T. Minh-ha y su dramatización estratégica. 
VI.2. Surname Viet Given Name Nam (1989), Trinh T. Minh-ha: un documental entre ficción y realidad sobre entrevistas a mujeres. 
En ciertas ocasiones, Gayatri C. Spivak se refiere a Trinh T. Minh-ha ${ }^{1}$ como alguien con quien comparte las mismas preocupaciones y que ha avanzado en los estudios del feminismo postcolonial. ${ }^{2}$ Drucilla Cornell cita unas frases de la obra escrita por Minh-ha y después comenta lo siguiente al comienzo del capítulo: The art of witnessing and the community of the ought of $b^{3}$ (idea a la que nos hemos aproximado en el tercer capítulo de este trabajo):

\begin{abstract}
Trinh T. Minh-ha's “Grandma's Story” evokes the power of women's stories to connect generations to generations and keep alive a history that would otherwise die out. From these stories and their power, the woman writer shapes herself. This oral tradition keep "alive the forgotten, dead-ended, turned-into-stoneparts of ourselves. "A
\end{abstract}

El trabajo de Minh-ha tiene como objetivo registrar el relato sobre la mujer escrito por la mujer, con el fin de interconectar distintas generaciones. Cornell argumenta que su historia evoca al poder de la historia de la mujer, generación tras generación, y que ella mantiene

\footnotetext{
1 Trinh T. Minh-ha es reconocida a nivel internacional como realizadora de cine de temática feminista postcolonial. También realiza trabajos de video-instalación. Su trabajo audiovisual ha sido presentado en Documenta XI, festivales internacionales del cine y algunos ciclos retrospectivos de la artista. Nació en 1952 en Hanoi, y posteriormente se trasladó a Saigon, Vietnam, e inmigró a EE.UU. en 1970. Luego realizó una estancia de estudios mientras trabajaba como profesora en París de 1974 a 1975 y en Senegal como profesora de música de 1977 a 1980. Gracias a la experiencia de vivir en Senegal, realizó su primera obra audiovisual Reassemblage (a color, 16mm, 40 min. de duración) en 1982. Tres años después, presenta Naked Spaces - Living is Round (a color, 16mm, de 135 min. de duración). La obra que estudiamos aquí, Surname Viet Given Name Nam, es la tercera obra audiovisual de la artista. Más tarde, ha realizado las películas Shoot for the Contents (102 min.), en 1991; A Tale of Love (108 min., de ficción), en 1995; The Fourth Dimension (87 min., en digital), en 2001; y por último en 2004 Night Passage (98 min., una obra de ficción en digital). También es reconocida como escritora teóricoinvestigadora sobre el feminismo postcolonial dentro del ámbito académico, especialmente en EE.UU. Es profesora del estudio de la mujer y retórica (del film) en la Universidad de California (Berkeley) La bibliografía completa de la artista se encuentra su página web oficial: http://www.trinhminh-ha.com/, consultada el 21 enero de 2011.

${ }^{2}$ Spivak, Gayatri Chakravorty: Crítica de la razón poscolonial. Hacia una historia del presente evanescente, trad. Marta Malo de Molina, Madrid: Akal, 2010, p. 10 [en el texto de Spivak el nombre de Minh-ha está escrito: Trinti, en el texto original es en inglés, también. Véase Spivak, Gayatri Chakravorty: A Critique of Postcolonial Reason: toward and History of the Vanishing Present, Harvard University Press, 1999, London, p.xi]

${ }^{3}$ Cornell, Drucilla: Between Woman and Generation. Legacies of Dignity, New York, Palgrave, 2002, pp. 71-120. Nos hemos centrado en el argumento de Cornell en el que se basa el capítulo III.

${ }^{4}$ Ibíd., p. 71 [cita de Minh-ha: Trinh T. Minh-ha, Woman, Native Other; Writing Postcoloniality and Feminism, Bloomington: Indiana University Press, 1989, p. 123]

"Historia de la abuela" de Trinh T Minh-ha, evoca el poder de las historias de las mujeres para conectar las generaciones a las generaciones y mantener viva una historia que de otro modo se extinguiría. A partir de estas historias y su poder, la escritora se forma a sí misma. Esta tradición oral mantiene "vivo el olvido, un callejón sin salida, convertido en piezas de piedra de nosotros mismos."
} 
vivo lo que de otro modo se perdería. Ello nos hace recordar la discusión que hemos seguido en otras expresiones: según Shoshana Felman y Gayatri C. Spivak ${ }^{5}$, el poder que tienen estas historias de mujeres para interrelacionar distintas generaciones y así mantener viva una historia que de otro modo se extinguiría. Un cambio en la forma o en el código cultural para una comprensión más razonable de la forma escrita perdería y eliminaría lo “esencial" de aquello que está siendo pronunciado. Esta conciencia se encuentra también en el trabajo audiovisual de Minh-ha, tal y como iremos averiguando a lo largo de nuestra aproximación.

En el presente apartado nos acercaremos, pues, a su obra Surname Viet Given Name Nam (Apellido Viet. Nombre Nam). Es una obra audiovisual realizada en EE.UU., grabada en película de 16mm., a color y de 108 minutos de duración. En este análisis aprovecharemos las hipótesis que hemos desarrollado durante nuestra investigación sobre el documental. Aunque es difícil categorizar el presente trabajo como documental en el sentido más estricto, seguramente nos puede facilitar el análisis de las modalidades documentales. Igualmente, las teorías feministas que hemos examinado hasta ahora nos guiarán en nuestro acercamiento a esta obra. Con el fin de facilitar su comprensión nos referiremos a las opiniones Bill Nichols sobre los trabajos de la artista en el siguiente sub-apartado.

\section{VI.2.1. Entre la representación interactiva y reflexiva de Trinh T. Minh-ha.}

Bill Nichols sugiere que la obra Surname Viet Given Name Nam se podría clasificar como representación interactiva, basándose en la división de cuatro categorizaciones argumentada en su libro La representación de la realidad, ya casi considerado como un clásico sobre el análisis de los documentales. Según argumenta Nichols, se pueden categorizar los documentales en cuatro modalidades: expositivo, de observación, interactivo y de representación reflexiva. En los capítulos en los que desarrolla la representación interactiva y reflexiva, coincide, de alguna manera, con lo que hemos desarrollado en el capítulo V. de nuestro trabajo, donde encontrábamos indicaciones sobre el trabajo de Trinh T. Minh-ha. Precisemos entonces esta división de modalidades en los documentales,

\footnotetext{
${ }^{5}$ Para más detalles váyase a los capítulos I., II., III.1. y IV.
} 
realizando un breve resumen de las ideas de Nichols ${ }^{6}$, para aclarar el carácter de la particularidad de la representación que nos lleva a nuestras consideraciones.

Empezaremos con la modalidad expositiva que es la más clásica. Nichols proporciona ejemplos de esta modalidad citando, entre otros, a Grierson, representante del documentalismo inglés, y a Flagerty, conocido como el padre del documental. De hecho, este estilo se ha establecido desde el comienzo de la historia del documental y todavía sigue siendo el estilo estándar del documental de tipo educativo, ilustrativo o didáctico. Esta modalidad expositiva nace como antítesis de las cualidades del cine de divertimiento en cuanto a las películas de ficción y de fantasía. Tiene la intención de revelar información acerca del mundo histórico y observar ese mundo de nuevo a través de la representación visual y posteriormente audiovisual. Para este tipo de representación se introduce la observación "omnisciente" y una perspectiva poética que persigue una mejor comprensión y conocimiento por parte de los espectadores.

La segunda modalidad, de observación, surge en los años sesenta en EE.UU. Es considerada como antítesis de la primera modalidad. El documental de representación expositiva, como consecuencia de su carácter didáctico, conlleva una condición moralizadora desde esa postura omnisciente. Cuando la técnica permite obtener unos equipos de filmación con una grabación sintónica de más fácil transporte se empieza a hacer uso de los documentales sin narración en "off". Ello se convierte en una representación basada en la observación como un registro, pero sin llegar a inmiscuirse. Los documentales del Direct Cinema coinciden con esta modalidad. En este punto, Nichols señala los trabajos de Leacock-Pennebaer y Frederic Wiseman como ejemplos.

La tercera es la modalidad interactiva, surgida en los años sesenta principalmente en Francia, casi simultáneamente con el documental de observación. El contexto se comparte en mayor o menor medida con la segunda modalidad. Sin embargo, según Nichols, en el documental interactivo se incluye una crítica a la segunda modalidad, ya que ésta mantiene

\footnotetext{
${ }^{6}$ Nichols, Bill: La representación de la realidad, trad. Josetxo Cerdán y Eduardo Iriarte, Barcelona, Paidós, 1997, pp. 65-114.
} 
una ambigüedad en lo que a la perspectiva del realizador se refiere, así como una cierta reflexión sobre la grabación de la cruda realidad, ignorando la presencia de las cámaras. Entonces, la tercera modalidad lo que intenta evidenciar es la perspectiva del realizador, el cual ejecuta una intervención interactiva con los individuos y participa en los sucesos. Por este motivo, se establece un estilo de entrevista y se introducen las tácticas/técnicas de intervención. Como consecuencia, esta representación permite que el realizador relate como testigo y participante en el suceso. Este aspecto nos parece comparable con la consistente reafirmación del narrador "omnisciente" en la modalidad expositiva, y parece que la función principal sería evitar el peligro de la reconstrucción de la realidad en los documentales clásicos. Esta modalidad coincide con los trabajos del Cinéma-vérité, y Nichols comenta los trabajos de Rouch, de Antonio y Connie Field como ejemplos.

La cuarta modalidad es la de representación reflexiva, una corriente apartada de lo que hemos visto hasta ahora y mucho más introspectiva. Las dos últimas modalidades que hemos visto, la segunda y la tercera, surgen como antítesis de la primera modalidad y podemos comprenderlas en una relación cronológica. No obstante, la cuarta modalidad ya existía desde la primera etapa de la historia documental. Esto es por lo que Nichols categoriza los trabajos de Dziga Vertov en esta modalidad de documental de representación reflexiva. El trabajo que en mayor medida representa a Vertov sería, sin duda alguna, El hombre con la cámara (1929), el cual coincide en el mismo año con la producción de Drifters de Grierson. Según la explicación de Nichols, el documental reflexivo se lleva al límite para que la atención recaiga tanto sobre el recurso fílmico como sobre el efecto. Nos parece que esta modalidad, a primera vista, es muy cercana a la representación de la película experimental. Pero si analizamos en profundidad el argumento de Nichols comprendemos que existe una proximidad entre las modalidades tercera y cuarta. También existe una amplia variedad de modalidades de representación reflexiva. Al mismo tiempo, la representación interactiva y la reflexiva tienen una profunda simpatía entre sí. Según Nichols, ya Vertov tenía interés en la modalidad interactiva. 
¿Y qué ocurre si el realizador interviene o interactúa? ¿Qué ocurre si se rasga el velo de la ausencia ilusoria? Ésta es la posibilidad que en la década de los veinte propuso Dizga Vertov como kino-prada. ${ }^{7}$

El interés del realizador en la intervención y la interacción dentro de la representación documental siempre ha existido. Ya lo confirmamos en el quinto capítulo, basándonos en un análisis de la historia del documental abordado desde el tema de la subjetividad. También se indicó el peligro de una simplificación radical de ese interés sobre el documental dentro de la dinámica del poder político: se construiría una representación unilateral y parcial a modo de ilustración de un mensaje ideológico o se convertiría simplemente en propaganda.

Entre los trabajos ejemplificativos de la representación interactiva se encuentran muchos documentales etnográficos y antropológicos como antítesis de los trabajos clásicos. Es decir, los trabajos clásicos de Flagerti, por ejemplo, representan la vida de la gente autóctona desde la postura colonizador-dominador y con un narrador omnisciente. Y como consecuencia de la oposición entre el dominio de colonizadores modernos y las personas autóctonas se enfatiza la esencia poética en el nombre de la cultura propia. Es decir, se encuentra una tendencia reactiva contra el dominio occidental que subraya el carácter del "otro". En muchas ocasiones, esa tendencia se reduce a una comprensión endurecida que se convierte en un principio etnocentrista (y posteriormente incluso nacionalista, en el caso de la posible consecución de la independencia como estado-nación), reconstruyendo retrospectivamente una identidad ideal y pura de la comunidad, con nostalgia hacia sus orígenes.

Así se establece el esquema de una dinámica que se divide en dos principios distintos, que se jerarquizan uno al otro, como vimos en el caso de la colonización en India según el estudio de Spivak. También se aclaró el problema de este esquema: una estructura opuesta no resuelve el problema, sino más bien todo lo contrario, funciona para mantener esa relación de antagonismo. Dicho de otro modo, cuanto más se enfatiza en la legitimidad y en

\footnotetext{
${ }^{7}$ Ibíd., p. 78.
} 
la injusticia, más se fortalece a la oposición. Esta estructura desvaloriza al oponente y, en consecuencia, el desprecio hacia el "otro" también se fortalece más que la anhelada legitimidad. En este sentido, estructuralmente la oposición sirve para que dos oponentes sigan manifestando sus principios.

En esta dinámica de relación antagonista se reproducen unos subalternos que no logran identificarse, ni el uno, ni el otro. Al mismo tiempo, sufren la impotencia de no poder salir de esta dinámica política-económica-cultural que les atrapa en la narrativa histórica. Hemos estudiado el caso de India como ejemplo, pero ésta es una situación que se repite marcadamente en zonas que han sufrido la experiencia de la colonización. Por ejemplo, Negritud es un movimiento literario cuyo objetivo es superar la crisis de identidad de los negros francófonos en las zonas ex-coloniales africanas, donde prevalece un esquema que divide y opone a blancos y negros. En Europa y África se muestra la misma tendencia, la cual fue criticada por la generación posterior por tener demasiada adaptación del modelo occidental que divide, compara y califica. Parece que Minh-ha es muy cuidadosa en este sentido y evita manifestarse abiertamente, quedándose solo a un lado y refiriéndose a la esencia de la otra cultura.

Trinh T. Minh-ha se niega a evocar o hablar en nombre de la esencia poética de otra cultura; por el contrario, interpreta la estrategia retórica de la empatía y la unidad trascendental y lo hace dentro de los términos de una expresión poética en vez de a través del metacomentario que podría adoptar un documental reflexivo. ${ }^{8}$

Por ejemplo, en el caso de la obra Surname Viet Given Name Nam, Minh-ha no reflexiona sobre cuál es la esencia pura de la cultura vietnamita, ni de la mujer vietnamita, sino que habla sobre las mujeres vietnamitas de forma fragmentada e interrumpida, si bien esto seguramente se corresponde con la dinámica política, económica, histórica y cultural. Podríamos sugerir, pues, que mediante una serie de relatos interrumpidos ella está señalando a la identidad vietnamita, pero al mismo tiempo lo que hace es desfigurar su imagen y mostrarnos las distancias y las diferencias en las identidades.

\footnotetext{
${ }^{8}$ Ibíd., p. 70.
} 
También resulta muy interesante cuando Nichols se refiere al metacomentario que se encuentra en esta obra, ello podría hacer que ésta se ajustase al carácter del documental reflexivo. Es decir, Surname Viet Given Name Nam se podría insertar en la modalidad de la representación interactiva, pero también contiene aspectos de la modalidad reflexiva, según Nichols. De acuerdo con sus referencias, a continuación vamos a aproximarnos a la obra.

\section{VI.2.2. Los relatos multivocales y su relación jerárquica.}

Nichols comenta una característica que se encuentra en todas las obras audiovisuales de Minh-ha del siguiente modo:

Aparece en todas las películas de Trinh T. Minh-ha en las que comentarios multivocales se basan en textos preexistentes sin ponerlos en relación jerárquica entre ellos. ${ }^{9}$

La modalidad de la representación expositiva, en su modo de expresión, construye una relación jerárquica. Es decir, establece un orden en las informaciones que se repiten y en el comentario omnisciente que sería una voz dominante en todos los aspectos dentro de la representación, la cual tiene como fin aclarar el argumento y facilitar una comprensión absoluta por parte de los espectadores. En el caso del documental interactivo se intentaba retirar el dominio de esta voz omnisciente, pero muchas veces se dejaba una estructura jerárquica para que fuera más entendible.
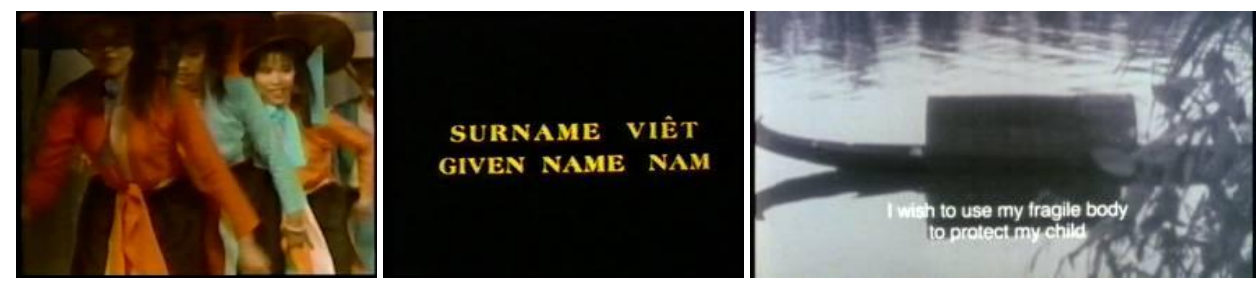

61. Surname Viet Given Name Nam (1989), Trinh T. Minh-ha

\footnotetext{
${ }^{9}$ Ibíd., p. 321.
} 
En otras palabras, la voz omnisciente "objetiva" del documental expositivo-que, recordemos, dominaba la expresión desde la postura del dominador-colonizador- cede espacio a la voz "subjetiva" de quienes intervienen en el documental interactivo. Pero, de todos modos, para la claridad del argumento del realizador y la mejor comprensión por parte de los espectadores, en la mayoría de los casos se mantiene una relación jerárquica de las voces en la expresión. Nichols dice que los trabajos de Minh-ha precisamente abandonan esa relación jerárquica. Trataremos de averiguar su manera de representarla a través de Surname Viet Given Name Nam.

Una sinopsis de la obra la encontramos en la retrospectiva que se realizó de su trabajo audiovisual en la Cineteca Nacional de México, celebrada en febrero de 2011, donde la describe del siguiente modo:

A través de entrevistas con cinco mujeres interpretadas por cinco actrices, la película exhibe la realidad de las vietnamitas. "Apellido Viet. Nombre Nam” se desarrolla alrededor de preguntas sobre identidad, memoria popular y cultura, explorando la problemática de la traducción, del desplazamiento y del exilio. A su vez, cuestiona la validez y la forma de entrevistar y representar; una cinta que pone en tela de juicio la naturaleza del género documental. ${ }^{10}$

Tal y como se indica, este documental tiene matices de ficción: escenas de entrevistas con personajes femeninos interpretadas por actrices. Pero, al mismo tiempo, una de estas actrices narra sus motivos para representar ese papel, junto a su experiencia vital como vietnamita. Es decir, este trabajo tiene ciertas características documentales y autorreferenciales, pero mantiene cierta distancia con la veracidad al construirse sobre la ficción. En un primer momento, entonces, dentro de la obra se encuentran una variedad de aspectos referentes a las modalidades de documental y de ficción.

\footnotetext{
${ }^{10}$ En http://www.cinetecanacional.net/ficha.php?cvePel=9412\&o=1\&ciclo=1453, consultada el 10 de junio de 2011 (presentación de la película en la web de la Cineteca Nacional de México).
} 
VI.2.2.1. Entre los soliloquios de mujeres representadas por otras mujeres.

En el audiovisual se representa a seis mujeres vietnamitas junto a la narración de la artista y a la de una de estas seis mujeres. Según el Film Script ${ }^{11}$, las entrevistas realizadas con las mujeres en Vietnam presentadas en esta película son referencias y traducciones del libro Vietnam, un peuple, des voix de Mai Thu Van (Paris: Pierre Horay, 1983). Para su proyecto filmográfico Minh-ha elige las entrevistas de cuatro mujeres (Ly, Thuvan, Cat Tien y Anh), personificadas por cuatro actrices: Tran Thi Hien, Khien Lai, Ngo Kim y Tran Thi Bich Yen. Al mismo tiempo, también hablan siendo ellas mismas, es decir, dentro de la obra estas cuatro mujeres representan cada una dos personajes; luego, dos mujeres se presentan siendo ellas mismas y conversan entre ellas. Son todas vietnamitas, tienen nombres vietnamitas y una apariencia asiática del extremo Oriente (excepto una, que tiene apariencia occidental). Casi todas hablan en inglés, pero podemos encontrar más de una entrevista en vietnamita. Las escenas en las que las actrices representan el rol de otro personaje ponen en evidencia, visualmente, las diferencias con las otras entrevistas y conversaciones.

En las escenas donde las actrices representan a los personajes, recitando el texto de la traducción del libro, ellas hablan en forma de soliloquio en inglés y se nota que no son hablantes nativas de dicha lengua. Cada una tiene su estilo, pero casi todas hablan en una voz baja y calmada, sin alegría, con escasos gestos expresivos.

Es en la primera parte de la obra donde se representan más escenas de soliloquio de estas mujeres. Cada una de las cuatro mujeres se encuentra sola en un espacio interior con la pared blanca. Una de ellas está sentada en el suelo frente a una tabla de picar, cortando verduras mientras habla; otra se pone enfrente o al lado de una mesa vacía, solamente con algunos enseres del hogar u otros instrumentos de su profesión, como un juego de tetera y tazas, una tela y unas tijeras, un estetoscopio, una rama con pequeñas flores o un candil. También hay una escena que no muestra el contexto espacial enfocando al personaje en primerísimo plano.

\footnotetext{
${ }^{11}$ Trinh, Minh-ha T., Surname Viet Given Name Nam en Framer Framed, New York y London, Routledge, 1992 , pp. 49-91.
} 
Uno de los aspectos interesantes de este trabajo, el que más llama la atención, es el manejo peculiar de la luz en las escenas de soliloquio. Las imágenes tienen una tonalidad suave de luz y son oscuras, en general. Esta tonalidad de luz aporta una impresión de vacío en la escena y se genera una sensación espacial de distancia entre la persona y la cámara. También hay escenas que introducen el foco de luz, pero no enfoca a la persona que está hablando, sino a los utensilios que están sobre la mesa, como el juego del té. De este modo, la mujer que habla permanece a la orilla o fuera del foco y se encuentra en el espacio oscuro o a contraluz. También hay escenas bastante oscuras en las que casi no se percibe el gesto de la mujer que habla al lado de un candil. Este montaje y colocación de la luz en las escenas del soliloquio de las mujeres crea una noción ambigua de lo que sucede. En cierto sentido, la escena crea una atmósfera bastante inquietante.
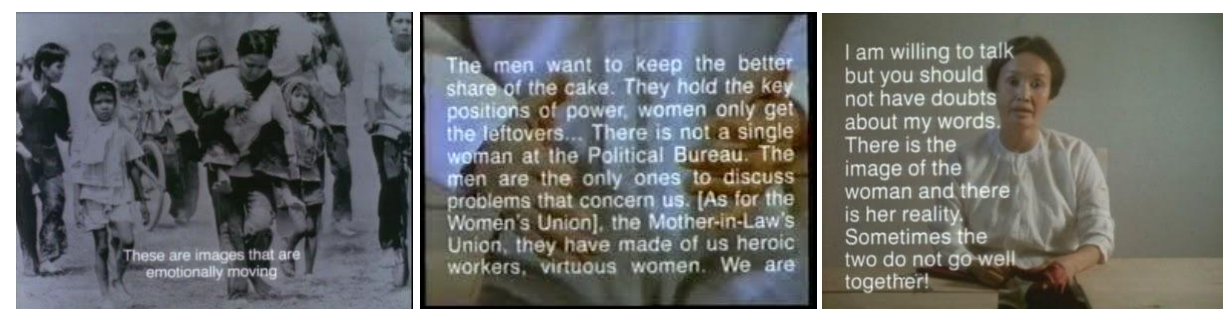

62. Surname Viet Given Name Nam (1989), Trinh T. Minh-ha

Otro aspecto que destaca en el montaje audiovisual es la yuxtaposición de imágenes de personajes que se solapan y crean una experiencia confusa. Sucede cuando en una escena una mujer cuenta a modo de soliloquio una historia acerca de la vida cotidiana vietnamita, y pasa a otra escena, sea con la misma mujer o con otra. De hecho, de vez en cuando, después del relato de una mujer vuelve a relatar la que había aparecido en la escena anterior. De este modo, repite la aparición de cuatro mujeres en diferentes encuadres y distinto picado de la cámara, y todas ellas narran las historias fragmentadas de otras mujeres como una experiencia propia. Solo este montaje ya participa en nuestra sensación de confusión entre una narración y otra, entre una mujer y otra.

Entre las escenas de soliloquio se encuentran unos montajes de fotografías de tipo publicitario, de archivo histórico o de registro familiar-personal vietnamita. Del mismo 
modo, se introducen imágenes en movimiento muy distintas de ceremonias, fiestas, paisajes, actos laborales en Vietnam, actividades de vietnamitas reunidos en EE.UU, etc. Para la introducción de las imágenes fotográficas se utilizan unas aplicaciones de efectos visuales. Por ejemplo, se muestra una parte de la mitad de la fotografía en fondo negro y después se muestra la otra mitad. O se enfoca una parte concreta de la escena y luego la otra, mostrando la transición del enfoque dentro de una misma fotografía, y finalmente se muestra su totalidad por medio del zoom. También se utiliza la cámara lenta para introducir algunas imágenes en movimiento.
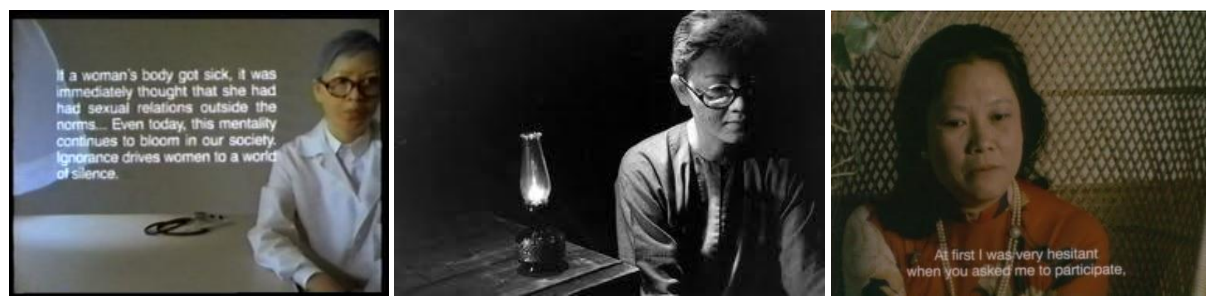

63. Surname Viet Given Name Nam (1989), Trinh T. Minh-ha

En la segunda mitad de la obra se empiezan a mostrar escenas de entrevistas, conversaciones o imágenes de la vida cotidiana en EE.UU. de las actrices. En esta parte, una mujer que sale en la escena habla de los motivos de su participación en la película del siguiente modo:

"At first I was very hesitant when you asked me to participate, bus then I thought: why would I refuse, when I am a Vietnamese woman myself, and the role in the film speaks the truth of the Vietnamese women still in Vietnam as well as of those emigrated to the U.S.? ..."

"My son's friend who is very fond of the Vietnamese told me 'You should take that role so as to speak up the repression of your mother and sister in Vietnam.' So, because I care about Vietnamese woman in general, I want to get involved in this film." 
"I still have many friends $n$ Vietnam. Compared with Cat Tien (my role) their condition is much worse. ..., ${ }^{\prime 2}$

Ésta es una parte de la entrevista a Kim en la que ella expresa sus motivos para participar en la película. Con este testimonio dentro del documental se nos muestra claramente que las escenas de soliloquios habían sido interpretadas por unas actrices con un guión. Al mismo tiempo, comprendemos que estas actrices viven y comparten la realidad de aquellas protagonistas. Y también que sienten la necesidad de hablar sobre la situación de represión de mujeres vietnamitas cercanas, como su madre, su hermana o su amiga. El motivo fundamental, pues, para interpretar ese papel es su condición como mujer vietnamita, similar a la de aquella a la que representa y de la cual conoce bien su situación.

En este sentido, no debemos entender su motivación simplemente reduciéndola a una actitud nacionalista. El motivo principal para su participación como actriz se basaría en compartir su experiencia y conciencia con las personas que se encuentran en una difícil situación en Vietnam. Es decir, ser vietnamita significa, en su caso, ser quien conoce, siente y comparte la realidad de la mujer en Vietnam. En este caso, las causas de su participación en la película no se identifican con el poder político vietnamita como nación, ni mucho menos con el régimen cultural patriarcal vietnamita. Por ello, en su soliloquio habla sobre el malestar generalizado en su país y sobre la sociedad a nivel político, económico, cultural e incluso sentimental (como un estado subalterno que no puede elegir). Otro personaje, Thu Van, representado por Khien Lai, habla del siguiente modo de la situación política y de una incómoda sensación en sus relaciones humanas:

\footnotetext{
${ }^{12}$ Ibíd., p. 85.

"Al principio, dudé mucho cuando me invitaron a participar. Pero luego pensé por qué iba a negarme si era vietnamita, y el papel de la película habla de la realidad de las vietnamitas en Vietnam, y también de aquellas que emigraron a Estados Unidos." "El amigo de mi hijo, que aprecia a los vietnamitas, me dijo: "Debería aceptar ese papel para que hable de la represión de su mamá y su hermana en Vietnam". Entonces, como me preocupan las vietnamitas, quiero participar en la película. "Aún tengo muchas amigas en Vietnam. Comparada con Cat Tien (mi personaje), su condición es mucho peor...” [traducción realizada por Ivonne Saíd y Juan Jacob para la subtitulación de la película, forma parte de Retrospectiva Trinh. T. Minh-ha que se ha celebrado del 18 al 24 de febrero 2011 en la Cineteca nacional de México, en: http://www.cinetecanacional.net/ciclos.php?cic=1453, consultada el 10 de junio de 2011].
} 
"[When I first met the women of the South,] we looked at each other with distrust, if not with hostility. Slowly we started talking to each other. From distrust, we have come to dialogue. And this was a radical turn that changed my political understanding. Before, I learnt in the political courses that capitalism was exploitation of man by man. Period. ",13

La siguiente frase comienza en voz en off y se escribe en la pantalla:

A society that imposes on its people a single way of thinking, a single way of perceiving life, cannot be a human society.

Thu Van, 35 years old, health technical cadre, Vietnam $1982^{14}$

Luego, sincronizada a esta voz, aparece Khien Lai personificando a Thu Van:

"In [our] socialist society, we discard all disturbing subjects so that we don't have to deal with them. We prefer to cultivate fear and suspicion. ...A society that imposes on its people a single way of thinking, a single way of perceiving life, cannot be a human society. "

"I ignore how a capitalist society functions, I ignore its disease. (Thu Van smiles). ...Between two modes of exploitation of man by man, it is difficult for me to choose!, 15

\footnotetext{
${ }^{13}$ Ibíd., p. 51

Cuando conocía a las mujeres del Sur, nos mirábamos con desconfianza, por no decir con hostilidad. Poco a poco, empezamos a hablarnos. Con desconfianza, iniciamos el diálogo. Y fue un giro radical que cambió mi comprensión política. Antes, aprendí en los cursos de política que capitalismo era que el hombre explotaba al hombre. Punto. [Traducción realizada por Ivonne Saíd y Juan Jacob en 2011]

${ }^{14}$ Loc.cit.

"Una sociedad que impone a su gente una forma de pensar, una forma de percibir la vida, no es una sociedad humana". [Traducción realizada por Ivonne Saíd y Juan Jacob en 2011]

${ }^{15}$ Ibíd., p. 56.

"En nuestra sociedad socialista, desechamos todos los temas inquietantes para no tener que resolverlos. Preferimos cultivar el miedo y la desconfianza. Una sociedad que impone a su gente una sola forma de pensar y una sola forma de percibir la vida, no es una sociedad humana".

"Ignoro cómo funciona una sociedad capitalista. Desconozco sus males. Entre dos formas de explotación del hombre, me cuesta trabajo elegir. [Traducción realizada por Ivonne Saíd y Juan Jacob en 2011]
} 
Por supuesto, es la artista -siendo una más de ellas- quien está propiciando el relato sobre la situación de estas mujeres al ofrecer este proyecto de representación. Los temas sobre los que ella habla en su soliloquio son la represión del régimen patriarcal-socialista, la discriminación entre la zona del norte y del sur, las contradicciones del matrimonio, la prostitución involuntaria, la difícil situación en los campos de refugiados, entre muchos otros. Una serie de historias de dificultades, violencia y humillación hacia las mujeres. Lo que hacen estas mujeres actrices en la presente obra es eso: reflejar el relato de la mujer sobre la mujer, y ello era, como vimos, condición indispensable para la autobiografía de la mujer (como argumentaba Shoshana Felman).

Seguramente, la mujer que personifica a otra mujer -a pesar de las duras experiencias vividas en muchas situaciones difíciles- se encontrará más segura si no está hablando de su propia experiencia personal. Sin embargo, ahora recordamos lo que argumentaba Spivak: quien se encuentra realmente en un estado subalterno, se acaba quedando mudo. A los que no conocen esta situación, como cualquiera que vive en una cultura dominante, le resulta más fácil ignorar al ser subalterno, así como a las mujeres que sufren represión. Sin embargo, ella, que como exiliada ha logrado escapar de aquella situación, no puede, ni quiere ignorarla, y considera que debe hablar sobre ella. Pero esta contrariedad la resuelve cuando quien habla sobre ella es otra persona que se encuentra en una situación más estable o, al menos, menos difícil.

VI.2.2.2. El espacio crítico donde se entrecruzan las voces múltiples y el silencio como fenómeno heterogéneo.

Además del soliloquio y de las entrevistas de mujeres, se introduce un comentario en voz en off, como comentaba Nichols, lo cual conlleva un carácter reflexivo. Es decir, el comentario no es de tipo omnisciente, sino introspectivo. A nivel del audio se escucha una variedad de sonidos: canto, música, efectos de audio, narración radio-televisiva, ruido y relato. 
Hay partes donde se escucha únicamente la música, también otras donde se superpone la música. Algunas veces, la imagen de un paisaje vietnamita se acompaña con una canción vietnamita. En ocasiones se insertan subtítulos en inglés, y otras veces, no. Hay escenas de soliloquios donde se superpone una voz de mujer a la voz de la protagonista. Este tipo de uso del audio provoca una sensación de imprecisión. Además, vimos, se introducen imágenes que nos desplazan al comienzo y al final de cada uno de los relatos. En las secuencias de soliloquios también se superponen textos sobre las imágenes de las mujeres hablando en ciertos planos. De este modo, se provoca una saturación de los lenguajes.

Parece que esta forma peculiar de presentar su trabajo proviene del interés de la artista en representar un carácter del lenguaje en relación con el silencio. Para precisar lo que piensa Minh-ha, dice:

It's very difficult to simply talk about silence as a homogeneous phenomenon. As you've noticed, even when there's sound or a lot of talking, you can still feel that interval. I really appreciate that, because, unlike with the films shot in Africa, "Surname Viet Given Name Nam", "Shoot for the Contents" and "A Tale of Love" feature language in its excess as it outdoes the will to speak and to mean. There are also moments when words become nonsense, which is another aspect of language that I often work with humorously. After so much speech, you come to a state where opposites really meet. You may say or hear one thing but you're supposed to mean or to understand exactly the opposite, which was the case with such terms as left and right, right and wrong, as related to China's politics. But that's the nature of language. When one pushes it far enough, words start to mingle, they are no longer opposites and the more one goes into it, the more one sees how these words used excessively can also silently open up a critical space. ${ }^{16}$

\footnotetext{
${ }^{16}$ When The Eye Frames Red, entrevista con Akira Mizuta Lippit, en http://www.trinhminh-ha.com/, consultada el 3 de marzo de 2011.

Es muy difícil hablar simplemente sobre el silencio como un fenómeno homogéneo. Como has observado, incluso cuando no hay sonido o se habla mucho, todavía se puede sentir ese intervalo. Realmente aprecio este hecho porque, a diferencia de las películas rodadas en África, "Apellido Viet. Nombre Nam", "Disparo a los Contenidos" y "Un cuento de amor" hacen de la lengua una característica en exceso, ya que supera a la voluntad de hablar y de querer. También hay momentos en los que las palabras se convierten en un sinsentido, que es otro aspecto del lenguaje que a menudo trabajo desde el humor. Después del discurso, se llega a un estado donde de
} 
Según su explicación, a la artista le interesa mostrar el intervalo dentro de su obra audiovisual, suponiendo que el silencio también es un fenómeno no homogéneo. En caso de Surname Viet Given Name Nam, que se caracteriza por el lenguaje del exceso, el intervalo del silencio supera a la voluntad de hablar. Es decir, consciente y estratégicamente se superponen en la obra varias pistas de audio con la intención de crear un intervalo para reflexionar sobre las distintas versiones del carácter y la calidad del silencio. En otras palabras, el silencio no es un estado que no tiene sonido. Cuando hay demasiadas voces cruzadas y es imposible escucharlas se genera un estado de intervalo, lo cual es uno de los tipos de silencio que funciona como un fenómeno heterogéneo.

Si solo nos esforzáramos en clarificar el contenido de lo que se dice no podríamos entender lo que se busca en la representación. También podríamos interpretar que se intenta provocar la ira de los espectadores. En este sentido, dentro de su representación audiovisual es muy importante fijarnos en lo que suena al mismo tiempo que en el silencio y sus variedades. Aunque no podemos negar esas intenciones de provocación que tiene y que influyen negativamente en los espectadores, obligados durante la observación de la obra a escuchar al mismo tiempo voces incomprensibles en un momento de reflexión.

En cambio, este exceso de voces nos guía al fijar otro aspecto del lenguaje. Este aspecto ya lo encontrábamos en la aproximación a la obra de Mona Hatoum de la sección anterior, donde las palabras se quedaban sin sentido, a menudo, cuando se trabaja desde la función del humor. Minh-ha pone como ejemplo la palabra "izquierda" y "derecha", "correcto" e "incorrecto" en las relaciones políticas chinas. Es decir, una palabra no indica un concepto absoluto, sino que dependiendo del contexto político-económico-histórico-cultural, la dirección y el estado de comunicación (¿quién dice qué a quién? ¿Dónde? ¿Cuándo? ¿Cómo?), una misma palabra puede decir una cosa y otra totalmente contrarias. Es la naturaleza del lenguaje, como dice Minh-ha, pero en muchas ocasiones ignoramos este aspecto y suponemos la evidencia de la comunicación a través del lenguaje audiovisual. En

verdad se juntan los opuestos. Se ppuede decir o escuchar una cosa, pero se supone que se debe decir o entender exactamente lo contrario, como fue el caso con términos como izquierda y derecha, lo correcto e incorrecto, en relación con la política de China. Pero esa es la naturaleza del lenguaje. Llevado suficientemente al extremo, las palabras comienzan a mezclarse, ya no son opuestos, y cuanto más se profundiza en ella, más se ve cómo estas palabras usadas en exceso también pueden abrir en silencio un espacio crítico. [Traducción propia] 
este sentido, confiar en la evidencia de la comunicación oculta la naturaleza del lenguaje y la realidad de una comunicación imposible. En un extremo, podemos decir que el arte contemporáneo es el que crea una ruptura, o al lo menos remueve ese tipo de creencia visualizando la naturaleza y la realidad de la comunicación. En este sentido, la obra de Minh-ha aparece como un intento artístico contemporáneo importante.

La artista pretende anular la simple oposición de palabras al introducir en el espacio crítico y reflexionar sobre la manera de hacer uso de estas palabras en exceso. La artista explica todo esto en la entrevista sobre su documental del siguiente modo:

When an interview is dense and intense, as in the case of those in Surname Viet Given Name Nam, then even in moments when one is not in front of the interviewee, the conversation continues, not in one voice, but sometimes in several voices, or in fragments that come and go and get superimposed on one another. There's nothing difficult in the film when one thinks inclusively in terms of what language does to us-how it speaks us as we speak it-rather than exclusively in terms of ourselves as the ones who manipulate language. Any one of those instances that may irritate the viewer by its so-called incomprehensibility is for me as clear as a river. They happen all the time in our daily reality with language. ${ }^{17}$

Ya que el lenguaje nos obliga vivir en esa situación en la que los múltiples sentidos de las mismas palabras entran en juego. Realmente, en la vida cotidiana somos capaces de escuchar, o no. Sobrevivimos distinguiendo y seleccionado las voces y el sentido, de una manera inmediata en un mundo "multi-voces". Pero en el cine estamos tan acostumbrados a quedarnos frente a la pantalla que nos convertimos en espectadores pasivos de la película.

\footnotetext{
${ }^{17}$ Ibíd.

Cuando una entrevista es densa e intensa, como en el caso de "Surname Viet Given Name Nam", entonces, incluso en momentos en que uno no está delante de la persona entrevistada, la conversación continúa, no en una sola voz, sino a veces en varias voces, o en los fragmentos que van y vienen y se superponen unos a otros. No hay nada difícil en la película cuando se piensa inclusive en términos de lo que el lenguaje nos hace a nosotros, cómo nos habla cuando lo hablamos, más que en términos exclusivamente de que nosotros somos los únicos que manipulamos el lenguaje. Cualquiera de estos casos pueden irritar al espectador por su supuesta incomprensión, eso está más claro que el agua para mí. Pero esto ocurre continuamente en nuestra realidad cotidiana del lenguaje. [Traducción propia]
} 
Esperamos que la película nos muestre todo ordenado, clasificando la imagen y el sonido basados en el lenguaje audiovisual, para que nos quede claro el orden al ver y escuchar. Lo cual significa que el lenguaje audiovisual cinematográfico ordenaría la mirada y la escucha para que los espectadores siguieran el filme sin desarrollar su capacidad de distinción y selección, dentro de un fenómeno audiovisual homogéneo. En el momento en el que una película, como la de Minh-ha, introduce una des-jerarquización en la representación entre voces, se puede provocar la ira e incomprensión de los espectadores. Simplemente este hecho nos hace reflexionar cuánto suponemos la evidencia del lenguaje audiovisual y cuán atrapados estamos en la idea de que el mundo debe ser preciso y comunicable de la forma más evidente posible.

Sin embargo, su película incluye voces simultáneas, y en vez de poner subtítulos, limita la opción de los espectadores a elegir, según su propio interés y conocimiento. Si no es una persona bilingüe de inglés y vietnamita, en realidad se ve limitado a tomar una decisión sobre qué parte observar para comprender lo que plantea la artista. Aunque haya ciertas excepciones, como ella comenta:

\begin{abstract}
Regarding the anecdote about which voice to translate when there are several simultaneous voices, I was amazed by the Japanese solution. Actually, with Japanese characters, that problem did not even arise; my distributor at Image Forum simply decided to have one voice subtitled vertically, the other, horizontally. Not only do calligraphic characters destroy the image much less, but you also have this flexibility of going vertical or horizontal. ${ }^{18}$
\end{abstract}

Al parecer, la misma artista se sorprendió de la flexibilidad que tienen los japoneses a la hora de subtitular, ya que hay dos opciones de escritura, en horizontal y en vertical, además de la reducción de las frases con los caracteres japoneses, que están integradas en el idioma.

\footnotetext{
${ }^{18}$ Ibíd.

En cuanto a la anécdota de qué voz traducir cuando hay varias voces simultáneas, me quedé asombrada por la solución japonesa. En realidad, con los caracteres japoneses, ese problema ni siquiera se plantea. Mi distribuidor en Image Forum simplemente decidió subtitular una sola voz, en vertical y, la otra, en horizontal. No solo se consigue que los caracteres caligráficos destruyan la imagen mucho menos, sino que también se tiene la flexibilidad de ir en vertical o en horizontal. [Traducción propia]
} 
Esta opción de escribir en dos sentidos, horizontal y vertical, sería lo mismo en el caso del idioma chino. Estos idiomas originariamente se escribían en vertical y después se adaptaron al estilo occidental en horizontal. Por eso, ahora es algo natural que existan las dos opciones a la vez. Pero de todos modos, en un momento dado, leer todo lo que se dice mientras se escuchan voces simultáneas también nos llevará a un punto en el que será imposible entenderlo todo. Si se pudiese captar el sentido de todo, se generaría bastante confusión. Sin embargo y al mismo tiempo, es un estado natural que vivimos en la vida cotidiana, según la artista.

Whatever takes shape does not do so simply in order to address form. In that sense, nothing really takes shape. By going towards things while letting them come to me in the mutually transformative process of filmmaking, I am not merely "giving form." Taking shape is not a moment of arrival, and the question is not that of bringing something vague into visibility. Rather, the coming into shape is always a way to address the fact that there is no shape. Form is here an instance of formlessness, and vice-versa. ${ }^{19}$

Representar una forma, como un ejemplo de la falta de la forma, nos parece una respuesta a la meditación Zen. La forma que representa la obra de Minh-ha no estaría constituida por expresiones abstractas, sino que muestra unas trayectorias de ida y vuelta entre el exceso y la falta, tanto a nivel auditivo como visual, aprovechando el registro de los relatos y entrevistas, e introduciendo múltiples imágenes y sonidos.

En las escenas del soliloquio se evidencia bastante la distancia espacial entre el personaje y la cámara, como hemos comentado anteriormente. En otra parte de la escena del soliloquio, se muestra el gesto del personaje en un gran plano, mientras ella relata y la cámara se mueve. Por ejemplo, se baja la cámara verticalmente, desde el gesto de los labios que narra

\footnotetext{
${ }^{19}$ Ibíd.

Lo que toma cuerpo no lo hace simplemente para hacer frente a la forma. En ese sentido, nada se concreta. Al ir hacia las cosas, mientras que dejo que ellas vienen a mí en el proceso de transformación mutua de hacer cine, yo no hago más que "dar forma". Dar forma no es un punto de partida, y la cuestión no es la de transformar algo vago en visible. Por el contrario, el dar forma es siempre una manera de abordar el hecho de que no hay forma. La forma es aquí un ejemplo de falta de forma, y viceversa. [Traducción propia]
} 
en primerísimo plano, hasta fijarse en el gesto de las manos que están frente al ombligo y después se vuelve a subir. Del mismo modo, se mueve horizontalmente hasta que la mitad de su cara sale del encuadre y continúa el movimiento de ida y vuelta, cortando la mitad del rostro. Esta manera enfocar al personaje no es nada habitual en el caso de una entrevista. De este modo, se descubren partes que no respetan la gramática del lenguaje audiovisual estandarizado.

En general, se suele evitar este tipo de movimiento de la cámara en escenas de entrevistas para que el espectador pueda concentrarse en lo que se dice. Cuando se realizan enfoques hacia alguna parte corporal, en general, se hace para demostrar un aspecto sentimental del personaje según el contenido del relato. También en la representación expositiva e incluso interactiva se introducen imágenes como una ilustración de lo que cuenta el personaje en la escena de la entrevista, para una mejor comprensión del contenido. Es decir, lo común en las entrevistas es que los espectadores se integren y se aproximen a los personajes. Pero lo que Minh-ha practica con este trabajo son imágenes introducidas en las entrevistas que no son una sencilla ilustración para una mejor comprensión. Ese movimiento de cámara, aquel modelaje de la luz casi oscuro, su manera de aproximarse a los personajes y espectadores,... son bastante distintos a lo habitual en el lenguaje cinematográfico.

En este sentido, podríamos decir que este flujo entre el exceso y la carencia no se resume en una integración, sino al contrario, lo que nos indica son unas distancias y discrepancias entre el sentido de los relatos, los espectadores y los personajes. En cierto sentido, podemos encontrar una misma conciencia compartida en la obra de Mona Hatoum, que indicaba varios niveles de distancia dentro de unas expresiones repetitivas.

Esa conciencia se plasma en el mantenimiento de cierta distancia con cualquier principio cultural, y se cuestiona la identidad de sí misma. Podríamos decir que es una conciencia común que vamos a encontrar en los trabajos de las mujeres en tránsito. Como ella expresa de la siguiente manera: 
So when you talk about this sense of travelling, of wandering, and of not fitting comfortably in one group, it's not so much something that constitutes an agenda on my part as something rather intuitive that corresponds to the way I live, to the skills of survival I've had to develop, and to my own sense of identity. I'm not at all interested in giving form to the formless, which is often what many creators reach for. Rather, I'm taken in by the creative process through which the form attained acutely speaks to the fragile and infinite reality of the world of forms-or, of living and dying. ${ }^{20}$

No encajar en ningún grupo étnico-político-histórico y tener la sensación de permanecer en un continuo estado de viaje, encontrando y descubriendo cosas continuamente, forma parte de la intuición de la artista y de las habilidades que ella ha ido desarrollando durante sus experiencias de supervivencia en otro país. Y nos parece que la representación audiovisual es la más adecuada para mostrar esta intuición. Entonces, la manera en que muestra la falta de forma, en el caso de Minh-ha, nos permite aproximarnos a su interés por el proceso creativo, con diferente método e interés por la construcción de la forma y la visibilidad de una identidad unificada. Esta referencia coincide con lo que indicaba Nichols sobre la postura de la artista que se niega a expresarse en nombre de la esencia poética de otra cultura.

La artista no representa una imagen típica establecida de una cultura específica, sino que muestra la diferencia y el desacuerdo de cada uno con su cultura o con otra cultura. En el plano de la lectura del guión se percibe también su forma de expresión, que indica la distancia, diferencia y discrepancia entre las gramáticas audiovisuales, en tránsito entre lo excesivo y la carencia. De la siguiente manera, ella resume una tendencia de su forma ambivalente de trabajar surgida en su obra audiovisual:

\footnotetext{
${ }^{20}$ Ibíd.

Así que cuando se habla de esta sensación de viajar, de andar y de no encajar cómodamente en un grupo, no es tanto algo que constituye un programa para mí, sino más bien algo intuitivo que corresponde a la manera en que vivo, a las habilidades de supervivencia que he tenido que desarrollar, y a mi propio sentido de identidad. No estoy en absoluto interesada en dar forma a lo que no la tiene, que a menudo es lo que muchos creadores tratan de alcanzar. Más bien, me encuentro en el proceso creativo a través del cual la forma plenamente alcanzada habla de la realidad frágil e infinita del mundo de las formas, o de vivir y morir. [Traducción propia]
} 
How to incorporate that sense of the infinite in film is most exciting, even though we know that we always need a beginning and an ending, and that making a film is already to stop the flow or to offer a form. But rather than reaching a point of completion where form closes down on form, a closure can act simultaneously as an opening when it addresses the impossibility of framing reality in its subtle mobility. This is certainly one way of looking at what happens with all of my films. ${ }^{21}$

Ese sentido ambivalente en la representación audiovisual de lo infinito en forma limitada nos hace imaginar una historia de la vida que sigue una forma en espiral, al contrario que un relato en círculo que parece cerrado y tiene un punto de partida y de llegada. Cuando se desplaza el punto de vista a otra dimensión, aquel punto que se veía cerrar el círculo, no cierra la línea, sino que ésta es la que se cruza y se abre.

De este modo, sería necesario analizar las "extrañas” yuxtaposiciones de las escenas del soliloquio donde una mujer habla personificando a otra mujer, con numerosas imágenes introducidas junto con los comentarios introspectivos y unos manejos del lenguaje excesivos. Así comprendemos lo que comenta Bill Nichols sobre la obra Surname Viet Given Name Nam al compararla con otras obras conmemorativas de la nouvelle vague:

Desavenencia; «provocación, intento de desagradar y por tanto cambiar al espectador». ${ }^{22}$ Puede tratarse de un objetivo deliberado en algunos casos y algunos pueden considerarlo de valor específico, como quienes asocian erróneamente los afectos de alienación de Brecht con los discursos de sobriedad y el equivalente artístico de la ética del trabajo protestante. En otros casos, puede ser un resultado de echar por tierra expectativa y socavar convenciones que no adquiere valor a menos que se canalicen hacia un modo de descubrimiento, percepción y

\footnotetext{
${ }^{21}$ Ibíd.

Cómo incorporar ese sentido de lo infinito en el cine es de lo más emocionante, aunque sabemos que siempre son necesarios un comienzo y un final, y que realizar una película es detener el movimiento u ofrecer una forma. Pero en lugar de llegar a un punto de terminación donde la forma encierra a la forma, el cierre puede actuar simultáneamente como una apertura cuando trata la imposibilidad de encuadrar la realidad en su movilidad sutil. Ésta es, con certeza, una forma de ver lo que sucede con todas mis películas. [Traducción propia]

${ }^{22}$ Wollen, Peter: Godard and Counter Cinema: Vient d'est, en Nichols, Bill (ed.): Movies and Methods, vol. 2, University of California Press, 1985, p. 502.
} 
transformación específico. La desavenencia, en otras palabras, puede tornar al espectador curioso en un espectador aburrido, o convertir al espectador de pago en un espectador resentido. Las frustraciones narrativas incluidas en Surname Viet Given Name Nam, por ejemplo, no buscan la ofensa por la ofensa, como perece ser el caso de Vent d'est (1969) o Numéro Deux de Godard. ${ }^{23}$

Precisamente, dice Nichols, la desavenencia que se encuentra dentro de la expresión audiovisual ocasionaría una frustración narrativa como en el caso de este audiovisual. Pero, a su vez, no es una provocación de la ofensa por la ofensa, sino que es una oportunidad para crear un momento reflexivo que espera abrir un espacio crítico que incite a los espectadores curiosos. Y suponemos que este espacio crítico sería un lugar para la autobiografía de la mujer.

\section{VI.2.3. La obra autobiográfica de la mujer anónima en relación a la artista.}

Para finalizar el presente apartado, añadiremos un comentario de la artista en la entrevista que hemos citado anteriormente. Minh-ha habla sobre la relación entre la vida personal del autor y la obra como película:

The question asked often revolves around whether the film tells of a personal experience. "Does this come from your personal life?" It makes things very difficult because certainly, I would have been totally unable to make a film if it hadn't engaged me strongly in a personal way, but this has little to do with one's own particular life. It would be of no interest if filmmaking and filmviewing merely invited identification rather than offered an encounter with what is larger than one's individual self-that is, with one's own spaciousness. ${ }^{24}$

\footnotetext{
${ }^{23}$ Nichols, Bill, Op.cit. p. 321.

${ }^{24}$ When The Eye Frames Red, entrevista con Akira Mizuta Lippit, Op.cit.

La pregunta formulada a menudo gira en torno a si la película habla de una experiencia personal. " Está basada en tu vida personal?" Esto hace las cosas muy difíciles, porque, sin duda, habría sido totalmente incapaz de hacer una película si no me hubiera comprometido firmemente de una manera personal, pero esto tiene poco que ver con la vida propia. No sería interesante realizar cine o ser espectador si se invitara a una mera identificación en vez de ofrecer un encuentro con algo mayor que la propia individualidad, que es con el espacio particular de cada uno.[Traducción propia]
} 
Minh-ha piensa que la memoria, la experiencia personal y una profunda comprensión de ellas serían los fundamentos para realizar la película. Pero dice claramente que una vida propia en particular poco tiene que ver. Este argumento es la esencia de la expresión autobiográfica. En el caso de la presente obra, que no habla de la vida particular de Trinh T. Minh-ha, comprendemos claramente lo que ella dice.

Sin embargo, ahora queremos ampliar esa interpretación de la obra autobiográfica de la mujer. Este trabajo no habla de la vida personal de Trinh T. Minh-ha, sino que es una representación de testimonios de mujeres interpretados por otras mujeres. El título de la presente obra, Surname Viet Given Name Nam, se refiere a los apellidos anónimos de las mujeres de Vietnam. Dentro de la película se repite tres veces la misma frase, reseñando el hecho de que el nombre que se les impone a todas las vietnamitas es el de su marido, incluso a aquellas mujeres exiliadas del país.

Esta obra, que hace una asociación con la mujer anónima, llamada la mujer de Viet-Nam está basada en fragmentos de los testimonios de supervivencia de las mujeres en el sistema patriarcal, la batalla ideológica, su difícil situación económica, la represión sexual o el estado de humillación del exiliado. Cada relato se figura y desfigura con la imagen de la mujer de Viet-Nam, indicando el abismo y el punto de conexión con la realidad de las mujeres que viven allí. Sus relatos son la expresión audiovisual que nos hace concienciarnos de una imposibilidad de representación de lo real, visualizando la distancia entre el parlante y el oyente, el personaje y la actriz, lo que ocurre y su relato, con el flujo de lo excesivo y de la carencia. Cada caso particular que presentan las mujeres es impactante, relevante, y todos deberían ser rectificados por la sociedad. Pero lo que se pretende en esta obra no es denunciar la injusticia que sufre una mujer particular, sino hablar de sí mismas, rompiendo una identidad acomodada en el discurso político, económico, histórico y cultural de Vietnam. En este sentido, podemos decir que es una obra autobiográfica de la mujer anónima, que tiene un marido con el apellido Viet y un nombre, Nam. Es una figura tanto imaginaria como real.

En este caso, si la vida particular de Minh-ha se proyecta en la obra o no, no constituye un factor importante de esta obra "autobiográfica". Como planteaba Drucilla Cornell, en una 
autobiografía de la mujer no cabe la forma de incluir una biografía de la madre-abuela o de otras mujeres que comparten la vida de esa mujer. Por ello, nos permitimos citar esta obra en nuestra serie de trabajos audiovisuales que abordan el tema de la expresión autobiográfica de la mujer en tránsito.

Obviamente, el tránsito cultural y el tránsito físico de las mujeres de Vietnam en la presente obra son puntos claves que permiten hablar a las mujeres. También coincide con lo que hemos desarrollado sobre la autobiografía de la mujer y sobre la imposibilidad de hablar de la mujer subalterna: la presente obra permite a una mujer que hable por otra mujer, nos muestra su proceso y nos permite ser testigos de sus testimonios. En consecuencia, sería una expresión de la autobiografía de la mujer, o por lo menos, sería una obra que origina y prepara la aparición de la autobiografía de la mujer. 
VI.3. Night Cries: A Rural Tragedy (1989), Tracey Moffatt: un cortometraje de la mujer sin palabras y la llegada de la canción. 
La tercera obra a la que nos vamos a aproximar en el presente capítulo es Night Cries: A rural Tragedy (1989) de Tracey Moffatt. Es diferente a las otras dos obras audiovisuales que hemos visto, esta obra está grabada en película de $35 \mathrm{~mm}$. Es un cortometraje de ficción en el que se han filmado las escenas con los actores que cumplen su papel de protagonista en el estudio de cine que facilita mayor control para la filmación. La obra trata el tema del amor y odio entre la madre y su hija, representa unos sentimientos cruzados con la memoria infantil de la hija. Las protagonistas principales, son naturalmente dos mujeres: la hija, de mediana edad y de origen aborigen, cuidando a su madre blanca anciana, que necesita asistencia indispensable por ser una anciana con dificultad de movimientos, ya que va en silla de ruedas.

Las características particulares del presente trabajo que nos interesan sumamente son dos, una es el estilo del montaje de las escenas, tiene un estilo estético que se centra en otros trabajos en colores saturados que utiliza la artista. En general, las películas de ficción filmadas en el estudio buscan una veracidad del montaje de la escena ocultando lo que es el montaje en el estudio. En cambio, en el presente trabajo no se nota el intento de ocultarlo. No digamos que no se busca la veracidad, pero los montajes son bastante esquemáticos y semióticos. Los detalles los averiguaremos durante nuestra aproximación.

El otro aspecto es el estilo de la actuación "experimental", sin ninguna pronunciación de palabras, ni conversación en las escenas. El audiovisual en sí no es silencioso, sino que lleva ciertos efectos de sonido, hasta que se escuchan alaridos, suspiros, risa y voces de sollozos humanos, pero los personajes nunca pronuncian ni una palabra. Las palabras que se oyen en esta obra son letras de una canción que se escucha en la parte de la introducción y al final de la obra. También, hemos seguido desarrollando la cuestión del relato, el silencio y el estado mudo de la mujer con el tema de la autobiografía. Entonces, enfocaremos esta sección en este aspecto, fijándonos en la manera de relatar sin palabras, con la calidad del silencio y el estado mudo de la mujer en relación a la llegada de la canción. 
Antes de analizar la obra, presentamos brevemente a la autora. Tracey Moffatt es una artista que trabaja la fotografía y el audiovisual, tanto en película de larga duración como en vídeo, y es reconocida a nivel internacional. Ha celebrado numerosas exposiciones, participado en la Bienal de Venecia y en 1999 presentó una exposición individual en la Fundació "La Caixa” en Barcelona.

Ella nació en 1960 en Brisbane, Australia como una aborigen y fue adoptada por una familia de descendencia anglosajona por la ley de la adaptación que se promulgó en Australia. Dentro de su trabajo, se encuentran temas que relacionan esta política con otros temas de su país. El maltrato y alienación de la gente y de su cultura autóctona como aborigen, sería una parte negativa de la colonización en Australia. La política nacional australiana para la adaptación del aborigen en la sociedad Anglo-Australiana realizó una separación coactiva de los niños aborígenes de sus propios padres. Esta política ha durado setenta años, actualmente está considerado como un tipo de genocidio contra los aborígenes ${ }^{1}$. En general, les llaman generaciones robadas a esos niños de origen aborigen que crecieron como adoptados en el contexto Anglo-Australiano alejados de la familia y su cultura natural. La obra que vamos a aproximar, Night Cries: A Rural Tragedy es uno de los trabajos basados en esas generaciones robadas.

\section{VI.3.1. La canción como fe de comunicación.}

La obra Night Cries: A Rural Tragedy ${ }^{2}$ filmada en película de $35 \mathrm{~mm}$, tiene una duración de 17 minutos. Como hemos comentado, es una película filmada en el estudio cinematográfico, se nota inmediatamente el control total de la tonalidad de la luz y los encuadres de la cámara.

Comienza con unas frases citadas en fondo negro con unos ruidos del tren, de animales.

\footnotetext{
${ }^{1}$ La obtención de la ciudadanía australiana de aborigen fue en 1967. Y en los años noventa se realizó la devolución de terreno robado a los aborígenes en la colonización, por reconocer el derecho de los autóctonos en un juicio. En el año 2008, el primer ministro del gobierno australiano pidió disculpas oficialmente a las generaciones robadas.

${ }^{2}$ Para nuestro aproximación hemos aprovechado Ubuweb para citar algunas transcripción: http://www.ubu.com/film/moffatt_rural.html, consulta: 15 junio 2011.
} 
"Look at that sunset Howard!...

It's like the daytime didn't

want to end ... like it was gonna

put up a big scrap and maybe

set the world on fire to keep the

night time from creeping on"

Rosalind Russell - Picnic ${ }^{3}$

Y posteriormente se oye un alarido de mujer que da título a la obra Night Cries, cuya palabra aparece diseñada o dibujada, en medio de la pantalla, y con el subtitulo A Rural Tragedy en la parte inferior sobre un fondo negro.

Después del título, se puede dividir el audiovisual, en tres partes a grandes rasgos, la primera parte es el prólogo, la segunda son las escenas del drama y la tercera, el epilogo. En la parte del prólogo y epilogo, aparece un hombre con traje y corbata cantando alegremente con un buen foco de luz en un plano medio con el fondo negro. Éste es Jimmy Little, un cantante popular australiano de origen aborigen. La canción de las dos escenas del prólogo y del epilogo es la misma, Royal Telephone; en el prólogo canta solo la primera parte sin ningún instrumento y en el epilogo, hasta la segunda parte, con instrumentos. Las letras de la canción son las siguientes:

Telephone to glory, oh, what joy divine!

I can feel the current moving on the line,

Made by God the Father for his very own,

You may talk to Jesus on this royal telephone.

Central's never "busy," always on the line;

You can hear from heaven almost any time;

There's a royal service, built for one and all;

When you get in trouble, give this royal line a call.

Telephone to glory, ... ${ }^{4}$

\footnotetext{
3 "Mira Howard que puesta del sol! ...

Es como el día que no quiere terminar ... como que iba a poner un trozo grande y tal vez al mundo en el fuego para mantener la noche del arrastramiento en el "

Rosalind Russell - Picnic [traducción propia]

${ }^{4}$ Teléfono a la Gloria, oh, que divina Gloria! Puedo sentir el movimiento continuo de la línea,

Hecha por Dios padre para los suyos, Tú puedes hablar con Jesús por este teléfono real.

La central nunca está ocupada, siempre está en línea, Puedes tener noticias sobre el cielo casi en cualquier momento Es un servicio real, construido para uno y todos. Cuando tengas problemas, llama a esta línea real.
} 
La canción canta el servicio telefónico "Teléfono Real” que ofrece el padre Dios a los suyos para que le puedan consultar en cualquier momento difícil, gratuitamente. Da un toque de ironía al servicio telefónico de consultas, que prácticamente está ocupado casi siempre y es costoso en la mayoría de ocasiones. Evidentemente, es una canción basada en el concepto del cristianismo que fomenta que, el padre Dios, está atento a todos los suyos, cuando uno tenga dificultad puede comunicar con Jesús directamente por teléfono.

La imagen de este cantante se introduce de vez en cuando en algunas escenas de la segunda parte, pero no se escucha la canción ni su voz dentro de la segunda parte, sino que solo se oyen unos ruidos. Las introducciones de las imágenes del cantante, sin voz pero con ruido, nos parecen muy significativas para nuestra aproximación en el presente trabajo.

Si nos permitimos analizar las imágenes del hombre cantando sin audio, es una expresión que nos indica un estado mudo que no llega a la canción de la misma manera que la fe de la comunicación. No está rechazando totalmente tener fe y una alegre armonía con la confianza de la comunicación basada en el cristianismo como un concepto fundamental de la cultura occidental y su penetración en el pueblo australiano de origen aborigen. Ya que ahí no se comprende un simple esquema antagonista de la cultura occidental contra una de etnia autóctona de aborigen que sean algo totalmente opuesto. Dentro de esta mezcla compleja, esta expresión nos hace reconocer un momento de tensión y confusión, al que no llega la canción de la fe. Profundizaremos después de comprender la estructura de la representación audiovisual de la segunda parte con unas breves descripciones que vamos a seguir ahora mismo.

\section{VI.3.2. Entre el silencio y el estado mudo, con mucho ruido.}

La segunda parte, es la parte principal de la presente obra. Nos parece posible dividirla en cinco fragmentos dependiendo del contenido de las escenas. Dentro de estas, como hemos comentado anteriormente, se encuentran dos personajes principales: una hija de piel morena y la madre piel blanca. El drama sigue la descripción de vida cotidiana de estas dos mujeres 
en la que la hija se dedica a la asistencia de la madre, con las tareas domésticas como base en el tiempo presente de la escena. La hija es gorda, con la piel morena, cabello con canas y de edad mediana, y la madre es una anciana totalmente canosa con la piel blanca desecada, que lleva un aparato mecánico en su brazo derecho y se encuentra en silla de ruedas.

Como dice el subtitulo, las escenas pasan en "el espacio rural" grabado en el estudio. Como hemos dicho, el montaje espacial de la escena es poco veraz y tal vez nos permite decir, es muy esquemático y semiótico de alguna manera. En el paisaje de las diferentes escenas, se ven unas dos líneas horizontales que dividen la pared del fondo y el suelo: una de crestas de las montañas y otra de desierto que parecen pintadas sin ninguna vegetación, con el fondo simplemente de una tonalidad del color cielo. Otro contexto del paisaje es el mar, se ve al fondo una proyección de la marejada y las olas que rompen chocando con las rocas que se notan artificiales colocadas delante.

Las escenas siguen con las dos mujeres que se quedan en una casa humilde, solitaria, en un erial con el "paisaje salvaje" de aquellos escenarios. La mujer de edad mediana cuida a la anciana que necesita ayuda para lo básico para seguir viviendo, para comer, ir al servicio y limpiarse, prácticamente para todo. Los espacios que nos muestra dentro de la casa son dos escenas: una es la sala principal de esta casa en la que comen y duermen estas dos mujeres, y la otra es la puerta hacia una caseta del aseo que solo muestra la parte inferior de la mujer de mediana edad. Como parte anexada a la casa, se encuentra una escena de la caseta cubierta de chapas de zinc, que es el aseo, comunicado con un pequeño camino marcado con unas piedras puestas en sus orillas con el fondo de aquel "paisaje" de cresta de montañas y desierto. Dentro de estas escenas de la vida cotidiana de estas dos mujeres introduce unas imágenes variadas: aquel cantante, una niña de piel morena con una mujer de piel blanca. Y esas imágenes introducidas muchas veces tienen diferente tonalidad de luz.

En general, la actuación de la hija nos enseña la frustración que siente asistiendo a la anciana y su situación en general. Por ejemplo, cada vez que la hija debe ayudar a la anciana, deja unas cosas que mantenía en su mano pero con un gesto agresivo y cierto ruido de golpe. También hay una escena en la que ella lava las ropas a mano, no se muestra el 
rostro, pero persiste el enfado de ella, visible por el gesto de estrujar y arrojar las ropas sacadas del agua agresivamente, además de patear el borde del cubo de lavar después de levantarse. Y con estos gestos siempre lleva el efecto de audio como ruido del golpe de los artículos al suelo, del agua al lavar y estrujar, del golpe de la ropa mojada al suelo, del cubo pateado. Como hemos dicho, nadie pronuncia ninguna palabra en la segunda parte de las escenas del drama de estas dos mujeres, pero por el gesto y ciertos efectos de audio nos hacen percibir la ira y el enfado de este personaje.

La anciana no muestra sus sentimientos o es difícil captar su estado emocional a través de las presentaciones de las escenas. O más bien, muestra gestos ambiguos, como el gesto de sentimientos o de necesidad fisiológica.

Hemos comentado que el drama de estas mujeres se podía dividir en cinco partes. La primera parte sería la parte de la introducción, nos explica la situación y la relación de estas dos mujeres y el estado emocional de la mujer de mediana edad. Empieza con una escena del almuerzo o la comida con la luz del día en la sala-comedor.

Se muestra una imagen de aquel paisaje a través del marco de las ventanas de la salacomedor al apagarse la voz de cantante. Con el movimiento del pan de izquierda a derecha, se muestra a la mujer de mediana edad mordiendo una manzana y mirando una revista, medio acostada en un sillón frente a las ventanas. Con el sonido resultante de morder y masticar la manzana, se cambia a la imagen de unos artículos desordenados en la mesa, moviendo el pan de derecha a izquierda, fundiendo imágenes tras imágenes los artículos de la mesa, luego introduce un ruido de choque de unos cubiertos y aparece un plato y una mano derecha con aparato sujetando una cuchara en la mitad izquierda de la pantalla. Y muestra una totalidad de la escena de la sala-comedor, una anciana en silla de ruedas comiendo con su mano derecha con cierta dificultad, quedándose en el borde izquierdo de la mesa, detrás de la mesa se sitúa la mujer estirando las piernas en el sillón frente a la anciana, con el fondo de la ventana al lado de una puerta abierta que queda a la izquierda y por la que se ve el paisaje. Luego, a la anciana se le cae la cuchara y ella mira a la mujer en 
el sillón, la mujer le mira y deja su revista con gesto bastante agresivo y se acerca a la anciana, pone los codos en la mesa, coge la cuchara y le hace comer.

Con este montaje, percibimos que una mujer cuida a una anciana, de forma no muy alegre, en una casa de ambiente rural y con tensión entre ellas.

Desde el plano panorámico de la sala-comedor, cambia del primerísimo plano del rostro de la anciana, al primerísimo plano de la mujer de edad mediana en frente, y ella gira la cara hacia la derecha mirando a esta dirección. Muestra un primer plano de unos cuadros con fotos de una niña morena, de una mujer blanca y de las dos juntas: la mujer blanca sentada teniendo la niña en sus rodillas. Vuelve después al primerísimo plano de la anciana masticando y cambia a otro plano enfocando a un cuadro con una foto de la mujer blanca joven bien arreglada, luego muestra el primerísimo plano de la mujer de edad mediana mirando a la derecha y ella se gira a mirar al frente. Y vuelve a la escena panorámica.

Con este montaje nos hace comprender varias cosas. Primero, nos hace fijarnos bien en la diferencia de estas dos mujeres, el color de la piel, el aspecto físico y la edad principalmente por comparar los rostros de la mujer de mediana edad y la anciana. Segundo, nos hace percibir la relación madre-hija por comparar la fotografía y estas dos mujeres. Tercero, el paso de tiempo al comparar la foto de la mujer blanca de mediana edad y la anciana.

Después de comer, la mujer lleva a la anciana al servicio, que está en la caseta que queda fuera de la casa, haciendo gestos de aburrimiento y de ira continuamente, y se va a bañarse dejando a la anciana en la caseta. 

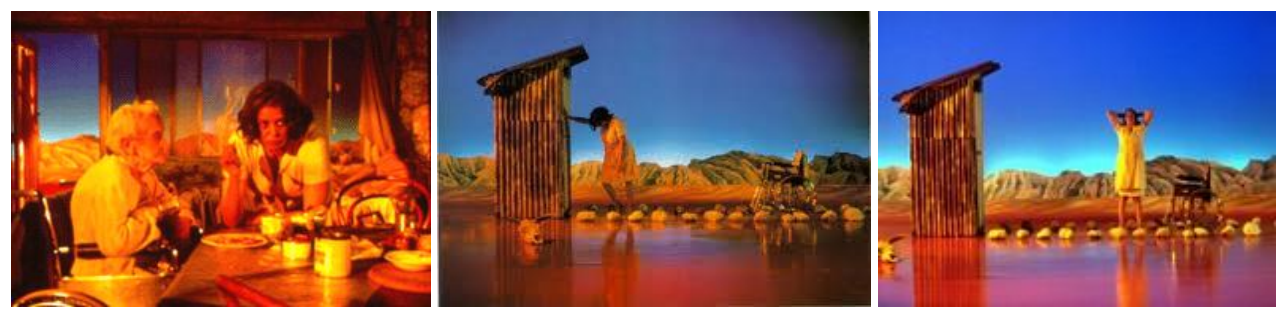

64. Night Cries: A Rural Tragedy (1989), Tracey Moffatt

Ahí se introducen dos tipos de imágenes fragmentadas. Una es la de una niña aborigen bien vestida y la mujer blanca de aquellas fotografías en la que arregla y limpia a la niña, con una escena de una tonalidad de luz muy fuerte. La otra, es la imagen de un trozo de chapa de zinc que resuena en la parte de la caseta. Se entrecruzan las imágenes de la mujer de mediana edad bañándose con una manguera y estas dos imágenes. Los sonidos metálicos suenan cada vez más, la imagen de la niña y de la mujer blanca se quedan en silencio. En la escena de la mujer bañándose, suena solo el ruido del aire y del agua, y se termina con un primer plano de la mujer de mediana edad remojada y con los brazos cruzados a la altura del pecho.

La secuencia que acabamos de describir nos parece muy significativa y transmite un estado emocional de la mujer de mediana edad distinta cuando rememora su pasado y cuando se enfrenta a la realidad actual y su difícil y tormentosa relación con la anciana. Comienza con una señal de la anciana para que la saquen de la caseta y la otra es un flash back de la niñez de la mujer, que recoge la memoria con su madre de manera muy luminosa y afectiva. La parte del flash back empieza con unos primeros planos enfocados hacia ciertos detalles de la escena y posteriormente se muestra un plano panorámico. Por este montaje, percibimos la manera de recordar de la hija, y el último plano de ella nos da la impresión de que está añorando cuando la madre la cuidaba a ella de niña. En cambio, también percibimos que está ignorando totalmente la señal de la anciana.

Con esta escena, nos da una impresión trágica al mismo tiempo que bastante cómica. Es notable la infelicidad para las dos mujeres, la cuidadora agresiva frustrada y la anciana mal tratada y con temor por la tensión con la cuidadora. Pero también no deja de darnos un 
toque cómico al comparar la imagen de la hija cuidadora que está entregada en la nostalgia de su niñez con la memoria de ser cuidada por su madre, mientras se oye insistentemente un sonido de chapa para que saque a la madre actual. Es horrible para la anciana ser olvidada encerrada en la caseta del servicio después de hacer sus necesidades, pero todavía es más horroroso por lo escatológico de la escena en comparación con la hija, con una pose romántica con el cabello sacudido por el aire, lo cual nos causaría risa. Esta tensión de tragedia y comedia, nos hace considerar el gesto de la hija huyendo a la nostalgia para evitar enfrentarse a la realidad e ignorar a la madre anciana encerrada en la caseta,.

En la segunda parte, la escena es de noche, la anciana duerme dentro de la mosquitera y la hija escribe algo con cierto entusiasmo bajo la luz de la luna en el sillón de la sala. En ese momento, al oír un tren se apaga la inspiración de la hija, se queda mirando a la ventana y pasa un reflejo de luz que señala el paso del tren. Ahí empieza a introducir una imagen luminosa de esta mujer en pie, en un andén del tren hecho de madera en el que hace mucho viento con un sobre en la mano, que lo echa a una bolsa de correspondencia colgada ahí. Luego, entrecruza la imagen de la mujer, su rostro en primer plano, y la anciana acostada con gesto de tener una pesadilla dentro de la mosquitera. Posteriormente, la anciana empieza a sacudir la cabeza y a gritar agitando las manos, luego cambia la escena a la vista panorámica de la sala-comedor, señalando la vuelta a la realidad, y la hija lleva a la anciana al servicio.

Esta vez no sabemos muy bien si esa imagen luminosa es solo una ilusión o un recuerdo del pasado reciente, pero de todos modos está relacionada como una imagen del sueño, al mismo tiempo que sería una pesadilla para la anciana. Con el grito de la anciana la hija, ha vuelto a la realidad y otra vez lleva a la anciana a la caseta para encerrarla.

La tercera parte, empieza con una escena de la hija lavando la ropa con el luz del día. Como hemos mencionado, muestra un gesto enfadado. Después de patear el borde del agua en que lavaba la ropa, muestra su furia sujetando el tendedero frente a la cara. En el primer plano, surge una escena con rocas sobre un fondo del mar en marejada, proyectada sin personajes, luego vuelve el primer plano de la hija y ella se va. Cambia la escena a la sala-comedor, la 
anciana duerme en su silla de ruedas escuchando una caja de música y a través de las ventanas se ve la silueta de la hija, que llega a la sala-comedor, da unas vueltas y se queda de pie con los brazos en jarras, como un gesto de enfado al encontrar a la anciana echándose la siesta a gusto. Después, la silueta se gira al otro lado y da latigazos, con fuerte ruido, la anciana hace gestos de asustarse, con cada ruido de latigazo repite el gesto de susto y la anciana baja la cabeza y se introduce un audio de risa sardónica que aumenta cada vez más. Al mismo tiempo, introduce a esta escena, entrecruzadamente, una imagen del cantante que se prepara para cantar cargado con su guitarra y empieza a cantar alegremente pero no se oye su voz, sino que se escucha solo un ruido de interferencias. Evidentemente esta escena indica un maltrato de la hija a la madre, pero a su vez la hija se siente en desventaja por culpa de la madre y explota su insatisfacción al encontrar una apariencia de la madre tranquila. La risa sardónica suena sádica, sin piedad. No se sabe exactamente qué tipo de canción está cantando, pero nos hace relacionarla con la que escuchamos en el prólogo de la presente obra, que fomentaba la fácil comunicación directa con Dios. Pero esta comunicación no se da a causa de las interferencias.
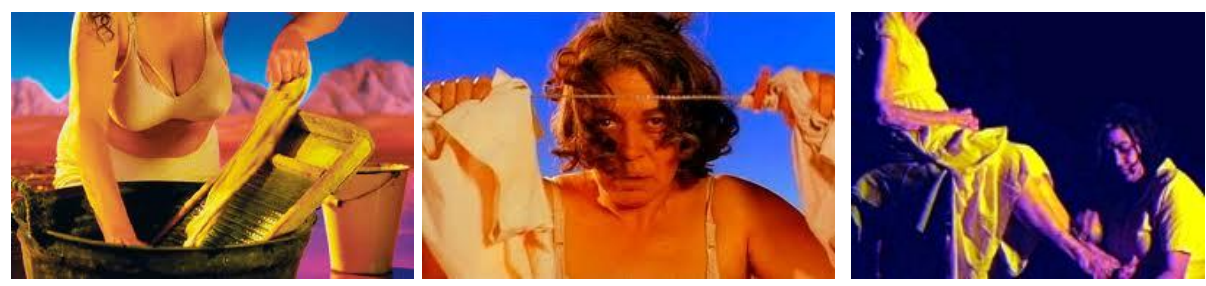

65. Night Cries: A Rural Tragedy (1989), Tracey Moffatt

Cuarta escena, en un fondo negro, sin ninguna indicación del contexto temporal ni espacial, la hija está sentada en el suelo sujetando un pie de la anciana, que está sentada en la silla de ruedas, y al mismo tiempo la limpia con una toalla mojada. Diferente a las otras escenas que hemos visto, es importante destacar el gesto de la hija que parece muy tranquila, por el sonido del agua que gotea de la toalla. Se introduce la imagen de una niña sin rostro que pasa entre las rocas con un ruido extraño, y un primerísimo plano de la hija de edad mediana iluminando solo la parte derecha de su rostro y que mira a la derecha con gesto de intentar recordar. Cambia la escena a la del mar, la madre blanca juega con la niña frente a 
dos niños de piel morena. La madre blanca habla algo con dos niños y se va, los tres niños de piel morena que quedaron empiezan a jugar.

Esta cuarta escena nos muestra aquella imagen de la niña que cruza unas rocas en un contra picado, la niña y los niños jugando y lanzando unas plantas marinas e introduce la artista repetidas veces una imagen de espaldas de la madre blanca tras las rocas. La autora empieza a entrecruzar unas imágenes, de la madre blanca de espaldas mirando a la izquierda en el plano medio, de la niña con gesto de sufrir y llorar y con el cuello enredado con plantas marinas en primerísimo plano, y de los niños que están maltratando a la niña enrollándole las plantas marinas. Luego la madre desaparece, es decir, se muestra la imagen de las rocas con el mismo plano sin ella, y se repite tras pasar esta imagen con la niña sufriendo en primer plano, finalizando con la imagen del cantante.

Durante esta escena del mar, empieza a sonar un ruido de interferencia hasta que se introduce la imagen del cantante que sube de volumen, pero ahí baja un poco el ruido y empieza a sonar un ritmo de tambor. Pero como en las escenas anteriores, aunque en la imagen del hombre cantando no se oye su voz, el gesto de la niña se calma tras aparece las imágenes del gesto del cantante. Otras veces, muestra gestos de su rostro o las manos del cantante en silencio y llega a mostrar un primer plano y otro después panorámico de la madre blanca abrazada a la niña dormida en sus rodillas, cubriéndola con una manta con un foco de la luz sobre fondo blanco. Esta escena nos hace recordar la imagen de la piedad.

La quinta parte, vuelve a la escena del paisaje donde está la caseta del servicio y la salacomedor vacio. Suena una respiración asistida artificialmente y el tono de luz de las escenas es obscuro de manera que no se puede distinguir si está atardeciendo o amaneciendo. Luego, se escucha el llanto de un bebé y se muestra la escena de un andén, la anciana acostada boca arriba y a su lado la hija igualmente acostada pero en posición fetal, con un contraste de luz y de sombra, y con un pequeño foco de luz hacia el rostro de la hija. La hija saca un pañuelo blanco y lo pone sobre la cara de la anciana. Se obscurece la escena dejando solo el foco de luz en el rostro de la mujer y empiezan a subir los títulos finales en la mitad derecha 
de la pantalla, suena la canción y sale Jimmy Little en la mitad izquierda del plano cantando como epilogo. La canción es la misma del prologo, con la siguiente letra.

Telephone to glory, oh, what joy divine!

I can feel the current moving on the line,

Made by God the Father for his very own,

You may talk to Jesus on this royal telephone.

Central's never "busy," always on the line;

You can hear from heaven almost any time;

There's a royal service, built for one and all;

When you get in trouble, give this royal line a call.

Telephone to glory, oh, what joy divine!

I can feel the current moving on the line,

Made by God the Father for his very own,

you may talk to Jesus on this royal telephone.

There will be no charges, telephone is free,

It is built for service, just for you and me;

There will be no waiting on this royal line,

Telephone to glory always answers just in time.

Telephone to glory, oh, what joy divine!

I can feel the current moving on the line,

Made by God the Father for His loved and own,

You may talk to Jesus through this royal telephone. ${ }^{5}$

La canción empieza fuera de las escenas del drama entre la hija aborigen y la madre blanca adoptiva. Con el montaje de las imágenes de flash back, de la memoria y del sueño, las canciones con sonido o en silencio, entre escenas teatrales, aunque no haya conversación ninguna, nos relata un estado complejo de la hija y la madre, su incomunicación y la soledad, indicándonos tanto lo expresivo como lo inexpresivo.

\footnotetext{
${ }^{5}$ Teléfono a la Gloria, oh, que divina Gloria! Puedo sentir el movimiento continuo de la línea, Hecho por Dios Padre para los suyos, Tú puedes hablar con Jesús por este teléfono real

La centralita nunca está ocupada, siempre está en línea, Puedes tener noticias sobre el cielo casi en cualquier momento; Es un servicio real, construido para todos y cada uno. Cuando tengas problemas, llama a esta línea real. Teléfono a la Gloria, oh, que divina Gloria! Puedo sentir el movimiento continuo de la línea, Hecho por Dios Padre para los suyos, Tú puedes hablar con Jesús por este teléfono real

No habrá recargos, el teléfono es gratis, Está construido para servir, solo para ti y para mí. No habrá esperas en esta línea real, Teléfono a la gloría siempre contesta justo a tiempo,

Teléfono a la Gloria, oh, que divina Gloria! Puedo sentir el movimiento continuo de la línea, Hecho por Dios Padre para los suyos, Tú puedes hablar con Jesús por este teléfono real [traducción propia]
} 
En este caso, la hija adoptada de origen aborigen y la madre blanca, nos muestra de una manera clara lo complejo del amor y del odio. Y la artista en su representación, nos indica de una manera simbólica y también podemos decir que esquemática, sus sentimientos cruzados. Pero desde otro ángulo, nos surge una pregunta: ¿ocurriría lo mismo si la relación fuera entre madre e hija biológicas? Podemos contestar, de forma inmediata, por supuesto que sí. En este sentido, el tema que trata esta obra no se reduce solo a la mujer específica como la hija adoptada aborigen, sino que está abierta a quien se siente destinado a encargarse de la asistencia de alguien por cierta relación de amor sin ninguna ayuda de los demás. Pero, también nos hace reflexionar sobre como en el contexto australiano, esta carga se concentraría en la hija adoptada aborigen. Es una realidad que rodea a la artista y nos hace partícipes de ella a través de su trabajo.

\section{VI.3.3. Una parodia trágica como testimonio de lo indecible.}

Ya que hemos comentado el trabajo Night Cries: A Rural Tragedy, deberíamos aproximarnos a aquel contexto de generaciones robadas y citar un comentario de la artista sobre Night Cries en una entrevista.

Night Cries is a very personal piece of work and has to do with the love-hate relationship I had with my mother and, yes, there is a religious and ritual component, but the film haunts and ten years later it hurst me to talk about it.

When I made it didn't even think it was about me... boy, did I expose myself.

Don't make me explain. Artists don't have to tell everything. ${ }^{6}$

Su comentario afirma que la obra tiene una parte muy personal de la artista, la relación familiar de amor y odio que tiene con la madre y con los elementos religiosos y rituales. Al mismo tiempo, evita comentar sobre la obra, citando como pretexto, el tiempo que ha pasado del año de la producción. Y luego comenta que no se puede explicar todo sobre sí misma. Ahí encontramos un fenómeno parecido al que ocurre en el momento de escribir la

\footnotetext{
${ }^{6}$ Gili, Marta: An interwiew with Tracey Moffatt en "Trecey Moffatt" Catálogo exposición, Fundació "La Caixa" 1999. P.108.
} 
autobiografía de la mujer. Por un lado, cuanto más sincera sea, más complicado será hablar claramente sobre uno mismo. Sobre todo, alguien que no se identifica con un principio cultural único, siendo más complejo por no poder aplicar un discurso establecido o ideas fijas sobre la identidad. Por otro lado, hablar de una forma concreta sobre la relación intima con una mezcla de amor y odio entre madre e hija, ya es bastante complicado. Además, en el caso de la artista teniendo el contexto político cultural de generaciones robadas, cada factor emocional y sentimental se confrontaría con la cuestión ética, enfocando cada vez más la relación entre dominador-dominado, que es una herencia negativa del colonialismo remarcando la diferencia entre la madre blanca y la hija aborigen.

En cambio, la opinión de la artista es muy parecida a la de Trinh T. Minh-ha, que hemos visto anteriormente. La memoria y su experiencia personal serían el fundamento para su trabajo artístico, pero no se debe mirar la obra como una ilustración de su vida. Siendo realista, las cosas particulares de la vida personal de la artista tienen que ver poco en la realización de la obra. La obra muestra escenas de asistencia de la hija sola a la madre anciana en la casa que está en un medio rural, entonces, ¿la artista realmente cuidó de ese modo a su madre o no? ¿ellas en la vida real viven algo parecido en esta casa o no? esta serie de preguntas no tiene mucho sentido en realidad. Es decir, las cosas particulares de la vida de la artista, como si cuidó realmente a su madre o vivió en un medio rural, no tienen mucho que ver con la realización de la obra, por lo menos esta obra. Lo más importante para la realización de este audiovisual basado en la experiencia personal es la imaginación artística. La imaginación en este sentido, es una capacidad de aceptar y compartir alguna sensación con los demás, como su experiencia, además de ser una capacidad de inventar cualquier fantasía. También los espectadores requieren de esa imaginación para ver la obra de arte. Y la obra de arte es algo que evoca la imaginación de cada uno.

Hemos desarrollado la cuestión de la imaginación basada en el argumento de Drucilla Cornell $7^{7}$ sobre la comunidad del "otro" y de Shoshana Felman ${ }^{8}$ con el análisis de Shoah. La obra de arte como testimonio en caso de Felman, nos exigía imaginar lo inimaginable a

\footnotetext{
${ }^{7}$ Los detalles a mirar al capítulo III.

${ }^{8}$ Los detalles mirar a al capítulo IV.
} 
través de mostrarnos la serie de fracasos del intento de decir lo indecible en forma de documental.

En cierto sentido, la obra de Moffatt, en la representación Night Cries que hemos tratado ahora, también es un intento de evocar lo indecible en la relación compleja entre amor y odio, dominador y dominante entre la madre y su hija dentro de la dinámica de la diferencia en un tiempo y espacio aislado.

Y volveremos a recordar, que es indecible lo que ocurre realmente en la vida de una mujer. La autobiografía de la mujer es algo que indica lo indecible de la mujer en los relatos de la mujer por otra mujer. El caso nos muestra esa sensación indecible entre amor y odio a la vez que introduce una forma como la parodia en el cine con un toque de fantasía. 
VI.4. May You Live in Interesting Times (1997), Fiona Tan: el documental como un viaje de búsqueda de la propia identidad. 
En el presente apartado nos aproximaremos al vídeo-documental May You Live in Interesting Times ${ }^{l}$ (de 60 minutos de duración, en color y en estéreo-digital) presentado en 1997 por Fiona $\mathrm{Tan}^{2}$, la cual explora su propia identidad visitando a sus familiares en viajes por Europa, Australia, Indonesia y China. Ésta es una obra audiovisual autobiográfica extraordinaria dentro de los numerosos trabajos realizados desde la mirada femenina de las artistas. A través del presente análisis -y ofreciendo ciertas referencias sobre el contexto cultural, social y político-, nos centraremos en las distintas posibilidades, gracias a las cuales, la artista consigue su auto-representación en el medio audiovisual, en este caso mediante relatos familiares en el tránsito entre algunos países de Europa, Oceanía y el Sureste Asiático.

Fiona Tan trabaja con diversos medios como la fotografía y la vídeo-instalación en lugares dispares del mundo. Ha realizado varios proyectos basándose en imágenes filmadas con la cámara aprovechando las múltiples residencias artísticas en distintos lugares del globo. Desde los años noventa comienza activamente a exponer sus trabajos y en el año 2009 fue seleccionada para exponer en el pabellón de Holanda de la Bienal de Venecia.

Tal y como ella expresa, con sus propias palabras, en el documental que analizamos a continuación, se considera a sí misma "una extranjera profesional”. De hecho, la vida de Fiona Tan es representativa del contexto multicultural: nace en 1966 en Indonesia, su madre es australiana descendiente de inmigrantes escoceses, y su padre, indonesio de descendencia china. Se traslada a Australia con su familia, y más tarde viaja a Ámsterdam para sus estudios superiores, lugar en el que hoy en día reside y trabaja.

La presente obra es un documental de su viaje. El proyecto lleva a la artista a viajar a través de varios países con el fin de visitar a su familia paterna y realizar entrevistas a sus parientes, incluso a algunas personas con las que ella se reúne por primera vez. En el documental se incorporan estos relatos de sus familiares, habitantes de lugares tan dispares

\footnotetext{
${ }^{1}$ Mostramos nuestro agradecimiento tanto a la artista y a la galería Frith Street Gallery de Londres como a su cortesía al permitirnos acceder al vídeo para la investigación actual durante el período que comprende desde el 25 de febrero al 6 de abril del 2011. Desde ahora en adelante, citaremos algunas trascripciones del documental y su traducción de la lengua inglesa al castellano (ambos realizado por la doctoranda del presente trabajo).

${ }^{2}$ La página web de la artista Fiona Tan es: http://www.fionatan.nl/, accedida el 5 de marzo 2011.
} 
que amplían por el mundo la diáspora familiar. De hecho, las entrevistas representan la mayoría de las escenas más importantes de la obra. Sin embargo, la descripción del viaje también nos ofrece una impresión muy particular: las imágenes que graban el tránsito, tanto del viaje internacional como de la circulación cotidiana dentro de la ciudad, con vehículos distintos que van desde el avión a la bicicleta, nos señalan esos márgenes.

El motivo del viaje es indagar sobre su propia identidad a través de la búsqueda de sus raíces familiares enfocada en los relatos de sus parientes. Sylvia Martin comenta sobre la obra de la siguiente manera:

\section{En la obra "May You Live in Interesting Times" (Que vivas en tiempos interesantes) la artista investiga de forma concreta sus raíces familiares con la cámara. ${ }^{3}$}

Así pues, la artista explora su identidad y para ello se basa en la cuestión de su existencia como half Chinese. Las preguntas iniciales son: ¿quién soy yo?, ¿de dónde vengo? ¿Soy china o no lo soy? Tras las entrevistas a sus parientes (desde los más cercanos, como el primo que reside actualmente donde ella, o los padres y hermanos que viven en Australia, hasta los tíos y primos que habitan en diversas partes del mundo) surgen más y más preguntas: ¿qué es ser chino? ¿Cómo es la imagen de los chinos según los diferentes sitios en los que han vivido? ¿Qué ocurrió para que emigraran?

Durante los relatos y la narración por parte de la artista, se muestran las imágenes filmadas en las entrevistas, en las cuales los personajes posan con el fin de retratar algunas de sus actividades cotidianas, el sitio donde viven o los paisajes donde ha estado la artista. También se introducen las imágenes de fotografías de la infancia de Fiona Tan, de su familia, sus antepasados, así como algunas imágenes de tipo home movie y otras de archivo histórico.

Junto a su cámara, la artista procura conseguir respuestas, siempre apoyándose en los relatos de cada uno de sus parientes. El tema de este documental es de índole privado, pues

\footnotetext{
${ }^{3}$ Martín, Sylvia: Videoarte, Colonia, Taschen Gmbh, 2006, p. 88.
} 
está basado en la experiencia, el sentimiento, el conocimiento cultural de su familia y de sí misma. Sin embargo, al mismo tiempo, la situación política y cultural y las relaciones sociales están siempre muy presentes en sus relatos privados. Esto nos recuerda a la indicación de Michel Renov según Annette Kuhn que vimos en el capítulo V, ya que el carácter inseparable de lo privado y lo público en los asuntos familiares es muy notable en el caso del documental de Fiona Tan.

La artista descubre una compleja mezcla cultural, lingüística, ideológica y religiosa en el seno de su familia, perceptible incluso en la identidad particular de cada persona. Las entrevistas fueron realizadas en inglés, holandés, indonesio, alemán y mandarín; cuando no son en inglés, se añaden subtítulos. Todos los protagonistas viven en tránsito cultural y sobreviven siendo extranjeros. Incluso los parientes que viven en China describen su experiencia como "extranjeros" en "su país".

En su exploración sobre su identidad personal, orientada hacia la búsqueda de los ancestros chinos por parte del padre, la artista no puede evitar el reencuentro con la historia social y política del siglo XX. En una escena, en la cual ella interroga a su madre sobre las causas del traslado de la familia a Australia, se ilustra la difícil situación de la colonia china en Indonesia. Como veremos, Fiona interrumpe a la madre por su actitud y le reclama que sin la presencia de la cámara había contado la historia con más emoción. La madre se defiende argumentando que se siente nerviosa porque se trata de un asunto muy delicado y que, para hablar de ello, debería pedir permiso a su marido. Después de esta conversación, la artista se empieza a centrar en la problemática social de Indonesia para conocer los significados de ser chino allí. Previa a esta investigación, la artista comenta algo muy importante que descubre durante el proceso del proyecto. 
Proximity is an intimacy, and a blindness. The film camera should see what I see, but it often surprises me. It would seem that sight is more a matter of projection. I wanted to find out what it meant to be Chinese in Indonesia. ${ }^{4}$

Solo vemos lo que sabemos. Quizá, si no lo sabemos, no podemos verlo. Y si somos tan ignorantes que, tal vez, ni siquiera nos damos cuenta de que no lo hemos visto. En muchas ocasiones, nos confundimos aún en las concepciones más íntimas, como en el caso de la familia: creemos que está basada en el profundo conocimiento e imaginamos que sabemos todo de las personas más cercanas. Fiona Tan, por su parte, se vale de esa intimidad familiar para filmar las entrevistas y crear un proyecto de investigación sobre su propia identidad en relación con la familia, de acuerdo con la idea inicial de que la cámara ve lo que ella ve. Sin embargo, no es tan sencillo: la cámara le revela y le obliga a reconocer lo que ella no había visto. Con esto, ella descubre y a la vez también nos conciencia sobre la relación entre proximidad, intimidad y ceguera.

El documental se inicia con una imagen filmada a una fotografía enmarcada en la pared con un fondo de melodía de metalófono. La fotografía, en blanco y negro, retrata a una mujer asiática sentada que posa apoyando el codo en una mesita. Al parecer es bastante antigua y fotografíada en un estudio. Una voz femenina se empieza a escuchar:

Graceful Girl, Beautiful Orchid, Loyal to Uprightiousness, Faithful and Virtuous, True to Justice, Fair Maiden, Loyal to Humanity, Uprising Sun, Lesley Eleanor, Noble Tiger, Brave Strongwood, Golden Clouds, Golden Rain. ${ }^{5}$

Mientras estas palabras se pronuncian en off la imagen se transforma en otra foto de una mujer y un hombre, también en blanco y negro, luego a diferentes retratos en vídeo: un hombre y una mujer de edad avanzada sentados, una mujer de pie en medio de dos hombres

\footnotetext{
${ }^{4}$ La proximidad es intimidad y es ceguera. La cámara debería ver lo que yo veo, pero a menudo me sorprende. Al parecer, la vista es más una cuestión de proyección. Yo quería saber lo que significaba ser chino en Indonesia. [Transcripción y traducción propia]

${ }^{5}$ Chica Graciosa, Orquídea Hermosa, Fiel a la honestidad, Fieles y virtuosos, Fiel a la Justicia, Feria de soltera, Fiel a la Humanidad, Amanecer, Lesley Eleanor, Tigre Noble, Madera Valiente y fuerte, Nubes doradas, Lluvia de oro. [Transcripción y traducción propia]
} 
(uno joven y el otro mayor), un señor en primer plano con un paisaje con edificios altos al fondo, otro hombre sentado en el sofá frente una ventana, un joven sonriente en la calle, una señora en una cocina, un hombre en un sofá acariciando a un perro, una mujer con un pájaro en su hombro, otra señora canosa sonriendo en gran primer plano con el fondo de la playa, otro hombre igualmente con el fondo de la playa, un joven con gafas, una joven con cabello negro y en último lugar una chica en primerísimo primer plano.

Hasta que aparece la mujer canosa, todos los que aparecen en la imagen tienen rasgos asiáticos y no se entiende muy bien la relación entre la voz en off y la imagen. Pero con la imagen del primer plano de la mujer canosa de piel blanca se pronuncia Lesley Eleanor, por lo que se puede imaginar que lo que se estaba diciendo eran los nombres de las personas. Sobre el mismo fondo del retrato en vídeo de Lesley Eleanor aparece un hombre asiático y las últimas tres personas parecen occidentales pero la voz en off sigue con expresiones metafóricas.

Se trata de las personas protagonistas de este documental, la familia de la artista. La última persona en primerísimo plano es el autorretrato audiovisual de la propia artista. Tras unos minutos, la voz en off presenta su nombre completo.

\section{My full name is Fiona Susan Kimling Tan. I'm half Chinese. ${ }^{6}$}

Kimling se escribe en carácter chino 金雨. La traducción literal sería lluvia de oro, Golden Rain. De esta manera, se corrobora que lo que se pronunciaba en off durante el paso de los retratos eran las traducciones literales de los caracteres chinos de cada uno de sus nombres. Durante todo el trabajo se continuará confirmando que las imágenes iniciales retrataban a los protagonistas de este documental, portadores de un nombre chino y de algunas otras herencias chinas, como veremos. Lo mismo ocurre con la artista, Fiona Tan, y la única excepción la conforma la madre de la artista.

\footnotetext{
${ }^{6}$ Mi nombre completo es Fiona Susan Tan Kimling. Soy medio china. [Transcripción y traducción propia]
} 
El documental está estructurado en 8 secuencias. Cada secuencia empieza con un telón que incluye el título en inglés, un proverbio en chino y unas pequeñas imágenes de fotos. La frase en inglés está escrita con letras blancas, horizontalmente, en medio de un fondo azul. Luego aparecen verticalmente una o dos cintas rojas a los dos lados o en la parte superior de la frase en inglés, en estas cintas están escritos los caracteres chinos de color negro y se colocan fotografías en blanco y negro. A veces no hay más que una sola imagen; otras veces, unas cuantas. Son imágenes extraídas de fotografías de la infancia de la artista, de sus antepasados, también hay de un gesto de mono, unas estatuas y un dibujo. De esta manera, el estilo del diseño del telón es consistente y varía solo dependiendo de dónde, cómo y cuándo se coloca la frase horizontal, la cinta roja vertical y la foto. El título de cada sección e incluso el título del documental provienen del aforismo chino; es decir, los títulos son las traducciones al inglés de proverbios chinos. Son los siguientes:

\section{願你生活 多姿多采 “May You Live in Interesting Times”, 飲水思源 “Whilst Drinking the Water Remember to Thank the Well”, 同床異夢 “Sleeping in the Same Bed Dreaming Different Dreams”,(A pesar de estar juntos, piensan diferente) 黄種 猶太人“Yellow Jews”, 禍从口出“Disaster Comes From the Mouth”, 新陳代謝 “Bringing in New Blood”, 知已知彼百彼百勝 “Know Yourself, Know Your Opponent, 100 Battles, 100 Victories”, 同宗同体“A Nation of Siblings”.}

A partir de ahora nos aproximaremos a cada una de las secciones, fijándonos sobre todo en el planteamiento de la artista en la narración, la conversación, el montaje de las imágenes y el sonido. Entre las características más interesantes de su trabajo nos fijaremos principalmente en las imágenes de los vehículos y del tránsito, el paisaje, los animales y los pequeños objetos que simbolizan y nos señalan el cuestionamiento de la artista. Además, prestaremos atención a los gestos de los protagonistas y a las fotografías insertadas. En cuanto al audio, nos interesaremos por el uso del sonido de un cascabel con el ruido de la

\footnotetext{
7 "Que vivas en tiempos interesantes", "Mientras que el agua potable recuerde dar las gracias a Bueno", "Dormir en la misma cama soñando sueños diferentes", "Judíos Amarillos", "Desastres salen de la boca", "Traer sangre nueva", "Conócete a ti mismo, conoce a tu oponente, 100 batallas, 100 victorias", "Una Nación de hermanos". [Transcripción y traducción propia]
} 
calle y la música igualmente captada en la calle. Por supuesto, no nos olvidaremos de reflexionar sobre la relación entre la imagen, el sonido y la voz en ciertos pasajes que nos parecen más interesantes.

\section{VI.4.1. May You Live in Interesting Times ( 願你生活 多姿多采 )}

Esta es una parte introductoria. La artista se presenta a sí misma y propone el cuestionamiento que va a desarrollar durante el trabajo. Después del telón, muestra una imagen desde atrás de una chica de cabello negro que mira una fotografía, sujetándola sobre la mesita, en la que hay una jaula colgada de una rama de un árbol. Inmediatamente, una imagen muestra un cuaderno pequeño y una mano que escribe: Peking, 7:30 am. Entonces, aparece la jaula en primer plano y la mirada de la cámara nos enseña que estamos en un parque. Cuando aparece la jaula, comienza a sonar una música de baile de salón, y con esta música de fondo se filma a algunas parejas chinas bailando en el parque. La imagen señala a un reproductor de vídeo en el que alguien presiona un botón y, alzando la mirada, se ve un monitor sobre el reproductor con la imagen detenida de aquellos señores bailando. De nuevo, aparece un cuaderno pequeño y dos manos, una escribe la nota y otra sujeta el cuaderno. Luego, vemos a una chica agachada y nos damos cuenta de que quien está tomando las notas sobre el vídeo es la artista. Ella empieza a presentarse mediante voz en off.

It started off as a search. Now it feels like I'm constantly in search of my search.

My full name is Fiona Susan Kimling Tan. I'm half Chinese. ${ }^{8}$

La cámara muestra una habitación y se detiene en unos planos, carteles, dibujos y fotografías colgados en la pared. Se acerca lentamente hacia la artista, sentada con la ropa al estilo chino frente a un monitor. Más tarde, dentro del monitor se ve una imagen similar a lo que nos ha presentado hace unos segundos y ella está viéndola y tomando notas. En el momento que ella pronuncia que es half Chinese se introduce una fotografía de una niña en

\footnotetext{
${ }^{8}$ Empezó como una búsqueda. Ahora parece como si yo estuviera constantemente en busca de mi búsqueda. Mi nombre completo es Susana Fiona Tan Kimling. Soy medio china. [Transcripción y traducción propia]
} 
la playa. Después de esta fotografía, las imágenes retratan la ciudad de Ámsterdam, un letrero de Hotel, unas miniaturas de casas, un molino en un muelle y una pequeña barca junto a él, la artista paseando en bicicleta por la ciudad, y unos cuantos paisajes de la ciudad y la playa.

I moved to Europe 12 years ago, and used to jokingly call myself a professional foreigner. Seeing things from a different view point had definite advantages, and yet, at times, it felt like I had lost part of myself whilst changing countries, customs and languages. Quite simply, who was I? Where did I come from? If I felt my father's culture inside me, it spoke a language I couldn't understand. ${ }^{9}$

De repente, comienza la entrevista a su prima, quien afirma que Fiona Tan es de descendencia china. Podemos saber que ella es su prima por el título escrito a mano que aparece en la esquina superior derecha de la pantalla, My cousin Lioni, Peking, así como por lo que ella dice a través de los subtítulos en inglés, ya que su lengua es el chino.

Fiona was born in Australia. She does not speak Chinese or look Chinese, but she does have Chinese blood. She is of Chinese descent. ${ }^{10}$

En este momento, se muestra la imagen de una niña que hace una acrobacia y se coloca en una pose "imposible" o “increíble”. Luego la imagen nos enseña la Gran Muralla. El encuadre permanece fijo mientras los turistas pasan y posan para tomar fotos. Por último, Fiona aparece para tomar fotos y luego introduce una imagen fotografiada allí. Cuando empieza la escena de La Gran Muralla ella adjunta un comentario:

\footnotetext{
${ }^{9}$ Me mudé a Europa hace 12 años, y para bromear solía autocalificarme como "extranjera profesional". Observar las cosas desde un punto de vista diferente tenía unas claras ventajas; sin embargo, a veces sentía que había perdido parte de mí misma al cambiar de países, costumbres y lenguas. En pocas palabras, ¿quién era yo? ¿De dónde provenía? Si sentía la cultura de mi padre dentro de mí, hablaba un idioma que yo no podía entender. [Transcripción y traducción propia]

${ }^{10}$ Fiona nació en Australia. Ella no habla chino ni tiene aspecto chino, pero tiene sangre china. Ella es de ascendencia china. [Transcripción y traducción propia]
} 
How could I be in anyway Chinese? Most of my family is Chinese? Did they consider me Chinese? The distance with which I look at my family is built into myself. ${ }^{11}$
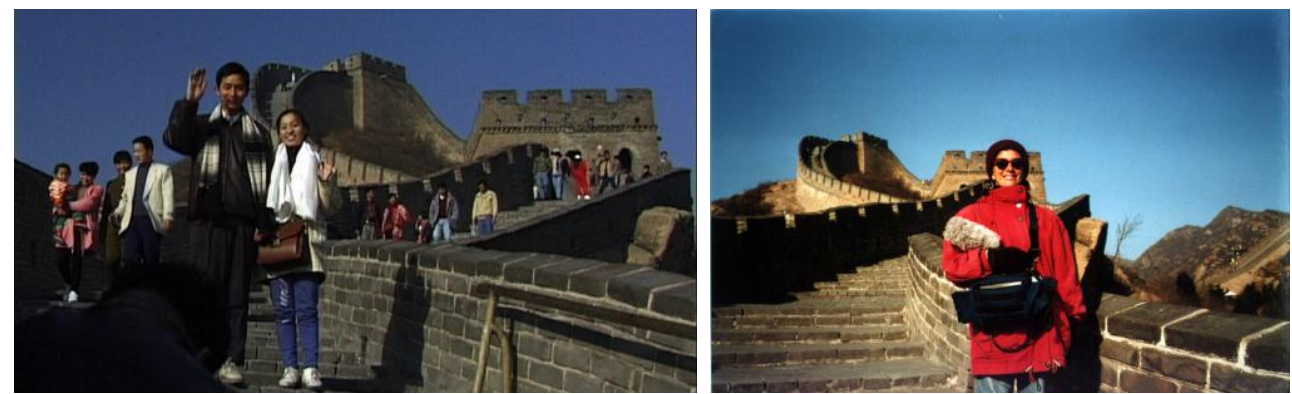

Fiona Tan May You Live In Interesting Times documentary film, 1997 cortesía de la artista y Frith Street Gallery, London 66. May You Live In Interesting Times (1997), Fiona Tan

Después de la fotografía de la artista en La Gran Muralla, la imagen muestra una carretera que baja poco a poco, una parte de un puente basculante que se está cerrando. Mientras la carretera baja con unas vías de tranvía, unas líneas y fechas de indicación, aparecen en unos edificios. También observamos un título: Ámsterdam, escrito con el mismo estilo, a mano, pero esta vez se encuentra en la esquina inferior izquierda de la pantalla y aparece el siguiente telón.

\section{VI.4.2. Whilst Drinking the Water Remember to Thank the Well ( 飲水思源)}

En esta parte, la artista realiza una entrevista a su primo Yan que vive en Ámsterdam. El título proviene de un pensamiento filosófico chino que dice:

The Chinese say: 'Water is life, and the well is your ancestors'.'

Gracias a esta entrevista se aclara que la artista fue acogida por la familia de Yan en la primera etapa de su estancia en la ciudad. La profesión de Yan, especialista de tratamientos

\footnotetext{
${ }^{11}$ ¿Cómo podría yo de algún modo ser china? ¿La mayor parte de mi familia es china? ¿Ellos me consideran china? La distancia con la que miro a mi familia está integrada en mí misma. [Transcripción y traducción propia]

${ }^{12}$ Los chinos dicen: "El agua es vida, y el pozo es tu antepasado”. [Transcripción y traducción propia]
} 
de medicina alternativa china, nos señala la imagen de unas prácticas de masajes, acupuntura y ampollas de vacío instaladas durante las entrevistas. La voz en off de la artista comenta que el padre de Yan creció junto con el padre de la artista tras quedar huérfanos. Durante la entrevista, Yan comenta que la identidad china es más fuerte que sus sentimientos como indonesio. Las imágenes de los tratamientos chinos corroboran su opinión. Él explica que la gran solidaridad entre los chinos es una característica muy positiva:

Yan: The Chinese have a distinct philosophy. We hold the aged in great respect.

That also goes for your father, Uncle Houw. Even though he is a fourth generation immigrant, his Chinese identity is still very marked. ${ }^{13}$

Cuando la artista llegó a Ámsterdam vivió junto a Yan y su madre en un ático. Según Yan, era natural cumplir con un deber, en este caso, recibir a su prima recién llegada a un sitio que no conoce y en el cual no tiene residencia. La artista ni afirma ni acepta la respuesta, sino que expone otra pregunta sobre si ella era china todavía. Yan contesta con una afirmación categórica:

Yan: Yes, you are. Let me give you a simple but interesting example. If your parents, sister or brother fell ill... You are the youngest, aren't you? The first thing you do is phone them. If necessary you would go to them, whether you can afford it or not. Europeans would not do that. If you don't believe me, ask ten Dutch people. Or ask Indonesians. But Chinese people do this much more readily. Our family ties are very strong. Certainly in our family. We were always together. We lived under the same roof. If there are problems, we help each other. When my father died, everyone immediately came over. The entire family. ${ }^{14}$

\footnotetext{
${ }^{13}$ Yan: Los chinos tenemos una filosofía distinta. Tenemos un gran respeto hacia las personas mayores. Esto también concierne a tu padre, el tío Houw. A pesar de que pertenece a la cuarta generación de inmigrantes, su identidad china está aún muy marcada. [Transcripción y traducción propia]

${ }^{14}$ Yan: Sí, lo eres. Déjame darte un ejemplo sencillo pero interesante. Si tus padres, tu hermana o tu hermano cayesen enfermos... Eres la más joven, ¿no? Lo primero que harías sería llamarles por teléfono. Si fuese necesario, irías a verlos, te lo pudieses permitir o no. Los europeos no harían eso. Si no me crees, pregunta a diez personas holandesas. O pregunta a los indonesios. Pero los chinos hacen esto con mucha más facilidad. Nuestros lazos familiares son muy fuertes. Ciertamente, en nuestra familia. Siempre estábamos juntos. Vivimos bajo el
} 
En esta última frase de la entrevista de Yan se introduce una imagen de home movie que parece ser la escena de un funeral. En contraste con la certeza expresada por su primo, la artista sigue preguntándose de la siguiente manera:

How could I be part of a family I knew almost nothing about? I fear Yan's explanations of my Chinese-ness was out of politeness. Family or culture, which determined my identity more ${ }^{15}$

Mientras, la imagen pasa a una escena grabada dentro del avión en la que se escucha que al cabo de un momento llegarían a Melbourne: la artista empieza el viaje hacia donde vive su familia para poder encontrar respuestas a las preguntas planteadas.

\section{VI.4.3. Sleeping in the Same Bed Dreaming Different Dreams ( 同床異夢 )}

En esta sección se realizan unas entrevistas a la familia de la artista en Melbourne: al padre, a la madre y a los hermanos mayores. Fiona Tan es la única que partió del sitio donde vive la familia, pero los hermanos ya se han independizado y no se ven casi nunca a pesar de vivir cerca. Esto lo podemos saber por la explicación de la artista en off.

Cada cual habla contestando las preguntas de su hija o de su hermana, según el caso. Uno exterioriza con emoción los recuerdos agradables, otro se siente incomódo o nervioso por los asuntos delicados y/o por la presencia de la cámara. Como menciona el título, 同床異夢 "Sleeping in the Same Bed Dreaming Different Dreams" (Durmiendo en la misma cama, soñando diferente), no solo existen similitudes en los comentarios dentro del seno de la familia, sino que también se señalan las diferencias. A pesar de compartir una vida como familia, apartando ciertas diferencias, cada quien habla desde su posición familiar, racial y cultural.

mismo techo. Si hay problemas, nos ayudamos unos a otros. Cuando mi padre murió, todo el mundo vino inmediatamente. Toda la familia. [Transcripción y traducción propia]

${ }^{15}$ ¿Cómo podría ser parte de una familia de la que no sabía casi nada? Me temo que las explicaciones de Yan sobre mi chinidad (esencia como china) estaban fuera de cortesía. Familia o cultura, ¿qué determinaba más mi identidad? [Transcripción y traducción propia] 
A modo de continuación de la sección anterior, tras el telón empieza la escena de la bienvenida de los padres en el aeropuerto recibiendo a su hija, la artista. En voz en off, ella primero los presenta con retratos en vídeo de los progenitores quietos sentados en las sillas frente a la fachada de la casa, con su perro caminando alrededor de ellos. Ella comenta sus impresiones de la casa, describiendo los olores que tanto añoraba y los recuerdos de su infancia, mostrando las imágenes de unas fotografías en la pared y en los estantes. La mayoría de las fotos son de perros, pero entre éstas también se encuentra una imágen de la artista. Imaginamos que se trata de fotografías de seres queridos de la casa considerados como parte de la familia.

Antes de comenzar la entrevista, en la escena, el padre traza unos carácteres chinos con un pincel chino. Quejándose de la calidad de la tinta, él escribe la frase original del título de este documental, 願你生活 多姿多采, en su propia caligrafía. Luego se introducen las imágenes de la entrevista al padre. Él habla de vez en cuando en holandés, otras veces en inglés, pero se puede apreciar que no son sus lenguas maternas. Mientras, en la imagen se advierte una estantería que contiene una gran variedad de libros, algunos de ellos son textos en inglés sobre China y otros están directamente escritos en chino. Primero, el padre nos narra su contexto familiar: sus padres fallecieron muy jóvenes y se quedó huérfano. Por esta razón, vivió con la hermana mayor que ya se había casado y esta situación le generó mucha confusión.

Respecto a su hija, el padre afirma que la cultura china le ha traspasado, ilustrando el comentario con ejemplos sobre la niñez de la artista y las costumbres familiares del año nuevo chino. El padre habla sonriendo con gran entusiasmo sobre las pequeñas ceremonias rituales familiares de aquellos momentos; al mismo tiempo, se oye también la voz alegre de la artista. Después, la artista explica en off que el padre y la madre se conocieron en la Universidad de Melbourne, se trasladaron a Indonesia y allí se casaron en 1960.

Mientras la imagen muestra al padre paseando a su perrito y practicando Tai Chi con sus compañeros, prosigue el relato del padre sobre la tendencia a las críticas negativas sobre el matrimonio interracial. Estos prejuicios, según él, están basados en el convencimiento de la 
superioridad de la civilización china. Tal y como comenta, China se autocalifica como “Central Kingdom” y para ser considerado como chino es importante la relación familiar, de acuerdo con la raza pura dentro de la propia comunidad china. No obstante, según el padre, el caso de la madre de la artista fue una excepción:

Father: And your mother was accepted by the family right from the beginning, there were no hassles at all on that score. And I ascribe that not to our being westernized, but more to the political outlook that we have, that only communism or socialism could bring about complete equality between races. ${ }^{16}$

La imagen muestra a la madre y a la artista leyendo en un sillón largo y al padre haciendo la siesta con su perro. La imagen cotidiana de una familia. Luego, se oye una canción en inglés y la imagen muestra a la madre cantando mientras examina a un bebé. Al parecer, la madre es médica. En este punto, empieza la entrevista a la madre. La artista le expone preguntas sobre su matrimonio y sobre las primeras etapas de su estancia en Indonesia.

Mother: Well I suppose being married to him is different because he is Chinese. I mean, he has a set of expectations about the way children treat their parents and to a certain extent about how children should behave and about family loyalties that would be different from the Anglo-Scottish background that I come from. And I feel as though there's more things taken for granted in the Chinese family and I feel as though the roles might better defined as though people know better what to expect and how they should behave, and so there is more of an expectation and less negotiation, perhaps. While we lived in Indonesia I gradually came to realize the importance of being in a Chinese family. I was totally moved into a new society and to a new way of living with all kinds of everything different. I remember I went to

\footnotetext{
${ }^{16}$ Padre: Y tu madre fue aceptada por la familia desde el principio, no hubo complicaciones al respecto. Y yo no lo atribuyo a nuestra occidentalización, más bien a la visión política que tenemos, el comunismo o el socialismo solo pueden lograr la plena igualdad entre las razas. [Transcripción y traducción propia]
} 
live in place where there were no other English speakers, so I had to find, I couldn't go on living in the role I'd been living, I had to find a new role. ${ }^{17}$

Entre las imágenes correspondientes a la entrevista a la madre se introducen varias fotografías de ella en blanco y negro en primer plano; al parecer fueron tomadas en Indonesia. Siempre aparece con otras personas y ella es la única con rasgos occidentales. En el último momento de la entrevista, aparecen imágenes de Indonesia: un paisaje de verdes campos y de personas asiáticas y morenas en un pueblo.

Según la entrevista a la madre de la artista, las diferencias culturales que ella ha afrontado se deben al hecho de haber contraído matrimonio con un chino y haberse trasladado a un lugar en el que no encuentra a nadie que hable su lengua. Las lealtades y el trato familiar, sobre todo en cuanto a la relación entre padres e hijos, es bastante distinta en comparación a su contexto cultural de procedencia anglo-escocesa. Ella describe su situación como la entrada a una nueva sociedad totalmente diferente de aquella a la que se había acostumbrado. Entonces, llega a la conclusión de que debe cambiar su papel social. Es decir, apartar a un lado sus experiencias y tratar de encontrar un nuevo rol con distintas características para poder adaptarse a la nueva sociedad. En su caso, la cuestión de la diferencia no influye directamente en su identidad, sino que se ha conseguido solucionarlo cambiando su papel social. En los casos de sus hijos, ocurriría algo distinto. Lo veremos en seguida.

Sigue la entrevista con los hermanos de la artista. Ella comenta en voz en off que son sus hermanos mayores, que ella es la única que de ha partido del país de forma permanente, que ellos casi nunca se ven y, quizás en parte debido a ello, que se sentían incómodos frente a la

\footnotetext{
${ }^{17}$ Madre: Bueno, supongo que estar casada con él es diferente porque es chino. Quiero decir, él tiene un conjunto de expectativas acerca de cómo los niños deben tratar a sus padres y, en cierta medida, acerca de cómo deben comportarse los niños y sobre las lealtades familiares que serían diferentes del contexto anglo-escocés del que provengo. Y me siento como si hubiera más cosas por sentadas en la familia china, como si los papeles estuvieran mejor definidos, como si la gente supiese mejor qué esperar y cómo comportarse, y así hay más expectativas y menos negociación, tal vez. Mientras que nosotros vivíamos en Indonesia, poco a poco me di cuenta de la importancia de estar en una familia china. Yo me había trasladado a una sociedad totalmente nueva y una nueva manera de vivir donde todas las cosas y maneras eran diferentes. Recuerdo que me fui a vivir a un lugar donde no había otros angloparlantes, así que tuve que encontrar, yo no podía seguir ejerciendo el papel en el que había estado viviendo, tenía que encontrar un nuevo papel. [Transcripción y traducción propia]
} 
cámara. Los hermanos se reúnen en la mesa del jardín, con una pequeña interrupción por parte de un niño (parece que se trata de un sobrino de la artista). Ellos contestan a las preguntas sobre su identidad. En concreto, la artista les pregunta: ¿se sienten orgullos de ser chinos? ¿De dónde se sienten? Primero, el hermano contesta, pero su respuesta no es clara. Su respuesta es sí y no a la vez. Él se siente como un "ciudadano del mundo" y sus hermanas, al escucharlo, exclaman con admiración y cierto tono de burla.

Fiona: So, erm, are you proud of the fact that you're half Chinese?

Andrew: I'd say neither proud nor ashamed, I don't... It doesn't sort of... It's not a conscious thought very often. /Fiona: Do you tell...? (Fiona iba a preguntar algo pero Andrew sigue)/ But I suppose it's always there, because my name's Chinese. But er...

Fiona: So what are you, Andrew? 100\% Australian?

Andrew: Uff. [Se ríe] /Fiona: Where do you fit in? / Andrew: I'd like to regard myself as a 'citizen of the world',18

Fiona and Elenor: ¡Ohhhhh! ${ }^{19}$

La respuesta del hermano no nos satisface al completo por su ambigüedad ("no es ni uno, ni el otro"). Su respuesta se puede considerar como una elusión, pero podría ser un error juzgar que él no está siendo sincero a las preguntas de su hermana. Precisamente, lo que él representa es ese estado que estudiábamos al analizar la identidad en el contexto multicultural y/o en tránsito cultural. En este sentido, sus comentarios son sinceros, sobre todo teniendo en cuenta la sensación incómoda que siente.

\footnotetext{
18 'Citizen of the world': prácticamente se ha convertido en una frase hecha, usada también de forma satírica para burlarse de las connotaciones o muy hippies o muy pijas que tiene y de la gente que suele emplearla. Sin embargo, este uso satírico no disminuye necesariamente su significado.

${ }^{19}$ Fiona: $Y$, munn, ¿estás orgulloso de ser medio chino?

Andrew: Yo no diría que ni orgulloso ni avergonzado, no... no una especie de... No es un pensamiento consciente que tenga muy a menudo. / Fiona: ¿Tú dices...? / Pero supongo que siempre está ahí, porque mi nombre es chino. Pero $m$ mm...

Fiona: Entonces, ¿qué eres, Andrew? ¿100\% Australiano?

Andrew: Uff [se ríe]. / Fiona: ¿Dónde encajas? / Me gustaría referirme a mí mismo como un "ciudadano del mundo".

Fiona y Eleonor: ¡Ohhhhh! [Transcripción y traducción propia]
} 
Tal vez, esta incomodidad no solamente se deba al enfrentamiento con la cámara, sino también al tipo de pregunta al que debe responder: ¿estás orgulloso de ser chino?, ¿te consideras cien por cien australiano? Estas preguntas que le colocan a uno en una disyuntiva, aunque no terminen de pronunciar, exigen una única elección y el rechazo a la otra opción. En este caso, la pregunta sobre su orgulloso como chino incluiría a modo de continuación: ¿o te sientes avergonzado de ello? Al reflexionar sobre el contexto cultural y sobre su identidad -de madre australiana con ascendiente escocés, de padre indonesio de origen chino, y habiendo nacido en Indonesia y crecido en Australia-, él debe rechazar la pregunta para poder precisar su respuesta. Proporciona así una doble negación: "no está orgulloso ni está avergonzado". Sin embargo, su respuesta no es perfecta ni precisa para su hermana ni para él mismo, porque crea ambigüedad en lo que ya es una compleja mezcla cultural y racial, entonces pronuncia una frase trivial como un gesto de resignación. La hermana mayor también escuchaba la conversación de sus hermanos y ofrece una respuesta algo más clara, procurando explicar la compleja situación.

Elenor: Part of the reason I like being Chinese, or part Chinese, it's sort of a superficial thing I suppose but the way I look, I like looking different, you know? People will often say to me. "There's something about you, you know? Where are you parents from?" or you know. They can't quite put their finger on it, it's not like they can say "Oh you look Chinese" or anything. And, I like that, I like that. I suppose it's like being exotic or, just being different. I like being different. But then the other side of that is, I'm neither Chinese nor Western, and so in another way I don't fit in anywhere, /Fiona: Mm, I think that's.../ and so it sort of just depends on how I'm feeling as to whether it's a good thing or whether it's a terrible thing.

Fiona: Mmm, I think that's exactly the way I feel. ${ }^{20}$

\footnotetext{
${ }^{20}$ Eleonor: Parte de la razón por la que me gusta ser china, o medio china, puede parecer algo superficial, pero supongo que es por como me veo, me gusta mi aspecto diferente, ¿entiendes? La gente a menudo dice: "hay algo en ti, ¿sabes? ¿De dónde son tus padres?" o cosas así. No pueden poner absolutamente su dedo en la llaga, ellos no pueden decir: "oh, pareces china" o nada. Y, por eso, me gusta, me gusta. Supongo que es como ser exótica o, simplemente ser diferente. Me gusta ser diferente. Pero entonces está la otra parte de esto: no soy china ni occidental, y visto de otro modo, no encajo en ninguna parte. /Fiona: Mmm, creo que es... /...por lo que solo depende de cómo me esté sintiendo acerca de si es bueno o si es una cosa terrible.

Fiona: Mmm, creo que es exactamente lo mismo que yo siento. [Transcripción y traducción propia]
} 
Como vemos, la artista Fiona Tan ratifica el comentario de su hermana. Pero, si volvemos a comparar la respuesta con la pregunta inicial, en realidad ella tampoco contesta a las preguntas o contesta casi lo mismo de su hermano pero de otra manera (" no soy china ni occidental, soy de otro tipo, no me ajusto en ninguna parte"). Por otra parte, en el último momento, no se olvida de adjuntar un comentario inteligente: ser diferente y no adaptarse a ninguna parte puede convertirse en algo positivo, pero eso depende de cómo se sienta, ya que también puede suponer sentimientos horribles.

Es cierto, y ya hemos visto varios casos que causaban graves confrontaciones y terribles complejos acerca de este peliagudo asunto. Por ejemplo, en Surname Viet Given Name Nan, de Trin. T. Minh-ha, se subraya la violencia creada por las diferencias raciales que analizamos en el apartado VI.2 del presente capítulo. En el caso de Rabbit in the Moon (1999), de Emiko Omori, también se comprende el grave sufrimiento causado por las diferencias físicas (V.4.1.). En el caso particular de la hermana de la artista del presente trabajo, como ella dice, las emociones dependen de cómo se siente uno día a día. Aunque ella expone lo más positivo, debemos prestar atención al hecho de que hay ciertas circunstancias contradictorias que le obligarán a sentir emociones más negativas.

Fiona Tan también es consciente de ello. Avanzando en la obra encontramos una entrevista a su primo en la que se cuestiona el mismo asunto, y se relatan las causas que le obligan a tener pensamientos negativos (precisamente, un suceso en Indonesia en 1965, el detonante principal de la diáspora de la familia de la artista). La escena retorna a una entrevista con la madre que cuestiona las razones que les hicieron decidirse a abandonar Indonesia.

Fiona: What happened to make you and Pappi decide to leave Indonesia?

Mother: Well, there had been a certain degree of unrest in Indonesia, and whenever there's unrest, it often seems to rebound on the Chinese community, that they are doubly in a state of uncertainty and perhaps scapegoatism is likely to happen, and that was certainly part of the times. ${ }^{21}$

\footnotetext{
${ }^{21}$ Fiona: ¿Qué pasó para que tú y papá decidieseis abandonar Indonesia?
} 
Sobre este suceso ocurrido a partir del año 1965 en Indonesia ofreceremos algunos detalles en adelante. Por ahora solo lo resumiremos brevemente. Al tener lugar un intento de golpe de Estado, el presidente confiere a un oficial del ejército la misión de reprimir a los rebeldes y mantener el orden público. Esto se convierte en una depuración social, casi en una caza de brujas, que genera una grave matanza y numerosos detenidos sin oportunidad de juicio. En este contexto, la comunidad china en Indonesia sufre al quedarse en una posición muy delicada. Los comentarios de la madre de la artista explican que, en ese contexto, la comunidad china se sumerge en un estado de gran incertidumbre. Nos podemos imaginar la frustración de la comunidad dentro de Indonesia; entonces, se busca otro chivo expiatorio y se le expulsa.

La artista interrumpe a su madre para exigirle más detalles:

Fiona: I'll just interrupt you there, because you've said it very, very carefully: there was some unrest in Indonesia, but what you told me last time was much more exciting.

Mother: Well I need to ask Pappi because am I allowed to say that? Is it alright to say that?

Fiona: To say what?

Mother: About the crew, and about his relatives being under suspicion, and I'm... too nervous to say that sort of thing. ${ }^{22}$

La entrevista termina en este punto. Si no se posee el conocimiento histórico y político de Indonesia en el contexto de la Guerra Fría, no se pueden entender muy bien los comentarios de la madre. Y, por otra parte, también nos deja con el misterio sobre lo que ella no puede

Madre: Bueno, había un cierto grado de malestar en Indonesia, y cada vez que había disturbios, a menudo parecían volverse contra la comunidad china, lo cual se convertía en un doble estado de incertidumbre y tal vez como chivo expiatorio es probable que sucediera, y que fuese ciertamente parte de esos tiempos. [Transcripción y traducción propia]

${ }^{22}$ Fiona: Te voy a interrumpir aquí, porque tú lo has dicho con mucho, mucho cuidado: hubo algunos disturbios en Indonesia, pero lo que me dijiste la última vez fue mucho más emocionante.

Madre: Bueno, tengo que preguntar a papá porque... ¿me permitirá decir eso? ¿Estaría bien decir eso?

Fiona: ¿Decir qué?

Madre: Acerca de la comunidad, y sobre sus familiares que estaban bajo sospecha, y estoy... demasiado nerviosa para hablar de ese tipo de cosas. [Transcripción y traducción propia] 
manifestar frente a la cámara. Según la reclamación de la artista, ella había escuchado más detalles que lo pronunciado durante la entrevista. Pero, al enfrentarse a la cámara, la madre habla con cierta ansiedad y evita exponer sus emociones. Ya mencionamos anteriormente que la artista se conciencia durante este proyecto sobre los efectos de la cámara y la realidad en la relación entre proximidad, intimidad y ceguera.

Proximity is an intimacy, and a blindness. The film camera should see what I see, but it often surprises me. It would seem that sight is more a matter of projection. I wanted to find out what it meant to be Chinese in Indonesia. ${ }^{23}$

Mientras se articula este texto en off, la imagen muestra una parte de una vivienda en primer plano. La cámara se pone en pan y se aclara visualmente que ésta era prefabricada y está siendo transportada en un camión que se marcha. Por la imagen, podríamos intuir muchas cosas, pero solo podemos captar lo que se ve dentro del marco. Al ampliar este marco, en varias ocasiones se nos exige cambiar las perspectivas y la idea que teníamos.

Cuando la madre menciona la situación de los chinos en Indonesia, la imagen muestra un espectáculo callejero de un mono encadenado con una máscara amarilla y quitándosela se mira al espejo.

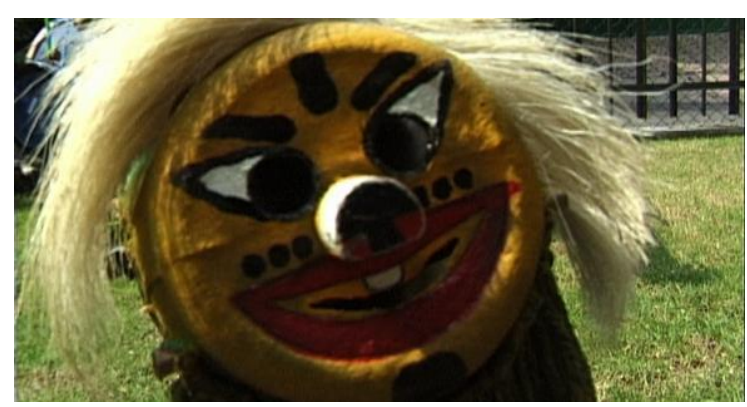

Fiona Tan May You Live In Interesting Times documentary film, 1997cortesía de la artista y Frith Street Gallery, London

67. May You Live In Interesting Times (1997), Fiona Tan

\footnotetext{
${ }^{23}$ La proximidad es intimidad y es ceguera. La cámara para filmar debería ver lo que yo veo, pero a menudo me sorprende. Al parecer, la vista es más una cuestión de proyección. Yo quería saber lo que significaba ser chino en Indonesia. [Transcripción y traducción propia]
} 


\section{VI.4.4. Yellow Jews ( 黄種猶太人 )}

Tras la imagen del espectáculo del mono con la máscara amarilla aparece el título "Judíos Amarillos”. En el telón que muestra el título, se mezclan una foto de esta máscara, el sonido del grito del mono y el tambor del espectáculo. La escena se puede interpretar como que este espectáculo está caricaturizando el ser "amarillo" al compararlo con un mono con máscara amarilla que se mira al espejo ladeando la cabeza. No se indica dónde se ha filmado dicha escena, pero por el contexto, comprendemos que se trata de Indonesia.

Después del telón, sigue una secuencia de un tren con una indicación a Java, isla principal de Indonesia donde se encuentra la capital, Jacarta. Desde el siglo XVII una gran influencia de Holanda ha calado en el país (ya que hasta 1945 permaneció como territorio holandés). En la imagen del interior del tren se advierte que ha cambiado el ambiente.

En esta secuencia, ella realiza una entrevista a una pareja, An y Rose. An es un hermano mayor del padre de la artista, y Rose es su mujer. La artista reflexiona sobre la cuestión de la identidad china en Indonesia a través de los relatos de sus tíos, ya mayores, con la idea clave de "judío amarillo". La cuestión de la identidad judía en el siglo XX que analizamos en el capítulo IV (según la interpretación de Shoshana Felman sobre Shoah, dirigida por Claude Lanzmann) nos servirá para la comprensión de la problemática judía. En el presente documental, la expresión "judíos amarillos" se refiere a los chinos que habitan en Indonesia. En verdad, ellos no tienen nada que ver con la religión judía ni con la herencia biológica judía. Pero para llamarles judíos debería existir algún aspecto similar entre los chinos en Indonesia y los alemanes en el Holocausto. En realidad, la expresión se relaciona con el suceso ocurrido a partir del año 1965 y la segregación de la comunidad china en Indonesia. Pero en esta sección todavía no encontramos comentarios explícitos sobre el suceso, deberemos esperar hasta la siguiente. Nos aproximaremos a ellos según el orden que la artista realiza en el documental.

Al igual que las secciones anteriores, ésta empieza con la imagen del vídeo-retrato de la pareja sentada, presentándolos en off: 
This is my Uncle An. He's the oldest surviving brother of my father. Staying with him and his dear wife, Aunt Rose, felt like visiting long-lost grandparents. ${ }^{24}$

Y en seguida empieza el relato del tío que tenía solo dieciséis años cuando se quedó huérfano. En aquel momento empezó a trabajar para sustentar económicamente a los hermanos y ello le forzó a continuar con el negocio que tenía el padre. Todavía lo mantiene y por eso él cree que los padres le están observando y le ayudan. El respeto, la lealtad y la fidelidad hacia los padres es un aspecto muy notable en la cultura china, e incluso en las diversas culturas bajo influencia china. Dentro de las filosofías chinas, sobre todo del confucionismo $^{25}$ y del taoísmo, los dos originarios de China, se insiste en la importancia del amor filial.

La imagen ilustra una costumbre ritual del tío de la artista en la que éste ofrece dos tazas de té a un altar donde está colocada una foto de sus padres. Durante la escena se inserta la imagen de una lagartija que corre por los rincones de la habitación. El tío relata en off que realiza dos veces al día este ritual, todos los días, y que en realidad no es ningún acto religioso, sino que se trata de un ritual propio. Contestando a la pregunta de la artista, él comenta que, cuando reza, en su interior consulta a sus padres las dificultades que está atravesando para que le escuchen y le ayuden. El tío enciende un incienso largo y se sitúa frente al altar y hace una reverencia al estilo chino. Entonces, de repente, la imagen cambia a la de un mausoleo confucionista-taoísta en el que una persona ora repitiendo el mismo movimiento corporal que hizo el tío, con el sonido de una melodía de platillos impactante y solemne. La imagen muestra una llama e inciensos gigantes que con su humo cubren el

\footnotetext{
${ }^{24}$ Este es mi tío An. Él es el hermano mayor sobreviviente de mi padre. Estar con él y con su querida esposa, la tía Rose, fue como visitar a los abuelos perdidos hace mucho tiempo. [Transcripción y traducción propia]

${ }^{25}$ Serie de enseñanzas morales, éticas y políticas de la escuela china fundada por Confucio (en los siglos VI-V a.C.). No somos capaces de resumir sus enseñanzas por su larga historia de dos mil quinientos años, por ello, citaremos una parte del apartado de Confucio en el Diccionario Akal de Filosofía para que nos aporte una idea: Sus enseñanzas aparecen recogidas en "Lun Yü" o "Analectas", formado por una colección de dicho de Confucio y sus discípulos, así como por conversaciones entre ellos. Su máximo ideal ético es el "Jen" ("humanidad», «bondad»), que incluyen un compromiso afectivo con el bienestar de los demás, una serie de atributos deseables (por ejemplo, el amor filial) dentro de la familia y las instituciones sociales y políticas, y otros atributos tales como el "yung ("coraje»o "valor»). Una parte importante de este ideal está formado por la observancia del "li" ( $\ll$ ritos»), las normas tradicionales que gobiernan la conducta de la gente en relación a su posición social, así como una disposición a adaptarlas a las circunstancias presentes. [Audi, Robert (ed.): Diccionario Akal de Filosofía, trad. Huberto Marraud y Enrique Alonso, Madrid, Akal, 2004. p. 195.]
} 
mausoleo, nos aporta cierta impresión de exotismo y misticismo. Aunque el tío insiste en que su oración no proviene de ninguna religión, sino que es un ritual propio, con este montaje se indican los orígenes culturales.

Al mismo tiempo, la artista construye una imagen exótica de la cultura china, ignorando el código cultural. Si respetase completamente el código cultural no combinaría la imagen de las plegarias con el sonido escandaloso de un espectáculo. Es una representación propia del extranjero: en muchas ocasiones, por no tener un conocimiento profundo y encontrarse al margen de la disciplina cultural, resulta fácil ignorar el código cultural. En ciertas ocasiones, esto se convierte en una dinámica en la que se rompen las rígidas restricciones de la cultura o en la que -al menos- se visibiliza dónde y cuándo aparecen los límites. En el arte contemporáneo, sobre todo a partir del planteamiento post-moderno, los artistas introducen a menudo esta estrategia para superar o señalar los límites de nuestro mundo. Sin embargo, dependiendo del contexto, al ignorar el código de la cultura se corre el riesgo de generar una violencia epistémica aplastante. Sobre todo cuando se trata de aproximaciones a la cultura no occidental deberá ponerse mayor esmero en las representaciones occidentales (por la presencia de tantos ejemplos negativos de colonialismo cultural). Como vimos en la discusión de Spivak, ya sea por parte de intelectuales, ya sea por parte de artistas, si no se es plenamente consciente de la relación de complicidad entre el poder político-económico y la cultura se arriesga a caer en un conocimiento equívoco de la realidad. También hemos recordado lo que representa la función del Orientalismo por E.W. Saide: la admiración a la imagen mística y exótica siempre está relacionada con una mirada despreciativa. En el caso del presente trabajo, hasta este momento no podemos juzgar si es por ignorancia o si se debe a una estrategia. Lo aproximaremos un poco más adelante.

De vez en cuando, la artista realiza una comparación de fotos antiguas con imágenes actuales por medio del vídeo. Por ejemplo, en la secuencia anterior había colocado una foto de la familia en la que se encuentran los padres jóvenes y los niños, luego mostraba una imagen en vídeo en la que cada quien se colocaba más o menos en la misma posición en la foto. Los padres ya no son jóvenes y los hijos ya son adultos, lo cual sella el tránsito del 
tiempo. Esta vez, con una fotografía de una parte de la ciudad el tío pronuncia "Everything changes with the times" ("todo cambia con el tiempo") mientras se muestra el paisaje del mismo lugar tiempo después.

Pasa a la imagen de una cena de la artista con los queridos tíos, luego vuelve a la entrevista con el tío. La artista pregunta a su tío de dónde se siente. El tío no oye bien y la artista repite casi tres veces misma pregunta. El tío se confunde con la pregunta y la artista insiste otra vez, inquiriendo: ¿Eres holandés o chino? El tío contesta que se siente más holandés que chino. La artista se sorprende por su respuesta. Entonces, el tío responde comentando que cuando iba a la escuela le llamaban "Jan" mientras que a cualquier niño chino le llamaban en nombre holandés. Se filma el gesto del tío con una sonrisa agradable y se inserta una foto en blanco y negro de la familia china con vestido folklórico en una habitación al estilo holandés. Como hemos mencionado, la declaración de la Independencia de Indonesia tiene lugar en 1945, y la concesión de la soberanía de Holanda en 1949. Esto quiere decir, naturalmente, que los que tuvieron acceso a la educación pública recibieron una educación holandesa. En la obra no se detallan los acontecimientos de la Independencia de Indonesia, pero en esta respuesta -a pesar de ser algo tan personal- vemos un reflejo de la Historia.

La respuesta de Yan, el primo afincado en Holanda como inmigrante chino-indonesio que se siente más chino que indonesio, contrasta con la del tío An que, aún residiendo en Indonesia, se siente más holandés que chino. También puede que se deba a la diferencia generacional y a la educación que han recibido, pero a lo mejor, con las situaciones a las que se enfrentan se evidencia más las diferencias. Gracias a esa diferencia se construye la identidad que se siente más dominante dentro de uno mismo. Si es así, sería un caso ejemplar de la teoría de Derrida sobre la identidad. Por último, la artista pregunta a su tío:

Fiona: So you were friendly with the Dutch?

An: Certainly. Business-wise. ${ }^{26}$

\footnotetext{
${ }^{26}$ Fiona: ¿Así que era amable con los holandeses? An: Por supuesto. Negocios-sabios. [Transcripción y traducción propia]
} 
El gesto serio con una leve sonrisa y la respuesta en sí nos hacen percibir un cambio en la emoción del tío al escuchar la pregunta. Podemos imaginarnos que la simpatía que muestra este señor mayor se fragmenta a distintos niveles a propósito de los holandeses: la nostalgia de su niñez, la cual sostiene su identidad cultural, y ser sociable con los holandeses en la vida práctica de un negociante.

La artista sigue preguntando, pero ahora contesta la tía Rose, la mujer del tío An. La cuestión trata sobre la religión. Frente al altar de la foto de sus suegros, ella interpreta su fe católica en relación a las compatibilidades con el ritual familiar.

Fiona: You pray to your ancestors but you also go to church?

Rose: Yes, but that's not allowed, so I am not yet a Roman Catholic. But the Catholic faith is very flexible. You can go to church and still honour your ancestors. That's the Catholic way. I don't know about other religions. I am glad that the Catholic faith has this flexibility. You may honour your ancestors. God says in His Ten Commandments: Honour thy father and mother. ${ }^{27}$

En un cambio de escena, aparecen imágenes del paisaje de un jardín o de un cementerio con grandes estatuas de Jesús, la Virgen María, la paloma blanca y unos dioses chinos. Estas estatuas pintadas de color están muy lejos de la escultura artística, son plásticamente mediocres y también resulta difícil juzgar su estilo (no son ni de Roma occidental, ni originalmente chinas). Parecen unos dibujos precarios en tres dimensiones, pero sí se percibe la imagen de Jesús y de los dioses chinos por sus iconos. No obstante, al mismo tiempo, esa precariedad en la técnica constructiva de las estatuas neutraliza la diferencia original de cada imagen religiosa. Ofrecen una impresión bastante unificada, de alguna manera. Precisamente -ignorando la calidad estética de cada imagen- por el hecho de no mantener un estilo técnico-artístico original se logra mantener un ambiente armónico. Esta impresión seguramente es un objetivo construido a través del montaje y de la música de

\footnotetext{
${ }^{27}$ Fiona: Rezas a tus antepasados, pero ¿también vas a la iglesia?

Rosa: Sí, pero eso no está permitido, así que no soy todavía un católico romano. Pero la fe católica es muy flexible. Puedes ir a la iglesia y también honrar a tus antepasados. Esa es la idea católica. Yo no sé acerca de otras religiones. Me alegro de que la fe católica tenga esa flexibilidad. Puedes honrar a tus antepasados. Dios dice en Sus Diez Mandamientos: Honra a tu padre y madre. [Transcripción y traducción propia]
} 
fondo. En cierto modo, se percibe una exageración de "la armonía y la paz" de estas estatuas por la música electrónica ambiental, además de la imagen de las estatuas que parecen dibujos de caricatura. Podríamos incluso decir que se deja ver una intención humorística por parte de la artista. Es una mezcla inverisímil: si se respetase el código cultural de cada origen, no podría aparecer lo que vemos. En este sentido, se convierte en un ejemplo de ignorancia de la cultura original. No obstante, inmediatamente nos surgen las preguntas: ¿cuál es la cultura original? ¿Cuál es la importancia, en este caso, de las imágenes religiosas que simbolizan la armonía y la paz? Sea como sea, ahí están. Quizás la mezcla y la flexibilidad que comenta la tía de la artista sean el carácter más notable de esa gente que vive en tránsito entre las diferentes culturas.

La imagen de la artista agachada, destapada de hombros, queda a la vista con un fondo de espejos de puertas tras ella, con el reflejo de ella recibiendo un masaje con un frasco de vacío de su tía. También aparece una estatua de la Virgen María, esta vez es una figura más corriente que se encuentra dentro de su habitación. Luego, vemos que los tíos de la artista están paseando juntos por la calle. La voz en off de la tía sigue relatando sobre su identidad:

\begin{abstract}
Rose: Where do we really belong? We are not really Chinese. We wish to become true Indonesians. We are Indonesians. That's why the Westerners call us 'Yellow Jews'. We don't know where we are. We know no other country. Maybe Westerners call us 'Yellow Jews' because we are yellow and have no country. But that is all in the past. The Indonesian government now recognizes us as true Indonesian citizens. We wish to stay in Indonesia as long as we are allowed to. We will be grateful when we're accepted as true Indonesians. That's why we have taken on proper Indonesian names! $!^{28}$
\end{abstract}

\footnotetext{
${ }^{28}$ Rose: ¿A dónde pertenecemos realmente? En realidad no somos chinos. Queremos ser indonesios de verdad. Somos indonesios. Es por ello que los occidentales nos llaman 'Judíos Amarillos". No sabemos dónde estamos. No conocemos ningún otro país. Tal vez los occidentales nos llaman "Judíos Amarillos' porque somos de color amarillo y no tenemos patria. Pero eso todo eso forma parte del pasado. El gobierno de Indonesia ahora nos reconoce como verdaderos ciudadanos de Indonesia. Queremos permanecer en Indonesia mientras nos sea permitido. Estaríamos agradecidos si nos aceptan como verdaderos indonesios. Por ello, ;hemos tomado nombres propios de Indonesia! [Transcripción y traducción propia]
} 
La tía habla sobre un "nosotros" representante de los chinos en Indonesia e insiste en su identidad social como ciudadana indonesia. También expresa su deseo de llegar a ser "verdaderos indonesios", con un gesto humilde, agradeciendo que se les permita vivir en el país y explicando que el hecho de haber escogido nombres indonesios es prueba de ello. Luego se refiere a la expresión "judíos amarillos" como representante de la mirada occidental hacia ellos, pero enfatizando que eso forma parte del pasado.

Según sus explicaciones, entendemos que "judíos” representa a las personas que no tienen país ni ciudadanía propios, digamos que no pertenecen ni a China ni a Indonesia, seres que no pertenecen a ninguna nación. A pesar de que ella no expone exactamente lo que ocurre en el pasado, recordaremos el testimonio de Karsky en Shoah, de Claude Lanzmann, analizada en el capítulo IV: los habitantes del gueto, maltratados y sin ningún tipo de apoyo político por pertenecer a ninguna nación, quedan fuera de la dinámica de la política entre naciones, también permanecen en una situación difícil, sobre todo a partir del suceso de 1965 al que nos aproximaremos en la siguiente sección. Tal vez por convertirse en sobrevivientes de la difícil experiencia de no estar integrados en ninguna nación, actualmente deben insistir en su humilde voluntad y deseo de ser un verdadero indonesio con ciudadanía reconocida por el gobierno.

Al terminar esta entrevista, la artista se replantea su búsqueda disertando en off después de un notable sonido de cascabel que proviene de un vendedor de la calle con un carretón de mano, tal y como muestra la imagen. Mientras que la artista habla, continuamos viendo la imagen de la calle, al fondo una pared de color rosa en un encuadre fijo, unas personas y unos vehículos pasan, unos desaparecen en medio de la imagen y otros aparecen y se van. Mediante esta estrategia de montaje se visibilizan las variedades del tránsito y el tiempo que ha pasado en la expresión no lineal. Después se insertan unas imágenes captadas de la ciudad, de la gente en el lugar de trabajo, de la misma artista paseando por calles medio derruidas. Y dice lo siguiente:

I realised that the question wasn't about the Chinese identity. My search was for the overseas Chinese identity. The Chinese identity in Indonesia was riddled with 
paradox and ambiguity. So this was what it was like to be an Indonesian-Chinese. I suspect I have inherited some of my fears and also flexibility from this. A marriage of cultural influences is most certainly visible, and I am its offspring. ${ }^{29}$

Este replanteamiento en su búsqueda tiene lugar casi a la mitad del documental. Lo que pretendía analizar la artista era la identidad china en el extranjero y la identidad china en Indonesia, que ha encontrado hasta ahora, es una cosa acribillada como paradoja y ambigüedad. Sería una cosa inexplicable con un único fundamento, ni se permanece únicamente en un lado ni en el otro; al mismo tiempo, se está en ambos. En otras palabras, los indonesios-chinos viven en esa identidad fragmentada, paradójica y ambigua. La artista se imagina que de ahí es de donde ella ha heredado su flexibilidad y también los miedos que perduran en su interior.

Después se muestran unas escenas de una boda al estilo javanés de una sobrina de la tía Rose y donde la artista asistió. La sección finaliza con la expresión de la artista de un proverbio que en la comunidad china simboliza una desgracia, y de nuevo la formulación de una pregunta con el fin de aclarar las causas de la diáspora familiar de la artista.

The Indonesian-Chinese have a saying, in typical self-depreciation, they say: "We disappear in the dark" and with the resilience I see in all my family, resurface to establish new lives after the troubles have died down. So what happened, to make so many family members leave Indonesia? ${ }^{30}$

\footnotetext{
${ }^{29}$ Me di cuenta de que la cuestión no era sobre la identidad china. Mi búsqueda era sobre la identidad china en el extranjero. La identidad china en Indonesia fue acribillada con la paradoja y la ambigüedad. Así que esto era lo que era ser un indonesio-chino. Sospecho que he heredado algunos de mis miedos y también la flexibilidad de éste. Un matrimonio de influencias culturales es sin duda visible, y yo soy su descendencia. [Transcripción y traducción propia]

${ }^{30}$ Los indonesios-chinos tienen un proverbio muy típico y auto-despectivo que dice: "Nosotros desaparecemos en la oscuridad". Con la resistencia que veo en toda mi familia, para resurgir y establecer una nueva vida después de los problemas es algo imposible. ¿Y qué pasó, para que tantos miembros de la familia abandonaran Indonesia? [Transcripción y traducción propia]
} 


\section{VI.4.5. Disaster Comes From the Mouth ( 禍从口出 )}

El título de la presente secuencia, "La desgracia sale de la boca", tiene el sentido de argüir que el hecho de parlamentar con descuido crea problemas. En general, en China se dice que "la enfermedad entra por la boca, la desgracia sale de la boca" (病从口入禍从口出); es decir, junto con una advertencia sobre la alimentación e higiene de la boca, se aconseja hablar con solicitud. De todos modos, casi se recomienda cerrar la boca para evitar cualquier tipo de infortunio.

Encontramos una serie de dichos que fomentan cuidar de lo que se habla, en la misma línea que "la desgracia sale de la boca". Por ejemplo, la frase "la boca es la puerta de la desgracia" tiene un sentido muy similar. Forma parte de una poesía titulada "Poesía de la lengua” (舌詩), escrita por el político chino Feng Dao (馮道, 882-954), y es la siguiente:

口是禍之門 (La boca es la puerta de la desgracia)

舌是斬身刀 (la lengua es una espada que corta su propio cuerpo)

閉口深蔵舌 (entonces, ciérrese bien la boca guardando la lengua hasta al fondo)

安身処処牢 (aunque, esté donde esté, mantendrá su propia seguridad con firmeza) ${ }^{31}$

Al hablar impensadamente se podría provocar el enojo de los demás y eso causaría arruinarse a sí mismo, por eso resulta mejor no pronunciarse. La poesía anima a quedarse callado para la propia seguridad. Todo esto resulta muy significativo al reflexionar sobre las entrevistas durante toda la obra y fijarnos en los márgenes entre lo que se dice y lo que no se dice. También simboliza el sufrimiento de un tío de la artista que permaneció en prisión por ser portavoz de la comunidad china, tal y como nos aclara la entrevista a su hijo en la presente sección.

\footnotetext{
${ }^{31}$ http://www2.odn.ne.jp/kotowaza/BBS/KANSI/13-kutiha-wazawaino.htm, accedido el 14 de abril de 2011. [Traducción propia]
} 
En concreto, en la presente secuencia se realiza una entrevista a dicho primo, el cual se exilió de Indonesia a Australia cuando era un adolescente y vivió con la familia de la artista. Naturalmente, la escena cambia a Melbourne, donde él permanece en la actualidad. Él relata precisamente lo que ocurrió a partir de 1965 en Java, Indonesia, lo que fuera la causa de la diáspora de la familia de la artista. Él habla sobre este suceso porque su padre es quien permaneció en prisión durante años y porque supuso la causa de su abandono de Indonesia.

Mientras la artista presenta en off al primo Jin y a su mujer, incluye una imagen de vídeoretrato de la pareja sentada en el sillón con su perro frente a ellos. Luego, al igual que con los personajes anteriores, se muestran las imágenes de su vida cotidiana, paseando por la calle, comiendo con la artista, la foto del trabajo, entre otras. La artista comenta lo siguiente:

This is my cousin Jin, and his wife, Leone. Jin left Jakarta as a teenager, and lived with us in Melbourne. His father, Uncle Chan, had looked after my orphan father as a boy, and my father in turn looked after Jan's three youngest children: Ho, Jin and Ming. Traditional family ties that bind the generations. Uncle Chan was an important political figure, a spokesman for the Chinese minority in Indonesia. His figure took on mythological proportions for me. Whilst I grew up, Uncle Chan was a political prisoner, in jail. ${ }^{32}$

Después de la presentación la artista empieza con la entrevista al primo Jin.

Jin: In September 1965, following the failed coup by the young military offices, army offices in Indonesia, generals took over the power from President Sukarno and the red drive then started. And as the chairman of the 'Aperkiperiki' my father was

\footnotetext{
${ }^{32}$ Éste es mi primo Jin y su esposa, Leone. Jin dejó Yakarta cuando era adolescente y vivió con nosotros en Melbourne. Su padre, el tío Chan, había cuidado de mi padre cuando quedo huérfano, y mi padre, a su vez cuidó a los tres niños más pequeños de Jan: Ho, Jin y Ming. Los vínculos tradicionales familiares que unen a las generaciones. El tío Chan fue una importante figura política, un portavoz de la minoría china en Indonesia. Su figura adquirió proporciones mitológicas para mí. Mientras crecí, el tío Chan fue un preso político en la cárcel. [Transcripción y traducción propia]
} 
included in the list of people to be arrested. So he got arrested on $4^{\text {th }}$ November 1965 , together with some 500,000 others. ${ }^{33}$

Conocida como G-30-S (Gerakan September Tigapuluh) en indonesio, y 30 September Movement en inglés, el intento de golpe de Estado ocurre el 30 se septiembre de 1965. Unos jóvenes oficiales izquierdistas son los responsables. Con el fin de reprimirlo, el presidente Sukarno confiere al oficial Suharto (quién se va a convertir en el presidente en el siguiente periodo), también exterminó a los que simpatizaban con éste golpe: los comunistas, junto con cualquier posible enemigo contra su política. Durante ésta caza de brujas, llamaron GeSTpu (Gerakan Septembre Tiga-pulih) a sus enemigos, colaboradores del golpe fracasado, comparándolo con la Gestapo Nazi que simboliza el poder por el terror.

Nunca se ha llegado a aclarar qué fue lo que pasó realmente en este suceso, si bien el resultado fue que Sukarno -quien dirigió la independencia de Indonesia y se autoproclamó presidente vitalicio, con una política contra los países del oeste y un programa político nacional "NASAKOM", el cual fomentaba la unificación del nacionalismo, la religión y el comunismo-, perdió su puesto político. Como consecuencia, el oficial Suharto fue designado presidente e impone la dictadura del desarrollo, reanudando las relaciones diplomáticas con los países del oeste. Existen varias hipótesis sobre si fue una maniobra de agentes secretos de los países del oeste o incluso una conspiración de Suharto, pero no se puede afirmar con certeza. Siguen sin existir aclaraciones, no solo a nivel político, sino también sobre el resultado de los graves y violentos incidentes. Nunca se ha realizado una investigación confiable y confirmable sobre el suceso en gran escala.

Durante el comentario de Jin sobre el suceso y la narración de la artista en off, se introducen algunas imágenes de archivo histórico en blanco y negro que muestran al presidente poniéndole una condecoración a un oficial, algunos oficiales sonrientes, junto a otras

\footnotetext{
${ }^{33}$ Jin: En septiembre de 1965, tras el golpe de Estado fallido de oficiales militares jóvenes, las oficinas del Ejército en Indonesia, los generales se hicieron cargo del poder del presidente Sukarno y la unidad [anti]rojos comenzó. Y como presidente de la aperkiperiki mi padre fue incluido en la lista de personas a ser detenidas. Así que fue arrestado el 4 de noviembre de 1965, junto con otros 500.000. [Transcripción y traducción propia]
} 
imágenes de personas siendo transladadas de una manera humillante. Una mujer se desvanece llorando con un aullido, unas figuras humanas suspendidas, un papel pegado donde está escrito GeSTpu, un cadáver quemado en el suelo o en un río. Luego, unas lápidas sepulcrales con carácteres chinos y algunas otras más pequeñas en la maleza. La secuencia termina con la imagen del río actual en Indonesia. El comentario en off es el siguiente:

In the unrest following the coup in '65, there are riots, plunderings, military actions. Reputably up to three million were murdered in Indonesia. Most of the victims were Chinese. Stories tell of how the river ran red with blood. The saying, "May you live in interesting times", is a curse. ${ }^{34}$

A continuación, la imagen muda a la de las vistas de la autopista desde el coche. Se ve una pancarta gigante con el eslogan de 'Successful elections strengthen the new rule ${ }^{35}$. La "nueva norma" se refiere a la política de Suharno durante los treinta años de su dictadura. En el año 1997, Suharno cede el poder gubernamental gracias al movimiento para la democratización de Indonesia que se dinamiza por la crisis financiera asiática. Nos imaginamos que ese eslogan simbolizaba la sucesión de su política. Además de eso, aunque no se encuentra una indicación directa, si consideramos también la destrucción del barrio chino en Jacarta por unos sublevados dentro de la manifestación para democratización contra Suharno en 1996, nos hace comparar los hechos con el pogrom ${ }^{36}$. También nos obliga a reflexionar sobre el énfasis que la tía de la artista daba a su voluntad de ser "verdaderos indonesios" y su deseo de sellar el término "Judíos Amarillos" como una frase muerta del pasado, seguramente debido a la preocupación y el miedo a una posible repetición del desastre histórico. La artista comenta de la siguiente manera en off:

\footnotetext{
${ }^{34}$ En los disturbios que siguieron al golpe en el 65, se encuentran disturbios, saqueos y acciones militares. Se estima que hasta tres millones fueron asesinados en Indonesia. La mayoría de las víctimas eran chinos. Las historias hablan de cómo el río corría rojo por la sangre. El dicho "que vivas en tiempos interesantes" es una maldición. [Transcripción y traducción propia]

${ }^{35}$ El éxito de las elecciones fortalece la nueva norma. [Transcripción y traducción propia]

36 "Pogrom" es una palabra rusa que significa un ataque o disturbio. Las connotaciones históricas del término incluyen ataques violentos por las poblaciones locales contra judios en el imperio ruso y por todo el mundo. En la época moderna, resentimiento económico y político contra los judíos, y el antisemitismo religioso tradicional, han sido usados como pretextos para los pogroms. [http://www.ushmm.org/wlc/es/article.php?ModuleId=10005757, accedido el 17 de abril del 2011]
} 
I couldn't help being impressed by my family's courage and stoicism. Two uncles spent many years in prison without trial. Many relatives were forced to leave Indonesia. The diaspora of my family takes over the story here. ${ }^{37}$

Comienza el sonido ruidoso de unos platillos al estilo chino y la imagen de una fiesta en el barrio chino con las Danzas de león (舞獅: tradicional espectáculo del baire con el disfraz de león). Una indicación de Brisbane introduce la siguiente sección.

\section{VI.4.6. Bringing in New Blood ( 新陳代謝 )}

Esta secuencia prosigue con la entrevista a los parientes de la diáspora, en concreto a una tía y a dos primos de la artista que abandonaron Indonesia por el encarcelamiento de su marido y su padre, respectivamente. El título de esta secuencia, 新陳代謝, se puede traducir literalmente como el metabolismo; originalmente, tiene el sentido de reemplazar lo nuevo por lo pasado que ya se va. Para empezar, la artista realiza una entrevista a su prima Ming, la hermana menor de Jin. Ming es la hija más pequeña del tío que permaneció durante mucho tiempo en la cárcel. Igual que su hermano Jin, ella se trasladó a Australia y vivió junto a la familia de la artista. Según el comentario de la artista en off, ella es como una hermana, ya que fueron juntas a la escuela y pasaron mucho tiempo en charlas de chicas. Como con los otros personajes, se presenta la imagen en primer plano mediante el vídeo-retrato, en este caso lleva un pájaro al hombro. Mientras comenta en off que se siente como si fuesen hermanas, en la imagen la artista se coloca a su lado y junta su hombro al de la prima, entonces el pájaro cambia del hombro de la prima al de la artista y ellas ríen. Con ello se reafirma el cariño y la relación íntima entre ellas.

En esta entrevista no se aborda el tema del suceso ni otros temas políticos. Las preguntas son acerca de las impresiones personales sobre Australia y sobre el primer encuentro con la artista. A través de las pocas palabras con las que contesta la prima, se percibe una

\footnotetext{
${ }^{37}$ Yo no podía dejar de estar impresionada por el coraje de mi familia y su estoicismo. Dos tíos pasaron muchos años en la cárcel sin juicio. Muchos familiares se vieron obligados a abandonar Indonesia. La diáspora de mi familia inicia su historia aquí. [Transcripción y traducción propia]
} 
diferencia en las sensaciones, entre estas íntimas primas y las coincidencias en su soledad. Por ejemplo, Ming comenta sobre las impresiones que tuvo la primera vez que vio a sus primos en Indonesia (a los hermanos de la artista):

Ming: The first time I met you in Indonesia I was thinking that my cousins, these three cousins, they're different than us. Might be because of the colour of your hair, the eyes, the skin, the freckles... We don't have freckles! And, erm, you had different things, different clothes, different shoes, different toothpaste. The smell, that's all I remember. ${ }^{38}$

Tras este comentario, la artista pregunta sobre el tipo de olor al que se está refiriendo. La prima contesta que era el olor de la gente de Occidente e intenta explicarlo según las series de preguntas de la artista: era un olor que no pertenecía a Indonesia, muy agradable, y que si pudiese describir, relacionaría con el jabón para bebés. Mientras está contestando a las preguntas prepara la comida en su cocina. La escena nos sugiere un clima relajado en el hogar y una tranquilidad en su vida cotidiana actual.

Luego muestra otras imágenes de ella en su hogar con su niño, viendo el vídeo del home movie, por ejemplo. Un comentario en off de la entrevista señala que ella considera que su hogar está en Australia porque ahí es donde contrajo matrimonio. Ella cree que su marido no podría encontrar su hogar en Indonesia. La artista pregunta si entonces la elección no es de ella, sino de su marido, y la prima responde con una negación. Inmediatamente añade un comentario sobre su deber de respetar los sentimientos del marido. En último lugar, junto a este comentario, se coloca una imagen de un vídeo-retrato de la familia de Ming: la pareja a pie sin calzado frente a su casa y los dos niños en triciclos dando vueltas alrededor de sus padres. La prima de la artista parece un poco incómoda, tal vez es una sensación que nos aportan sus comentarios durante esta entrevista.

\footnotetext{
${ }^{38}$ Ming: La primera vez que te conocí en Indonesia había pensando sobre mis primos, los tres primos, que son diferentes a nosotros. Podría ser por el color de su pelo, los ojos, la piel, las pecas... ¡Nosotros no tenemos pecas! $Y$, erm, que había cosas distintas, diferentes tipos de ropa, zapatos diferentes, pasta de dientes diferentes. El olor, eso es todo lo que recuerdo. [Transcripción y traducción propia]
} 
La imagen ahora la forman unas vistas desde un tren cruzando un puente con una indicación a Colonia. Luego, se descubren en el pasaje frente a la catedral a unos niños patinando y a un joven en un monopatín bajando una escalera de la calle. En este momento, la artista busca a algunos de sus familiares que viven en esa ciudad con el fin de continuar con el siguiente tema: la "chinacidad" de la familia en diáspora.

I grew up with the knowledge of a family scattered all over the globe. Some, like me, have ended up in Europe. I wanted to see whether the family was still Chinese. ${ }^{39}$

En concreto, va a realizar las entrevistas a la tía y a uno de sus hijos que abandonaron Indonesia debido a la reclusión de su marido. Primero presenta a la tía Kip en off con una imagen de vídeo-retrato en la ella aparece en la cocina de su restaurante.

This is my Aunt Kip. I admire her strength. She reminds me of a matriarch in a traditional Chinese clan. ${ }^{40}$

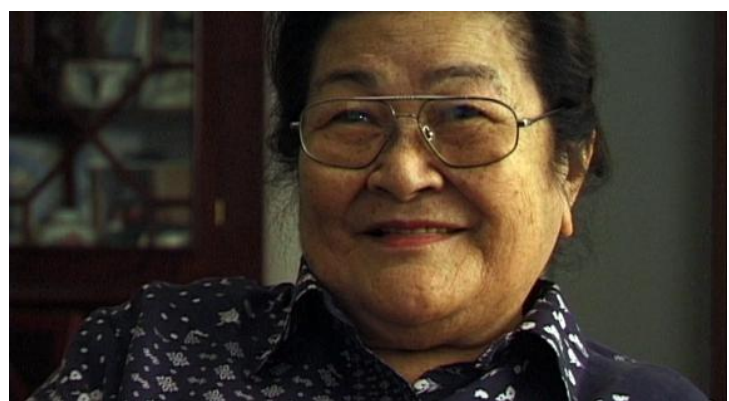

Fiona Tan May You Live In Interesting Times documentary film, 1997cortesía de la artista y Frith Street Gallery, London 68. May You Live In Interesting Times (1997), Fiona Tan

En la escena, la tía está sirviendo unos guisos. Mientras, introduce comentarios de la tía, la cual relata sobre las hijas que tiene en otros países, sus hijos, el negocio de un restaurante en la ciudad donde vive, los momentos en que empezó a vivir allí y su jubilación al cumplir los setenta años. Al parecer, ella habla en indonesio, y lo subtítulos están en inglés.

\footnotetext{
${ }^{39}$ Crecí con el conocimiento de una familia dispersa por todo el mundo. Algunos, como yo, han terminado en Europa. Quería ver si la familia seguía siendo china. [Transcripción y traducción propia]

${ }^{40}$ Esta es mi tía Kip. Admiro su fortaleza. Me recuerda a una matriarca de un clan chino tradicional. [Transcripción y traducción propia]
} 
Kip: My eldest daughter lives in Miami, the second lives in Norway and the third lives in Washington. The fourth lives in Cologne. She owns the restaurant Bali. My son Gie also lives in Cologne. I've lived here since 1979. I started a restaurant here and worked there for ten years until I turned seventy. Then I didn't want to work anymore.

Fiona: How do you look back on your life?

Kip: It doesn't matter. I always had to look after the children. I had to earn money for the children. I am not bitter. It was hard, but that does not matter. My wish is that we as a family stick together. That's the most important. We all used to work together. Gie, Uncle, Noni. ${ }^{41}$

La pregunta de Fiona Tan, su sobrina, insta a la tía anciana a reflexionar sobre su vida mirando atrás. Ella contesta que su vida no importa. Ella tenía cinco hijos, debía cuidar de ellos, además de encontrarse en el exilio y sin la presencia de su marido. Debía buscar y preocuparse por el dinero para que la familia pudiese seguir adelante. Imaginamos que su vida no ha sido más que una cadena de dificultades, pero ella asegura no estar amargada. Y otra vez enuncia: no importa lo duro que fuese. Su único deseo es estar juntos, conseguir que la familia esté unida. En esta entrevista no se habla sobre el posible complejo de ser chino ni se cuestionan las identidades. Parece que es tan obvio lo de ser chino por parte de su tía, por su forma de ser que se aclara en las palabras de la tía Kip. La artista considera a esta tía como una matriarca de un clan chino tradicional, admirándola en su fortaleza. En este caso, la tía simboliza a la madre que ofrece su vida y todo su esfuerzo para la unión de la familia sin importarle lo personal ni llegar a amargarse en los aprietos.

En este punto sigue la entrevista al primo de la artista, Gie, el hijo de Kip que vive en la misma ciudad. Antes de empezar la entrevista, la artista presenta en off la imagen en vídeo-

\footnotetext{
${ }^{41}$ Kip: Mi hija mayor vive en Miami, la segunda vive en Noruega y la tercera vive en Washington. La cuarta hija en Colonia. Ella es propietaria del restaurante Bali. Mi hijo Gie también vive en Colonia. Yo he vivido aquí desde 1979. Empecé con un restaurante aquí, el cual trabajé durante diez años hasta que cumplí los setenta. Entonces yo no quería trabajar más.

Fiona: ¿Cómo miras hacia atrás en tu vida?

Kip: Eso no importa. Siempre tuve que cuidar a los niños. Tenía que ganar dinero para los niños. No estoy amargada. Fue duro, pero eso no importa. Mi deseo es que nosotros estemos unidos como familia. Eso es lo más importante. Estamos acostumbrados a trabajar juntos. Gie, el tío, Noni. [Transcripción y traducción propia]
} 
retrato de su primo en la calle: él está quieto, de pie, encogiéndose de hombros, sonríe pero sus ojos se mueven precipitadamente como si estuviese buscando algo. Nos da la impresión de que no está de mal humor, pero sí bastante incómodo por estar quieto frente a la cámara.

This is my cousin Gie. When I first met him, he used to work in the family restaurant in Cologne, whilst all the while studying architecture in Paris. A crazy existence. But after his daughter was born, he stopped working in the family restaurant. ${ }^{42}$

Esta vez, la entrevista al primo sí que persigue el cuestionamiento de la identidad como chino. Éste, con cierto sentido del humor, niega la pregunta y así también la búsqueda de la artista.

Fiona: Would you do the same now?

Gie: Never. I would never do that now. We grew up in a family in which duties to your parents are one of your main tasks in life. When I was seventeen, I left Indonesia to live in Europe. Of course, I started to wonder who I really was. Even at seventeen I was faced with questions. Firstly: Why was my father in prison? Was that because he was Chinese? So then I wondered: What does it mean to be Chinese? Is that something negative, something Fiona: Are you Chinese?

Gie: In some respects yes, in others no. You see, I still can't define what it means to be Chinese. That is wrong? Or is it not wrong, not negative? ${ }^{43}$

El primo asegura que no podrá contestar ni ahora ni nunca; es decir, le resulta imposible contestar a la pregunta sobre la cuestión de su identidad como chino. Esto lo aclara su

\footnotetext{
${ }^{42}$ Este es mi primo Gie. Cuando lo conocí, él trabajaba en el restaurante familiar en Colonia mientras estudiaba arquitectura en París. Una loca existencia. Pero después de que su hija naciese él dejó de trabajar en el restaurante familiar. [Transcripción y traducción propia]

${ }^{43}$ Fiona: ¿Podrías hacer lo mismo ahora?

Gie: Nunca. Ahora nunca lo haría. Hemos crecido en una familia en la que los deberes hacia los padres son uno de nuestras principales tareas en la vida. Cuando tenía diecisiete años, me fui de Indonesia a vivir a Europa. Por supuesto, empecé a preguntarme quién era yo realmente. Incluso a los diecisiete años me vi enfrentado a estas preguntas. En primer lugar: ¿por qué mi padre estaba en prisión? ¿Era por ser chino? Entonces me pregunté: ¿Qué significa ser chino? ¿Es algo negativo, algo que está mal? ¿ ¿no es malo, no es negativo? Fiona: ¿Eres chino?

Gie: En algunos aspectos sí, en otros no. Ya ves, todavía no puedo definir lo que significa ser chino. [Transcripción y traducción propia]
} 
experiencia desde que abandonó Indonesia. Por aquel entonces, él tenía diecisiete años y llegó a Europa, un sitio muy distinto para él. Las diferencias que afronta le obligan a cuestionar su propia identidad; como consecuencia, surgen una serie de preguntas, casi igual que le ocurrió a la artista. En su caso, la prisión de su padre es una de las principales causas del exilio familiar. Por ello, la primera pregunta que se plantea es: ¿por qué mi padre está en prisión? ¿Es por ser chino? Es entonces cuando se llega a preguntar cuál es el significado de ser chino. En esta reflexión llega a cuestionar si la identidad china es algo negativo o no. Él ha empezado a preguntárselo ya desde hace muchos años y todavía no sabe definir con exactitud qué significa ser chino, ni puede juzgar si es algo negativo o no. De este modo, la respuesta a la pregunta sobre su identidad china sería en parte afirmativa y en parte negativa.

De nuevo, el dilema y la ambigüedad sobre la propia identidad como chino. En el caso del primo, sus padres son indonesios-chinos y se nota la apariencia física asiática con el cabello liso negro, los ojos negros y algunos otros rasgos. Pero, siguiendo con la cuestión sobre la identidad china, él acepta que es chino solo en parte. Con este ejemplo se afirma que el problema de la identidad no se reduce solo a cuestiones físicas y/o biológicas.

Esta entrevista y sus respuestas son comparables a las de los hermanos de la artista. Vimos que la hermana de la artista comentaba que poseer diferencias físicas y una cierta apariencia exótica era algo que le gustaba, lo consideraba como algo positivo. Sin embargo, en el caso del primo, el hecho de tener a su padre en la prisión -posiblemente por ser chino-, así como ser esto causa del exilio y el enfrentamiento a una cultura diferente, tiene como consecuencia inevitable que él reflexione sobre la imagen negativa de ser chino. Con lo que observamos en su caso, los pensamientos positivos o negativos en cuanto a la identidad híbrida china no solo dependen del gusto personal, sino también de las circunstancias -tanto privadas como públicas- que rodean a uno.

Mientras el primo habla de la reclusión de su padre, se repite una imagen fílmica en blanco y negro de la cárcel de Indonesia que ya había sido introducida en una secuencia anterior, en la entrevista al primo Jin. Luego, introduce una escena en la que la artista y el primo Gie miran un cuadro grande en el que se representa a unos trabajadores chinos con sombreros 
coniformes. Mientras, hablan sobre la cuestión de la posible negatividad de ser chino y se siguen insertando unas imágenes de iconos chinos. Una de ellas muestra una tela blanca que ondea por el viento y que refleja la proyección de la silueta de un muñeco con sombrero coniforme junto a la de una lagartija. En voz en off, la artista adelanta el siguiente viaje a Hong Kong, añadiendo una pregunta más:

Could I speak of a migrant identity? That seemed a contradiction in terms. I decided to go to Hong Kong, home of the overseas Chinese. I have a cousin who lives there. $^{44}$

Como ella comenta, y según lo que hemos visto hasta ahora, el término de "identidad migrante" en sí es bastante contradictorio. Entonces, ¿qué pasa en Hong Kong, la cuna y asiento de los emigrantes chinos que traspasan el océano? El viaje de la artista sigue.

\section{VI.4.7. Know Yourself, Know Your Opponent, 100 Battles, 100 Victories ( 知己知彼 百 勝百彼 )}

El dicho original es "si te conoces a ti mismo y conoces a tu enemigo, cien batallas, cien victorias” (知已知彼 百戦百勝). La frase deformada de “si conoces a tu enemigo y te conoces a ti mismo, puedes ganar cien batallas sin una sola pérdida” (知已知彼 百戦不殆) aparece en un pasaje del libro El arte de la guerra (孫子兵法) escrito por Sun Tzu (孫子, a.C.544-a.C.496).

\section{故曰知彼知已百戰不殆 \\ 不知彼而知已一勝一負 \\ 不知彼不知已每戰必殆}

(En la guerra, así pues, quien conoce al adversario y se conoce a sí mismo, liberará cien batallas sin correr ningun peligro, quien no conoce al contrario pero sí a sí

\footnotetext{
${ }^{44}$ ¿Podría hablar de una identidad migrante? Parecería una contradicción en los términos. Decidí ir a Hong Kong, cuna de los chinos de ultramar. Tengo un primo que vive allí. [Transcripción y traducción propia]
} 
mismo, ganará una batalla y en la otra estará perdido, quien no conoce al contrarioni tampoco a sí mismo, es todas las batallas será sin remisión, vencido. $)^{45}$

Este dicho nos enseña la importancia de conocerse a sí mismo, fomenta tanto el autoanálisis como el análisis y la recogida de información de los demás como estrategia de supervivencia.

En la presente sección se realiza una entrevista a un primo que vive en Hong Kong. Es la primera vez que conocen con el motivo del presente proyecto de documental. Primero, aparece una imagen panorámica de la ciudad de Hong Kong en la que se puede observar una mezcla considerable de la cultura occidental y oriental. Es una de las principales ciudades del Asia sudoriental, colonizada desde 1842 tras el tratado de Nankín al finalizar la primera guerra anglo-china, conocida como la Primera Guerra del Opio. En 1997 se reintegró a China, sin embargo mantiene una cualidad de autonomía que sigue el estilo del que predominó con el Reino Unido. La imagen muestra un autobús de dos pisos. En el fondo, los letreros con carácteres chinos simbolizan la mixtura de la cultura anglo-china de la ciudad. La artista comenta en off lo siguiente:

Most people in Hong Kong were born elsewhere. Theoretically, this melting pot of east and west could be my home. Only I don't particularly like it here. ${ }^{46}$

Tras algunas imágenes del paisaje y las correspondientes explicaciones de la ciudad, la artista presenta a su primo Ching en voz en off con su vídeo-retrato:

This is cousin Ching. I don't know him very well. We are meeting for the first time.

Strangely enough, though, I do feel familiar and comfortable with him. ${ }^{47}$

\footnotetext{
${ }^{45}$ Ramires Bellerin, Laureano (ed. trad.) Arte de la Guerra de Sunzi. Versión resutaulada a partir de mano escrito de Yinquesshan Mardid, La espera de libros. 2006. P.127.

${ }^{46}$ La mayoría de la gente en Hong Kong ha nacido en otros lugares. Teóricamente, esta fusión de Oriente y Occidente podría ser mi hogar. Lo único es que no me gusta particularmente este lugar. [Transcripción y traducción propia]

${ }^{47}$ Este es primo Ching. Y no lo conozco muy bien. Nos reunimos por primera vez. Curiosamente, sin embargo, me siento cómoda y familiarizada con él. [Transcripción y traducción propia]
} 
Después, el comentario de la artista explica que fueron a comprar comida rápida mientras las imágenes descubren su paseo nocturno. La artista y su primo llegan a una tienda con un mostrador lleno de lagartijas que sirven en una especie de caldo. La escena pasa al lugar donde la familia del primo cena junto a la artista. En la casa, comen el caldo de lagartija con los ruidos rítmicos de los recipientes y las cucharas. La artista se lleva la cuchara a la boca temerosamente y se escucha una conversación en off: el primo pregunta a la artista si le gusta la comida y ella contesta que está muy buena. Entonces, el primo comenta que allí a la gente le gusta comer bien y que son capaces de comer cualquier cosa con cuatro patas, excepto las mesas. Una famosa expresión sobre la comida china.

Cambia la escena. Ahora, se muestra un paseo en barco del primo y la artista, así como las vistas desde el barco y otras imágenes de gentes y paisajes. Mientras tanto, sigue el comentario del primo sobre los habitantes de Hong Kong:

Ching: Many people in Hong Kong are selfish. They just work for themselves. The degree of tolerance among colleagues and friends is very limited. In China there was much more solidarity amongst colleagues. This is what I've found. ${ }^{48}$

La artista cuestiona al primo sobre cómo se siente un chino una vez ha emigrado y retorna al hogar. Después de todo, solía ser una infracción legal salir de China. El primo ilustra su experiencia al volver a China como estudiante indonesio.

Ching: When I came to China as an Indonesian student, I was received very warmly. We were received as guests. They gave us very special treatment. Those who returned to China were initially treated well. They were considered friends. They were considered brothers. They were even regarded more highly than the local population. They were treated as true relatives. Many people who returned to China in the fifties, full of confidence, to rebuild their country, suffered greatly. There was no food, especially during the famine of the sixties. But they did not leave. That

\footnotetext{
${ }^{48}$ Ching: Mucha gente en Hong Kong es egoísta. Solo trabajan para sí mismos. El grado de tolerancia entre los colegas y amigos es muy limitado. En China había una solidaridad mucho mayor entre colegas. Esto es lo que he comprobado. [Transcripción y traducción propia]
} 
changed during the Cultural Revolution. The overseas Chinese were regarded as potential spies. They were treated so badly during the Cultural Revolution that many of them left. ${ }^{49}$

El primo siente que al llegar a China como estudiante indonesio le trataron bien y se generó cierto grado de confianza y una simpatía de amistad fraternal hacia la población que regresaba al país. En los años cincuenta, muchos de los que habían vuelto a China con esta confianza y con el propósito de trabajar para reconstruir el país no se fueron, a pesar de sufrir la escasez de comida, sobre todo, y a pesar de la hambruna de los años sesenta. Esto quiere decir que estaban dispuestos a sacrificarse por el desarrollo del país y por responder a esa amistad fraternal. No obstante, la Revolución Cultural cambia el panorama.

La Revolución Cultural (文化大革命) es una campaña de masas que duró desde 1966 hasta 1976. Mao Zedong, líder del partido comunista de China, dirige la acusación a los altos cargos del partido y a algunos intelectuales como traidores de la revolución. La acusación se convierte en una radicalización de la revolución China a todos los niveles -culturales, sociales y políticos- que fomenta el fuerte rechazo de la tradición (considerada como la herencia del feudalismo) y la lucha contra el imperialismo-capitalismo. La interpretación más habitual de estos sucesos es que en el fondo supuso una lucha por el poder dentro del partido: si la simplificamos al extremo, Mao y su seguidores aprovecharon el momento para recuperar el poder que se les había retirado por el fracaso del Gran Salto Adelante (大躍進 1958-1960), una propuesta de política económica y social que provocó una grave hambruna. La campaña de la Revolución Cultural fue organizada por el poder formado por la Guardia Roja, cuyos miembros era apenas unos adolescentes que adoraban a Mao y que fomentaban la violencia contra el enemigo. El suceso se convirtió en una grave depuración

\footnotetext{
${ }^{49}$ Ching: Cuando llegué a China como estudiante indonesio me recibieron muy cálidamente. Fuimos recibidos como invitados. Nos dieron un trato muy especial. Los que regresaban a China inicialmente fueron tratados así. Se les consideraba amigos. Ellos se consideraban hermanos. Adquirieron una consideración aún más alta que la población local. Fueron tratados como verdaderos parientes. Muchas personas que regresaron a China en los años cincuenta, llenos de confianza, para reconstruir su país, sufrieron mucho. No había comida, especialmente durante la hambruna de los años sesenta. Pero no se marcharon. Esto cambió durante la Revolución Cultural. Los chinos de ultramar eran considerados como potenciales espías. Ellos fueron tratados tan mal durante la Revolución Cultural que muchos de ellos se marcharon. [Transcripción y traducción propia]
} 
ideológica y una caza de brujas por todo el país. Las cifras de víctimas apuntan desde algunos millones hasta unos cuantos cientos de millones, incluyendo a los desaparecidos.

El primo de la artista comenta que los que regresaban del extranjero eran considerados como espías y muchos se vieron obligados a abandonar del país otra vez. Durante la entrevista, cuando se menciona la Revolución Cultural, se introduce una imagen en blanco y negro del archivo histórico. Una chica de la Guardia Roja con un gesto lleno de vida, sonriente, nos hace pensar en el contraste de su expresión con el horror vivido en todo el país.

A final de la secuencia, con la imagen de un paisaje de Hong Kong, la artista añade un episodio que vivió con una taxista que le dijo que era valiente por admitir ser mitad china. Luego, la artista se propone otra pregunta sobre su llegada a China: ¿sería bienvenida o ridiculizada? Con esta pregunta decide viajar a China.

\section{VI.4.8. A Nation of Siblings ( 同宗同体 )}

Ésta es última secuencia del documental. A modo de continuación de la secuencia anterior, la artista visita China. Tras el telón, en una escena en el aeropuerto, la cámara sigue a la artista que empuja el carro con las maletas a la salida con mucha población, naturalmente china. La artista dice en $o f f$ :

According to Chinese custom, nationality is handed down through the father. That means that this is my fatherland. ${ }^{50}$

Al finalizar esta voz en off, se muestran unas imágenes del paisaje y la gente de China con un audio de la Ópera de Pekín de fondo. También observamos una escena de una función en un teatro al aire libre, parece que es un acto de Viaje al Oeste (西遊記, por Wú Chéng'ēn

\footnotetext{
${ }^{50}$ Según la costumbre china, la nacionalidad se transmite a través del padre. Esto significa que ésta es mi patria. [Transcripción y traducción propia]
} 
吴承恩 $1504-1582)^{51}$. Luego aparece una prima de la artista, la cual ya había salido en la primera sección, ella vive en Pekín.

This is my cousin Lioni, the one who said that I wasn't a foreigner. ${ }^{52}$

La artista le pegunta cuándo ha sido el momento más difícil para ella en su vida. La prima Lenny contesta que fue durante la Revolución Cultural. Igual que el primo Ching, ella habla en plural. Está hablando en nombre de la comunidad china que ha vuelto de Indonesia. De hecho, ella está segura de que estas dificultades son consecuencia de su procedencia indonesia. Según ella misma dice, tenía que cuidarse extremadamente de no hacer nada inapropiado porque durante la Revolución Cultural eran observados con mucho recelo. Procuraron que se entendieran las motivaciones positivas, y se esforzaron por ello, pero nunca lo consiguieron.

Hemos mencionado algunos aspectos de la Revolución Cultural, a la que se le atribuye una gran violencia tanto a nivel físico como mental. Brutalidad, destrucción, saqueo, detención, tortura, asesinato, difamación, humillación, expulsión y trabajos forzados como castigo son solo algunas de sus características. Cuando alguien ya ha sobrevivido a una caza de brujas de este tipo, conociendo la sospecha que causa en los demás, una de las maneras de mantener su seguridad es quedarse quieto y no llamar la atención, aunque no siempre funcione. Por mucho que se trate de una persona ejemplar, o que ésta se mantenga quieta y sumisa, la desconfianza y la sospecha hacen que los demás inventen cualquier pretexto sin ningún criterio ni justicia alguna. La otra posibilidad es huir de allí, y esto es precisamente el principio de la diáspora de la familia de la artista, tal y como hemos visto anteriormente.

Lioni: That was during the Cultural Revolution. However much we tried, they did not understand us. They mistrusted our motives. They were suspicious of us. I think

\footnotetext{
${ }^{51}$ El viaje al Oeste es una de las cuatro obras grandes de la historia de literature china. Sobre su autor, existe opinions diversas. Wú Chéng'ēn (吴承恩) está indicada como el autor de esta obra por Lu Xun (鲁迅) en Historia Concisa de la Ficción China (中国小说史略, 1930). También se encuantran unos tesis de que Wú Chéng'ēn fue último editor de esta obra y otras tesis que niegan totalmente su participación.

${ }^{52}$ Este es mi primo Lioni, quien dijo que yo no era extranjera. [Transcripción y traducción propia.]
} 
we bore a heavy burden then. We had to take great care that we didn't do anything wrong.

Fiona: And is that because you came from Indonesia?

Lioni: Yes.

Fiona: And why, can you please elaborate on that?

Lioni: We had returned from Indonesia. At that time, they could not find out how things were with my father. Why didn't they trust me? I behaved well, but who could tell if perhaps I would a spy? That was the problem. That situation continued until 1975. They Yiu Yuandong, who now holds high office, admitted me to the Party. ${ }^{53}$

Lo que dice ella coincide con lo que decía el primo Ching. Incluso dentro de la familia no se podía evitar esa sospecha y existía desconfianza con los que habían vuelto del extranjero. La situación no se calma hasta 1975, cuando ella pudo ingresar en el Partido. Obviamente, el Partido es el único partido que existe en la República China, el partido comunista.

Se introduce una escena de la cena, la prima y su marido en la cocina sirviendo y los demás esperando. Mientras, el marido pregunta a su mujer: ¿estás segura de que le gusta? ¿cómo lo sabes? Formula las preguntas en su idioma, pero se adjunta el subtítulo en inglés (Are you sure she likes it? How do you know?). La prima contesta sonriendo. Más tarde, en la imagen todo el mundo está comiendo en la sala, incluso la artista. Esta escena nos indica la confianza de la prima en que su prima artista es capaz de recibir la cultura china con cierta naturalidad. Para ella no es necesario preguntar si le gusta la comida china, porque es la comida de su cultura. Luego vuelve la escena de la entrevista a la prima.

\footnotetext{
${ }^{53}$ Lioni: Eso fue durante la Revolución Cultural. Por mucho que lo intentásemos, no nos entendían. Se desconfiaba de nuestros motivos. Ellos sospechaban de nosotros. Creo que en ese momento llevábamos una pesada carga. Teníamos que tener mucho cuidado de que no hacer nada malo.

Fiona: ¿Y eso es porque veníais de Indonesia?

Lioni: Sí.

Fiona: ¿Y por qué, por favor puedes hablar con más detalles sobre eso?

Lioni: Había regresado de Indonesia. En ese momento, no podía saber cómo estaban las cosas con mi padre. ¿Por qué no confían en mí? Me he comportado bien, pero ¿quién sabe si tal vez era una espía? Ese fue el problema. Esa situación se mantuvo hasta 1975. Ellos, Yiu Yuandong, que ahora tiene un alto cargo, me hizo entrar al Partido. [Transcripción y traducción propia]
} 
Lioni: I work in China. I want to give my all to China to help build its future. China is a great country. If China is strong, it will reflect on the rest of the world.

Because you have Chinese blood, you are a descendant of China. ${ }^{54}$

La prima habla sobre sus sentimientos de amor a la patria. Su comentario es un ejemplo representativo de un miembro del Partido. No podríamos juzgar si está mintiendo o está hablando con falsedad; además, por la situación que ha vivido -buscando un delicado equilibrio entre confianza y desconfianza, atrapada en la narratividad de la Historia que indicaba Spivak- entendemos que ella no puede hablar de otro modo. Añade un comentario sobre la pertenencia de la artista a la cultura china, ella no es ninguna extranjera. Señala una imagen, al estilo de vídeo-retrato, con la prima junto a su marido y su hijo frente a su apartamento. Después del comentario, aparece una imagen de la artista en bicicleta junto a una masa de gente, también en bicicleta, en una amplia calle de la ciudad de Pekín. La artista habla en off de la siguiente manera:

I suppose I could live here, learn the language, dye my hair, adopt the ways, become a model citizen. But even that wouldn't make me Chinese. I am, and always would remain, a foreigner. ${ }^{55}$

La imagen de la artista en bicicleta en la calle es comparable a la de Ámsterdam. Y habla de la posibilidad de vivir y adaptarse al estilo en esta ciudad. Pero comenta que seguirá siendo una extranjera de todos modos. Para revalidar esta opinión, introduce una escena en la peluquería: primero, muestra la imagen de un espejo que refleja a la artista que se está tintando el pelo; luego, a la artista con una peluquera. La artista le pregunta:

Fiona: My father's Chinese. Do you think I look Chinese?

\footnotetext{
${ }^{54}$ Lioni: Yo trabajo en China. Quiero ofrecer todo mi ser a China para contribuir en la construcción de su futuro. China es un gran país. Si China es fuerte, se reflejará en el resto del mundo.

Porque tienes sangre china, eres una descendiente de China. [Transcripción y traducción propia]

${ }^{55}$ Supongo que podría vivir aquí, aprender el idioma, teñirme el pelo, adoptar las formas, convertirme en una ciudadana modelo. Pero ni siquiera eso me haría china. Yo soy, y siempre seguiré siendo, una extranjera. [Transcripción y traducción propia]
} 
Hairdresser: Must I tell you again? You are not Chinese, because you have a big nose. ${ }^{56}$

Obviamente, la chica responde en su idioma y con el subtítulo entendemos lo que ha contestado. La respuesta de la chica empieza con la frase de ¿tengo que contestar otra vez? Esto demuestra el trabajo de dirección en el documental. Dicho de otro modo, esta frase nos confirma que existen escenas que han sido grabadas, donde la artisa pide hacer o repetir cosas para registrarlas. Al mismo tiempo, esta frase nos hace comprender que la respuesta salió tal cual de la boca de la peluquera, la primera vez como una opinión natural, y la artista le pidió que la repitiese de nuevo. Se deja entrever el tipo de dirección de la artista en su trabajo, el cual no se basa en un guión previamente elaborado. Ya que se trata de una frase muy corta que además podemos advertir solo a través de su traducción, en este caso la podría haber eliminado si no fuese porque es una huella muy consciente de su estilo de dirección. Con todo, se comprende que es una frase clave que nos indica la arbitrariedad de la artista en la obra; al mismo tiempo, nos presenta un intento por hacer visible una contingencia a la que se enfrenta la artista en su proyecto.

La escena ahora muestra un paisaje de la arquitectura china: la Puerta de Tian'anmen (天安) con el retrato gigante de Mao y el palacio de la Ciudad Prohibida (紫禁城).

\begin{abstract}
Culture is always a palace and a prison. The migrant, I, must deal with questions of being inside or out. My father had recorded the name of our ancestral village, the village where the Tan family originated. I spent hours in hotel rooms scanning maps of the Fujin province for its name. It was with great excitement that I learned from my translator that we had finally located it. ${ }^{57}$
\end{abstract}

\footnotetext{
${ }^{56}$ Fiona: Mi padre es chino ¿Crees que me veo como china?

Peluquera: ¿Debo decírtelo otra vez? No eres china, porque tienes una nariz grande. [Transcripción y traducción propia]

${ }^{57}$ La cultura siempre es un palacio y una prisión. El migrante, yo, debe lidiar con las cuestiones sobre si se encuentra dentro o fuera de ella. Mi padre había registrado el nombre de nuestro pueblo ancestral, el pueblo de donde es el origen de la familia Tan. Pasé horas en habitaciones de hotel explorando mapas de la provincia Fujin buscando su nombre. Con gran entusiasmo, me enteré de que mi traductor finalmente lo había localizado.

[Transcripción y traducción propia]
} 
La cultura siempre es un palacio y una prisión quiere decir que es un sistema que protege, acomoda y aporta seguridad; pero, al mismo tiempo, atrapa despóticamente. Un ser migrante en tránsito entre culturas se cuestiona sus entradas y salidas de este palacio-prisión.

Durante los comentarios sobre el pueblo originario de la familia Tan, en la provincia de Fujin (福建省), la imagen muestra el plano y el paisaje del lugar. La artista realiza una visita al pueblo ${ }^{58}$ : llega frente a un edificio, una casa solariega de cuatrocientos años propiedad de la familia Tan, y realiza una entrevista junto con el traductor. Todos los habitantes del pueblo tienen el apellido Tan. Según lo que explica el traductor, todos los hombres de este pueblo son parientes de sangre y la artista forma parte de esa gran familia Tan. Entran al edificio, le enseñan un libro del registro de los nacimientos de todo el pueblo. Tras algunas conversaciones, se encuentran con algunos ancianos nacidos en Indonesia que han regresado al pueblo. En último lugar, los del pueblo se reúnen con la artista frente a la casa y permanecen quietos para tomar una foto de la reunión, pero en formato de vídeo.

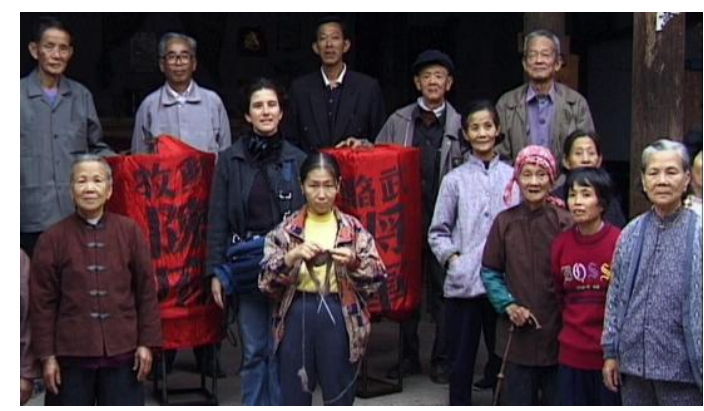

Fiona Tan May You Live In Interesting Times documentary film, 1997cortesía de la artista y Frith Street Gallery, London 69. May You Live In Interesting Times (1997), Fiona Tan

$\mathrm{Y}$, finalmente, la artista realiza un comentario en off a modo de conclusión de este proyecto:

Despite the excitement of finding Zhangzhou, I must now, as the dust settles, admit to myself that that charming little village could never be my home. I could never live there. I started this journey in search of mirrors, and have found many. I wanted to

\footnotetext{
${ }^{58}$ El nombre del pueblo se escucha como Shan-ho, al parecer es Zhangzhou (福建省漳州市東山縣陳城鎮白埕村 赤塗), según el letrero en la piedra que aparece en la imagen del paisaje de ese lugar.
} 
learn about the family, and at some level, deeper than words, deeper maybe even than images, this has been extremely satisfying. There remains for me a painful confrontation. I'll never feel entirely a part of my family. No, I'm not Chinese, although most of my family still is. But rightly or wrongly, I'll never entirely feel western either. I'm still not sure to what extent my image of self is determined. The sense of being foreign runs so deep, I wonder if I deliberately seek it out. My selfdefinition seems an impossibility. An identity defined only by what it is not. I can't say that through this search I have gained more of a cultural identity, at least I know better why. ${ }^{59}$

La conclusión a la que llega Fiona Tan en este proyecto es la imposibilidad de autodefinición. Las multiplicidades que ha encontrado en su viaje hacen que sea imposible reducirse a una sola identidad, tanto a nivel del texto como de la imagen. En su caso, en el cuestionamiento de su identidad la artista no puede evitar una realidad: no es totalmente china, pero, al mismo tiempo, no es occidental. La imposibilidad de definirse conforme a una u otra cultura ya estaba clara durante la conversación con sus hermanos en la tercera secuencia. Luego también se ha confirmado con la entrevista al primo Gie.

El viaje a China y las entrevistas a los primos nacidos en Indonesia con los que se reúne en Hong Kong y Pekín nos ofrecen otro punto de vista sobre los migrantes chinos. La artista reflexiona sobre las posibilidades de integración a estas grandes ciudades de China en las que ella, sin embargo, se siente una extranjera. Además, niega la posibilidad de vivir en el pueblo de origen de la familia a pesar de sentir tanta emoción en su visita.

\footnotetext{
${ }^{59}$ A pesar de la emoción al encontrar Zhangzhou, debo ahora, a medida que el polvo se asienta, admitir que aquel pueblo pequeño y encantador nunca podría ser mi hogar. Nunca podría vivir allí. Comencé este viaje en busca de espejos, y he encontrado muchos. Quería aprender acerca de mi familia, y en algún plano, más profundo que las palabras, más incluso que las imágenes, ha sido muy satisfactorio. Me queda un enfrentamiento doloroso. Nunca me sentiré del todo parte de mi familia. No, yo no soy china, aunque la mayor parte de mi familia todavía lo es. Pero, con razón o sin ella, nunca me sentiré totalmente occidental tampoco. Todavía no estoy segura de hasta qué punto la imagen de sí misma está determinada. La sensación de ser extranjera es tan profunda que me pregunto si yo lo busco deliberadamente. Mi auto-definición parece un imposible. Una identidad definida solo por lo que no es. No puedo decir que a través de esta búsqueda he ganado más de una identidad cultural, por lo menos sé mejor por qué. [Transcripción y traducción propia]
} 
De lo que ella se siente más segura es que no es china. Al mismo tiempo, no es totalmente occidental. Esté donde esté, se sentirá extranjera. Por supuesto, esto no significa que no exista un ser que se sienta completamente chino u occidental. Prueba de ello es que dentro de la diáspora familiar también se encuentran parientes que continúan sintiéndose chinos. Pero, en el caso de la artista, y al igual que su primo Gie, ella sigue sin estar segura de hasta qué punto se puede delimitar la imagen de uno mismo, quizás nunca se puede.

La respuesta sobre su propia identidad se eterniza en la ambigüedad, solo puede definirla por lo que no es. Nosotros, como acompañantes en su viaje de búsqueda de la identidad, hemos sido espectadores de las entrevistas, los paisajes, los eventos y las vidas cotidianas de sus parientes en una mezcla de fragmentos de múltiples culturas y una combinación híbrida de generaciones. Lo que nos ha mostrado la artista se basa en relatos personales e íntimos, lo cual nos ha posibilitado visibilizar unos sentidos y unos márgenes imposibles de obtener en la lectura de la Historia dentro de los discursos nacionales. 
VI.5. A Needle Woman (1999-2001 y 2005), Kimsooja: una representación del performance de una mujer muda en tránsito. 
En el presente apartado nos aproximaremos al trabajo de Kimsooja ${ }^{1}$, A Needle Woman $^{2}$, una vídeo-instalación en versión multicanal para la cual la autora ha realizado varios proyectos sobre el mismo asunto. Anteriormente, hemos revisado varios trabajos de autoras en versión mono canal que abordaban el tema era la autobiografía de la mujer en tránsito. Ahora, vamos a analizar esta obra, cuyas imágenes audiovisuales son performances realizadas por la artista en varios países del mundo. Éste es un trabajo que también nos confirma la amplia variedad que existe en cuanto a la representación audiovisual sobre la autobiografía de la mujer en tránsito.

Kimsooja trabaja con diversos medios como la fotografía, la instalación, el performance y el vídeo. Destaca el hecho de que en sus trabajos se encuentre a menudo una tela tradicional coreana, bastante colorida, que sirve como cubrecama de las recién casadas, como símbolo muy significativo para la mujer en la cultura coreana. Ya que las chicas coreanas aprenden a coser confeccionando esta colcha y en el momento de casarse llevan sus cosas personales cubiertas por ella. La costura es considerada como una labor femenina en su cultura (también lo es en otros muchos contextos culturales) y sería un factor importante a considerar en su obra.

Al mismo tiempo, el tránsito es el tema fundamental de su trabajo artístico. Lo que cubre con la colcha coreana se llama bottari, y se encuentra en sus obras, es el equipaje que transporta. El bottari también proviene de la costumbre coreana de aprovechar esa colcha para transportar los objetos, cubriéndolos. Se encuentran muchas referencias sobre el bottari, el cual simboliza no solo los objetos físicos que se transportan, sino también el

\footnotetext{
${ }^{1}$ El apellido de la artista es Kim y el nombre es Sooja. En la cultura bajo influencia china se acostumbra a dar más importancia al apellido que al nombre, sobre todo en el ámbito público (se pronuncia primero el apellido y posteriormente el nombre). Al parecer, para evitar el cambio del orden a la manera occidental, esta artista junta su apellido y su nombre. La artista nace en Daegu, Corea del sur. Tras estudiar pintura en Seúl realiza una estancia en París como estudiante de litografía. Tuvo la oportunidad de participar en una residencia artística en PS1, Nueva York, a partir de 1992. Ha participado en la Bienal de Estambul en 1997 y posteriormente en la de Venecia varias veces. Es una artista reconocida a nivel internacional. En 2006 presenta la exposición A Mirror Woman en el Palacio de Cristal del Centro de Arte Contemporáneo Reina Sofía.

${ }^{2}$ Hasta ahora, la artista ha realizado cuatro proyectos con el título A Needle Woman: el primero, mono canal, en 1999 en Kitakyushu (Japón) 6:33 loop.; y el último en 2009 en París, mono canal 25:00 loop. La primera versión es igualmente un vídeo de su performance, pero la artista se encuentra acostada sobre una roca con el fondo con el cielo. La cuarta tiene misma tendencia del segundo y tercer proyecto que estudiaremos en el presente apartado. En el proyecto de 2009 fue realizado una proyección del performance filmado por el comisariado de Nuit Blanche. En http://www.kimsooja.com/works_performance_video.html, visualizado el 22 de julio del 2011.
} 
tránsito del olor, el sentimiento, la memoria, la personalidad y la vida de la persona que lo utilizaba.

La artista realizó una performance sentada sobre numerosos bottari amontonados en un camión que recorre Corea del sur $^{3}$ titulada Cities on the move: 2727 kilometers bottari truck, Korea. Posteriormente, presenta la imagen de ese recorrido en un vídeo que tiene mucho parecido con la obra a la que nos vamos a aproximar: dentro de la imagen, la artista es un punto de referencia inmóvil y el contexto, en este caso el paisaje, se mueve. Es decir, aunque en realidad el vehículo donde viaja la artista y la cámara que lo registra se estarían moviendo, dentro del marco de la pantalla lo único que se mueve y cambia su aspecto es la imagen del paisaje. De este modo, la obra plasma la relación entre el tránsito a nivel físico y visual en la imagen y también el tránsito del tiempo. Y percibimos el interés de la artista por la vida en tránsito, por la imagen y el performance en sí.
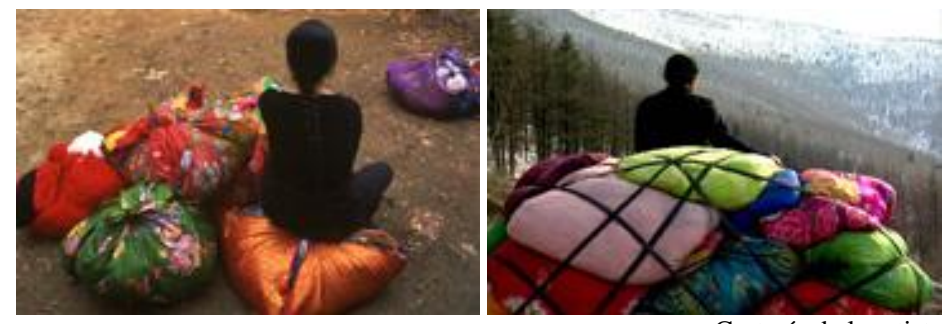

Cortesía de la artista

70. Bottaris (1997 - 2001), Kimsooja [izquierda]

71. Cities on the Move: 2727 Kilometers Bottari Truck, Korea (1997), Kimsooja [derecha]

Al mismo tiempo, la introducción del bottari nos hace pensar en la vida de la mujer coreana en tránsito. Porque aquella tela que cubre el bottari invoca al proceso de convertirse en mujer: al coserla, se aprende el rol de la mujer, y esta preparación concluye al obtener tanto un requisito simbólico como una herramienta física en forma de cubrecama o colcha para el casamiento. Ésta es una habilidad que forma parte del conocimiento femenino. Al llegar al matrimonio, la mujer prepara el bottari cubriendo los objetos para llevárselos a casa del

\footnotetext{
${ }^{3}$ El trabajo en vídeo de este recorrido por el país se llama Cities on the move: 2727 kilometers bottari truck, Korea. Es un vídeo mono canal a color 7:03 loop. En el año 2007 realiza un performance con el mismo tema en París, Bottar truck-migrateurs. En http://www.kimsooja.com/videos_singlechannel.html, visualizado el 2 de septiembre de 2011.
} 
marido. En este sentido, la tela nos indica a la vez la rutina de la vida de la mujer coreana y el tránsito como un fenómeno arraigado en su vida: de la casa paterna a la casa del marido, y posteriormente al mundo.

A partir de este punto, la artista empieza a desarrollar en sus trabajos este tema del tránsito. En concreto, la obra a la que nos vamos a aproximar no contiene ya las colchas o bottari, no existe ninguna indicación a estas costumbres que obligan a la mujer a adaptarse al matrimonio patriarcal. Sin embargo, el tema del tránsito sigue siendo fundamental: de una manera más precisa, ahora en su trabajo audiovisual la artista cuestiona la confrontación de una mujer en tránsito con varias culturas distintas. Lo veremos en seguida.

\section{VI.5.1. La representación audiovisual de performance.}
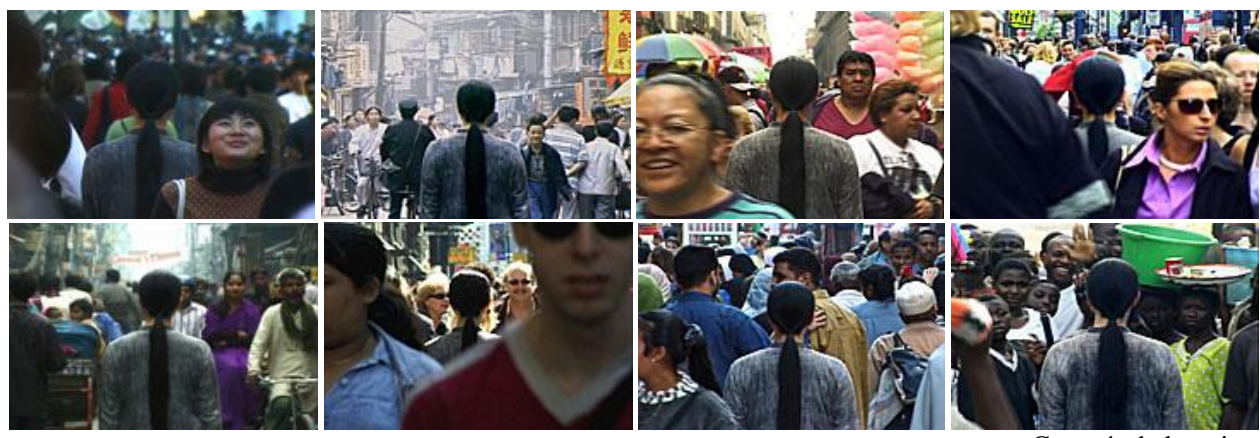

Cortesía de la artista 72. A Needle Woman (1999-2001) Kimsooja

Como hemos visto, existen varias versiones de la obra A Needle Woman en mono canal y multicanal. La primera, presentada en 1999, es un vídeo mono canal de una duración de 6 minutos 33 segundos en bucle filmado de su performance realizada en Kitakyushu (Japón). Diferente a las otras versiones, en la imagen del vídeo la artista se encuentra acostada sobre una roca en medio de la naturaleza. La segunda versión es la de 1999-2001, y es a la que nos vamos a referir. Tiene ocho canales de vídeo proyectados que conforman una instalación silenciosa, con una duración también de 6 minutos 33 segundos, que han sido editados en bucle. Las imágenes han sido filmadas en Tokio (Japón), Shanghái (China), 
México D.F. (México), Londres (Reino Unido), Delhi (India), Nueva York (EE.UU.), El Cairo (Egipto) y Lagos (Nigeria).

La tercera versión de A Needle Woman es de 2005. Es una instalación de seis canales de vídeo proyectados en silencio que dura 10 minutos y 30 segundos editada en bucle. Las imágenes son de Patán (Nepal), Jerusalén (Israel), Sana' (Yemen), La Habana (Cuba), Río de Janeiro (Brasil) y N'Djamena (Chad).

Y la última versión, realizada en 2009 en París, es una videoproyección mono canal que dura 25 minutos editada en bucle. La imagen es muy parecida a la del segundo y tercer proyecto. Este proyecto fue realizado por el comisariado de Nuit Blanche; es decir, su performance fue realizada y filmada en la ciudad de París para la proyección como forma parte de dicho evento en la misma ciudad. Y la proyección fue en el ambiente exterior diferente a otros proyectos. En esta ocasión, vamos a revisar los trabajos en multicanal.

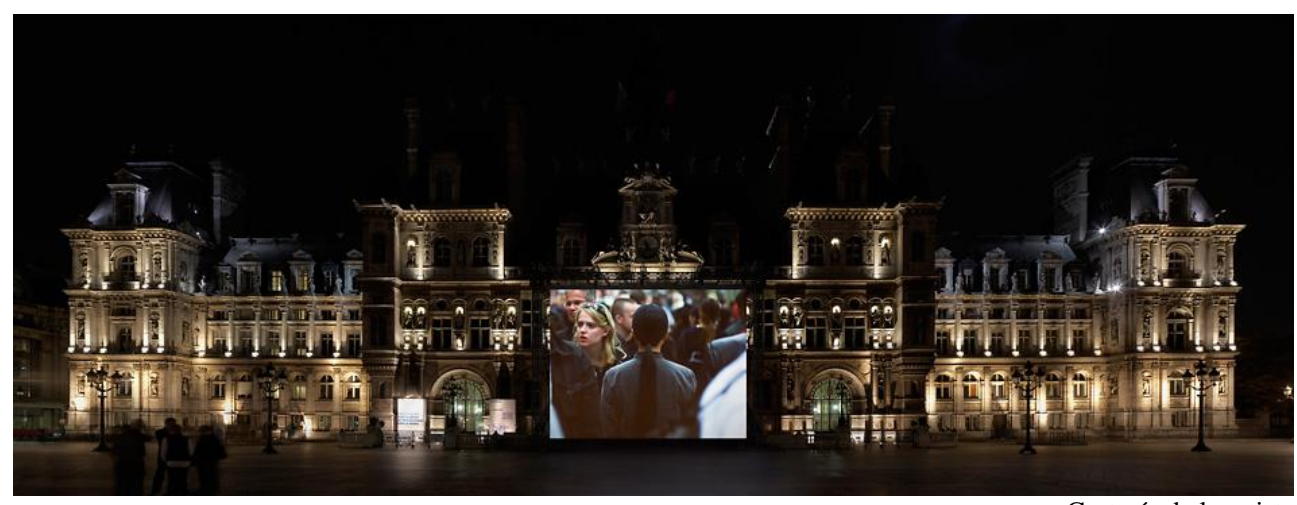

Cortesía de la artista 73. A Needle Woman (instalación en Nuit Blanche, París, 2009), Kimsooja

Para el presente análisis utilizaremos un texto de Kenji Nakamura, subdirector del NTT InterCommunication Centre $(I C C)^{4}$ de Japón y comisario de la exposición individual de Kimsooja en Japón, el cual ha organizado una exposición individual de la artista en dicho centro. En esta exposición se presentó la segunda versión de A Needle Woman. En esta ocasión, pues, seguiremos el análisis y la argumentación de Nakamura como base para

\footnotetext{
${ }^{4}$ En http://www.ntticc.or.jp/About/introduction.html, consultada el 29 agosto de 2011.
} 
nuestro desarrollo y añadiremos nuestra perspectiva crítica en los casos necesarios. Nakamura describe el trabajo del siguiente modo:

Vestida de oscuro, austera, en bata casi monástica, el pelo largo atado con descuido, una mujer se encuentra en el centro de la pantalla, de espaldas a la cámara - es la misma artista, Kim Sooja. Únicamente ella es monocromática y no se mueve. Lo único que hace es estar allí, por ejemplo, en medio de la concurrida zona de Shibuya de Tokio. A veces, desaparece de la vista cuando su figura inmóvil es tragada por el flujo continuo multicolor de tráfico peatonal que transita con pasos precipitados o despreocupadamente por delante y detrás de ella. ${ }^{5}$

Como describe Nakamura, una mujer asiática con ropa sencilla oscura y con el cabello negro liso largo recogido aparece de espaldas en el plano medio de cada imagen. Esta mujer, que es la artista, está realizando una performance en medio de una corriente de gente de varios lugares del mundo, desde Tokio hasta Lagos, en su segundo proyecto entre los años 1999 y 2001. La imagen presenta a la artista con la misma ropa y corte de cabello quedándose de pie, inmóvil, como una aguja clavada en el medio de la pantalla. Como la misma artista expresa, esto genera un gran contraste que hace que se perciba en mayor medida el movimiento y el volumen de la corriente de gente de cada lugar. La artista, como una aguja, está de pie, con la espalda recta y la cabeza levantada. Además, al encontrarse de espaldas no podemos percibir ningún gesto, emoción, ni sentimiento. Ello precisamente nos hace focalizar más nuestra atención en los gestos de la gente que rodea a la artista.

\footnotetext{
${ }^{5}$ En http://www.ntticc.or.jp/Archive/2000/A needle_woman/about_j.html, consultada el 15 septiembre de 2009. Esta cita es una traducción propia del texto original en japonés. Se encuentra la versión en inglés, lo adjunto a continuación que se encuantra en http://www.kimsooja.com/texts/keiji.html, consultada el 15 septiembre de 2009: Dressed in a dark, austere, almost monastic robe, long hair tied loosely, a woman stands in the middle of the screen, back to the camera -it is the artist Kim Sooja herself. She alone is in monochrome, she alone does not move. Though since all she does is stand there, amidst the crowded Shibuya area of Tokyo, for example, she does at times vanish from view when her motionless figure is swallowed by the on-going multicolored flow of foot traffic that crisscrosses heedlessly in front and back of her.
} 


\section{VI.5.2. "Tanta gente y ninguna comunicación": una performance en medio de la multitud.}

La obra A Needle Woman de Kimsooja es comparable con el trabajo de Fiona Tan n.t.(Leidsestr.) $)^{6}$ de 1997, un vídeo en silencio tipo "endless" reproducido en un monitor de TV. El vídeo presentaba una imagen de la artista de pie, de frente, en plano medio, en la calle de Ámsterdam donde ella reside, con el mismo contexto del tránsito de la gente y de algunos medios de locomoción como el tranvía y el coche.

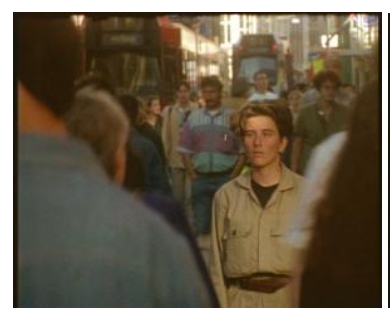

Fiona Tan n.t. (Leidsestraat) endless video, 1997 cortesía de la
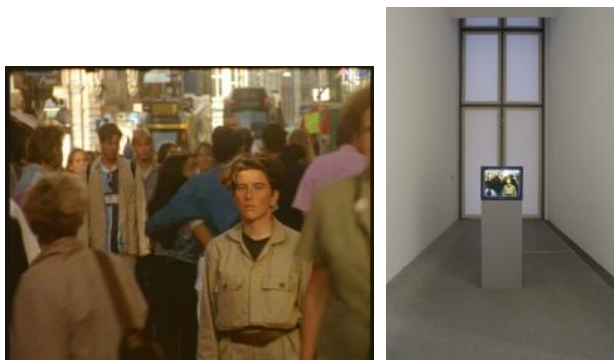
74. n.t.(Leidsestr.) (1997), Fiona Tan

El trabajo de Tan, de forma diferente al de Kimsooja, graba con cámara rápida a la gente y a los vehículos que pasan muy deprisa a su alrededor, pero la artista es la única persona que nos permite observar con detalle todo al quedarse quieta. Esto hace que nos centremos en el gesto de la artista, por presentarse de frente y por no poder captar bien el público o los gestos de los demás. Pero su rostro es inexpresivo, apenas percibimos un pequeño movimiento de sus ojos y la dirección de su mirada.

He aquí un comentario de Marcha Dubro sobre esta obra cuando se expuso en Sackler Gallery $^{7}$ en 2011:

\footnotetext{
${ }^{6}$ Endless es un vídeo a color, en silencio, en digital betacam safety master, DVD, DVD player y monitor 21 ”. Se puede ver un minuto de grabación de la obra en la página oficial (http://www.fionatan.nl/video/50, visualizado el 22 de julio 2011).

7 Sackler Galleries, Washington D.C., exposición del 23 septiembre al 16 de enero 2011. En http://www.fionatan.nl/works/37, consultada el 22 de julio de 2011.
} 
At the event, Carol Huh, assistant curator of contemporary Asian art, told me "All of Fiona Tan's works are about questioning identity. She asks herself 'Who am I', and answers in her work. She unsettles assumptions about recorded images." We stood in front of the opening work, on an old TV monitor, showing Tan standing motionless in the middle of traffic zooming frantically along one of the busiest streets in Amsterdam, where the artist lives.

Huh pointed out about the 1997 work, entitled "n.t. (Leidsestr.)”, "So many people, so little contact, no communications." 8

"Tanta gente, tan poco contacto, no hay ninguna comunicación"... es una idea que ilustra exactamente la reflexión final de la obra. La cámara rápida nos deja observar la cantidad de gente sin poder ver nada en profundidad, excepto a la artista y al movimiento de la gente, así como de los vehículos que le rodean, en contraste con la inmovilidad de la artista. El ligero movimiento y el cambio de dirección de su mirada hacen que imaginemos que busca algún contacto entre la gente que pasa delante de ella. Al mismo tiempo, su rostro sin expresión nos obliga a percibir la incomunicación que existe a pesar de estar rodeada de tanta gente.

Diferente al caso de Fiona Tan, el trabajo de Kimsooja no nos muestra el rostro de la artista. Pero parece que ocurre exactamente lo mismo en relación con la comunicación. Lo percibimos por los gestos de la gente que cruza la calle, frente a la artista. Algunos se quedan extrañados, se giran o se paran a mirarla, tanto a ella como a la cámara. Pero la mayoría de la gente, una vez lanza una mirada inmediata o capta su posición física para evitar tropezar con ella, la ignora totalmente.

\footnotetext{
${ }^{8}$ Dubrow, Marcha: Smithsonian's Sackler Gallery 9/25 opened its first exhibit devoted to a video artist, Fiona Tan (http://www.examiner.com/art-travel-in-washington-dc/smithsonian-s-sackler-gallery-9-25-opens-its-first-exhibitdevoted-to-a-video-artist-fiona-tan, consultada el 22 de julio de 2011).

En el evento, Carol Huh, ayudante del conservador de arte asiático contemporáneo, me dijo: "Todas las obras de Fiona Tan cuestionan la identidad, se pregunta: ¿quién soy yo?, y ella responde en sus obras. Desestabiliza los supuestos sobre las imágenes grabadas.

Nos detenemos frente al trabajo de apertura, en un monitor de TV viejo, muestra a Tan de pie, enfocándola inmóvil en medio del frenético tráfico en una de las calles más transitadas de Ámsterdam, donde la artista vive. Huh señaló sobre el trabajo de 1997, titulada "n.t. (Leidsestr.)”: «Tanta gente, tan poco contacto, no hay ninguna comunicación»". [Traducción propia]
} 
El caso de la imagen de Lagos (Nigeria) es peculiar. La gente se sitúa frente a la artista, con cierta distancia respecto a ella, y algunos hacen gestos para que responda. Pero no percibimos diálogo ni comunicación entre la artista y la gente. Porque ella no responde a nada, lo único que podemos percibir es que ella sigue frente a la gente, quieta, y no muestra ninguna señal de comunicación. En esta escena hay gente que no ignora la presencia de la artista, pero este gesto tampoco equivale directamente a la comunicación.

Además lo que percibimos de la mirada de esas personas es que sienten curiosidad tanto de ella como de la presencia de la cámara que está colocada detrás de la artista. Recordamos lo que hemos confirmado durante el desarrollo de nuestro quinto capítulo: en nuestro mundo contemporáneo, es demasiado romántico creer que lo que ocurre frente a la cámara es igual a lo que pasa sin cámaras. Es decir, la presencia o ausencia de la cámara cambiaría bastante el aspecto de lo filmado, sobre todo del gesto de las personas. Entonces, al igual que en el trabajo de Tan, la relación es la misma, a saber, “tanta gente, y ninguna comunicación”.

Entre ambas obras también difiere el sistema de presentación: Fiona Tan presenta la suya con vídeo mono canal reproducido en un monitor, la de Kimsooja es una proyección en multicanal. Cada imagen señala a gente que rodea a la artista pero con distinto contexto cultural al de ellas. En el caso de la obra de Tan podemos entender que nos presenta una incomunicación con la gente de la ciudad donde vive la artista siendo una residente "extranjera". Pero la artista no subraya las diferencias físicas ni culturales, como la forma de vestir y los rasgos físicos extranjeros. Aunque ella es de ascendencia china, como hemos visto en el apartado anterior, no sería muy visible si no se indicase en su biografía. En cambio, en el trabajo de Sooja, es evidente que ella es "extranjera" por su forma de vestir y su aspecto físico. Aquí sí vemos un énfasis en la diferencia entre la artista "extranjera" y la gente de cada país.

También son muy notables las diferencias entre los distintos lugares de filmación debido a la yuxtaposición de las imágenes. Al tratarse de un mismo encuadre, con la artista como eje de las imágenes, se visualizan más las diferencias físicas de la gente, su tránsito y del paisaje en cada lugar. La función multicanal clarifica notablemente la diferencia y la 
confrontación de los distintos países, tanto a nivel geográfico, como cultural. Y en cada imagen, la artista como "mujer aguja” se presenta como un ser distinto a los demás.

\section{VI.5.3. La proyección multicanal: instalación e interacción.}

La instalación está compuesta por proyecciones de vídeo multicanal de la performance. Tiene otra función muy distinta a la reproducción de vídeo en un monitor. Obviamente, el monitor de televisión hace más visible su materialidad, y el trabajo de Tan lo utiliza para la reproducción de su vídeo. Se cobra un sentido televisivo del vídeo que nos hace vincular más cosas para la interpretación en su totalidad. Solo indicaremos que la introducción del monitor funcionaría en el vídeo como el marco para la pintura, en el sentido que hemos reflejado con el tema de lo sublime de la obra de arte en el capítulo IV.

En cambio, en el momento de una proyección sobre la pared en un espacio expositivo, hay casos en los que se nota menos la función del marco que divide la imagen y lo que uno ve en la imagen. En el cine aún se percibe la separación entre la pantalla y los espectadores por la oscuridad del espacio y la luz de la pantalla. En la sala de exposición también se sigue la tradición de la división del cine si se colocan sillas o algún elemento para que el espectador se siente frente a la imagen. Pero en otros tipos de instalaciones con varias proyecciones cada vez se reduce más la sensación de separación entre la imagen y el espectador. Cada vez es más ambiguo o menos notable el límite que separa a la imagen y el público, siendo obras donde el espectador se encuentra mucho más sumergido.

Así es. Existen instalaciones que dan al espectador la sensación de estar dentro de la imagen. Una técnica sería proyectar la imagen en un espacio donde los espectadores transiten; es decir, les proyecta la imagen a ellos y sus sombras se reflejan en la imagen proyectada. La proyección de Kimsooja no se ciñe a esta técnica. La imagen no refleja ninguna intervención visual física de los espectadores. Sin embargo, no podemos negar la posibilidad del planteamiento de esta obra para que el espectador se sienta dentro, o al menos entre las imágenes proyectadas. Nakamura indica este aspecto de la siguiente manera: 
Las obras de Video de Kim Sooja no son ni simples registros audiovisuales establecidos en la ciudad de diferentes lugares y el campo, ni son cintas como obras completas en sí mismas. Solo se convierten en "acabadas" a través de las interacciones psicosomáticas engendradas entre las imágenes y el espectador. $Y$, por esta razón, la visualización en un monitor no es suficiente, las obras deben ser proyectadas en un espacio o encuadre especialmente creado. ${ }^{9}$

Nos interesa la indicación de Nakamura sobre el aspecto incompleto del trabajo de vídeo de Sooja y el sentido que tiene la proyección para generar un espacio que pueda compartirse con los espectadores. El presente trabajo audiovisual no está completo sino es con un tránsito o circulación de los espectadores en un espacio proyectado de las imágenes multicanales para establecerse como una obra. Nakamura desarrolla su argumento fijándose en este aspecto de la obra de Kimsooja, e indica del siguiente modo la posibilidad de participación de los espectadores en el espacio de las proyecciones de su performance:

Tiene que ser esta interacción psicosomática con el espectador, un diálogo entre la figura del artista visto desde atrás y el flujo de personas a su alrededor en una manera que viendo los vídeos se convierte en la participación en su actuación. Pues aunque en la fase de rodaje original ella aparece sola, cuando se proyecta como parte de una instalación en la que se necesita la nueva vida de otra performance por parte de la participación del espectador, los espectadores crean sus propios significados. ${ }^{10}$

\footnotetext{
${ }^{9}$ En http://www.ntticc.or.jp/Archive/2000/A needle woman/about j.html, consultada el 15 septiembre de 2009. [Traducción propia del texto original en japonés] La versión en ingles en http://www.kimsooja.com/texts/keiji.html, consultada el 15 septiembre de 2009:

Kim Sooja's videoworks are neither mere audiovisual records set in different locations town and countryside; nor are they tape works complete in themselves. They only become "finished" through the psychosomatic interactions engendered between the visuals and the viewer. And for this reason, viewing on a monitor is insufficient; the works must be projected in a specially created space or setting.

${ }^{10} \mathrm{En}$ http://www.ntticc.or.jp/Archive/2000/A needle woman/about j.html, consultada el 15 septiembre de 2009. [Traducción propia del texto original en japonés] La versión en ingles en http://www.kimsooja.com/texts/keiji.html, consultada el 15 septiembre de 2009:

There must be this psychosomatic interplay with the viewer, a dialogue between the figure of the artist seen from behind and the flux of persons around her in such a way that watching the videos becomes participation in her performance. For although at the original shooting stage she was performing alone, when projected as part of an installation it takes on new life as another viewer-participation performance, the viewers creating their own meanings.
} 
La indicación de Nakamura resulta interesante porque nos invita a ser escépticos con sus afirmaciones en varios puntos. ¿La "interacción psicosomática” que prepara un diálogo inmediato de los espectadores con las imágenes de los peatones y la artista proyectados se debe solo al hecho de presentar en un espacio medio oscuro la proyección? Igual que para el uso de la palabra "interacción” en la otra ocasión, aquí tampoco encontramos a qué modo de diálogo se refiere Nakamura, por eso no podemos precisarlo bien, si bien pensamos que para que haya un diálogo en términos generales, es indispensable que haya un lenguaje comprensible para todos.

Sin embargo, lo que podemos encontrar en las imágenes proyectadas no es una sencilla comunicación, sino el impacto de la confrontación. Si participamos en el performance, estando rodeados de las proyecciones e identificándonos con la artista en la corriente de gente desconocida que la rodea en los distintos contextos, despertará en nosotros la conciencia de ser diferentes e inmediatamente surgirá una sensación de terror frente a la dinámica del tránsito de la masa anónima. Bien, quizá estemos exagerando demasiado la sensación del enfrentamiento... pero, al menos, lo que sentirá el espectador al participar en este tipo de performance es una tensión por encontrarse solo entre personas desconocidas y diferentes. Si nos identificamos con el movimiento de la gente pasará lo mismo: encontraremos a una mujer quieta, que no se comunica con los demás, reafirmando sus diferencias. Desde nuestro punto de vista, sería difícil encontrar un mismo lenguaje -mucho menos "el diálogo"- que puedan compartir la gente, la artista, la imagen y el espectador.

Nakamura argumenta que se construye un significado compartiendo la realidad entre pantallas y espectador a través de la "interacción” de los espectadores y las imágenes de la proyección. Describe la obra del siguiente modo:

Casi no ocurre nada en la pantalla. Tampoco las imágenes ofrecen el significado. Sin embargo, las imágenes de quietud casi estática despiertan una mezcla de 
diversas emociones de incertidumbre y autorrealización, el espectador y lo observado comienzan a compartir una realidad singular. ${ }^{11}$

La imagen de la artista quieta de pie con la gente pasando no nos presenta ni una acción espectacular ni un incidente exagerado, tal y como estamos acostumbrados a ver en televisión. La artista no pronuncia nada y se niega a mostrar su gesto, dándonos la espalda. Esta obra es muy distinta del trabajo de Tracey Moffatt que vimos en el apartado VI.3, el cual mostraba un carácter narrativo aprovechando el lenguaje audiovisual con el montaje y efecto del audio que nos guiaba hacia la comprensión de la trama y los sentimientos de los personajes, a pesar de no tener el sonido de la conversación de los actores. El trabajo de Sooja es una muestra de un plano largo en silencio total. Es cierto que la imagen y su expresión son bastante contenidas y nos pueden ofrecer la impresión de que no ocurre nada. Incluso se podría pensar que son aburridas, en el sentido contrario a la expresión “espectacular” del Hollywood comercial.

Sin embargo, no podemos estar de acuerdo con Nakamura cuando dice que las imágenes no implican significado; de hecho, a través de ellas florecen unas sensaciones como efecto de la confrontación frente a la masa, como ya hemos indicado. La artista comenta en varias ocasiones sobre su experiencia, la más fuerte de su vida, para este proyecto de performance en el caso de Shibuya en Tokio en 1999:

Me sentí completamente sobrecogida y cargada por la fuerte energía que se desprendía de la multitud. No pude más que detenerme en plena calle, en medio de todo ese tráfico denso de peatones. Al sentirme sobrecogida por la energía de la multitud, me centré en mi cuerpo, me quede inmóvil. Sentí entonces una fuerte conexión con mi propio centro. Al mismo tiempo era cociente de la separación

\footnotetext{
${ }^{11}$ En http://www.ntticc.or.jp/Archive/2000/A_needle_woman/about_j.html, consultada el 15 septiembre de 2009. [Traducción propia del texto original en japonés] La versión en ingles en http://www.kimsooja.com/texts/keiji.html, consultada el 15 septiembre de 2009: Almost nothing happens on screen. Nor do the visuals offer up meaning. Yet as the quietive, near-static visuals awaken a mixture of diverse uncertain and fulfilling emotions, the viewer and the viewed begin to share a singular reality.
} 
tajante entre multitud y mi cuerpo. Fue un momento "Zen" en el que un rayo impactó en mi cabeza. ${ }^{12}$

En este sentido, que la artista esté de pie inmóvil no solo significa que está quieta, sino que además está apoyándose sobre sí misma, con una fuerte conexión con su centro, contra la energía de la multitud. Es consciente de la separación existente entre la multitud y su propio cuerpo. Es una escena de tensión sobrecogedora. También el silencio, en su caso, no solo representa una tranquilidad relajada sino una presión consecuencia del estado de mudez. La artista explica este estado de momento "Zen” en el que un rayo impactó en su cabeza, ¿será esto una experiencia que traspasa el límite emocional-corporal, donde ella se conciencia a sí misma de que su cuerpo queda separado de los demás? Podemos percibirlo en la imagen y, aunque aparentemente "no ocurre nada", es bastante impactante la presión de la masa sobre la artista sola, sujetándose a sí misma con cierta fuerza. Debido a la yuxtaposición de las imágenes de su performance -donde ella se enfrenta a la multitud de desconocidos y a la soledad absoluta de ser distinta- se nos confirman estos aspectos insistentemente. Por estas razones, permanecemos escépticos hacia el comentario de Nakamura que dice que la imagen no aporta ningún significado. Nos parece que la imagen y la forma de presentación de esta obra existen con un carácter ambivalente, las imágenes proyectan la tensión que ha sentido la artista en su realización de la performance, pero aún existe un aspecto más allá. Seguimos el comentario de la artista sobre su experiencia en la misma performance de Tokio:

Durante la acción hubo momentos en que me hice consciente de mi propia presencia; conforme pasaba el tiempo fui capaz de liberarme de la tensión entre multitud y mi cuerpo. Más adelante experimenté un instante de paz, satisfacción y revelación creciendo como una luz blanca, brillando sobre las oleadas de gente que caminaba dirección a mí. ${ }^{13}$

\footnotetext{
${ }^{12}$ Rudio, Oliva Maria, Entrevista con Kimsooja en VV.AA: Artecontexto, no.11. Madrid, Artehoy Vegap, 2006. p. 64.

${ }^{13}$ Loc.cit.
} 
Según la artista, consigue un instante de paz y satisfacción dentro de la dinámica existente entre la multitud y su propio cuerpo, liberándose de su tensión. Como si fuera disuelto aquel rayo caído en su cabeza del cual despertó su consciencia. El silencio y la imagen de que "casi no ocurre nada", si la observamos bien podría ofrecernos estos aspectos de flujo y reflujo, entre tensión y su liberación como un instante de paz.

Como hemos afirmado en apartados anteriores, entre el silencio y la expresión contenida se puede provocar un intervalo que posibilita un espacio crítico e implica un momento de reflexión para los espectadores. Es decir, este intervalo crearía para el espectador la oportunidad de reflexionar para sus adentros, dejando así de ser un espectador totalmente pasivo. En este sentido, es posible que los espectadores curiosos por percibir este intervalo, reflexionen e imaginen "la realidad singular" a la que se enfrenta la artista. Pero, insistimos, esto no es consecuencia ni del diálogo ni de la comunicación fácil de una tranquilidad armónica planteados por Nakamura. Siguiendo su argumento como una condición de “interacción psicológica" y de participación de los espectadores en su performance, nos parece comprender que...

Al no ver su parte inferior del cuerpo, los espectadores pueden situarse directamente detrás de ella para observar las escenas. Aquí las imágenes trascienden la mera visualidad para lograr una realidad en todo el cuerpo. Así, su imagen no debe ser proyectada demasiado grande, idealmente se debería parecer más o menos al tamaño equivalente al real del observador. ${ }^{14}$

Es probable que el encuadre, la altura y la distancia de la cámara para registrar el performance estuviesen calculados para reproducir la visión de alguien que esté detrás de ella. Pero lo que indica Nakamura sobre el tamaño y el encuadre de la imagen sería muy variable, dependería tanto del tamaño físico de los espectadores como del espacio de las

\footnotetext{
${ }^{14}$ En http://www.ntticc.or.jp/Archive/2000/A_needle_woman/about_j.html, consultada el 15 septiembre de 2009. [Traducción propia del texto original en japonés] La versión en ingles en http://www.kimsooja.com/texts/keiji.html, consultada el 15 septiembre de 2009:

By not seeing her lower body, viewers can place themselves directly behind her to observe the scenes in physical identification with her. Herein the images transcend the mere visual to attain a whole-body reality. Thus her image should not be projected too large; ideally she should appear roughly the life-size equivalent of the viewer.
} 
instalaciones y la manera de colocar las imágenes y los proyectores. Para contrastar, tenemos un ejemplo excesivo lo cual es el proyecto del 2009 en París que ha plantado la artista. Quizá con este ejemplo, dejaría caber muchas dudas en lo que argumenta arriba.

Hemos expuesto nuestras dudas y las partes que nos parecen incongruentes sobre el argumento de Nakamura. No obstante, al mismo tiempo no rechazamos que exista una posible interpretación de la participación en la obra por parte del espectador. Quizá, para ser más precisos, no deberíamos decir una participación de los espectadores en la performance, sino una posible experiencia de revivir la performance en la vídeoinstalación multicanal. Obviamente, esa sensación de revivir la experiencia, basada en la facultad de la imaginación, es uno de los fundamentos para la trascendencia artística. Digamos que no solo esta obra requiere esa imaginación, sino que todas las obras de arte la requieren.

En un término más amplio, incluso podríamos decir que tal vez el simple acto de observar conlleve a la participación. De ahí que escandalice tanto mostrar imágenes de violencia y de sexo en público, porque la participación en la violencia y el sexo en público se convertirían en una cuestión ética, aunque fuera de una manera pasiva. En este sentido, no negamos la posible participación de los espectadores en la performance al mirar las imágenes. Podemos imaginar que la intención de la artista también sería plantear una posible participación en la performance, o más bien, compartir una experiencia "revivida" del performance con los espectadores en el modo de la proyección multicanal.

\section{VI.5.4. Un desacuerdo con la unificación armónica del mundo.}

Para concluir su argumento sobre el trabajo de Kimsooja, Nakamura propone una crítica a los discursos basado en las teorías postmoderna y poscolonial, citando la obra de Trinh. T. Min-ha:

Lo que tal vez explica porque los trabajos de Kim Sooja han demostrado inintencionadamente estar de actualidad en los círculos "post-modernos" y "postcoloniales". A pesar de que sus objetivos son más universales, ha sido tachada de 
realizar textos bien intencionados pero triviales. De alguna manera, mientras que el género es totalmente diferente, su relación con la tela recuerda a la película “Surname Viet Given Name Nam”, de Trinh T. Minh-ha. Ambas obras han provocado demasiado debate, casi más que disfrute como obras en sí mismas. ${ }^{15}$

Por supuesto, aceptamos que existe una tendencia a utilizar las obras como ejemplo de los discursos, solo enfocando ciertas partes y olvidándose de observar el trabajo como una expresión autónoma. También sabemos que ciertas interpretaciones previas, a veces, construyen una imagen tergiversada de la obra.

Estamos de acuerdo en que es muy importante observar las obras y escuchar lo que se dice en ellas en realidad, sin ningún tipo de prejuicio. Y ahora tenemos que declarar nuestro total desacuerdo con la opinión de Nakamura sobre el tema de Surname Viet Given Name Nam, de Trinh T. Minh-ha, puesto que ésta no es una obra que solamente presenta una universalidad homogénea. Estamos seguros de que sin ninguna preparación, el público puede ver la obra y disfrutar de ella. Pero también, seguramente, la teoría postcolonial ayudaría a profundizar más en la apreciación de su trabajo expresivo y a encontrar más aspectos interesantes, graciosos, emocionales, incluso estéticos, que se ignorarían bajo una perspectiva "universal". Entendemos que, según los estudios que hemos seguido de Gayatri Spivak, la teoría poscolonial no funcionaría etiquetando las cosas, sino que funcionaría más desplazando la función de etiquetar como único criterio del prejuicio eurocentrista que fomenta "la universalidad". En este sentido, no entendemos muy bien lo que se refiere Nakamura sobre la teoría postcolonial que funcione como dispositivo de etiquetación. Supuestamente ha de haber una confusión allí, a lo mejor hubo mala comprensión sobre los términos y la teoría postcolonial en su totalidad.

\footnotetext{
${ }^{15}$ En http://www.ntticc.or.jp/Archive/2000/A needle woman/about j.html, consultada el 15 septiembre de 2009. [Traducción propia del texto original en japonés] La versión en ingles en http://www.kimsooja.com/texts/keiji.html, consultada el 15 septiembre de 2009:

Which perhaps explains why Kim Sooja's works have been proven so unintentionally topical in "post-modern" and "post-colonial" circles. Even though her aims are more universal, she has been burdened with well-meaning but trivial readings. In some ways, while totally different in genre, her relationship with fabric recalls TRINH T. Minh-ha's film "Surname Viet Given Name Nam”. Both their works have provoked altogether too much discourse, almost more than their enjoyment as works in themselves.
} 
La tela es texto, y la artista misma ha hecho no pocas declaraciones sobre su uso. Así, muchas de las etiquetas de esas telas no están necesariamente equivocadas. Pero el hecho es que, siendo conocedora ella de estas capas de significado, continúa utilizando tejidos, tal vez para indicar que al tiempo que reconoce sus inicios con las propias telas, su idea es buscar la trascendencia a un nivel más universal. Por lo tanto, su trabajo de vídeo, totalmente ausente de tejidos, bien puede constituir una búsqueda de medios capaces de deshacerse de todas las etiquetas. Podemos ver su actuación de estar simplemente de pie, como un absurdo, un sinsentido minimalista sin adornos, un minimalismo existencial. Kim Sooja aparece en el vídeo totalmente libre de todo. ${ }^{16}$

Ciertamente, la artista misma comentaba su estado emocional en la performance, en la que podía lograr liberarse de la tensión. Quizás supone una repetición, pero insistimos en que su liberación en la performance y lo que refleja en su vídeo no son una libertad absoluta del todo, sino una especie de fuga dentro de la tensión y la confrontación. Estamos seguras de que eso se percibe muy bien solo al ver A Needle Woman de 1999-2001. Pero para confirmar lo que pretende la artista, comentaremos brevemente el proyecto siguiente de $A$ Needle Woman, la versión de 2005.

\footnotetext{
${ }^{16}$ En http://www.ntticc.or.jp/Archive/2000/A needle woman/about j.html, consultada el 15 septiembre de 2009. [Traducción propia del texto original en japonés] La versión en ingles en http://www.kimsooja.com/texts/keiji.html, consultada el 15 septiembre de 2009:

Fabric is text, and the artist herself has made not a few statements about her use of fabric. Thus the many labels are not necessarily wrong. But the fact that, fully aware of these deeply compounded layers of meaning, she continues to use fabrics perhaps indicates that while recognizing her own beginnings in cloth, her thinking is to seek transcendence to a more universal level. Thus, her videowork, wholly removed from fabric, may well constitute a pursuit of means able to cast off all labels. We may see her performance of simply standing as a nononsense, unadorned minimalist action, an existential minimalism. Kim Sooja in video appears totally free from everything.
} 

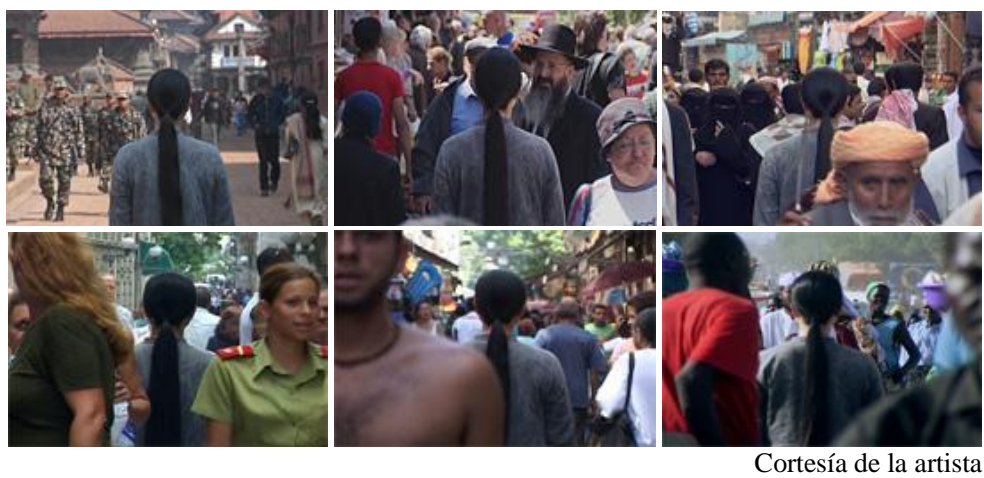

75. A Needle Woman (2005), Kimsooja

Según la entrevista citada anteriormente, la artista comenta que ha elegido las ciudades más problemáticas del mundo para la realización de esta versión de 2005. Los problemas a los que hace referencia son: la pobreza y la injusticia, el colonialismo, los conflictos religiosos o políticos entre países o internos, incluyendo la guerra civil, y la violencia. En su viaje vivió una fuerte experiencia al enfrentarse a las miserias del mundo, y encontró un bloqueo en el tránsito entre países.

Fui testigo de conflictos entre Yemen e Israel y solo pude viajar desde Sana', en Yemen, hasta Jerusalén atravesando Jordania, dado que no hay vuelos directos entre estos dos países y los yemeníes no me hubieran dejado entrar a su país viniendo desde Israel.

Mientras te encuentras en esta clase de situaciones no hay lugar para el medio. La gente cree que vivimos en una era de globalización y que podemos viajar libremente y que todos estamos conectados sin importar el lugar del mundo en que te encuentres. Pero de hecho, no es cierto, y el mundo sigue estando lleno de discriminación, odio y conflictos. ${ }^{17}$

La última parte de su comentario nos hace reflexionar sobre la imagen que tenemos de la globalización. Es cierto que se está aumentando el tránsito internacional, pero al mismo tiempo, como comenta la artista, existen muchos lugares bloqueados. El caso del viaje a

\footnotetext{
${ }^{17}$ Rudio, Oliva Maria, Op.cit., p. 65.
} 
Cuba desde EE.UU. también es imposible, por ejemplo. Dentro de la misma entrevista, comenta las dificultades que ha encontrado, no solo en el transporte físico, sino también por no poder llamar por teléfono a otra ciudad y mucho menos a un país extranjero, sin acceso a internet. Ésta es una realidad que olvidamos que existe en otros lugares, la cual imposibilita esa comunicación de la que suponemos ser de una disponibilidad absoluta. Mediante este comentario nos aseguramos de que su trabajo no señala a una comunicación fácil, ni el diálogo entre otros, por lo menos a nivel de la consciencia de la artista.

La obra resulta de una vídeo-instalación de seis canales, faltando dos proyecciones en las que no pudo realizar la acción y grabación (Darfur en Sudán, y Kabul en Afganistán).

Cuando terminé estas piezas, las ciudades, vistas a cámara lenta, acabaron resultando similares unas a otras independientemente de los problemas particulares de cada una. ${ }^{18}$

Se encuentra una imagen en la que soldados armados vienen hacia la artista, con esto se manifiesta el estado de conflicto. Pero el aspecto superficial de las imágenes es más o menos similar a las otras ciudades, según ella dice. Igual que la versión de 1999-2001, se percibe la tensión entre la gente pasando y su propio cuerpo, pero el silencio y la cámara lenta de las dinámicas urbanas de la gente nos muestra aquella ambivalencia entre la tensión y su liberación.

Para finalizar nuestra aproximación al trabajo de A Needle Woman, adjuntamos un comentario de la artista respecto a su obra con el tema de la búsqueda de la identidad de ella misma:

Me pongo de pie como una aguja para mostrar el vídeo “A Needle Woman” como un espejo del mundo, para pensar mi propia identidad entre otros. ${ }^{19}$

\footnotetext{
${ }^{18}$ Loc.cit.

${ }^{19}$ Ibíd. p. 66.
} 
Su trabajo muestra claramente el pensamiento que plantea: pensar la identidad de sí misma en relación con los demás; y al mismo tiempo, ser un espejo del mundo para poder reflexionar sobre lo que le rodea. Concluimos que su trabajo es a la vez una autorepresentación y una expresión para mirar hacia un mundo en desunión con imposibilidades de comunicación desde un punto de vista viajero, como la artista.

Y diríamos que el silencio que mantiene ella en la performance simboliza precisamente el estado de mudez frente a la confrontación de diferencias. Ella no intenta pronunciarse sobre su identidad, pero su vestido y su aspecto físico indican características de su origen. Luego, conforme a las relaciones con los distintos contextos, nos señala cómo se presenta ella y cómo se ve. O más bien, las miradas de los demás hacia ella en cada sitio nos señalan su identidad.

A través de esta obra los espectadores nos enfrentamos a ver las miradas de cada país hacia una presencia muda extranjera, una mirada que nos hace revivir una parte de ser viajeros confrontando distintas culturas. Es muy esquemático, pero nos parece que su trabajo forma parte de una expresión audiovisual de la autobiografía de la mujer en tránsito que indica cierta ruptura, y su estado mudo al mismo tiempo, intenta mostrar su identidad a través de las miradas de los demás como punto de partida para una posible comunicación que todavía no existe. 
VI.6. Les Veuves de Noirmoutier (2004-2005), Agnès Varda: la otra dimensión de la mujer en tránsito. 
En la sección anterior, nos hemos aproximado al trabajo de videoinstalación multicanal de Kimsooja. En esta ocasión, queremos añadir un ejemplo más de una instalación audiovisual con múltiples pantallas, de un estilo distinto con el tema de la mujer en tránsito. En concreto, vamos a aproximarnos a Veuves de Noirmoutier (2004-2005) de Agnès Varda. Esta obra se ha presentado en la Galeria Aboucaya y posteriormente en la Fundation Cartier pour l'Art Contemporain, como una pieza de su exposición individual L'ILE ET ELLE en 2006.

Agnès Varda es una realizadora de cine francés, reconocida a nivel internacional y considerada como una precursora de la nouvelle vague, sobre todo, de la "Rive Gauch", que eran teóricamente los más vanguardistas y que tenían tendencia al pensamiento de izquierdas, como los realizadores Alain Resnais, Chris Marker, Jean Rouchi (que tienen también experiencia en realizar documentales) y los escritores Marguerite Duras y Alain Robbe-Grillet, distinguiéndose de los seguidores de la revista "Cahier du Cinéma" que dirigía André Vazan. Varda nació en Bruselas (Bélgica) en 1928. Su padre era griego con ascendencia de familia de Asia Menor y su madre era francesa, trasladándose la familia más tarde a Francia. Estudió historia del arte en el colegio Louvre y tras trabajar como fotógrafa, inició su carrera de cineasta con la Pointe Courte en 1955.

Varda vive y trabaja principalmente en Francia, donde es considerada como extranjera por ser belga. Pero la diferencia cultural que ella ha experimentado entre Bélgica y Francia, tal vez no es tan drástica, en comparación con los casos que hemos visto. Estamos seguros de que hay cierta influencia de transición en su vida cotidiana, reflejada a sus obras, a lo mejor en la dinámica de la política cultural entre Bélgica y Francia, sobre todo dentro de la dinámica francófona, se podría encontrar un resumen de la jerarquización cultural imperialista que hemos visto en la relación superior e inferior. Sin embargo, en nuestras aproximaciones en la presente apartado nos interesa más centrarnos en otra perspectiva de la mujer en tránsito. 
El tránsito que hemos citado hasta ahora, estaba mas centralizado en el transito geográficocultural. Las obras que hemos tratado tenían la notable característica de ser una mujer exiliada, extranjera, frente a una cultura dominante occidental, además de la cuestión feminista. Las artistas también tenían un contexto cultural diferente al occidental y hemos aclarado un aspecto autobiográfico en las obras como consecuencia de su vida en tránsito. Sin embargo y al mismo tiempo, hemos comentado en cada ocasión que las cuestiones planteadas, por estas artistas a través de sus trabajos, no son especialmente el problema de los emigrantes y exiliados. Por lo que hemos averiguado hasta ahora, cuestiona una consciencia común, crítica, de los problemas de la identidad de la mujer, respetando las diferencias de sus contextos culturales.

La cuestión de identidad, preguntarse a sí mismo ¿quién soy yo? y ¿a que cultura pertenezco? no es precisamente por ser extranjero o exiliado. Casi todas las obras que hemos visto, nos concienciaban que existe una realidad que hace sufrir por la etiqueta estereotipada de "palestina", "vietnamita", “aborigen", "china" o "un ser otro". Pero al mismo tiempo, nos mostraban la imposibilidad y el límite de la identidad de un individuo contemporáneo desde el punto de vista de la mujer, que es una postura que nos enfrenta a la contradicción dentro del discurso moderno-imperialista basado en el pensamiento androcentrista. En este sentido, hablar de una obra que cuestiona la identidad de la "viuda" nos ofrece el poder reflexionar en otra dimensión de la mujer en tránsito, no geológico, sino más bien de tipo cultural o institucional.

La obra Veuves de Noirmoutire es una instalación audiovisual, sencilla, es un conjunto de entrevistas a mujeres viudas y una performance. No cuestiona la nacionalidad, ni la contradicción entre las diferencias culturales de las protagonistas, como los trabajos que hemos visto hasta ahora, pero, cuestiona la identidad de la mujer como viuda.

Hemos visto con casos excesivos de autoinmolación de las viudas por el análisis de Spivak en capítulo III. Las mujeres viadas entre capas de las presiones patriarcal convencional de cultura autóctona y de colonizador occidental se quedaba en el estado mudez. La obra de 
Varda nos muestra un proceso de hacer hablar las viudas conservando sus particularidad al mismo tiempo indicando el silencio y lo indecible de "viudas". Aunque no se trata del tema poscolonialismo, nos parece interesante reflexionar esta obra para concienciarnos la manera de hacer escuchar la voz y el silencio de la mujer en presente obra.

La teoría y critica feminista, que hemos visto anteriormente, desvela que la mujer ha sido presionada como objeto y ha sido obligada a quedarse invisible dentro del sistema moderno europeo del androcentrismo histórico, social, del pensamiento y la economía, entre otros. Con esta situación, abordar el problema sobre cada una de las mujeres y recuperar su historia, visibilizando su ser dentro del sistema actual, es uno de los temas importantes de nuestra época contemporánea. Dentro del contexto del arte, funcionando sincrónicamente con el fuerte movimiento feminista, numerosas artistas han debatido sobre la expresión de la mujer en diversos contextos, principalmente a partir de los años setenta.

Para las artes visuales, que suponen la cumbre del arte moderno en la pintura y la escultura, el cuerpo de la mujer ha sido un motivo y un tema importante durante su larga historia. Allí la mujer ha sido representada bajo diversas formas como objeto, reflejando el gusto, idealidad o inferioridad para el deseo del hombre, para que éste pueda sentir superioridad y dominio como Sujeto establecido por la complicidad entre el artista varón y los espectadores igualmente varones. Es decir, la imagen de la mujer en el arte y otras expresiones visuales hasta la época moderna, ha seguido siendo lo que conviene a la comunidad masculina y ha permanecido como un reflejo de su idea y deseo.

El arte feminista de principio de los años sesenta y setenta, empezó a rechazar esa idealización de la mujer por parte del Sujeto masculino y lanzó la realidad de la mujer para romper la imagen reflejo del deseo de los varones. En muchos casos los trabajos son histéricos, agresivos y escandalosos, ya que sacuden y amenazan el código social preestablecido. Estas expresiones de la mujer, han introducido activamente nuevas técnicas y soportes en sus obras. 
Una de las razones de esta introducción positiva, es que consideraban que los nuevos medios podían liberarles de las metodologías del arte tradicional. Lo que pensaron fue liberarse de la mentalidad y de la perspectiva del arte del dominado por el Sujeto masculino. Nos explicamos mejor: para la realización de una obra, se necesita cierto aprendizaje y el ejercicio básico de las técnicas en el caso de las artes visuales; al igual que se necesita aprender y practicar un idioma para la comunicación y la comprensión de una lengua. Este aprendizaje, a fin de cuentas, obliga a mentalizar a la sociedad sobre la manera de mirar y comprender el canon de las formas desde la época renacentista. La capacidad de componer formas y colores bajo esta comprensión, es la tradición de la técnica básica de representación artística visual. Este sistema, obviamente no es libre de la tendencia androcentrista criticada por las feministas.

El arte moderno que ha introducido diversas expresiones del "otro", como la forma y color de la estampa japonesa y las máscaras africanas, sin embargo, se ha situado por encima de las mismas, calificando su diferencia al compararlas según el método tradicional del Arte Occidental. Este proceso, inevitablemente, mentaliza e interioriza la mirada del Sujeto europeo masculino desde la época renacentista, así que los nuevos medios pueden evitar esta interiorización del Sujeto masculino, omitiendo este ejercicio y aprendizaje de la técnica básica para la expresión visual. Sin embargo insistimos en que no es tan fácil este proceso.

Tenemos que recordar que el lugar de la creación fotográfica y cinematográfica estaba totalmente bajo dominio de la superioridad masculina. La metodología de montaje y representación de la imagen se basa en la estructura del modo visual europeo. Y no debemos olvidar que los dispositivos en sí, desde la cámara hasta la tecnología del ordenador y la red no están libres de esta estructura. La circunstancia es casi la misma que considera Shoshana Felman ${ }^{1}$ para el análisis del lenguaje y la literatura en la posible autobiografía de la mujer en el caso de las artes visuales y que vimos en el capitulo I.

\footnotetext{
${ }^{1}$ Véase a capítulo I.
} 
Hay que ser cuidadosos al pensar que ya se superó la represión de la mujer, sin embargo no hay razón de ser pesimista porque actualmente hay muchos intentos y trabajos importantes e interesantes, direccionados hacia la recuperación de la expresión de la mujer. A partir de los años sesenta, aumentó el número de artistas feministas con cierta consciencia de su propia autobiografía, dentro de ellas se encuentran muchas obras apoyadas en los nuevos medios como hemos visto a lo largo de presente capítulo.

La obra documental Los Espigadores y La Espigadora (2000) ${ }^{2}$ es la primera obra audiovisual realizada con cámara digital por Agnès Varda. La obra se estructura en la palabra clave de "espigar" y recoge imágenes y entrevistas. Varda compara a "la espigadora" contemporánea con la cámara Mini-DV en la mano, haciendo una referencia al cuadro famoso Des glaneuses (1857) de Jean-François Millet. La artista misma es la protagonista principal dentro de su obra, muestra su perspectiva peculiar recogiendo imágenes principalmente de espigadores contemporáneos. Al mismo tiempo introduce unas imágenes recogidas por la cámara en su vida cotidiana y el viaje en busca de los espigadores. Esta obra también podríamos considerarla como un documental autobiográfico, por lo menos es Self Documentary ${ }^{3}$ al construir un sujeto de autor dentro de su expresión audiovisual.
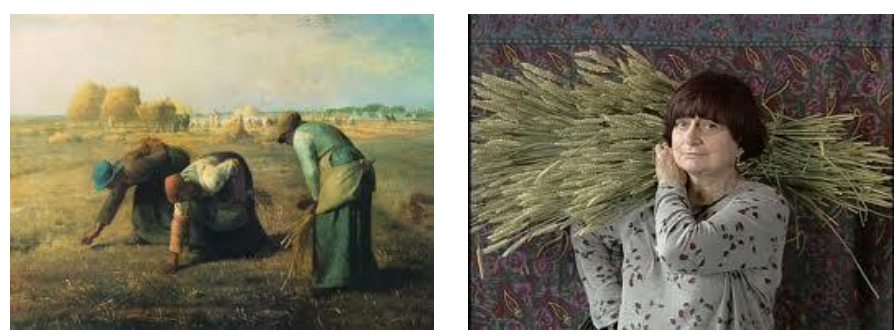

76. Des glaneuses (1857), Jean-François Millet [izquierda] 77. Los Espigadores y La Espigadora (2000), Agnès Varda [derecha]

\footnotetext{
${ }^{2}$ Digital, color, 78minutos de duración, 2000.

${ }^{3}$ Sobre el concepto de Self Documentary, mirar el capítulo V, particularmente en V.3.3.2.
} 
A partir de este trabajo, Varda empieza a exponer y actualmente se considerada no solo realizadora de cine, sino también artista audiovisual. En el 2006, en la Fundation Cartier pour l'Art Contemporain, presentó Lîle et Elle la exposición individual que hemos comentado anteriormente, con fotografías, collages, y objetos de las películas como diversos tipos de instalación, incluido el video. Este documental filmado digital por primera vez para la artista, sería un punto de partida de su carera artística en el ámbito de las artes visuales.

\section{VI.6.1. La autorepresentación de la mujer contada por otras mujeres; entrevistas y performance.}

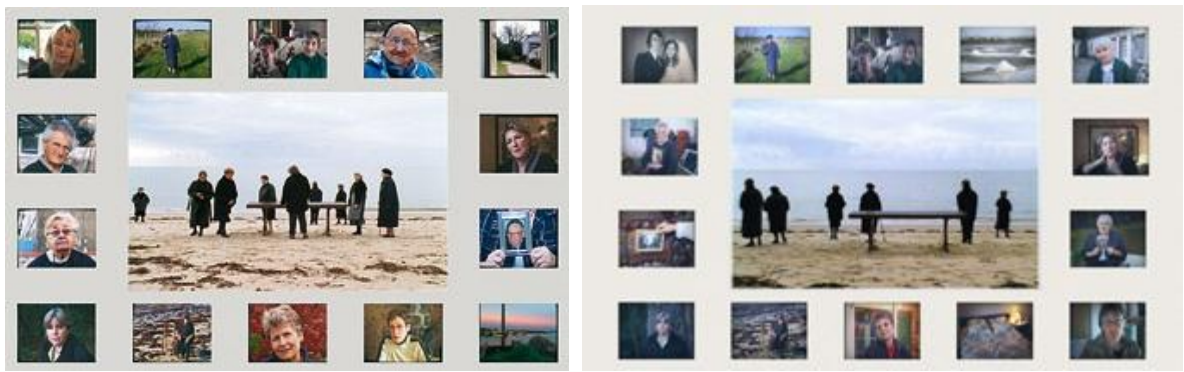

78. LesVeuves de Noirmoutier (2004-2005), Agnès Varda

Nos centraremos en la video instalación Les Veuves de Noirmoutier. Esta instalación consta de una pantalla grande en la pared y alrededor de la cual hay 14 monitores pequeñas, cada una muestra la imagen de una viuda entrevistada o la imagen de una ventana vista desde el interior hacia afuera. Frente a esta pared, se encuentran 14 sillas y 14 audífonos que corresponden a las pantallas dispuestas como un cuadro. La artista describe su trabajo en siguiente manera:

Il faut choisir de les écouter une à une pour les entendre. Des chaises et des écouteurs sont là pour ça. Il y a 14 moniteurs, 14 câbles au sol et 14 chaises. La place de chaque chaise correspond à la place de chaque moniteur et le casque d'écoute crée un lien personnel entre chaque spectateur et chaque veuve. Le lien qui 
les unit, c'est le câble qui va de la bouche qui parle à l'oreille qui écoute. Chaque veuve de cette île dit des paroles de veuves que j'ai enregistrées et filmées moimême avec un caméscope PD100-DVCAM (Alors que l'image centrale avait été filmée par Éric Gautier avec un caméra $35 \mathrm{~mm})^{4}$

Como comenta la artista, las entrevistas de las viudas que rodea la pantalla grande fue registrado por ella misma con una cámara de video digital y reproducido en los monitores. Las viudas a veces con la fotografía de su boda, de su marido, o del marido junto a ella, hablan de sus vidas o rememoran a sus maridos. En una de los 14 monitores, se encuentra Varda misma, muda, sentada en una silla en la playa, junto a otra silla vacía a su lado, de fondo suena una música instrumental. La pantalla grande que está en medio de las 14 pantallas, no tiene audio, fue filmada por la cámara e la película de $35 \mathrm{~mm}$.
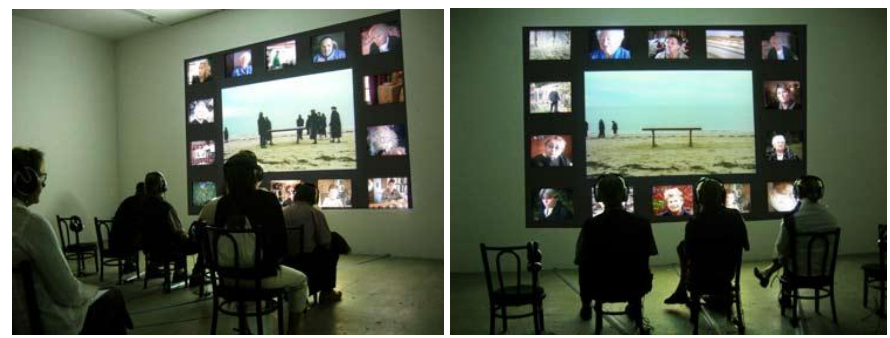

79. Les Veuves de Noirmoutier (2004-2005) Agnès Varda

En la imagen central, se encuentra una mesa cuadrada puesta en la playa y al fondo se ve la línea del horizonte paralela a la línea de la pantalla horizontal, así como a la línea de la mesa. En esta escena, entran algunas mujeres con ropas negras y dan la vuelta alrededor de la mesa, cada cual con su ritmo, a cierta distancia, y luego salen de la escena caminando en diferente dirección. Ellas son las que hablan en las distintas pantallas que rodean la escena

\footnotetext{
${ }^{4}$ Varda, Agnès, L'îLE ET ELLE, Agnès Varda, Paris, Fondation Cartier pour l'art contemporain, 2006. P.72. Tenemos que elegir a escuchar uno a uno para escucharlos. Las sillas y los auriculares están ahí para eso. Hay 14 monitores, 14 cables en el suelo y las sillas 14. El lugar de cada silla corresponde a la posición de cada monitor y los auriculares crean una conexión personal entre cada viuda y espectador. El vínculo que los une es el cable que va desde la boca que susurra al oyente. Cada viuda de la isla de las palabras de viudas que yo salvé y filmado con una cámara de vídeo-PD100 DVCAM (Mientras que la imagen central fue filmado por Eric Gautier, con una cámara de 35mm). [Traducción propia]
} 
con las dos mujeres que son protagonistas en otra obra, Le Triptyque de Noirmoutier (20042005).

Este trabajo refleja dos clases de documental, el documental de una performance y de las entrevistas. Muestran los relatos de unas mujeres y en el mismo plano presentan otras historias diferentes con un performance donde aparecen ellas mismas. Son diferentes individuos y llevan relatos y memorias personales diferentes. Podemos ver esta expresión, que supera el límite de la forma de presentación cinematográfica, reuniendo el tiempo y la imagen en una misma pantalla.

Varda muestra con el tema de la viudedad, una comparación entre la diversidad de las historias de la vida de la mujer a través del relato de la mujer. El marido ha fallecido y una mujer acepta la muerte de una persona íntima, otra a la que le cuesta aceptarlo y otra que queda entremedio. Un ejemplo se encuentra en el siguiente comentario:

Inés A: Pour le moment la maison est encore pleine de la présence de T., de son odeur, de ses... On a mangé, il y a deux jour, des haricots vert qu'il avait achetés au marché.

C'est tout récent quoi ! Et t'aimerais croire qu'il va revenir, que c'est une blague. ${ }^{5}$

En cambio, hay otra mujer que debía enfrentarse la realidad de perder a su marido sin entregarse en el sentimentalismo.

Agnès $H$. : Au $1^{\text {er }}$ veuvage, j'étais enceinte de 7 mois 1/2 et j'avais déjà 3 enfants de 8 , 7 et 6 ans. C'était la misère, rien à manger quoi... Rein du tout. ${ }^{6}$

\footnotetext{
${ }^{5}$ Ibíd., p. 74.

Inés A.: Por el momento la casa aún está llena de la presencia de T, de su olor, de sus... Comimos, hace dos días, judías verdes que había comprado en el mercado. Es todo tan reciente! Y me gustaría creer que él va a volver, que es una broma. [traducción propia]

${ }^{6}$ Ibíd., p. 75.

Agnes H.: Cuando enviudé, estaba embarazada de 7 meses y medio y tenía tres niños de 8, 7 y 6 años.

Era la miseria, sin nada que comer, ... nada en absoluto. [Traducción propia]
} 
La dificultad física y económica también son factores muy importantes en la vida de la viuda, sobre todo, el estar embarazada y tener niños pequeños como en su caso, nos hace recordar una trayectoria difícil de la mujer y pensar sobre la división del cargo social económico del hombre y la mujer.

O solo seguir viviendo con la costumbre habitual de acordarse de la ausencia del marido.

Odette A. lo comenta así.

Je dors toujours du même côté. Côté gauche, moi. Son armoire était toujours pleine dernièrement, je n'avais jamais voulu toucher à ses habits parce que je trouve que ça a l'odeur. C'est vrai ! ...ça me faisait mal. ${ }^{7}$

De otro modo, una mujer comenta la experiencia de ser viuda con el sentimiento difícil de explicárselo a los demás. Jeanne G. toma como ejemplo las simples expresiones de saludar como código social y en qué manera le puede afectar reconocer su situación.

\section{Jeanne G. : Si on me disait «Comment á va ?» maintenant je l'accepte mieux mais au début j'étais véxée. Et alors «Est-ce que ça va mieux?» c'était atroce pour moi. Est-ce qu'on peut aller mieux ? Ce n'est pas une maladie. ${ }^{8}$}

Estos testimonios de cada viuda con su experiencia y su modo de relatar se pueden escuchar, con los auriculares instalados en la sala de exposición, mirando la imagen de la mujer colocada con otras pantallas. Y dentro de estas pantallas de mujeres entrevistadas por la artista, se encuentra una silla vacía al lado de la artista sentada, colocadas en la arena de la playa. Es la imagen de ella, con una tonalidad del color modificada, en comparación con las otras mujeres de las pantallas, que se queda muda aunque tenga los auriculares conectados.

\footnotetext{
${ }^{7}$ Loc.cit.,

Odette A.: Siempre duermo del mismo lado. Del lado izquierdo. Su armario estaba siempre lleno últimamente, nunca quise tocar su ropa, porque creo que huele. ¡Era verdad! ... Eso me dolía. [Traducción propia]

${ }^{8}$ Ibíd., p.76.

Jeanne G.: Si me decían que «¿Cómo estás?» Ahora lo acepto más, pero al principio me molestaba. Y luego «vas mejorando?» Era terrible para mí. ¿Es posible mejorar? Esto no es una enfermedad. [Traducción propia]
} 
La memoria de su marido y la realidad de su ausencia, son como una parte de la vida de las viudas. Viven junto con su memoria y muestra lo inexpresable de la ausencia y la muerte de la pareja por medio del recurso de la silla vacía y el silencio de la misma autora. Hay muchas maneras de interpretar esta obra, pero en cierto sentido, nos hace reflexionar y pensar sobre el sentido y significado de seguir viviendo con la muerte y la ausencia de la persona íntima y amada de los que nos acompañan en la vida cotidiana ignorando a la muerte.

Por supuesto, no se borra la complejidad y la contradicción entre el amor y el matrimonio como institución. El marido siempre es el ser amado, al mismo tiempo, es el que sujeta a la mujer. Existe alguna diferencia de grado y nivel, sin embargo, el régimen del casamiento siempre está reservado a la relación del dominio patriarcal. De esta manera, la relación entre el marido y la mujer, bajo la estructura del poder heredado de la familia y el valor social, y ensalzado de una perfección por el amor, es espinoso y absurdo de vez en cuando, rechazando el análisis y la crítica, dado que todo ello es mucho más complejo que una simple relación amorosa de pareja.

Para la mujer, la muerte del marido, en cierto sentido es una liberación, pero al mismo tiempo es una pérdida irrecuperable. Quizás es lo esencial que todo el mundo debe experimentar con la pérdida de un ser muy íntimo, asociado con el amor, tras su muerte. Es decir, como muestra ejemplarmente la relación entre padres e hijos, como una relación fundamental del amor, la relación amorosa no escapa de la relación de poder; la muerte de un ser amado es una liberación de esa relación de poder entrecruzada entre el dominador y el dominado, al mismo tiempo, es una pérdida irremediable.

Particularmente, categorizar a la mujer cuyo marido ha muerto como viuda, ya la coloca de nuevo en la relación del dominio patriarcal. A nivel de reconocimiento convencional de la vida cotidiana, viuda es un calificativo de la mujer infeliz estereotipada que perdió a su amo en la narrativa patriarcal. En las entrevistas de la obra de Varda, se encuentran algunos comentarios sinceros donde expresan el malestar por este estereotipo. Sin embargo, por 
estos comentarios no hay que apresurarse a juzgar que ellas no se sienten tristes y la sensación de la pérdida por la ausencia del marido, al contrario, ellas también sobreviven soportando apenas lo que es insoportable por la pérdida de su querido.

Estas sensaciones solo puede mostrarse para sobreponerse a los relatos particulares, basados en la vida de cada una, respectivamente. Su vida y su experiencia nunca pueden contarse contrastando si es feliz o infeliz, libre o presa. Dentro del flujo y de la sucesión de los relatos de las mujeres, apenas nos hace indicar que existe algo indecible que se percibe como que hay algo más allá en este asunto sobre la sensación de la mujer. Como comentan Felman y Spivak, la vida de la mujer nunca puede reducirse a un estereotipo convencional. La obra de Varda, parte de esta complejidad de sí misma, e intenta encontrar la historia que todavía no es una historia de sí misma, en los relatos particulares de las mujeres que se encuentran en circunstancias similares. Como comentaba la artista, esta obra se posibilita que cada uno de espectadores se ponga a escuchar a las viudas a través del cable como un medio que articula entre la boca que sale murmullos al oído de uno con su casco. La artista misma confirma que las entrevistas de esas viudas posiblemente convierte un documental televisivo.

Je ne suis pas la seule à avoir été impressionnés par certaines de ces Paroles de Veuves. Elles pouvaient composer un documentaire ciné-télé (si d'aucuns en rêvaient... ARTE le fera) d'autant plus intéressant que parmi les sujets de société choisis par les médias, la tranche de population «veuves» n'apparaît pas, ou rarement.

J'ai préféré un dispositif plus complexe et c'est bien en cela que de cinéaste d'art et d'essai (c'est le terme employé, même si on en n'est plus aux essai) je suis devenue artiste plasticienne (c'est le terme en usage). ${ }^{9}$

\footnotetext{
${ }^{9}$ Ibíd., P.73.

Yo no soy la única de estar impresionada por algunas de estas Palabras de Viudas. Éstas se podrían componer un documental de televisión (aunque algunos sueños solo ... ARTE le fera) más interesante que entre los temas sociales elegidos por los medios de comunicación, el segmento de la población "viudas" no es, o rara vez.
} 
Varda aclara su preferencia al modo de presentar el tema en la instrucción audiovisual con cierta consciencia de ser artista plástica dejando un lado la presentación del cine de arte o de ensayo. La razón de elegir esta forma de presentación explica en siguiente modo.

Dans un film, je n'aurais pas pu montrer simultanément tant de visage en images mouvantes. Les multi-écrans proposent du collectif et du particulier en même tems. Par exemple, quand on a déjà écouté deux de ces femmes et l'histoire et celles dont on ne sait rien. ${ }^{10}$

Para la artista, es muy importante de conservar las particularidades de cada uno del relato de las viudas, al mismo tiempo, indicar claramente la colectividad entre ellas. Al montar una película o documental, es casi imposible mantener la simultaneidad de ambos elementos. Es decir, un film se introduce el orden jerárquico que se oprime la simultaneidad. Ahora, nos hace recordar la obra de Trint T. Minh-ha, en la que se encontraba un rechazo de la jerarquización de las voces con un "extraño" yuxtaposición. Pero eso generaba una impresión de ambigüedad y el caso de Varda, ya abandona la forma como film y proponer una dispositiva más compleja.

Dentro de estas 14 relatos de las viudas cuenta de la artista misma. Varda, al aparecer, sin hablar en el audiovisual, con una silla vacía que indica una ausencia a su lado, presenta lo inexpresable. Varda también ha perdido a su marido y es viuda, ella misma es una de las viudas que hablan de sí mismas, pero intencionadamente no habla. Podemos imaginar que es un gesto para evitar ser representante de las viudas. Por supuesto, la obra de Varda tiene una clara intención, un concepto y una dirección, visible en la entrevista de ella a las otras mujeres. Pero Varda evita hablar, podemos considerar que la actitud de Varda intenta evitar

Yo prefería un dispositivo más complejo y es en esto que un director de cine de arte y ensayo (el término utilizado, incluso si uno no está a prueba) que yo he convertido una artista olastica (es el término utilizado). [Traducción propia]

${ }^{10}$ Loc.cit.

En una película, no pude mostrar ambos a la vez la cara en las imágenes en movimiento. La pantalla multi-oferta propone de la colectividad y el individuo, al mismo tiempo. Por ejemplo, cuando ya se ha escuchado a dos de estas mujeres y de la historia y los que no sabemos nada. [traducción propia] 
ser una representante transparente, como critica agudamente Spivak, y se sitúa en la postura del mediador de los testimonios de las mujeres, que comparten algunas sensaciones y situaciones respetando las diferencias, siendo una de ellas por la condición de ella misma.

La imagen grande en medio de la instalación audiovisual, muestra una mesa rectangular, sin sillas y en un espacio vacío de la playa, con un tránsito de las mujeres vestidas de negro, que van y vienen, girando alrededor de la mesa, unas no dejan de girar y otras se quedan mirando al mar, posteriormente se van todas en silencio. Esta imagen nos hace asociar con varias cosas, sobre todo, nos hace recordar el cortejo fúnebre. La mesa rectangular vacía puede compararse a la base de un ataúd, pero ya no está ahí. Las mujeres giran alrededor de él, que ya no está ahí y entre ellas no hablan sino que guardan silencio. Ellas están en el mismo sitio, pero no se encuentran entre sí.

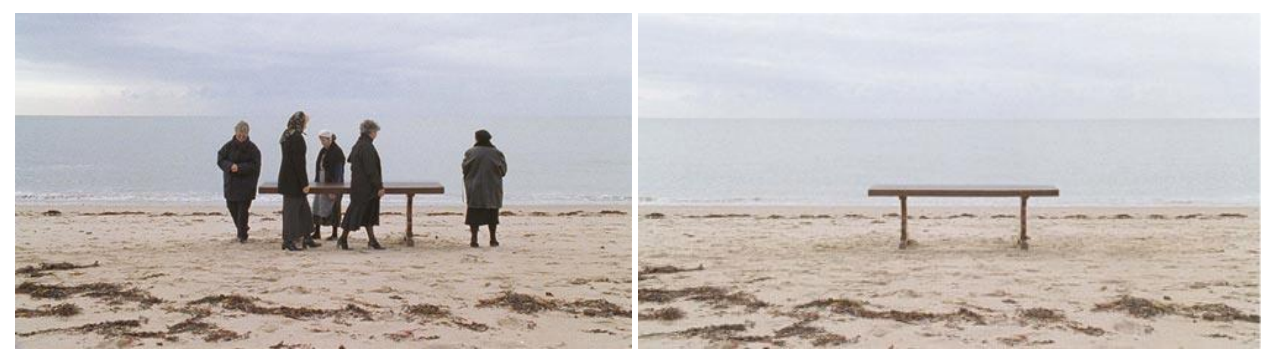

80. Les Veuves de Noirmoutier (2004-2005), Agnès Varda

Comparándolo con las performance de Kimsooja y también de Fiona Tan, (que hemos visto en el apartado anterior) que mantenían el silencio en la corriente de gente señalándonos así una incomunicación con ciertas diferencias confrontadas, la calidad del silencio de esas mujeres en esta performance, es muy distinta. Lo que mostraban las artistas en aquellas performances en medio de la corriente de gente desconocida, era el estado mudo dentro de la confrontación y la incomunicación.

En cambio, las mujeres que caminan ahí para los espectadores que han oído sus relatos, ya no son anónimas, pero al mismo tiempo siguen siendo anónimas dentro de la escena de la performance, sin ningún tipo de diálogo, ni contacto o comunicación entre ellas. Pero cada 
una, en su pantalla, habla de su experiencia, pero en la escena de la performance con el vestido negro de viuda, ellas comparten el silencio. Dando la vuelta del muerte, de lo indecible. Es decir, el silencio en este performance es punto de ruptura al mismo tiempo sería de una articulación entre ellas. Y esta articulación, quizá, se excede hacia quienes comparten el silencio.

Con todo, Agnès Varda, visualiza el silencio de las mujeres viudas, al mismo tiempo, habla de la mujer por otra mujer dando cierta particularidad de cada una de las mujeres y nos hace escuchar su voz sin ignorar la parte de lo indecible de la mujer. Seguramente, la técnica audiovisual multicanal y la forma de presentación como instalación, han sido fundamentales para que Agnès Varda logre este tipo de expresiones. Y este trabajo audiovisual nos hace presentir la autobiografía de la mujer que argumentaba Shoshana Felman. 
VI.7. En memoria de Harue: vida y muerte de una inmigrante japonesa en México, 1929-1949 (2006-2009), Miki Yokoigawa: biografía y autobiografía de la mujer en tránsito. 
En este apartado realizaremos un análisis del audiovisual En memoria de Harue: vida y muerte de una inmigrante japonesa en México, 1929-1949. Es un trabajo de vídeo documental, digital, a color, de 32 minutos 40 segundos de duración. Esta obra fue producida como resultado del Trabajo de Investigación realizado por la doctoranda de la presente tesis. Intentaremos aproximarnos a este video documental basándonos en los mismos principios que hemos venido desarrollando hasta el momento.

Esta obra trata sobre la búsqueda y recuperación de la memoria de una mujer inmigrante japonesa, que viajó a México en el año 1929. La obra muestra ese proceso de búsqueda del personaje mediante entrevistas a sus familiares, con el fin de acercar al espectador la imagen de esa mujer y la memoria de su familia, así como la recuperación del álbum familiar. Al mismo tiempo, este documental constituye un registro del viaje a México de la autora que provocó su reencuentro con una persona con la que tuvo una íntima relación. A través de esta búsqueda de imágenes y relatos de una inmigrante japonesa ,se intenta evocar la vida de una mujer en tránsito olvidada por sus actuales descendientes, así como reflexionar acerca de la proximidad y el distanciamiento que se produce, muchas veces, en las relaciones íntimas familiares.

Para una mejor comprensión del contexto en que se enmarca este trabajo documental, ofreceremos a continuación, una breve explicación sobre el fenómeno de la inmigración japonesa en México. En la historia del Japón moderno aparece un grupo llamado Enomoto Imindan ${ }^{1}$ como primera migración gubernamental y corresponde a 34 japoneses que emigran a Chiapas, México, en 1897. El proyecto que incorporaría, a largo plazo, a un número mucho mayor de japoneses, fracasa. Pero ello no implica el cese de la migración a México. Ésta continúa solo que con ciertas interrupciones. Por ejemplo, el gobierno del

\footnotetext{
${ }^{1}$ Existe un documento en la biblioteca del Colegio de México y su copia en la Biblioteca Nacional Japonesa (Los documentos de la Nichiboku Kyodo Gaisha, compañía japonesa mexicana, sociedad cooperativa). Que es el pacto que comenta, a grandes rasgos, la propiedad inmobiliaria que el Estado recibía como contraprestación a la inmigración de quince mil japoneses en la región de Chiapas. Sin embargo, nunca llegó el fondo financiero. Como consecuencia, el proyecto fracasó y la colonia se desplomó tan solo en tres meses. En: http://rnavi.ndl.go.jp/kensei/entry/i3-d3.php, accedido el 3 de noviembre de 2011.
} 
Imperio Japonés prohíbe la emigración a causa de la revolución mexicana en $1908^{2}$, mas luego resurge la emigración gubernamental al mismo destino, y otra vez se prohíbe al percatarse de algunas infracciones de los tratados que ambos países mantenían (como en el caso de las malas condiciones laborales en que se encontraban algunos japoneses residentes en México).

Según una tabla cronológica de la historia de la inmigración japonesa en México, de la sección del archivo de inmigración de la Biblioteca del Ciudadano de Wakayama ${ }^{3}$, hasta 1901 fueron a México más de diez mil obreros y después de la prohibición de la emigración contratada hacia México de 1908, y la revolución mexicana, el número de japoneses desciende aproximadamente a 720 en el año 1930.

Por la interrupción de los tratados mencionados anteriormente, la inmigración japonesa a México se reduce sustancialmente, pero continúa a pequeña escala por la relación de parentesco y/o pueblo de origen. Cabe citar a los llamados Yobiyose, aquellos inmigrantes japoneses que lograban éxito o estabilidad en su trabajo e invitaban a otros inmigrantes a México para trabajar. También se invitaba a las mujeres para que los inmigrantes varones se casasen con ellas, preferentemente chicas provenientes de sus mismos pueblos. Se encuentran además algunos casos de japoneses que llegaron a México al no poder entrar en Estados Unidos, o como refugiados, debido al fuerte movimiento político anti-japonés que existía en dicho país, sobre todo en la costa de California. Francis Peddie ${ }^{4}$, un doctorando canadiense en historia de la Universidad de York y uno de los pocos investigadores que estudia la inmigración japonesa en México, cita un estudio de la población en México en 1940:

\footnotetext{
${ }^{2}$ Tabla cronológica de la historia de la inmigración japonesa en México (Wakayama shimin toshokan imin shiryoushitu). En: http://www.lib.city.wakayama.wakayama.jp/wkclib_doc/sub15.htm, accedido el 15 de junio de 2009.

${ }^{3}$ Ibíd.

${ }^{4}$ En: http://www.yorku.ca/gradhist/students/cv/FrancisPeddieCV.htm, accedido el 1 de noviembre de 2011.
} 
El “Censo General de Población de 1940” identificó solo a 1.550 japoneses, 1.172 hombres y 378 mujeres. $^{5}$

Otros estudios indican cifras diferentes. No se sabe exactamente cuántos japoneses había en México durante la época, pero no fue una migración masiva, en comparación con el volumen de desplazamientos que se registraron hacia EE.UU. o Brasil.

Quizá por este motivo, el estudio sobre la inmigración japonesa en México es muy pobre ${ }^{6}$. Tanto en relación al trato del gobierno hacia la población japonesa, como por la orden de concentración durante la guerra, que no tiene ningún reconocimiento general en México ni en Japón. En comparación con la abundancia de estudios y datos que existen en EE.UU. sobre la concentración de los japoneses durante la Guerra Pacífica. ${ }^{7}$, lo ocurrido en México queda casi escondido. Francis Peddie hace referencia al trato discriminatorio hacia los japoneses, mencionando la concentración impuesta, la detención injusta y la repatriación forzada de los inmigrantes japoneses hacia muchos países de América. Él comenta que se ha informado públicamente de estos sucesos como hechos reprobables en la historia del país. En el caso de Canadá, por ejemplo, se ha informado incluso en la educación pública escolar acerca de la concentración de los japoneses en el momento de la Guerra Pacífica.

En mi estudio de la preparatoria recibí información acerca de la concentración de los japoneses en Canadá como parte de la historia oficial del país, es decir, era parte del currículo escolar. Como la memoria ejemplar de Tzvetan Todorov, el hecho fue presentado como una muestra de intolerancia que surgió en ese momento

\footnotetext{
${ }^{5}$ Salazar Anaya, Delia: La población extranjera en México (1895-1990), México, Instituto Nacional de Antropología e Historia, 1996, pp. 462-464. En Peddie, Francis: Una presencia incómoda: la colonia japonesa de México durante la Segunda Guerra Mundial, en: Estudio de la historia moderna y contemporánea de México, ISSN 0185-2620, n. 32, julio-diciembre de 2006, p. $74 . \quad$ En: http://www.ejournal.unam.mx/ehm/ehm32/EHM000003203.pdf, accedido el 1 de noviembre de 2011.

${ }^{6}$ Encontramos a María Elena Ota Mishima, difunta historiadora del Colegio de México, quien estudió sistemáticamente la colonia japonesa en México, como una de los pocos investigadores que tratan el tema. Su trabajo fue Siete migraciones japonesas en México, 1890-1978, México D.F., Colegio de México, Centro de estudio Asia y África, 1982. Es un trabajo fundamental para el estudio del tema.

${ }^{7}$ Como hemos mencionado en los apartados V.4.1., en EE.UU. para la investigación y educación permanente respecto al tema se encuentra el Japanese American National Museum (http://www.janm.org/, accedido el 15 de julio de 2009).
} 
de la historia de Canadá que tenemos que reconocer para aprender ${ }^{8}$. En cuanto a México, la conciencia histórica de un mal cometido no existe. Por eso, la pregunta fundamental que examinaremos en este artículo es por qué este episodio es tan desconocido en la historia mexicana, incluso en la colonia mexicano-japonés misma. 9

Tal y como cuestiona Peddie, en México, apenas se había informado sobre la concentración de los japoneses durante la guerra. Según el estudio de Ota Mishima, que cita Peddie, el trato de los mexicanos a los inmigrantes japoneses tanto a nivel oficial como popular, fue bastante amistoso desde el inicio de la migración y más tarde incluso se generó cierta confianza mutua como vecinos hasta la fecha del comienzo de la guerra. Parece que el caso fue excepcional en comparación con el fenómeno anti-japonés de EE.UU. y otros países de América Latina. Y también contrasta con la migración japonesa en la zona del Extremo Oriente Asiático que hemos visto en el apartado V.4.2. Los inmigrantes japoneses en México gozaban del respeto y la amistad de sus anfitriones. Citaremos una indicación sobre el estado de los inmigrantes japoneses en Ensenada, la costa de Baja California, donde la protagonista de nuestro documental residió durante un tiempo.

...los pescadores que desempeñaron un papel importante en el crecimiento de la industria pesquera en Ensenada. Como maestros de nuevas técnicas en estos campos, los japoneses se ganaron el respeto y la amistad de los mexicanos de Baja California. Según Ota Mishima, la presencia japonesa en la frontera norte fue percibida como benéfica para México; no eran explotadores extranjeros, sino contribuyentes al desarrollo de México. ${ }^{10}$

Sin embargo, estas circunstancias cambian al comienzo de la guerra. Los japoneses inmigrantes y sus familias, por orden del gobierno de Manuel Ávila Camacho (1940-1946),

\footnotetext{
${ }^{8}$ Todorov, Tzvetan: Los abusos de la memoria, Barcelona, Paidós, 1995, pp. 54-55.

${ }^{9}$ Peddie, Francis: Una presencia incómoda: la colonia japonesa de México durante la segunda guerra mundial, en: Estudio de la historia moderna y contemporánea de México, n. 32, julio-diciembre de 2006, p. 74. En: http://www.ejournal.unam.mx/ehm/ehm32/EHM000003203.pdf, accedido el 1 de noviembre de 2011.

${ }^{10}$ Ibíd. La cita es de: Ota Mishima, María Elena: Destino México. Un estudio de las migraciones asiáticas a México, siglo XIX y XX, México D.F., El Colegio de México, 1997, p. 83.
} 
debían desde 1942 viajar a determinadas ciudades y permanecer allí. Dependiendo de la región donde se situaban originalmente, varió la fecha de concentración, pero de todos modos, todo inmigrante japonés tenía un plazo máximo de ocho días para abandonar su domicilio y presentarse en la delegación de la ciudad de destino.

Además de esto, el gobierno mexicano bloqueó la cuenta bancaria de los inmigrantes japoneses y solo les permitía sacar pequeñas cantidades de dinero para su supervivencia. Con esta limitación económica, ellos tuvieron que solventar la vivienda, la alimentación y el trabajo, al llegar a la ciudad. Piénsese por ejemplo, la injusta situación de aquellos que vivían en Baja California y tenían que presentarse en la delegación de la ciudad de México (lo que significaba un viaje de 3000 kilómetros). La orden de concentración fue el 2 de enero para los habitantes japoneses en la zona. Tuvieron que soportar el frío del invierno, viajando en ferrocarril o en cualquier otro medio de transporte, sufragando los gastos con sus reducidos presupuestos. Peddie indica que algunos viajaban sin comer durante días, en ocasiones falleciendo bebés y ancianos durante el viaje. En algunos casos, se llegaron a pagar sobornos para que los oficiales de aduanas aceptaran sus documentos (algo, obviamente, fuera de toda regla).

De esta manera, la orden de concentración, supuso una gran carga para los inmigrantes japoneses a distintos niveles. Algunos líderes de la colonia japonesa, con éxito en sus negocios o mejor posicionados políticamente, se prepararon para recibir a los inmigrantes japoneses que llegaban de otros lugares de la república mexicana, por medio de la colaboración de ciudadanos mexicanos de confianza. Sin embargo, la mayoría de los inmigrantes japoneses, durante la guerra, tuvieron que soportar circunstancias menesterosas. Además, hay referencias sobre la explotación y los trabajos forzados que tuvieron lugar, o sobre los robos de dinero y artículos de valor bajo amenazas, aprovechándose de su inestable situación política. Son las circunstancias que rodeaban a los japoneses residentes en México en aquel momento y es también el contexto de la familia japonesa a la que se aproxima este documental. 
Como comentaba Peddie, dentro de la colonia japonesa actual, casi no se ha informado sobre la concentración forzado. Es decir, los que tienen esta experiencia no hablaron sobre este viaje ni cómo vivían durante la concentración y/o la generación posterior no escuchó sobre su memoria. Se encuentra una ruptura de la historia sobre este suceso dentro de la familia y la colonia japonesa en sí. Consideramos que evitan halar y escuchar sobre su experiencia negativa por la causa de crisis psicológica, igual que el caso de la concentración de japoneses en EE.UU. y de judíos en Europa. ${ }^{11}$ Lo que surgió en México no es un caso excesivo como lo de los campos de concentración, pero la memoria de ser maltratada, humillada con pobreza en estado político civil inestable, cabe entender que se convierte como un trauma. El documental que vamos a aproximar, no se trata de examinar ni denunciar sobre esta concentración durante la guerra, pero intenta escuchar y hacer hablar a una mujer que viajó y vivió aquella experiencia que no se había hablado ni había sido escuchado.

Nuestra protagonista principal se llama Harue Kamei. Es una inmigrante japonesa que viajó a México para casarse con un inmigrante japonés residente en ese país. El matrimonio fue acordado entre ambas familias mediante el intercambio de fotos y $\operatorname{cartas}^{12}$. La pareja tuvo cinco hijos. La tercera hija, Atsuko, es quien nos relata sus recuerdos sobre su madre. Atsuko tienía 71 años cuando fue entrevistada; es decir, los relatos que nos entrega, acerca de la memoria de su madre, son episodios que ocurrieron hace más de cincuenta años. El hijo de Atsuko y nieto de Harue, Ernesto Madokoro, es un amigo íntimo de la autora. Él ocasiona esta búsqueda y colabora con el proyecto del documental que indaga la imagen de su propia abuela materna, a la que nunca conoció.

\footnotetext{
${ }^{11}$ Sobre el caso de concentración de los japoneses véase al apartado V.3., de los judíos en Europa, el capítulo IV.

${ }^{12}$ Las mujeres que habían emigrado a la colonia japonesa en América por un matrimonio concertado mediante el intercambio de fotos y cartas se denominan Shashin-hanayome ("la novia de foto"). Este tipo de matrimonio es una aplicación del Miai que era muy común en Japón. El Miai es una forma de presentación de un posible matrimonio acordado mediante el intercambio de datos (como fotografías, etc.) entre familiares o conocidos de confianza. En el caso del Miai con un emigrante, los novios no se conocían hasta después de adquirir el compromiso y la llegada de la novia-prometida al lugar al que había emigrado el novio. Nuestra protagonista, Harue, que fue enviada a México, también era Shashin-hanayome. En relación con este asunto encontramos la película de ficción de Kayo Hatta, La foto del compromiso (de 91 min. de duración, a color, 1995), basada en episodios de inmigrantes japoneses en Hawai, similares al episodio de la abuela recogido por la realizadora. A esta película le dieron el Premio del Público en el Festival de Sundance, pero no ha llamado mucho la atención en Japón.
} 
El documental se desarrolla registrando el proceso de apertura de unas cajas que contienen fotografías familiares y la búsqueda de fotografías de la abuela, para conocer su vida a través de las imágenes y las entrevistas realizadas a su hija Atsuko. Mediante la recuperación de la memoria sobre "la abuela", Atsuko nos aclara poco a poco la trayectoria de la familia, en particular, de la colonia japonesa en México, en general. A su vez, el relato acerca de Harue forma parte de la autobiografía de Atsuko, quien ilustra su niñez con los recuerdos de su madre, sus hermanas y los vecinos japoneses inmigrantes en aquel momento. Se constituye por tanto, un testimonio basado en todo aquello que escuchó de su madre.

Por otra parte, el documental nos muestra la perplejidad de Ernesto frente a las memorias de aquellas personas que desconocía hasta que surgió el proyecto. La cantidad de material fotográfico encontrado, es excesivo, y causa cierto malestar porque, a lo que realmente se enfrenta, es a una enorme falta de información y de recuerdos, a pesar de la cantidad de fotografías existentes en torno al núcleo familiar.

Este documental tiene un carácter de Self Documentary, quien se dirige la cámara, hace preguntas y exige a Ernesto y a su madre Atsuko que recuerden la imagen de Harue, es la doctoranda. En este sentido, según Nichols ${ }^{13}$, el documental se clasificaría en la modalidad interactiva, en la que el realizador participa en el evento y comenta como un testigo, el hecho de participar en el mismo. Pero ahora no profundizaremos en ello, lo dejaremos para después, tras analizar el trabajo audiovisual.

El documental está estructurado en dieciocho secuencias. El contenido se puede dividir en tres partes, contemplando prólogo y epílogo. La primera parte se compone de seis secuencias (incluido el prólogo) que presentan el motivo y el contenido del proyecto. Dentro de estas secuencias se visualiza el contexto del viaje y la casa donde se buscan las fotografías. Se presentan las cajas y muestran las fotografías que fueron guardadas en ellas; al mismo tiempo, se presenta a Ernesto y su relación próxima con la autora. La segunda parte, también presentada en seis secuencias, se muestran las fotografías antiguas, según el

\footnotetext{
${ }^{13}$ Hemos desarrollado en el apartado VI.2.1 la clasificación de las modalidades documentales según Bill Nichols.
} 
relato de Atsuko y busca las huellas de la vida de la abuela. La tercera parte consta igualmente de seis secuencias (incluido el epílogo) y se trata de ordenar las fotografías "encontradas", con el propósito de organizar un futuro álbum de la abuela a modo de conclusión.

\section{VI.7.1. El viaje en la busca de una imagen olvidada.}

La primera secuencia es el prólogo de la obra. Después del anuncio del título con fondo en blanco, aparece un plano de detalle de la cara de una chica asiática. A partir de la imagen de la mitad inferior del rostro comienza la siguiente narración:

Mi mejor amigo Ernesto ha nacido en México como hijo de inmigrantes de origen japonés. Su madre también ha nacido en México, entonces, su abuela estuvo en México. Pero Ernesto no sabe nada sobre su abuela: ¿cuándo llegó? ¿Por qué vino a México? ¿Cómo era? y ¿Cómo se llamaba? Solo sabía que la abuela sufría una grave enfermedad en sus últimos momentos y murió joven, la pérdida de ella causó gran tristeza a la familia, por eso trataron de no recordar. En este ambiente Ernesto nunca preguntó sobre la abuela, ni había visto fotos de ella y dice: "debería haber unas fotos de ella en algunas cajas, porque hay muchas fotos en la casa”. Decidí viajar a México para buscar las fotos y, con ellas, la memoria de la abuela.

El tono de voz de la narración es grave, con acento de hispanoparlante no nativo. Se introducen imágenes del plano detalle de los labios pronunciando las palabras, que luego se funden con otras. También se ve la imagen de un ojo que parpadea. Cuando se funden las imágenes, en la narración también se oyen simultáneamente dos voces, pero se distingue lo que están diciendo. La imagen y la voz son de la autora, explicando el contexto y el motivo del proyecto documental. Sin embargo, esta secuencia no enseña ningún referente espacial ni temporal, ya que sigue mostrando únicamente el plano detalle. Solo se percibe que se trata de una chica asiática, una amiga de Ernesto que decide viajar a México, interesada en llevar a cabo una búsqueda de la memoria de la abuela materna de su amigo, hasta entonces una anónima, como la propia autora. 

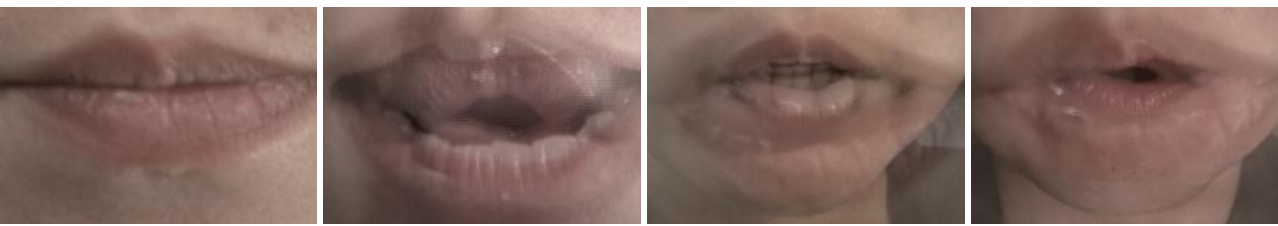

81. En memoria de Harue: vida y muerte de una inmigrante japonesa en México, 1929-1949, (2006-2009), Miki Yokoigawa

En esta secuencia, las imágenes fragmentadas del rostro de la autora nunca nos muestran con totalidad. Unas imágenes del labio están desenfocadas y la transición de imágenes fundidas nos muestra dos capas de labios que articulan, pero no nos deja ver con precisión. Son de la misma persona, pero hay una discrepancia entre las imágenes. Y las voces dobladas insisten más en esta discrepancia. A pesar de que la frase de la narración que anuncia su decisión de viajar a México demuestra cierta claridad, la imagen de los labios está desenfocada señalando una ambigüedad. Empieza el documental hablando en primera persona, yo, pero este yo se presenta con imágenes y voces fragmentadas, además de ser anónima.
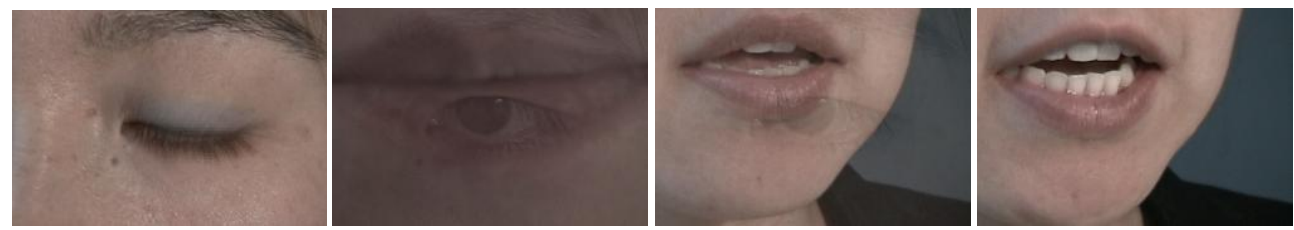

82. En memoria de Harue... (2006-2009), Miki Yokoigawa

Tras el prólogo se introduce un título que dice: Sept-oct 2006 en la Ciudad de México, con un fondo negro como comienzo de la segunda secuencia. Se muestran imágenes de México D.F. desde la vista del coche que conduce un chico de rasgos asiáticos. Es Ernesto. Por el estéreo del auto se escucha música de Wakaretemo sukinahito (Amados, incluso después de la separación. Los indios \& Silvia, 1978), que es una canción popular japonesa. De vez en cuando, la cámara gira hacia él, que canta la canción mientras conduce. Al mismo tiempo, desde el auto se muestran el tráfico y el paisaje, fundiendo una imagen con otra. Se oye la misma voz del prólogo con la siguiente narración: 
México lindo y querido. Ciudad de contaminación y tráfico, hay mucho ruido, asalto, chantaje, horror junto con alegría y amor. He vuelto y me queda poco tiempo para despegarme de esta ciudad que me hace sentir cierta nostalgia... viví 4 años aquí, no sé si es poco tiempo o mucho tiempo.

Ernesto y yo nos conocimos en esta ciudad. Él sigue aquí. Yo sigo viajando.
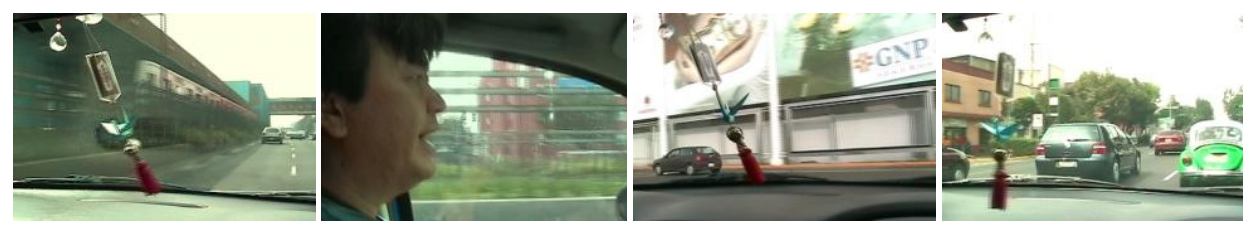

83. En memoria de Harue... (2006-2009), Miki Yokoigawa

Con este comentario, la autora nos hace comprender que su viaje a México es un regreso temporal. Nos habla de un tiempo de distanciamiento entre Ernesto y ella, que continúa en tránsito. La canción del estéreo que oímos trata sobre un rencuentro con el ex-novio. Su letra indica los nombres de lugares de Tokio que serían un paseo de la pareja esa noche, como si hubiera continuado con aquella cuando terminó la relación. Pero es japonés y no tiene subtítulos. A pesar de las indicaciones de lugares japoneses, lo que vemos ahora son unas rutas en auto por México D.F. Cabe entender que la canción simboliza la relación entre la autora y Ernesto, un rencuentro que anularía la separación. Pero no se indica, sino que permanece bastante ambiguo al no mostrarse su traducción. Es decir, para los que no comprenden japonés simplemente sería una canción extranjera y no se percibiría aquello que simboliza. Solo se nota que Ernesto la conoce bien por su canturreo de algunas estrofas. Se nos insinúa de esta manera una intimidad entre ellos, quienes comparten la lengua y la canción como un secreto frente a los que no la conocen.
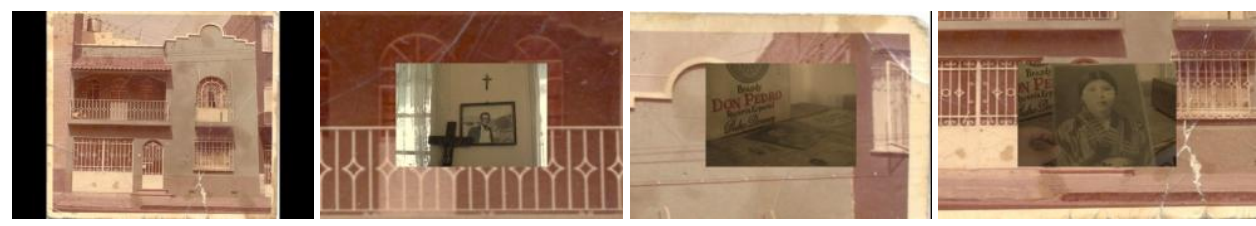

84. En memoria de Harue... (2006-2009), Miki Yokoigawa 
La tercera secuencia comienza con la imagen de una fotografía antigua de la fachada de la casa de Ernesto. Es una fotografía en color. Se nota que es bastante antigua por las arrugas, manchas, puntas del cuadrado dobladas y su tono descolorido. Con esta imagen fija de la fotografía se escucha una narración en off que dice lo siguiente:

La casa fue construida por el padre de Ernesto. El padre era japonés. Llegó a México antes de la Segunda Guerra Mundial. Le gustaba mucho fotografiar. Decía: "El momento nunca se repite. Por eso hay que tomar fotos del momento." Así que hay muchas fotos en su casa.

Al empezar la narración aparece una imagen de vídeo en forma de rectángulo horizontal en el medio de la fotografía de la casa. El vídeo comienza con un retrato del padre de Ernesto y luego pasa a una transición de imágenes de cuadros y portarretratos en el interior de la casa. Una mano va quitando cuadros y recoge la fotografía antigua de una joven japonesa vestida de kimono (vestido japonés) en colores sepia. Se escucha en off:

Sin embargo, la fotografía de la abuela materna de Ernesto se encuentra casi escondida.

Al mismo tiempo, la imagen de la fachada se muestra en su totalidad y después fragmentada y mostrando sus detalles. Con esta operación, las arrugas de la superficie de la fotografía se observan más claramente y casi parece una resquebrajadura. También se perciben más las manchas y el maltrato en las orillas de la fotografía. Eso nos habla del tiempo que ha pasado, tanto para la casa (indicado en esta imagen), como por la fotografía, en su calidad de objeto físico.

Después de la imagen del retrato de aquella joven japonesa vestida de kimono, el vídeo en medio de la fotografía, continúa mostrando imágenes de la sala, llena de cuadros de fotos colgados en la pared y pasa a enseñar el comedor con la siguiente narración de voz en off:

La sala está llena de fotos de la familia. 
En el comedor, los amigos de Ernesto juegan después de cenar. Se reúnen frecuentemente en su casa. Son de la colonia japonesa. Son de México y sus abuelos son japoneses.

Como de costumbre, los señores sentados en el comedor, y las señoras de pie en la cocina.
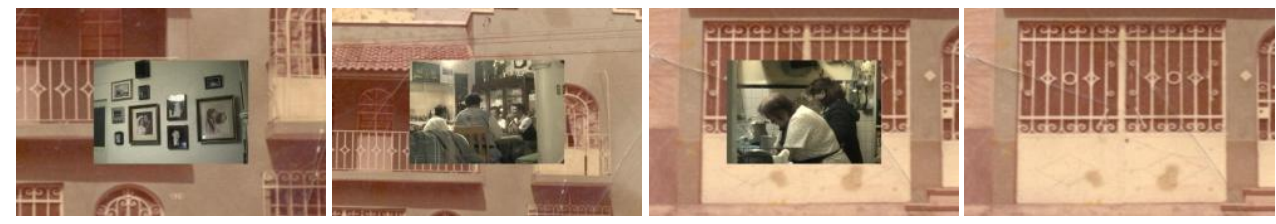

85. En memoria de Harue... (2006-2009) , Miki Yokoigawa

Mientras se oye la narración, de fondo se escuchan conversaciones en español con entonación mexicana y se ve a unos chicos que juegan al dominó y que beben. Ernesto se levanta a servir unas copas, detrás de él se ve a una señora y una chica trabajando en la cocina, y la cámara les enfoca a ellas en zoom. Finalmente, el vídeo desaparece fundido con una fotografía que muestra las puertas del garaje y sus rejas de hierro. Junto con la imagen de las mujeres en la cocina, se ofrece la impresión de que ambas estuvieran atrapadas en una jaula. Mediante este montaje de vídeo -como una especie de ventana en medio de la imagen de la casa- percibimos el estado interior y exterior de la misma, en relación con las fotografías, con lo familiar y con los amigos de la colonia japonesa.

La cuarta secuencia comienza con un plano detalle de unos logotipos de salsa de soja japonesa en una caja de cartón. Transcurridos unos segundos, el zoom se aleja y la cámara nos muestra dos cajas de cartón. Se escucha a un hombre anunciándole a la autora: "hay más cajas de fotografías y un álbum”. El tono de voz del hombre es muy amable en contraste con la voz de la autora, cuya reacción es algo brusca al saber que aún hay más cajas de fotos. Luego, él nos enseña un álbum que pone frente a las dos cajas de cartón. Al abrir su tapa, suena la caja de música que lleva en el interior, al cerrarla, ésta se apaga. 

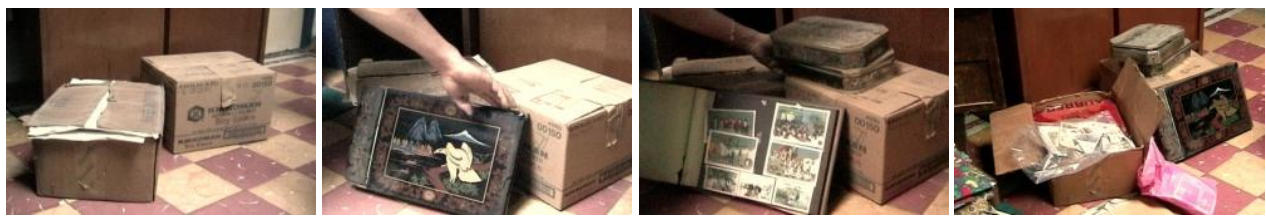

86. En memoria de Harue... (2006-2009), Miki Yokoigawa

Enseguida vemos desde diferentes ángulos. Desde arriba se muestra que abre una caja de cartón y salen muchas fotos. Se ve la imagen de las fotografías tiradas en el suelo y la imagen de una foto de niños en plano detalle. Escuchamos una pregunta de la autora: “¿Cuál eres tú?”. El hombre contesta señalándose con el dedo. Se levanta la cámara y muestra la imagen del niño señalado en la fotografía en la mitad del lado izquierdo de la pantalla, y en la otra mitad el rostro de Ernesto. Él sonríe, pero en un segundo dice: “ya” con un tono de queja.
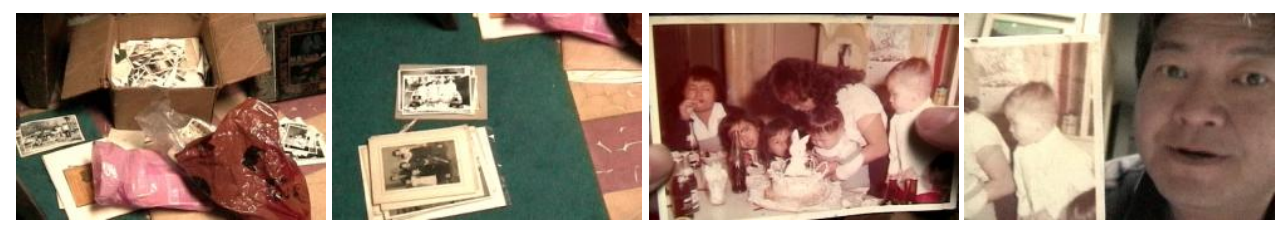

87. En memoria de Harue... (2006-2009), Miki Yokoigawa

La quinta secuencia empieza con esa imagen de las fotografías tiradas en el suelo que se había mostrado antes de la fotografía del niño, Ernesto. El vídeo en tiempo rápido y en retroceso y el audio de la música del álbum nos devuelven a la imagen de la caja de las fotografías. Vemos pasar fotografía tras fotografía desde el ángulo superior en un proceso de vaciar la caja de fotos. La música del álbum continúa durante toda la secuencia y se introduce una narración en off que dice lo siguiente:

Era curioso, con tantas fotos antiguas hechas en México aparecían casi solo japoneses o de la colonia japonesa. Estaban también las fotos de Japón. Entre las familias en México y Japón se intercambiaban fotos y noticias familiares... Las fotos que han llegado a México se han quedado en esa caja. Pero Ernesto no podía identificar muchas de las personas fotografiadas. Me repite que hay que preguntar a su madre. Que es ella quien lo sabe. 
Esta narración nos aporta principalmente dos detalles importantes: una, la tendencia a la incomunicación entre "los japoneses" y los demás (en este caso los mexicanos) en México, visible a nivel del registro fotográfico y de la conservación; la otra, el esfuerzo por la comunicación a través de la correspondencia y el intercambio de fotografías entre familiares y personas que viven separadas geográficamente. Ahora, estas fotografías nos descubren las huellas de los propósitos que tenían ellos, quizá también para las siguientes generaciones. Todo ello conduce a pensar que lo que se queda en las fotografías antiguas es solo un rastro y pareciera que sin relatos sobre ellas, su sentido se nos escapa. También se nos indica que quien puede explicarnos las fotografías, en este caso, es Atsuko.
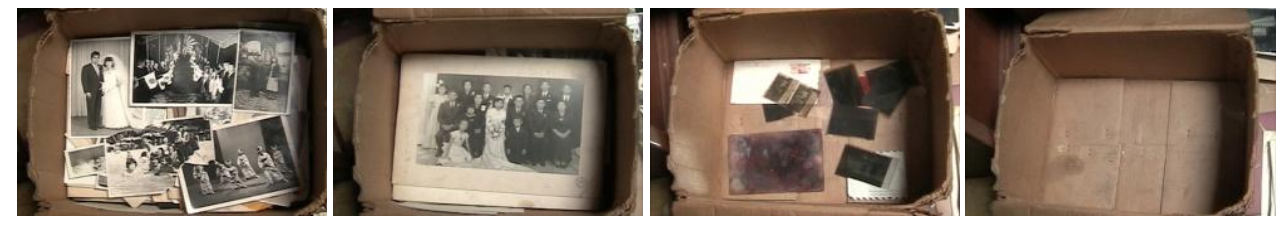

88. En memoria de Harue... (2006-2009), Miki Yokoigawa

Después de la narración, continúan las imágenes, fotografía tras fotografía. Nos da la impresión de que se trata de una secuencia demasiado larga para mostrar unas fotos que son casi iguales. Muchas son de bodas o fiestas, de bebés y otras son retratos de la familia y de la colonia japonesa. Se encuentran unas de los príncipes del emperador japonés que parece que han visitado México, pero no hay indicaciones sobre eso, solamente quien conozca su apariencia podría distinguirlo. Esta impresión “excesiva” en la repetición de las fotografías puede ocasionar una sensación de aburrimiento. Pero esa sensación corresponde a la que se tiene al encontrarse frente a una gran cantidad de registros fotográficos que evocan huellas profundas, pero que carecen de significado para el observador.

Finalmente, la caja se vacía y se ve el fondo del cartón, se apaga la música y se muestra otra caja abierta. Aquí comienza la sexta secuencia, mostrando varias fotografías amontonadas al lado de la caja. Luego aparece Ernesto mirando unas fotografías sacadas de las cajas y encuentra algunas de un viaje a Acapulco (en la costa del Pacífico de México, una de las playas más accesibles desde México D.F.). 

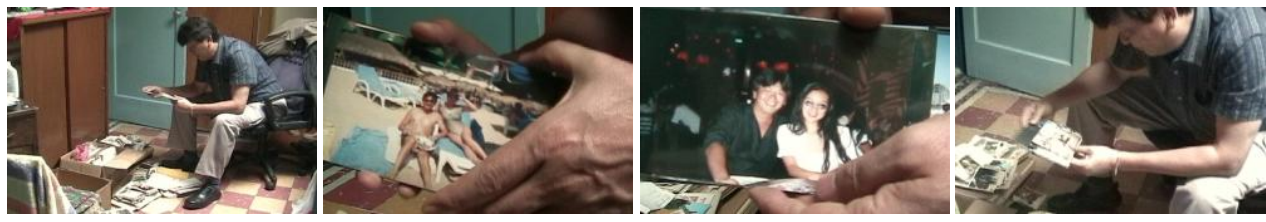

89. En memoria de Harue... (2006-2009), Miki Yokoigawa

Nos enseña fotografías en color de una pareja en la playa y en un bar. Mientras, se escucha la voz de Ernesto que comenta: “Aquí está Miki. ;Miki en Acapulco!”. La autora se queja un poco en japonés y en la pantalla se lee el subtítulo en español. Al terminar la conversación se oye la narración en off:

\section{Mi foto también forma parte de la colección.}

Hasta esta secuencia, como final de la primera parte, se ha identificado a la autora, Miki, como amiga de Ernesto. Ambos son protagonistas de este proyecto de recuperación de la memoria de la abuela materna de él. La voz de la narración es la de la autora del documental, quien habla en primera persona a lo largo del presente trabajo. Por otra parte, se percibe el contexto de su búsqueda: las fotografías y sus cajas, la casa donde se guardan y conservan no solo estas cajas y fotos, sino también las costumbres de la colonia japonesa, tanto físicas como psicológicas, y la ciudad donde se encuentran ellos.

\section{VI.7.2. La evocación y los relatos fragmentados en torno a las fotografías.}
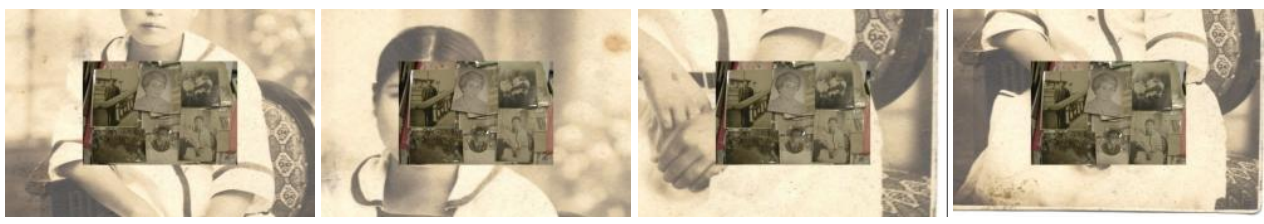

90. En memoria de Harue... (2006-2009), Miki Yokoigawa

La séptima secuencia inicia la segunda parte. Comienza con una imagen de fotografías superpuestas: se observa una ventana de vídeo enseñando fotografías antiguas en medio de otra imagen antigua y ampliada. La imagen del fondo cambia mostrando detalles de la propia foto y se oye la narración con algo de ruido: 
Para mí, los que aparecen en las fotos antiguas son desconocidos. La mayoría son de la familia de Ernesto. Muchos eran desconocidos también para Ernesto, incluso la abuela era una desconocida si la madre de Ernesto no nos llega a contar sobre ella. Un fin de semana yo tenía esparcida las fotos de desconocidos. Entonces, se acercó la madre de Ernesto, miró las fotos y empezó a contar sobre aquellas personas sin que yo se lo pidiera.

Esta narración explica el contexto en el que comienza la entrevista con Atsuko. Durante la entrevista, se ve una ventana de vídeo situada a la izquierda de la pantalla, en la que Atsuko mira las fotos mientras habla. Al lado derecho de la ventana aparece la imagen de la fotografía a la cual se refiere. De vez en cuando, la fotografía cubre toda la pantalla. Cuando Atsuko indica a alguien dentro de un retrato de grupo, se superpone sobre la foto una capa azul traslúcida y un círculo en el color original de la fotografía distingue al personaje señalado.

Durante esta secuencia, escuchamos a Atsuko que relata sobre las personas, eventos y asuntos por su recuerdo. Los relatos provocados por las fotos se entrecruzan el límite que se divide lo privado, lo público y lo político. Recordamos lo que afirmaba Michel Renov en el argumento de Annette Kuhn, aunque se puede dividir las imágenes "privadas" como fotos familiares y "públicas" como cine, noticias, fotografías o pinturas, por lo menor lo que respecto a la memoria, no es fácil de separar entre atmosfera privada y pública. ${ }^{14}$ Atsuko se refiere a su madre. Nos cuenta cómo se acordó su matrimonio, cómo ocurrió su muerte, qué pasó con sus hijos y la experiencia del aprendizaje del idioma japonés (como el medio de comunicación con la madre) para la propia Atsuko y sus hermanos en México. Es una serie de los relatos fragmentados de privado, asuntos familiares e intimidad de su niñez con la memoria de la madre. Sin embargo, no puede evitar a rememorar el reflejo de lo público y lo político en su vida y la trayectoria de su familia. Durante la entrevista, se observan detalles de las fotografías en el fondo de la ventana del vídeo. Funciona como una ilustración del relato en ciertas veces, pero luego se desplaza su posición.

\footnotetext{
${ }^{14}$ Vea a nota 5 de apartado $\mathrm{V}$.
} 

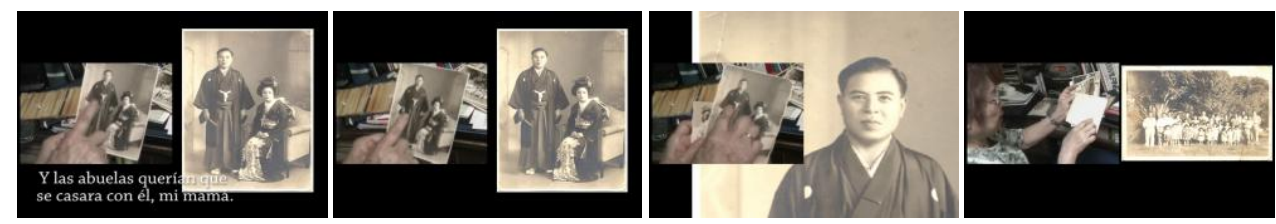

91. En memoria de Harue... (2006-2009), Miki Yokoigawa

Primero Atsuko nos habla sobre la fotografía de una boda, que parece haber sido tomada en un estudio profesional. En ella se ve a una pareja con vestimentas nupciales de estilo japonés. ${ }^{15}$ La foto es de un japonés que ha crecido con Harue, la madre de Atsuko. Como los tíos de Harue no tenían hijos, la adoptaron en su familia, al igual que al hombre de la foto. El tío era sacerdote sintoísta, el que poseía una posición honorífica políticamente y económicamente en aquel momento, evidentemente el motivo de la adopción era para tener el sucesor. Atsuko comenta que las abuelas de Harue y otros familiares quisieron casarlos, pero Harue no estuvo de acuerdo y ese es el motivo por el cual se traslada a México, donde finalmente contrae matrimonio con el padre de Atsuko. Este episodio le fue contado por su madre y ahora Atsuko nos lo transmite a nosotros. Y adjunta un episodio de su niñez: ella le había comentado a su madre que el hombre de la fotografía le parecía más guapo que su propio padre y la madre le contestó que no. Escuchamos la voz de Atsuko bastante alegre con risa al referirse a esta anécdota.

Este inicio de entrevista señala unos niveles distintos de relato acerca de la foto. Primero, se precisa quién es la persona fotografiada (el hombre que creció junto con la madre de Atsuko): es un dato importante y también el punto de partida para comprender los episodios posteriores en la vida de Harue y su descendencia. Segundo, se nos explica la razón de la llegada de Harue a México. La fotografía de la boda de aquel hombre hace recordar a Atsuko y así transmitirnos lo que su madre le relató hace muchos años. Tercero, el episodio de "quién es más guapo" evoca a la conversación que esta fotografía ocasionó entre madre e hija, recuerdo que Atsuko nos cuenta con cierta alegría.

\footnotetext{
${ }^{15}$ La fotografía de la boda, es muy parecido la que en Osaka Story de Toichi Nakata, la que es de la boda de sus padres. La novia sentada vestida de Kimono muy decolada y hombre de pie a su lado.
} 

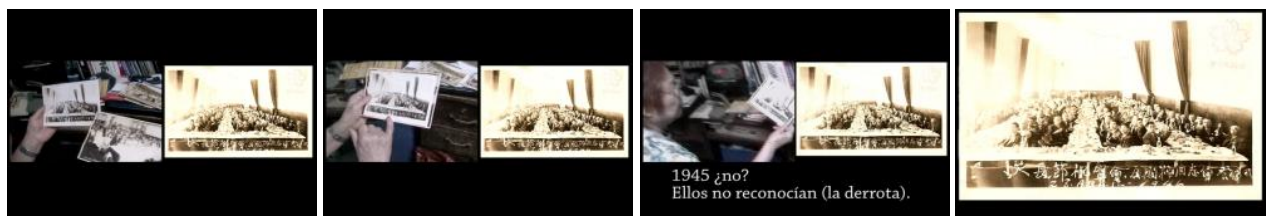

92. En memoria de Harue... (2006-2009), Miki Yokoigawa

Todas las fotografías que aparecen durante esta secuencia tienen una directa relación con Harue, salvo una. Se trata de una fotografía del marido de Atsuko durante la fiesta de celebración de la victoria de la Segunda Guerra Mundial. El grupo se llamaba a sí mismo Kattagumi ("grupo de la victoria"). La fotografía muestra a hombres vestidos de traje, sentados a una mesa muy larga dentro de un amplio y elegante salón, levantando sus copas en señal de brindis. En la parte inferior de la foto se encuentra una frase en japonés, cuya traducción sería: "Fiesta de celebración del cumpleaños del emperador e inauguración de reunión nacionalista, 28 de abril de 1946”. La derrota fue aceptada el 15 de agosto de 1945 , la fecha en que se registra la reunión a favor de la victoria es ya más de medio año después de la derrota.

El Kattagumi o Kachigumi surge durante la posguerra en diversas colonias japonesas a lo ancho del globo, sobretodo en América. Es un fenómeno reaccionario que causó problemas y finalmente la división entre los japoneses inmigrantes, ya que el grupo no aceptaba la derrota del Imperio Japonés. A pesar de que persistieron durante cierto tiempo, tras constatar la situación real los Kattagumi se fueron disolviendo de manera natural. Como comenta Atsuko: "hasta hubo la escuela de puro de ellos”, quiere decir, hasta organizaron un colegio que se reunían únicamente ellos para la enseñanza de su tendencia política, como un intento por mantener la ideología y la política del Imperio Japonés a través de la educación. Esta fotografía evidencia una postura política dentro de la colonia japonesa de aquel momento. Y Harue y Atsuko vivían dentro de ese contexto. 

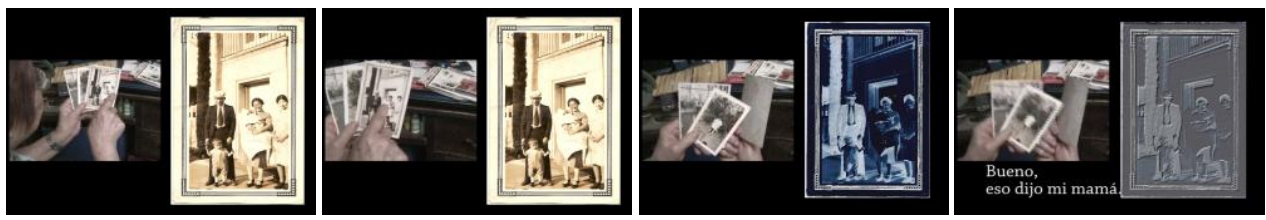

93. En memoria de Harue... (2006-2009), Miki Yokoigawa

En relación con la guerra, se encuentra una fotografía del viaje que Harue y su familia realizaron a National City, en EE.UU. para visitar a un pariente del marid. En la foto se ven dos parejas con un niño y bebé. Durante la entrevista, Atsuko mira la parte del reverso de la foto donde deberían estar los datos de referencia escritos en japonés. Nos dice que su madre solía escribir todo en las fotos. Pero esta vez la escritura al reverso había sido borrada y solo quedaban algunas huellas raspadas. Según lo que su madre le contó, cuando se dictó la orden de la "Concentración” en 1942, cualquier escrito en la fotografía tenía que ser borrado. Cuando Atsuko habla de este episodio, la imagen de la fotografía a la derecha se obscurece y oímos un murmullo: "bueno, eso dijo mi mamá”.

A continuación, Atsuko comenta unas fotografías tomadas durante el viaje de su madre en barco a través del Pacífico y otras de picnics con las compatriotas de la colonia japonesa en Baja California, la costa de México que da al océano Pacífico. Los relatos siempre son muy fragmentados y los entrelaza con otros episodios. Algunas fotos llevan datos escritos al reverso o en la superficie, y en otras han sido borrados. A pesar de ello, lo que cuenta Atsuko es muy concreto y nos da la impresión de que se acordaba muy bien de aquellos momentos, sobre todo de lo que le contó su madre, a pesar de que hace ya cerca de sesenta años.
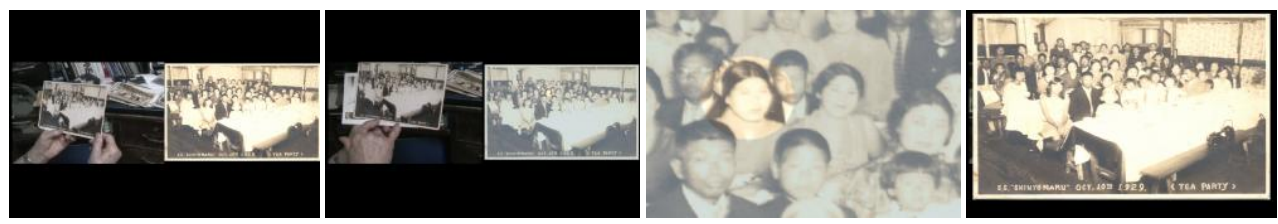

94. En memoria de Harue... (2006-2009), Miki Yokoigawa

En la ventana izquierda a menudo aparece solo Atsuko con las fotos. En muchas ocasiones se enfoca su gesto al observar las fotografías o cómo indica con su mano a alguien que 
aparece retratado. Por la pregunta o los comentarios de la autora, que se encuentra tras la cámara, Atsuko contesta pero muy pocas veces mira directamente a la cámara. En ocasiones la conversación se desarrolla en japonés y otras veces en español, luego, se mezclan algunas palabras. Cuando se habla en japonés o con voz muy baja, se introducen subtítulos. Cuando se reitera en español lo que alguna de ellas ha dicho en japonés, o cuando por el sentido de la conversación se puede captar la idea, no lleva subtítulos.

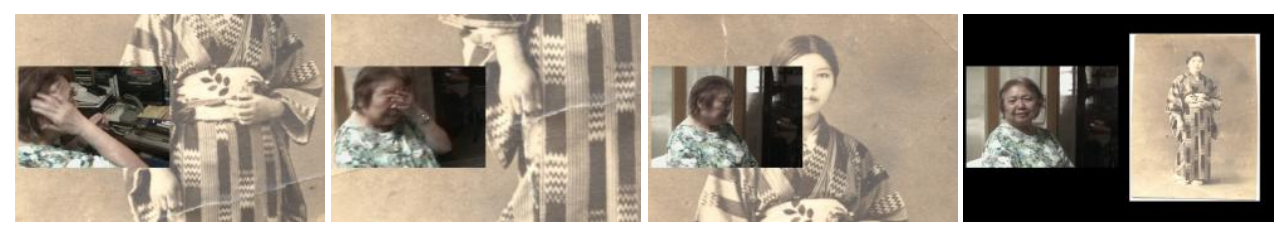

95. En memoria de Harue... (2006-2009), Miki Yokoigawa

Al final de la entrevista la autora realiza tres preguntas concretas a Atsuko, mientras el vídeo muestra un plano medio de Atsuko contestando a las preguntas y de fondo unos detalles de fotos antiguas. La primera pregunta es sobre el matrimonio de sus padres. Atsuko recuerda que había un señor del mismo pueblo de la madre que decía que si su madre se hubiese casado con él, estaría muy bien como la mujer del sacerdote sintoísta. Este comentario del vecino suena helénico despreciando la decisión que ha tomado Harue que resultó venir a México por rechazar a casarse con el sucesor. También nos indica que no estaba tan buena la circunstancia de ella por ser la mujer de un inmigrante comparación con la aquella que hubiera sido. Es un comentario ejemplar de calificar la vida de la mujer dependiendo del hombre que la posee, en su caso, del esposo.

La segunda pregunta es sobre el aprendizaje de la lengua japonesa en México. Ella y su hermano lo aprendieron para poder comunicarse con su propia madre, quien nunca supo hablar español. En cambio, la hermana menor de Atsuko no lo aprendió porque no alcanzó a ser criada por su madre, que enfermó luego del nacimiento del bebé. La tercera pregunta suscita el comentario sobre la muerte de la madre de Atsuko y coincide con lo que comentaba al inicio del documental: ella estuvo enferma durante años. Cuando falleció la madre, Astuko tenía catorce años y su hermana menor, cuatro o cinco. A raíz de esta conversación percibimos que entre los hermanos de Atsuko hay cierta fisura, en este caso 
distinguiendo los que tienen memoria de la madre y de los que no la tienen, y eso ha influido en el aprendizaje y en la relación que mantiene cada uno con la lengua japonesa. No hay fotos de la madre con la hermana menor de Atsuko; en contraste, se encuentran algunas fotos de la madre con sus hijas mayores, quienes actualmente viven en Japón. Eso nos hace reflexionar sobre la confusa relación que existe entre la proximidad, la interrupción y la separación de los hermanos de Atsuko con su madre.

Comparación con otras obras que tenía tema con la madre, como de Mona Hatoum o de Tracey Moffatt, la relación y el gesto que muestra Atsuko es muy diferente. El caso de Hatoum, ella misma no comentaba de su madre, sino pronunciaba las frases demasiado cariñosas, pero muy obsesivas, de la madre, traduciéndola. Con esto nos señalaba una sensación incomoda de ser hija querida. La de Moffatt, nos mostraba una frustración de la hija adoptada la que es cuidadora forzada a la madre anciana. Las dos nos surgían referenciar sobre la relación entre madre e hija como dominadora y dominante. Las obras mostraba las posturas de las artistas también, una que halle tomando y mediando la distancia con ella y la otra maltratándola por permanecer encerrada con ella portando como dominadora absoluta. En este sentido el relato de Atsuko no nos señala ningún conflicto con la imagen de la madre. Al parecer, por su muerte demasiado pronto, ni les dio tiempo para el conflicto entre madre e hija. En otra palabra, el abismo y la ruptura entre la madre y sus hijos, es absoluto ni puede medir.
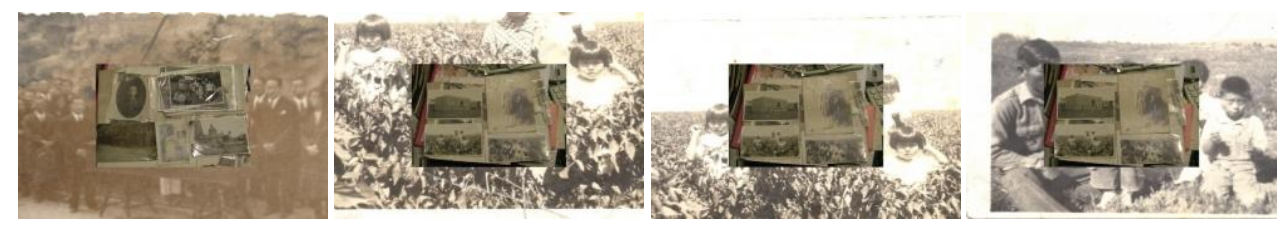

96. En memoria de Harue... (2006-2009), Miki Yokoigawa

Después de la entrevista a la madre de Ernesto, otra vez aparece una imagen de doble capa: un vídeo inserto en medio de una imagen fotográfica. El vídeo de nuevo nos muestra fotografías antiguas y el fondo cambia enfocando diferentes detalles de las fotografías. Las fotografías cambian, pero se mantiene el mismo encuadre. El audio contiene algún ruido. También escuchamos un resumen de lo que ha contado en la entrevista anterior en off: 
La abuela de Ernesto llegó a México tras rechazar un matrimonio. Viajó con otros emigrantes japoneses para encontrar a su futuro marido. El casamiento fue llevado a cabo por el intercambio de fotos y cartas. Pero no pudimos encontrar ni una foto de su boda. La pareja tuvo 5 hijos. Los primeros 4 nacieron en Baja California. Antes de la guerra, envió a las 2 hijas mayores a Japón para su educación primaria, diciendo: "nosotros también volveremos pronto". No obstante, el destino de su viaje próximo no era Japón. La $3^{a}$ hija que se quedó en México es la madre de Ernesto. Y me comentó que guardaba 2 kimonos de su madre.

Como se ha visto repetitivamente al abrir la caja en la quinta secuencia, las imágenes de fotografías de boda abundan. También hemos visto al comienzo de la entrevista una foto de la boda japonesa del hombre que creció con la madre de Atsuko. Ello nos obliga a comparar el exceso de fotos de otras bodas con la falta de fotografías de la boda de la propia protagonista. Además, el motivo principal de su llegada al país era casarse. Nos surge, por tanto, una pregunta: ¿por qué no está la foto? Sin embargo, Atsuko no contesta a esta pregunta, ni en este momento ni hasta al final del documental.

Por otra parte, percibimos dos cosas: la división interna de la familia y la voluntad de Harue y su esposo de volver a Japón. Las niñas pequeñas que hemos visto en una foto regresan a "su país", un lugar que no conocían, y la familia se queda en "el país extranjero", la tierra natal para los hijos. Las hermanas mayores que también podrían hablarnos sobre su madre, se fueron a Japón siendo niñas. Tenían ocho y seis años (se aclara en otra entrevista) antes de la Guerra Pacífica (1939 aproximadamente) y desde entonces nunca volvieron a ver a su madre. Entonces, estos hechos aclaran que Atsuko es una de las pocas personas que puede contarnos acerca de su madre en México, tal y como comentaba Ernesto. Es decir, se determina la posición de Atsuko como la tercera hija que se quedó a su lado. Esta narración nos facilita la comprensión de su contexto particular como inmigrante y la articulación de los relatos fragmentados que hemos escuchado anteriormente, además de lo que vamos a escuchar de ahora en adelante. La última frase de la narración introduce la siguiente escena. 

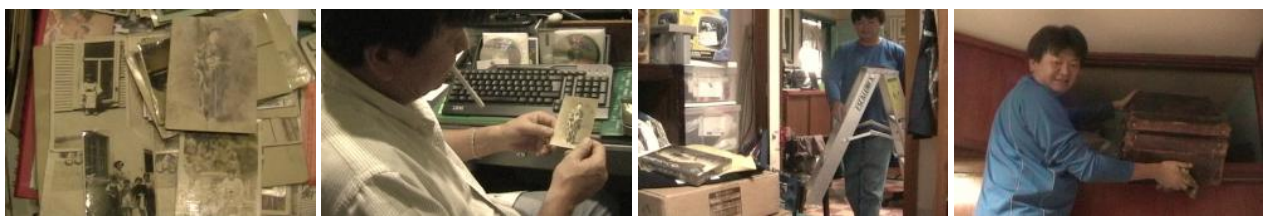

97. En memoria de Harue... (2006-2009), Miki Yokoigawa

La décima secuencia comienza con la imagen de varias fotos antiguas dispuestas sobre el escritorio. Entre ellas se encuentra la fotografía de una japonesa vestida de kimono y se escucha la voz de Ernesto: “'este es el kimono que dice que tiene?”. Durante un instante, aparece Ernesto mirando dicha foto y haciendo un gesto mientras suspira: “;Uffff!” y levanta un brazo al oír el comentario de la autora que se encuentra detrás de la cámara: "Sí, ¡me lo vas a sacar, eh!”. Cambia la escena, están en una de las habitaciones de la casa. Él trae una escalera, se monta en ella y busca una maleta en el estante superior del armario, mientras se escucha la narración en off:

Cada cosa que le pedía a Ernesto le molestaba, tenía que insistir un poco. Sobre todo no le gustaba sacar las cosas que guardaba su madre.

Mientras Ernesto intenta encontrar y sacar la maleta, sigue conversando con la autora. Su voz no suena molesta, finalmente ríe, pero no es una risa alegre, sino más bien algo irónica. Cuando termina la conversación, se ve una maleta de cuero bastante vieja colocada sobre la cama. Al abrirla se aprecia que está llena de cosas. Se escuchan unos murmullos de queja por parte de Ernesto y se encuentra el kimono que aparecía en la foto. Luego, cuando empieza la siguiente narración, la cámara hace un giro alrededor de la maleta mostrando las cosas amontonadas. En el último momento, enfoca a Ernesto sujetando el kimono para mostrarlo al completo.
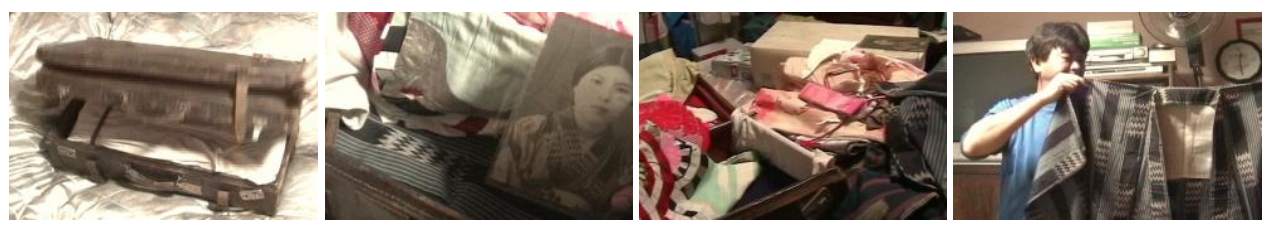

98. En memoria de Harue... (2006-2009), Miki Yokoigawa 
Son muchas cosas, ocupaba mucho espacio sin orden.

Creo que son las cosas que le importaban a la madre, pero no al hijo.

Después de la narración aparece Atsuko doblando el kimono para guardarlo. Explica lo que sabe sobre el kimono según lo que había oído de su madre y Ernesto interviene con una burla.

Ernesto: A ver póntelo, a ver si te vale, a ver si estás flaquita.

Atsuko: Estaba... yo también tuve mis buenos tiempos,

Ernesto: Ay, sí.

Atsuko: Aunque no lo creas (habla riéndose, y se oye la risa de Miki).

Como se aprecia en esta conversación, el comportamiento de Ernesto con su madre es como el de un niño, no es agresivo pero sí bastante ofensivo. La madre se defiende a sí misma recurriendo al sentido del humor. Es una escena cotidiana entre madre e hijo. En ese momento, se introduce una narración:

Había muchas cosas de las que ni ella se acordaba, pero cuando abrimos unas cajas o maletas que se quedaban en el rincón de la casa, ella se acordaba de muchas cosas. Así, no podía tirar nada, así que otra vez las guardamos...
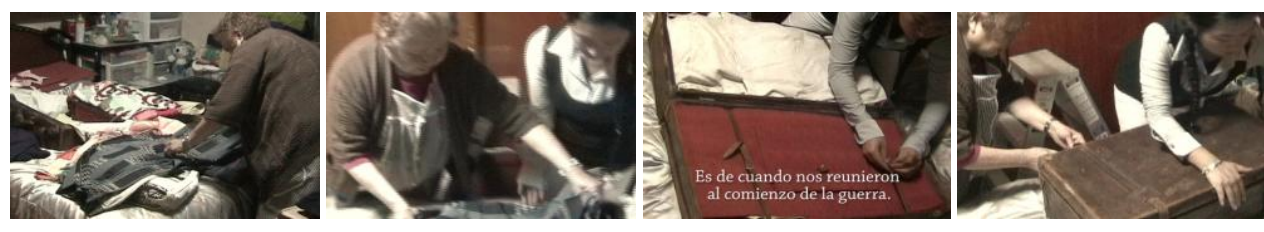

99. En memoria de Harue... (2006-2009), Miki Yokoigawa

Mientras se escucha la narración, la imagen muestra cómo Atsuko y la autora guardan los vestidos otra vez en la maleta antigua. En el momento de cerrar la maleta, ambas inician una conversación en japonés y se ven los subtítulos en español. 
Atsuko: Esta es de piel muy vieja.

Miki: Sí, cierto.

Atsuko: Es de cuando nos reunieron en la Ciudad de México por el comienzo de la guerra.

Miki: ¿Qué, lo trajo?

Atsuko: Sí... guardando varias cosas...

Atsuko comenta que la maleta fue traída hasta México D.F. a comienzos de la concentración de la población japonesa, durante la Guerra del Pacífico entre Japón y EE.UU. Nos enteramos de la anécdota de la maleta por casualidad, pues no hubo una pregunta intencionada por parte de la autora, sino que Atsuko comienza el relato de manera espontánea, motivada seguramente por el hecho de enfrentarse a esa maleta antigua. Si hubiese estado sola, habría recordado el asunto pero sin mencionarlo. Diríamos casi con total certeza que le provoca hablar de ello únicamente el hecho de tener una compañía que le escucha. Luego, interviene Ernesto preguntando de dónde son las maletas, y la madre contesta: “Ay, de México.” Y se pasa a otra escena.
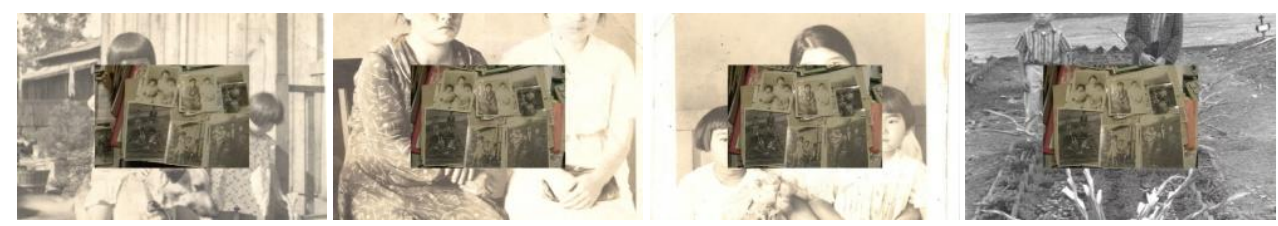

100. En memoria de Harue... (2006-2009), Miki Yokoigawa

Enseguida comienza la narración sobre la concentración de los japoneses en México, con fotos antiguas y sus detalles como fondo, siguiendo el mismo estilo de imágenes superpuestas que hemos visto anteriormente.

El viaje con esa maleta fue por la orden de la concentración, al comienzo de la Guerra del Pacífico entre Japón y Estados Unidos. El gobierno mexicano dejó una semana para reunirse. La familia viajó hasta Guadalajara con las maletas llenas con todo lo que podía cargar. Dejó todo lo demás. No encontramos las fotos durante la guerra. 
Luego la familia se fue a la Ciudad de México para ser candidata para el intercambio de los prisioneros. Pero nunca logró irse a Japón. Tuvo su última hija y la familia se quedó en la Ciudad de México.

En esta narración volvemos a escuchar que no se han encontrado fotos tomadas durante el tiempo de guerra. No podemos ver ninguna de esas escenas registradas como fotografía en este documental: ni el viaje forzado por orden estatal de los japoneses como prisioneros o ciudadanos hostiles, desde la costa en Baja California hasta México D.F., atravesando Guadalajara; ni la vida durante la concentración en la guerra. Hasta el fin de la narración se oyen de fondo unos ruidos disonados, ralentizados, como si fueran los gemidos de un monstruo. Vemos imágenes de personas anónimas, pero durante la narración escuchamos que no se encuentran fotos de la boda con el acompañamiento de un ruido un tanto extraño. En esta secuencia la autora afirma una discrepancia entre lo visible y lo invisible, comparando con la que vemos y lo que escuchamos. Si precisamos bien, dentro de lo que oímos se percibe una división entre la narración y el ruido que representarían las partes comprensibles e incomprensibles.

La duodécima secuencia empieza con la vista general de un cementerio en el que se observan numerosas lápidas de diversos estilos, en su mayoría cristianas. Cuando se enfoca en una tumba, el vídeo se reduce en la parte izquierda como una ventana, quedando superpuesta sobre una fotografía en blanco y negro, de la que solo vemos algunas partes. $\mathrm{Al}$ mismo tiempo, se oye a la autora preguntar a Ernesto el nombre de su abuelo. Él responde: “Kiyohiko”. El vídeo muestra la cruz de piedra que lleva inscrito el nombre del abuelo y el de otro hombre (Marcos Namikawa, su yerno) en plano detalle. Aquí comprobamos otra vez la ausencia de huellas de "la abuela", cuyo nombre no aparece en la lápida.
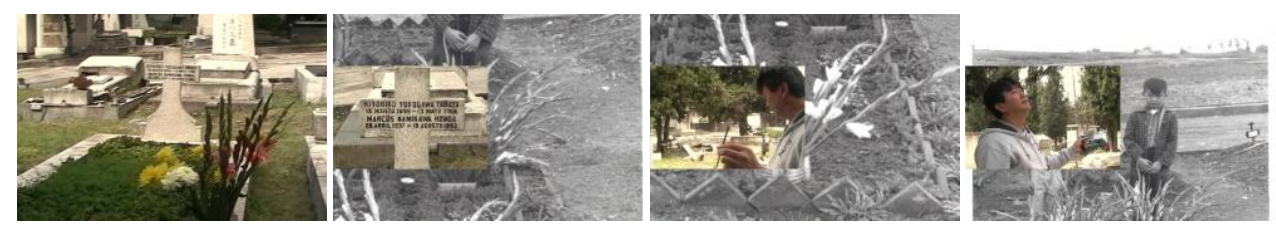

101. En memoria de Harue... (2006-2009), Miki Yokoigawa 
El vídeo continúa con la imagen de Ernesto encendiendo un incienso que luego pone a orillas de la tumba, cubierta de vegetación. A continuación se ve otra vez a Ernesto mirando una foto, con varios árboles de fondo. Mira a su alrededor y luego comenta: "no había árboles". Nos muestra la fotografía que sujeta en su mano, imagen que aparece a la izquierda del encuadre. La tumba del abuelo se ve a la derecha. La fotografía que enseña Ernesto es la misma que veíamos como fondo en el vídeo y que después se muestra completa en toda la mitad derecha de la imagen. Mientras, el vídeo transcurre en la izquierda sobre un fondo negro. La fotografía es vertical y muestra a dos niños de pie junto a la cabecera de la tumba (uno bajito a la izquierda, otro alto a la derecha), uno a cada lado de la cruz, que es pequeña y está casi escondida por las flores que adornan el sepulcro. La tumba es rectangular y no lleva piedra por encima, sino tierra. Detrás de los niños no hay más que un camino y de fondo se ve el horizonte. Luego se muestra nuevamente la foto en plano detalle a la derecha. En el vídeo, la cámara se levanta hasta enfocar la tumba y se encuentra con Ernesto de pie a la derecha de la cruz. En este momento, la imagen de la fotografía a la derecha se desprende de sus márgenes superior e inferior, de forma que su tamaño coincide con el del vídeo que se encuentra a la izquierda. De este modo, ambas ventanas se aprecian como una sola cinta de imagen sobre el fondo negro.
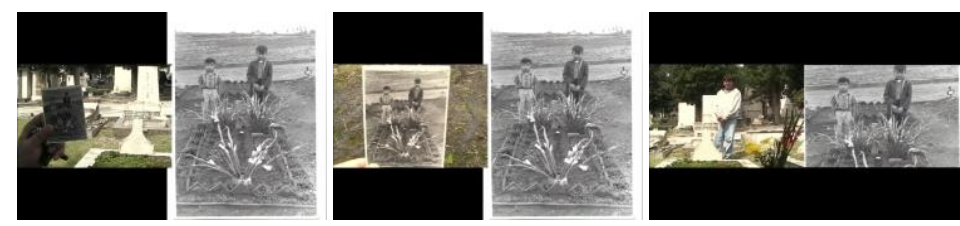

102. En memoria de Harue... (2006-2009), Miki Yokoigawa

La yuxtaposición del vídeo y la fotografía en la misma pantalla nos sugieren que el vídeo muestra la tumba en el presente y que la foto es del pasado. Del mismo modo, notamos que el niño de la derecha de la foto es Ernesto, quien en la fotografía actual aparece de pie en el mismo sitio. El cambio de una imagen a otra es evidente y nos hace reflexionar sobre el paso del tiempo. Recordaremos que el documental de Fiona Tan que vimos en el apartado VI.4 utilizaba la fotografía antigua para aludir a la transición de tiempo, pero siguiendo el lenguaje cinematográfico convencional que evita la yuxtaposición paralela y que prefiere expresarlo en la colocación lineal de las imágenes dentro de una única pantalla. Por ejemplo, 
en la imagen del puente en Indonesia durante la entrevista al tío An, primero mostraba la imagen de la fotografía antigua y después la fundía con el vídeo actual.

Durante esta segunda parte nos hemos aproximado a la memoria de la abuela de Ernesto a través de los relatos fragmentados que nos entrega su madre, evocados por fotografías antiguas y por el hallazgo de algunos objetos como su kimono y la maleta de cuero. $\mathrm{Al}$ mismo tiempo, a través de la narración y de la visita a la tumba del abuelo de Ernesto, hemos podido apreciar la ausencia de una huella clara de "la abuela".

\title{
VI.7.3. El álbum de la abuela y cerrar las cajas de la memoria.
}

Esta es la última parte, con la que concluye el documental. Se inicia con una secuencia de Ernesto mirando una enorme cantidad de fotos. El vídeo va con tiempo y audio rápidos. Algunos comentarios de Ernesto y de la autora suenan casi como ruidos. Debido al efecto de rapidez, las voces se oyen más agudas de lo normal y los movimientos de Ernesto se parecen a los de un dibujo animado. La secuencia resulta algo cómica.

\begin{abstract}
Para buscar la imagen de la abuela abrimos las cajas de las fotos. Cuando supe que tenía sus fotos, me sentí en la obligación de buscarlas. Yo estaba impaciente por saber de ella, y quería saber por qué no tenía Ernesto la misma curiosidad que yo, ahora ya sé por qué le molesta tanto abrir las cajas y las maletas guardadas. En cierto sentido, las cajas eran de Pandora. No digo que solo salieron los males y las desgracias, pero nos ha causado bastante caos, sobre todo a Ernesto.
\end{abstract}

Durante esta secuencia de vídeo el tiempo va rápido. Cuando se oye una conversación cambia en tiempo real, en la que Ernesto comenta: "Hay muchas... ya me cansé", y la autora plantea, “¿lo dejamos para mañana?”. Él responde que sí. A pesar de su respuesta, Ernesto continúa mirando las fotos, sin levantar la vista. 
El encuadre cambia y lo retrata en plano general, aún observándolas. Con el comentario de Ernesto percibimos que él se aburre de seguir mirando fotografías. Sin embargo, una vez concentrado mirando las fotos de la familia, se le hace difícil abandonar y eso nos facilita entender por el montaje de cambio del plano que se trata de una retórica que nos señala el paso el tiempo dentro de la escena. Al final de la secuencia comienza la narración de la siguiente escena. Aparece el título "Repartir las fotos" en fondo negro y se introduce una narración:

Ya no sabía qué hacer con tantas fotos. En la casa hay muchas cosas de recuerdos, y muchas fotos. Quiere huir de su peso. No puede estar cargado todo el tiempo. Y decide repartir algunas fotos a los que partieron de la casa.

Luego, unas y otras se quedan en la caja, otra vez.

Mientras se escucha la narración, vemos cómo Ernesto reparte las fotos y las distribuye en sobres. De este modo se inicia la secuencia decimocuarta. Después de dividir las fotos, Ernesto se queda mirando otras fotografías, la cuales guarda nuevamente en la caja que abrió al comienzo del documental. La cierra, pone el álbum encima en ella y la deja en un rincón en el suelo, comentando: "por el momento" en japonés, frase que aparece subtitulada al español.

En la decimoquinta secuencia, Ernesto intenta reparar la caja de música del álbum. El vídeo sigue en tiempo rápido. La caja suena de vez en cuando.

Dejó de sonar la caja de música que tenía el álbum solo por abrirla unas cuantas veces. El álbum tenía muchas páginas vacías. Entonces, nos surgió la idea de renovar el álbum con las fotos antiguas.

Ernesto parece un poco más animado para reparar la caja de música, pero en el último momento levanta su cara hacia la cámara y comenta "Ya no sirve”. Y la voz en off comenta: 


\section{El álbum se quedó sin música.}

Esta escena muestra el fracaso en el intento por recuperar y recomponer una parte del álbum. La introducción de la música de la caja en aquella secuencia que abría la caja de las fotografías de la primera parte del documental nos remite a la relación entre música, fotografía y evocación nostálgica. El fracaso en reparar la caja nos indica que algo no se alcanza o no se recupera. Es una escena que nos señala un fallo en la intención de rehacer el álbum, es decir el plan desde el inicio tiene su parte fracasada. Cabe interpretar la voluntad de la autora al mostrar esta secuencia con el comentario de Ernesto como el fallo del proyecto de la búsqueda sobre la imagen de "la abuela" en sí desde su inicio. Pretendía tanto recuperar la memoria y encontrar la imagen de "la abuela"... Pero, en algún sentido, desde el inicio de su proyecto alguna parte estaba rota y "ya no sirve”.

La decimosexta secuencia empieza con la imagen de unas fotos antiguas en blanco y negro. Se aleja la cámara con un movimiento de zoom y se muestran en su totalidad el álbum y esas fotos antiguas colocadas sobre la mesa cubierta con un mantel verde. Se escucha una pregunta de Ernesto: ¿quién es? Entonces la imagen pasa al plano detalle de la fotografía en blanco y negro que Ernesto sostiene, y que es de una anciana en kimono. Dice la voz de Atsuko: "no sé". En ese momento, su hijo comenta: "es tu abuela” y contesta riendo: "pues, no sé, abuela o tía abuela, no sé". Se quita la foto frente a la cámara y aparece detrás la mirada de Atsuko, de manera inesperada, en plano detalle. La cámara se aleja rápidamente con movimiento de zoom y nos muestra a Atsuko en la cabecera de la mesa, y a la autora tomando notas en el extremo derecho del encuadre. Durante esta escena, tanto la autora como Ernesto realizan preguntas a Atsuko, para ir completando las fichas. Las veces en que la autora aparece en el vídeo la cámara está dirigida por Ernesto. Las veces en que aparece Ernesto, la dirige la autora.
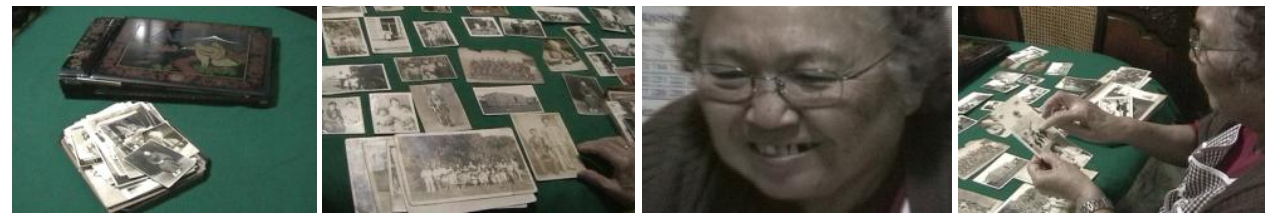

103. En memoria de Harue... (2006-2009), Miki Yokoigawa 
Este inicio de secuencia con una foto no identificada nos señala que la madre de Ernesto no lo sabe todo, sino que existen varias fotos que se encuentran fuera del alcance de su conocimiento. No saber de su abuela no es algo particular de Ernesto, incluso su madre no conoce mucho sobre sus propios abuelos.

El vídeo pasa a la imagen de las fotografías colocadas en la mesa. Atsuko indica a las personas que conoce. Desde que comienza a hablar sobre las fotos de sus hermanas previas al viaje a Japón, el vídeo se reduce en una ventana colocada en la parte izquierda en medio del encuadre y aparece la imagen de la fotografía a la derecha. Hay veces en que la imagen de la fotografía cubre toda la pantalla, otras veces en que se ve la ventana del vídeo encima de una imagen detallada de la fotografía. Se oye la conversación de estas tres personas: Atsuko, Ernesto y la autora, y de vez en cuando se escuchan algunas frases y música de la telenovela japonesa que Atsuko veía en ese momento.

De aquí en adelante, en esta secuencia se habla acerca de catorce fotos. La primera foto es de Atsuko de niña sentada en las rodillas de su madre, junto a su hermana que sostiene su muñeca también sobre las rodillas. Con la segunda foto, escuchamos una anécdota sobre ellas. Es en la que aparece una niña montada sobre un perro y detrás una señora en cuclillas junto a otra una niña de pie con la cabeza gacha, y en la orilla inferior derecha de la foto se ve asomar la punta de un zapato. Es una fotografía de las tres hermanas junto a una vecina en Ensenada (pueblo de Baja California). La niña que monta al perro es la hermana mayor, la más grande. La otra niña que baja la cabeza no se sabe si es Atsuko o su hermana, la mediana. Atsuko comenta que una de las dos se enfadó y no quiso salir en la foto, por eso solo se ve su pie. Esta anécdota la ha oído de su madre. Mientras se escucha el relato de Atsuko, en el vídeo se muestra la imagen ampliada de la foto a la derecha, cubierta por una capa azul traslúcida, con círculos que indican a las niñas y al pie.
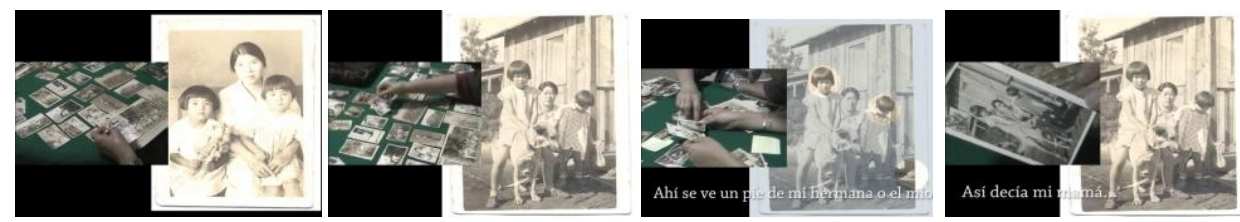

104. En memoria de Harue... (2006-2009), Miki Yokoigawa 
Como revela esta entrevista, al igual que la anterior, Astuko nos está contando tanto sobre la fotografía como sobre lo que ha oído de su madre. Por sí misma no es capaz de recordar aquel momento de la fotografía, pero se acuerda de lo que comentaba su madre después. Por su voz y su risa alegre percibimos sus ganas de narrar el episodio con detalles. Lo que ocurre en aquella escena de fotografiado no es un gran acontecimiento familiar ni social, es algo que pasa entre hermanos y amigos de la niñez, pero a pesar de eso y precisamente por eso, para ella es importante contarlo personalmente como un episodio igual que cualquiera. Por otra parte, es tan importante porque es también la memoria de su madre. Todo lo que sabe sobre su niñez y la separación de las hermanas mayores, que se han ido a Japón, se lo ha comentado su madre enseñándole las fotografías y entregándole detalles, del mismo modo en que Atsuko nos relata ahora en el vídeo. Esta memoria se ha grabado en ella y tiene ganas de contárnosla con alegría cuando tiene la ocasión. Es, efectivamente, lo que buscaba la autora y nos lo muestra en esta secuencia del proyecto.

La tercera foto es la que vimos durante la escena de la primera entrevista, el viaje de los padres de Atsuko a EE.UU., a la que habían borrado los datos que tenía escritos en el reverso. Ernesto comenta: "por la guerra, todo se borró.” Y la madre le corrige: “No, lo tuvo que borrar. Porque no podía haber nada escrito en las fotos." Durante esta entrevista también escuchamos varias veces la mención de la falta de datos o la supresión de los escritos.

La cuarta fotografía es de las tres hermanas con una vecina. La autora le pregunta a Atsuko por las fecha de la foto y ella contesta, no con el año, sino con la edad aproximada que tenía en el momento en que la fotografiaron. Es algo que se repite durante toda la entrevista. La quinta foto es una que les han sacado en un campo de chile, Atsuko aparece en brazos de la madre, con las dos hermanas a los lados.

A continuación se encuentra una fotografía que no se puede identificar si es de la abuela o del padre de Ernesto. Es una fotografía en blanco y negro sacada en Japón, parece del colegio porque se ven varios niños en kimono ordenados en filas. Para indicar al posible padre o la posible abuela de Ernesto, se superpone una capa azul traslúcida con círculos 
sobre la fotografía. En el reverso de la fotografía no aparecen los datos y Atsuko comenta: "todo está borrado", contestando la pregunta del hijo. Esta escena también demuestra que sin información real solo podemos hacer suposiciones. En cambio, si se tuvieran todos los datos, el sentido de lo que se presenta visualmente cambiaría. Esta escena nos da cuenta, además, de las consecuencias que tuvo la mencionada obligación estatal de borrar datos de las fotos, tanto que hasta interviene en la memoria privada de personas de distintas generaciones.

La séptima fotografía es de la primera comunión de Atsuko. Es una foto vertical, en blanco y negro, de ella posando con un vestido blanco. Ella comenta que fue en el año cincuenta y que entonces tenía quince años. Se oye una pregunta de la autora: ¿y un año antes? A partir de aquí se empieza de hablar acerca de la foto del funeral de su madre. Escuchamos la explicación de Atsuko sobre cómo fue el funeral, contestando a las preguntas que le hace la autora o Ernesto. Confunde el año, pero vemos que se acuerda exactamente de la fecha en que murió su madre. La foto queda a la derecha del vídeo, luego se amplía al tamaño de la pantalla ocultando la ventana del vídeo.
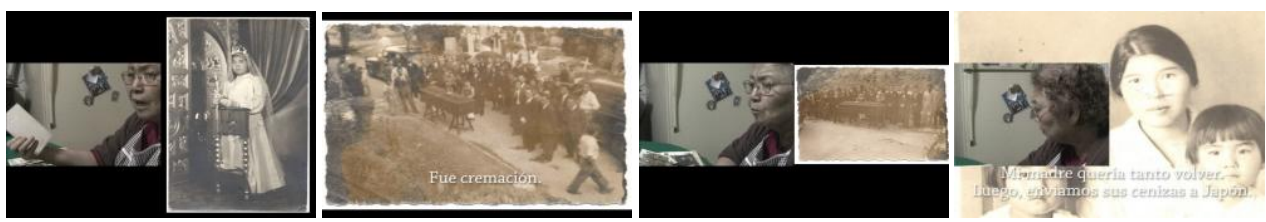

105. En memoria de Harue... (2006-2009), Miki Yokoigawa

La madre de Atsuko no fue enterrada en México, sino que la incineraron y sus cenizas se enviaron a Japón porque la madre decía continuamente que su voluntad era regresar; sin embargo, la familia no sabía cuándo podría volver. Luego, escuchamos que Atsuko menciona el nombre de su madre: Harue, contestando a la pregunta que Ernesto le hace. Es la primera y única vez que ella pronuncia su nombre durante el documental. Cuando oímos este episodio y el nombre de la madre, se muestra el rostro de Harue ampliado en la primera fotografía que vimos en esta secuencia, como fondo de la ventana del vídeo de Atsuko respondiendo a la pregunta de su hijo. 
En seguida escuchamos el caso del padre, enterrado en México. La imagen del fondo de la ventana del vídeo muestra partes de la fotografía de la tumba que vimos anteriormente. El comentario coincide con lo que se vio anteriormente, pero añadiendo una anécdota más: quedaba un mechón de cabello cortado de la madre en el altar sintoísta de la casa y cuando murió su marido lo pusieron en su ataúd. En el momento de hablar sobre la muerte de sus padres, la voz de Atsuko se apaga y evita mirar a la cámara. Tras comentar el detalle del cabello, Atsuko se ve seria y gira la cara hacia otro lado. A continuación, nos muestra la foto de la tumba de su padre y de los niños de pie junto a ella. Es la foto que hemos visto antes. Atsuko afirma que está enterrado allí y el vídeo muestra sus manos sujetando la foto. Ernesto comenta que "no había árboles". Atsuko lo confirma: a los dos lados de la tumba había espacio libre, lo hubieran comprado pero entonces no tenían dinero suficiente para hacerlo.
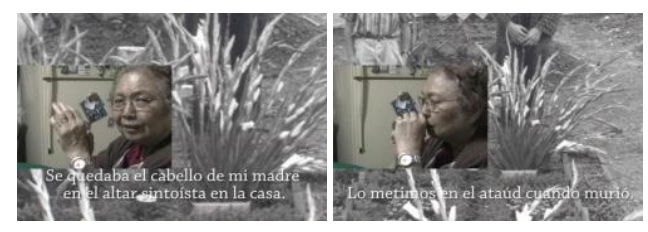
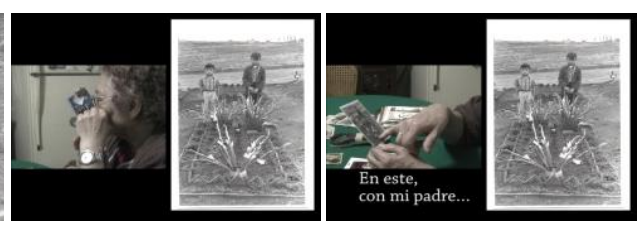

106. En memoria de Harue... (2006-2009), Miki Yokoigawa

La imagen cambia a otra foto de la primera comunión (un año después de la muerte de la madre de Atsuko), donde se ve un grupo de chicas y chicos de la colonia japonesa. Atsuko indica a las personas que conoce: Rosa (su hermana menor) y otras amigas. El fondo de la ventana del vídeo muestra la parte de esa foto ampliada con la capa azul superpuesta y con los círculos indicando a Rosa (de cinco años) y a la propia Atsuko (de quince años). No obstante, son hechos que ocurrieron hace más de medio siglo y Atsuko, ahora con más de setenta años, puede tener recuerdos confusos. Comparar los comentarios que ella misma hace sobre una y otra foto de su primera comunión nos obliga a reflexionar acerca del carácter de la memoria (una vez tan segura, y minutos después, ya no tan segura sobre el mismo acontecimiento). 

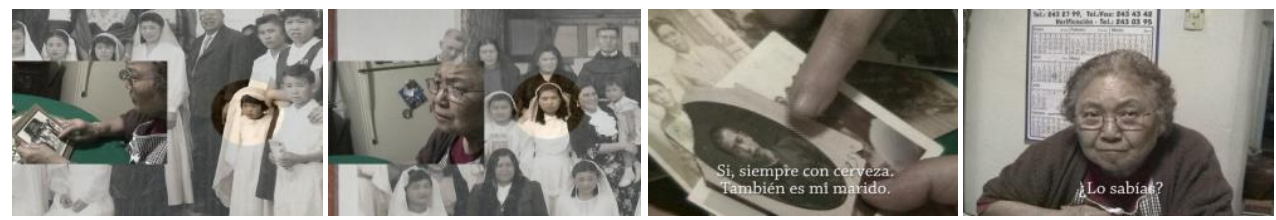

107. En memoria de Harue... (2006-2009), Miki Yokoigawa

En la escena siguiente Atsuko habla sobre dos fotografías de su marido, el padre de Ernesto. El vídeo se amplía al tamaño completo de la pantalla. Ella comenta unas fotos y añade que su marido llegó a México el año en que ella nació. Luego, el vídeo vuelve como ventana a la posición central izquierda, para mostrar a la fotografía de la familia del marido de Japón en la parte derecha de la pantalla.
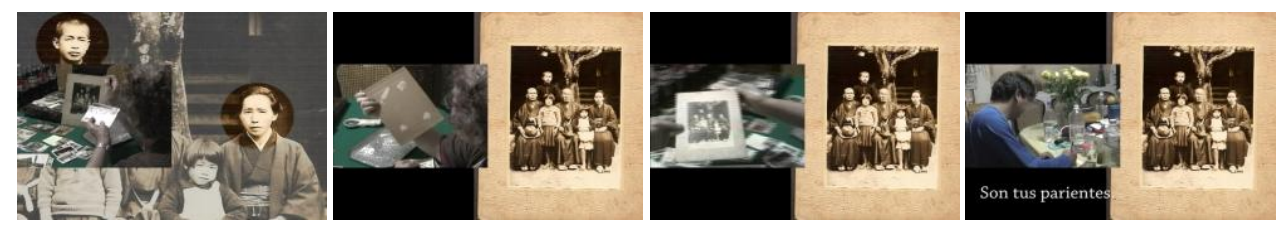

108. En memoria de Harue... (2006-2009), Miki Yokoigawa

En esta foto vemos a un hombre a la izquierda, un anciano en medio y una mujer a la derecha, todos sentados. Entre ellos están dos niñas de pie y detrás de ellos se ve a un chico vestido de estudiante. Atsuko señala una a una a las personas que aparecen en ella. En el fondo de la ventana del vídeo aparecen ampliadas las imágenes de cada uno. Luego, Ernesto pregunta la fecha de la fotografía, pero Atsuko no sabe contestar. Entonces el hijo comenta: "tú debes saber”, y la madre pregunta: “Ay, ¿por qué?”. Ernesto dice entonces: "Porque son tus parientes". Y ella contesta con un tono de reclamo, pero riendo: "iSon tuyos!'”. Con esta conversación se corrobora que el hijo pone sobre su madre toda la carga de la memoria familiar, como si ella tuviera que saberlo todo. Lo cual no es cierto, y quizás no es justo tampoco. La escena finaliza con la imagen de Ernesto haciendo las fichas.

En la decimoséptima secuencia, vemos a Ernesto colocando las fotografías antiguas en las páginas vacías del álbum. Lee los datos escritos en las fotografías y los escribe a pie de foto, sobre la página. Ernesto comenta varias cosas, pero sin levantar la vista de las fotos y con 
voz muy baja, por lo que no se le entiende bien. Su murmullo va subtitulado. Por último, la autora le hace una pregunta y Ernesto contesta haciendo el álbum.

Miki: ¿Qué es la memoria de la abuela?

Ernesto: Muy poco y muy triste... (Transcurre un instante. Mientras, se oye el ruido del avión que pasa por arriba de la casa) y... (de nuevo una pausa bastante larga) y es una lástima de que haya vivido tan poquito. Me hubiera gustado conocerla más, porque yo creo que fue una gran señora... (sus últimas palabras no se comprenden)

La decimoctava secuencia continúa con la imagen de Ernesto creando el álbum, pero el tono de color del vídeo cambia a blanco y negro, con un pequeño reflejo en la pantalla. El audio sigue igual que en la escena anterior. La cámara se aleja poco a poco de la pantalla con movimiento zoom y aparece un marco de cartón alrededor de la pantalla, que al apreciarse en su totalidad nos permite comprender que se halla dentro de una caja de cartón. Mientras en el vídeo Ernesto sigue pegando fotos, se oye la voz de la autora que le pregunta acerca de su familia. Ernesto responde el nombre de "la abuela" ("Harue"), pero no conoce el nombre de la abuela paterna.
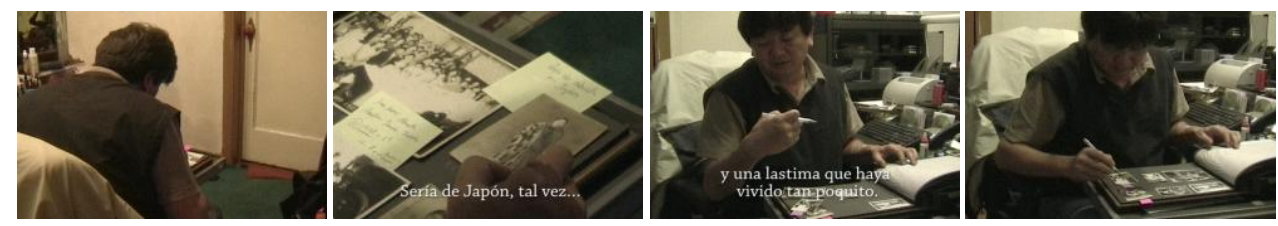

109. En memoria de Harue... (2006-2009), Miki Yokoigawa

La autora continúa haciendo preguntas sobre los abuelos y resulta que Ernesto no sabe nada sobre la familia paterna. Comenta que nunca oyó acerca de ellos y que no tuvo oportunidad de hablar con su padre sobre el tema. Obviamente, resulta más difícil para él por la distancia entre Japón y México. Además, su padre falleció cuando Ernesto tenía quince años. La autora anuncia el fin de la filmación y da las gracias a Ernesto. Él contesta: “De nada. Buenas noches". En ese momento, aparecen dos brazos que van cerrando poco a poco la caja de cartón y le ponen la cinta. Se superpone una epístola dedicatoria y el agradecimiento. La imagen se funde a blanco y permanece el texto. 

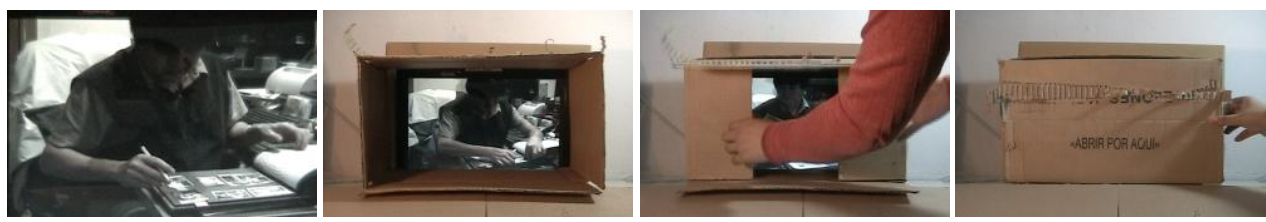

110. En memoria de Harue... (2006-2009), Miki Yokoigawa

Si bien este documental se iniciaba porque Ernesto no sabía nada sobre su abuela materna, durante este proyecto él ha conocido alguna parte de su vida. No obstante, al final se topa de nuevo con su ignorancia al saber mucho menos aún de sus otros abuelos. Al igual que las fotografías sacadas de la caja vuelven a la caja, y el kimono, a la maleta de piel, "la historia que todavía no se ha convertido en una historia" se guarda en una caja y se encierra "por el momento". En este sentido, la historia se abandona "por el momento".

\section{VI.4. Entre relatos de memoria y olvido.}

En el documental escuchamos el relato alegre de Astuko al hablar sobre las fotografías. Surge una idea diferente a la explicación inicial acerca del tabú sobre su abuela. La muerte de Harue fue un gran golpe de tristeza para la familia, de eso no hay duda. Vemos a Atsuko hablar con voz apagada sobre la muerte de sus padres y percibimos que todavía le cuesta hablar de ello. Sin embargo, en general, ella no evita hablar de la madre y su memoria no se reduce tan solo a relatos dolorosos. A lo mejor ella no evitaba hablar sobre su madre por tristeza, sino porque no sabía mucho sobre ella. Es decir, no tenía tantas historias para contar. Astuko perdió a su madre cuando tenía catorce años, después tuvo que superar numerosas complicaciones en su vida, además había estado incluso más tiempo conviviendo con otras personas. Ello no anularía la memoria de su madre, pero es cierto que tendría pocos recuerdos que compartir por haber vivido poco tiempo con ella.

También podemos suponer que la generación de Atsuko no evita hablar de ella, sino que son las generaciones posteriores las que no quieren escuchar. $\mathrm{O}$ tal vez, no saber mucho sobre los propios padres es una realidad que se debe ocultar. De esta manera, sellando la historia de la abuela, como una historia que no se debe recordar, se intentaba ocultar la realidad del desconocimiento. Ernesto, como miembro de la generación posterior, mediante 
el pretexto de que su madre evitaba hablar, intentaba estructurar su propio mundo establecido, separado y oculto de la memoria de la generación anterior. Un mundo sobre un conocimiento abstracto del sufrimiento de la generación anterior que afirma el tiempo presente. En este sentido, la memoria de la abuela sería un trauma o más bien una falta que agita y amenaza la estabilidad del presente. Como hemos visto en el capítulo IV, lo normal es oprimir el trauma y buscar la estabilidad mental sellando la falta. En este sentido, el comportamiento de Ernesto es bastante comprensible y el caso no es exclusivamente suyo. En este sentido, a él no le interesaba el fantasma del pasado que puede sacudir la estabilidad del presente, reafirmando así la posición del individuo presente en oposición al un pasado poco claro.

Así, se ha anulado la vida y la muerte de la abuela Harue, sellando la memoria de recuerdos duros como trauma y/o falta en "la historia" familiar. La abuela se convierte de este modo en una mujer anónima desconocida, su voz muda y su imagen queda escondida o apenas vislumbra como una fantasma flotando en un rincón en la casa. Al mismo tiempo, con esta anulación se construye una legítima historia de la colonia japonesa como un mito de los fundadores: un emigrante-colono valiente-heroico, un negociante con éxito, un líder político y su historia de contribución a la colonia. Dentro de esta historia nunca será escuchada la voz de las mujeres como Harue y Atsuko. Este documental, aunque fracasa en lo que se refiere a la recuperación de la memoria perdida de la abuela, reclama a la historia que escuche a las voces de aquellas mujeres que vivieron y compartieron exactamente igual que aquellos protagonistas cuya historia pareciere más legítima.

El flujo y reflujo del relato de Atsuko -con una mezcla de japonés con notable acento poblano como herencia de sus padres, y español con acento mexicano- nos hace reflexionar sobre aquellos que no se quedan solo a un lado, sino que al mismo tiempo están en ambos. Recordamos aquí una entrevista que realizaba Fiona Tan a su hermana en el documental (VI.4). Ella, muy consciente de su postura, respondía a la pregunta “¿de dónde eres?” de manera contundente: "soy de otro tipo, no me ajusto en ninguna parte" "16. La autora del presente documental no hace este tipo de pregunta, sino que solo observa y escucha. No

\footnotetext{
${ }^{16}$ Véase VI.4. Nota 20. p.548.
} 
obstante, también nos muestra el modo del relato con pathos que muchas veces es una mezcla confusa de lenguas, tiempos, memoria y olvido. Las traducciones de los subtítulos nos facilitan la comprensión de lo que dice esa voz. La narración en off nos explica el contexto y la intención de la autora, y también en cierto modo nos facilita una comprensión más razonable. Sin embargo, no se olvida de indicarnos la falta de datos y fotos, y ausencias de las personas. En este sentido, el comentario no proviene de un narrador omnisciente que nos dirige solo al conocimiento completo, sino que señala la falta de conocimiento. Es decir, se refiere a la fisura dentro de la historia, al mismo tiempo que articula y asocia los relatos y las imágenes fragmentadas de la mujer.

Las imágenes de las fotografías encontradas también ayudan a nuestra comprensión. En varias ocasiones, observamos las imágenes fotográficas como ilustración del relato y/o de su explicación. Pero, al mismo tiempo, algunas se desplazan de su posición como datos visuales por el medio del montaje, mostrándose de forma fragmentada y enfocando los detalles superficiales, con repetición de las mismas.

En esta obra se presenta aquello de lo que no se puede hablar, la muerte y la vida de una mujer, la contradicción y la ruptura de la perfección narrativa de una historia. Se revelan asuntos privados de una mujer anónima y la autora como mediadora intenta expresar una biografía audiovisual de una madre y una hija. Pero lo peculiar de este trabajo es que el proyecto no se lleva a cabo solo por mujeres, sino junto a un hombre. La colaboración entre madre, hijo y amiga aporta un carácter dinámico al proyecto. Uno está aburrido de escuchar, otra se pone nerviosa frente a la cantidad de datos perdidos o a las memorias excesivas, otra no se acuerda bien y se confunde en su propia memoria.

Ésta es una ambigua situación entre memoria y realidad, proximidad y ceguera, alegría y disgusto. Y este triángulo de tres personas, nunca en armonía, genera cierta disonancia. Esta disonancia es una fisura entre ellos, pero al mismo tiempo, es donde se articulan. Quizá esta disonancia y las referencias sobre la falta salvan a esta obra para no caer en una construcción de un mito de la madre-abuela. 
El documental nos presenta una lectura de la autora de estas mujeres de diferentes generaciones, insistiendo tanto en lo que se puede alcanzar como en lo que escapa de la expresión audiovisual. Nos obliga a aproximarnos mucho a aquellas personas, pero dejando cierta distancia e indicando el abismo que no puede atravesar. Nos presenta un encuentro fallido con la imagen fantasma de aquella mujer que flota dentro de la casa, registrando sus huellas. El proyecto de búsqueda de una inmigrante anónima que ocasiona el recuerdo, la imaginación, el pensamiento y la actitud de enfrentamiento con lo que se mantiene y lo que se ha perdido de "la abuela" construyendo y deconstruyendo su imagen. Es un documental que registra un acto performativo.

Podríamos decir que la realización del proyecto en sí es un acto performativo como mencionaba Cornell sobre el viaje de Spivak que buscaba a una mujer anónima Rani y que resulta fracaso. El documental es una representación de la lectura de la autora. Y mediante la narración en primera persona la autora testifica cómo ha conocido a aquella mujer inmigrante, cuya memoria supone casi un trauma familiar. La conciencia de un ser que no permanece solo a un lado, sino en ambos al mismo tiempo. Es un documental de un viaje a México, pero no solo eso, sino un viaje a la colonia japonesa de distintas generaciones en búsqueda del testigo de la mujer inmigrante olvidada. De este modo, es posible considerar el presente documental como una de las obras autobiográficas de la mujer en tránsito que plantean una forma de lectura sobre su propio acto performativo, esperando una nueva lectura para presentar el vínculo perdido de la mujer.

La obra presenta aquello de lo que no se puede hablar, la muerte y vida de la mujer, la contradicción y ruptura de la perfección narrativa histórica, revelando asuntos privados de una mujer anónima basado en los registros de historias relatadas de sus experiencias, memorias y biografía, siendo artista quién habla de la otra mujer. Por lo tanto consideramos que este documental también forma parte de la expresión audiovisual de la autobiografía de la mujer en transitó según lo que indicaba Shoshana Felmn, leer y hablar de las mujeres por otras mujeres esperando una nueva lectura para representar el vínculo perdido de la mujer. 
Para cerrar el capítulo que hemos dedicado en aproximar a las diversas expresiones autobiográficas de las mujeres artistas en tránsito citaremos unas frases de Ana MartinezCollado:

Vivir, escribir, recordar, producir. Construir/deconstruir imágenes desde la experiencia -memoria de la biografía- e imágenes desde la historia. ¿Y todo desde dónde? Desde un lugar que no estaba escrito, desde una posición crítica a nuestra cultura, desde la experiencia como “mujer”. Escribir relato/narrativas visuales de aquella subjetividad que se experimenta como extranjera. Narrativas en las que los fragmentos de lo leído, lo escuchado, lo visto, se producen a través de un nuevo proceso de referencias entretejidas. ${ }^{17}$

Y el viaje continuará.

\footnotetext{
${ }^{17}$ Martinez-Collado, Ana, Apuntes de las prácticas artísticas en España desde los años noventa. Retos y desafíos de la teoría estética feminista desde un punto cualquiera del rizoma en la sociedad de la información global en VV.AA. Producción artística y la teoría feminista del arte: nuevos debates I, Vitoria-GasteizkoUdalak, Ayuntamiento de Vitoria-GasteizkoUdalak, 2008. p. 105.
} 
CONCLUSIONES 
Una vez desarrollados los contenidos, exponemos a continuación las conclusiones de la tesis que hemos planteado, siguiendo un orden relacionado con el índice y subrayando las aportaciones que consideramos más destacadas.

En cuanto a las teorías feministas, hemos examinado la posibilidad y/o imposibilidad de hablar de la mujer -como mujer- dentro del desarrollo teórico sobre la autobiografía femenina de Shoshana Felman. En su texto, ella argumenta que la única posibilidad radica en la lectura y la escucha sobre la historia de una mujer contada por otra mujer. Felman aclara que la vida de cualquier mujer conlleva un trauma, ya sea consciente o inconscientemente, así que es natural que la biografía de la mujer la constituyan el testimonio y la historia de ese trauma. Por esta razón, hemos realizado un breve repaso de la polémica del psicoanálisis desde la postura feminista bajo la influencia de la deconstrucción derridiana. Felman argumentaba que tenemos que aprender a leer entre las fisuras del texto para poder hablar de la otra mujer que vive en continua ruptura como el "otro" ser.

De la misma manera, nos hemos acercado a la teoría de Gayatri C. Spivak sobre la imposibilidad de habla del ser subalterno, el cual permanece mudo en el punto de fisura entre las historias, las ideologías y las políticas. El planteamiento de Spivak nos mostró la importancia de la teoría poscolonial para evitar la incomprensión de algunas cuestiones de posicionamiento que imposibilitan poder hablar. Vimos la gramatología derrdiana para poder aproximarnos a su pensamiento. Spivak cuestionaba también la problemática de la postura como representante de los subalternos, pues quien habla en nombre de los marginados se convierte, en casi todas las ocasiones, en quien quita la voz y oprime así la posibilidad de hablar por sí mismos. Luego, criticaba también el optimismo al esperar que se podía animar a hablar a los "marginados", basándose en el análisis del caso del subalterno sexuado obligado a permanecer mudo entre diferentes historias, ideologías y culturas. En este punto, hemos considerado la necesidad de la intervención artística y de la postura del mediador. 
Posteriormente, estudiamos los argumentos de Drucilla Cornell cuando analiza el proyecto de Spivak, comparándolo con lo sublime. Según Cornell, el acto de Spivak puede considerarse como un acto performativo que tiene un carácter sublime, ya que contiene la posibilidad de partir hacia una nueva comunidad abierta. En este punto, hemos realizado un breve repaso de la crítica contra la comunidad estética, con el ejemplo extremo del nazismo y de su relación entre estética y política. Lo que planteaba Cornell es una comunidad que se basa en lo sublime e indispensablemente incluye al "otro", apoyándose en la dignidad que supera y vincula a las distintas generaciones. Estas son teorías feministas que han cimentado fundamentalmente la teoría de nuestro proyecto de investigación.

Hemos expuesto la problemática y el peligro de la agitación y el cambio social generado por el poder artístico siguiendo la argumentación de Philippe Lacoue-Labarthe y Jean-Luc Nancy y apoyándonos en una crítica analítica sobre la estetización de la política.

Asimismo, hemos reflexionado sobre la posibilidad del testimonio como arte. Tras el análisis de Felman sobre Shoah de Claude Lanzmann, comprendimos que solo podría realizarse a través de un soporte audiovisual como el documental, ya que éste es un género cinematográfico realizado sobre imágenes tomadas de la realidad. Hemos confirmado la capacidad de la expresión audiovisual por su poder de comunicación como un conjunto de imagen, audio y textos. Y, sobre todo, hemos clarificado que en la expresión audiovisual se puede evidenciar la problemática de la función de la traducción, la cual ayuda a comprender lo que se dice, pero puede transformar o confundir el sentido original del idioma del "otro".

Durante el desarrollo de los estudios del documental en Japón y nuestra aproximación a su trayectoria histórica desde la perspectiva de la subjetividad, señalamos la teoría de Deleuze como punto de partida de nuestro análisis, el cual contaba con ejemplos del Cinéma Vérité en su libro La imagen - tiempo publicado en su primera edición en 1985. También nos acercamos a la influencia de las teorías feministas que habían sido introducidas en los documentales que abordaban los asuntos de lo privado, lo íntimo y lo personal. Estas referencias nos permitieron establecer un criterio para nuestro análisis de la trayectoria del documental y de algunas obras de arte en particular. 
Observamos el cambio radical en la expresión durante los años sesenta y setenta como una circunstancia que preparaba la expansión de Private Documentary y Self Documentary de los años noventa, y hemos tratado de contextualizar diferentes aspectos relevantes. En el caso del documental japonés, tratar el tema subjetivamente en sus representaciones tenía el sentido de criticar a los documentalistas y sus obras propagandísticas de generaciones anteriores que fomentaron una política nacional.

Hasta los años setenta en Japón se había establecido una conciencia sobre la necesidad de la construcción del sujeto en las producciones documentales basadas en la crítica a las películas propagandísticas, dominadas por el poder estatal en el período anterior a la guerra y durante la misma. Esta conciencia se transformó en una tendencia en el documental con una influencia recíproca de los movimientos sociales. Como consecuencia, el tema principal de los documentales se centraba en los asuntos sociales de la época, con mínimas excepciones. Los años ochenta, por otra parte, constituyeron el germen y origen del Private Documentary y Self Documentary, a los cuales nos hemos aproximado (tanto a la parte de los soportes alternativos, como la película de $16 \mathrm{~mm}$ y el vídeo analógico, como a su contenido que situaba en el centro a lo personal e íntimo y a la temática de lo privado, basado en la técnica digital que llegaría en la siguiente década).

Entonces, hemos explicado la tendencia general de este tipo de trabajos en relación con la técnica digital a través del análisis comparativo sobre los trabajos de Private Documentary y Self Documentary de los años noventa. Según Tetsuya Mori, lo importante del Self Documentary es la construcción de la retórica subjetiva entre el realizador y el tema, entre los actores reales y/o el fenómeno en la expresión audiovisual. En este sentido, no necesariamente se tratan los asuntos privados, personales o familiares, sino que su importancia estriba en la forma de hablar en primera persona. Es decir, el Self Documentary es una forma personal de representación retórica subjetiva basada en el registro de la relación entre el autor y los actores y/o fenómenos reales a través del tratamiento del tema con todas sus problemáticas. 
Descubrimos tanto la voz de la mujer como su silencio en el campo del documental. Reflexionamos sobre los documentales que abordan la identidad y la memoria traumática de las autoras que buscan su articulación con el "otro". Hemos analizado algunas obras de realizadoras norteamericanas de origen japonés como Rea Tajiri, Emiko Omori y Chizuko Omori, según la interpretación de Efrén Cuevas Álvarez. Hemos procurado ampliar este análisis profundizando en las conciencias de las artistas que les llevan a tratar la memoria traumática de sus familias, en relación con sus propias crisis de identidad en un determinado contexto histórico, social y político. Reafirmamos la necesidad e importancia de la intervención artística en este tema. También hemos profundizado en los trabajos de Sumiko Haneda, Nanako Kurihara, Linda Hattendorf y Young-joo Byun, todas ellas realizadoras que buscan la articulación con los "otros" intentando hallar la voz de los subalternos.

Finalmente, hemos analizado las obras audiovisuales seleccionadas. Son obras que tienen diferentes dispositivos en su expresión audiovisual: un vídeo monocanal cuyo montaje se basa en fotografías, una película de $16 \mathrm{~mm}$, un cortometraje de $35 \mathrm{~mm}$, un vídeo documental televisivo, una videoproyección de vídeos multicanal sin audio, una videoinstalación multicanal con auriculares y un vídeo documental con carácter experimental.

La primera obra analizada, Measures of Distance (1988), de Mona Hatoum, basa su representación en las discrepancias entre los sentimientos de una madre y su hija, y posibilita la autobiografía de la mujer en su obra. También indicábamos lo curioso de su trabajo, el cual lograba reservar una postura de respeto a la dignidad y a la cultura del "otro" sin ser una expresión extremadamente dramatizada, mostrando a la vez el dilema y el estado contradictorio en la comunicación. Consideramos que es un trabajo que nos lleva más allá de la teoría de Cornell, en la que se ponía el énfasis en la dramatización de la realidad de las mujeres.

La segunda obra, Surname Viet Given Name Nam (1989), de Trinh T. Minh-ha, atraía nuestra atención por su carácter como un documental entre ficción y realidad realizado mediante entrevistas a mujeres. Consideramos que esta obra lograba representar a la mujer 
anónima, también llamada la mujer de Viet-Nam. La expresión se buscaba a través de distintos fragmentos de testimonios de "otras mujeres" situadas dentro del sistema patriarcal sobre las batallas ideológicas, su difícil situación económica, la represión sexual o el estado de humillación del exiliado. Cada relato se figura y desfigura con la imagen de la mujer de Viet-Nam que indica el abismo y el punto de conexión con la realidad de las mujeres que allí viven. Sus relatos son una expresión audiovisual que nos conciencia de la imposibilidad de representación de lo real, visualizando la distancia entre el parlante y el oyente, el personaje y la actriz, lo que ocurre y su relato, con el flujo de lo excesivo y de la carencia.

En la tercera obra, Night Cries: A Rural Tragedy (1989), de Tracey Moffatt, cabía señalar el modo de relatar una compleja relación entre hija y madre, su incomunicación y soledad, indicando tanto lo expresivo como lo inexpresivo en una locución sin conversación. El tema de esta obra no se reducía solo a representar a una mujer concreta (la hija adoptada aborigen en el contexto australiano), sino que la obra también nos confronta a la realidad que supone la carga y la responsabilidad que tiene la hija como cuidadora de su madre. La obra evoca a lo indecible en la compleja relación que existe, dentro de la dinámica de la diferencia y en un tiempo y espacio aislado, entre el amor y el odio, el dominador y el dominante; en fin, la madre y su hija. También confirmamos que el carácter autobiográfico de la mujer indica lo indecible de la mujer en los relatos de una mujer contados por otra mujer. Este caso nos mostraba ese sentimiento inexpresable entre amor y odio, a la vez que introducía una forma de parodia en el cine con un toque de fantasía.

La cuarta obra, May You Live in Interesting Times (1997), de Fiona Tan, es el documental de un viaje de búsqueda de la propia identidad. La artista nos mostraba que con el fin del viaje se confirma la imposibilidad de la auto-definición. La multiplicidad que encontraba en su viaje imposibilitaba reducirle a una sola identidad. De este modo, la respuesta sobre su propia identidad se eterniza en la ambigüedad del audiovisual que solo puede definirla por lo que no es. Habíamos concluido que el documental convierte a los espectadores en compañeros de su viaje de búsqueda de la propia identidad a través de las entrevistas, los 
paisajes, los eventos y la vida cotidiana de sus parientes, en una mezcla de fragmentos de múltiples culturas y una combinación híbrida de generaciones.

En A Needle Woman (1999-2001 y 2005), de Kimsooja, hemos analizado el carácter de la representación de su performance como una mujer muda en tránsito. Averiguamos el pensamiento de la artista en su obra: pensar la propia identidad en relación con los demás y, al mismo tiempo, ser un espejo del mundo para poder reflexionar sobre lo que nos rodea. Pensamos que el silencio que mantiene la artista en la performance simboliza precisamente el estado de mudez de la mujer frente a la confrontación con sus diferencias. Ella no se propone pronunciarse sobre su identidad, pero su vestido y su aspecto físico nos indicaban las características de su origen. De forma bastante esquemática, concluimos que su trabajo forma parte de una expresión audiovisual de la autobiografía de la mujer en tránsito que indica cierta ruptura; y su mudez, al mismo tiempo, intenta mostrar su identidad a través de las miradas de los demás como punto de partida para una posible comunicación que todavía no existe.

Por el contrario, en Les Veuves de Noirmoutier (2004-2005), de Agnès Varda, se mostraba otra dimensión de la mujer en tránsito. Prestamos atención tanto a lo que se habla como al silencio de las mujeres, comparando distintos aspectos dentro de la misma obra. En esta expresión audiovisual se nos muestra como se conservan las particularidades de cada una de las mujeres en el relato de las viudas; al mismo tiempo, se indica claramente el sentido de colectividad que hay entre ellas. La artista, que no hablaba en el audiovisual, mostraba con una silla vacía la ausencia a su lado, presentando lo inexpresable como una más de las viudas que relataban su experiencia. Aquí descubrimos un carácter peculiar del silencio respecto a otras obras al fijarnos en la representación del performance. Varda nos presentó una performance donde las mujeres sin diálogo comparten el silencio de lo indecible, ese silencio se convierte en punto de ruptura y articulación entre ellas, en contraste con la performance de Kimsooja y Fiona Tan, cuyo silencio señalaba una incomunicación y una ruptura. 
La séptima obra, En memoria de Harue: vida y muerte de una inmigrante japonesa en México 1929-1949 (2006-2009), de la doctoranda, es un documental que presenta una lectura acerca de mujeres de diferentes generaciones, insistiendo tanto en lo que se puede alcanzar como en lo que se escapa en la expresión audiovisual. Entorno a los relatos y a las imágenes de fotografías antiguas de Harue, se pretende construir y deconstruir su imagen. Es un documental que registra ese acto performativo que mencionaba Cornell sobre el viaje fracasado de Spivak en la búsqueda de una mujer anónima, Rani. La obra es una narración en primera persona como testimonio de una mujer anónima. Presenta aquello de lo que no se puede hablar, la muerte y vida de la mujer, la contradicción y ruptura de la perfección narrativa histórica, revelando los asuntos privados de una mujer anónima mediante los registros de sus experiencias, memorias y biografía relatados por otros (en este caso, es la artista quien habla de la otra mujer). Concluimos que esta obra también forma parte de la expresión audiovisual de la autobiografía de la mujer en tránsito, según lo que indicaba Shoshana Felman: se lee y habla de las mujeres por otras mujeres para esperar una nueva lectura que presente el vínculo perdido de la mujer.

A lo largo del presente trabajo hemos desarrollado una investigación sobre la biografía y autobiografía de la mujer en tránsito en expresiones audiovisuales contemporáneas analizando las obras seleccionadas. Hemos mencionado distintas expresiones audiovisuales, a distintos niveles de lo visible e invisible, lo decible e indecible, lo comprensible e incomprensible. Hemos analizado los contextos de cada obra y artistas, intentando minimizar el riesgo de simplificar o ignorar su cuestión fundamental. Lo que hemos planteado es una investigación basada en unos estudios de la representación audiovisual que contrasta la realidad con la ficción y la subjetividad. Esperamos que nuestro trabajo sirva para futuros investigadores, así como para que surjan investigaciones personales que en un futuro nos permitan seguir trabajando e investigando la creación audiovisual. 
BIBLIOGRAFÍA 


\section{Bibliografía Activa:}

Bal, Mieke: Conceptos Viajeros en las humanidades. Una guía de viaje, trad. Yaiza Hernández Velázquez, Murcia, Cendeac, 2009.

Beauvoir, Simone de: El segundo sexo. El volumen II. La experiencia vivida, trad. Alicia Martorell, Madrid, Cátedra, 2002.

Benjamin, Walter: La obra de arte en la época de su reproductibilidad técnica, trad. Andrés E. Weikert, México D.F., Editorial Ítaca, 2003.

Burgos, Elisabeth: Me llamo Rigoberta Menchú. Así nace mi conciencia, México D.F., Siglo veintiuno editores, 1985.

Cornell, Drucilla: Between Women and Generations. Legacies of Dignity, New York, Palgrave, 2002.

De Man, Paul: La ideología estética, trad. Manuel Asensi y Mabel Richart, Madrid, Cátedra, 1998.

---------: La retórica del romanticismo, trad. Julián Jiménez Heffernan, Madrid, Akal, 2007.

Deleuze, Gilles: La imagen-movimiento. Estudios sobre cine 1, trad. Irene Agoff, Barcelona y Buenos Aires, Paidós, 1984.

---------: La imagen-tiempo. Estudio sobre cine 2, trad. Irene Agoff, Barcelona, Paidós, 1986.

Felman, Shoshana y Laub, M.D. Dori: Testimony. Crises of Witnessing in Literature, Psychoanalysis, and History, New York y London, Routledge, 1992.

Felman, Shoshana: What Does a Woman Want? Reading and Sexual Difference, Baltimore, London, The Hopkings University Press, 1993.

Foucault, Michel: Foucault collection 4. Kenryoku-Kankin [Colección de Michel Foucault 4. Poder-confinamiento], trad. ed. Kobayashi, Yasuo, Tokio, Chikumashoten. 2006.

Guasch, Anna María: Autobiografías visuales. Del archivo al índice, Madrid, Ediciones Siruela, 2009. 
: El arte último del siglo XX. Del posminimalismo a lo multicultural, Madrid, Alianza Editorial, 2000.

Heidegger, Martin: Somamichi: Gesamtausgabe. I. Abteilung: Veröffentlichte Schriften 1910-76 Band 5 Holzwege. trad. Yoshio Kayano y Hes Brockard, Tokyo, Shobunsha, 1988.

Joshi, V. C. (ed.): Rammohun Roy and the Process of Modernization in India, New Delhi, Vicas Publishing House, 1975.

Kant, Immanuel: Crítica del juicio, trad. Manuel García Morente, Madrid, Espasa Calpe, 2007.

Kofman, Sarah: El enigma de la Mujer. ¿Con Freud o contra Freud?, trad. Estella Ocampo, Barcelona, Gedisa Editorial, 1997.

Kuhn, Annette: Familiy Secrets: Acts of Memory and Imagination, London, Verso, 1995

Kracauer, Siegfried: De Caligari a Hitler: una historia psicología del cine alemán, trad. Héctor Grossi, Barcelona, Paidós, 1985.

Lacoue-Labarthe, Philippe y Nancy, Jean-Luc: El mito nazi, trad. Juan Carlos Moreno Romo, Barcelona, Anthropos Editorial, 2002.

Lanzmann, Claude: Shoha, trad. Federico de Carlos Otto, Madrid, Arena Libros, 2003.

Lyotard, Jean-François: Le différend, Paris, Minuit, 1983.

Martín, Sylvia: Videoarte, Colonia, Taschen Gmbh, 2006.

Martínez-Collado, Ana: Tendenci@s. Perspectivas feministas en el arte actual, Murcia, Cendeac, 2008.

Muguiro, Carlos (et. ál.): El cine de los mil años, una aproximación histórica y estética al cine documental japonés (1945-2005), Navarra, Festival Internacional de Cine Documental de Navarra, Navarra Dirección General de la Comunicación, 2006.

Nancy, Jean-Luc: La presentación prohibida. Seguido de la Shoah, un soplo, trad. Margarita Martínez, Madrid y Buenos Aires, Amorrortu editores, 2006. 
Nichols, Bill: La representación de la realidad. Cuestiones y conceptos sobre el documental, Barcelona, Paidós, 1997.

(ed.): Movies and Methods, vol. 2, Berkeley, University of California Press, 1985.

Nornes, Abé Mark: Japanese Documentary Film. The Meiji Era through Hiroshima, Minneapolis, University of Minnesota Press, 2003.

Novaliz: Estudios sobre fichte y otros escritos, trad. ed. Robert Caner-Liese, Madrid, Akal, 2007.

Ota Mishima, María Elena: Destino México. Un estudio de las migraciones asiáticas a México, siglo XIX y XX, México D.F., El Colegio de México, 1997.

Peddie, Francis: Una presencia incómoda: la colonia japonesa de México durante la segunda guerra mundial, Estudios de Historia Moderna y Contemporáneo de México/ ISSN 0185-2620, n. 32, julio-diciembre 2006.

Ramires Bellerin, Laureano (ed. trad.): Arte de la Guerra de Sunzi. Versión restaurada a partir de mano escrito de Yinquesshan, Mardid, La espera de libros. 2006.

Romaguera I Ramió, Joaquim y Alsina Thevenet, Homero (eds.): Textos y Manifiestos del Cine, Estética. Escuela. Movimientos. Disciplinas. Innovaciones, Madrid, Ediciones Cátedra, 1989.

Said, Edward W.: Orientalismo, trad. María Luisa Fuentes, Barcelona, Roandom House Mondadori/ Debolsillo, 2009.

Sato, Makoto: Documentary no shujigaku [La retórica del documental], Tokio, Misuzushobo, 2006.

Sato, Tadao (et. ál.): Nihonno dokymentary I, Dokyumentary no miryoku [El documental japonés I, El atractivo del documental], Tokio, Iwanamishoten, 2009.

: Nihonno dokymentary II, Seiji, Shakai hen. [El documental japonés II, El volumen de la política social], Tokio, Iwanamishoten, 2010.

: Nihonno dokymentary III, Seikatsu, Bunka hen [El documental japonés III, el volumen de vida y cultura], Tokio, Iwanamishoten, 2010. 
Smith, William Eugene y Smith, Aileen. M.: Minamata, London, Chatto \& Windus, Ltd., 1975.

Sontag, Susan: Ante el dolor de los demás, trad. Aulelio Major, Madrid, Santillana Ediciones Generales, 2003.

Spivak, Gayatri Chakravorty: Crítica de la razón poscolonial. Hacía una historia del presente evanescente, trad. Marta Malo de Molina, Madrid, Akal, 2010.

---------: ¿Puede hablar el subalterno? trad. Santiago Giraldo. En revista Colombiana de Antropología, vol.39, enero-diciembre 2003.

: ¿Pueden hablar los subalternos? trad. Manuel Asensi Pérez, Barcelona, Museu d'Art Contemporani de Barcelona, 2009.

Todorov, Tzvetan: Los abusos de la memoria, trad. Miguel Salazar. Barcelona y Buenos Aires, Paidós, 2000.

Trinh, T. Minh-ha: Framer Framed, New York y London, Routledge, 1992.

Ueno, Toshiya y Mouri, Yoshitaka: Cultural Studies nyumon [Introducción a los estudios culturales], Tokio, Chikumashoten, 2000.

Varda, Agnès: L'ÍLE ET ELLE, Agnès Varda, Paris, Fondation Cartier pour l'art contemporain, 2006.

VV.AA: Artecontexto, no 11. Madrid, Artehoy Vegap, 2006.

VV.AA: Emigration and Immigration Studies in Japan. Survey and Bibliography I, The Meiji era - Sept. 1992, Tokio, Akashishuppan, 2007.

VV.AA: Emigration and Immigration Studies in Japan. Survey and Bibliography II, Oct. 1992 - Sept. 2005, Tokio, Akashishuppan, 2007.

VV.AA: Exit Book, n 11, Madrid, Olivares y Asociados, 2009.

VV.AA: Gendaishisou. Vol.35-13. Documentary [El pensamiento de hoy, Vol.35-13. El documental], Tokyo, Seido-sha, 2007. 
VV.AA: Producción artística y la teoría feminista del arte: nuevos debates I, VitoriaGasteizko Udalak, Ayuntamiento de Vitoria-Gasteizko Udalak, 2008.

VV.AA: Tracey Moffatt, Barcelona, Fundació La Caixa, 1999.

Yomota, Inuhiko: Eigashi eno shoutai [La invitación hacia la historia del cine], Tokio, Iwanamishoten, 1998.

Yomota, Inuhiko (ed. at.): Eiga to hyoushoukanousei [El cine y la imposibilidad de representación], Tokio, Sangyotosho, 2003.

Yokoigawa, Miki: Idealidad y realidad en la representación del cuerpo femenino: algunos casos de arte contemporáneo, México D.F. Tesis para obtener el grado de Maestría en Artes Visuales, Antigua Academia San Carlos de Escuela Nacional de Artes Plásticas de Universidad Nacional Autónoma de México, 2001.

Watson, Julia y Smith Sidonie: De/Colonizing the Subject: The Politics of Gender in Women's Autobiography, Minneapolis, University of Minnesota Press, 1992.

Wright, Elizabeth: Lacan y el posfeminismo, trad. Gabriela Ubaldini, Barcelona, Editorial Gedisa, 2004

\section{Bibliografía pasiva}

Agel, Henri: Esthétique du cinéma, Trad. Okada Shinkichi, Tokio, Hakusuisha, 1958.

Baigorri, Laura (et. ál.): Vídeo en Latinoamérica. Una historia crítica Madrid, Brumaria, 2008.

Bergson, Henri: La materia y la memoria, Paris, Presses Universitaires de France, 1896, trad. Tajima Setsuo, Busshitsu to kioku, Tokio, Hakusuisha, 2001.

Bourdieu, Pierre: Razones prácticas. Sobre la teoría de la acción, trad. Thomas Kauf. Barcelona, Editorial Anagrama, 2007.

Butler, Judith: El género en disputa. El feminismo y la subversión de la identidad, trad. Maria Antonia Muñoz, Barcelona, Paidós, 2007.

Chang, Iris: The rape of Nanking, trad. Fu Shou Ko, Tokio, Dojidaisha, 2007. 
Cornell, Drucilla: En el corazón de la libertad, trad. María Cóndor, Madrid, Ediciones Cátedra, 2001.

Copjec, Joan: Imaginemos que la mujer no existe. Ética y sublimación, trad. Teresa Arijón. Buenos Aires, Fondo de Cultura Económica, 2006.

: El sexo y la eutanasia de la razón. Ensayos sobre el amor y la diferencia, trad.

Gabriela Ubaldini, Buenos Aires, Paidós, 2006.

Crary, Jonathan: Techniques of the observer: On Vision and Modernity in the 19 Century, trad. Endou Tomomi, Tokio, Ibunsha, 2005.

David-Menard, Monique: Les construcyions de l'universel, trad. Kawasaki Soichi, Tokio, Serikashobo, 2001.

Derrida, Jaques: Otobiografías. Enseñana de Nietsche y la política del nombre propio, trad. Horacio Pons, Buenos Aires y Madrid, Amorrort, 2009.

Didi-Huberman, Georges: Image, soredemonao [Image malgré tout], trad. Hashimoto Kazumichi, Tokio, Heibonsha, 2006.

Escudero, Nel: Las claves del documental, Madrid, Instituto Oficial de Radio y Televisión, 2000.

Francés, Miquel: La producción de documentales en la era digital, Madrid, Cátedra, 2003.

Freud, Sigmund: El malestar en la cultura, trad. Ramón Rey Ardid. Madrid, Alianza Editorial, 1970.

Gregorio Gil, Carmen: Migración femenina. Su impacto en las relaciones de género, Madrid, Narcea, 1998.

Guasch, Anna María: Arte y archivo, 1920-2010. Genealogías, tipologías y discontinuidades, Madrid, Akal, 2011.

Kin, Shijon: “Zainichi” no hazamade [Entre “residentes en Japón”], Tokio, Heibonsha, 2001.

Kouda, Sumio: Bito sukouno kanatae [Más allá de lo bello y lo sublime], Tokio, Koyoshobo. 1999. 
Kristeva, Julia: El lenguaje, ese desconocido, trad. María Antoranz. Madrid, Editorial Fundamentos, 1969.

: Onnano jikan [Le temps des femmes], trad. Tanazawa Naoko y Amano Chihoko. Tokio, Keisousha, 1991.

Kuspit, Donald (ed.): Arte digital y videoarte. Transgrediendo los límites de la representación, trad. Marta Caro, Madrid, Círculo de bellas artes, 2006.

Manovich, Lev: El lenguaje de los nuevos medios de comunicación, trad. Òscar Fontrodona. Barcelona, Paidós, 2005.

Martí Marí, Silvia: El impacto de lo cotidiano: realidad, sujeto e intimidad en el arte (fotográfico) de los años noventa, Valencia, Tesis Doctoral, Departamento de Escultura, Facultad de Bellas Artes de San Carlos, Universidad Politécnica de Valencia, 2003.

Michaud, Éric: La estética nazi. Un arte de la eternidad, trad. Antonio Oviedo, Buenos Aires, Adriana Hidalgo Editora, 2009.

Minato, Chizuru: Kioku [Memoria], Tokio, Kodansha. 1996.

Morton, Stephen: Gayatri Chakravorty Spivak, trad. Hashimoto Tetsuya. Tokio, Seidosha, 2005.

Nakamasa, Masaki (ed.): Bino politics [Políticas de la bella], Tokio, Ochanomizu shobou. 2003.

Nancy, Jean-Luc: La comunidad desobrada, trad. Pablo Perera, Isidro Herrera, Alejandro del Río, Madrid, Arena Libros, 2001.

Oka, Mari: Kioku/Monogatari [Memoria/Narrativa], Tokio Iwanamishoten, 2000.

Piñero Gil, Carmen Cecilia y Piñero Gil, Eulalia: Arte y mujer. Visiones de cambio y desarrollo social, Madrid, Horas y horas, 2009.

Rancière, Jacques: Fuwa, aruiwa ryoukainaki ryoukai [La Mesentente, politique et philosophie], trad. Shoichi Matsuba, Hidetomi Omori y Shigeo Fujie, Tokio, Inscript, 2005

: La división de lo sensible. Estética y política, Salamanca, Consoricio

Salamanca, Centro de Arte de Salamanca, 2002. 
: La fable cinématographique, Paris, Senil. 2001.

Malaise dans l'esthétique, Paris, Galilée. 2004.

Sakiyama, Masaki: Sabaltanto rekishi [Los subalternos y la(s) historia(s)], Tokio, Seidosha, 2001.

Soler, Colette: Lo que Lacan dijo de las mujeres. Estudio de psicoanálisis, trad. Ana Palacios, Buenos Aires, Paidós, 2006.

Spivak, Gayatri Chakravorty: A Critique of Postcolonial Reason. Toward a History of the Vanishing Present, Cambridge, Massachusetts, London, Harvard University Press, 1999.

: Derridaron. Grammatology nituite [Translator's Preface, extracted from Of Grammatology by Jaques Derrida], trad. Yoshiki Tajiri, Tokio, Heibonsha, 2005.

Bunkatoshiteno Tasha [In Other Worlds, Essays in Cultural Politics], trad. Akira

Suzuki, Masako Oono, Nobumitsu Ukai y Makoto Kataoka, Tokio, Kinokuniya shoten, 1990.

--------: Sabaltanwa katarukotogadekiruka [Can the Subaltern Speak?] trad. Tadao Uemura, Tokio, Misuzushobo, 2002.

Stavrakakis, Yannis: Lakanto seijitekinamono [Lacan \& the Political], trad. Makoto Ariga. Tokio, Kikkasha, 2003.

Ukai, Satoshi y Takahashi, Tetsuya (et. ál.): "SHOHA” no Shougeki. [El impacto de “SHOAH”], Tokio, Miraisha, 1995.

Umeki, Tatsuo: Datsukouchiku to kokyosei [deconstrucción y lo público], Kyoto, ShoriaSha, 2001

Uta, Grosenik y Sabine, Blebmann (et. ál.): Art Now, Colonia, Taschen, 2002.

VV.AA: Arte, ideología y capitalismo, trad. César Rendueles. Madrid, Cíclo de Bellas Artes, 2008.

VV.AA: 100 Documentales para explicar historia de Flaherty a Michael Moore, Madrid, Alianza Editorial. 2010. 
VV.AA: Historia y estética del videoarte en España, Sevilla, Zamora, Comunicación social, 2011.

VV.AA: Lo personal es político: feminismo y documental. Colección de punto de vista no.6. Navarra, Gobierno de Navarra, INNAC, 2011.

VV.AA: Niki de Saint Phalle. Eiga "Daddy"omite Nikiokataru [Niki de Saint Phalle. Hablar sobre Niki por ver la película Daddy], Niki-bijutsukan (ed.), Tokio, Saikisha, 1997.

VV.AA: Qu'est-ce que l'art vidéo aujourd'hui? Paris, Meaux Arts éditions / TTM, 2008.

Yomota, Inuhiko y Hori, Junichi (et. ál.): Godard-Eizo-Lekishi. "Eigashi”o yomu [Godardimagen-historia. Leer “Histoire(s) du cinéma”], Tokio, Sangyotosho, 2001.

Yomota, Inuhiko: Nihon Eiga 100nenshi [Cien años de historia del cine japonés], Tokio, Shueisha, 2000.

-------- (ed.): Okinawa Eiga [Cine Okinawa], Tokio, Sakuhinsha, 2008.

Weinrichter, Antonio, Desvíos de lo real. El cine de no ficción, Madrid, T\&B editores, 2005.

-------: Metraje encontrado. La apropiación en el cine documental y experimental, colección punto de vista no.4, Navarra, Fondo de publicación del gobierno de Navarra. 2009.

Zuñiga, Joseba: Cultural Audiovisual, Andoain, Escuela de cine y vídeo, 2009.

Žižek, Slavoj: Ideorogino suukounataishou [The sublime object of ideology], trad. Sho Suzuki, Tokio, Kawadeshobo, 2003.

Zupančič, Alenka: Rialno rinri - Kantto Lacan [Ethics of the real: Kant, Lacan], trad. Go Tsuyoshi, Tokyo, 2003.

\section{Diccionario:}

Audi, Robert (ed.): Diccionario Akal de Filosofía, trad. Hubero Marraud y Enrique Alonso, Madrid, 2004.

Cuéllar, Alejandro y Carlos A.: Vocabulario Básico del audiovisual, Valencia, Ediciones de la Filmoteca IVAC, 2004. 
Hiromatsu, Wataru (et. ál.): Iwanami Tetsugaku shisou jiten [Diccionario Iwanami del filosofía pensamiento], Tokio, Iwanamishoten, 1998.

Konigsberg, Ira: Diccionario técnico Akal del cine, trad. Enrique Herrando Pérez y Francisco López Martín, Madrid, 2004.

Martínez Torres, Augusto: Diccionario de directores de cine, Madrid, Ediciones del Prado. 1992.

Souriau, Étienne (et. ál.): Diccionario Akal de Estética, trad. Ismael Grasa Adé, Xavier Meilán Pita, Cecilia Mercadal y Alberto Ruiz de Sameniego, Madrid, Akal, 1998.

VV.AA: Diccionario de la lengua española. Vigésima segunda edición, Madrid, Real Academia Española, Espasa Calpe, 2001.

VV.AA: Nueva gramática de la lengua española. Manual, Madrid, Real Academia Española, Asociación de Academias de la Lengua Española, Espasa Libro, 2010.

VV.AA: Ortografía de la lengua española, Madrid, Real Academia Española, Asociación de Academias de la Lengua Española, Espasa Libro, 2010.

\section{WEB:}

Academia

del

Cinema,

vol.

35:

http://archive.mag2.com/0000208600/20080114000000000.html, accedido el 10 de febrero de 2009.

Albert Ruda en la que se estudia la responsabilidad en el caso Minamata de Japón: http://www.tesisenxarxa.net/TDX-0630106-114151/index.html, accedido el 1 de febrero de 2011.

Another Day of Housewife (1977-1987) vídeo, color y sonido, 18 minutos de duración en la web de MoMa PS1: http://www.moma.org/collection/browse_results.php?object_id=118191, accedido el 1 de abril de 2011.

Buenos Aires $9^{\circ}$ Festival Internacional de Cine Independiente, presentada por Contemporary Films: http://www.contemporaryfilms.com/, accedido el 22 de marzo de 2011. 
Campo de concentración de Dachau:http://www.kz-gedenkstaette-dachau.de/timeline/19331945.html, accedido el 6 de diciembre de 2008.

Chisso Corporation: http://www.chisso.co.jp/english/index.asp , accedido el 14 de febrero de 2009. http://www.houseofjapan.com/local/chissos-spin-off-plan-ok, accedido el 1 de febrero de 2011.

La conferencia Feminism and Deconstruction de G. C. Spivak en la web del Museu D’Art Contemporani de Barcelona:

http://www.macba.cat/controller.php?p_action=show_page\&pagina_id=72\&inst_id=23061, consultado el 23 de mayo de 2009.

Days of Waiting: The Life \& Art of Estelle Ishigo:

http://www.farfilm.com/web/title_dow.htm, accedido el 20 de diciembre de 2008.

Dubrow, Marcha, Smithsonian's Sackler Gallery 9/25 opened its first exhibit devoted to a video artist, Fiona Tan:

http://www.examiner.com/art-travel-in-washington-dc/smithsonian-s-sackler-gallery-9-25opens-its-first-exhibit-devoted-to-a-video-artist-fiona-tan, consultada el 22 de julio de 2011.

Eguchi Yukiko, MaMa, Yamagata International Documentary Film Festival (YIDFF): http://www.yidff.jp/97/cat091/97c102-3.html, accedido el 31 de marzo del 2009.

Encyclopedie Noveaux Media: http://www.newmedia-art.org/index.htm, accedido el 13 de junio de 2009.

FAV (Feminist Active Documentary Video Festa): http://www.renren-fav.org/main/, 20 de marzo de 2011. http://www.jca.apc.org/video-juku/English.html, 15 de marzo de 2011.

La filmografía y biografía de Pierre Perrault en la web NFB.ca, la cual facilita las películas producidas por la National Film Board of Canada: http://www.onf.ca/selections/denysdesjardins/loeuvre-de-pierre-perrault/, accedido el 2 de diciembre de 2010.

http://www.onf.ca/explorez-par/realisateur/Pierre-Perrault/, 2 de diciembre de 2010. http://www.onf.ca/selections/denys-desjardins/loeuvre-de-pierre-perrault/, 2 de diciembre de 2010 .

Fiona Tan (Web oficial): http://www.fionatan.nl/works/35, 2 de diciembre de 2010.

Fujioka, Astuhiro: La renovación y la modernización de la técnica en la década de 1930 y su representación fílmica, en: CinemaganiNet! No. 6 de 2002, Online Research Journal of 
Cinema, http://www.cmn.hs.h.kyoto-u.ac.jp/CMN6/fujioka.html, accedido el 10 de febrero de 2009.

Fujiko Nakaya: http://processart.jp/nakaya/e/profile_e.html, accedido el 20 marzo de 2011.

Go For Broke National Education Center: http://www.goforbroke.org/default.asp, 28 marzo de 2010

Japanese American National Museum: http://www.janm.org/, accedido el 20 noviembre de 2007.

Jiyukobo, Sumiko Haneda: http://www.jiyu-kobo.com/, 15 marzo de 2011.

Katsuhiko Fukuda en una página de Nagoya Cinémathèque: http://cineaste.jp/1/960.htm, accedido el 31 de marzo del 2009.

Kazuo Hara en Festival Internacional de cine de las Palmas de Gran Canaria del 2011: http://lpafilmfestival.com/events/charla-con-kazuo-hara?locale=es, accedido el 25 de noviembre de 2011.

Kim Sooja: http://www.kimsooja.com/menu.html, 15 de septiembre de 2009.

http://www.ntticc.or.jp/Archive/2000/A needle woman/about_j.html, 15 septiembre de 2009.

Limda Hattendorf:

http://www.thecatsofmirikitani.com/, 21 marzo de 2011.

http://amky.org/senhordobrasil/, 21 marzo de 2011.

http://amky.org/senhordobrasil/story.html, 21 de marzo de 2011

Mako Idemitsu: http://www.makoidemitsu.com/www/video.html, accedido el 23 de marzo de 2011.

Makoto Sato: http://www.arsvi.com/w/sm09.htm, accedido el 28 marzo de 2010.

Mona Hatoum:

http://www.rtve.es/alacarta/videos/programa/metropolis-mona-hatum/1071615/, visualizado el 10 de junio de 2011.

http://www.whitecube.com/artists/hatoum/, accedido el 20 de junio de 2011.

http://virtual.fundacionbotin.org/visita_mona/index.html, accedido el 15 de mayo de 2011. 
Minamata museum:

http://www.minamata195651.jp/, accedido 1 de febrero de 2011.

http://www.minamata195651.jp/guide en.html, 1 de febrero de 2011.

http://www.houseofjapan.com/local/chissos-spin-off-plan-ok, 1 de febrero de 2011.

Nieve marina. WEB TEPIA Video: http://www.stream.tepia.jp/small_play.html, o por el menú de los vídeos: http://www.stream.tepia.jp/bunrui_contents.html?cateClass3=20701, accedido el 15 julio de 2009.

NTT-IOC (Japón): http://www.ntticc.or.jp/About/introduction.html, consultada el 29 agosto de 2011.

Perdón para los norteamericanos japoneses:

http://www.civics-online.org/library/formatted/texts/civilact1988.html, accedido el 18 noviembre de 2008.

Peter Whitehead:

http://www.thestickingplace.com/wp-content/uploads/2009/01/retro_whitehead11.pdf, accedido el 15 de noviembre de 2009.

“Poesía de la lengua” (舌詩), escrita por el político chino Feng Dao (馮道, 882-954) http://www2.odn.ne.jp/kotowaza/BBS/KANSI/13-kutiha-wazawaino.htm, accedido el 14 de abril de 2011.

"Pogrom" http://www.ushmm.org/wlc/es/article.php?ModuleId=10005757, accedido el 17 de abril de 2011.

Radical Software: http://www.radicalsoftware.org/e/index.html, accedido el 15 de julio de 2009.

Renov, Michael: New subjectivities: Documentary and Self-Representation in the PostVérité Age. Transformations in Film as Reality (Part Three) Documentary Box \#7. http://www.yidff.jp/docbox/7/box7-1-e.html, accedido el 5 diciembre de 2008.

Sachi Hamano, Tantansha (productor de Hamano): http://www.h3.dion.ne.jp/ tantan-s/, accedido el 21 marzo de 2011.

Sackler Galleries: http://www.fionatan.nl/works/37, 22 de julio de 2011.

Tatsuya Mori: http://moriweb.web.fc2.com/mori_t/index.html, accedido el 30 de marzo de 2009. 
Tesis doctoral de Albert Ruda en la que se estudia la responsabilidad en el caso Minamata en Japón: http://www.tesisenxarxa.net/TDX-0630106-114151/index.html, 1 de febrero de 2011.

The Broadcast Library de Yokohama, en Japón. http://www.bpcj.or.jp/english/, visualizada el 3 de febrero de 2011.

The Japan Council against Atomic and Hydrogen Bombs, http://www.antiatom.org/, el 28 de marzo de 2010.

The Ministry of Foreign Affairs of Japan:

http://www.mofa.go.jp/mofaj/press/pr/wakaru/topics/vol28/index.html, accedido el 15 de junio de 2009.

Trinh T. Minh-ha (web oficial): http://www.trinhminh-ha.com/, consultada el 21 enero de 2011.

Trinh T. Minh-ha, el ciclo de Cineteca Nacional de México: http://www.cinetecanacional.net/ficha.php?cvePel=9412\&o=1\&ciclo=1453, consultada el 10 de junio de 2011.

Trinh T. Minh-ha, (Entrevista), When The Eye Frames Red, entrevista con Akira Mizuta Lippit: http://www.trinhminh-ha.com/, consultada el 3 de marzo de 2011.

UBUWEB: La correspondencia en vídeo entre Shuji Terayama y Shuntaro Tanigawa (un poeta japonés) fechado en 1982-1983. En: http://www.ubu.com/film/terayama.html, accedido el 10 de junio de 2011. También en el mismo sitio se puede ver el vídeo Video Letters, 1932-1983, 75' NTSC, a color: http://www.ubu.com/film/terayama_videoletter.html, visualizado el 10 de junio de 2011.

UBUWEB: Measures of Distance (1988), vídeo de 15'26"' de duración, PAL, son, a color. En: http://www.ubu.com/film/hatoum_measures.html, visualizado el 13 de mayo de 2011.

UBUWEB: Tracey Moffatt.

http://www.ubu.com/film/moffatt_rural.html, consultada el 15 junio de 2011.

Video Act: proyecto dirigido por Yutaka Tsuchiya AcTV:

La Web principal: http://www.videoact.jp/, accedida el 31 de marzo de 2009. http://www.videoact.jp/actv, accedido el 31 de marzo de 2009.

http://www.youtube.com/group/VIDEOACT?gl=JP\&hl=ja, visualizado el 31 de marzo de 2009. 


\section{Listado de imágenes:}

1. Roadworks (1985), Mona Hatoum, p.17

2. Zen TV (1965), Nam June Paik, p.17

3. Proyecciones Públicas: A-Bomb Dome, Hiroshima (1999), Krzysztof Wodiczko, p.18

4. Las meninas(1656), Diego Velázquez, p.204

5. El tres de mayo de 1808 en Madrid (1813-1814), Francisco de Goya, p.207

6. La Liberté guidant le peuple (1930), Eugène Delacroix, p.207

7. Richard Glazar en Shoah (1985), Claude Lanzmann, p.213

8. Franz Suchomel en Shoah (1985), Claude Lanzmann, p.214

9. Entrevista con el testigo, la interprete y el autor en Shoah (1985), Claude Lanzmann, p. 220

10. Jan Karski en Shoah (1985), Claude Lanzmann, p.235

11. Nuit et brouillard (1955), Alain Resnais, p.244

12. Kantorowski y Srebnik frente a la iglesia de Chelmno en Shoah (1985), Claude Lanzmann, p.256

13. La salida de la fábrica (1895) y La llegada del tren (1897), los hermanos Lumière, p.298

14. Cinematógrafo de Lumière, p.300

15. Cinematoscopio y Black Maria de Edison y W.K.L. Dickson. p.300

16. Cantante-narrador y los operadores de Ningyoujoururi con su marioneta en el teatro, p.302

17. Tatakau Heitai (Fighting Soldiers, 1939), Fumio Kamei, p.310

18. Kyoshitsu no kodomotachi (Niños en clase, 1956), Susumu Hani, p.315

19. Ikiteite Yokatta (Still, It's Good to Live, 1952), p.319

20. Hadaka no shima (The Naked Island 1960), Kaneto Shindo, p.325

21. Wasurerareta kougun (El ejército de emperador olvidado, 1963), Nagisa Oshima, p.330

22. Ningen johatsu (A Man Vanishes/ Desaparición de un hombre) de Shohei Imaura, p.333

23. Titicut Follies (1967), Frederick Wisman, p.336

24. Le Joli mai (El bonito mayo,1962), Chris Marker, p.336

25. Marine Snow, Sekiyu no kiguen (Nieve marina. El origen del petróleo, 1960), Shinkicho Noda, p.337 
26. Minamata- Kanjasan to sono sekai (Minamata: los pacientes y su mundo, 1971), Noriaki Tsuchimoto, p.340

27. Nihonkaihousensen. Sanrizuka no natsu (Frente de liberación japonés, el verano de Sanrizuka, 1968), p.340

28. Fotografía de la serie Minamata y Tomoko Uemura in her Bath (1972), William Eugene Smith, p.341

29. El plano de Kumamoto y Nigata, Japón, p.346

30. Agani ikiru (Vivir en Aga 1992), Makoto Sato, p.346

31. Kyokushiteki erosu, Renka1974 (Eros privado extremo, canción de amor 1974), Kazuo Hara, p.349

32. Kusatori zoshi ("A Grasscutter's Tale”, El libro de escarda, 1985), Katsuhiko Fukuda, p.358

33. MaMa (1987), Yukiko Eguchi, p.362

34. Yukiyukite shingun (The Emperor's Naked Army Marches On, 1987), Kazuo Hara, p.367

35. Fatherless (1999), Yoshiya Shigeno y Masaya Muraishi, p.373

36. Home (2001), Takahiro Kobayashi, p.373

37. Atarashi Kamisama (1999), Yutaka Tsuchiya, p.377

38. Osaka Story (1994), Toichi Nakata, p.387

39. Caricatura editorial de The Yellow Terror In All His Glory (1899), p.405

40. Who's Going to Pay for These Donuts, Anyway? (1992), Janice Tanaka, p.407

41. Family Gathering (1988), Lise Yasui, p.407

42. Go for Broke! (1951) de Robert Pirosh, p.410

43. Rabbit in the Moon (1999), Emiko Omori, p.411

44. History and Memory (1991), Rea Tajiri, p.416

45. Póster de la demanda de emigración a Brasil, p.421

46. The Mrunuring (1995) Young-joo Byun, p.425

47. Ah, Manmou-kaitakudan (2008), Sumiko Haneda, p.427

48. Un senhor do Brasil. Visitando brasileiros no Japão (2008), Nanako Kurihara. p.429

49. The Cat of Mirikitani (2009), Linda Hattendorf, p.430

50. Auto-Vision (1964), Karl Gerstner, p.438 
51. Television Décollage (1963), Wolf Vostell, p.439

52. Radical Software, Volume II, Number 1(Winter 1972), Changing Channels, p.439

53. Vertical Roll (1972), Joan Jonas, p.441

54. Woman's House (1972), Mako Idemitsu, p.442

55. Shuhu no itinichi (1977), Mako Idemitsu, p.442

56. Semiotics of the Kitchen (1975), Martha Rosler, p.443

57. Technology/ Transformation: Wonder Woman (1978/1979), Dara Birnbaum, p.444

58. Daddy (1973), Niki de Saint Phalle y Peter Whitehead, p.445

59. I Am Not The Girl Who Misses Much (1988), Pipilotti Rist, p.446

60. Measures of Distance (1988), Mona Hatoum, p.462

61. Surname Viet Given Name Nam (1989), Trinh T. Minh-ha, p.489

62. Surname Viet Given Name Nam (1989), Trinh T. Minh-ha, p.492

63. Surname Viet Given Name Nam (1989), Trinh T. Minh-ha, p.493

64. Night Cries: A Rural Tragedy (1989), Tracey Moffatt, p.518

65. Night Cries: A Rural Tragedy (1989), Tracey Moffatt, p.520

66. May You Live In Interesting Times (1997), Fiona Tan, p.537

67. May You Live In Interesting Times (1997), Fiona Tan, p.547

68. May You Live In Interesting Times (1997), Fiona Tan, p.562

69. May You Live In Interesting Times (1997), Fiona Tan, p.575

70. Bottaris (1997 - 2001), Kimsooja, p.582

71. Cities on the Move: 2727 Kilometers Bottari Truck, Korea (1997), Kimsooja, p.582

72. A Needle Woman (1999-2001) Kimsooja, p.583

73. A Needle Woman (instalación en Nuit Blanche, París, 2009), Kimsooja, p.584

74. n.t.(Leidsestr.) (1997), Fiona Tan, p.586

75. A Needle Woman (2005), Kimsooja, p.598

76. Des glaneuses (1857), Jean-François Millet, p.607

77. Los Espigadores y La Espigadora (2000), Agnès Varda, p.607

78. LesVeuves de Noirmoutier (2004-2005), Agnès Varda, p.608

79. LesVeuves de Noirmoutier (2004-2005), Agnès Varda, p.609

80. LesVeuves de Noirmoutier (2004-2005), Agnès Varda, p.615 
81. En memoria de Harue: vida y muerte de una inmigrante japonesa en México, 19291949, (2006-2009), Miki Yokoigawa, p.627

82. En memoria de Harue... (2006-2009), Miki Yokoigawa, p.627

83. En memoria de Harue... (2006-2009), Miki Yokoigawa, p.628

84. En memoria de Harue... (2006-2009), Miki Yokoigawa, p.628

85. En memoria de Harue... (2006-2009), Miki Yokoigawa, p.630

86. En memoria de Harue... (2006-2009), Miki Yokoigawa, p.631

87. En memoria de Harue... (2006-2009), Miki Yokoigawa, p.631

88. En memoria de Harue... (2006-2009), Miki Yokoigawa, p.632

89. En memoria de Harue... (2006-2009), Miki Yokoigawa, p.633

90. En memoria de Harue... (2006-2009), Miki Yokoigawa, p.633

91. En memoria de Harue... (2006-2009), Miki Yokoigawa, p.635

92. En memoria de Harue... (2006-2009), Miki Yokoigawa, p.646

93. En memoria de Harue... (2006-2009), Miki Yokoigawa, p.637

94. En memoria de Harue... (2006-2009), Miki Yokoigawa, p.637

95. En memoria de Harue... (2006-2009), Miki Yokoigawa, p.638

96. En memoria de Harue... (2006-2009), Miki Yokoigawa, p.639

97. En memoria de Harue... (2006-2009), Miki Yokoigawa, p.641

98. En memoria de Harue... (2006-2009), Miki Yokoigawa, p.641

99. En memoria de Harue... (2006-2009), Miki Yokoigawa, p.642

100. En memoria de Harue... (2006-2009), Miki Yokoigawa, p.643

101. En memoria de Harue... (2006-2009), Miki Yokoigawa, p.644

102. En memoria de Harue... (2006-2009), Miki Yokoigawa, p.645

103. En memoria de Harue... (2006-2009), Miki Yokoigawa, p.648

104. En memoria de Harue... (2006-2009), Miki Yokoigawa, p.649

105. En memoria de Harue... (2006-2009), Miki Yokoigawa, p.651

106. En memoria de Harue... (2006-2009), Miki Yokoigawa, p.652

107. En memoria de Harue... (2006-2009), Miki Yokoigawa, p.653

108. En memoria de Harue... (2006-2009), Miki Yokoigawa, p.653

109. En memoria de Harue... (2006-2009), Miki Yokoigawa, p.654

110. En memoria de Harue... (2006-2009), Miki Yokoigawa, p.655 